
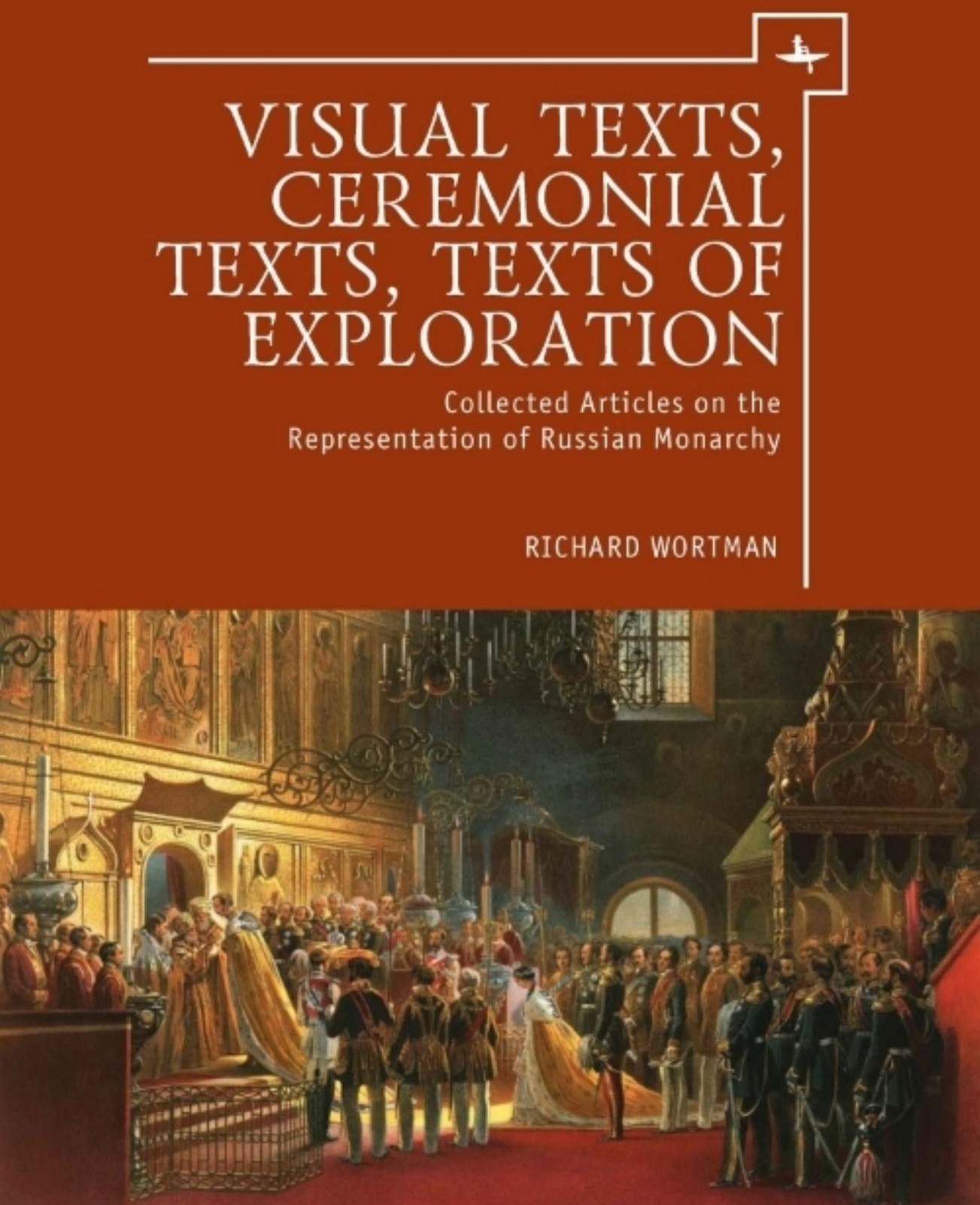


\section{Vissal Texts, Ceremmonial Texts, Texts of Explooation}

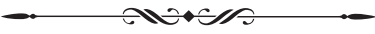

Collected Articles 
Imperial Encounters in Russian History

\author{
Series editor: \\ Gary Marker \\ (State University of New York, Stony Brook)
}

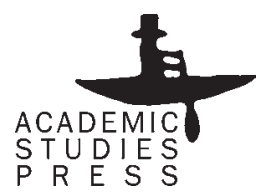




\title{
Visual Texts, Ceremonial Texts, TexTs of Explooation
}

\author{
cकs \\ Collected Articles \\ ON THE REPRESENTATION OF \\ Russian MONARCHY
}

Richard Wortman 
Library of Congress Cataloging-in-Publication Data:

A catalog record for this book as available from the Library of Congress.

Copyright @ 2013 Academic Studies Press

All rights reserved

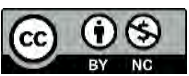

Effective August 2, 2016, this book will be subject to a CC-BY-NC license. To view a copy of this license, visit https://creativecommons.org/licenses/by-nc/4.0/. Other than as provided by these licenses, no part of this book may be reproduced, transmitted, or displayed by any electronic or mechanical means without permission from the publisher or as permitted by law.

ISBN 978-1-61811-258-3 (cloth)

ISBN 978-1-61811-259-0 (electronic)

Book design by Ivan Grave

Published by Academic Studies Press in 2013

28 Montfern Avenue

Brighton, MA 02135, USA

press@academicstudiespress.com

www.academicstudiespress.com 
To the memory of the Slavic and Baltic Division of the New York Public Library and the spirit of scholarly calling it inspired among the many generations of its readers. 



\section{Table of Contents}

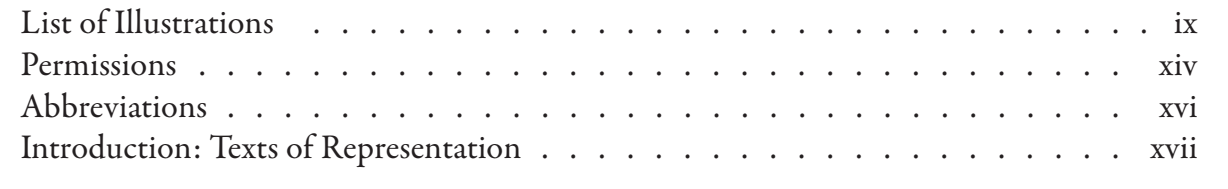

\section{Part I \\ CEREMONY AND CEREMONIALTEXTS}

1. The Mythology of Empire: Imperial Russian Coronation Albums

(With Edward Kasinec) . . . . . . . . . . . . . . . . . . . . . 3

2. Ceremony and Empire in the Evolution of Russian Monarchy . . . . . . . . 27

3. Signs of Empire: Exotic Peoples at Imperial Russian Coronations . . . . . . . 47

4. Publicizing the Imperial Image in 1913 ................. 71

\section{Part II \\ THE IMPERIAL MYTH IN ARTISTIC TEXTS}

5. Alexei Olenin, Fedor Solntsev, and the Development of a Russian National Esthetic

6. Cultural Metamorphoses of Imperial Myth under Catherine the Great and Nicholas I 122

7. Myth and Memory-Imperial Evocations of 1812. Alexander 1 and the Russian People

8. "Glas naroda": Visual Representations of Russian Monarchy in the Era of Emancipation

9. The "Russian Style" in Church Architecture as Imperial Symbol after 1881 . . 208

10. St. Petersburg the Imperial City and Peter Tchaikovsky . . . . . . . . . . . 238

\section{Part III \\ EXPLORATIONS AND EMPIRE}

11. Texts of Exploration and Russia’s European Identity _ . . . . . . . . . . . 253

12. Russian Noble Officers and the Ethos of Exploration . . . . . . . . . . . . 274 


\section{Part IV \\ INTELLECTUAL HISTORY}

13. Koshelev, Samarin, and Cherkasskii and the Fate of Liberal Slavophilism . . . 297 14. Iolstoy and the Perception of Poverty: Iolstoy's "What Then Must We Do?" 320

15. Property Rights, Populism, and Russian Political Culture . . . . . . . . . . 333

\section{Part V \\ AFTERTHOUGHTS AND REMEMBRANCES}

16. Thought, Culture, and Power: Reflections of a Russianist

17. The Moscow-Tartu School: Review of S. Iu. Nekliudov, ed.,

Moskovsko-tartuskaia semioticheskaia shkola. Istoriia, vospominaniia,

razmyshleniia (Moscow: Shkola "Iazyki russkoi kul'tury", 1998) . . . . . . . . 377

18. Brief Recollection of Vladimir Nabokov . . . . . . . . . . . . . . . . . 387

19. Marc Raeff: Memorial Thoughts ...................... 389

20. Leopold Haimson: Remembrance on the Occasion of his Memorial Service,

March 25,2011 . . . . . . . . . . . . . . . . . . . . . . 393

Index . . . . . . . . . . . . . . . . . . . . . . . 397 


\section{List of Illustrations}

\section{ARTICLE 1}

Figure 1-Empress Anna Ioannovna. Opisanie koronatsii e. v. imp. i samoderzhitsy vserossiiskoi Anny Ioannovny (Moscow, 1730). Slavic and Baltic Collection, New York Public Library.

Figure 2-Empress Elizaveta Petrovna. Obstoiatel'noe opisanie torzhestvennykh poriadkov blagopoluchnogo vshestviia $v$ tsarstvuiushchii grad Moskvu $i$ sviashchenneishago koronovaniia imp. Elizavety Petrovny (St. Petersburg, 1744). Slavic and Baltic Collection, New York Public Library.

Figure 3-The Crowning Ceremony of Empress Elizaveta Petrovna. Obstoiatel'noe opisanie... Slavic and Baltic Collection, New York Public Library.

Figure 4-Empress Catherine II at the "Tsar's Place." Engraving after a drawing by Louis de Veilly, Slavic and Baltic Collection, New York Public Library.

Figure 5-The Crowning of Emperor Nicholas I. Henry Graf, Vues des cérémonies les plus intéressantes du couronnement de leurs majesties imperials l'empereur Nicholas Ier et l'impératrice Alexandra à Moscou (Paris, 1928). Library of Congress.

Figure 6-Emperor Alexander II Crowns Empress Maria Aleksandrovna. Opisanie sviashchenneishago koronovaniia... imperatora Aleksandra Vtorago i imperatritsy Marii Aleksandrovny vsei Rossii (n.p., 1856). Slavic and Baltic Collection, New York Public Library.

Figure 7-The Crowning of Emperor Alexander III. Opisanie sviashchennago koronovaniia... imperatora Aleksandra Tret'ego i gosudaryni imperatritsy Marii Fedorovny vsei Rossii (St. Petersburg, 1883). Slavic and Baltic Collection, New York Public Library. 
Figure 8-Emperor Nicholas II Crowns Empress Aleksandra Fedorovna. V. S. Krivenko, ed., Koronatsionnyi sbornik: Koronovanie v Moskve, 14 maia 1896 (St. Petersburg, 1899). Slavic and Baltic Collection, New York Public Library.

\section{Article 3}

Figure 1-Muslim Delegates from the Caucasus. Vues des cérémonies les plus intéressantes du couronnement de leurs majesties imperials l'empereur Nicholas Ier et l'impératrice Alexandra à Moscou. Slavic and Baltic Collection, New York Public Library.

Figure 2-Triumphal Coronation Entry to Moscow of Alexander II and Maria Aleksandrovna. Russkii khudozhestvennyi listok, 1856.

Figure 3-Caucasian Deputies at the Coronation of Alexander II. Opisanie sviashchenneishago koronovaniia... imperatora Aleksandra Vtorago $i$ imperatritsy Marii Aleksandrovny vsei Rossii. Slavic and Baltic Collection, New York Public Library.

Figure 4-Kirgiz Huntsman-Coronation Album of Alexander II. Opisanie sviashchenneishago koronovaniia... imperatora Aleksandra Vtorago $i$ imperatritsy Marii Aleksandrovny vsei Rossii. Slavic and Baltic Collection, New York Public Library.

Figure 5-Deputies of "Asiatic peoples under the power of Russia." Koronatsionnyi sbornik: Koronovanie v Moskve, 14 maia 1896. Slavic and Baltic Collection, New York Public Library.

Figure 6-Deputies from Khiva-Coronation Album of Nicholas II. Koronatsionnyi sbornik: Koronovanie v Moskve, 14 maia 1896. Slavic and Baltic Collection, New York Public Library.

\section{ARTICLE 4}

Figure 1-Tercentenary Coin. Collection of author.

Figure 2-Nicholas II as Huntsman. A. Elchaninov, The Tsar and His People (London, Hodder and Stoughton, 1914).

Figure 3-Nicholas II in Soldiers' Uniform holding Tsarevich Alexei. A. Elchaninov, The Tsar and His People.

Figure 4-Tsarevich Alexei Nikolaevich among the Poteshnye (third from left). A. Elchaninov, The Tsar and His People.

Figure 5-Nicholas II Tastes Sailors' Ration on the Yacht, The Standard. A. Elchaninov, The Tsar and His People. 
ARTICLE 5

Figure 1-Fedor Solntsev-Meeting of Prince Sviatoslav Igorevich with Byzantine Emperor John I Tzimisces. Copyright (C) 2013, State Russian Museum, St. Petersburg.

Figure 2-Fedor Solntsev-Window Frame from the Terem Palace. Drevnosti rossiiskago gosudarstva (Moscow: Tipografiia Aleksandra Semena, 1849).

Figure 3-Fedor Solntsev-The "Monomakh Cap." Drevnosti rossiiskago gosudarstva.

Figure 4-Fedor Solntsev-Orb from the "Grand Regalia" of Tsar Michael. Drevnosti rossiiskago gosudarstva.

Figure 5-Fedor Solntsev-"Helmet of Alexander Nevskii." Drevnosti rossiiskago gosudarstva.

\section{ARTICLE 7}

Figure 1-Ivan Terebenev-The Russian Hercules. 1812 v karikature (Moscow: Central Museum of the Great Patriotic War, 1999).

Figure 2-Russkaia Azbuka-Letter "B"-The French Eat Crow. http://www. museum.ru/museum/1812/English/Library/Azbuka/index.html

Figure 3-Russkaia Azbuka-Letter "F"-The French like Mice are Caught in a Trap. http://www.museum.ru/museum/1812/English/Library/ Azbuka/index.html

Figure 4-Alexander I's triumphal entry into Paris. Otechestvennaia voina 1812 goda $v$ khudozhestvennykh $i$ istoricheskikh pamiatnikakh iz sobranii Ermitazha (Leningrad: Gos. Ermitazh, 1963).

Figure 5-Prayer Service on La Place de la Concorde, March 29, 1814. N. K. Shil'der, Imperator Aleksandr Pervyi, vol. 3 (St. Petersburg: A. S. Suvorin, 1899), 289.

Figure 6-Alexander Vitberg-Project for Cathedral of Christ the Redeemer, Moscow. Zhivopisnoe obozrenie, Vol. 4, 1838.

Figure 7-Dedication of Alexandrine Column, August 30, 1834. A. Ricard de Montferrand, Plans et détails du monument consacré à la mémoire de l'Empereur Alexandre (Paris: Thierry, 1838).

Figure 8- "Veterans of 1812" at the Borodino Centennial. L'Illustration.

Figure 9-Nicholas II following Procession of the Cross at the Borodino Centennial, August 25, 1912. L'Illustration. 


\section{Article 8}

Figure 1- Nicholas I Crossing the Danube. Stoletie Voennogo Ministerstva: Imperatorskaia glavnaia kvartira; istoriia gosudarevoi svity; tsarstvovanie Imperatora Nikolaia I (St. Petersburg: Voennoe Ministerstvo, 1908).

Figure 2- Alexander II followed by Grand Dukes Nicholas Aleksandrovich and Alexander Aleksandrovich. RNB, Print Division.

Figure 3- Alexander II, Maria Aleksandrovna, and Grand Duke Nicholas Aleksandrovich. GARF.

Figure 4- Vasilii Demut-Malinovskii-Ivan Susanin Monument, Kostroma. Vsemirnaia illiustratsiia, No. 2, 1883.

Figure 5- M. A. Zichy-Alexander II's Coronation Entry into Moscow. Alexander II Coronation Album. Opisanie sviashchenneishago koronovaniia... imperatora Aleksandra Vtorago i imperatritsy Marii Aleksandrovny vsei Rossii.

Figure 6- Vasilii Timm-“The Emancipation of the Peasants." Russkii khudozhestvennyi listok, 1862.

Figure 7- "The Voice of the Russian People." New York Public Library, Miriam and Ira Wallach Division of Arts, Prints, and Photographs.

Figure 8- “The Unforgettable Day of February 19, 1861." GARF.

Figure 9- "The Presentation of Bread and Salt to the Tsar." New York Public Library, Miriam and Ira Wallach Division of Arts, Prints, and Photographs.

Figure 10- "The Solemn Presentation (torzhestvennoe podnesenie) of Bread and Salt to the Tsar." GARF.

Figure 11- M.O. Mikeshin-Monument to Millennium of Russia, Novgorod. Niva, 1872.

Figure 12- "The Dedication of the Millennium Monument." New York Public Library, Miriam and Ira Wallach Division of Arts, Prints, and Photographs.

Figure 13- "The Festive Dedication of the Millennium Monument." New York Public Library, Miriam and Ira Wallach Division of Arts, Prints, and Photographs. 


\section{Article 9}

Figure 1-Constantine Thon-Cathedral of Christ the Redeemer, Moscow. Vsemirnaia Illiustratsiia, 1879.

Figure 2-Alfred Parland-The Cathedral of the Resurrection (Christ on the Blood), St. Petersburg. A. A. Parland, Khram Voskreseniia Khristova (St. Petersburg: R. Golike and S. Vil'borg, 1909).

Figure 3-M. Preobrazhenskii-Alexander Nevskii Cathedral, Reval. M. Preobrazhenskii, Revel'skii Pravoslavnyi Aleksandro-Nevskii Sobor (St. Petersburg: A. E. Vineke, 1902).

Figure 4-Church and Bell Tower, Borki. Niva, 1894.

Figure 5-Leontii Benois, Church for 2000 people, Gusev. Zodchii, 1893.

Figure 6-Parish Church, Estland. Al'bom vidov tserkvei Estliandskoi gubernii, sooruzhennykh pod vedeniem Revel'skogo nabliudatel'nogo komiteta po postroike tserkvei, prichtovykh i shkol'nykh zdanii (Reval: n. p., n.d.)

Figure 7-Alexander Gogen-Orthodox Church, Port Arthur. Stroitel', 1902

Figure 8-Stepan Krichinskii-Tercentenary Church, St. Petersburg. GARF, fond 601 .

\section{ARTICle 10}

Figure 1-A. Ricard de Montferrand-The Alexandrine Column on Palace Square, St. Petersburg. Montferrand, Plans et détails du monument consacré à la mémoire de l'Empereur Alexandre (Paris: Thierry, 1838).

Figure 2-Boris Orlovskii-Statue of Alexander I. Author's photograph.

Figure 3-Chariot with Figure of Winged Victory. Author's photograph. 


\section{Permissions}

1. (with Edward Kasinec) "The Mythology of Empire: Imperial Russian Coronation Albums.” Biblion 1, No. 1 (Fall 1992): 77-100.

2. "Ceremony and Empire in the Evolution of Russian Monarchy." In Kazan, Moscow, St. Petersburg: Multiple Faces of the Russian Empire; Kazan, Moskva, Peterburg: Rossiiskaia imperiia vzgliadom iz raznykh uglov, edited by Catherine Evtuhov, Boris Gasparov, Aleksandr Ospovat, and Mark Von Hagen (Moscow: O.G.I., 1997), 23-39.

3. "Signs of Empire: Exotic Peoples at Imperial Russian Coronations." English original of "Simvoly imperii: Ekzoticheskie narody $\mathrm{v}$ tseremonii koronatsii rossiiskikh imperatorov." In Novaia imperskaia istoriia post-sovetskogo prostranstva [Biblioteka zhurnala "Ab Imperio"], edited by I. Gerasimov et al. (Kazan: Tsentr issledovanii natsionalizma i imperii, 2004), 409-426.

4. "Publicizing the Imperial Image in 1913." In Self and Story in Russian History, edited by Laura Engelstein and Stephanie Sandler (Ithaca: Cornell University Press, 2000), 94-119. Copyright 2000, Cornell University Press. Used by permission of the publisher.

5. "Solntsev, Olenin, and the Development of a Russian National Esthetic." In Visualizing Russia: Fedor Solntsev and Crafting a National Past [Russian bistory and culture, v. 4], edited by Cynthia Hyla Whittaker (Leiden: Brill, 2010), 17-40. With thanks to Brill Publishers.

6. Paper delivered at conference "After the Storm. The Historical Memory upon 1812 in Russia and Europe" at the German Historical Institute in Moscow, May 28th-30th 2012.

7. "Myth and Memory-Imperial Evocations of 1812." Paper delivered at the conference "After the Storm. The Historical Memory upon 1812 in Russia and Europe" at the German Historical Institute in Moscow, May 28-30, 2012. 
8. “'Glas naroda': vizual'nye representatsii rossiiskoi monarkhii v epokhu emansipatsii." In Petr Andreevich Zaionchkovskii: Sbornik statei i vospominanii $k$ stoletiiu istorika, edited by L.G. Zakharova, S.V. Mironenko, and T. Emmons (Moscow: Rosspen, 2008), 429-450.

9. “'The Russian Style' in Church Architecture as Imperial Symbol after 1881." In Architectures of Russian Identity: 1500 to the Present, edited by James Cracraft and Dan Rowland (Ithaca: Cornell University Press, 2003), 101-116. Copyright 2003, Cornell University Press. Used by permission of the publisher.

10. "St. Petersburg the Imperial City and Peter Tchaikovsky." Keynote Address, Carnegie Hall Tchaikovsky Festival, October 15, 2012.

11. "Texts of Exploration and Russia's European Identity." Reprinted by permission from Russia Engages the World, 1453-1825, ed. Cynthia Hyla Whittaker (Cambridge, MA: Harvard University Press, 2003), 90-117. Copyright 2003 by the New York Public Library, Astor, Lenox, and Tilden Foundations.

12. "Russian Noble Officers and the Ethos of Exploration." Russian History/ Histoire russe Vol. 35, Nos. 1-2 (Spring-Summer 2008): 181-197.

13. "Koshelev, Samarin, and Cherkassky and the Fate of Liberal Slavophilism." Slavic Review 21, no. 2 (Summer 1962): 261-279. Article based on "Koshelev, Samarin, and Cherkasskii: Three Views of Russia's Political Future" (A.M. Thesis, University of Chicago, 1960).

14. "Tolstoy and the Perception of Poverty: Tolstoy's "What Then Must We Do?"” Rossija=Russia. Studi e Ricerche a Cura di Vittorio Strada Torino 4 (1980): 119-131.

15. "Property Rights, Populism, and Russian Political Culture." In Civil Rights in Imperial Russia, edited by Olga Crisp and Linda Edmondson (Oxford: Clarendon Press; New York: Oxford University Press, 1989), 13-32. By permission of Oxford University Press.

16. "Thought, Culture, and Power: Reflections of a Russianist." Modern Intellectual History vol. 5, No. 1 (April 2008): 121-140.

17. Review: Moskovsko-tartuskaia semioticheskaia shkola. Istoriia, vospominaniia, razmyshleniia, edited by Sergei Iur'evich Nekliudov (Moscow: Iazyki russkoi kul'tury, 1998); Kritika 1, no. 4 (Fall 2000): 821-829.

18. "Recollection of Vladimir Nabokov", English version of "Vospominaniia o Vladimire Nabokove," Zvezda, No. 4 (1999): 156-157.

19. "Mark Raeff." Ab Imperio 1 (2009): 331-336.

20. "Leopold Haimson" http://blogs.cuit.columbia.edu/haimson/?page_ $\mathrm{id}=11$ 


\section{Abbreviations}

GARF-Gosudarstvennyi Arkhiv Rossiiskoi Federatsii

RGIA-Rossiiskii Gosudarstvennyi Istoricheskii Arkhiv

Scenarios of Power-Richard Wortman, Volume 1, Scenarios of Power: From Peter the Great to the Death of Nicholas I (Princeton: Princeton University Press, 1995); Volume 2, Scenarios of Power: From Alexander II to the Abdication of Nicholas II (Princeton: Princeton University Press, 2000).

RNB - Manuscript Division, Rossiiskaia Natsional'naia Biblioteka. 


\section{Introduction \\ Texts of Representation}

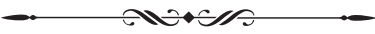

$\mathrm{T}$ he first volume of my articles, Russian Monarchy: Representation and Rule, emphasized the central role of symbolic representation in the political culture of Russian monarchy. In Russia, the presentation of the emperor introduced by Peter the Great as superordinate hero wielding absolute power for the benefit of the state persisted as a precondition of monarchical rule for two subsequent centuries. With Peter, the act of borrowing and displaying forms of western imagery became an attribute of power. ${ }^{1}$ The emulation of foreign models produced what Louis Marin called a "doubling effect" of representation-removing the monarch from his local confines and locating him in a realm of irresistible and efficacious enlightened rule. ${ }^{2}$ The representation of the monarch became paramount, transcending considerations of law, prudence, or rational argument, and shaping the practices and attitudes of governmental officials to accommodate a culture of power.

Official texts exalted Russian rulers in mythical narratives of heroic conquest and transformation. Articles in this volume focus on such texts as artifacts of a monarchical culture: explicit and unequivocal statements of political truths that set the tone and established the goals of each reign in narratives I have termed "scenarios." The laws of the realm carried symbolic weight, opening with preambles that set the provisions in the context of myth, justifying the decrees, statutes, and rules in terms of the designs of the current reign. Ceremonial texts-program books, later accounts in newspapers and

1 See Scenarios of Power, 1: 14-15. (See Abbreviations).

2 Louis Marin, Le portrait du roi (Paris: Les éditions de minuit, 1981), 9-13. 
illustrated journals-presented the events of the court in accounts that may or may not have corresponded to their actual performance and defined their meanings. Painting and architecture were called upon to evoke an imagined political landscape. For the historian, this complex of texts gives a sense of the verbal and visual universe of Russian monarchy and how its rulers envisioned the potentialities of the Russian state.

The articles in the first two parts of this volume, and to a certain extent in the third, are devoted to the interplay between the mythical narrative of the regime and the texts that gave it visual expression. Visual imagery and presentation over time has nearly vanished from historical accounts of Russian monarchy. My research soon made it clear that Russian monarchy inhabited a multifaceted visual culture. In the 1980s, when I was unable to visit the Soviet Union, I encountered numerous published visual sources in western repositories that gave vivid evidence of the public face of the monarchy. The Russian collection of the Helsinki Slavonic Library contained a wealth of illustrated journals and books that had not left an imprint on historical accounts. In 1984, after Edward Kasinec assumed the position of Director of the now lamented Slavonic and Baltic Division of the New York Public Library, he set about finding visual sources languishing ignored in the stacks. He brought the Division's collection of Russian imperial coronation albums to my attention, and we collaborated on the first scholarly analysis of their evolution and significance.

My encounter with these vivid and dramatic scenes opened new insights into the thinking and self-images of Russian monarchs and the figurative idioms they used to make their scenarios known. The texts disclosed what Steven Lukes has described as cognitive maps of the political order, showing the "particular models or political paradigms of society and how it functions" that distinguish political ritual. ${ }^{3}$ The illustrations revealed a supernal world of ceremony, demonstrating the emperor's mastery of the esthetic sphere, suggesting that he was not bound by the limits of the everyday or subject to mundane judgment. Elaborately choreographed parades and dignified processions displayed his powers of control and direction-a simulacrum of a state presumably directed by the ruler's will. Crowds lining avenues

$\overline{3}$ Steven Lukes, Essays in Social Theory (London: MacMillan, 1977), 68. 
and filling squares attested to his capacity to maintain "exemplary order" and to win popular support. Altogether these texts illustrated what Clifford Geertz described as "the power of grandeur to organize the world." 4

Art and architecture were mobilized to evoke the transcendence of the monarchy and to make its presence felt throughout Russia. Paintings produced the "doubling" effect that intensified the presence of the subject of monarch. "The device of representation transforms force into might (puissance), force into power (pouvoir)," Louis Marin wrote. "The king is only truly king, that is the monarch, in images." Imposing palaces and spacious parks likened his residences to the realm of the gods and classical heroes, whose figures were exalted in commanding statues; churches were constructed that brought a reinvented past into the landscape of contemporary Russia.

The meanings of the illustrations, however, were not self-evident: they had to be defined and explained. Ceremonial texts revealed the intent that the regime sought explicitly to convey-first to the court elite, and then to the broader layers of society subordinated to in the state and participating in its culture-what Christian Jouhaud, in his description of Louis XIII's triumphal entry into Paris in December 1628, characterized as an "official version of a celebration of power." 6 We observe what has been called "the publicization" of ceremonies: ceremonial texts made intent explicit, to be honored publically and shared by the governing elite. Comparison with earlier such texts also reveals continuities and changes in the ceremonies and their modes of performance. Imperial ceremonies were not static: texts defined their meanings to suit the goals and imagery of the current ruler, making

$4 \quad$ Clifford Geertz, Negara: The Theatre State in Nineteenth Century Bali (Princeton: Princeton University Press, 1980), 102.

5 Louis Marin, Le portrait du roi, 11-12.

6 Jouhaud writes of "the primacy of discourse, of the written word and of knowledge over the traditional ritual of the entry" (Christian Jouhaud, "Printing the Event: From La Rochelle to Paris," in The Culture of Print: Power and the Uses of Print in Early Modern Europe, ed. Roger Chartier [Princeton: Princeton University Press, 1989], 301-2). For other examples, see J. LeGoff, "A Coronation Program for the Age of St. Louis: The Ordo of 1250," in Coronations: Medieval and Early Modern Monarchic Ritual, ed. János M. Bak (Berkeley, CA: University of California Press, 1990), 46-57; J.-C. Bonne, "The Manuscript of the Ordo of 1250 and Its Illuminations," in Bak, Coronations, 58-71. 
known his scenario of power. The ceremonies then entered into a ceremonial tradition, clothing change as fidelity to the mythic history of the dynasty.

Commentaries in program books gave forceful statements of the significance of ceremonies. Coronation albums explained the meanings of the rites in the cathedral and the processions and celebrations before and after. Other texts, for example A. Ricard de Montferrand's explanation of the significance of the dedication of his Alexandrine column in 1834, or the historical introductions to Fedor Solntsev's illustrations in the Antiquities of the Russian State, followed the same practice. In the nineteenth century, journals, many of them illustrated, and newspapers assumed this role. In a culture ruled by a strict, even often arbitrary censorship, print expressions, not only in official organs, gave pointed indicators to the official meanings of events. On the other hand, the Khodynka field massacre in the midst of celebrations of Nicholas II's coronation provided the occasion for both statements of public sympathy from the tsar, and candid accounts of what seemed his insensitive attendance at a ball given by the French ambassador, all of this widely available in the Russian as well as the international press. In this setting, the tsar's scenario began to unfold against conflicting narratives that called into question the image of spiritual and moral supremacy intrinsic to the imperial myth.

My work does not deal with audience response, except to the extent that it was dictated by the scenario itself: in an authoritarian state the response is a necessary element of the performance. The central constitutive element of official representation from the reign of Peter the Great was a myth of conquest. The rule of the monarch found its principal grounds for sovereign power not in divine mandate, or dynastic inheritance, though these principles were also invoked, but performance and representation of his symbolic transcendence, which subsumed the onlookers in the drama. The conquest motif loomed large in tsarist ceremonies and imagery and the emotional force of the presentations was indeed potent, prompting an affect captured by the word torzhestvennost'. Torzhestvennost' may be translated as solemnity, or festivity, but it really means a combination of the two-the solemn and the festive, or perhaps solemn festivity, evoking the force of grandeur. Torzhestvo also means victory, and it carries the exaltation of triumph. The evocation of torzhestvennost' exalted the state and its elite by inspiring what has been 
described as a "rapture of submission" a powerful emotional bond between the distant ruler and his lowly subjects. ${ }^{7}$ Official accounts describe this vicarious sharing of the rapture of conquest and submission, the onlookers struck dumb, shedding tears of admiration and sympathy (See Articles 7 and 10).

My articles in this volume analyze specific cultural texts that figured significantly in the scenarios of Russian rulers. ${ }^{8}$ Article One, "The Mythology of Empire: Imperial Russian Coronation Albums," written with Edward Kasinec, brings Russian coronation albums into a historical narrative that I later elaborated at length in my Scenarios of Power. Article 2, "Ceremony and Empire in the Evolution of Russian Monarch," draws on similar texts to understand the presentations that elevated the tsar as conqueror and embodiment of empire. Article 3, "Signs of Empire: Exotic Peoples at Imperial Coronations," published originally in Russian, and slightly modified, focuses on the albums to trace the process of absorption of nonRussian nationalities into the rites and festivities of the coronation, which until the late nineteenth century were presented as events consecrating the Russian monarch in the presence of a westernized, principally Great Russian elite. Article 4, "Publicizing the Imperial Image," discusses the new forms and media representing Nicholas II's appeal for mass support, souvenirs, popular biography, postage stamps and commemorative coins and medals, and film-the devices of modern publicity utilized by European monarchies in order to assert his popularity in competition with the Duma-and to display his direct rapport with the people.

Articles in Part II address the role of art and architecture in the creation of a cultural ambience for each scenario that established the esthetic supremacy of the monarchy. The emperor drew on the talents of poets, artists, and architects to set the cultural tone for each reign-the cultural interlocutors of the monarchy. Among of the many artistic texts that Edward Kasinec rescued from the Slavonic Division's stacks was the six-volume compilation of watercolors by Fedor Solntsev, The Antiquities of the Russian State, published in 1849. Kasinec and Wendy Salmond then organized

\footnotetext{
7 The term, "rapture of submission," (vostorg poddanstva) has roots in religious literature, B. I. Berman, “Chitatel' zhitiia," in Khudozhestvennyi iazyk srednevekov' ia (Moscow, 1982), 166-7, 179.

8 In those articles previously published in English, I have made only editorial changes.
} 
an exhibition in the spring of 2007 and a symposium about Solntsev and his influence, which culminated in a conference volume edited by Cynthia Hyla Whittaker.9 I argue that The Antiquities represented a major component of Nicholas's scenario, which is described in Article 5, "Fedor Solntsev, Alexei Olenin, and the Development of a Russian National Esthetic." Article 6, part of which overlaps with Article 5, compares two examples of the role of poets, musicians, and artists in fashioning a foundation tale that would elevate the monarchy in the esthetic idiom of its time, first by Catherine the Great, the second by Nicholas I. Article 7, "Myth and Memory-Imperial Evocations of 1812," describes how official representation, invoking artistic, architectural, as well as ceremonial texts defined and redefined the memory of 1812 in terms of the changing settings of the myth.

Article 8, "Glas naroda: Visual Representations of Russian Monarchy in the Emancipation Era," shows examples of officially inspired lubki, popular prints that were issued after the reform to demonstrate the hoped for the popular devotion and gratitude to Alexander II presumed in his scenario of love. I was introduced to these prints by the work of Professor Larissa Zakharova of Moscow State University and with the help of Sergei Mironenko, the director of the State Archive of the Russian Federation (GARF). The strange but striking evocations of meetings, actual and imagined, between tsar and grateful peasants cast in the idiom of the lubki gave expression to the lofty expectations of social concord entertained in official circles during the reforms.

During the nineteenth century, the construction and dedication of revival churches provided emphatic statements of the rulers' understanding of the meaning of Russia's religious past in the light of their scenarios. Article 9, “'The Russian Style' in Church Architecture as Imperial Symbol after 1881," describes the regime's mobilization of architects to appropriate the principle of L'architecture parlante to validate the regime's claims to Russia's past during the reign of Alexander III. Musical compositions provided the melodies and cadences that elevated the monarchy through the eighteenth and nineteenth century. Article 10, "St. Petersburg the Imperial City and Peter Tchaikovsky,"

9 Cynthia Hyla Whittaker, ed., Visualizing Russia: Fedor Solntsev and Crafting a National Past [Russian history and culture, v. 4] (Leiden: Brill, 2010), 17-40. 
my keynote Address for the Carnegie Hall Tchaikovsky Festival, in October, 2012, shows how forcefully Tchaikovsky's music resonated with spirit of torzhestvennost' and the ethos of the monarchy he revered.

Part III relates my later encounter with Russian texts of exploration, also occurring in the precincts of the Slavonic division, in conjunction with the splendid exhibition, "Russia Engages the World, 1453-1825," organized by Kasinec and Cynthia Hyla Whittaker, at the New York Public Library in 2003. Article 11, written for the accompanying exhibition volume, "Texts of Exploration and Russia's European Identity" explores the role of Catherine the Great and Alexander I in promoting both continental and maritime expeditions to the Urals, Siberia, the Far East, Alaska, and the Pacific, on the basis of diaries of naval officers who captained sea voyages to the Pacific and around the world. ${ }^{10}$ Article 12, "Russian Noble Officers and the Ethos of Exploration," continues the story, focusing on explorations by Peter Semenov (Tian-Shanskii) and Michael Veniukov sponsored by the Imperial Geographical Society, which was established and thrived under the patronage of the Grand Duke Constantine Nikolaevich.

Part IV goes back to my early encounters with texts of the intelligentsia. My first published work, Article 13, "Koshelev, Samarin, and Cherkassky and the Fate of Liberal Slavophilism," taken from a section of my Master's Thesis, "Koshelev, Samarin, and Cherkasskii: Three Views of Russia’s Political Future" (University of Chicago, 1960), discusses the liberal ideas disclosed in writings of three Russian Slavophiles who were actively involved in the process of emancipation. It reveals my early focus on personal texts to reveal the dilemmas that underpinned their political outlooks. Their failure to find an institutional basis for political progress in Russia prefigured similar quandaries throughout the nineteenth century and indeed resurfacing today. Reflecting my early interest in psychology, Article 14, "Tolstoy and the Perception of Poverty: Tolstoy's "What Then Must We Do?"” examines the text as an expression of the personal crisis prompted by the author's frustrated efforts to cope with the painful scenes of poverty that confronted him in Moscow and his inability to find sympathy or support in Russian society.

10 Russia Engages the World, 1453-1825, ed. Cynthia Hyla Whittaker (Cambridge, MA: Harvard University Press, 2003). 
In my reading of documents of Russian intellectual history, I could not fail to note the absence of references to a right of property, especially as I lived in a society where property right represented a transcendent value. Article 15, "Property Rights, Populism, and Russian Political Culture," discusses the weakness of a principle of private property right in documents of Russian political culture and its implications for liberal programs of change in the early twentieth century.

Part V reveals my thinking as I began to approach the problems of state organization and monarchical rule with the sensibility and analytical tools of an intellectual historian. Article 16, "Thought, Culture, and Power: Reflections of a Russianist," traces the changes in my intellectual orientation that led me turn to the study of Russian legal institutions, and then of Russian monarchy. Article 17, a review of a collection edited by Sergei Nekliudov, Moskovsko-tartuskaia semioticheskaia shkola. Istoriia, vospominaniia, razmyshleniia, gives a sense of the contributions of the Moscow-Tartu school, which helped define my approach to monarchical political culture, its symbols, and representation.

The final pieces are miscellaneous remembrances of my past, Article 18, "Recollection of Vladimir Nabokov," recalls my brief encounter with the writer as an auditor of his lectures. The last two contributions are recollections delivered at memorial services for scholars who inspired me with their ideas, knowledge, and devotion to the scholarly calling, Marc Raeff, and my mentor, Leopold Haimson. 


\section{Part I}

\section{Ceremony and \\ Ceremonial Texts}

cकis? 



\section{The Mythology of Empire: Imperial Russian Coronation Albums (With Edward Kasinec) ${ }^{1}$}

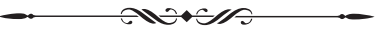

$\mathrm{T}$ he official descriptions (Opisaniia) of the coronations of Russian emperors and empresses, published in sumptuous albums, represent a valuable source for understanding the culture and mentality of Russian monarchy. While the events and personages are amply if dryly summarized in other accounts, the descriptions give a unique account from the point of view of the monarch and the court. They present the coronations as the rulers wished them to be seen, by contemporaries as well as by posterity. Richly illustrated with engravings and (or) lithographs, they provide visual as well as verbal statements of the evolving mythology of monarchy and empire. Although the religious ceremonies remained basically the same over this period, the performance of the rituals and the secular celebrations changed and assumed different meanings with each reign. These are revealed in the representations of the coronation displayed in the albums.

There were a total of eight official albums published to commemorate coronations in imperial Russia. The first was issued by Peter the Great to justify and celebrate the crowning of his wife, the Empress Catherine Alekseevna (Catherine I) in 1724. The first deluxe volumes that warrant the name album were published in 1730 and 1745 to commemorate the coronations of the Empresses Anna Ioannovna and Elizabeth Petrovna. Preparations for a similar volume after the coronation of Catherine II

1 We wish to thank Jeannette M. Harper of the Hillwood Library Museum, David Kraus of the European Division of the Library of Congress, and Robert H. Davis Jr., Librarian of the Slavic and Baltic Division of the New York Public Library, for their assistance in the preparation of this article. Mr. Benjamin Goldsmith deserves special thanks for his help in compiling a census of coronation albums. 
were halted, perhaps due to considerations of cost; the Opisanie appeared later in the Kamer-fur'erskii zhurnal for the year 1762 as a historical document, while the illustrations by de Veilly were printed in the 1790s and in separate editions during the nineteenth century. ${ }^{2}$ The practice of issuing published Opisaniia then fell into disuse until the publication in 1828 of an album to mark the coronation of Nicholas I in Paris. The coronations of Alexander II in 1856, of Alexander III in 1883, and Nicholas II in 1896 were all commemorated with albums, each of which gives characteristic expression to the new tsar's rule.

Scholars are fortunate to have at their disposal several excellent collections of Russian coronation albums in the United States. The Slavic and Baltic Division of the New York Public Library and the Hillwood Museum Library in Washington D. C. have complete or nearly complete collections. The Library of Congress and the Getty Center Library have several albums, while individual albums may be found at Columbia University, Princeton University, Cornell University, and the University of Wisconsin.

The Opisanie that Peter the Great issued in 1724 for the coronation of the Empress Catherine represented as much of an innovation as the crowning of an empress and the new European style regalia introduced at the ceremony. ${ }^{3}$ It was a secular publication, printed at the Senate presses in Petersburg, as well as the Synodal press in Moscow, that commemorated what previously had been a religious event. Previously, the account of each coronation had taken the form of a Chin venchania (Ceremony of Crowning), which included descriptions of the religious ceremonies as well as processions to and from the cathedrals. Peter's volume was the first to describe a coronation that included both religious and secular ceremonies: the arrival of the emperor in Moscow, the promulgation of the date of the crowning, the parades and celebrations after the religious services. It made the religious ritual an event of secular import, justifying and glorifying the power of the all-Russian emperor.

2 Kamer-fur'erskii tseremonial'nyi zhurnal, 1762 (St. Petersburg: Ministerstvo Imperatorskogo Dvora, 185?).

3 Opisanie koronatsii e.v. Ekateriny Alekseevny.... (St. Petersburg: Senate Press, 1724; Moscow: Synod Press, 1725). 
In addition, by publishing the account in a volume to be circulated among the public, Peter gave the event an aspect of permanence that the account in the newspaper Sankt-Peterburgskie vedomosti could not. With it, the coronation became a state act, as well as an ecclesiastical one that figured in the historical mythology of the new Petrine absolute monarchy.

Peter's Opisanie, indeed, shows a clear shift of focus from the religious ceremonies to the celebrations surrounding the event. The account of Catherine's procession to the Voznesenskii Convent in the Kremlin to visit the graves of her female "ancestors" takes up almost as much space as the description of the ceremonies in the Assumption Cathedral. It includes precise and lengthy descriptions of the uniforms of the Cavalier-Guards, and the livery of the courtiers, pages, and servants. The account of the feast in the Palace of Facets is just as long as the description of the religious ceremonies and includes mention of the names of the court officials participating in the banquet, a clear sign of their standing at court. The Opisanie continues with accounts of the feast for the people on the Kremlin square and the ceremonies of greetings to the empress in the palace. The events concluded with a "great festival" on Tsaritsyn Meadow, celebrated with "magnificence and riches" (s magnifitsentsieiu $i$ bogatstvom) and later, "deep into the night, reached its conclusion with the igniting of splendid and really artful fireworks" (77-78).

The text of the description was evidently composed with European readers in mind, though it appeared only in a Russian edition, since it gives elementary explanations of the setting and the character of the decorations of the cathedral. The Kremlin is the "fortress in the center of Moscow," in which the ancestors of the emperor had kept their residence. The cathedral was decorated "in the most costly array allowed by Greek law (for Greek law does not allow images [of] the saints to be covered by any tapestries or other ornaments.)" The descriptions of the regalia at the end emphasized their sumptuousness and costliness with clear reference to western standards. The orb, the Opisanie made clear, was patterned precisely on a Roman model. Statements about the lavishness and elegance of candelabra in the cathedral, and the banquet hall in the Palace of Facets, and the scope of the celebrations, showed that the coronation had become a means to show that Russia could rival the west in taste and splendor as well as military power. 
Catherine I's coronation album was published to justify Peter's crowning of his wife, the first time a Russian monarch had crowned his consort. In a similar vein, Anna Ioannovna's and Elizabeth Petrovna's coronations helped to legitimize their uncertain claims after Peter had decreed the elimination of heredity as a principle of succession. Their albums justified their rights to rule by demonstrating their dedication to the well-being of the nation acclaimed by general rejoicing. ${ }^{4}$ Illustrations now replaced words in showing the resplendence of the regalia, the dress, and the scene, making the album itself a work of art.

The model for the Russian volumes appears to have been the lavishly illustrated account published in 1723 for the coronation of the twelve-year old Louis XV in Paris. Referred to as "le premier monument d'un règne," the volume contained engravings of various stages of the ceremonies from la levée $d u$ roi through the royal feast. It also contained allegorical representations of the meaning of the rituals and depictions of the costumes of the king, the peers, and the guards in attendance. 5

The coronation albums of the empresses Anna and Elizabeth were also intended as initial monuments of their reigns. The planning and production of the volumes were placed under the direction of the empress's high advisors. V. N. Tatishchev, who had sided with Anna against the wealthy aristocrats in the Supreme Privy Council and was ober-tseremoniimeister at her coronation, assumed responsibility for the 1730 volume. Elizabeth's Procurator-General, N. Iu. Trubetskoi, directed the elaborate preparations for her Opisanie. The librarian of the Academy of Science, Johann Shumacher, supervised the publication of both volumes as well as the preparation of the engravings executed by the accomplished engravers in Russia.

The Opisanie published in 1730 to mark the coronation of Anna Ioannovna was the smallest of the coronation albums, measuring about 32 by 21 centimeters, with 46 pages of text. It was published in an edition

$\overline{4}$ See my article, "The Representation of Dynasty and the 'Fundamental Laws' in the Evolution of Russian Monarchy," Kritika: Explorations in Russian and Eurasian History vol. 13, No. 2 (Spring 2012): 265-300. Article 2 in Russian Monarchy: Representation and Rule (Boston: Academic Studies Press, 2013).

5 Le sacre de Louis XV, roi de France et de Navarre dans l'église de Reims (Paris: n.p., 1723); Rudolf H. Wackernagel, Der Krönung von 1696-1825 (Berlin: de Gruyter, 1966), 160. 
of five-hundred copies. ${ }^{6}$ The illustrations make clear that the celebration of the empress's coronation was as important as the rites themselves. ${ }^{7}$ The text emphasized her claims to the throne by birth. Vignettes on the back of the title page of the promulgation ceremony and the feast for the people indicate the rejoicing that justified such claims. Of the nineteen engravings, ten are of the items of regalia, the procession to the cathedral and one of the crowning itself. The others show the announcement of the coronation by heralds, an innovation of an innovation of Peter II's coronation in 1727, the reception of ambassadors and the fireworks, depicted in two elaborate foldout engravings.

The most striking feature of Anna's album is the prominence of the empress herself. This contrasts with the Louis XV volume, in which the monarch is barely discernible in the midst of his courtiers and guards and the vastness of the cathedral. Anna is shown in full length in the frontispiece engraving by Christian Albert Wortmann, after a drawing of the court painter, Louis Caravaque (Figure 1). She stands in the palace, an imposing presence in her décolleté coronation gown, holding the orb and scepter. A statue of a Cupid or satyr looks down upon her from the wall. The empress, although small in size, is conspicuous in the illustrations of the procession to the cathedral and the crowning, her features highlighted in the midst of the dozens of other small, identical figures surrounding her.

The engravings of the procession from the palace to the Assumption Cathedral and the moment of crowning both give a sense of enormous scale and space. In the engraving of the procession, a large fold-out illustration signed by Ottomar Elliger, the figures, the empress among them, are dwarfed by the expanse of the square and the height of the cathedral. The procession moves in groups across the square, cavalier-guards, deputies from various provinces, courtiers, and high officials. Numbers, discretely placed above the figures, refer to the designations of particular groups and individuals in the text. The square is partly empty. Some spectators stand in the square and others crowd the galleries of the Bell Tower of Ivan the Great.

The engraving of the crowning, the only rite of the coronation depicted, gives a highly exaggerated sense of the spaciousness of the cathedral. The

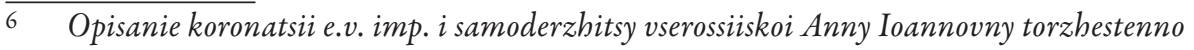
otpravlennoi v tsarstvuiushchem grade Moskve (St. Petersburg: Synod Press, 1730).

7 The illustrations are listed in V. A. Vereshchagin, Russkie illiustrirovannye izdaniia XVIII i XIX stoletii (St. Petersburg: V. Kirschbaum, 1898), 168-9. 


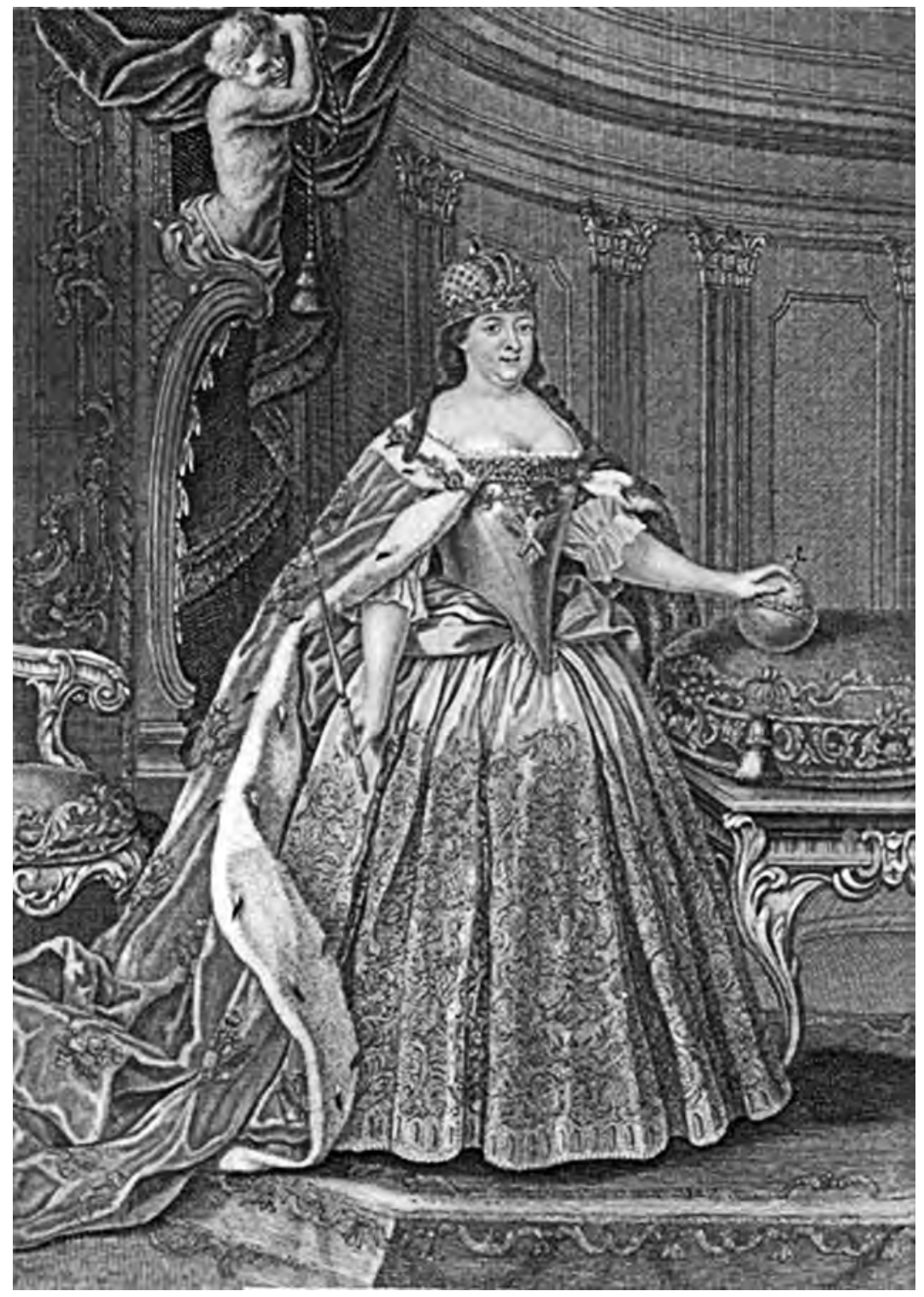

Figure 1-Empress Anna Ioannovna. Opisanie koronatsii e. v. imp. i samoderzhitsy vserossiiskoi Anny Ioannovny (Moscow, 1730). Slavic and Baltic Collection, New York Public Library. 
empress is shown on her throne after the crowning, being blessed by the archbishop. All look towards her; she is the cynosure of attention, the center of the expanse. The album also contains illustrations of the various items of regalia and coronation vessels, revealing in images, rather than words, the jeweled resplendence of the ceremony. The last illustration is a vignette of Anna receiving ambassadors.

Elizabeth's coronation album, celebrating the return of Petrine Russia in symbols and displays, is considerably larger, more richly illustrated, and more imposing than the volume published for Anna's coronation. The dimensions are approximately 47 by 28 centimeters and there are 168 pages of text and 52 illustrations. The German version, also available at the New York Public Library, was given exclusively as a gift. The album was initially to be published in an edition of 1,200 copies: 600 in Russian, 300 in French, and 300 in German. Shumacher, however, reasoned that since the plates were ready, the cost of individual volumes could be reduced by increasing the edition to over 2,000. He suggested that they be sent to the colleges, offices, chancelleries and monasteries, "in which these books will be kept for the eternal honor and glory of Her Imperial Majesty." The price would be enough to defray the costs and the delivery.

That the celebrations and particularly the processions were principal subjects of the volume is clear from the title, Complete Description of the Solemn Ceremonies of the Successful Entry into the Capital City of Moscow and the Coronation of Empress Elizabeth Petrouna. ${ }^{8}$ Twenty-seven of the fiftytwo illustrations are of the processions, triumphal columns, celebrations, and fireworks; twenty-five depict the coronation ceremonies, items of regalia, and plans of the cathedral. As in Anna's album, the crowning is the only rite in the cathedral to be depicted.

The album endeavored to encompass the total event of the coronation, the celebration of the return of the Petrine era, the age of gold, of Astraea. In his instruction to the Academy, Trubetskoi indicated that the volume was to begin with a vignette of a view of Moscow, since "by permission of Her Imperial Majesty this celebration was performed in the ruling city of Moscow," and to close with a vignette of the masquerade, "as the conclusion

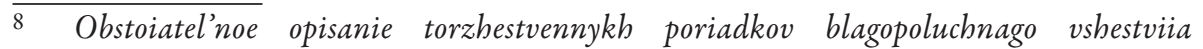
$v$ tsarstvuiushchii grad Moskvu i sviashchenneishago koronovaniia imp. Elizavety Petrovny (St. Petersburg: Imp. Akademiia Nauk, 1744). 
of the coronation, since this celebration thus came to a conclusion." Accordingly, the text of the album begins with a miniature scene of the Kremlin, the Moscow river, and surrounding region and ends on page 128 with a witty vignette of the masquerade dance floor, with costumed figures deftly turning legs and torsos.

"This coronation description is the chief masterpiece of Russian engraving under Elizabeth," the jurist and art historian Dmitrii Aleksandrovich Rovinskii wrote, and the engravings are indeed numerous and extraordinary.9 The album contains the works of several artists and engravers. As in Anna's album, a frontispiece portrait renders an image of the Empress, engraved by Johannes Stenglin after a portrait by Caravaque. She appears in the same pose as Anna in the 1730 volume-décolleté, an angel in the form of a Cupid adorning the wall (Figure 2). For the most part the volume was the masterpiece of Ivan Sokolov, who executed twenty-five of the volume's plates.

Sokolov's four engravings of the processions to and from the Kremlin are tours de force of artistic representation and engraving. The most striking is the immense fold-out illustration of the triumphal entry into Moscow. The first rendering of the entry procession in a coronation album, it alludes to the triumphs of Peter's reign, particularly the Poltava triumph of 1709. The entry, Trubetskoi wrote in his instructions, was to be depicted on a single large sheet, after an engraving of Peter's time "according to the example of the triumphal entry to Moscow after the battle of Poltava of the emperor Peter the Great, whose blessed memory is worthy of eternal glory and other processions similar to this...."10

Several hundred tiny figures, all rendered in profile, weave in a snaking line across the space of the fold out from the country palace depicted on the top, through the triumphal arches, towards the Kremlin. There are covered sledges, hundreds of horsemen, carriages, marching guardsmen, noblemen, courtiers, and servants in livery. Perspective was abandoned in showing the soldiers, for it would obscure the "free look of the ceremony." Only the empress is shown full face, through the window of her carriage, and only her escort is presented

9 D. A. Rovinskii, Podrobnyi slovar' russkikh graverov XVI-XIX vv. (St. Petersburg: Imp. Ak. Nauk, 1894), 2: 949-52. Rovinskii provides a complete list of fifty-two illustrations.

10 Materialy dlia istorii Imperatorskoi Akademii Nauk (St. Petersburg: Imp. Ak. Nauk, 1895), 7: 37 . 


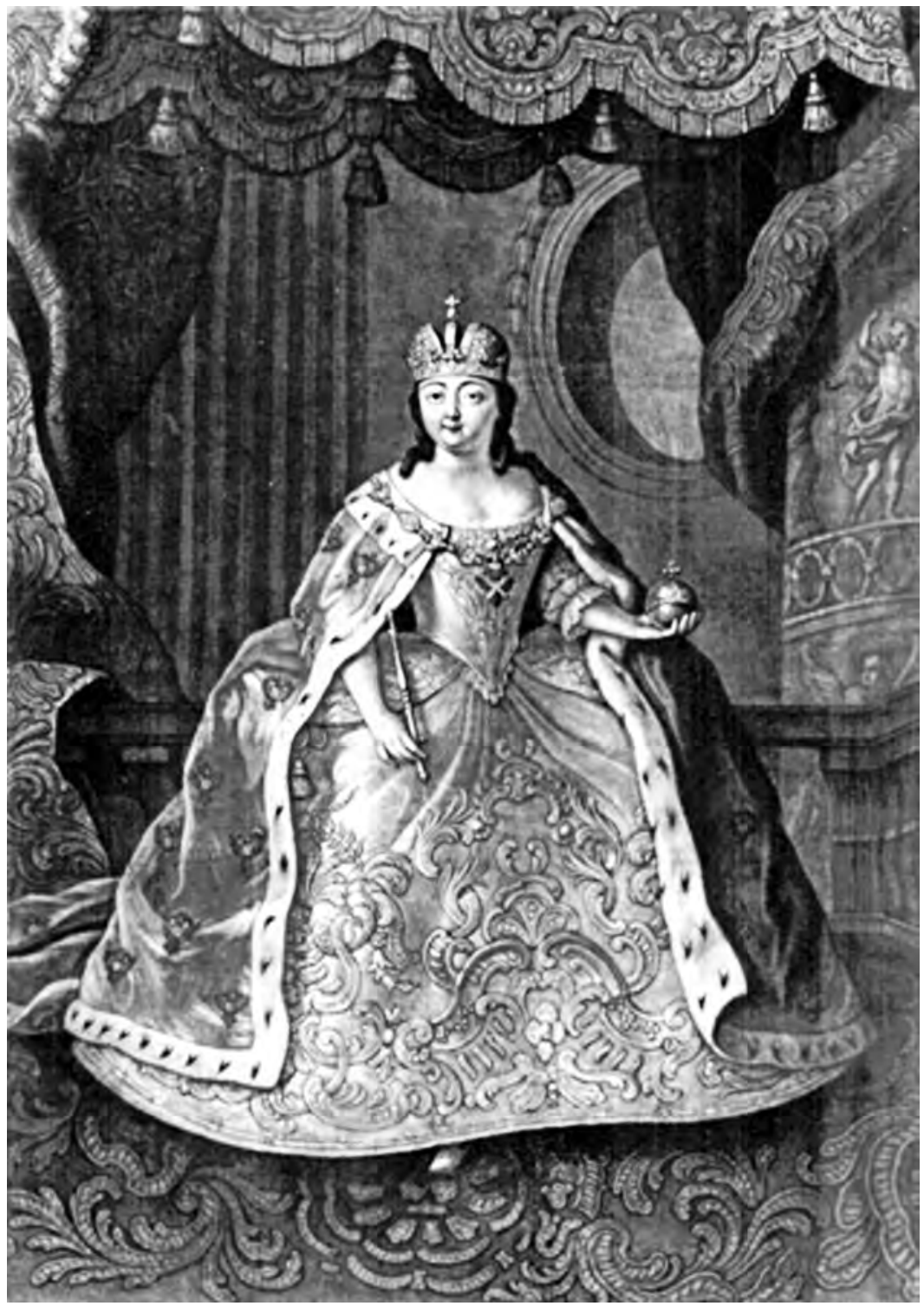

Figure 2-Empress Elizaveta Petrovna. Obstoiatel'noe opisanie torzhestvennykh poriakdov blagopoluchnogo vshestviia $v$ tsarstvuiushchii grad Moskvu $i$ sviashchenneishago koronovaniia imp. Elizavety Petrovny (St. Petersburg, 1744). Slavic and Baltic Collection, New York Public Library. 
in perspective, according to specific instructions from the editorial committee supervising the publication (5: 1026). The technique set the empress and her entourage apart from the rest of the procession, showing the hierarchy of the court. The next plate shows the empress and her escort in perspective in greatly magnified detail. Again, the text designates the various groups and includes the notable figures in the court by numbers placed on the plate.

There is no background except for the representations of the empress's suburban palaces at the top of the page, the beginning of the procession. The court and the empress constitute the significant presence here; Moscow is invisible, banished from the scene.

The absence of the physical setting is even more remarkable in the illustration of the procession to the Assumption Cathedral. Even the Kremlin is omitted here, as the principal figures and groups, clearly marked, make their way from one significant place-the Kremlin palace, to the other-the Assumption Cathedral. The procession to the Palace of Facets follows the same form. The illustrations are meant to present the important individuals figuring in the new reign. They represent authority in the form of a procession, the elite accompanying their sovereign.

The centrality of the entry procession in Elizabeth's coronation is indicated by the elaborate engravings of the triumphal arches by Sokolov, the only such illustrations to appear in a coronation volume. The album contains full renderings of the four triumphal arches erected along the route of the entry procession in addition to details of the emblems, devices, and allegories decorating the arches. The significance of the various symbols is explained precisely in the text. The volume thus provides an elaborate statement of the pretensions and symbolic content of the monarchy in mid-eighteenth century Russia and the role the coronation was to play.

For example, the principal illustration on the rear facade on the column on Miasnitskii Street depicts Providence as a beautiful woman pointing to the throne, with the inscription "native born." Illustrations on the sides indicate the extent of the realm and the international glory of the empress. On the right, allegorical female figures representing the parts of the empire, Moscow, Kazan, Astrakhan, and Siberia hold a map of the empire, with the inscription, "This is your property." On the left, the world, in the person of four allegorical figures of the continents sitting on a globe, rejoices. The explanation states that Europe was most happy of the four, indicating where the ruling empress looked for approval. A picture of Apollo and the muses 
on Parnassus had the legend, "Now we will not remain silent." Figures of Mars and Neptune, as well as the Saints Boris and Gleb showing the empress as an exemplification of both pagan and Christian ideals. The album, as the title suggests, commemorated both secular rejoicing, and "the most sacred coronation" of the empress.

The depictions of the ceremonies of promulgation and crowning make rigorous use of the technique of perspective according to instructions from editors, who found the initial drawings lacking. Linear perspective was the technique favored by the absolute monarchs of Western Europe to show the hierarchical gradations of their courts. The lines of perspective converged at the eyes of the monarch; those close to him viewed the world more or less as he did, with important objects appearing large, lesser ones, smaller in the distance. ${ }^{11}$ The initial version of the announcement ceremony failed to meet these demands. The editorial committee objected that the figures had no proportions and were so scattered across the square that the "promulgation has nothing to do with them." There should be a great multitude of people who should be disposed in a proper manner. The final version presents a square receding according to the laws of perspective, with the cavalry men arranged neatly into four rectangles while others circle behind them. The heralds are in the front of the picture, while groups of spectators, vaguely suggested in the fore and rear ground, look on.

The members of the committee, seconded by Trubetskoi, also objected to lack of perspective in the preliminary sketches for the engraving of the crowning ceremony. They wanted all attention to focus on the event, in the manner of a theatrical presentation, and requested that the court stage designer, Girolamo Bon, revise the drawings. The engraving uses perspective to good effect, giving a sense, rather exaggerated, of considerable depth and soaring height (Figure 3). The walls of the cathedral appear covered with paintings and the icons on the iconostasis are suggested. In the midst of a vast space, Elizabeth is the cynosure, all eyes focused upon her. As in Anna's album, this is the only moment of the coronation rites to appear in the illustrations.

The incomplete illustrations for Catherine II's coronation had a different character. They ignore the mass of the cathedral and draw the eye of the

11 Roy Strong, Splendor at Court: Renaissance Spectacle and the Theater of Power (Boston: Houghton-Mifflin, 1973), 73-4. 


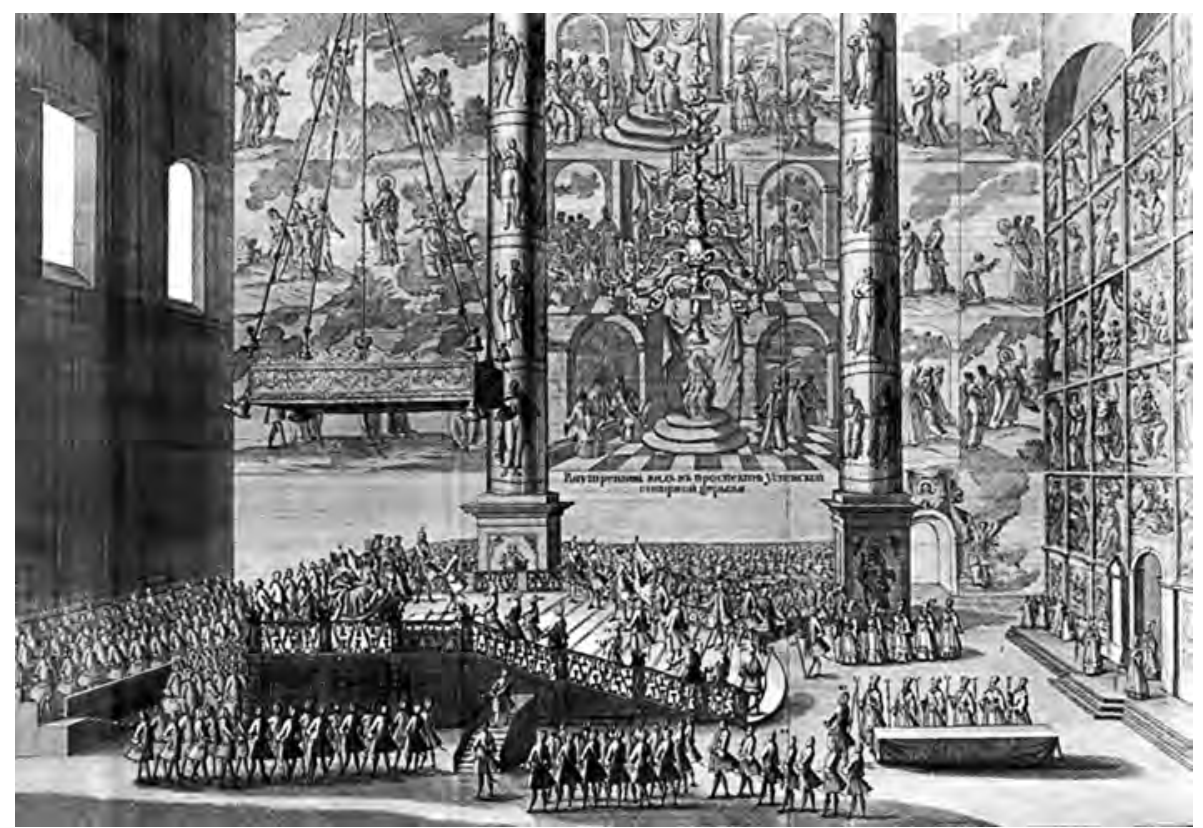

Figure 3-The Crowning Ceremony of Empress Elizaveta Petrovna. Obstoiatel'noe opisanie... Slavic and Baltic Collection, New York Public Library.

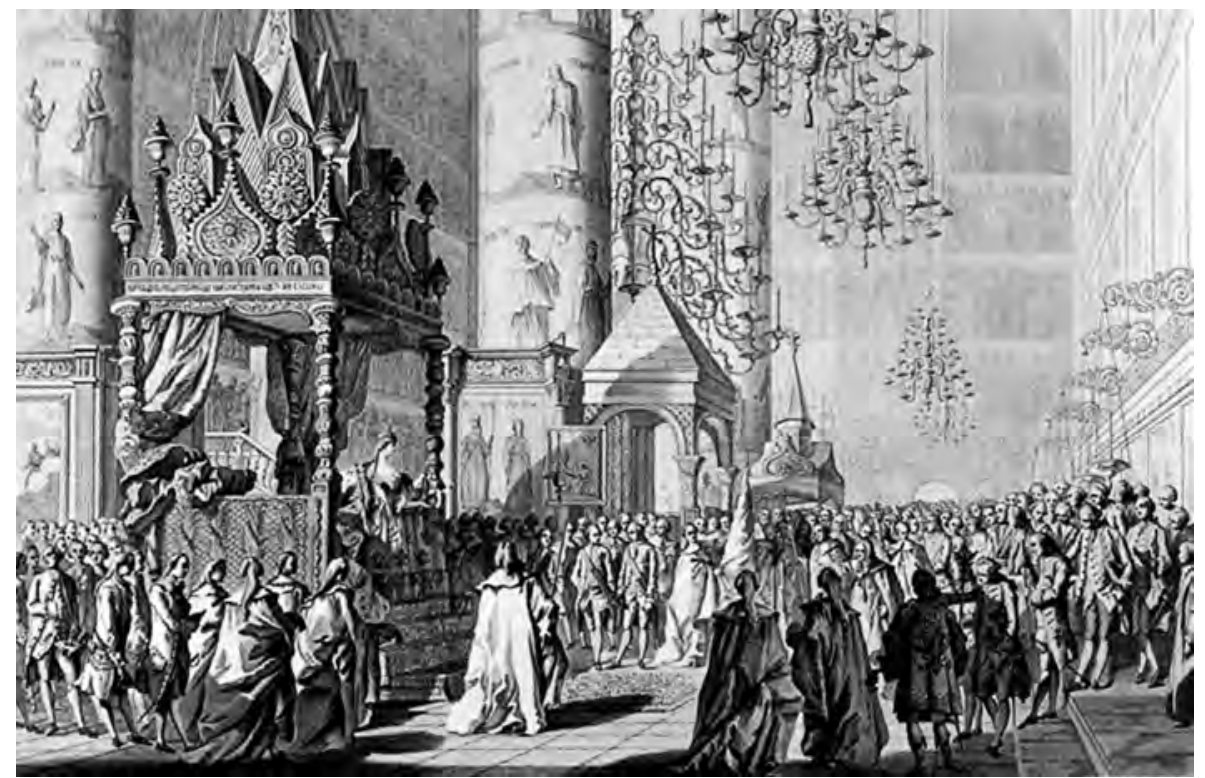

Figure 4-Empress Catherine II at the "Tsar's Place." Engraving after a drawing by Louis de Veilly, Slavic and Baltic Collection, New York Public Library. 
viewer to the few figures engaged in the scene, expressing the personal drama of the ritual rather than the spectacle of the totality. ${ }^{12}$ In engravings by several artists after Jean Louis de Veilly, the use of perspective and shading created a more realistic, less otherworldly sense of the proceedings. The drawings emphasize the central importance of the person of the empress and those close to her. The procession to the Assumption Cathedral includes only the Red Staircase (Krasnoe Kryl'tso) and the figures in the immediate vicinity. After the crowning, the empress is shown standing proudly in full regalia at the "tsar's place"; her courtiers nod recognition with studied nonchalance (Figure 4). For the first time, the reading of the credo, the anointment, and even the taking of communion within the sanctuary are illustrated. The empress is shown in massive coronation gown and mantle taking communion at the altar as the courtiers peer in. The illustration was meant to make clear to all that the formerly Lutheran princess was being given the clerical status enjoyed by her predecessors. A series of memoranda appended to the coronation description confirmed that the empresses Anna and Elizabeth had followed this rite, with the implication that Catherine should as well.

Albums were not issued for the coronations of Paul I in 1797 and Alexander I in 1801, perhaps reflecting the elimination of doubts about succession after Paul's restoration of the principle of primogeniture of succession and the more austere attitude towards court festivities that prevailed during Alexander's reign. Nineteenth-century albums present different narratives exalting the rulers of Russia. They argue and demonstrate the vitality and popularity of the principle of monarchy in Russia rather than the virtues of the particular monarch. They celebrate the religious and popular grounding of the dynasty rather than the benefits accompanying the new reign.

12 On the illustrations, which are available in the Slavic and Baltic Divisions of the New York Public Library, see Ia. V. Bruk, U istokov russkogo zhanra, XVIII vek (Moscow: Iskusstvo, 1990), 77, 87; Rovinskii, Podrobnyi slovar' russkikh graverov XVI-XIX vv., 2: 535-36; Vereshchagin, Russkie illiustrirovannye izdaniia XVIII $i$ XIX stoletii, 614; N. S. Obol'ianinov, Katalog russkikh illiustrirovannykh izdanii, 1725-1860 (Moscow: A. Mamontov, 1914-1915), 2: 369. 
The publication of coronation albums resumed with Nicholas I's coronation in 1826. The album, published in Paris in 1828 at the house of Didot, sought to portray the stability and popularity of the monarchy to a European audience to quiet the uncertainties over Nicholas's succession and the Decembrist revolt. The volume is extremely modest compared both to Elizabeth's album and the one issued for Alexander II's coronation in 1856. It is 66 centimeters in length and 50 centimeters in width, with only fourteen pages of text and fourteen plates. Russian readers could find more complete descriptions in the newspapers and in the sentimentalist account published by P. P. Svin' in in the journal Otechestvennye zapiski.

The author of the brief French language text, one Henry Graf (whom we have been unable to identify), described the coronation from the point of view of a western admirer of Russian monarchy. Henry Graf explained the ceremony's importance and the monuments of the Kremlin to those who knew little of Russia. He presented the coronation as a demonstration of the religious and popular grounding of the monarchy; it appears as a Russian counterpart to the elaborate coronation of Charles X in Rheims in 1825. The coronation of Nicholas I was to redeem the Russian monarchy from the revolutionary efforts of the Decembrists, much as the coronation of Charles X sought to replenish the religious sources of French monarchy after the defeat of the revolution.

The album also marks the return to the emphasis on luxury and magnificence as a sign of autocratic power, after the more austere manner of Alexander. Graf does not spare his rhetoric in describing the magnificence of the setting, the regalia, and the celebrations and fireworks that followed. The French title, Vues des cérémonies, makes clear that the plates were of the greatest importance; the picturesque and exotic aspect of the events were to appeal to the European reader and to place the Russian emperor, who had crushed an uprising, in a touching picturesque setting. The scenes were "drawn on the spot by the best artists of the country"- the lithographer Louis Courtin and the artist Victor Adam. The illustrations are of a cruder character than that encountered in other volumes: the figures, even of the tsar and the empress, are somewhat awkward and artless, as if the artists were imitating a popular style.

Only one plate is included of a ceremony in the cathedral: according to the caption, the crowning of the emperor (Figure 5). However, we see not the crowning of Nicholas, but the tsarevich Constantine Pavlovich 


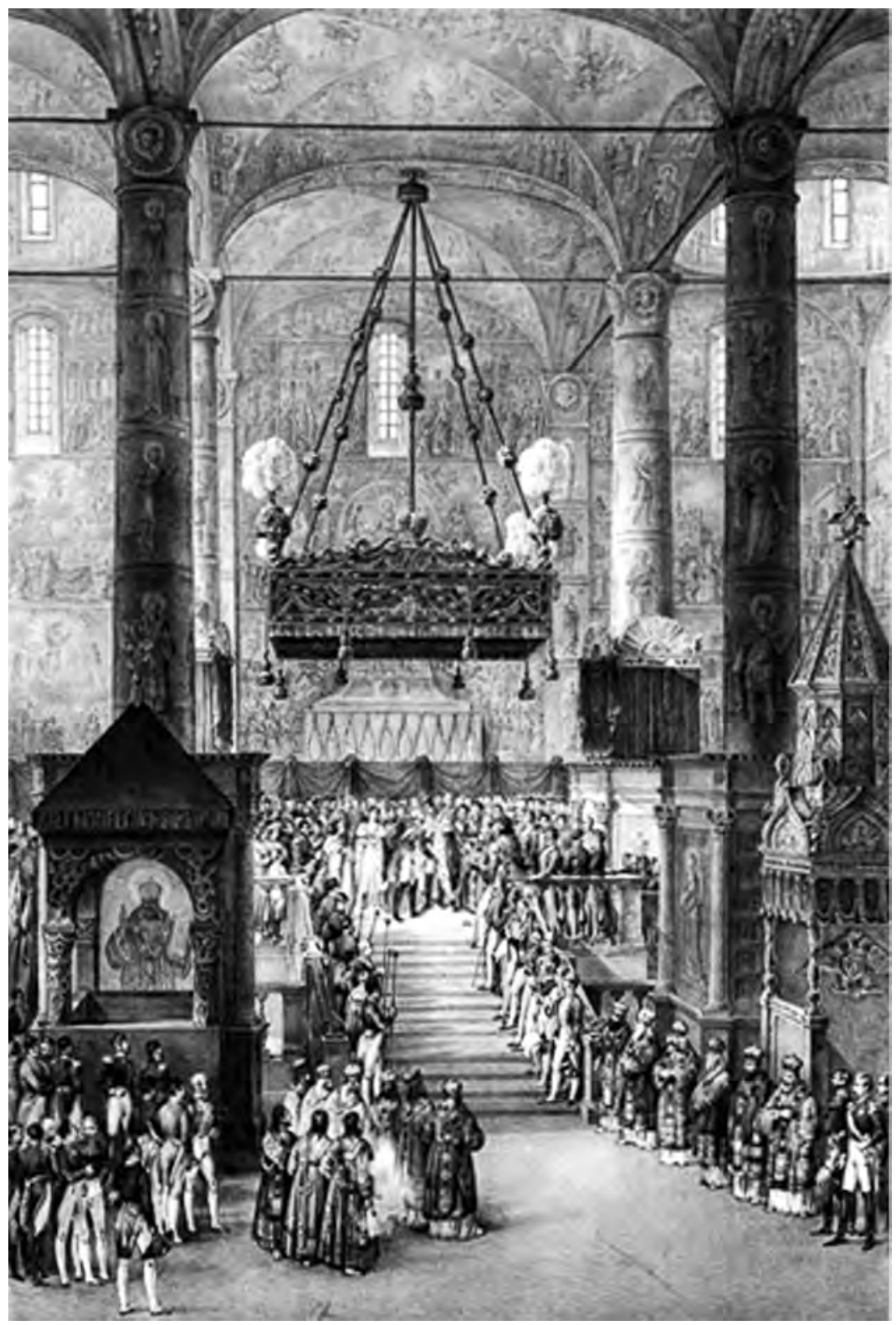

Figure 5-The Crowning of Emperor Nicholas I. Henry Graf, Vues des cérémonies les plus intéressantes du couronnement de leurs majesties imperials l'empereur Nicholas Ier et l'impératrice Alexandra à Moscou (Paris, 1928). Library of Congress. 
embracing him after the crowning, an act of affection and homage that was meant to dispel lingering uncertainties about Constantine's acceptance of his younger brother's accession. The final illustration, of the emperor's and empress's departure, emphasizes their simplicity and closeness to the people. Nicholas and Alexandra sit in a calèche with only one servant and the coachman in attendance. They are in immediate contact with the people, without the protection of Guards' Regiments, Graf stresses in the text. The picture tried to present a visual answer to the notion of the Russian emperor as a despot and to show him as a ruler beloved by his subjects and secure in their midst.

The description of Alexander II's coronation is the most lavish and ostentatious of all the albums. "The volume is of such immense size," Sacherevell Sitwell wrote, "that the term 'elephant folio' has no meaning, and, indeed, this may be the largest book that ever issued from the printing press." No cost was spared in the production of the book, published by the Academy of Arts and under the direction of its Vice-President, Prince G. G. Gagarin. The title was printed in large old Church-Slavonic script in gold leaf, red, and black. Alexander personally rejected the editor's proposal to use old-Slavonic script in the text. Special large type was cast for the volume. The one-hundredtwenty-five pages of the volume were printed on Chinese paper. The album was prepared not merely for the rich but for the diplomatic elite and the aristocracy of Europe. Four hundred volumes were published, two hundred in Russian, and two hundred in French, to be given to high figures in the court and foreign guests attending the ceremony. The album, which cost 123,000 rubles to produce, was clearly not an instrument of mass publicity, but an expression of the unity of European rulers and aristocracy when Russia was isolated on the international scene. ${ }^{13}$

13 Opisanie sviashchenneishago koronovaniia Ikh Imperatorskikh Velichestv Gosudaria Imperatora Aleksandra Vtorago i Imperatritsy Marii Aleksandrovny Vseia Rossii (St. Petersburg: Imp. Akademiia Khudozhestv, 1856); "Koronatsionnyi sbornik i khudozhestvennyi al'bom," RGIA, 472-65-113, 1. The 1856 publication date is fictional; the work was not published until 1861. "O rasporiazheniiakh dlia sostavleniia opisaniia koronovaniia," RGIA, 472-64-69, 203-04; "O rasporiazheniiakh dlia sostavleniia opisaniia koronovaniia," RGIA, 472-64-67, 60, 139, 428; "O rasporiazheniiakh dlia sostavleniia opisaniia koronovaniia," RGIA 474-6469, 78; Sacherevell Sitwell, Valse des fleurs: A Day in St. Petersburg and a Ball at the Winter Palace in 1868 (London: Faber and Faber, 1941), 64. 
The album contains fifty-two illustrations, fifteen in color lithography, printed at the house of Lemercier in Paris under Gagarin's careful supervision. ${ }^{14}$ The remainder were printed in black and white lithography and engraving. Black and white illustrations in the text reproduce the smaller scenes, following the emperor through the stages of the ceremony. A full black and white engraving, after a sketch by M. A. Zichy, presents a montage of the entry procession-scenes of Alexander's leaving the Petrovskii Palace, the empress in her carriage passing by the grandstand, the Kremlin Towers, Red Square, and the statue to Minin and Pozharskii. The large color illustrations present scenes of the tsar and tsaritsa appearing before inspired spectators. For the first time, considerable space is devoted to showing the empress as wife of the ruler. Alexander II and Maria Aleksandrovna are presented on the second plate, in a painting by Zichy, full-length in separate oval medallions with a lattice design between them. Zichy depicts Alexander's crowning of the empress, but there is no depiction of his own crowning. Zichy succeeds in placing the imperial couple and the spectators in the same frame, capturing the emotions that presumably united Alexander with his elite (Figure 6). We can understand what Sitwell meant when he wrote of these, "Not works of art, but fascinating in their improbability." $15 \mathrm{~V}$. F. Timm's painting of the anointment shows the empress bowing devoutly a few feet behind Alexander as he receives the chrism on his brow.

The large enthralled figures with rapt faces who occupy the foreground several lithographs demonstrate the popular love that was supposed to surround the tsar. Zichy's painting of the entry into Moscow is framed by the grandstand where large figures show animation and excitement at the appearance of the tsar (See Article 8, Figure 5). Facing towards the tsar is a peasant woman in folk dress and a tiara hat. Before the spectators, we see large figures of the last row of the Cavalier-Guards, proud mustachioed men dressed in elegant white uniforms and gold helmets. Alexander appears in middle-ground riding towards us in his green general uniform and cape, the center of the picture, the many blue figures of his suite suggested behind him. F. Blanchard's rendering of the fireworks shows peasants and tribesmen at the side of the tsar's pavilion, marveling at a display of red and white lights

14 Vereshchagin, Russkie illiustrirovannye izdaniia XVIII i XIX stoletii, 625; Obol'ianinov, Katalog ruskikh illiustrirovannykh izdanii, 1725-1860, 2: 384-85.

15 Sitwell, Valse des fleurs, 65. 


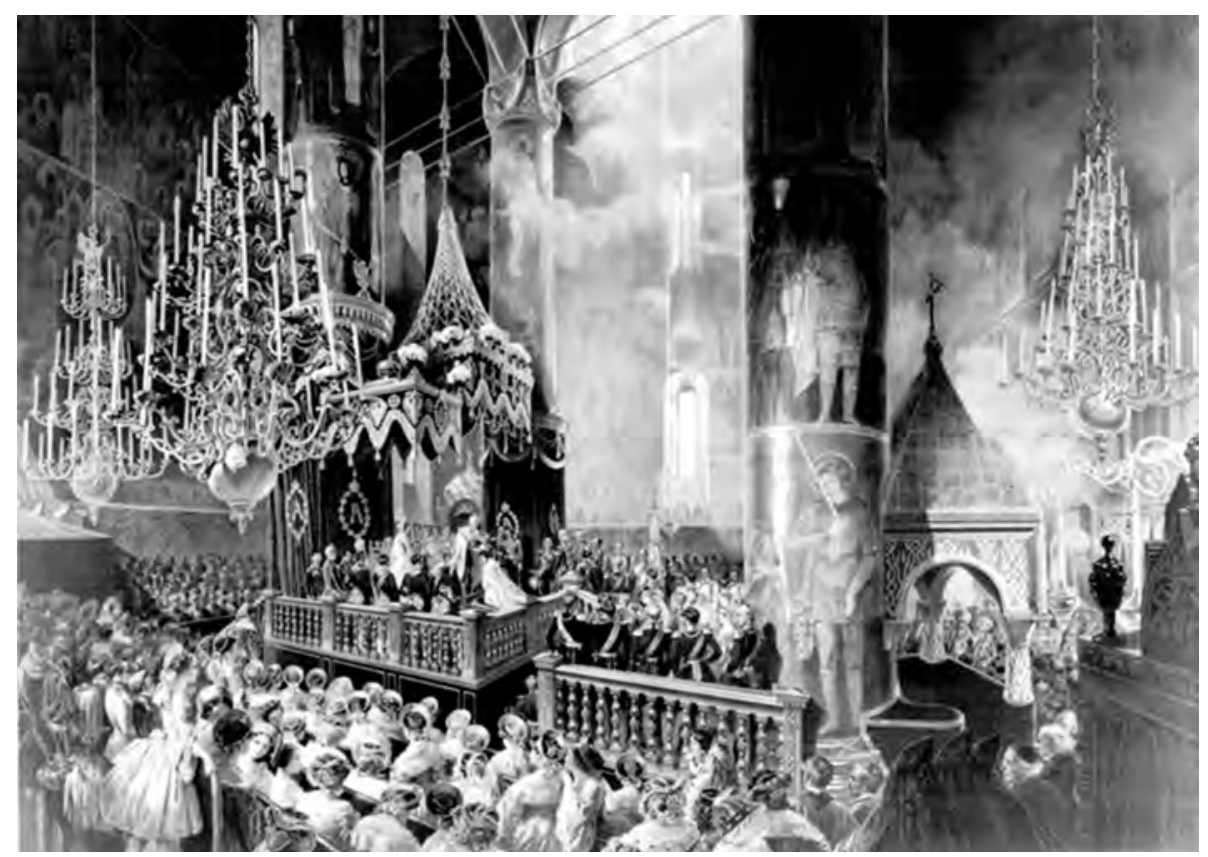

Figure 6-Emperor Alexander II Crowns Empress Maria Aleksandrovna. Opisanie sviashchenneishago koronovaniia... imperatora Aleksandra Vtorago i imperatritsy Marii Aleksandrovny vsei Rossii (n.p., 1856). Slavic and Baltic Collection, New York Public Library.

in the sky. A bearded man raises his hand in wonder, a horse rears others look with interest or wonder. Still others mill about and engage in conversation.

Alexander III's coronation album contains more explicit mass and national appeals on behalf of the monarchy. This is the first album published not by the Academy of Sciences, but by the Agency for the Preparation of State Papers, Ekspeditsia Zagotovleniia Gosudarstvennykh Bumag, which disposed of more advanced equipment. The format is simple and relatively modest, signaling the more frugal manner of the new tsar. It is smaller, $67 \times 54$ centimeters, and modestly bound with twenty-six colored plates. The text is brief, sixty-five pages, of which only eleven describe the ceremonies of the coronation themselves. It cost 92,376 rubles to produce the 300 copies in Russian and 200 in French-considerably less than the 400 copies published for Alexander II's coronation.

The title is again printed in old orthography, but in this volume the national elements are more prominent. The brief text emphasizes 
the national significance of the event. "It is this sacred, solemn, and allnational act that gives expression to the historical union of the Tsar with his State, his precept with his church, that is with the soul and conscience of his people, and finally, the union of the Tsar and the people with the Tsar of Tsars, in whose hands rests the fate of tsars and peoples." 16 The Slavic revival script now serves less as an exotic flourish of decoration than as a sign of national character. For the first time in a coronation album, there are artistic references to the pre-Petrine coronations-small historical sketches of Muscovite scenes, of the bringing of regalia and the tsar at his coronation feast. The program for the gala performance of Life for the Tsar, showing the Kremlin towers, was also in old Russian style.

The color illustrations reproduced by chromolithography, are in the realistic manner favored by the Itinerants (peredvizhniki), and several of the painters belonged to the school: K. A. Savitskii, N. N. Karazin, I. N. Kramskoi, V. D. Polenov, V. V. Vereshchagin and K. E. Makovskii. The illustrations focus on the massive figure of Alexander himself; his person becomes the overpowering presence in the album. The full page portrait by A. P. Sokolov of Alexander on his coronation throne in mantle, holding the orb and scepter, was the first of its kind in a coronation album. Sokolov's painting allows no distance between the viewer and the looming impassive figure of the emperor. Kramskoi's rendering of the moment of crowning is also close up, focused completely on Alexander, who occupies almost two thirds of the picture (Figure 7). The emperor dwarfs the clergymen at his side, his beard and balding head dominating the picture. The cathedral is a mere blur in the background. Alexander has an intimidating, crushing aspect but his face is soft and pallid. Kramskoi's painting of the tsar's taking of communion in the altar has a similar ambiguity. Alexander is the central overpowering presence upon whom all attention is focused, but he takes the wafer with caution and humility. His figure is both mighty and feeble.

Other paintings also center on the emperor and empress to the exclusion of the surroundings. Makovskii's painting of the people's feast on Khodynskoe pole shows the reviewing stand, and little of the people. The emperor stands proud in his long boots and Russian cap, while the empress

16 Opisanie sviashchennogo koronovaniia Ikh Imperatorskikh Velichestv Gosiudaria Imperatora Aleksandra Tret'ego i Gosudaryni Imperatritsy Marii Fedorovny Vseia Rossii (St. Petersburg: Eksped. Gos. Bumag, 1883), 2. 


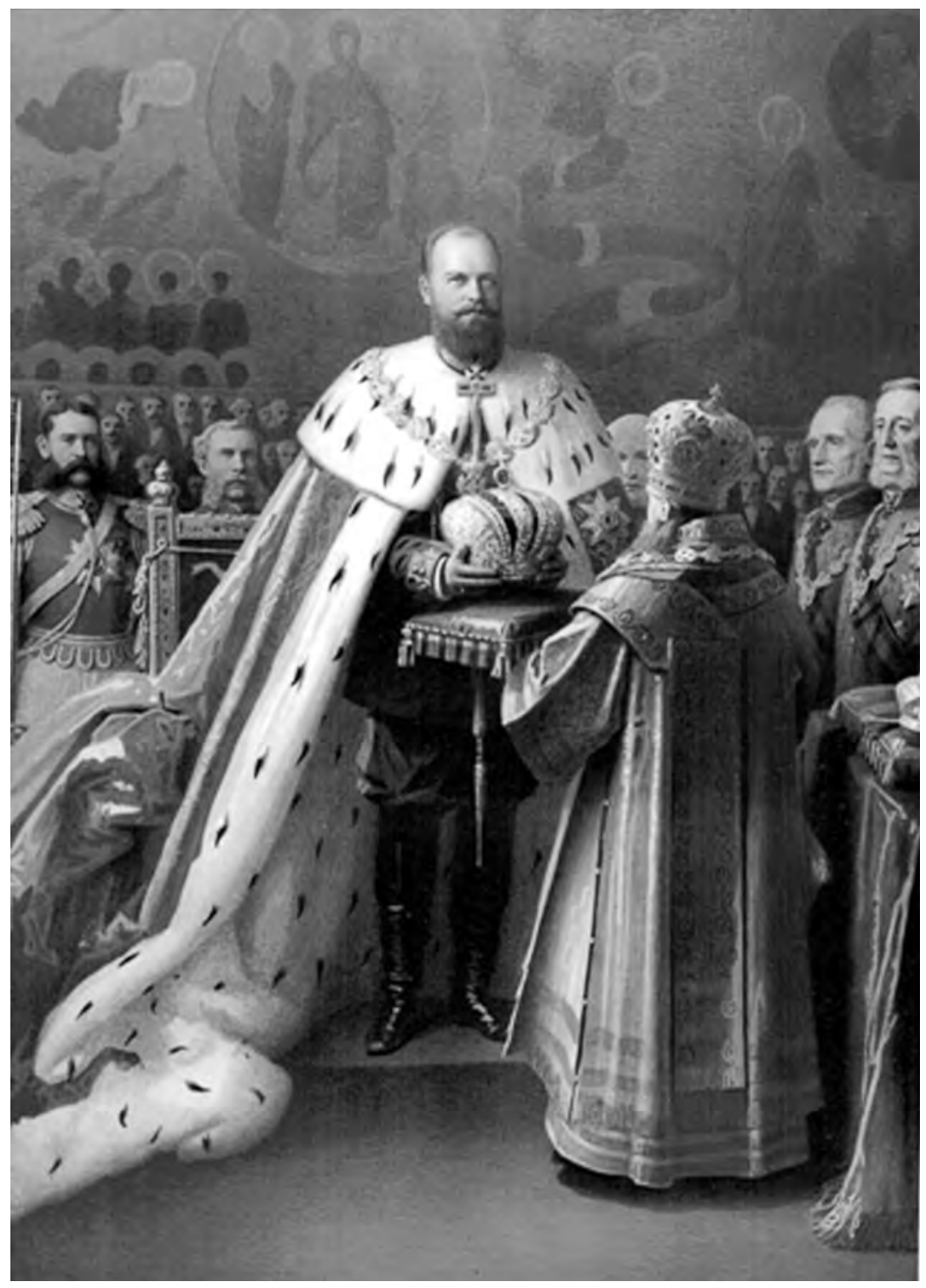

Figure 7-The Crowning of Emperor Alexander III. Opisanie sviashchennago koronovaniia... imperatora Aleksandra Tret'ego i gosudaryni imperatritsy Marii Fedorovny vsei Rossii (St. Petersburg, 1883). Slavic and Baltic Collection, New York Public Library. 
wears a bonnet and bustle. Also notable are the many paintings of military ceremonies, appearing for the first time in a coronation album. They show the emperor at the consecration of the standards of the Preobrazhenskii and Semenovskii Regiments, the religious parade, the parade of the Semenovskii Regiment, and the feast for the regiments at Sokolniki. The paintings display the new simplified Russian-style uniforms that Alexander III introduced. The emperor appears as a commanding figure, in his distinctive military dress, on horseback and wearing Russian boots and hat. ${ }^{17}$

The last coronation album, for Nicholas II's coronation in 1896, was published under the Ministry of the Court and Appanages in the Agency for the Production of State Papers. ${ }^{18}$ As its title Coronation Collection (Koronatsionnyi Sbornik) indicates, the album is not simply an Opisanie but an assortment of mementos and illustrations of the events, photographs of the participants, along with the usual accounts of the rituals and celebrations. It fills two volumes, each 43 by 33 centimeters; the same materials appeared in a one-volume French translation. The edition was the largest yet for a coronation album, with 1,300 copies published in Russian and 350 in French, and the cost of 165,905 rubles far exceeding the editors' initial estimates.

The opening 132 pages of the first volume are devoted to an illustrated history of coronation ceremonies. The description of the coronation and the coronation festivities takes up only the second half-272 pages-of the first volume; of these, fewer than fifty are used to describe the ceremonies on the day of the coronation. The remainder present the celebrations around the event and descriptions of the parades. The second volume includes photographs of foreign delegations and estate delegations from Russia and full color facsimiles of several of the menus and theater programs for the event. The Sbornik was a souvenir for an international social fête, the occasion for which was a ceremony of coronation. At a moment when the religious consecration of the emperor was assuming increasing importance in official ideology, the celebrations had become a major event in the European social

$17 \quad$ A special album was devoted to the assembling, disposition, and responsibilities of the regiments gathered for the coronation. Opisanie sbora i zaniatii voisk pod Moskvoiu vo vremia sviashchennogo koronovaniia ikh Imperatorskikh Velichestv $v 1883$ godu (St. Petersburg: V. Kirshbaum, 1883).

18 Koronatsionnyi sbornik: Koronovanie v Moskve, 14 maia 1896 (St. Petersburg: Eksped. Gos. Bumag, 1899). 
season, an episode in the international competition of spectacle and display, with Nicholas II and the empress Alexandra as the centerpiece.

The styles of the illustrations are varied. As in Alexander III's coronation album, old-Russian or pseudo-Russian motifs were prominent. "Slavonicized" lettering introduces the various sections. The cover by N. S. Samokish has the Russian seal, surrounded with an old Russian floral motif. At the top is a medal showing the profile of the emperor and empress. Victor Vasnetsov designed lettering and floral motifs for a number of the pages, and an old Russian style menu for one of the feasts. A. Riabushkin contributed the program for Life for the Tsar.

The historical introduction and the description of the coronation are illustrated profusely with hundreds of drawings and lithographs. Illustrations in the text by E. and Nikolai Samokish-Sudkovskii give rather literal renderings of the particular ceremonies and events. Elena SamokishSudkovskaia's black and white drawing of Nicholas and Alexandra preparing to embrace after her crowning reveals the prominence of the marital bond in the ceremonies at the outset (Figure 8). However, the artistic highlights of the volume are undoubtedly the remarkable watercolors, reproduced beautifully in chromolithography, including works by Valentin Serov, Ilia Repin, Albert Benois, Konstantin Makovskii, and Andrei Riabushkin.

The use of watercolor lends an element of lightness and iridescence lacking in the rather monolithic forms of earlier lithographs. Impressionist and Art Nouveau influences are evident, the promptings of artistic expression dominating the figures and ceremonies depicted. The artists present the coronation as a magnificent show of color and light. Serov turns the anointment ceremony into a study of color and form of the white robes of the tsar and the blue of the courtiers, the yellow of the clergy, with patches of red visible from the rear of the cathedral. The flattening of perspective and the glitter of the candelabra produces an effect of airiness and bustle that hardly conforms to the solemnity of the occasion. Riabushkin's painting of Nicholas descending from the Red Staircase (Krasnoe kryl'tso) highlights red and brick colors, lending the scene an almost quilt-like appearance, while Albert Benois gives a sense of the shimmering of the water and the colors of the sky during the illumination. Repin captures the stiffness and awkwardness of Nicholas's meeting with the peasant elders (starshiny). The peasants stand in a row. The emperor, evidently awkward, looks away from them as if trying to avoid their gaze. 


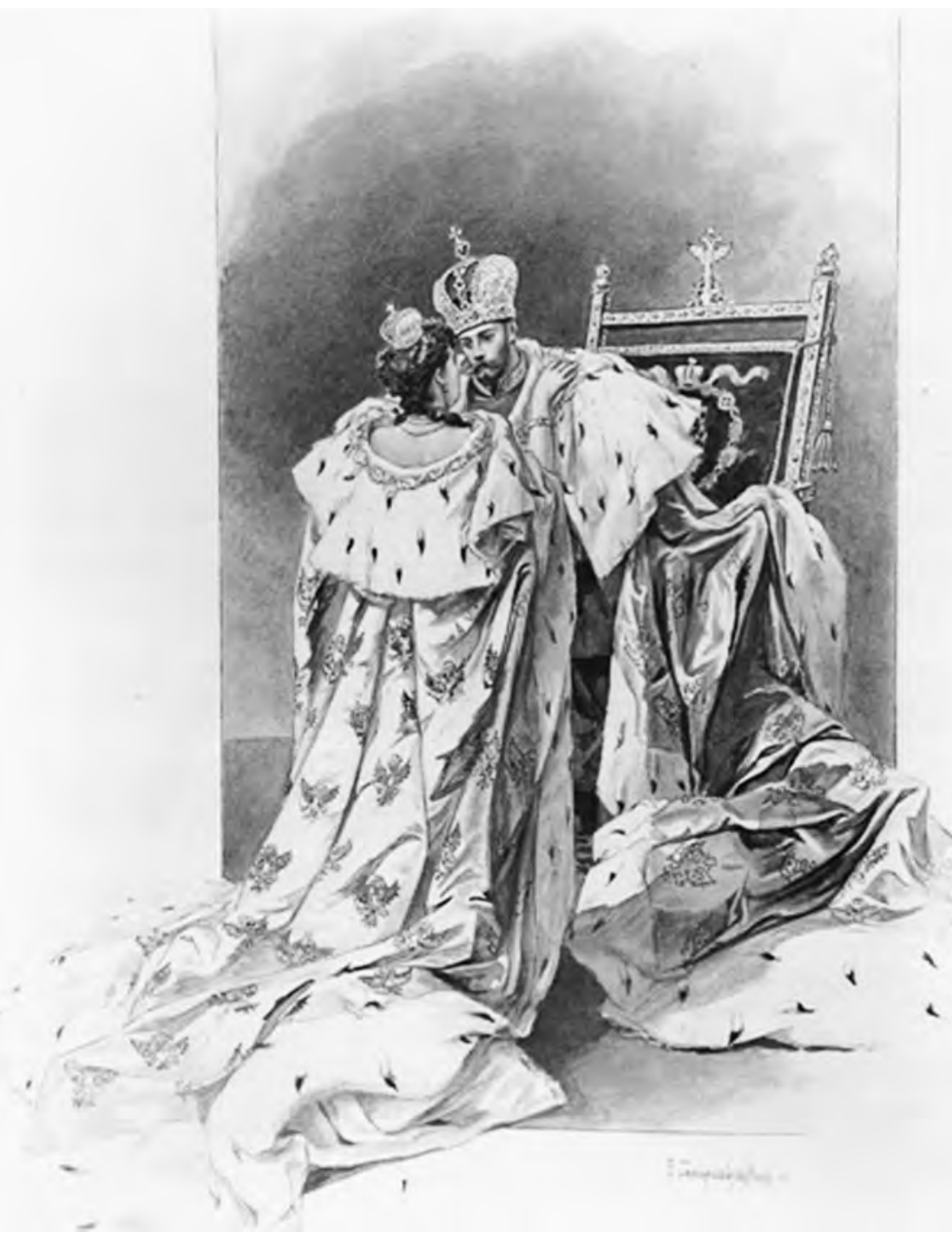

Figure 8-Emperor Nicholas II Crowns Empress Aleksandra Fedorovna. V. S. Krivenko, ed., Koronatsionnyi sbornik: Koronovanie v Moskve, 14 maia 1896 (St. Petersburg, 1899). Slavic and Baltic Collection, New York Public Library. 
Russian coronation albums give us valuable glimpses into the mental world of Russian monarchy. They reveal how the coronation, the principal ceremony of the monarchy, consecrated the dominant political views, religious beliefs, and artistic tastes of each reign as attributes of god-ordained authority. Eighteenth-century albums placed the coronation in a context of secular celebrations for the monarch who promised an era of prosperity and happiness. The albums of the nineteenth century emphasized the historical and religious significance of the coronation, which they presented as a national and religious act. They used art to show the solemn moments of the ceremony and the splendor of the celebrations, to enshrine the event in a book that would preserve a recollection of the ruler during these inspiring moments at the beginning of each reign. 


\section{Ceremony and Empire in the Evolution of Russian Monarchy}

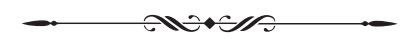

The Roman and Byzantine empires were prototypes for the symbols, myths, and ideology of the absolute state in early modern Europe. Russian monarchs, unlike the kings of France and England, continued to draw their paradigms of sovereignty from the imperial past. The Russian state never evolved a conception of self-sufficient monarchical authority, reinforced with theological and juridical defenses of sovereignty. Russia had no Bodin or Hobbes. Sovereignty was represented by images of empire, and these were elaborated in imperial ceremony, rhetoric, art, and architecture.

In Russia, "empire" recalled the two historical prototypes of absolute monarchical power: Rome and its successor, Byzantium. The concept of empire evoked a cluster of related meanings that exalted the stature of the princes of Moscow and later the emperors of Russia. Empire meant imperial dominion or supreme power unencumbered by other authority. It referred to the Christian empire, the heritage of the Byzantine emperor as the defender of Orthodoxy. Finally, it implied imperial expansion, extensive conquests, encompassing non-Russian lands. These meanings were conflated and served to reinforce each other. The expansion of empire confirmed the image of supreme power and justified the unlimited authority of Russian emperors. The religious, eschatological motif enhanced their moral dominion, a theme emphasized by Boris Uspenskii and other scholars of the Tartu school.

The cluster of meanings connected with ceremonies continued to dominate political symbolism and later thought. When Ivan III rejected the crown of king offered by Holy Roman Emperor Frederick III in 1489, he replied that he "had never wanted to be king by anyone, and that he did 
not wish it."' A king's crown signified mediated sovereignty, or in the eyes of Russian rulers and their servitors, no sovereignty at all. Sovereignty was and later would be identified with the historical, religious, and symbolic appurtenances of empire. Ivan III, guided by the hierarchs of the Orthodox Church, set about acquiring these appurtenances. The titles of tsar and autocrat, the Byzantine double-headed eagle, and in 1547 a coronation modeled on Byzantine prototypes vested the prince of Moscow in symbols and ceremonies of empire.

Empire was a historical, religious and symbolic construct, dramatized in myth and enacted in ceremony. Religious services, coronation rites, and statements of orthodox clerics identified Moscow as the successor to Byzantium as the protector of Orthodox Christianity. But the Orthodox Church was only one of the signs of empire. In Russian monarchical imagery, religious sanction-the tsar as chosen-of-God and the anointed-of-Godwas continually supplemented with demonstrations, actual or ceremonial, of imperial success. Neither religious sanction nor the force of tradition proved sufficient grounds for the secular pretensions of Russian monarchs.

Conquest was another sign of empire, for empires expanded, and expansion was a sign of a powerful flourishing state. Imperial dominion is based on a fact, or myth of conquest. The exercise of force indicates the presence of great might, defying internal or external challenge and establishing authority as uncontested and irresistible. The rulers then are set above and apart from the rule. Military triumph is vested in a cultural and symbolic supremacy, elevating the imperial elite into a higher realm, making obedience akin to worship.

This imperial myth minimizes national differences while magnifying social distinctions. The distinctions are between two sharply separate worlds: those who partake in the exercise of sovereignty and those who submit. The state then follows the pattern of what Ernest Gellner has called an agroliterate society, that is, a traditional society organized horizontally, in which the privileged groups seek to separate themselves as much as possible from the lower classes, rather than to establish ethnic or cultural ties. ${ }^{2}$ Russians then

$1 \quad$ Dimitri Strémoukhoff, "Moscow the Third Rome: Sources of the Doctrine," in The Structure of Russian History: Interpretive Essays, ed. Michael Cherniavsky (New York: Random House, 1970), 112.

2 Ernest Gellner, Nations and Nationalism (Ithaca, NY: Cornell University Press, 1983), 11. 
are subjects as much as other nationalities, and the elites of other ethnic groups may be coopted into the great Russian nobility (rossiiskoe dvorianstvo). There is a rough equality of subjects, and a rough equality of elites.

Ceremonies until the second half of the nineteenth century dramatized this separation. The theater of power was a play performed principally for the participants. It is the various strata of the elite who gather to celebrate their collective domination, justifying it, Max Weber pointed out, first of all to themselves; the myths then would be accepted by "the negatively privileged layers." 3 The elite creates and performs what Marshall Sahlins called their "heroic history," while the masses remain in a state of "historylessness," following the overarching symbolic patterns of their society unknowingly. ${ }^{4}$

Heroic history glorifies domination by conquest. In Russia, the conquest motif played a particularly important role: symbols required more than ecclesiastical confirmation; they also required proof that the tsar embodied destiny, demonstrated by victories on the battlefield and by the recognition of other sovereigns. From the sixteenth to mid-nineteenth centuries, imperial symbol and imperial expansion fostered a mutually self-confirming dynamic. Ceremony sacralized conquest, placing it in the context of myth, stated in the narratives of sacred and secular history. By the same token, conquest provided an ongoing enactment of the myth set in ceremony. This essay examines the conquest motif in terms of three of the ceremonies of imperial Russia-the imperial coronation, the triumphal entry, and the imperial trip. It will conclude with a discussion of the adaptation of the myth to encompass the principles of nation and race in the nineteenth century.

\section{The Coronation}

The Russian coronation, introduced in 1547 , was a statement of imperial pretensions. The coronation gave ecclesiastical consecration to the sovereign claims of the prince of Moscow. The central legends performed at the coronation connected Russia to both Byzantium and Rome. They were set

3 Max Rheinstein, ed., Max Weber on Law in Economy and Society (New York: Simon and Schuster, 1967), 335-7.

4 Marshall Sahlins, Islands of History (Chicago: University of Chicago Press, 1985), 3551; Max Weber, Wirtschaft und Gesellschaft : Die Wirtschaft und die gesellschaftlichen Ordnungen und Mächt: Nachlass, Teilband 4: Herrschaft (Tübingen: J.C.B. Mohr, 2005), MWG, 1/22-4, p. 147f.. 
forth in "The Tale of the Vladimir Princes," which was composed by members of the clergy in the sixteenth century. "The Tale" was the counterpart to the mythological genealogies that the Hapsburg emperors and the French and English kings contrived to link themselves to imperial Rome. ${ }^{6}$ "The Tale of the Vladimir Princes" introduced into the historical record a brother of Augustus, Prus, who presumably ruled the Prussian lands and was a direct ancestor of Riurik. It then traced the lineage of the Moscow princes back to Riurik. The authors of the "Tale of the Vladimir Princes" also described a long tradition and "ancient" regalia for the newly composed Russian imperial coronation. The second part of the "Tale," "The Legend of Monomakh," drew a direct connection with the Byzantine Empire.

According to the "Legend of Monomakh," the Prince of Kiev, Vladimir Monomakh, wrested imperial regalia from the Emperor Constantine Monomakh-the prince's grandfather, who had actually died before the prince's accession-to forestall an attack against Byzantium. The regalia of Monomakh consisted of the "Life-Giving Cross," a pectoral cross with a piece of the wood from the cross of the crucifixion, the barmy, a counterpart to the Byzantine emperors' shoulder pieces, the crown "Monomakh's cap" (which was actually of Tatar origin), and a chain of the "gold of Araby."7

The opening, principal part of the early Russian coronation was the conferral of the regalia of Monomakh. The first coronation, of Ivan IV, did not include an anointment ceremony. The rite opened with a dialog between Ivan and Macarius, Ivan asking the Metropolitan to consecrate his hereditary claims to the title of Russian tsar. Ivan stated that since Vladimir Monomakh all his ancestors had been crowned. He also mentioned his father's command that he be crowned, "according to our ancient rite" (po drevnemu nashemu

5 R. P. Dmitrieva, Skazanie o kniaz'iakh vladimirskikh (Moscow-Leningrad: Ak. Nauk SSSR, 1955).

6 For a study of these myths, see Marie Tanner, The Last Descendant of Aeneas: the Hapsburgs and the Mythic Image of Emperor (New Haven, CT: Yale University Press, 1993).

7 Giuseppe Olshr, "La Chiesa e lo Stato nel cerimoniale d'incoronazione degli ultimi sovrani Rurikidi," Orientalia Christiana Periodica vol. 16 (1950): fasc. 3-4: 283, 292-3; D. I. Prozorovskii, "Ob utvariakh pripisyvaemykh Vladimiru Monomakhu," Zapiski otdeleniia russkoi $i$ slavianskoi arkheologii Imperatorskogo russkogo arkheologicheskogo obshchestva, 3, 1882, 1-64; Dmitrieva, Skazanie o kniaz'iakh vladimiriskikh, 116-7; Robert Craig Howes, ed., The Testaments of the Grand Princes of Moscow (Ithaca, NY: Cornell University Press, 1967), 97-103. 
tsarskomu chinu). The Metropolitan replied by confirming the tsar's ancestral rights to the imperial crown. Then he pronounced the benediction and conferred the regalia. ${ }^{8}$

The Legend of Monomakh was the guiding myth of the early Russian coronation, and the regalia of Monomakh became the insignia of power of the Muscovite tsardom. The ceremonies surrounded them with the gestures of liturgical veneration owed to sacred relics, and their conferral remained the central phase of the ceremony. The tolling of the bells of the church, the darkness of the cathedral and aroma of incense, the saints looking down from the walls and the iconostasis, combined to produce an atmosphere of timeless mystery, as if the generations of princes and emperors had joined the living in the consecration of power.? Ceremony turned the fiction of imperial succession into sacred truth.

The Legend of Monomakh played much the same role as the legend of the Holy Ampulla in the French coronation ceremony. Both evoked sources of the charisma transmitted to the bearer of power by sacred articles: the regalia in Russia, the oil in France. Both invoked descent to establish the historical connection of the present ruler to the recipients of the initial charismatic gift. However, their individual motifs suggest the different characters of the charisma they bestowed. The vial containing the oil of Clovis, which consecrated the power of Capetian kings according to the French legend, was borne in the beak of a dove sent from heaven. It attested to the providential origins of French monarchy; God bestowed his sanction directly on the clergy and kings, without imperial mediation. The legend expressed an early sense of the continuity of the realm and the unity of the nation around the king. ${ }^{10}$

$8 \quad$ M. V. Shakhmatov, "Gosudarstvenno-natsional'nye idei 'chinovnykh knig' venchaniia na tsarstvo moskovskikh gosudarei," Zapiski russkogo nauchnogo instituta v Belgrade, Vol. 1 (1930): 250-1, 259-60; David B. Miller, "The Coronation of Ivan IV of Moscow," Jahrbücher für Geschichte Osteuropas vol. 15 (1967): 559-61; Dmitrieva, Skazanie o kniaz'iakh vladimiriskikh, 44-52; Drevniaia rossiiskaia vivliofika (Moscow: Kompaniia Tipograficheskaia 7 (1788): 1-4; E. V. Barsov, Drevne-russkie pamiatniki sviashchennogo venchaniia tsarei na tsarstvo $v$ sviazi s grecheskimi ikh originalami (Moscow: Universitetskaia tip. [M. Katkov], 1883), 72-5; Olshr, "La Chiesa e lo Stato," 295-7.

9 On the early Russian notion of time, according to which "descendants repeat their forbears like an echo," see A. M. Panchenko, "Istoriia i vechnost' v sisteme kul'turnykh tsennostei russkogo barokko," Trudy otdela drevnerusskoi literatury 34 (1979): 189-99.

10 Ralph E. Giesey, "Models of Rulership in French Royal Ceremonial," in Rites of Power: Symbolism, Ritual and Politics since the Middle Ages, ed. Sean Wilentz 
The Monomakh legend accentuated the derivative character of Russian sovereignty: sanction came not from God directly, but through the mediation of the Byzantine Empire, and political and ecclesiastical authority strove to recapture a Byzantine image. The oil of Clovis, descending from heaven, bestowed miraculous powers, like the power to cure scrofula on the French kings. The Monomakh legend was a secular myth; it invoked neither miracle nor pretensions to supernatural powers. Rather, it derived from the Kievan prince's valor in his invasion or threatened invasion of Constantinople. The prince, according to the precept, would rule in heaven as a result of his deeds on earth, his "imperial exploits (tsarskie podvigi) and labors." 11 The Muscovite coronation, in this way, gave the image of conqueror religious sanction. It united the destiny of the Orthodox Church with the success of secular empire.

In addition to the claims by mythological descent and the valor of the tsar's ancestors, the coronation introduced concrete confirmation of empire in its statements of expanse and breadth of territory. In the first coronation, Ivan IV stated his claims to the throne "of all Rus'." After the conquest of Kazan and Astrakhan, he began to use the term "Rossiia," greater Russia. In future coronations the description of the tsar's realm expanded. By the close of the seventeenth century, the territories enumerated at the coronation gave a forceful statement of the extent of the realm. Tsar Fedor Alekseevich, during his coronation in 1676, used the words "Velikaia Rossiia" to describe the extent of the tsar's imperial authority. This change expressed the unity of all the Russian areas, Great, Little, and White Russias, as well as Kazan, Astrakhan and Siberia. Fedor's chin went a step further and referred to the Great Russian Tsardom, Velikorossiiskoe Tsarstvie, a term denoting an imperial, absolutist state, subordinating Russian as well as non-Russian territories. ${ }^{12}$

(Philadelphia: University of Pennsylvania Press, 1985), 43; Janet L. Nelson, "The Lord's Anointed and the People's Choice: Carolingian Royal Ritual,” in Rituals of Royalty: Power and Ceremonial in Traditional Societies, ed. David Cannadine and Simon Price (Cambridge: Cambridge University Press, 1987), 137-80.

11 Barsov, Drevne-russkie pamiatniki..., 80-84; Miller, "The Coronation of Ivan IV of Moscow," 567-69; Ihor Sevcenko, "A Neglected Source of Muscovite Political Ideology," in The Structure of Russian History, 92; Douglas Joseph Bennet, Jr., "The Idea of Kingship in Seventeenth Century Russia" (PhD Dissertation, Harvard University, 1967), 91-94.

12 Drevniaia Rossiiskaia Vivliofika, 7: 328-37; Shakhmatov, "Gosudarstvennonatsional'nye idei... moskovskikh gosudarei," 256-8. 


\section{The Triumphal ENTRY}

In fifteenth- and sixteenth-century Europe, the Roman advent (adventus) became an important expression of monarchical sovereignty and independence from ecclesiastical authority. The Roman advent identified the monarch with the original sense of the word imperator - the triumphant military leader. Holy Roman Emperors and kings of France rode into cities on horseback, wearing armor, as conquerors, giving striking demonstrations of the capacity to wield force. The Roman advent conferred dominion on the basis of demonstrated prowess. Its consecration of power, the anthropologist A. M. Hocart observed, fulfilled the same function as a coronation. ${ }^{13}$ It showed that the monarch owed his power to his exploits on the battlefield, not to divinely ordained traditions of succession. The arches that covered the way also gave the monarch's power new meaning. They marked what Arnold Van Gennep has described as a passage from profane to sacred, the general or ruler entering his own domain, earned by the feat of conquest. ${ }^{14}$ Decorated with classical allegories and emblems, they lifted the monarch into a classical pantheon, making his achievements the equivalent of the prodigies of the gods.

The first ceremony resembling a triumphal entry in Russia took place six years after the coronation of Ivan IV, immediately following the conquest of Kazan. Ivan passed through various towns and then entered Moscow with his army. Like an advent, this was an expression of a ruler's claim to conquered territory by making a ceremonial spectacle of force. Unlike Roman triumphs, the ceremony attributed Ivan's successes to God and the clergy. The principal references were to Byzantium and the "Legend of Monomakh." Before Ivan entered Moscow, he removed his armor and dressed himself in the Monomakh cap, the barmy, and the Life-Giving Cross. ${ }^{15}$

Peter the Great introduced the Roman adventus as a celebration of the secular authority of the monarch at the beginning of his reign. The first

13 A. M. Hocart, Kingship (London: Oxford University Press, 1969), 86-9.

14 Arnold Van Gennep, The Rites of Passage (Chicago: University of Chicago Press, 1960), 15-21; "Triumphus," in Paulys Encyclopaedie der classischen Altertumswissenschaft (Stuttgart: J. P. Metzler, 1939), 31: 496.

15 Michael Cherniavsky, "Russia," in National Consciousness, History, and Political Culture in Early-Modern Europe, ed. Orest Ranum (Baltimore: Johns Hopkins University Press, 1975), 125. 
took place after the battle of Azov, on September 30, 1696. In the very year of the death of his half-brother, Ivan Alekseevich, when Peter began to rule by himself, he announced a new symbolic language and political imagery. The procession of the armies through the city lasted from nine in the morning to nightfall. The entry celebrated the exploits of the commanders Marshal Le Fort and General Shein, and, by implication, of Peter himself, who appeared as “The Great Captain." Peter walked behind Lefort's sleigh, at the head of the sailors. He wore a black German coat and a hat with a white feather and carried a halberd. Turkish prisoners were displayed along the way.

His armies passed through a classical arch, built at his own command. An enormous relief figure of Hercules held one side of the vault and pediment, under the words "with Herculean strength." On the other side stood a figure of Mars beneath the inscription "with the courage of Mars." Hercules and Mars confronted Russians with the western metaphors of monarch-hero, monarch-god, marking the abandonment of the humble and effacing mien of the Muscovite tsar. Roman allusions were everywhere. The inscriptions on the vault trumpeted the extent of Peter's own superhuman achievement. The words, "I have come, I have seen, I have conquered," were inscribed in three places on the arch, and repeated in the verses read by the Duma Clerk and postmaster, Andrei Vinius from the arch. ${ }^{16}$

In the first decade of the eighteenth century, Peter staged advents into Moscow to mark his successes in the Northern War. These became elaborate displays, with triumphal arches decorated by allegories, explained in texts meant to make the meanings absolutely explicit. The triumph presented after the battle of Poltava in 1709 was the most grandiose of the Northern War. It marked Peter's assumption of the persona of military leader, imperator in its original sense, eleven years before his formal acceptance of the title.. Peter entered, now on horseback, not as the captain but as the military leader, behind the Preobrazhenskii Regiment, guarding Swedish captives. The Poltava entry demonstrated that the triumphal entry had displaced the religious procession as the central public ritual of Russian monarchy. During

16 M. M. Bogoslovskii, Petr I: Materialy dlia biografii (Leningrad: Ogiz, Gos. Sotsial'no-ekon. Izd-vo, 1940), 1: 344-8; V. P. Grebeniuk, "Publichnye zrelishcha petrovskogo vremeni i ikh sviaz's teatrom," in Novye cherty $v$ russkoi literature (XVII-nachalo XVIII v.) (Moscow: n.p., 1976), 134. 
the entry, Peter took over the religious imagery that had been reserved for the Patriarch. ${ }^{17}$

The Petrine imperial advent was a ceremonial expression of sovereignty, of dominion. It was an expression of dominion over Russians-his victories justifying the symbolic conquest of the city of Moscow. The traditions, culture, and religion of Moscow in this respect were subordinated to Peter's western elite, whose center would become the new city of Petersburg. The sovereign authority of the monarch had been reaffirmed, replenished, with new symbols indicating the distance between the ruler and the subject population regardless of national background.

\section{Coronation and Advent}

Peter displayed his new, redefined image of empire in the coronation he staged for Catherine I in 1724. He removed "Legend of Monomakh" from the investiture ceremony and replaced the items connected with the Tale with new western regalia. A European crown and mantle replaced the Monomakh cap and the sacred barmy.

The coronations of Anna Ioannovna and Elizabeth Petrovna introduced additional modifications in Peter's spirit, and the ceremonies for Elizabeth's coronation in 1742 remained fundamentally unchanged for the duration of the empire. That coronation consisted of far more than the processions and ceremonies of the Kremlin. It was a major celebration beginning with an entry into the capital and concluding with long and elaborate festivities.

The imperial Russian coronation that we know in the eighteenth and nineteenth centuries fused the elements of the triumphal entry and western court festivities with the solemn investiture and consecration in the Assumption Cathedral. It consecrated each sovereign who had assumed the throne by celebrating and reaffirming the sacred and traditional character of the Westernized empire. The triumphal entry was a glorification of force, an unambiguous statement that the monarch's power derived from a heroic act of conquest that anteceded consecration. It presented the westernized

$\overline{17}$ V. M. Zhivov and V. A. Uspenskii, “Tsar' i Bog: semioticheskie aspekty sakralizatsii monarkha v Rossii," in Iazyki kul'tury i problemy perevodimosti (Moscow: Nauka, 1987), 114-5; Boris Uspenskii, "Historia sub specie semioticae," in Soviet Semiotics, ed. D. P. Lucid (Baltimore: Johns Hopkins University Press, 1977), 110. 
elite of the new capital, to use Clifford Geertz's term, "taking possession" of Moscow. ${ }^{18}$ The rows of guards' regiments, the massive array of horses, elaborate sumptuous western dress, and carriages showed the conquest of the old capital by the new. The processions to and from the Cathedral on the day of the coronation also presented a magnificent display of the social and national components of the Russian elite.

The investiture remained the principal moment of the coronation ceremony. Changes introduced after 1724 enhanced the focus on the sovereign as absolute monarch and ruler of the empire. At the coronation of Elizabeth Petrovna in 1742 , the empress read the credo, assumed the imperial mantle, and received the benediction from the archbishop, following the order of previous eighteenth century coronations. Then, at her command, the crown was brought to her; she lifted it, and she herself, rather than the archbishop, placed it on her head. After the conferral of the scepter and the orb, she sat on the throne and listened to a protodeacon recite her full title. The recitation included the principalities and lands that made up her realm, a proclamation of the vast extent of her imperial dominion. All future Russian sovereigns would crown themselves, and the recitation of the vast extent of empire remained a central moment in the investiture ceremony, making it clear that the coronation was a consecration of the empire as well as the emperor or empress. ${ }^{19}$

\section{Empire and Subject Peoples: The Imperial Trip}

The ceremonies of empire in the eighteenth and first half of the nineteenth century remained expressions of sovereign dominion. The presentations of the myth took on different forms to adapt it to current western conceptions of antiquity, as well as to the circumstances of the moment. During the reign of Catherine II, legislation, literature, and architecture affirmed the imperial theme. At the Nakaz commission of 1767, the Moscow Metropolitan declared Catherine the successor to Justinian and Russia the heir to the Byzantine legal tradition. Literary panegyrics and artistic allegories set Catherine in the tradition of Numa and Solon. Such literary devices continued throughout her reign. La Harpe, the tutor of Alexander Pavlovich, thought of himself

\footnotetext{
18 Clifford Geertz, "Centers, Kings, and Charisma: Reflections on the Symbolics of Power," in Rites of Power: Symbolism, Ritual, and Power Since the Middle Ages, 16.

19 See Scenarios of Power, 1: 89-109.
} 
as Seneca, instructing the future emperor. In Russia, George Knabe pointed out, the image of Rome played a distinctive role, replacing Russian reality with an emblematic reality of classical antiquity. ${ }^{20}$

Meanwhile, the rapid expansion of the empire gave substance to the imperial myth of extent, revealing the Russian sovereign as the ruler of savage peoples-what Victor Zhivov describes as the "ethnographic myth" of empire. ${ }^{21}$ Catherine's method of rule in the new territories was to co-opt native elites and to assimilate them into the Russian nobility. The rank and file of the Cossacks were reduced to a condition approximating serfdom, completing a process of differentiation under way since the previous century. This received symbolic expression in the charters and items of regalia-the banners, the staffs, bunchuki and the maces, the pernachi, which Peter and Catherine granted to the atamans of the Don Cossacks. Likewise, she granted nobility to the Tatar aristocracy in Crimea, who received the privileges and honors of Russian noblemen. ${ }^{22}$

The imperial nobility was revealed as an association of the powerful and the educated of Russian and other nationalities, who rejoiced in their devotion to a supreme, beneficent ruler. Noblemen displayed their bond in open demonstrations of their western culture. ${ }^{23} \mathrm{New}$ ceremonies stressed

20 S. M. Soloviev, Istoriia Rossii s drevneishikh vremen (Moscow, 1965), 14: 71-3; Stephen L. Baehr, The Paradise Myth in Eighteenth Century Russia: Utopian Patterns in Early Secular Russian Literature and Culture (Stanford: Stanford University Press, 1991), 54-5, 113, 120-2; G. S. Knabe, "Rimskaia tema v russkoi kul'ture i v tvorchestve Tiutcheva," in Tiutchevskii Sbornik: stat'i o zhizni i tvorchestve Fedora Ivanovicha Tiutcheva, ed. Iu. Lotman (Tallin: Ėèsti raamat, 1990), 255-6.

21 V. M. Zhivov, "Gosudarstvennyi mif v epokhu Prosveshcheniia i ego razrushenie v Rossii kontsa XVIII veka," in Vek Prosveshcheniia: Rossiia i Frantsiia; Vipperovskie chteniia (1989): 154.

22 Robert H. McNeal, Tsar and Cossack, 1855-1914 (New York: MacMillan,1987), 2-3; John P. LeDonne, "Ruling Families in the Russian Political Order, 1689-1825," Cabiers du Monde russe et soviétique Vol. 38, No. 3-4 (July-December 1987): 310-1; Bruce W. Menning, "The Emergence of a Military Administrative Elite in the Don Cossack Land, 1708-1836," in Russian Officialdom: The Bureaucratization of Russian Society From the Seventeenth to the Twentieth Century, ed. Walter McKenzie Pinter and Don Karl Rowney (Chapel Hill: University of North Carolina Press, 1980), 130-61. Alan W. Fisher, "Enlightened Despotism and Islam Under Catherine II," Slavic Review Vol. 27, No. 4 (December 1968): 547.

23 Andreas Kappeler, Russland als Vielvölkerreich: Entstehung, Geschichte, Zerfall (Munich: Beck, 1992), 50-1, 64-5, 135-8. 
the multinational character of the elite and the similarity of Russia to Rome. Native elites participated in shows of mutual fealty, expressed as affection for the sovereign. The opening of the description in the Opisanie of Catherine the Great's coronation immediately revealed her relationship with the elite and the empire. ${ }^{24}$ It told how the elders of the Zaporozhets Cossack host, led by their hetman, Kirill Razumovskii-a former lover of Catherine-greeted the empress at her suburban palace as their source of joy and their "true mother." Deputies of the Zaporozhets, Don, and other Cossack hosts marched to the Assumption Cathedral in the entry procession, making up four divisions of the procession, as did representatives of the Baltic merchantry and nobility. Catherine received congratulations from Baltic, Cossack, and Caucasian deputies, as well as of "Asiatic peoples," at the audiences on the days after the coronation. An engraving of the meeting with Asiatic peoples was executed for the projected coronation album. ${ }^{25}$

Catherine extended the ambit of imperial ceremony by travel, originating what may be called the ceremonial trip, which served as an expression of imperial supremacy and social and imperial integration. In 1764, she visited the Baltic provinces. She received a cordial welcome from the local nobility in the hope of confirmation of their special privileges. The entry was not an advent but a joyous welcome, like European festive entries: triumphal arches, balls, and fireworks presented the Baltic Ritterschaft united with the elite of the empire. ${ }^{26}$ These displays permitted a show of personal devotion of the local population to their sovereign.

Catherine's journey of 1787 to the newly conquered territories along the Black Sea was a lavish spectacle presenting the imperial myth. The fortress at Kherson carried the inscription "The Road to Byzantium." The city of Ekaterinoslav was to be Catherine's and Potemkin's counterpart to Petersburg, a perfect imperial city, to show the monarch's creation of a realm of cultivation and political order in a "new Russia." In the new territories,

24 Opisanie Vshestviia v Moskvu i Koronovaniia Gosudaryni Imperatritsy Ekateriny II, in Kamer-Fur'erskii Zhurnal (St. Petersburg) Vol. 63 (185?); Henceforth Opisanie Vshestviia. A brief account appeared in Sankt-Peterburgskie vedomosti, No. 80 (October 1, 1762), pribavlenie.

25 Opisanie Vshestviia, 7-11, 59-61, 136-7, 141-2, 146. The Opisanie was not published at the time. The illustrations were first issued in 1796.

26 V. A. Bil'basov, Istoriia Ekateriny Vtoroi (London: I.N. Skorokhodov, 1895), 2: 2902; Solov'ev, 13: 315-22. 
Catherine staged ceremonies of recognition with the native leaders of the region. At Kremenchug, she met with a delegation of Tatar noblemen, the murzy. An escort of murzy accompanied her into the town of Bachisarae, where she met the assembled dignitaries of the region. At a banquet, she entertained the Austrian Emperor and the muftii-the chief cleric, now recognized as a figure with administrative authority in the territory, along with the highest civil and military ranks. The journey to New Russia arrayed the leaders of the conquered territories with the notables of the court in ceremonial displays of the elite of empire. ${ }^{27}$

The ceremonial trip became a principal form of imperial presentation in the nineteenth century. Alexander I displayed a marked aversion to ceremonies other than parades. But he followed Catherine's example by taking trips to display the multi-national character of the empire. His appearances before the Baltic nobility reaffirmed the special relationship between the throne and the Baltic provinces, which had been breached by Catherine in 1783 and 1785 and then restored by Paul. ${ }^{28}$ In the last years of his reign he visited the Urals, Western Siberia, and finally the Caucasus, "the border of Asiatic Russia." The accounts presented Eastern peoples, "aziatsy," as little more than ornaments to the rule of the emperor, his noblemen, and officials, who joined the Russian population in their acclaim for the emperor. The article on Alexander's visit to Orenburg in 1824 describes the "foreign and crude peoples"-Kirghiz, Bashkirs, and Tatars-who were enraptured by his "goodness" (blagost'). The emperor is greeted by Kirghiz khans, but they are described as natives, "simplehearted" (prostodushnye) as they bring their gifts, and hardly as members of the noble elite. They add color and excitement to the military review. The author describes the scene of soldiers, Cossacks, and Bashkir warriors in battle dress on the field, performing astounding displays of horsemanship, as native Bashkirs, Khivans, Tatars and Kirghiz looked on. The emperor gave the Bashkir riders-along with the lower ranks attending the review—one ruble, a pound of beef, and a charka of vodka each. ${ }^{29}$

27 A.V. Khrapovitskii, Zhurnal Vysochaishego puteshestviia eia Velichestva Gosudaryni Imperatritsy Ekateriny II Samoderzhitsy Vserossiiskoi v Poludennye Strany Rossii $v 1787$ g. (Moscow: N. Novikov, 1787), 75-6.

28 Edward C. Thaden, Russia's Western Borderlands, 1710-1870 (Princeton: Princeton University Press, 1984), 25-7, 98-9.

29 "O prebyvanii Ego Velichestva Gosudaria Imperatora v Orenburge (Pis'mo k izdateliu)," Otechestvennye zapiski (1825), 21: 404-27. 


\section{Nationality ANd EMpire}

In the course of the nineteenth century, representatives of "Asiatic peoples" became increasingly prominent in official and foreign accounts of imperial ceremonies. The extent of territory and the variety of peoples provided crucial signs of sovereign power, as the prestige of the Russian emperor suffered blows from revolutionary challenge and military defeat. The rule of Eastern peoples supported the national pretensions of the autocrat and the westernized elite. Their authority, it was affirmed, derived from the unquestioning faith and devotion of the Russian people. The association between the concepts of empire and nation grew all the stronger in the second half of the nineteenth century, when imperial domination acquired a mass appeal. In this respect, the European model of a great power representing a nation holding colonies of lesser people began to replace the earlier, Roman classical model of an international elite serving a monarch in ruling a subject population of various ethnic backgrounds. ${ }^{30}$

The presentation of exotic figures from the East to elevate the image of the Russian emperor and people is a prominent theme evident in the principal description of the coronation of Nicholas I, written by Pavel Svin'in for his journal, Otechestvennye zapiski. ${ }^{31}$ Svin'in's account of the throng on the Kremlin square acclaiming the coronation recessional articulates both social and national distinctions. The court elite, officials, and marshals of the nobility, in their western uniforms, accompanied the emperor in full regalia, the empress, and the imperial family on the procession from the Assumption Cathedral to the Archangel and Annunciation Cathedrals and then back to the Red Staircase. Six grandstands, arranged in a semi-circle like an amphitheater on the square, were filled with Senators and officials of lesser ranks, foreign visitors, as well as deputies from the Asiatic peoples. Svin'in elaborated on the beautiful folk costumes of the Russians, the Circassians in their brilliant belts and pearls, the Kirghiz, Kabardins, Georgians, Armenians, Kalmyks, all in military costumes and exulting at the appearance of the emperor.

30 On the colonial character of nineteenth-century Russian imperial expansion see Kappeler, 174-76.

31 "Istoricheskoe opisanie Sviashchennogo Koronovaniia i Miropomazaniia ikh Imperatorskikh Velichestv Gosudaria Imperatora Nikolaia Pavlovicha i Gosudaryni Imperatritsy Aleksandry Feodorovny," Otechestvennye zapiski (1827), 31: 369-73. 
The assemblage was presented as a microcosm of the empire. "It seemed that everything attractive and brilliant in Russia was assembled here." The Russian group was foremost among the national groups, but still subordinate. Svin'in described beautiful Moscow women, in their plumed hats, veils and shawls of other Russian national costumes, and Russian merchants in sibirki. Then he enumerated the various Eastern nationalities, whose variety augmented the national myth. All united in their love for the imperial family. Those on the square, dressed in native costumes, bore witness to the supremacy of the imperial elite, whose members wore European uniforms and gowns that set them above nation. ${ }^{32}$

The masquerade revealed the same relationships. The event was attended by nearly 5,000 guests, including members of the nobility, merchantry, and native leaders. Viewing the scene from the balcony, the author saw the ladies' gowns sparkling in silver and gold. The "Asian ladies" wore "sumptuous furs and valuable brocades." But he was most preoccupied by the dress of the Russian women: they wore "Russian sarafans, with Russian bands (poviazki) and kokoshniki on their heads, bathed, one might say, in pearls and diamonds." As they danced the polonaise, their "patriotic attire" (otechestvennyi nariad) transported him back to the times "when Russians were not ashamed of their splendid dress, proper for the climate, having a national character, and incomparably more beautiful than foreign dress." To confirm the universal acceptance of this "truth," Svin'in cited the opinion of an "enlightened foreigner," who declared his preference for these ladies to those dressed in the latest European fashion. ${ }^{33}$

The coronation of Alexander II in September 1856 celebrated the might and extent of empire in the wake of the humiliations of the Crimean War and the Peace of Paris. The national character of imperial dominion was made even more explicit than it had been at Nicholas I's coronation: the Russian people's love for their sovereign infused him with the power to conquer and rule an empire. The spectacle of exotically dressed oriental deputies, paying homage to the Russian sovereign, confirmed the success of the empire.

Russian writers in the official Russkii khudozhestvennyi listok, foreign correspondents from the Russian mouthpieces abroad, L'Indépendance Belge and Le Nord, and William Russell of the London Times all reiterated these

32 Ibid., 31: 371-3.

33 "Istoricheskoe opisanie," Otechestvennye zapiski (1827), 32: 26-34. 
themes. The variety and colorful dress of the peoples marching in the procession demonstrated the might of the imperial state. Russkii khudozhestvennyi listok described the deputies of Asiatic peoples as "tangible proof of the vastness of our state, which some justly call a special kind of planet." Their appearance in the procession "eloquently convinced all of the power of the one, whom they had come from their own lands to greet." 34

Foreigners' reports cited in Russkii vestnik and Russkii khudozhestvennyi listok described the pageant of Eastern types in native costumes, Bashkirs, Cherkess, Tatars, Armenians, Georgians, and Cossacks from various hosts. William Russell of the London Times remarked that "the wealth of an immense state was presented for show with eastern luxury, which was combined this time with the taste of the educated west." He marveled, "What a recollection of the majesty and might of Russia will these people bring back to their distant tribes! They flashed by us in all of their brilliance, a dream from A Thousand and One Nights." L'Indépendance Belge observed the vitality of the deputies from the Eastern peoples, "these proud warriors, with bold movements, in glittering eastern dress...." Their "half-tamed" horses showed the civilizing forces of the state: they were "a striking symbol of the triumph of the power of the well-ordered over the power of disorder." 35

The reports affirmed that it was the love of the Russian people for their sovereign that enabled the empire to create such prodigies. A Russkii khudozhestvennyi listok columnist pointed out that all the foreign correspondents were amazed by the ceremony's lavishness and splendor, but, he thought, they had not completely expressed the idea that Russia possessed "secret deposits of gold and gems, unknown to the world." These jewels consisted in the unifying love of the people. The author turned the pageant into a symbolic equivalent of popular sovereignty. "And that is true! Russia has valuables, lost by the decrepit powers of the West. The young feeling of infinite love and devotion for the anointed of the Lord and for the sovereign guardians of the earthly fate of the beloved fatherland has been preserved in Russia." This feeling, moreover, was religious in character. The author quoted William Russell's comment that "the piety and deep religious feeling of the Monarch and his people, their visible humility before God, recalled the faith and

34 Russkii khudozhestvennyi listok, No. 29 (October 10, 1856), 1.

35 Cited in "Sovremennaia letopis," Russkii vestnik (September, 1856), 170-1 and Russkii khudozhestvennyi listok, No. 27 (September 20, 1856), 1-2. 
ceremonies of past centuries, and greatly overshadowed the appearance of military power of this state." It was the Orthodox faith of the Russian people that empowered their sovereign to rule an empire. ${ }^{36}$

The masquerade in the New Kremlin Palace was a festive display of the unity of empire and nation. The correspondent of Le Nord described an emperor enjoying a rapport with his people. In no other court, he marveled, would the doors be thrown open to common people. No democratic country would permit such a "mixture of citizens of all estates." Alexander, now described as "the Russian tsar," entered arm-in-arm with the "tsaritsa." The crowd momentarily parted before him. The shouts of Hoorah were thunderous, "shaking the ancient vaults of the Kremlin," and Alexander and Maria Aleksandrovna, now the emperor and empress, gave visible signs of their satisfaction. ${ }^{37}$

The correspondent of Le Nord presented the diverse attire of the participants as a statement of the democratic and national character of the monarchy. Frock coats were more apparent than uniforms. The ladies of the court wore the Russian gown, with sarafany and kokoshniki. The emperor and the Grand Dukes appeared for the first time at a major function in the uniform of His Majesty's Rifles, the regiment formed by Nicholas I in 1853 out of the peasant militia from the imperial family's Moscow domains. The uniform of His Majesty's Rifles was in national style: wide sharovary over high boots, a Russian style kaftan, a black lambskin cap. "This purely Russian form of clothing very much became the tsar," Count G. A. Miloradovich wrote. ${ }^{38}$

The presence of Asian noblemen attested to their acceptance of the suzerainty of the Russian element in the empire. For the poet Fedor Tiutchev, who attended the ball as a chamberlain of the court, the masquerade expressed the Eastern character of Russia. It allowed him to imagine himself in the realm of dream-it was the dream of Russia embracing the East. Tiutchev saw old

36 Russkii khudozhestvennyi listok, No. 31 (November 1, 1856), 1-2; Cited also as part of Russell's report in "Sovremennaia letopis," Russkii Vestnik (September, 1856), 170.

37 Cited in V. V. Komarov, V pamiat' sviashchennogo koronovaniia Gosudaria Imperatora Aleksandra III i gosudaryni Imperatritsy Marii Fedorovny (St. Petersburg: Komarov, 1883), 31-2.

38 Ibid., 32-3; Graf G. A. Miloradovich, Vospominaniia o koronatsii Imperatora Aleksandra II kamer-pazha dvora ego velichestva (Kiev: Kievo-Pecherskaia Uspenskaia Lavra, 1883), 16-7; On the Imperial Rifles see E. E. Bogdanovich, Strelki imperatorskoi familii (St. Petersburg: E. Golike, 1899). 
aristocrats in costume he knew, including "quite authentic" Mingrelian, Tatar, and Imeretian princes in magnificent costumes, two Chinese, "living and real." "And two-hundred steps from these halls resplendent with light and filled with this crowd that is so contemporary lay the tombs of Ivan III and Ivan IV." He wondered how they would react if they saw this scene. "Ah, how much dream there is in what we call reality." 39

The capture of Shamil in August 1859 provided an early occasion to vaunt Russia's success as a western imperial power. The nobility of Tiflis (Tbilisi) heralded the event in an address to the viceroy of the Caucasus, Prince Alexander Bariatinskii, which they presented with illustrations of scenes of the recent campaign. "Europe is astonished to hear of the great deed that has just been achieved. She will appreciate Your works for the good of all humanity and will receive lovingly in her midst hundreds of thousands of people who have lived until now beyond the laws of citizenship and have recognized only one law-the might of the sword and arbitrariness." 40

The tribal chief was displayed as an ornament of empire, a living trophy of conquest and civilization in well-publicized appearances along his route from the Caucasus to Petersburg. Alexander brought him into his scenario of love, meeting him at Chuguev, embracing and kissed him. He invited Shamil to review troops at his side. In Kharkov, he was entertained with a circus and illuminations. Officials made sure to honor him as well, arranging celebrations of his arrival everywhere. When Shamil reached Petersburg, he was escorted to see the statue of his erstwhile foe, Nicholas I, and the sites of the city. ${ }^{41}$

Shamil and his family were installed at Kaluga, what Thomas M. Barrett describes as "a museum of the East" where Shamil, his sons, and sons-in-law appeared in full tribal dress-wondrous specimens from a lesser civilization, objects of curiosity for anthropological study. At the order of the War Minister, Dmitrii Miliutin, all officers passing through the town were obliged to visit him. Russkii khudozhestvennyi listok printed pictures of Shamil and his

39 I. S. Aksakov, Biografiia Fedora Ivanovicha Tiutcheva (Moscow: M. G. Volchaninov, 1886), 262-3; "Lettres de Th. I. Tjutsheff à sa seconde épouse née Baronne de Pfeffel," Starina i novizna XIX (1915): 160-1.

40 Russkii khudozhestvennyi listok, No. 3 (1860): 7.

41 See the excellent description of Shamil's reception in Thomas M. Barrett, "The Remaking of the Lion of Dagestan: Shamil in Captivity," Russian Review vol. 53, No. 2 (July 1994): 355-7. 
relatives. An article described the family customs of Dagestani tribesmen and Shamil's efforts to bring order to family relations among his people. ${ }^{42}$

Shamil, Barrett observes, captured the imagination of educated society and became "a striking example of the fruits of tsarist expansion." ${ }^{33}$ He represented the new phase of Russian expansion, when the empire evolved from an elite to a mass phenomenon. ${ }^{44}$ In the following decades, conquests in Central Asia and the Far East gave substance to the image of a national empire, whose people had a mission to rule lesser races in the East. In this respect, Russia had begun to emulate the colonial powers of the west, which had made empire a sign of national supremacy.

The interconnection between empire and sovereignty has had several significant implications for development of Russian government and political attitudes in the past century. First, it discouraged compromise in dealing with movements for political reform and representative government. Whereas no ruler easily bows to demands for popular sovereignty, monarchies that develop local traditions of sovereignty have proved more flexible in adapting to the nation-state. The Prussian king, later the German emperor, accepted a constitutional monarchy, which he succeeded in dominating and manipulating. For the Russian autocrat this was unthinkable. The imperial mentality limited his options for monarchical rule and created rigidities of governmental policy. Alexander II regarded representative government as certain to bring the downfall of the empire. He wrote to the heir, Nicholas Aleksandrovich, in 1865, "Constitutional forms on the model of the West would be the greatest misfortune here and would have as their first consequence not the unity of the State but the disintegration of the Empire into pieces" 45 (emphasis in original).

42 Ibid., 357; Russkii khudozhestvennyi listok (1860), No. 9, 27-29, No. 10, 31-33; (1861), No. 5, 17-18.

43 Barrett, "The Remaking of the Lion of Dagestan," 365.

44 On this development see the discussion by Alfred J. Rieber, "Russian Imperialism: Popular, Emblematic, Ambiguous," Russian Review vol. 53, No.2 (July 1994): 331-5.

45 GARF, 665-1-13, January 30, 1865. Alexander expressed the same view in a conversation with D. D. Golokhvastov in September, 1865. S. S. Tatishchev, Imperator Aleksandr II, ego zhizn'i tsarstvovanie (St. Petersburg: A. S. Suvorin, 1903), 1: 534 . 
By the same token, the imperial mentality contributed to a rigidity in dealing with national territories or groups, for the concept of monarchical sovereignty was so intertwined with the notion of the extent of empire that any loss of territory or diminution of control of territory threatened the prestige of the rule, diminishing sovereignty itself. In maintaining its authority over Poland and trying to strengthen its hold over Finland, the emperor was also acting in defense of the principal foundation of his autocratic power.

The identification of sovereignty with empire has made it difficult for Russian rulers, thinkers, and political activists to find a national tradition of Russian sovereignty that did not involve imperial dominion. Many of them have looked back to a Muscovy of the seventeenth century, pictured without conflict and devoid of attributes of empire. It was this type of historical mythology that governed the scenarios of power of the reigns of Alexander III and Nicholas II. However, a purely national conception of rule has proved difficult or impossible to reconcile with Russian conceptions and traditions of sovereignty. Even today, a national, democratic grounding for political authority_rather than authority used to express the grandeur of vast and irresistible force dominating other peoples-remains elusive and foreign to the Russian political tradition. 


\section{Signs of Empire: Exotic Peoples at Imperial Russian Coronations}

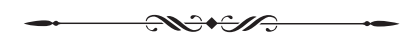

I mperial myths of Russian monarchy from the eighteenth to the twentieth century elevated the ruler and his servitors as bearers of sovereignty in Russia. They established a sacred or heroic origin of an empire, epitomized by a Russian state that absorbed both western and eastern noblemen into its ruling elite. In this way, empire was identified with the monarchical state. Yet imperial myths also projected an image of an empire of vast reaches that comprised a multitude and variety of peoples, what Victor Zhivov has described as "an ethnographic myth of empire." 1 The words "Asiatic" and "exotic" invested these peoples with an aspect of foreignness while they continued to be designated as Russian subjects-"poddannye rossiiskie." 2

The exotic peoples were both part of and foreign to the Russian state order-marginal elements, prompting responses of both fascination and fear, both idealization and disdain. The ambiguity of belonging to a continental empire where the boundaries between metropole and periphery were shifting and ill-defined gave rise to conflicting feelings of pride and unease toward the legacy of imperial rule over exotic peoples. When Peter the Great accepted the title of imperator in 1721 at the celebrations of the Peace of Nystadt, he avoided this issue. The historian Olga Ageeva has suggested that at this point "empire" meant little more than a state ruled by a monarch with the status and cultural

1 V. M. Zhivov, "Gosudarstvennyi mif v epokhu Prosveshcheniia i ego razrushenie v Rossii kontsa XVIII veka," in Vek Prosveshcheniia: Rossiia i Frantsiia; Vipperovskie chteniia (GMII im. A. S. Pushkina, 1989), 154.

2 Elena Pogosjan, "O zakone svoem i sami nedoumevaiut: Narody Rossii v etnograficheskikh opisaniiakh, sostavlennykh i izdannykh v 1770-1790-e gg." forthcoming, 1 . 
pretensions of an emperor, with little sense of empire as territorial expanse. Neither the renaming ceremony nor the later coronation album presented references to empire. ${ }^{3}$ But other attributes of empire-great extent and great variety of different peoples-figured at the time in sermons and in the performance of Peter's antic pageants, though not in the elevation of the emperor's image.

This paper will examine the interplay of these two themes as they emerged in the representations of the imperial coronation, the central ceremony of Russian monarchy. As I have elaborated in Scenarios of Power, these representations displayed the hierarchy of state, designating who belonged to the elite, and dictated the manners, dress, and forms of decorum its members were to adopt. The ceremonies and their representations in coronation albums and official accounts gave a sense of what empire meant and whom it included. The coronation thus at once celebrated and defined the nature of Russian monarchy. Both Russians and foreign observers looked to the coronation as a sign of the nature, stability, and extent of the monarch's power. Such a ceremonial mentality-understanding reality in terms of presentation and representation-persisted in accounts by both native and foreign observers of Russian monarchy, until its demise.

\section{Eighteenth Century Coronations: The Noble, Enlightened Elite}

Peter the Great created the Russian imperial coronation in 1724, when he crowned his wife Empress Catherine I and replaced the Muscovite coronation, venchanie na tsarstvo, with new rites and regalia borrowed from the west, thus creating the imperial Russian koronatsiia. The ceremonies of crowning and anointment were followed by European-style secular celebrationsreceptions, balls, and fireworks displays. These innovations gave ceremonial expression and confirmation to the European cultural identity of the Russian tsar, now renamed emperor and the Russian noble elite who served him. ${ }^{4}$

3 O. G. Ageeva, "Imperskii status Rossii: $\mathrm{k}$ istorii politicheskogo mentaliteta Russkogo obshchestva nachala XVIII veka," in Tsar' $i$ tsarstvo $v$ russkom obshchestvennom soznanii (Moscow: In-t rossiiskoi istorii RAN, 1999), 120, 123.

$4 \quad$ B. A. Uspenskii, Tsar' i imperator: Pomazanie na tsarstvo i semantika monarshikh titulov (Moscow: Iazyki russkoi kul'tury, 2000), 48. 
Catherine I's coronation in 1724 presented the Russian state as little more than the Petrine elite. The procession to the Assumption cathedral, led by a new western style guards' regiment, Cavalier-Guards, comprised leading figures in the court, military, and civil administration, and the "national nobility" (shliakhetstvo natsional'noe), but no representatives of subject nationalities. It was a display of the solidarity of the leading figures of the Petrine state. ${ }^{5}$

The celebration presented a spectacle of uniformity of those who adopted the forms of service, the way of thinking, and the manners and dress of the westernized monarchy. The uniformity of appearance corresponded to the uniformity (Gleichschaltung) of institutions, and laws, that Peter contemplated and Mark Raeff has described as the rationalistic ideal of the eighteenthcentury cameralism-"the basic social uniformity that was considered necessary for harmony and to assure security and stability."6

Coronation ceremonies of the first half of the eighteenth century presented increasingly elaborate displays of the order and uniformity of the Russian state. Few representatives of other national or social groups appeared, and their presence was made inconspicuous. At the coronation of Anna Ioannovna in 1730, the representatives of Baltic Towns and the nobility of Estland and Lifland appeared as a deputation in the procession to the Uspenskii Sobor. The lavish album commemorating Elizabeth Petrovna's coronation in February 1742 mentions the same groups, as well as deputations of Little Russian merchantry, Cossack starshiny (elders) and officers in the description of the procession to the cathedral. The engravings of the processions in both coronation albums, however, make no physical distinction between these groups and the others marching in the procession. They are all alike, and all wear European dress. ${ }^{7}$ The grand entry of Empress Elizabeth into the city of Moscow, a central festive event in all future coronation celebrations, displays the St. Petersburg elite entering the capital. National delegates do not appear

Opisanie koronatsii e.v. Ekateriny Alekseevny, 19-25.

6 Marc Raeff, Political Institutions and Ideas in Imperial Russia (Boulder, CO: Westview, 1994), 146.

7 Opisanie koronatsii e.v. imp., i samoderzhtsy vserossiiskoi Anny Ioannovny.... (St. Petersburg: Senate press, 1730), 8-18; Obstoiatel'noe opisanie torzhestvennykh poriadkov blagopoluchnogo vshestviia $v$ tsarstvuiushchii grad Moskvu i sviashchennogo koronovaniia imp. Elizavety Petrovny (St. Petersburg: Imp. Ak. Nauk, 1744), 40-9, Plate 26. 
in the illustrations. The elaborate engravings by Ivan Sokolov depict the figures of nobility, court, and state with identical faces and dress, within the individual rank or category. The engraving of the procession to the Assumption Cathedral shows the same uniformity of dress of the highest elite and facial characteristics as they proceed to the coronation rites. ${ }^{8}$

On the other hand, figures of exotic peoples had been prominent and startling in pageants during the reigns of Peter and Anna Ioannovna. The elite onlookers regarded them as amusing and intriguing objects of ethnographic curiosity. The literary scholar Elena Pogosjan has analyzed Peter's pageant on the Treaty of Nystadt and the masquerades Anna staged for the celebration of the 1740 treaty with Turkey after the victory at Khotin. In both cases, an array of "Russian subjects" appeared dressed in native dress-Laps, Samoeds, Kalmyks, Iakuts, Chuvashs, and others, some of them merely performers in the costumes of those peoples. The displays reenacted legends, particularly about Siberian peoples that confirmed tales of Herodotus and Pliny and evoked an imaginary empire composed of strange and wondrous oddities, complementing Peter's museum of monsters and freaks. Many observers took them as attributes of the actual as well as the imaginary empire, confirming the emperor's image of ruler of diverse and numerous peoples. ${ }^{9}$

These figures, imagined and real, were not allowed to intrude into the sacred precincts of the Russian coronation in the first half of the eighteenth century. Exotic peoples are mentioned only in passing in the coronation descriptions (Opisaniia), as participants in audiences after the rites to congratulate the empresses. Anna's coronation album describes audiences with Georgian and Militinskii princes, and the (Oriental) Muganskii and Chinese (Kitaiskii) "Khans." ${ }^{10}$ Elizabeth held audiences with Asian princesKalmyks, Udins, Kirghiz, Bashkirs, and Armenians, Don and Iaik Cossacks with their starshiny, in addition to the Caucasian dignitaries mentioned in Anna's album. ${ }^{11}$ Their audiences do not appear among the illustrations. The various nationalities were not viewed as constituent elements of the Great

8 Obstoiatel'noe opisanie... koronovaniia imp. Elizavety Petrovny, 6-9, Plate 5.

9 Elena Pogosjan, ““I nevozmozhnoe vozmozhno”: svad'ba shutov v ledianom dome kak fakt ofitsial'noi kul'tury," Trudy po russkoi i slavianskoi filologii: Literaturovedenie (Tartu: Tartu Ülikooli Kirjastus, 2001), 4: 90-109.

10 Opisanie koronatsii... Anny Ioannovny, 44-5.

11 Obstoiatel'noe opisanie... koronovaniia imp. Elizavety Petrovny, 110-5. 
Russian state-Rossiiskoe Gosudarstvo-and therefore did not figure in its central, emblematic ceremony.

In the course of the eighteenth century, the image of the empire broadened from a state ruled by an emperor to a land consisting of large expanses, what Willard Sunderland called "territorial consciousness." The numerous expeditions begun by Peter the Great and pursued on a larger scale by Catherine the Great resulted in a mapping of the empire. It also produced a new consciousness of the peoples inhabiting the empire and a growing corpus of information about them. ${ }^{12}$ As a result, the participants in the coronation began to include a few representatives outside the core group of the Petrine state who epitomized the East rather than the West, the wild and colorful elements of the border regions who did not belong to the Westernized elite of the empire.

The coronation of Catherine II included a few representatives of empire. Cossack leaders from Little Russia, as members of the Russian nobility, took a prominent part in the proceedings. Cossacks, of course, were Russians rather than "Asiatics," but they were Russians who resembled steppe warriors and their presence as the frontiersman of the empire attested to Russian expansion to the south and the east and later added a dashing and exotic element to the imperial entries. The opening of the description of Catherine's coronation told how the elders of the Zaporozhets Cossack host, led by their hetman Kirill Razumovskii-a former lover of Catherine-greeted the empress at her suburban palace as their source of joy and their "true mother."13 Deputies of the Zaporozh'e, Don, and other Cossack hosts marched to the Assumption Cathedral in the entry procession, making up four divisions of the procession, as did representatives of the Baltic merchantry and nobility. The Opisanie mentions her audiences with Cossack and Caucasian deputies, as well as of "Asiatic peoples," at the audiences on the days after the coronation. ${ }^{14}$

During Catherine's reign, ethnographic information gathered during the various expeditions of Catherine's reign was made known by Johann Georgi

12 See Willard Sunderland, "Becoming Territorial: Ideas and Practices of Territory in 18 ${ }^{\text {th}}$-century Russia," in Russian Empire: Space, People, Power, 1700-1830, ed. Jane Burbank, Mark Von Hagen, and Anatolyi Remnev (Bloomington, IN: Indiana University Press, 2007), 33-66.

13 Opisanie Vshestviia v Moskvu i Koronovaniia Gosudaryni Imperatritsy Ekateriny II, printed in KFZ, 1762, vol. 63 (St. Petersburg, 185?). The Opisanie was not published at the time. The illustrations were published in 1796.

14 Opisanie Vshestviia....imp. Ekateriny II, 7-11, 59-61, 136-7, 141-2, 146. 
in his landmark four-volume Description of All Peoples Inhabiting the Russian State (Opisanie vsekh obitaiushchikh v Rossiiskom gosudarstve narodov). ${ }^{15}$ Georgi confirmed that the Russian empire was the most diverse of empires. "Hardly any other state in the world possesses such a great variety of different nations, survivals of peoples, and colonies as the Russian state." 16 In Catherine's scenario, the diversity of the population explicitly attested to the imperial character of rule. It was an attribute of the enlightened ruler-the heir to the greatness and might of ancient Rome. Catherine took great pride in citing the numerous territories she ruled. In the preface to the Charter of the Nobility, she enumerated thirty-eight provinces and lands under her rule. ${ }^{17}$ The accounts of her trip to New Russia and Crimea, as well as the verse that glorified it, compared Russia to ancient Greece and rhapsodized about the many peoples in the new territories ruled by the Russian empress. ${ }^{18}$

In Catherine's reign, these peoples were understood as objects of the monarch's enlightenment project. ${ }^{19}$ Georgi and other scholars of the Academy Expedition believed that all peoples possessed reason, but that reason developed only through education, imposed from above. Enlightenment would bring the elimination of national traits. Those at earlier stages, Georgi wrote, the Tungus, the Chukchhi, were ignorant, simple, and possessed a beguiling innocence. It was "the uniformity of State organization" that could transform all nationalities, including ethnic Russians, into educated, Europeanized Russians. The state, Georgi concluded, was "leading our rude Peoples by giant steps toward the common goal of general enlightenment in Russia, of a wonderful fusion

15 I. G. Georgi, Opisanie vsekh obitaiushchikh v Rossiiskom gosudarstve narodov (St. Petersburg: Imperatorskaia Akademiia Nauk, 1779), 4 vols.; Nathaniel Knight, "Constructing the Science of Nationality: Ethnography in Mid-Nineteenth Century Russia” (PhD Dissertation, Columbia University, 1995), 32-40; S. A. Tokarev, Istoriia russkoi etnografii (Moscow: Nauka, 1966), 103-10.

16 Tokarev, Istoriia russkoi etnografii, 103

17 Andreas Kappeler, Russland als Vielvölkerreich: Entstehung, Geschichte, Zerfall (Munich: Beck, 1992), 99.

18 On Catherine's trip, see Andrei Zorin, Kormia dvuglavogo orla...: Literatura $i$ gosudarstvennaia ideologiia $v$ Rossii $v$ poslednei treti XVIII-pervoi treti XIX veka (Moscow: NLO, 2001), 97-156; Andreas Schönle, "Garden of the Empire: Catherine's Appropriation of the Crimea," Slavic Review vol. 60, No. 1 (Spring 2001): 1-23.

19 Elena Pogosian shows that Georgi's survey was prompted by the Academy of Sciences program of 1778 , which anticipated a process of enlightenment among the various nationalities. Elena Pogosian, "O zakone svoem...," 3-4. 
of all into a single body and soul, and of creating, as it were, an unshakable Giant that will stand for hundreds of centuries." It is indicative that the one national group that Georgi omitted from his broad survey was the Russians; they did not represent for him a people "inhabiting the Russian state," nor governed by it, but representing constituents of the Russian state itself. When Russians were introduced in the second edition, apparently not by Georgi himself, they were characterized as a "ruling nation." 20

The multi-ethnic westernized Russian nobility (Rossiiskoe dvorianstvo) exemplified the ruling elite of this nation. Russian noblemen, Baltic Germans, Cossack leaders, Little Russian noblemen, and representatives of Muslim khanates shared a common ethos of service to the Russian monarch and a common European culture that represented the principal bonds uniting the empire. ${ }^{21}$ An account of the coronation of Alexander I in 1801 by a nobleman, M. N. Makarov, written in the sentimental mode of the late eighteenth century, expressed the sense that religion and reason were transforming members of the nationalities into loyal Russian noblemen. Makarov observed a Kalmyk deputy crossing himself and weeping at the sight of the Dormition Cathedral. The Kalmyk, Makarov believed, was on his way to becoming an Orthodox Russian and inspired him to think that "the time will come when the light of Christ will dawn upon the wearer of the turban and the heathen."22

\section{Coronations as Expressions of National Unity}

Eighteenth-century imperial scenarios precluded national distinctions: exotic peoples were objects of curiosity and investigation, to be transformed into subjects once the imperial project of enlightenment had wrought its transformations. Nineteenth-century coronations, beginning with the crowning of Nicholas I in 1826, incorporated them as evidence of the domination of a nation. The distinctive national character of the Russian state

20 Opisanie vsekh obitaiushchikh v Rossiiskom gosudarstve narodov, 1: ix; Iurii Slezkine, "Naturalists versus Nations: Eighteenth-Century Russian Scholars Confront Ethnic Diversity," in Russia's Orient: Imperial Borderlands and Peoples, 1800-1917, ed. Daniel R. Brower and Edward J. Lazzerini (Bloomington, IN: Indiana University Press, 1997), 38-9; Knight, "Constructing the Science of Nationality," 32-40.

21 Kappeler, Russland als Vielvölkerreich, 135-8.

22 M. N. Makarov, "Vospominaniia o koronatsii Imperatora Aleksandra I," Pamiatniki novoi russkoi istorii (Moscow: Maikov, 1871), 1: 64, 75-9. 
was its command of the obedience of it subjects, whose number and diversity attested to the Russian's tsar's sway. The non-Russian nationalities made their first appearance at Nicholas I's coronation as spectators of the entry procession to Moscow. They participated in the events surrounding and following the coronation, described in the semi-official account published by the artist and travel writer Pavel Svin'in. ${ }^{23}$

Svin' in made clear that the various "Asiatic peoples" remained in the background during the coronation rituals as spectators enthralled by the display of the Russian people's popular devotion to their sovereign. He remarked on the presence of deputies from Asiatic peoples among the Senators and other officials in the grandstands on Kremlin Square. Then he elaborated on the beautiful folk costumes of the Russians, of the Circassians in their brilliant belts and pearls, and the Kirghiz, Kabardins, Georgians, Armenians, Kalmyks all in military costumes and exulting at the appearance of the emperor. Svin'in presented this assemblage as a microcosm of the empire. "It seemed that everything attractive and brilliant in Russia was gathered here." 24

All of Svin'in's accounts made clear the preeminence of the Russian participants. In his eyes, Russians were distinguished for their exceptional beauty. He described comely Moscow women in plumed hats, the veils and shawls of other Russian national costumes, and Russian merchants in sibirki. Then he enumerated the various Eastern nationalities, whose variety augmented the national myth. ${ }^{25}$ All united in their love for the imperial family. Those on the square, dressed in native costumes, bore witness to the supremacy of the imperial elite, whose members wore European uniforms and gowns that set them above the national groups.

The masquerade revealed the same relationship between Russians and nationalities. The event was attended by nearly 5,000 guests, including members of the nobility, merchantry, and native leaders. Viewing the scene from the balcony, the author saw the ladies' gowns sparkling in silver and gold. Svin'in

23 On the symbolic statements of official nationality see my article, "Ofitsial'naia narodnost' i natsional'nyi mif," in Rossiia/Russia: kul'turnye praktiki v ideologicheskoi perspektive, Rossiia, XVII-nachalo XX veka, ed. N. N. Mazur, No. 4 [11] (1999): 233-44.

24 "Istoricheskoe opisanie Sviashchennogo Koronovaniia i Miropomazaniia ikh Imperatorskikh Velichestv Gosudaria Imperatora Nikolaia Pavlovicha i Gosudaryni Imperatritsy Aleksandry Feodorovny," Otechestvennye zapiski (1827), 31: 369-73. Ibid., 31: 371-3. 
described "Asian ladies" (aziattsy), who wore "sumptuous furs and valuable brocades," but he was most preoccupied by the dress of the Russian women "dressed in Russian sarafans, with Russian bands [poviazki] and kokoshniki on their heads, bathed, one might say, in pearls and diamonds." As they danced the polonaise, their "patriotic attire" (otechestvennyi nariad) transported him back to the times "when Russians were not ashamed of their splendid dress, proper for the climate, having a national character, and incomparably more beautiful than foreign dress." To confirm the universal acceptance of this "truth," Svin'in cited the opinion of an "enlightened foreigner," who preferred these ladies to those dressed in the latest European fashion. ${ }^{26}$

The coronation album, published in Paris in 1826, also presented the masquerade as an image of empire. The author, one Henry Graf, wrote, "It seemed to have reunited everything that Europe and Asia had to offer in beauty, wealth, and pomp." ${ }^{27}$ A plate showed Muslim delegates from the Caucasus in the stands during the people's feast on the grounds of Devich'e Pole, the first illustration of Muslim subjects in a coronation album (Figure 1).

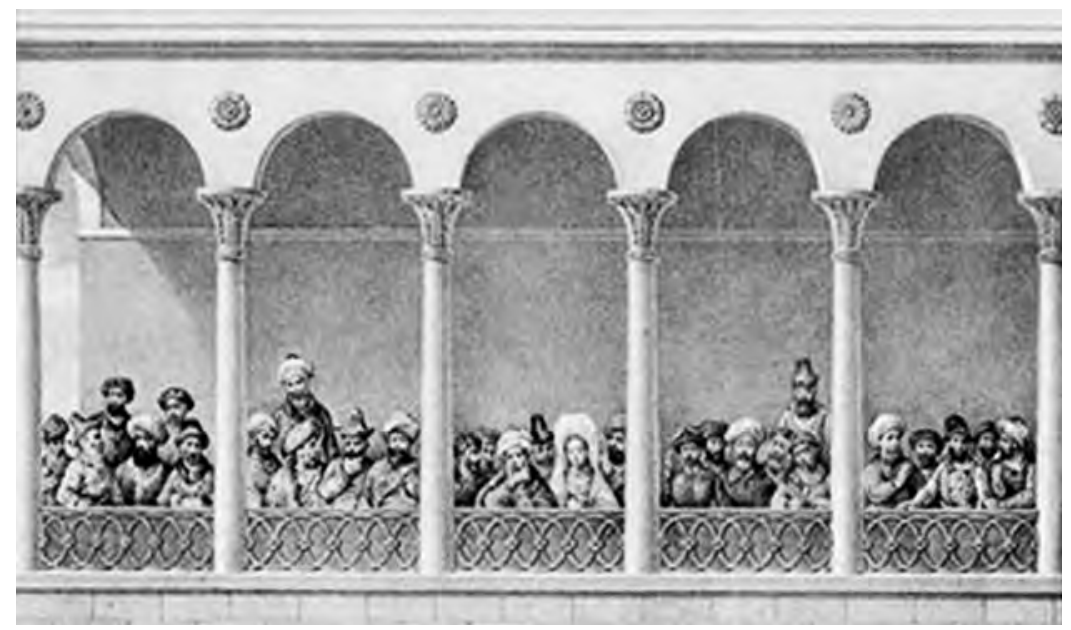

Figure 1-Muslim Delegates from the Caucasus. Vues des cérémonies les plus intéressantes du couronnement de leurs majesties imperials l'empereur Nicholas Ier et l'impératrice Alexandra à Moscou. Slavic and Baltic Collection, New York Public Library.

$26 \quad$ Ibid. (1827), 32: 26-34.

27 Vues des cérémonies les plus intéressantes du couronnement de leurs majestés Impériales l'empereur Nicholas Ier et l'impératrice Alexandra à Moscou (Paris: Didot, 1828), 11. 
Svin'in carried the condescending ethnographic conventions of Georgi into his coronation narrative. The "Asiatic peoples" were charming, diverting primitives, who attested to the variety of the empire and its civilizing mission. The distance remained, if it had not grown even larger between the imperial court, uplifted by the victory over the French and international revolution. In the imagery of Nicholas's reign, the empire was dominated by the image of a mass of Russians, with no distinction between Little Russians, White Russians, Great Russians, and others who had been assimilated into the official elite. Michael Pogodin wrote, "Occupying an expanse that no other monarchy on earth has ever occupied, neither the Macedonian, nor the Roman, Arabic, the Frankish or the Mongol, it is settled principally by tribes who speak one language, have, consequently, one form of thought [obraz mysli], practice one Faith, and like an electronic circuit, quaver at a single contact." 28 The monarchy was thus identified with a Great Russian nation and the nationalities reduced to ornaments of its power and glory.

The coronation of Alexander II in 1856 marks a further development of the image of a national empire, introduced in Nicholas I's reign. The coronation celebrated the successes of imperial expansion in previous decades, compensating for the humiliating Russian defeat in the Crimean War. Now, in the context of Alexander's "scenario of love," the nationalities were as if drawn into the mythical image of a nation adoring the sovereign. The emperor's coronation entry displayed the loyalty and submission of the people Russian armies had succeeded in conquering in the Caucasus, Central Asia, and Middle Asia. For the first time, representatives of Asiatic peoples marched with the Russian elite.

The coronation entry showing the multi-national character of the Russian empire was played to an international audience, including the many representatives of the western press attending the event. The coronation album, published in French as well as Russian, described a cavalcade of empire, a display of diversity, color, and extent, departing from the ordered reserve of previous coronations. Behind the horsemen of the "Black Sea Cossacks" rode those from "peoples subject to Russia" (podvlastnykh Rossii narodov), the coronation album noted. It then went on to enumerate those who "were

$\overline{28}$ M. P. Pogodin, Istoriko-kriticheskie otryvki (Moscow: A. Semen, 1846), 2. 
distinguished by their picturesque attire": Gurishtsty, Mingrel'tsy, Kurds, Tatar beks, and representatives of Cherkessian tribes. "The manly look of the riders and the rich saddles of the steeds drew especial attention to this part of the procession." 29 The emphasis was on the colorful warriors, the empire as painting. A print by Vasilii Timm depicts the first part of the procession (Figure 2). "Deputies of Asian peoples under Russian authority" on the upper right follow the emperor's personal convoy, a squadron of Black Sea Cossacks and the "aristocratic nobility" (znatnoe dvorianstvo). An inset in the album showed the dashing figures of the Caucasian deputies (Figure 3).

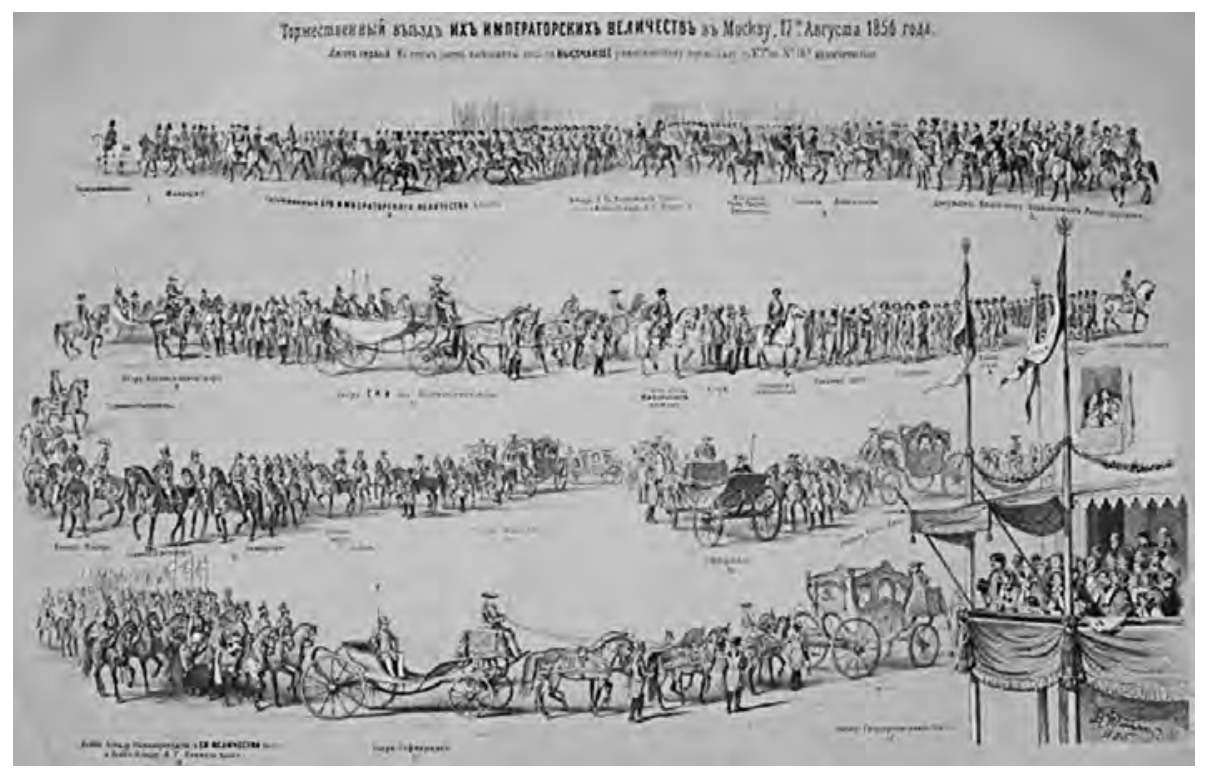

Figure 2-Triumphal Coronation Entry to Moscow of Alexander II and Maria Aleksandrovna. Russkii khudozhestvennyi listok, 1856.

The press, both domestic and foreign, took up this theme. The reporters presented the dress and the manner of these horsemen as signs of the varied peoples of the empire, its vitality and vast reaches. Russian writers in the semiofficial Russkii khudozhestvennyi listok, foreign correspondents from the

29 Opisanie sviashchenneishago koronovaniia Ikh Imperatorskikh Velichestv Gosudaria Imperatora Aleksandra Vtorago i Imperatritsy Marii Aleksandrovny Vseia Rossii (St. Petersburg: Ak. Khudozhestv, 1856), 15. 


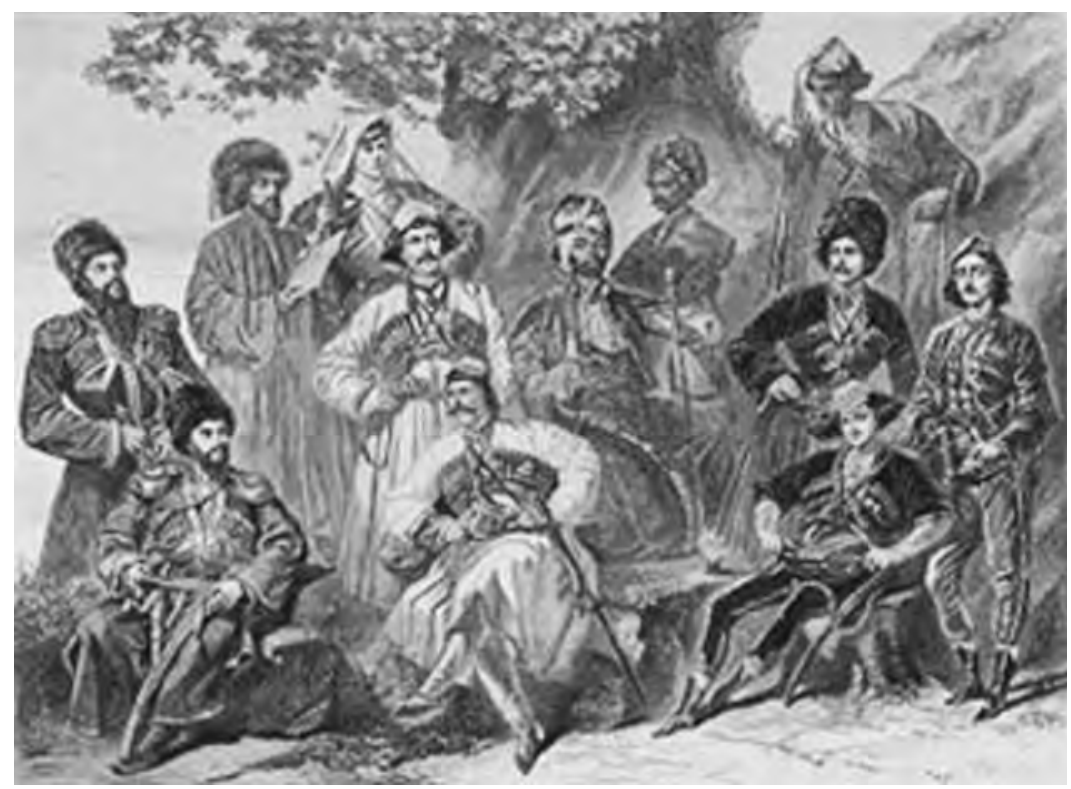

Figure 3-Caucasian Deputies at the Coronation of Alexander II. Opisanie sviashchenneishago koronovaniia... imperatora Aleksandra Vtorago i imperatritsy Marii Aleksandrovny vsei Rossii. Slavic and Baltic Collection, New York Public Library.

Russian mouthpieces abroad, L'Indépendance Belge and Le Nord, and William Russell of the London Times reiterated these themes. Russkii khudozhestvennyi listok described the deputies of Asiatic peoples as "tangible proof of the vastness of our state, which some justly call a special kind of planet." Their appearance in procession "eloquently convinced everyone of the one whose power they recognize, whom they had come from their own lands to greet."30

Foreigners' reports cited in Russkii vestnik and Russkii khudozhestvennyi listok described the pageant of Eastern types in native costumes: Bashkirs, Cherkess, Tatars, Armenians, Georgians, different varieties of Cossacks. William Russell marveled, "What a recollection of the majesty and might of Russia will these people bring back to their distant tribes! ... They flashed by us in all of their brilliance, a dream from A Thousand and One Nights." L'Indépendance Belge observed the vitality of the deputies from the Eastern peoples, "these proud warriors, with bold movements, in glittering eastern

$\overline{30}$ Russkii khudozhestvennyi listok, No.29 (October 10, 1856): 1. 
dress." Their "half-tamed" horses proved the civilizing force of the state: they were "a striking symbol of the triumph of the power of the well-ordered over the power of disorder." 31

It was the love of the Russian people, the press emphasized, that gave their sovereign the might to conquer and rule an empire. A Russkii kbudozhestvennyi listok columnist pointed out that all the foreign correspondents were amazed by the ceremony's lavishness and splendor, but, he thought, they had not completely expressed their idea: that Russia possessed "secret deposits of gold and gems, unknown to the world." These jewels consisted of the unifying love of the people. The author turned the pageant into a symbolic equivalent of popular sovereignty. "And that is true! Russia has valuables, lost by the decrepit powers of the West. The young feeling of infinite love and devotion for the anointed of the Lord and for the sovereign guardians of the earthly fate of the beloved fatherland has been preserved in Russia." 32 This feeling, moreover, was religious in character. The author approvingly quoted William Russell's comment that "the piety and deep religious feeling of the Monarch and his people, their visible humility before God, recalled the faith and ceremonies of past centuries, and greatly overshadowed the appearance of military power of this state." 33 It was the Orthodox faith of the Russian people that empowered their sovereign to rule and captivate the feelings of an empire.

The masquerade in the New Kremlin Palace was a festive display of the unity of empire and nation. Gone was the condescension of Svin'in's account. The correspondent of Le Nord described an emperor enjoying a rapport with all his people. In no other court, he marveled, would the doors be thrown open to common people. No democratic country would permit such a "mixture of citizens of all estates." He presented the diverse attire of the participants as a statement of the democratic and national character of the monarchy. Frock coats were more apparent than uniforms. The ladies of the court wore the Russian gown, with sarafans and kokoshniki. The emperor and the Grand Dukes appeared for the first time at a major function in the uniform of His Majesty's Rifles, the regiment formed by Nicholas I in 1853 out of the peasant

\footnotetext{
31 "Sovremennaia letopis', Russkii vestnik (September 1856): 170-71; Russkii khudozhestvennyi listok, No. 27 (September 20, 1856): 1-2.

32 Russkii khudozhestvennyi listok, No. 31 (November 1, 1856): 1-2.

33 Cited also as part of Russell's report in "Sovremennaia letopis', Russkii vestnik (September 1856): 170. Italics in original.
} 
militia from the imperial family's Moscow domains. His Majesty's Rifles wore a uniform in national style: wide sharovary over high boots, a Russian style kaftan, a black lambskin cap. ${ }^{34}$

The love of the Russian people for the sovereign was projected on the other people of the empire, envisioning an empire united by mutual affection. The participation of Asian noblemen at the ball attested to their acceptance of the suzerainty of the Russian element in the empire. For the poet Fedor Tiutchev, who attended as a chamberlain of the court, the masquerade expressed the Eastern character of Russia. It allowed him to imagine himself in the realm of dream-the dream of Russia's embracing the East. Tiutchev saw old aristocrats in costume he knew besides "quite authentic" Mingrelian, Tatar, Imeretian princes in magnificent costumes, and two Chinese. "And twohundred steps from these halls resplendent with light and filled with this crowd that is so contemporary lay the tombs of Ivan III and Ivan IV." He wondered how they would react if they saw this scene. "Ah, how much dream there is in what belongs to reality," he wrote. ${ }^{35}$

The coronation ushered in a period of good feelings, accompanying the spirit of reforms, expectations that the reforms would heal the rift between state and society, tsar and people, with the deeds of a beneficent monarch. The image of the Russian people united in dedication to their monarch now was extended to include the nationalities of the empire. Indeed, one of the reasons for including the national participants was to encourage their devotion to the emperor. V. V. Grigor'ev, who was serving in Orenburg at the time of the coronation, arranged to have several Kirghiz deputies invited. In addition to the effect of their colorful costumes, he emphasized the "governmental significance" of their presence. "I have no doubt that this measure will be ten times more effective in instilling a favorable disposition towards and respect for Russia in the members of the [Kirghiz] horde than ten military

$\overline{34}$ V. V. Komarov, V pamiat' sviashchennogo koronovaniia Gosudaria Imperatora Aleksandra III i gosudaryni Imperatritsy Marii Fedorovny (St. Petersburg, 1883), 313; Graf G. A. Miloradovich, Vospominaniia o koronatsii Imperatora Aleksandra II kamer-pazha dvora ego velichestva (Kiev: Kievo-Pecherskaia Uspenskaia Lavra, 1883), 16-7; On the Imperial Rifles see E. V. Bogdanovich, Strelki imperatorskoi familii (St. Petersburg: R. Golike, 1899).

35 I. S. Aksakov, Biografiia Fedora Ivanovicha Tiutcheva (Moscow: M. G. Volchaninov, 1886), 262-3; "Lettres de Th. I. Tjutsheff a sa seconde épouse née Baronne de Pfeffel," Starina i novizna XIX (1915): 160-1. 
expeditions to the Steppe and all possible circulars from the Commission." 36 The coronation album singled out the Kirghiz for their skills at falconry, which they displayed on a hunt with the tsar illustrated in the album (Figure 4).

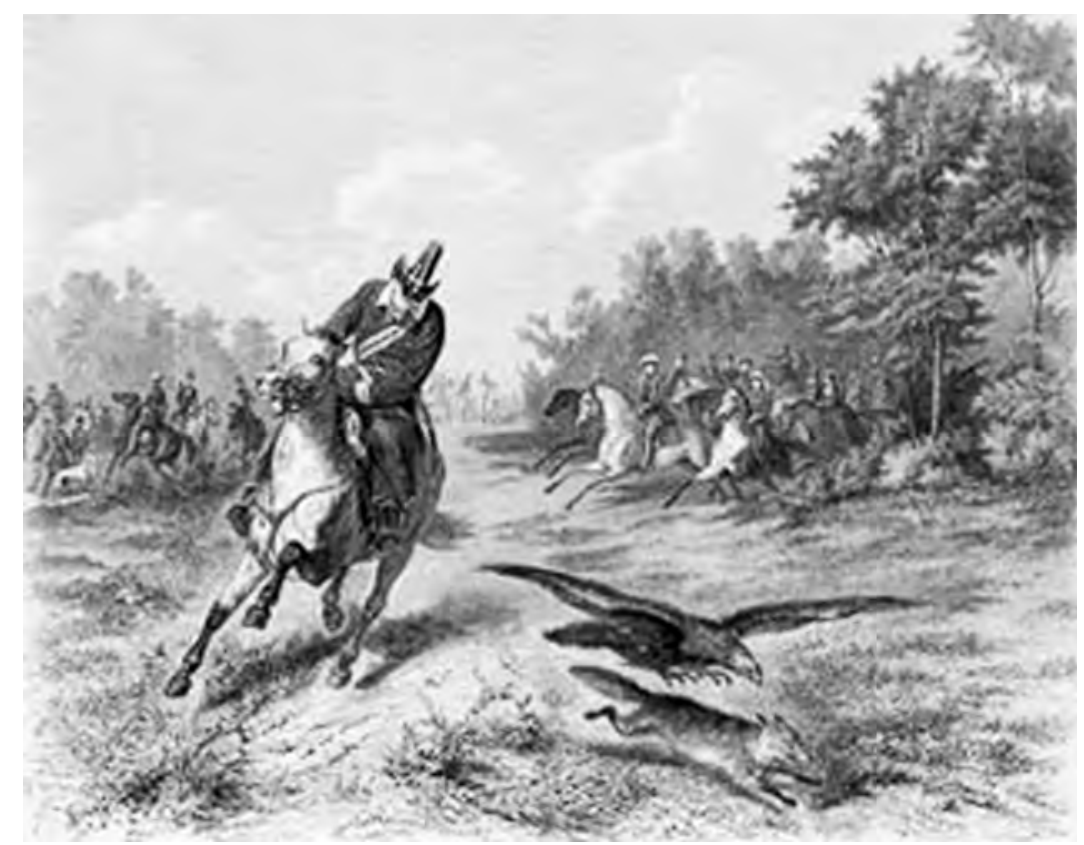

Figure 4-Kirgiz Huntsman-Coronation Album of Alexander II. Opisanie sviashchenneishago koronovaniia... imperatora Aleksandra Vtorago i imperatritsy Marii Aleksandrovny vsei Rossii. Slavic and Baltic Collection, New York Public Library.

The focus on the Caucasian horsemen was indicative of the fascination of the Russian public with the war against Shamil in the Caucasus and the figures of daring, primitive tribesmen fighting for independence and dignity. ${ }^{37}$ After Shamil's capture in August 1859, the emperor brought the fierce adversary, the fierce leader of the Chechens and other mountain peoples, into his scenario of love. He received him as a friend and exhibited him at balls and

36 N. I. Veselovskii, Vasili Vasil'evich Grigor'ev po ego pis'mam i trudam, 1818-1881 (St. Petersburg: A. Transhel', 1887), 146. I thank Nathaniel Knight for this reference.

37 More than thirty books on Shamil and the Caucasus were published between 1854 and 1860. Kappeler, Russland als Vielvölkerreich, 149. On the fascination with the Caucasus see Susan Layton, "Nineteenth-Century Mythologies of Caucasian Savagery," in Russia’s Orient, 80-99. 
parades, as a living trophy of conquest. When Alexander met Shamil at the military camp at Chuguev in Kharkov province, the newspaper Syn otechestva reported that he embraced and kissed his captive and invited him to wear his sword during the review of troops at his side. Shamil's biographer wrote, "The former Imam, astonished by this tenderness, this soft, ineffably kind greeting, the like of which he had never heard, understood at this moment, the true majesty of the mighty tsars...." The ruler of Russia "gave the wild man of the mountains a touching example of dealing with one's foe." Shamil later recalled the episode with tears in his eyes. ${ }^{38}$

The sense of imperial unity was a prominent theme in Michael Katkov's Moskovskie vedomosti. He described a widespread sense of imperial solidarity awakened by the Polish uprising of 1863. Ivan Babst and Constantine Pobedonostsev, accompanying the heir, Nicholas Aleksandrovich, on a trip through the provinces, described how various national groups joined the Russian people in their support for the emperor. On the steps of the governor's house in Astrakhan, the heir at their side, they beheld a strange motley throng in national costumes, among them Greeks, Armenians, Persians, Kalmyks and Tatars. Though there were few Russian faces in the crowd, the authors still felt themselves in Russia, "in one of the remote regions of a great tsardom, united by the powerful bond of state power and a consciousness of state unity." There, amongst the mixture of "dress, faces, and dialects," the basic tone was provided by the "founding and gathering element of the Russian tribe." 39

The mission of enlightenment persisted, inspiring the expectation that the education of native elites would contribute to the unity and progress of the state. Rather than an effort to subject all nationalities to the same laws and institutions, assimilation now would take the form of instilling a spirit of imperial citizenship (grazhdanstvennost') in the populations of regions such as the Caucasus, Tatarstan, Bashkiriia, and Turkestan. ${ }^{40}$ Officials and generals

38 Thomas M. Barrett, "The Remaking of the Lion of Dagestan: Shamil in Captivity," Russian Review vol. 53, No.2 (July 1994): 353-56; M. N. Chichagova, Shamil' na Kavkaze i v Rossii (St. Petersburg: S. M. Muller and I. Bogel'man, 1889), 107. See also Austin Jersild, Orientalism and Empire: North Caucasus Mountain People and the Georgian Frontier, 1845-1917 (Montreal and Kingston: McGill-Queens University Press, 2002), 110-25.

39 K. P. Pobedonostsev and I. Babst, Pis'ma o puteshestvii gosudaria naslednika tsesarevicha po Rossii ot Peterburga do Kryma (Moscow: Grachev, 1864), 356-7.

40 See Dov Yaroshevskii, "Empire and Citizenship," in Russia’s Orient, 69-71. 
sought to spread the ideas of citizenship to the Caucasus by introducing schools, opera houses, and the notion that the natives could be transformed into loyal servants of empire. This policy produced such native leaders as Hasan Melikov-Zardobi and I. Gasprinskii. However, the imperial Russian state soon proved inhospitable to native leaders, who had their own ambitions and lacked the noble credentials and loyalties of earlier members of the elite. ${ }^{41}$

\section{Coronations as Expressions of Colonial Domination}

The failure and unwillingness to integrate the national leaders into the Russian governing elite, as well as the refusal of Russian rulers to countenance public participation of any kind, resulted in a new national myth expressed in the scenario of Alexander III. His coronation, dominated by a spirit of hostility toward the reform efforts of the previous decades, presented a third image of empire-Russia as colonial power. Following European and American examples, Russians began to cast themselves as Herrenvolk, bringing civilization to those they regarded as lesser peoples, particularly aziattsy. ${ }^{42}$ The national myth, elaborated at the coronation, elevated a notion of an ethnic, Orthodox, ruling elite, conquerors, and therefore, like other European powers, rulers of native peoples. The emperor appears in the illustrations of these events in the national dress he favored-Russian hat and boots. ${ }^{43}$

The forty-nine foreign correspondents, invited at government expense to attend the festivities, transmitted the images of the national empire to their readers. While watching the entry into Moscow on May 10, 1883, the English correspondent Charles Lowe felt he was witnessing a Roman triumph. He caught sight of a "scarlet crowd" in the distance that looked like

$41 \quad$ Austin Lee Jersild, "From Savagery to Citizenship: Caucasian Mountaineers and Muslims in the Russian Empire," in Russia's Orient, 101-14; Edward J. Lazzerini, "Local Accommodation and Resistance to Colonialism in Nineteenth-Century Crimea," in idem, 169-87.

42 Kappeler, Russland als Vielvölkerreich, 264-6; see Jersild, Orientalism and Empire, 126-44.

43 Opisanie sviashchennogo koronovaniia Ikh Imperatorskikh Velichestv Gosiudaria Imperatora Aleksandra Tret'ego i Gosudaryni Imperatritsy Marii Fedorovny Vseia Rossii (St. Petersburg: Eksped. Gos. Bumag, 1883). 
a British regiment. But it turned out to be the emperor's personal convoy, consisting of "three-squadrons of Circassians and Don Cossacks, all finelymade, handsome men, and bravely mounted." He cited the opening lines of Shakespeare's Julius Caesar.

\section{What conquests brings he home! \\ What tributaries follow him to Rome \\ To grace in captive bonds his chariot wheels!}

Then came deputies from the numerous "Asiatic tribes" and "Cossack tribes." "All eyes turned on these picturesque strangers from the Far East," he wrote, "who pace along on their richly-caparisoned steeds ... on they ride before the mighty Monarch." 44 A color lithograph of the painting by Konstantin Savitskii of the entry, with the Asiatic deputies on the right, brings out their variegated dress, distinguishing them from the uniform pattern of the orders of the state.

The coronation played a special role in the presentation of a nationalist imperialism. Not only did the presence of the colorful Asiatic peoples impress foreign observers, but the celebrations also impressed representatives of subject peoples with the power and wealth of the Russian tsar. A delegation of Chieftains from Turkestan invited to the coronation were so overwhelmed with the magnificence of the events and the shows of military might that they decided that further resistance was hopeless. They formed a Russian party that petitioned for admission to the Russian empire in $1884 .{ }^{45}$ The coronation descriptions no longer expressed admiration for the Eastern representatives in the entry procession. The "peoples ruled by Russia" are again mentioned in the coronation album, riding behind the Black Sea Cossacks, but without further comment. ${ }^{46}$ A coronation volume published by the Pan-Slavist Vissarion Komarov expressed sentiments of national superiority and colonial disdain. The author described the Asian representatives as "a messy crowd, bumping into each other... a murderously funny procession of savages." They

\footnotetext{
44 The Times, May 23, 1883, 5.

45 John Le Donne, The Russian Empire and the World, 1700-1917: The Geopolitics of Expansion and Containment (New York: Oxford University Press 1997), 132; Prince A. Lobanov-Rostovskii, Russia and Asia (New York: MacMillan, 1933), 172. 46 Opisanie sviashchennogo koronovaniia... Gosiudaria Imperatora Aleksandra Tret'ego i Gosudaryni Imperatritsy Marii Fedorovny Vseia Rossii, 4-5.
} 
wore "the most motley robes," which were extraordinarily garish and strange costumes in bright colors. "Some dress like women, others tightly like ballet dancers." One could not but "give a good laugh" at a Kalmyk mulla who rode on horseback wearing a wide red robe and a yellow cap, "like those worn by chorus girls in Russlan and Liudmilla." 47

The change in attitude reflected a broader shift in the conceptions of national identity reflected in both official and public discourse. As John Slocum and Paul Werth have demonstrated, non-Russian nationalities began to be characterized in terms of ethnicity, rather than religion or simple backwardness, reflected in a shift in terminology for other nationalities, from inovertsy - peoples of other religions - to people of other ethnic stock, inorodtsy, or aliens. The new discourse increasingly precluded the possibility of transformation, either the religious hopes for conversion or the secular visions of enlightenment, which had been conflated. ${ }^{48}$

The theme of the Russianness of the tsar and the empire was displayed prominently throughout the coronation ceremonies. Many of those present remarked on the Russian appearance of the tsar. D. N. Liubimov, a secondary school student serving in the "Holy Guard" for the coronation, later recalled the great majesty of Alexander dressed in the imperial regalia. "This extraordinary garb that so befit the holy places of the Kremlin became him perfectly: his enormous height, his stoutness, his great beard. A truly Russian tsar, of Moscow and all Rus'” State Secretary A. A. Polovtsov wrote in his diary, "One felt that here it was not a case of an empty formality, but of a celebration having a national sense and taking place not without a fierce underground struggle." He noted that the courtiers attending to the tsar were nearly all from old Russian families, while the German noblemen were holdovers from the previous reign. ${ }^{49}$

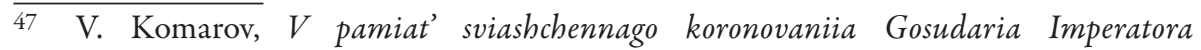
Aleksandra III $i$ Gosudaryni Imperatritsy Marii Fedorovny (St. Petersburg: V. Komarov, 1883), 56-7.

48 See Paul Werth, "Changing Conceptions of Difference, Assimilation, and Faith in the Volga-Kama Region, 1740-1870," in Russian Empire, 171-88; John W. Slocum, "Who, and When, Were the Inorodtsy? The Evolution of the Category of 'Aliens' in Imperial Russia," Russian Review vol. 57 (April 1998): 173-90.

49 N. Liubimov, "Russkaia smuta deviatisotykh godov, 1902-1906," Bakhmeteff Archive, Columbia University, 93; A. A. Polovtsov, Dnevnik gosudarstvennogo sekretaria A. A. Polovtsova (Moscow: Nauka, 1966), 1: 95. 
The only national delegation marching to the Assumption Cathedral for the rites of coronation was made up of delegates from Finland. In addition to peasant elders, appearing for the first time in a coronation procession, there marched the heads of estate and zemstvo institutions, and provincial marshals, as well as a large number of judges and officials from Moscow institutions, indicating the highly Muscovite character of the event. Representatives of all the Cossack hosts attended, among them their atamans, who were admitted to watch the rites in the cathedral. .0

The post-coronation celebrations emphasized the primacy of Russia. At the banquet, the imperial family and the court witnessed the debut of Tchaikovsky's Cantata Moskva, extolling Russia as a great bogatyr'. The gala performance consisted of the first and last scenes of Mikhail Glinka's Life for the Tsar and a new ballet called Night and Day, choreographed by Marius Petipa to the music of Ludwig Mincus. If Life for the Tsar celebrated the resurrection of authority, Night and Day allegorized Russia as the dominant nationality in a multi-national empire. The ballet returned to the eighteenthcentury theme of renovation. The traditional image of the sun represented the monarch, who illuminated and gave warmth to everything. The spirits of night give way to glorious day, with birds, fountains and flowers ushering in the new reign. Butterflies burst from a hive and alight on flowers. "All the nationalities of the Russian empire [Russkoe tsarstvo], in holiday costumes"Finns, Georgians, Don Cossacks, Siberian Shamans, Poles-“unite" to greet the rising light of day." Each group performed its own dance, then all join a general Russian round dance, in the center of which stood "the most beautiful and stoutest woman, that is, Rus." At the conclusion, they came together while a chorus intoned glory to the "beautiful sun, our tsar on earth." 51

Nicholas II's coronation in 1896 was a sumptuous play to an international audience, Russia's engagement in the rivalry of grandiose celebrations among the great powers in the late nineteenth and early twentieth centuries. The coronation presented Russia as a monarchy with broad democratic support,

\footnotetext{
50 Komarov, V pamiat' sviashchennago koronovaniia Gosudaria Imperatora Aleksandra III, 120-1.

51 Ibid., 308-11.
} 
adapting to the contemporary forms of mass publicity and consumption. It assumed a grander scale than Alexander III's coronation: there were greater numbers of foreign correspondents, guests, and emissaries, whose pictures graced the second volume of the album. The more than three hundred foreign correspondents, artists, and photographers attending the coronation interpreted the variety of national types in the entry as a demonstration of submission to the Russian throne.

The coronation album provides no general montage of the entry. There is a striking portrayal of Nicholas II on horseback, but the photograph of the procession gives an impression of jumble and closeness, a contrast to the idealizations of artistic representation. The Asiatic deputies marched towards the beginning of the procession, an initial demonstration of the variety of the empire, but the coronation album made clear their subsidiary status.

After a detachment of gendarmes, the entry opened with the "Cossacks of the Emperor's own convoy." The album described these "dashing swarthy horsemen" in red Circassian coats, fur hats, brandishing their swords. "At their appearance, the admiration of the crowd burst forth into hurrahs and shouts of pleasure," the New York Times correspondent wrote. They were followed by a company of Cossacks of the Guard. The album described them as "Handsome fellows, their papakbi cocked to the side, holding frightening lances in their hands like feathers and merrily looking out at God's world." Then came a long line of "deputies of Asiatic peoples under the power of Russia"-representatives of Caucasian peoples, Turkmen, Tekins, Sarts (Uzbeks), and Kirghiz. The description was not without a note of condescension: "original (original'nye, i.e. a bit odd) characteristic figures, quaint (prichudlivye) clothing, and ornate saddles of these eastern horsemen aroused the special interest of the people." The sketch by N. Samokish shows a group of these horsemen, looking somewhat disheveled and distracted ${ }^{52}$ (Figure 5).

Other accounts in the press, however, were more admiring. A report in Novoe vremia marveled over the "proud representatives of our Asia." The procession, the original costumes, "carried the spectator to the hot steppes of Asia, to the Ural mountains, to the canyons of Dagestan, to the expanses of Bukhara." The American journalist Richard Harding Davis marveled at the

52 Koronatsionnyi Sbornik: Koronovanie v Moskve, 14 maia 1896 (St. Petersburg: Eksped. Gos. Bumag, 1899), 1: 209-10; New York Times, May 22, 1896, 7. 


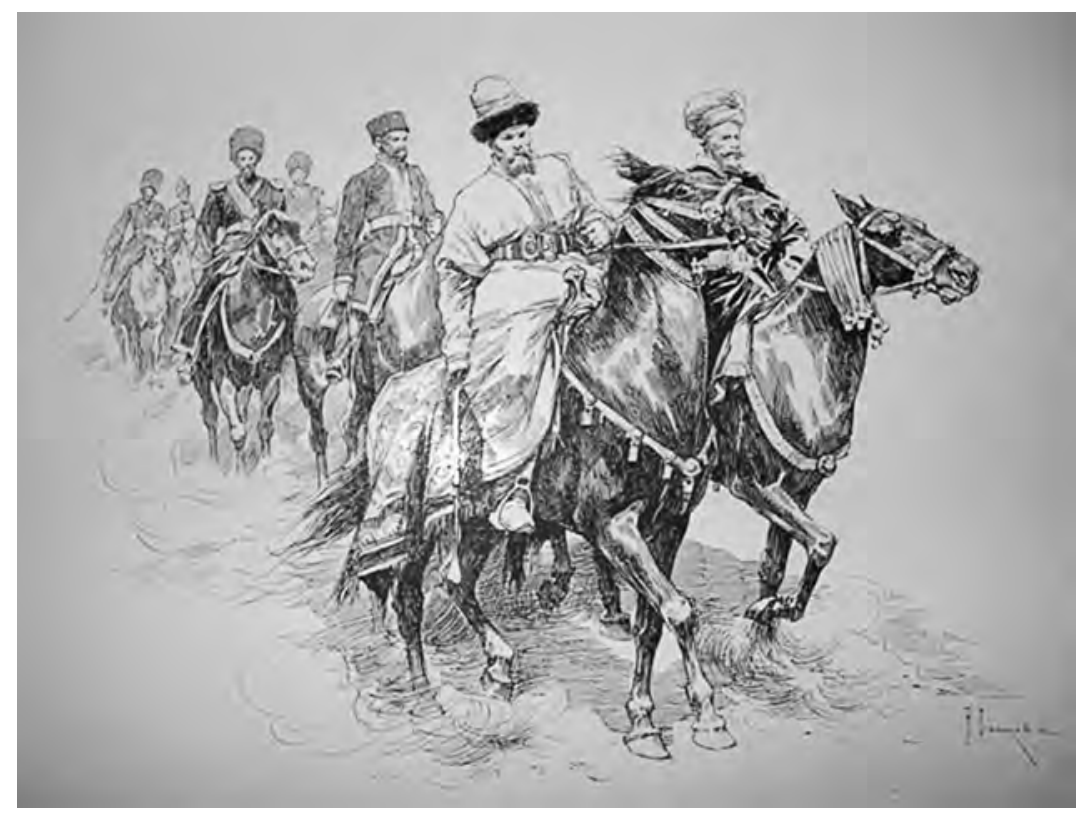

Figure 5-Deputies of "Asiatic peoples under the power of Russia." Koronatsionnyi sbornik: Koronovanie v Moskve, 14 maia 1896. Slavic and Baltic Collection, New York Public Library.

variety of costumes and national groups in a procession that included "the representatives of what had once been eighteen separate governments, each of which now bowed in allegiance to the Russian Emperor." Each of these representatives, he wrote, "bore himself as though his chief pride was that he owed allegiance to a young man twenty-eight years old, a young man who never would be seen by his countrymen in the distant provinces from which he came, to whom the Czar was but a name and a symbol, but a symbol to which they prayed, and for which they were prepared to give up their lives." 53 In photographs of the Bukhara and Khiva delegations, uniformed officials sit side by side with the notables of the protectorate, dressed in traditional attire (Figure 6).

53 Novoe Vremia, May 11, 1896, 1; Henry LaPauze, De Paris au Volga (Paris, 1896), 79, 85; Richard Harding Davis, A Year from a Reporter's Notebook (New York: Harper \& Bros., 1898), 28-34; B. A. Engel'gardt, “Torzhestvennyi v"ezd v Moskvu gosudaria Imperatora Nikolaia II," in Sergei Zavalishin, Gosudar' Imperator Nikolai II Aleksandrovich (New York: Vseslavianskoe izd-vo, 1968), 23-4. 


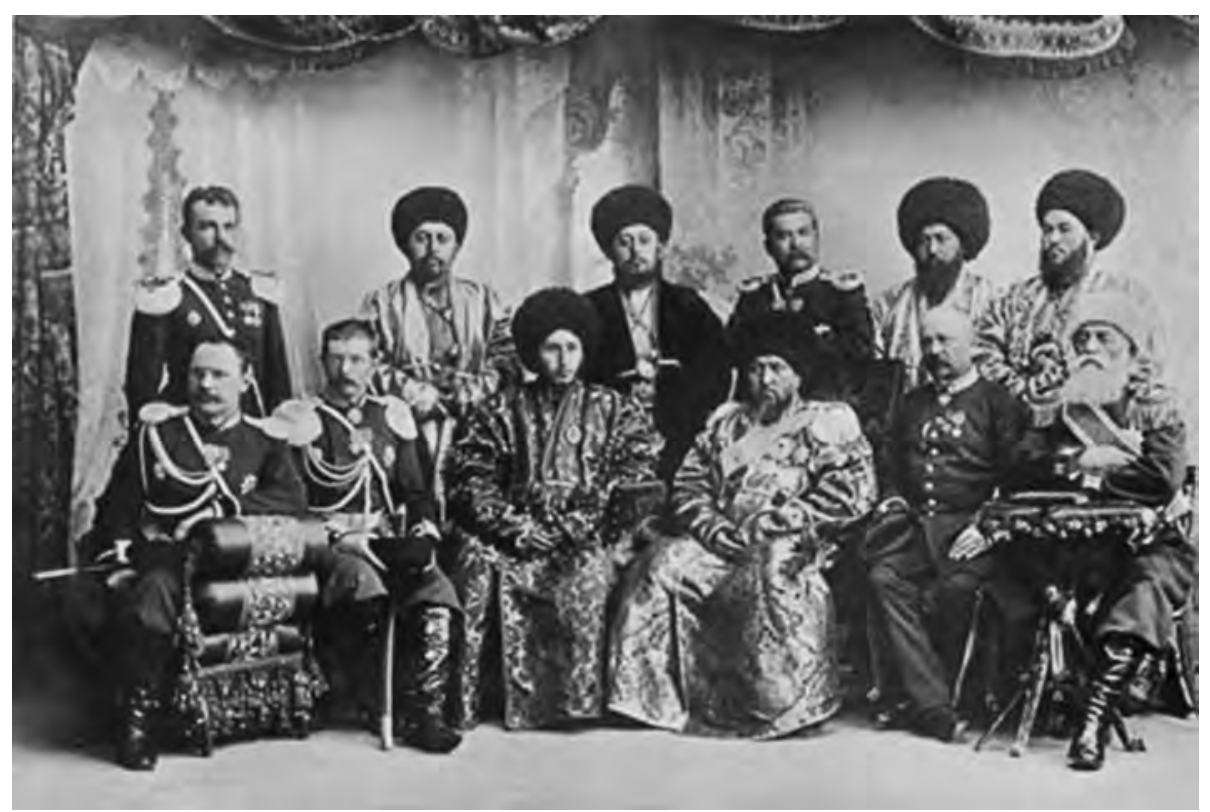

Figure 6-Deputies from Khiva-Coronation Album of Nicholas II. Koronatsionnyi sbornik: Koronovanie v Moskve, 14 maia 1896. Slavic and Baltic Collection, New York Public Library.

The Cantata performed at the banquet, written by Alexander Glazunov and the popular playwright and chief of repertoire for the imperial theaters of St. Petersburg, Victor Krylov, intoned rhetoric about the vast expanse of the empire and Russia's imperial destiny. The singers gave voice to the joy of the parts of the empire, North, South, East, and West at the coronation of its sovereign. "Russia is united in a single feeling," the chorus sang. The mezzo-soprano, in the role of the South, sang of their forefathers' defeat of the Tatars. The basso, as the North, told how nature fell silent before the wondrous celebrations. The East, a soprano, announced that Russia was awakening Eastern nations, while the West, again the mezzo-soprano, told how Europe had shared enlightenment with Russia. Russia was the force of progress in the East.

The Kamchatkian, the Kalmyk, and Sarmatian

Leave their wretched hovels,

And they greet the softening influence of morals,

The mercy and kind impulses,

Like sons, with open arms. 
Then Russia, "conscious of its strength," turns in friendship to the West, in mutual love and accord, a reference to the image of Russian tsar as bringer of peace. The empire was a national achievement, dating not from the Petrine reforms, but from the rise of Moscow, whose spirit permeated the coronation. Fittingly, the cantata ended with the chorus's apostrophizing Moscow.

Moscow of the golden cupolas...

In your walls was born the start,

Of all these sovereign labors. ${ }^{54}$

In conclusion, by the second half of the nineteenth century, colorful horsemen and nomads from the Caucasus and Central Asia marked Russia as an imperial nation. They showed the extent of Russia's power, exalting an empire rivaling the west in extending domination over savage and exotic peoples. Over the course of the century, a homogeneous noble elite was increasingly surrounded by shows of diversity, first of national groups, who had come to feel a sense of devotion to the emperor, then of peoples who had been subdued and subjected by the Russian state. In this way, Russian coronations from the time of Peter to the crowning of the last tsar set forth a symbolic program for each reign. They evoked the visions that would define the relationship of each monarch to his subjects and consecrated the truths that would establish both the goals and unbending principles of his rule of a multinational empire. Foreign visitors and correspondents shared this ceremonial mentality, marveling at both the miraculous integrative force of love and benevolence, and the apparent, if illusory, might of the Russian nation and the Russian tsar.

54 Koronatsionnyi Sbornik, 1: 280-3. 


\section{Publicizing the Imperial Image in 1913}

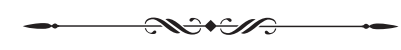

\section{New Modes of Representation}

From the reign of Peter the Great, Russian monarchs sought to vest themselves in European personas that reflected current western ideals of rulership and culture. At the same time, they presented themselves as embodiments of the Petrine ethos of state service, subordinating the gratifications of private life to the superordinate goals of the imperial state. Nicholas II ascended the throne in 1894 unburdened by the imperative to transcend or deny his self. His model was contemporary royalty, particularly the English royal family and aristocracy, who took on the individualistic tastes of western society. Marriage and the family, his deep personal religiosity, his love for sport and recreation all were of paramount concern for him, competing with and often outweighing his official obligations. His authority, he was convinced, demanded no self-transformation on a heroic mythical pattern. He saw himself as a human being ordained by God and history to rule Russia autocratically. Following the precepts of the national myth introduced during the reign of Alexander III, he believed that the Russian people, specifically the peasants, were devoted to him personally, a conviction that he held tenaciously in spite of the widespread insurrections among the peasants in the first years of the twentieth century.

A disjuncture between the transcendent image of the autocratic emperor and Nicholas's own self-representation was evident from the beginning of his reign. This became particularly acute after the ebbing of the revolution of 1905 and the establishment of representative institutions in Russia. He then began to demonstrate his bond with the masses of the peasants. This bond was not a sentiment of gratitude for a generous monarch bestowing benefactions on the people, as it had been characterized for Alexander II; nor was it the 
union of tsar and people, through the Orthodox Church, proclaimed during the reign of Alexander III. It was presented as a spiritual bond between simple religious people-between the tsar who ruled and the peasants who wanted to be ruled without restrictions on the power of their "little-father" (batiushka) tsar.

To display this popular support, Nicholas made use of great historical celebrations and mass publicity, following the example of European monarchs and leaders. While he disliked the public functions of the court, he appreciated the mass adulation of crowds of people and publicity of his warm domestic life. At the historical celebrations-the bicentenary of the battle of Poltava in June 1909, the jubilee of Borodino in August 1912, and the tercentenary of the Romanov dynasty in February and May of 1913-he presented himself as heir to the traditions of Peter the Great, Alexander I, and the first Romanov tsars. He stood and chatted with groups of peasants as if they were kindred spirits, evoking a bond between tsar and people that presumably showed him to be a truer representative of their feelings than their elected deputies.

Nicholas's publicity campaign reached its height during the tercentenary of 1913. Pictures of the tsar and the imperial family appeared on new postage stamps, commemorative coins, and kitsch, the souvenirs of celebrations. Films acquainted a mass public with scenes of the imperial family at ceremonies and episodes from Russia's past. Articles in the press and a widely circulated official account of Nicholas's life acquainted a growing reading public with his habits, tastes, and ostensibly democratic predilections.

The new genres of representation assured that the tsar's image would be conspicuous during the celebrations of 1913. At the same time, their coarse forms and context could associate the lofty figure of the tsar with the everyday and commonplace. Mass-produced coins lacked the finish and class of the old limited editions. Stamps were cheap slips of paper that ended in the trash. Actors could give inept or vulgar portrayals of the tsar on the stage. Newsreels were screened in sequence with trite romances and crime stories. Descriptions of the tsar's personal life gave him an aspect of the ordinary, devastating to the worshipful admiration the tsar still hoped to command.

The new genres coexisted with the traditional elevation of the tsar as all-powerful autocratic monarch, working with superhuman effort for the power and expansion of the empire. They introduced a dichotomy into imperial imagery, creating symbolic confusion in the midst of the political 
crises of 1913 and 1914. But this problem eluded Nicholas, who saw publicity as a confirmation of his broad popularity and the strength of his alliance with the masses of the Russian people against the educated classes and the institutions they dominated.

The commemorative rubles issued on the occasion of the Romanov tercentenary demonstrated both the possibilities and the perils of the new forms of publicity. For Nicholas's coronation in 1896, the government had circulated 190,845 commemorative rubles, nearly three times the number of the 66,844 made for Alexander III's coronation in 1883. For the tercentenary celebration, as many as 1.5 million commemorative rubles were issued. The increased numbers brought the commemorative ruble to a broader public, beyond the court, the administration, and the armed forces. ${ }^{1}$

However, the rise in production was accompanied by a noticeable decline in quality. The busts of Nicholas, bareheaded, dressed in the uniform of the imperial rifles, and Michael, wearing the Monomakh cap, decorated the obverse of the coin (Figure 1). A breakdown of a die after the minting of the

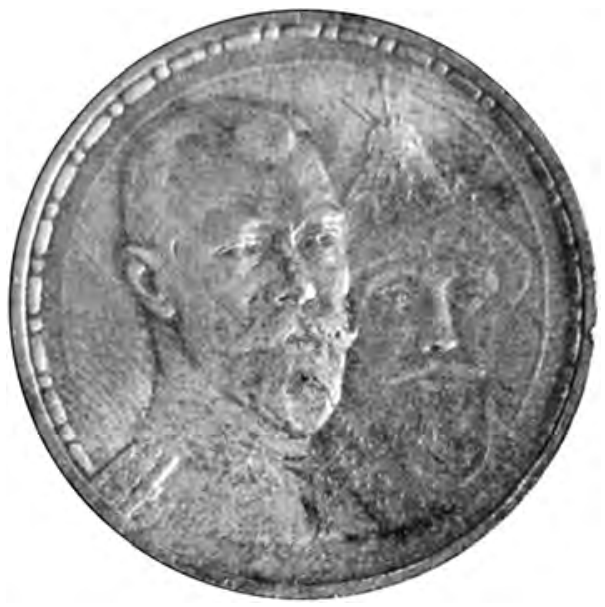

Figure 1-Tercentenary Ruble.

Collection of author.

$1 \quad$ Robert G. Papp, “The Road to Chervonets: The Representation of National Identity in Russian Money, 1896-1924," Unpublished paper for American Numismatic Society Summer Seminar, 1996, 10, 16-17, 19. 
first 50,000 resulted in a flattening of the image of Michael, giving him a ghostly look. The jeweler F. P. Birnbaum wrote, "the layout of portraits is unsuccessful in both the decorative and sculptural relation," and a polemic in Novoe vremia focused on whom to blame for the failure. The numismatist S. I. Chizhov criticized the "market" appearance of the ruble, which was not, in his eyes, "a work of art." He pointed out that "the artist should not have placed a Greek decoration that has no relationship to the Romanov house on both sides of the ruble." 2 The tercentenary medal, which also bore images of Michael and Nicholas, prompted further dissatisfaction. A. I. Spiridovitch, the chief of Palace Security, wrote that it was "as ugly as possible, and one asked, stupefied, how our mint could strike such a medal on the occasion of so memorable a jubilee." 3

The issue of postage stamps carrying the portraits of Romanov tsars on January 1, 1913 represented a more fundamental break with imperial traditions. In Europe, the faces of monarchs began to appear on postage stamps in the middle of the nineteenth century. The decision to introduce the practice in Russia was certainly made with the consent of Nicholas, who was an ardent philatelist. Of the tsars, Nicholas's portrait was represented most frequentlyon the seven kopek, ten kopek, and five ruble stamps. The seven and ten kopek stamps, intended for single-weight letters sent in Russia and abroad, gave his portrait the broadest dissemination. Peter the Great was shown on the one and four kopek stamps, Alexander II on the two kopek, Alexander III on the three kopek. Of the pre-Petrine tsars, Alexei Mikhailovich appeared on the twentyfive kopek and Michael Fedorovich on the seventy kopek. ${ }^{4}$

$\overline{2} \quad$ Ibid., 17; F. P. Birnbaum, "Iubileinyi rubl', medal'ernoe iskusstvo i Monetnyi Dvor," in Faberzhe i Peterburgskie iuveliry, ed. T. F. Faberzhe, A. S. Gorynia, and V. V. Skurlov (St. Petersburg: Zhurnal Neva, 1997), 357-60. The article was originally printed in Iuvelir in 1913; S. Chizhov, "Iubileinye rubli 1912 i 1913 godov," Numizmaticheskii sbornik (Moscow, 1915), 101-2.

3 Général Alexandre Spiridovitch, Les dernières années de la cour de Tsarskoe-Selo (Paris: Payot, 1929), 2: 357, 401.

4 Michael Ercolini, "An Introduction to the Stamps of the 1913 Romanov Issue," The Journal of the Rossica Society of Russian Philately No. 122 (April 1994): 1114; Niva, January 5, 1913, 20; A. F. Giers refers to Nicholas and stamp collecting: A. F. Girs, "Vospominaniia byvshego ofitsera L-Gv. Preobrazhenskogo Polka i Minskogo gubernatora A. F. Girsa o svoikh vstrechakh s Gosudarem Imperatorom Nikolaem II," Bakhmeteff Archive of Russian and East European Literature and History, Columbia University, 11. 
Stamps had to be canceled and devout Orthodox, and supporters of the monarchy condemned what they regarded as a desecration of the sacred image of tsar. The Bishop Nikon, writing in the official organ of the Holy Synod, deplored the number of kopeks printed with the tsars' faces, saying they demeaned the pious tsars worshiped by the people. Worse, he wrote, "these portraits of the tsars must be soiled with a postmark, as if to profane us all the more." Nikon asked himself if he was still living in Russia, "or has the kike come and conquered our tsardom?" The newspaper Zemshchina, an organ of the extreme right-wing Union of Russian People, pointed out that the law specified sentences of penal servitude for those who defiled the imperial image. Many postmasters refused to desecrate the face of the tsar with postmarks and left stamps uncanceled. The government suspended the series in February 1913, but resumed printing it later that year. ${ }^{5}$

The mass production of souvenirs with portraits of members of the imperial family troubled the censors in the Ministry of the Court, but apparently not the emperor or empress. The Ministry received applications to produce a variety of household items carrying the portraits of members of the imperial family, among them trays, candy boxes, metal cases, china, and calendars. "The placing of the portraits of imperial personages on objects having a utilitarian character is usually not permitted," an official of the court censorship responded to one such application. All the requests, however, were approved, sometimes with restrictions, as in the case of a request to market scarves with the portrait of the tsar. The censor authorized this "as long as these are of a size not suitable for use as handkerchiefs." 6

The effort to popularize the image of the tsar in 1913 even led to the lifting of the ban on the presentation of Romanov rulers on the stage, which had been in effect since 1837. Enforcement had been irregular, but the rule had been consistently applied to grand opera. ${ }^{7}$ For example, at the end of

5 Episkop Nikon, "Vera Khristova ne terpit dvoedushiia," Tserkovnye vedomosti (February 9, 1913), 283-4.

6 “Ob izdaniiakh kasaiushchikhsia 300-letiia Doma Romanovykh," RGIA, 472-49$1083,70,134$, and passim. The growth of the market, however, exceeded the capacity of the office of court censors, and some items, like a cheap jubilee medal produced by a private firm, had not even been submitted for approval. Ingeborg Kaufmann, "Das dreihundertjährige Thronjubiläum des Hauses Romanov: Russland 1913" (MA Thesis, Humboldt University, Berlin, 1996), 68-9.

7 In the early twentieth century, the censorship permitted three different performances showing Peter the Great, one of them a comic opera, and one play about Catherine 
all performances of Mikhail Glinka's Life for the Tsar, a procession led the newly-elected Michael Romanov into Moscow, but the curtain always fell before he appeared. The gala performance at the Mariinskii Theater in St. Petersburg in February 1913, however, concluded for the first time with Michael's entry to Moscow. He led a procession of the principal historical figures of the early seventeenth century. Michael, played by Leonid Sobinov, rode in a gilded carriage led by companies of musketeers. With two boiars at his side, he received bread and salt from groups of boiars and a golden goblet from the oldest, Andrei Trubetskoi. ${ }^{8}$

Permission was also extended to the Malyi Theater, in St. Petersburg, which presented tsar Michael in a play of E. M. Bezpiatov, Ob, Quiet Light (Svete tikhii), about the period of the election. The performance took place only after the censors' objections had been overridden by authorization from the throne. 9 The Ministry of the Court also permitted both the Moscow Malyi Theater and the Alexandrinskii Theater to present three excerpts from Nikolai Chaev's drama The Election of Michael Romanov, including the scene of the meeting of the Great Embassy with Martha and Michael in the Ipat'evskii Monastery. When the cast sang "God Save the Tsar!" at the close of the performance, the actor Davydov, who played Michael, amazed the audience by raising his voice above all the others. Shouting the final "Hoorah!," he extended his arms forward and threw his hat into the air, to loud "hoorahs!" from the crowd. ${ }^{10}$

The medium of film was most congenial to Nicholas, for it enabled him to establish direct visual contact with a mass audience without jeopardizing either his privacy or security. It also made his ceremonies and celebrations known to large numbers of his subjects, many of whom were illiterate or who

the Great. On the other hand, proposals to portray Michael Romanov, Fedor Romanov, and Alexander I in plays marking the anniversary of 1812 were refused. "Po povodu izgotovlennoi Lefortovskim Otdeleniem Damskogo Popechitel'stva o bednykh v Moskve kinematograficheskoi lenty s izobrazheniem sobytii za vremia 300-letiia tsarstvovaniia Doma Romanovykh," RGIA, 472-49-1252, 27.

8 The procession at the conclusion of Life for the Tsar reproduced the picture in the 1672 album, reprinted in 1856: Kniga ob izbranii na tsarstvo Velikago Gosudaria, Tsaria i Velikago Kniazia Mikhaila Fedorovicha (Moscow, 1856); Russkoe slovo, January 18, 1913, 4, February 23, 3; Birzhevye vedomosti, February 22, 1913, 5 .

9 Russkoe slovo, January 18, 1913, 4

10 Moskovskie vedomosti, February 23, 1913, 3, March 3, 1913, 2-3. 
could not hope to witness them firsthand. ${ }^{11}$ From 1911-1914, the censors approved more than one hundred requests to screen newsreels of the tsar submitted by such firms as Pathé, Khanzhonkov, Drankov, and Gaumont. These films gave the public glimpses of Nicholas at various ceremonial occasions, including the Borodino festivities, the tercentenary processions in Petersburg and Moscow, the Blessing of the Waters, military reviews, parades of the play regiments (poteshnye), the launching of ships, and receptions of foreign dignitaries. Moviegoers also could see the emperor and his family attending ceremonies in Crimea. A newsreel of his birthday celebration in 1911 showed Nicholas crossing himself continuously during the religious services. Others presented scenes of the empress at the "day of the White Flower" for the Red Cross in Yalta and the family's visit to the estate of Prince Lev Golitsyn, where the tsar examined the prince's vineyards and caves. ${ }^{12}$

The censors tried to ensure that the screening of these films took place with the appropriate dignity, and not in sequence with figures of lovers and bandits. They, in effect, understood the reception of early film programs, discussed by the film historian Yuri Tsivian-that the combination of short film subjects on a single program raised the possibility of associating one with the other. The censors prescribed that newsreels of the emperor and imperial family should be separated from the rest of the program, "not mixed up with the other pictures," and they should be shown without musical accompaniment. The curtain was to be lowered before and after the showing of the imperial family, and films of them were to be projected by hand, "at a speed that ensures that the movements and gait of those represented on the screen does not give rise to any comment." 13

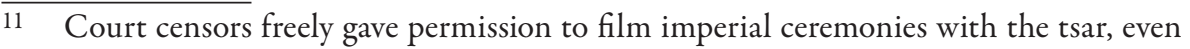
though the ban on showing films of the imperial family remained in force until 1910 (Yuri Tsivian, Early Cinema in Russia and Its Cultural Reception [London: Routledge, 1994], 126); on the censorship and the film, see Yuri Tsivian, "Censure Bans on Religious Subjects in Russian Films," in Une invention du diable? Cinéma des premiers temps et religion, ed. Roland Cosandey, André Gaudreault, and Tom Gunning (Sainte-Foy: Les presses de l'université Laval, 1992), 76-7.

12 "Po voprosu tsenzury kinematograficheskikh snimkov s izobrazheniem Vysochaishikh Osob," RGIA, 472-49-988; N. N. Kalinin and M. A. Zemlianichenko, Romanovy i Krym (Moscow: Rurik, 1993), 83.

13 Audiences went to the theater, Tsivian writes, to see an entire program, a show consisting of a series of short subjects, and "the impression made by one picture imposed itself involuntarily on the next” (Tsivian, Early Cinema in Russia, 127). 
To publicize and associate himself with the great accomplishments of the dynasty, Nicholas encouraged the production of historical films. He personally approved the release of two productions to mark the tercentenary-Alexander Khanzhonkov's "The Enthronement of the Romanov House, 1613-1913," and Alexander Drankov's "Three Centuries of the Ruling House of the Romanovs, 1613-1913: Historical Pictures." Khanzhonkov's film depicted the last years of the Time of Troubles and Michael's election. ${ }^{14}$ Only the first quarter of Drankov's footage was devoted to 1613; the remaining sections presented an overview of the principal events of the subsequent three centuries. ${ }^{15}$ Both films consisted of a succession of tableaux vivants. Their format, like that of many other films of the time, conformed to the structure of the popular lubok literature: the actors struck conventional heroic poses from lubki to illustrate the particular historical event. ${ }^{16}$

The semi-legendary context of the lubok permitted imaginative portrayals of tsars by actors. The censors accepted the dramatic portrayal of Michael Romanov on the screen, played by the actress S. Goloslavskaia in Khanzhonkov's production and by Michael Chekhov in Drankov's, as well as the presentation of eighteenth century monarchs in tableaux vivants of eighteenth-century courts. Nineteenth-century emperors, however, had to be presented with care and dignity, for their memory as persons had not faded, and therefore they could not properly be portrayed by actors. Drankov used busts to represent Alexander I and Nicholas I, and portraits for Alexander II and Alexander III. Their images alternated with tableaux of the great moments of their reigns, such as the struggle with Napoleon, the emancipation of the serfs, and the court reform of 1864 . Nicholas II appeared at the end of the film himself, in a succession of clips of ceremonial occasions-the coronation, the dedication of the Petersburg monument to Alexander III in 1909, Nicholas with his troops and at the Borodino celebrations. Setting Nicholas in sequence

14 The film apparently concluded with a scene of Michael's anointment, which has not survived. Votsarenie Doma Romanovykh, 1613-1913, RGAK (Rossiiskii Gosudarstvennyi Arkhiv Kinofotodokumentov), I-12890.

15 "Trekhsotletie tsarstvuiushchego Doma Romanovykh, 1613-1913: Istoricheskie Kartiny," RGAK, I-22645.

16 Many of the authors of lubok tales in the penny newspapers became screenwriters at this time: S. Ginzburg, Kinematografiia dorevoliutsionnoi Rossii (Moscow: Iskusstvo, 1963), 114-18; Jeffrey Brooks, When Russia Learned to Read: Literacy and Popular Literature, 1861-1917 (Princeton: Princeton University Press, 1985), 109. 
with images of the foremost of his predecessors associated him with their glory and achievement. Showing him at major celebrations recalled the moments of exaltation that confirmed the popular backing of the monarchy.

These films, however, affronted some conservative sensibilities. Prince Kudashev wrote to Moskovskie vedomosti that he found Khanzhonkov's presentation of the siege of the Trinity Monastery, which showed the portals as well as the icons painted on the walls, "frightening and unusual." "A place, which as a shrine is dear to the people ... has been turned into decoration for the film to be performed." Kudashev not only deplored the showing of the pectoral cross, but also was appalled that actors were dressed up as monks "on this very spot," and that one actually was permitted to play Patriarch Hermogen, whom the people worshiped as a saint. ${ }^{17}$

\section{“The Crowned Toiler”}

The most important means to popularize the tsar and the monarchy during the celebrations was the printed word. At the end of 1905, the leaders of the government and Nicholas himself had resolved to create newspapers that could reach the people and argue the government's program against the opposition. The government dispensed large sums to support more than thirty newspapers across Russia. Under the aegis of the Minister of the Interior, the newspaper Rossiia was established as a private organ, supported by the governmentwhat was called ofitsioz. ${ }^{18}$ Sel'skii vestnik was made an independent periodical, the change symbolized by the replacement of the former "manager" of the newspaper by an editor who was given leeway to make the newspaper more appealing to mass readership. ${ }^{19}$ However, like other government-supported organs, neither of these attracted large numbers of readers. ${ }^{20}$ The Assistant

17 Moskovskie vedomosti, March 3, 1913, 1.

18 On the official press during and after the revolution of 1905, see A. V. Likhomanov, Bor'ba samoderzhaviia za obshchestvennoe mnenie $v$ 1905-1907 godakh (St. Petersburg: Rossiiskaia Natsional'naia Biblioteka, 1997).

19 James H. Krukones, To the People: The Russian Government and the Newspaper Sel'skii Vestnick ("Village Herald"), 1881-1917 (New York: Garland Publishing, 1987), 190-204.

20 In 1906, the numbers of circulated copies of Rossiia ranged from 1,037 to 7,217. Likhomanov, 110-11. Circulation of Sel'skii vestnik fell from over 100,000 before 1905 to less than half of this. By 1912, it had risen to only 47,500 and was increasing 
Minister of Interior, S. E. Kryzhanovskii, explained the failure of official organs in terms of "the nearly complete absence of people prepared for publicistic activity. This is not surprising since newspaper work was the province of oppositional circles that had at their disposal large staffs, mainly of Jewish origin." 21

Official organs achieved far greater success in their publication of brochures and books. Rossiia and Sel'skii vestnik circulated brochures in the millions. ${ }^{22}$ The peasants, Jeffrey Brooks pointed out, were unaccustomed to newspapers but liked to read chapbooks and popular journals. Moreover, in the words of one student of peasant attitudes, S. A. Rappaport (An-skii), for the peasants, "Printed means it is true, printed means it is just." 23 With the help of Peter Stolypin, Sel'skii vestnik acquired a printing press and storehouses. It published books on such practical matters as agriculture and law and also set up outlets at towns along the Trans-Siberian Railway. During the Borodino and tercentenary celebrations, the editors expanded their lists to include works on history and patriotic studies. ${ }^{24}$

These celebrations provided the occasion for a vast expansion and distribution of monarchist literature in the countryside. In 1911, Sel'skii vestnik entered into an agreement with the house of Ivan Sytin, the commercially successful publisher of the newspaper Russkoe slovo. Sytin commanded a vast distribution network in the provinces. Books and pamphlets were also distributed through the Trusteeships of the People's Temperance, libraries, schools, the Church and the military. During the Borodino jubilees, the books and pamphlets published by Sel'skii vestnik jointly with Sytin reached $2,860,000$ copies. Portraits of the imperial family and war heroes numbered $700,000.25$ According to Sytin, his house published 3.8 million copies of books

slowly in 1913 (Krukones, To the People, 204). This compares to close to four million for Novoe vremia in 1912, and close to 300,000 for Russkoe slovo. Louise McReynolds, The News Under Russia's Old Regime: The Development of a Mass Circulation Press (Princeton: Princeton University Press, 1991), Tables 5 and 8.

21 S. E. Kryzhanovskii, Vospominaniia (Berlin, n.d.), 101-2.

22 Likhomanov, Bor'ba samoderzhaviia za obshchestvennoe mnenie v 1905-1907 godakh, 112-3; Krukones, To the People, 209-10.

23 Brooks, When Russia Learned to Read, 31-2.

24 Krukones, To the People, 208-13.

25 Ibid., 213; On Sytin, see Charles A. Ruud, Russian Entrepreneur: Publisher Ivan Sytin of Moscow, 1851-1934 (Montreal and Kingston: McGill-Queens University Press, 1990). 
and pamphlets for the tercentenary, while Sel'skii vestnik reported 2.9 million books and 1.9 million portraits. ${ }^{26}$

Sel'skii vestnik also promoted and distributed the "Tercentenary Icon," which the Synod had approved in December 1912. The icon featured the likenesses of all the saints whose whose names were borne by rulers of the Romanov house. It came in large versions suitable for churches, schools, state and public institutions, and small ones for private use. The kiot, the icon case, could be of wood, marble or silver. ${ }^{27}$ The editor of Sel'skii vestnik, P. P. Zubovskii, claimed that it was the most popular of the bric-a-brac sold for the Tercentenary. Zubovskii wrote, "The Russian people know how to pray and enjoy praying for what they love." 28

The very scope of official publications and other items associated with the ruling house confirmed the sense of the popularity of the monarchy for Nicholas and many of his advisors. Such literature made known the tsar's person and life, showing the qualities they thought would strengthen the bond between him and the people. This was the goal of the unprecedented authorized account of the life of a ruling tsar, The Reign of the Sovereign Emperor Nicholas Aleksandrovich, published under the auspices of Sel'skii vestnik. The author, Professor and Major-General Andrei Georgievich Elchaninov, was a major-general in Nicholas's suite. ${ }^{29}$ Elchaninov's book was released in early 1913, before the February celebrations, and appeared in excerpts or installments in many major newspapers during and after the

26 Brooks, When Russia Learned to Read, 314; "Ob izdanii redaktsieiu Sel'skogo vestnika knigi General-Maiora A. El'chaninova, 'Tsarstvovanie Gosudaria Imperatora Nikolaia Aleksandrovicha,' i podnesenii eia Ego Imperatorskomu Velichestvu," RGIA, 472-49-1187, 56-57.

27 Sel'skii vestnik, January 18, 1913, 4.

28 Krukones, To the People, 214.

29 Prof. A. Elchaninov, Tsarstvovanie Gosudaria Imperatora Nikolaia Aleksandrovicha (St. Petersburg-Moscow: Izd. Sel'skii vestnik, 1913). The intermediary between the editor and the tsar was Prince Michael Andronikov ("Ob izdanii redaktsieiu Sel'skogo vestnika knigi General-Maiora A. El'chaninova,” passim). Elchaninov was and a Professor of Military Art in the General Staff Academy. He had written specialized books on fortification and cavalry, a biography of the eighteenthcentury military hero Alexander Suvorov, and a commemoration of the threehundredth anniversary of the siege of the Trinity Monastery during the Time of Troubles (Novyi Entsiklopedicheskii Slovar' Brokgauza i Efrona [St. Petersburg: n.p.], 17: 474). 
events. ${ }^{30}$ French and English translations followed in 1914. ${ }^{31}$ Elchaninov presented Nicholas to the Russian people and to Russia's allies as a tsar expressing the needs and advancing the interests of his people-a democratic ruler on the Russian throne.

Elchaninov organized his text to permit the broadest possible dissemination in newspapers. The book comprises twelve brief chapters. The themes are set forth in the first chapter, but repeated throughout so that the chapters could stand on their own. The prose is simple, but elevated in tone like a panegyric. It is realistic panegyric, devoid of extended metaphor or allegory. The author depicts Nicholas as a virtuous, exceptionally able and feeling human being on the basis of considerable detail from Nicholas's personal life and recent history. He gives his account a patina of verisimilitude, even if the idealization of his subject deprives the text of credibility. The mixture of panegyric and journalism clearly favors the former.

The book presents a unique statement of how Nicholas understood his office and wished himself to be perceived. Elchaninov gathered considerable material about Nicholas's personal life from observations and impressions of those close to the tsar, who clearly acted with Nicholas's consent. ${ }^{32}$ The personal detail prompted the Court Censor to express misgivings about the book's "intimate character." "Similar publications have not been authorized

$\overline{30}$ For example, Novoe vremia, Moskovskie vedomosti, Russkoe slovo, Grazhdanin, Kopeika, and Zemshchina printed one or more excerpts from the book. An article in the New York Tribune summarizing the sections on the tsar's family life was headlined, "Intimate Details of the Czar's Daily Routine Given in a Book by a Well Known Professor Reveal Him as a Kindly Man of Family" (New York Tribune, April $13,1913,9)$.

31 The English version was titled The Tsar and His People (London: Hodder and Stoughton, 1914), the French version Le règne de S. M. l'Empereur Nicholas II (Paris, 1913). Grand Duke Pavel Aleksandrovich wrote to Nicholas on May 29, 1913, that his wife Olga Pistolkors had decided to translate the book into French "so that foreigners, and especially the French, had a correct idea of Russia and her tsar, a country that is a friend and ally" (B. P. Semennikov, Nikolai II i velikie kniaz'ia [Leningrad-Moscow: Gosizdat, 1925], 58).

32 Elchaninov remarks in the last lines of Chapter I that the reader should thank not "my humble and unworthy self" but "all those who, standing in close proximity to the throne, have honoured me with their confidence and enabled me to give to the world their observations and impressions" (Tsarstvovanie...., 16; The Tsar and His People, 9). 
until the present day," he observed. When Nicholas reviewed and corrected the page proofs in January 1913, he made one very significant change, which affirmed his absolute unwillingness to cooperate with the Duma. He insisted that Elchaninov delete the sentence, "In his work, the Sovereign Emperor considers his closest assistants in legislative work the reformed State Council and the State Duma, which he has summoned to life." $33 \mathrm{He}$ also requested the removal of sentences describing prayers for the recovery of the heir, which placed undue emphasis on Alexei's recent illness. ${ }^{34}$

The text of Elchaninov's book therefore can be read as an exposition of Nicholas's conception of his own mythical role and it functioned, like previous panegyrics, to confirm to the tsar the truth of his idealized image. In this respect, Elchaninov extols the qualities of heroic self-sacrifice to duty and to the people, characteristic of Nicholas's predecessors. Nicholas's dedication, Elchaninov emphasized, came from his personal designation by God during his coronation. The book opens at the moment after his investiture, when the tsar kneels before the congregation and begs God to help him "in his high service to order all for the good of his people and the glory of God." Nicholas's every word and deed, Elchaninov wrote, was occupied with this "mission, which cannot be compared with any obligation of our own." 35 Heeding his coronation vow, Nicholas is "the true father of his people," who thinks and works only for them. "He never lays down his work, on week days, and weekends, resting only during his short period of sleep, offering in small things, as in great, a lofty example of 'loyalty in the performance of his duty.'"36

The conscientious, diligent, and able performance of his duty became the principal sign of the tsar's title to rule. His dedication set him apart from his subjects, but also revealed him laboring like them: he is "the crowned toiler" (ventsenosnyi truzhenik), who, "following the precept of the founder of the dynasty...Tsar Michael Fedorovich, ceaselessly devotes himself

33 "Ob izdanii redaktsieiu Sel'skogo vestnika knigi General-Maiora A. El'chaninova," $2,4,8$. The deleted sentence was on page 97 of the proofs.

34 "Ob izdanii redaktsieiu Sel'skogo vestnika knigi General-Maiora A. El'chaninova," 8. These deleted passages were on pages 34 and 45 of the proofs.

35 Tsarstvovanie..., 7-8; The Tsar and His People, 1-2. The vow or supplication was introduced at the coronation of Anna Ioannovna in 1730. See Scenarios of Power, 1: 101-2.

36 Tsarstvovanie..., 8; The Tsar and His People, 3. 
to serving his people." ${ }^{37}$ Like other authors expressing Nicholas's view of the tercentenary, Elchaninov makes Michael's self-sacrifice for his people the central act of 1613.38 The synchronic mode of the myth is reflected in the persistence of this ethos as the characteristic distinguishing all members of the dynasty.

The title of the first chapter, "The Sovereign Helmsman of the Russian Land" (Derzhavnyi Kormchii Russkoi Zemli), sets Nicholas on this timeless plane: Pushkin's image of Peter the Great as helmsman is juxtaposed with the initial designation of Russian unity in the chronicles "The Russian Land." Nicholas is endowed with Peter's traits of absolute control, will, and sense of direction: he acts on behalf of the Russian land, the nation. The concept of nation, however, was not present in the legislation or manifestos of Peter's time. Peter had directed his energies to the organization and strengthening of the Russian administration, the very institutions that now eluded Nicholas's influence and control. Elchaninov gives a picture of one who is sure of himself and is in absolute control of the government. This is clearly an answer to the widespread conception at the time of Nicholas as passive and distant from state affairs.

Like Drankov's film, Elchaninov sets Nicholas in a historical frame with his illustrious forbears, associating him with their glories and heroism. At the conclusion, he draws explicit parallels between the crisis of the early twentieth century and the troubles faced by Romanov tsars in the early seventeenth, eighteenth, and nineteenth centuries. Each had triumphed by uniting with the people. Michael had received his power from the people and then "with a gentle but firm hand, in unity with his people, led his country back to the path of glory and greatness." Peter had brought Russia out of the chaos left by "the Empress Sophia." Russia was "raised to a greater height than ever before by "the unity of the people with the Tsar." When Napoleon had taken Moscow, "the people with one accord offered their soul, full of love and devotion, to their Tsar, and by a united effort, with the aid of the army repulsed the terrible

\footnotetext{
37 Tsarstvovanie..., 16; The Tsar and His People, 9.

38 See for example I. Bazhenov, "Prizvanie Mikhaila Feodorovicha k prestolu," Iubileinyi sbornik kostromskogo tserkovno-istoricheskogo obshchestva (Kostroma, 1913), 58-9; Moskovskie vedomosti, Feb. 22, 1913, 3; P. G. Vasenko, ed., Boiare Romanovy i votsarenie Mikhaila Feodorovicha (St. Petersburg: Komitet dlia ustroistva prazdnovaniia, 1913), 142-52; S. A. Toluzakov, Podvig 300-letiia sluzheniia Rossii gosudarei doma Romanovykh (St. Petersburg, Iakor,1913), 3-4, 312.
} 
invasion and soon planted their standards on the walls of Paris." In all three cases, "as soon as the people responded to the Tsar's summons to unite with him, the sun once more shone on the Russian Land!"39

Elchaninov places Nicholas within the recurring motif of triumph of tsar and people. He shows Nicholas as leader of his people, taking initiative for the political, agrarian, and military reforms of his reign. He presents tragedies and defeats as minor setbacks on the path to national unity and resurgence. The Khodynka massacre at Nicholas's coronation is mentioned only as an occasion for a show of Nicholas's pity and largesse to the suffering. The Russo-Japanese war is passed over with the assertion, "In spite of the unfortunate war with Japan, our country's international position is stronger than ever before, and all nations vie with one another in seeking to secure our friendship." 40

Elchaninov's detailed description of Nicholas at work brings out the tsar's dedication and self-discipline. Chapter Two, "The Crowned Toiler," takes us through Nicholas's usual work day. ${ }^{41}$ By nine in the morning, the tsar finishes his breakfast, "a simple frugal meal in keeping with his whole way of living," and is at work in his study. From ten to eleven, he takes walks, alone or with the tsarevich, but usually, he forgoes this to receive reports from high officials of the imperial court, ministers, or other "less exalted personages." At eleven, he tastes the soldiers' rations from His Own Infantry Regiment and the Imperial Escort, usually with the tsarevich. From twelve to two, he takes lunch-ample but simple, then holds audiences from three until four. From five to six he has tea with the family, though sometimes this hour too is devoted to business. At free moments, he would exercise-walking, bicycling, or canoeing_often with his children. He works from six until dinner at eight, sometimes giving audiences to officials. At nine-thirty, he returns to work until he retires at 12 or 12:30, "and often much later." According to the author, the tsar spent ten to twelve hours working each day.

Following the image of helmsman, Elchaninov shows Nicholas taking charge of everything personally. He gathers information himself and reads all correspondence. Nicholas trusts no one to make decisions, delegates

\footnotetext{
39 Tsarstvovanie..., 132-4; The Tsar and His People, 145-8.

40 Tsarstvovanie..., 14-16; The Tsar and His People, 6-9.

41 Tsarstvovanie..., 17-31; The Tsar and His People, 9-28.
} 
no responsibility, and does not even allow a secretary to help him. This section makes clear Nicholas's complete independence from the institutions of statethe Ministries and the Duma. Thus he remains true to the myth of allcompetent absolute monarch, without concession to the complex demands of modern leadership. In most cases, the tsar thinks through a problem by himself, grasps its import, and composes the answer. When the tsar needs assistance, he turns not to government officials but to "heads of the various departments of the Palace, members of the Imperial suite, and others." He attentively studies the bills submitted to him by the State Council-more than 900 from 1909-1911. The tsar annotates reports in his own hand, and the author cites several of his notes. For example, "I am persuaded of the necessity of a complete reform of our law statutes to the end that real justice should at last reign in Russia." 42

Much of the tsar's time is spent attending audiences, with ministers, ambassadors, officials and private individuals. He held these frequently, sometimes receiving several hundred people in his day. "Courteous, attentive, and with a full and exact knowledge of every subject dealt with, the Tsar goes straight to the heart of the question, with a rare skill in anticipating a speaker's train of thought." 43 Private audiences last three to four minutes, those with ministers and ambassadors longer, but the tsar quickly understands the thread of all conversations and treats all according to their merits. All feel the tsar's proverbial charm. He gives pecuniary aid justly to supplicants. He knows exactly what to say, speaks concisely, but always finds sympathetic words and is informed about the life and work of all those he speaks to. He makes no distinction according to status. "The humblest person is honored by the Tsar's knowledge of his past and services and by his inquiries after his family and relatives." Elchaninov presents a tsar who both displays his concern for his people and serves as a model for them. The chapter ends with Nicholas's own words, "I do the work of three men. Let every one learn to do the work of at least two." 44

Three of the twelve chapters of the book are devoted to Nicholas's family life. Elchaninov makes it clear that the family is a separate and even superior field of the tsar's virtue. Nicholas is a model father. He has few friends. The

\footnotetext{
42 Tsarstvovanie..., 25, 31, 123-31; The Tsar and His People, 18-21, 28, 133, 141-4.

43 Tsarstvovanie..., 24; The Tsar and His People, 17.

44 Tsarstvovanie..., 29, 31; The Tsar and His People, 28.
} 
family is Nicholas's favorite company. Nicholas, the worker-tsar, "tsar'rabotnik" does not like "worldly pleasures" and "raises His Family in this spirit." "Entertainments at the Palace are comparatively rare. Great balls and processions are presented only when necessary, as a duty of service. A modest, frugal way of life is evident here too..." 45

The imperial family is an enclosed sphere, completely separate from court and state. The members are united by love and a sense of the significance of every detail of their life, giving the sense of a domestic novel, much as Queen Victoria had been presented in the last decades of the nineteenth century. ${ }^{46}$ In this respect, Nicholas II's elevation of the family was quite different from his great-grandfather's. Nicholas I had made his family the symbol of the state, the center of the court and the bureaucracy; Nicholas II kept his family apart from these institutions. ${ }^{47}$

One of the three chapters is devoted to the vigorous outdoor recreation preferred by the imperial family. They enjoy swimming, hunting, tennis, rowing, horseback-riding, bicycling, motoring, and picking mushrooms and berries. The text dwells on their automobile rides in Crimea and their walks and berry-collecting on the Finnish archipelagoes. The involvement of parents and children alike with family life is most strikingly reflected in their passion for photography. "All the Tsar's family have cameras and bring back from every visit numbers of excellent photographs." These are not pictures to be shown to the public, but to themselves and to friends. The imperial family shares the self-absorption of the middle-class family, one of the features that has made them so much more appealing to posterity than they were to their contemporaries. 48

The recreations present Nicholas as an ordinary man, enjoying the pleasures of nature and sport. But as a Romanov he also must do things better than anyone else. In swimming "he has no equals amongst his suite; he is able to dive and remain under water for minutes together" (sic). He is extremely proficient at billiards. The greatest attention is bestowed on Nicholas's hunting

45 Tsarstvovanie..., 50, 54; The Tsar and His People, 47, 51. The word "tsar'-rabotnik" in the original is not translated directly in the English edition.

46 Thomas Richards, The Commodity Culture of Victorian England: Advertising and Spectacle, 1851-1914 (Stanford: Stanford University Press, 1990), 102-3, compares the life at the court of Victoria to a domestic novel.

47 On Nicholas I's conception of the family, see Scenarios of Power, 1: 325-42.

48 Tsarstvovanie..., 41-4; The Tsar and His People, 37-41. 


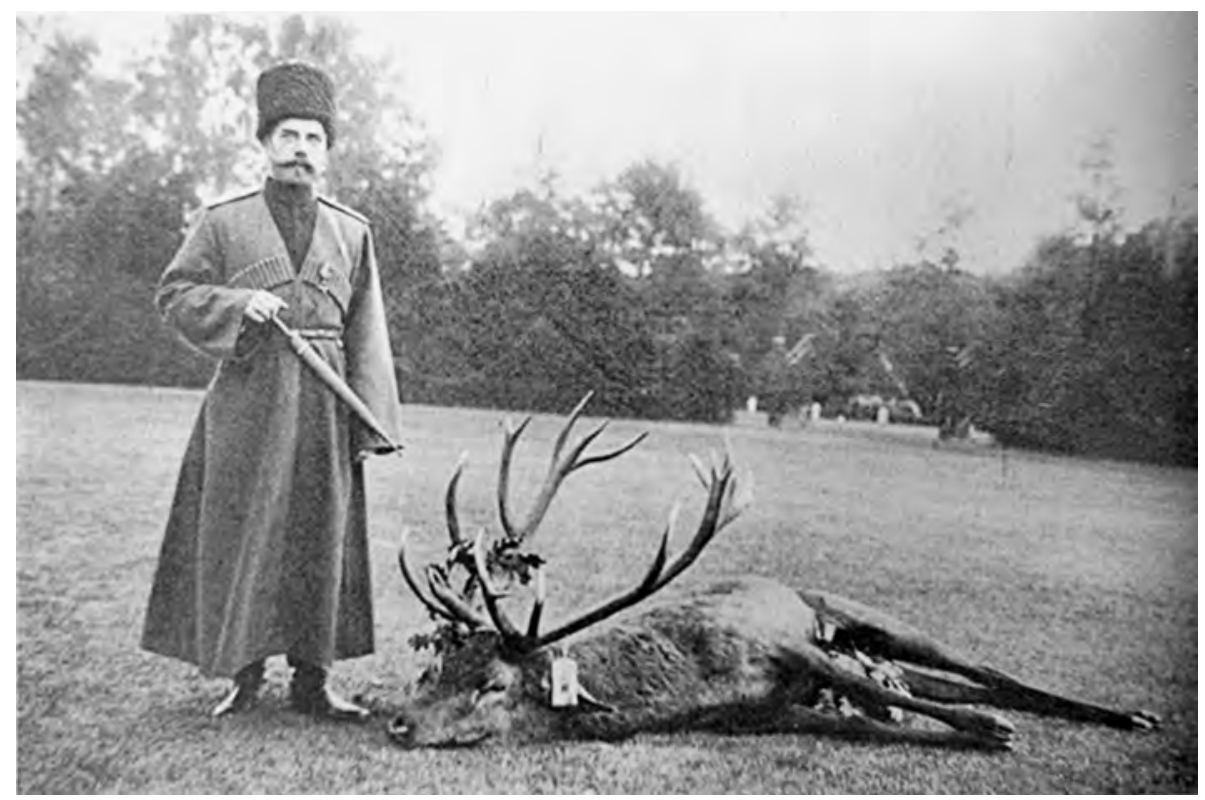

Figure 2-Nicholas II as Huntsman. A. Elchaninov, The Tsar and His People (London, Hodder and Stoughton, 1914).

excursions, which are described in great detail and with illustrations (Figure 2). "Given his excellent marksmanship and his cool self-possession, it is not surprising that the Tsar should generally make the largest bag." ${ }^{\prime 49}$

Nicholas also has broad cultural interests. He loves opera, particularly Russian opera, though also the works of Richard Wagner. His favorite newspapers are Novoe vremia, the mass circulation conservative nationalist daily, Russkii invalid-the military newspaper-and among foreign periodicals, Figaro and L'Illustration. Nicholas's great passion, however, is for history, and he believes that history is the source of Russia's greatness. "The Tsar brings to the consciousness of Russian society the sense that only that state is strong which respects the heritage of its past and he himself is the first

49 Tsarstvovanie..., 36-8, 50-2, 54-5; The Tsar and His People, 33-4, 49, 52. From his youth Nicholas prided himself on his triumphs in these sports and gladly heard flattery about his prowess. He wrote to his father on June 24, 1887, his first year on maneuvers at Krasnoe Selo, about his victories in billiards and boasted that he was considered the best player in his division ("Pis'ma V. Kn. Nikolaia Aleksandrovicha k Aleksandru III," GARF, 677-1-919, 110). 
to honor that heritage." Nicholas studies old manuscripts and follows the work of the Alexander III Historical Society. He eagerly studies history, "paying special attention to the reign of the most tranquil Tsar Alexei Mikhailovich." He recites to his children the old Russian folk epics, byliny, and tells them tales of the exploits of heroes like the great Russian general, Alexander Suvorov. The breadth and precision of his knowledge is "astonishing." 50

$\mathrm{He}$ has an especially great knowledge of Russian literature. His favorite writers, whose works he reads to his family, are Nikolai Gogol and I. F. Gorbunov, a theatrical monologist who delivered and published sketches from the life of the people. The family also enjoys Cossack songs and dances accompanied by balalaikas. The tsar is partial to Russian foods, particularly borsch, kasha, pancakes and the "monastery" kvas, the recipe for which came from the Sarov Monastery. "Only Russian champagne is drunk in the Palace." 1 The palace servants are "for the most part Russians." Nicholas is "careful to notice and support every unique Russian initiative, every manifestation of the Russian national genius. Similarly he likes to have the country's affairs directed by Russians." 52 Such tastes associated Nicholas and the other members of the imperial family with the Russian people as distinguished from other nationalities making up the empire.

The Orthodox religion, Nicholas believed, brought him closer to the Russian people. Elchaninov's chapter "The Orthodox Tsar" describes the imperial family's intense devotion-their attendance of all services and observances of fasts. 53 The tsar's rooms are hung with sacred icons; he loves the old chants and ceremonies, and when he meets priests he kisses their hands. The church and clergy, however, play a minor role, since Nicholas was convinced that he had a direct relationship to God. "In all his work, he seeks the instruction and support of God, from whom he derives his power as 'the Lord's anointed." Nicholas's religious observance expressed the bonds he felt between himself and God and between himself and the people, not between himself and the clergy. Much of the chapter is dedicated to his appearance in July 1903 at the canonization of Serafim of Sarov, which he and Alexandra promoted with little support from the church hierarchy. "The worshipers

\footnotetext{
50 Tsarstvovanie..., 34, 54; The Tsar and His People, 31, 34, 51-3.

51 Tsarstvovanie..., 38, 55; The Tsar and His People, 34; 52-3.

52 Tsarstvovanie..., 26, 38; The Tsar and His People, 22, 34.

53 The chapter title is misleadingly translated "The Tsar and the Orthodox Church."
} 
were deeply impressed by the sight of the Emperor and Empress in their midst as simple pilgrims, unattended by any suite or high officials." A photograph shows Nicholas carrying relics of Serafim at the Sarov observance. The tsarevich Alexei, who was conceived soon after the visit, also loves to read the saints' lives, particularly Serafim's, we are told. ${ }^{54}$

Elchaninov briefly describes the warm and helping relationship between Emperor and Empress and gives details of his daughters' education and tastes. But it is the tsarevich who is at the center of the tsar's attention. "The Tsar's relations with his son are extremely touching, their love for one another is extraordinarily deep and strong." Nicholas takes Alexei with him when he reviews the troops, and when possible "spends three or four hours a day with him in healthy outdoor work...."55

To the emperor and the empress, the tsarevich of course represented the continuation of the dynasty within the family. The next year, a luxury edition of a book on the childhood and upbringing of Russian emperors was published to mark Alexei's tenth birthday. The cover carries an inset of Alexei in Russian hat and early Russian costume. At the sides are griffons-from the Romanov Coat-of-Arms, holding shields. ${ }^{56}$ Elchaninov presents the heir as a symbol of the rejuvenation of the Russian army and nation, "the future hope of the Russian people." Alexei is described as "thoroughly proficient in rifle exercises (with a wooden gun), skirmishing order, the elements of scouting, the rules and requirements of military discipline and performs the exercises correctly and smartly." He "delights in gymnastic exercises," and participates in the activities of the poteshnye, the Russian equivalent of Boy Scouts, in Crimea, made up of soldiers' sons. ${ }^{57}$ Alexei appears in eleven of the forty-seven photographs in the volume, more than any member of the family except the tsar himself. We see him selling flowers in Yalta, and held by his father, who is wearing "the full military outfit of a soldier of low rank"58 (Figure 3). He stands at his father's side on the yacht "Standard," and in the ranks of his unit of poteshnye (Figure 4).

\footnotetext{
54 Tsarstvovanie ..., 66-72; The Tsar and His People, 62-9.

55 Tsarstvovanie..., 36; The Tsar and His People, 31-2. Tsesarevich is the legal term for the heir, officially designating that he is next in line to the throne.

56 I. N. Bozherianov, Detstvo, vospitanie i leta iunosti Russkikh Imperatorov (St. Petersburg: A. Benke, 1914).

57 Tsarstvovanie..., 14, 60; The Tsar and His People, 7, 56-7.

58 Tsarstvovanie..., 45; The Tsar and His People..., 38.
} 


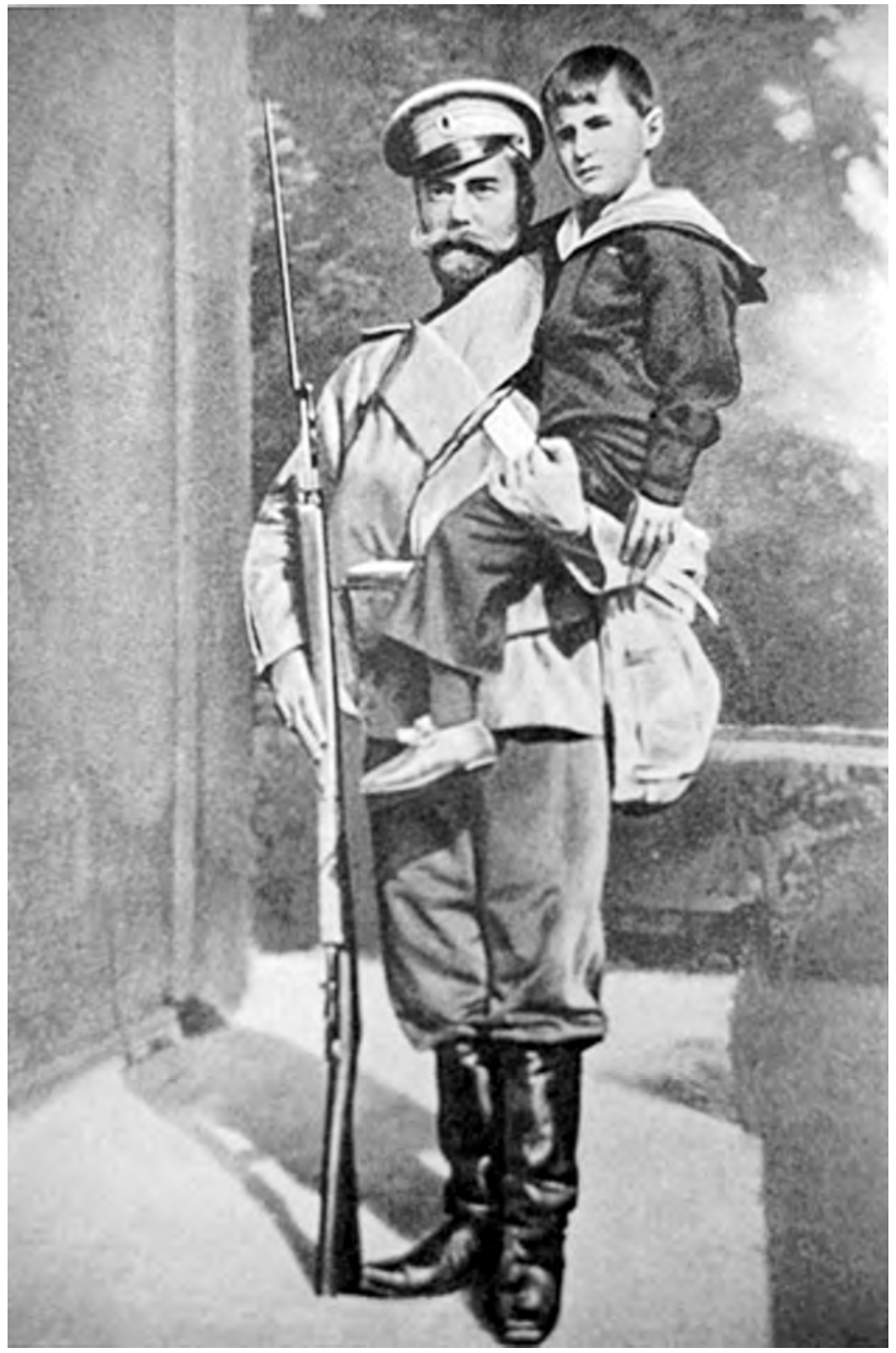

Figure 3-Nicholas II in Soldiers' Uniform holding Tsarevich Alexei.

A. Elchaninov, The Tsar and His People. 


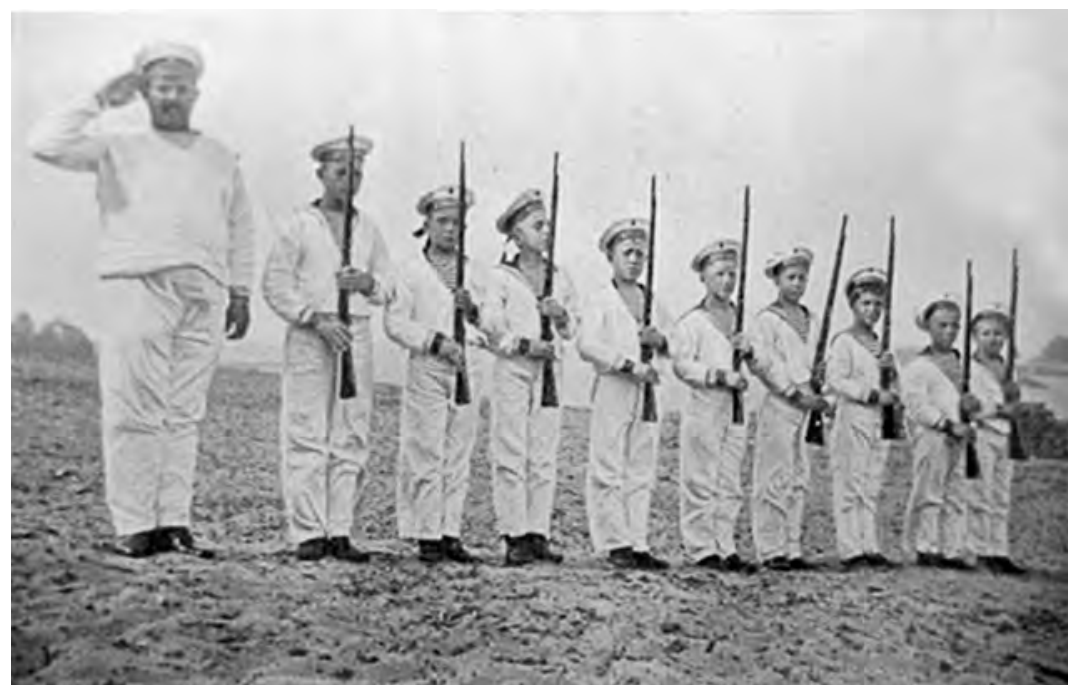

Figure 4-Tsarevich Alexei Nikolaevich among the Poteshnye (third from left). A. Elchaninov, The Tsar and His People.

Russian emperors were traditionally presented as paternalistic defenders of all estates of the realm and Elchaninov does not fail to characterize Nicholas in this manner. But he devotes little space to the tsar's relations with the nobility and the merchantry, and the new classes of Russia; the professions and the industrial workers are ignored. These groups, along with other nationalities, clearly do not fit his image as people's tsar. For Nicholas, the Russian peasants are the Russian nation.59 Elchaninov writes, "The emperor devotes much attention and care to the welfare and moral improvement of the weakest of the estates in their economic condition, if also the most numerous-the peasantry." To demonstrate this point, he describes Nicholas entering peasant huts "to see how they live and to partake of their milk and black bread."60 $\mathrm{He}$ enumerates the agricultural reforms that the tsar presumably initiated in their interest-the abolition of mutual responsibility for taxes in 1903, of corporal punishment in 1904, and in 1906 of redemption payments and civil disabilities such as those connected with the passport system. The list

59 This theme is captured better in the English title The Tsar and His People, than in the Russian The Reign of the Sovereign Emperor Nicholas Aleksandrovich.

60 Tsarstvovanie..., 76-80; The Tsar and His People..., 73-8. 
concludes with statutes introduced by Stolypin to permit the dissolution of the peasant commune and to create a class of independent peasant proprietors, though there is no reference to Stolypin in this context. The tsar, Elchaninov emphasizes, is a "firm upholder of the new system of land tenure" and had introduced it on his Peterhof estate. A photograph shows Nicholas examining a new model of plough at Peterhof. ${ }^{61}$

The lower ranks of the Russian armed forces were made up of peasants, and Elchaninov emphasizes the tsar's personal rapport with the common soldiers. Nicholas, he asserts, felt particularly close to the "Rifles of the Imperial Family," which comprised peasants from the imperial estates, and he preferred to wear their uniforms, particularly when traveling abroad. Elchaninov also cites the details of a highly publicized episode of the tsar hiking with the weight of the backpack of a rifleman of the sixteenth rifle regiment. He goes on to point out that Nicholas not only takes "every opportunity of seeing the army at close quarters," at reviews, and maneuvers, but also on such occasions "converses personally with the men, gives them fatherly advice, thanks them for their service, praises them for their smartness, and gives them monetary or other rewards." Nicholas displays the same concern for the lower ranks of the navy. In photographs, he tastes the sailors' rations on the "Standard" (Figure 5), kisses, chats with, and decorates Sub-Ensign Shepel for bravery in the Russo-Japanese War. ${ }^{62}$

Through these descriptions, Elchaninov tries to give Nicholas the features of Peter the Great as he was presented in the popular literature-"as a Westernized gentleman, but also as a good comrade who does not recognize class distinctions." 63 Nicholas, like Peter, is portrayed as a military leader and reformer. The opening sentence of the chapter on the armed forces states that the tsar "personally directs all military affairs." Elchaninov attributes recent reforms of the military to him, among them increases in pay and pensions, the reform of the General Staff Academy, and other improvements in the recruitment and education of the rank and file. Nicholas, he claims, also promoted the production of airplanes, the construction of fortresses, and the rebuilding of the Baltic, Black Sea, and Pacific fleets. ${ }^{64}$

\footnotetext{
61 Tsarstvovanie..., 80-2; The Tsar and His People, 79-81.

62 Tsarstvovanie..., 92, 96-102; The Tsar and His People, 97-8, 103-8

63 Brooks, When Russia Learned to Read, 79.

64 Tsarstvovanie..., 87-92; The Tsar and His People, 91-7.
} 
PART I. CEREMONY AND CEREMONIAL TEXTS

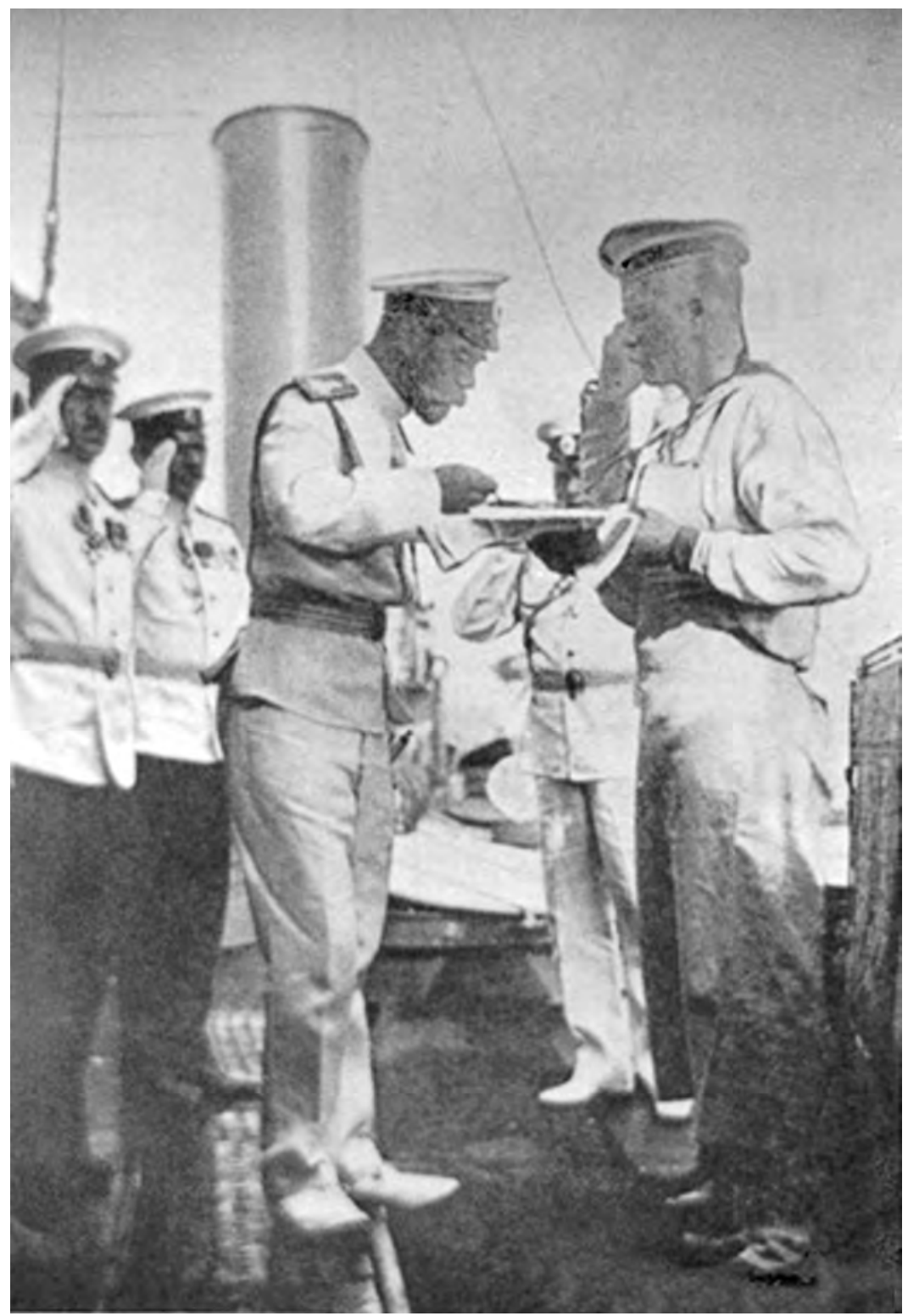

Figure 5-Nicholas II Tastes Sailors' Ration on the Yacht, The Standard. A. Elchaninov, The Tsar and His People. 
The lasting bond between tsar and the Russian peasantry is revealed most vividly at national celebrations, which are mentioned throughout the book and treated in a separate chapter as well. Elchaninov describes Nicholas's conversations with peasants at Poltava, Chernigov, Grodno, and Borodino, and their tearful exclamations when they hear his simple and kind words. He cites their speeches of gratitude at length, as expressions of the feelings of the people as a whole. For example, at Chernigov, a peasant from Liubech by the name of Protsko, proclaims, "We have come to you our Father, not alone, but with our children 'poteshnye,' future heroes and defenders of Tsar and country, and to bless your future exploits." Protsko then presents the tsar with an icon of "the first Russian monk," St. Antony of Pechersk, who came from Liubech. He continues, "In Your reforms we see the prosperity of Russia. Follow bravely in the footsteps of your ancestors, the Tsar-Liberator, Alexander II of blessed memory, and the Tsar-Peacemaker, Alexander III, of blessed memory; fear no foe-God and Russia are with you." 65

At meetings with the peasants, Nicholas shows that he is one of them, sharing common Russian traits and interests. They need no deputies to voice their point of view, for the tsar has a special, abiding rapport with them. They have given their assent not at the ballot box, but at celebrations, where they reveal the unspoken ethnic, personal bonds, "the invisible threads," which linked them to him.

Thousands of invisible threads center in the Tsar's heart which is, as in the words of the Scripture, "in the hand of God"; and these threads stretch to the huts of the poor and the palaces of the rich. And that is why the Russian people always acclaims its Tsar with such fervent enthusiasm, whether at St. Petersburg in Marinski Theatre, at the opera A Life for the Tsar, or at the dedication of memorials to Russian glory at Borodino, or on his way through towns or villages. ${ }^{66}$

This bond with the people allows Elchaninov to minimize the importance of the State Council and the State Duma, which stand between tsar and people. He construes the establishment of representative institutions as the tsar's own initiative, and the institutions themselves as extensions of the imperial will. As evidence of the tsar's early constitutional intentions, Elchaninov cites

65 Tsarstvovanie..., 82-3; The Tsar and His People, 82-3.

66 Tsarstvovanie..., 115; The Tsar and His People, 121. 
the evasive manifesto of February 26, 1903. In the spring of 1905, Nicholas decided that over the years following the emancipation of the serfs, "the Russian people had become educated up to and accustomed to dealing with public and political affairs." This conclusion had moved him to "revive in all its original force the custom, practiced by the first Tsars of the Romanov dynasty, of allowing the people, through their representatives, to examine matters of State and to investigate the needs of the State." The revolutionary turmoil of 1905 apparently played no role in Nicholas's decision.

Presenting the tsar as the creator of the Duma, Elchaninov describes Nicholas's reception of the deputies of the first Duma in the Winter Palace and cites his speech welcoming "the best people" of the land. But the ensuing "troubles" showed the tsar that the Duma deputies were not the best people, and convinced him to change the electoral law on June 7, 1907. The new electoral system sharply curtailed the number of deputies of the nationalities, particularly in the outlying areas of the empire. "Aliens (inorodtsy)," Nicholas II declared, should not "settle questions that are purely Russian." Elchaninov does not indicate that the new law also reduced representation of the urban population, especially workers and professionals. ${ }^{67} \mathrm{He}$ emphasizes Nicholas's great concern for peasant deputies, without mentioning that many of them belong to oppositional parties. At his reception for the Duma deputies in December 1912, Elchaninov remarks, the peasants were placed in the rear, but Nicholas "marked them out for special attention, beyond the greeting he gave to all the members." 68

Like all his forbears, Nicholas inhabited a realm of myth, validated by ceremonial performances of homage and adulation. As in the past, symbolic agency was invoked when the monarch's preeminence was challenged, and the devices of myth reshaped the appearances of reality to vindicate the tsar's self image. But Russian institutions and society had changed drastically by 1913. The establishment of the Duma and the expansion of a mass circulation press,

$\overline{67}$ Tsarstvovanie..., 116-22; The Tsar and His People, 123-32; on the expanded use of the term inorodtsy in this period, see John W. Slocum, "Who, and When, Were the Inorodtsy? The Evolution of the Category of "Aliens" in Imperial Russia," The Russian Review vol. 57 (April 1998): 186-90.

68 Tsarstvovanie..., 80; The Tsar and His People, 78. 
which after 1905 thrived under relaxed censorship restrictions, had introduced new competitors for the attention of the Russian public. Nicholas, viewing himself as a democratic tsar, vied with the political parties through the media of publicity.

Alexander II had also claimed the love of the people, but his representations had been directed principally to the elite, and sought to elevate him above his subjects by his supreme benevolence and beneficence. Nicholas addressed the masses directly. He vied with the Duma, and in so doing relinquished the Olympian superiority to politics that had been fundamental to the imperial myth. By bringing his life and rule into a public dialogue, he abandoned the monologic self-sufficiency characteristic of a myth that allowed no response but affirmation in elevating the absolute power of the Russian emperor. ${ }^{69}$ At the same time, the modern genres of publicity demeaned his image and associated him with the everyday and ordinary. Such devices may have helped to popularize Victoria's homey, grandmotherly character, but she was not a ruler seeking grounds to restore absolute monarchy. ${ }^{70}$ Nicholas's image assumed traits of the European monarchs, whose modus vivendi with parliamentary institutions Russian monarchs had vowed to avoid.

Indeed, Elchaninov's book, with its uncertain genre, veering between grandiloquent panegyric and democratic propaganda, typified the contradictory goals of tsarist representation in 1913. On the one hand, Nicholas is the all-competent monarch, performing prodigies. On the other, the excess of detail about Nicholas's daily life, could only further diminish the super-human image of the Russian emperor. On one hand, he is the epitome of elegant western royalty, the aficianado of tennis, yachting, and fancy automobiles, the recreations of Western high society. On the other, he is the "crowned toiler" sharing a hard life of work with peasants and soldiers. The resulting image lacks coherence and is so at variance with well-known facts that it could hardly have gained the credence of contemporary readers.

The main importance of The Reign of the Sovereign Emperor Nicholas Aleksandrovich, however, was not its influence on the Russian public, but its effect on the tsar himself. The publication of the book presumed a positive

$\overline{69}$ See Scenarios of Power, 1: 7 on the epic and monologic character of the imperial myth.

70 On the publicity and marketing of Victoria's image see Richards, The Commodity Culture of Victorian England, 73-118. 
response, and showed his involvement with the masses of the Russian people. It was self-validating, reinforcing Nicholas's idealized conception of himself. It reflected and magnified his belief in his virtues as father and Christian, as well as his capacities as ruler and military commander. It sustained his sense of calling to rule the state and to command the army following the tradition of his forbears, Peter the Great and Alexander I. Elchaninov narrowed the mythical reality of the Russian sovereign to the personal world of the allcompetent monarch, isolated from the institutional and social realities of Russia. He glorified him apart from the institutions of the Russian state, and this image distinguished him from all his predecessors, who identified their own supremacy, to a greater or lesser degree, with the supremacy of the state.

The tercentenary celebrations convinced Nicholas that he had the support of the vast majority of the Russian people. Elchaninov's book confirmed his sense of prowess and destiny. In late 1913, Nicholas began to act on his convictions and sought, unsuccessfully, to curtail the powers of the Duma. During World War I, he continued this struggle by refusing to compromise with the Duma, thereby precluding a unified government to cope with the military emergency. In 1915, he realized his fatal dream and assumed the position of commander-in-chief of the Russian armed forces. In this respect, Nicholas utilized the genres of modern publicity to preserve his own mythical construction of reality and his belief in his historical mission to restore autocratic rule in Russia. 


\section{Part II}

The Imperial Myth

in Artistic Texts

cकis? 



\section{Alexei Olenin, Fedor Solntsev, and the Development of a Russian National Esthetic}

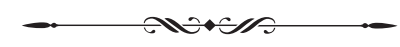

D uring the reign of Nicholas I (1825-1855), the idea of nationality (narodnost') represented far more than an ideological justification for absolutism in Russia. Nicholas sought to present the monarchy as an embodiment of Russian culture, to discover and foster an indigenous artistic tradition that would elevate his rule. Just as he brought the political police and the work of codification under his personal purview in his chancellery, he watched over and directed artistic creativity. His decree of February 9, 1829 announced that he was taking the Academy of Arts under his "special most gracious patronage" (osoboe vsemilostiveishee svoe pokrovitel'stvo). The Academy was removed from the Ministry of Education and placed under the authority of the Ministry of the Court, whose Minister reported directly to him. ${ }^{1}$

Two of Nicholas's servitors-Alexei Olenin (1763-1843) and Fedor Solntsev (1801-1892) — played seminal roles in the process of creating a national esthetic. Olenin, a wealthy and eminent noble official, was an accomplished artist, archaeologist, and ethnographer. ${ }^{2}$ Solntsev was the son of a peasant born on the estate of Olenin's friend and distant relative Count A. I. MusinPushkin. The count, recognizing the young peasant's talent, sent him to study

$1 \quad$ The first Minister of the Court was Peter Volkonskii, a cousin of Alexei Olenin. Imperatorskaia sanktpeterburgskaia akademiia kbudozhestv, 1764-1914: kratkii istoricheskii ocherk (St. Petersburg: Akademiia Khudozhestv, 1914), 38; Mary Stuart, Aristocrat-Librarian in Service to the Tsar: Aleksei Nikolaevich Olenin and the Imperial Public Library (Boulder, CO: East European Monographs, 1986), 137.

2 See the two excellent biographies of Olenin, Mary Stuart's and V. Faibisovich, Aleksei Nikolaevich Olenin: Opyt nauchnoi biografii (St. Petersburg: Rossiiskaia natsional'naia biblioteka, 2006). 
at the Imperial Academy of Arts. Solntsev proved a virtuoso draftsman and watercolorist, and Olenin made him his protégé. 3

For Nicholas, the Byzantine Empire came to represent the supreme example of absolute monarchy, and Byzantine art and architecture the true source of Russia's artistic and architectural heritage, as evidenced in the Kievan and Muscovite epochs. As a twenty-one year-old Grand Duke, he revealed his concern for early Russian church architecture in 1817, when he visited Patriarch Nikon's New Jerusalem Monastery near Moscow, built from 1658 to 1685 , and encouraged plans for its restoration. Three years later, the artist M. N. Vorob'ev was dispatched to Constantinople and the Holy Land to gather intelligence on the Ottoman Empire. Alexei Olenin, as Director of the Academy of Arts, suggested that he also paint watercolors of Byzantine churches. When these were exhibited at the Academy from 1823 to 1827, Nicholas viewed them approvingly and visited Vorob'ev in his studio. ${ }^{4}$

Once he ascended the throne. Nicholas hoped to promote a national style of architecture by constructing copies of early Russian churches that incorporated principles of Byzantine architecture. Early Russian churches came in many shapes and sizes, and Nicholas lacked a clear idea of which represented the true national style. At the outset of his reign, he directed the architect V. N. Stasov to design examples for the Church of the Tithe in Kiev and for the Russian colony in Potsdam and Kiev, but they did not meet the emperor's unspoken requirements. ${ }^{5}$ In 1827 , Nicholas began seeking designs for St. Catherine's church in Petersburg and for the Christ the Redeemer

3 In his memoir, Solntsev wrote that his father was "a peasant on the estate (pomeshchichii krest'ianin) of Count Musin-Pushkin, who, however, never considered him a serf” (Academic F. G. Solntsev, "Moia zhizn' i khudozhestvennoarkheologicheskie trudy," Russkaia starina vol. 16 [1876], 110). Most accounts suggest that his father nonetheless had the status of a serf. Richard Stites, Serfdom, Society and the Arts in Imperial Russia: The Pleasure and the Power (New Haven, CT: Yale University Press, 2005), 290-1, 293.

4 Nicholas included him in his suite to paint landscapes and battle scenes during the Russo-Turkish War of 1828. On Olenin's role in Vorob'ev's assignment as a spy in these areas, and the detailed instructions he gave him, see Stuart, AristocratLibrarian in Service to the Tsar, 105-6; See also P. N. Petrov, "M.N. Vorob'ev i ego shkola," Vestnik iziashchnykh iskusstv vol. 6 (1888): 297-303; E. A. Borisova, Russkaia arkhitektura vtoroi poloviny XIX veka (Moscow: Nauka, 1979), 95.

5 E. I. Kirichenko, Russkii stil' (Moscow: Galart, 1997), 92; Karl Friedrich Schinkel: Fübrer zu seinen Bauten (Munich: Deutscher Kunstverlag, 2006), 1201; V. I. Piliavskii, Stasov-arkhitektor (Leningrad: Izd. literatury po stroitel'stvu, 
Cathedral in Moscow, which the architect Alexander Vitberg had designed in neoclassical style for Alexander I. Nicholas asked for a building that "would attest to compatriots as well as to foreigners of the zeal of Russians for the Orthodox faith." But the projects he received, nonetheless, followed neoclassical prototypes. Solntsev recalled the tsar's angry exclamation, "They all want to build in the Roman style. In Moscow we have many splendid buildings completed to the Russian taste." 6

Nicholas had only a vague sense of a "Russian taste," and his architects could not fathom his intent. Although he was considerably more certain in his views than most Russian rulers, he too needed guidance in this sphere. He sought an official of high standing, knowledgeable in the arts, who also had insight into the tsar's inclinations and was deft in his manner of discourse, who could "divine the imperial will." 7 The official who possessed such talents and shared the tsar's predilections for a national art was Alexei Olenin. By the time the twenty-nine year-old Nicholas ascended the throne in 1825 , Olenin was a sixty-two year-old eminent and venerable figure among the cultural and political elite of the capital. He had served since 1808 as acting State Secretary to Alexander I and as well as Director of the Imperial Public Library. In 1817 Alexander appointed him Director of the Academy of Arts. Olenin continued to serve as director of both institutions after Nicholas's accession in 1825. On the day of his coronation, August 22, 1826, Nicholas confirmed Olenin in the position of State Secretary. A year later he appointed him to the State Council. ${ }^{8}$

Olenin was known as an expert in the artifacts of early Russia and sought to revive their memory in order to introduce them into current art

arkhitekture i stroitel'nym materialam, 1963), 209-10; Elena Simanovskaia, Russkii aktsent garnizonnogo goroda (Potsdam, P.R. Verlag, 2005), 44-7.

6 Borisova, 100-1, 127; Academic F. G. Solntsev, "Moia zhizn' i khudozhestvennoarkheologicheskie trudy," Russkaia Starina vol. 16 (1876): 278.

7 Mikhail Dolbilov has described the practice of "divining the imperial will" (ugadyvat' vysochaishuiu voliu), which all tsar's ministers and advisors endeavored to master in the nineteenth century. "Divining the imperial will" could also involve subtle manipulation, planting ideas in the tsar's mind while making him believe they were his own (M. D. Dolbilov, "Rozhdenie imperatorskikh reshenii: monarkh, sovetnik i 'vysochaishaia volia' v Rossii XIX v.,” Istoricheskie zapiski, No. 9 [127] [2006]: 5-48).

8 Faibisovich, Aleksei Nikolaevich Olenin, Chapters 2 and 3; Stuart, AristocratLibrarian in Service to the Tsar, 12-17, and Chapter 3. 
and architecture. He also shared Nicholas's belief that indigenous styles could be fused with classical and western forms to create an eclectic art that was at once both native and belonging to the universal artistic heritage of classicism. Unhappy with the projects submitted for the St. Catherine church, Nicholas turned to Olenin for advice. Olenin recommended a young architect, Constantine Thon, whose earlier work had been entirely in the spirit of neoclassicism. Thon too was bewildered by the tsar's instructions. Divining the tsar's vague intentions, Olenin directed him to sketches executed by his own protégés, Fedor Solntsev and the architect N. E. Efimov. 9 These served as guides for the plans Thon drafted for the St. Catherine Church, which he submitted to the tsar to the tsar in 1830 . Nicholas was pleased, and the church became the exemplar of the "Thon style," which in 1841 would be decreed the official model for Russian church architecture.

The "Thon style" combined neoclassical structural elements with the Russian-Byzantine design exemplified in the five-cupola structure of the Assumption Cathedrals in Vladimir and Moscow. Thon's Christ the Redeemer Cathedral and New Kremlin Palace both begun in the 1830s unveiled the features of a new eclectic, neo-Byzantine style. The cathedral's proportions and arcades as well as its cupolas were typically neoclassical; the exterior design asserted its Russian character. The New Kremlin Palace also followed the principles of neoclassical design and proportions. The interlace embellishments around its windows lent a national touch. The juxtaposition of Western and Russian styles evoked the desired sense of connection Nicholas sought between the westernized monarchy and Russia's distinctive past. ${ }^{10}$

The fusion of the heritage of classical art with the motifs of Russia's own national traditions had been Olenin's lifelong goal. He had grown up as an admirer and exponent of the classical tradition. The "Greek Project" of Catherine the Great and Grigorii Potemkin had shaped the tastes of the

$\overline{9} \quad$ Thon had graduated from the Academy in 1815. His early projects had won Olenin's admiration and he had recommended him for a stipend to travel abroad and study in Italy. Ton was well known for his project to restore the imperial palace on the Palatine hill in Rome (V. G. Lisovskii, "Natsional'nyi stil"” v arkhitekture Rossii [Moscow: Sovpadenie, 2000], 70-1).

10 See Scenarios of Power, 1: 381-7. 
imperial court during his formative years. ${ }^{11}$ A ward of the President of the Academy of Sciences, Princess Dashkova, and a pupil in the Page Corps, Olenin numbered among the elite, and as such, he was dispatched to Dresden, ostensibly to study artillery. There he could view the renowned collections of Renaissance and Baroque art in the Zwinger Palace and the Green Vault and read the works of Johann Winckelmann as well as other eighteenthcentury German scholars. When he returned, he propounded the ideas of "the father of art history," so much that he became known as "the Russian Winckelmann." 12

In the first decade of the nineteenth century, Olenin sought to establish a historical link between indigenous Russian art and the art of Greece and Rome. The discovery of early Russian artifacts in Crimea in the last decades of the eighteenth century provided evidence of direct contacts between ancient Greece and early Russian towns. Olenin soon became engaged in the publication and analysis of these findings. ${ }^{13}$ At the same time, German scholars were extending Winckelman's concept of the range of ancient art to include monuments and everyday objects unearthed during archaeological

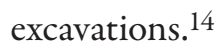

Olenin followed their example, seeking and collecting objects that could reveal details about the culture and mores of past times in addition to their artistic achievements, and, as Director of the Academy of Arts, introducing

11 Faibisovich links his views with Catherine the Great's "Greek Project," her plans to create a Greek empire, allied with Russia, which she promoted during Olenin's formative years at the end of the eighteenth century. Faibisovich, Aleksei Nikolaevich Olenin, 241-6; Stuart, Aristocrat-Librarian in Service to the Tsar, 5-6).

12 Stuart, Aristocrat-Librarian in Service to the Tsar, 8-9; He also frequented the salon of the Russian ambassador, A. M. Belosel'skii, an art and music lover who befriended Voltaire, Beaumarchais, and Marmontel, and authored works on poetry and music. Faibisovich, Aleksei Nikolaevich Olenin, 32-43.

13 The Tmutorokan stone, discovered in 1792 by Musin-Pushkin, bore an inscription from the year 1036 indicating the proximity of the Russian town of Tmutorokan to "territories of the Greeks." In 1806, Olenin published A Letter to Count A. I. Musin-Pushkin, which confirmed Musin-Pushkin's conclusions with the use of sophisticated comparative materials from chronicles and artifacts such as coins and helmets as well as the "Lay of the Host of Igor," which had also been discovered by Musin-Pushkin (Faibisovich, Aleksei Nikolaevich Olenin, 246-9; Stuart, Aristocrat-Librarian in Service to the Tsar, 18-19).

14 Suzanne L. Marchand, Down From Olympus: Archaeology and Philhellenism in Germany, 1750-1970 (Princeton: Princeton University Press, 1996), 10-11, 40-53. 
courses in archaeology and ethnography. He developed a special passion for ancient "beautiful and manly weapons," as well as coats of armor and helmets, which he collected in large numbers and recorded in skillful drawings. In 1807, when Alexander I appointed him to serve in the Kremlin Armory, he began a lifelong study of the objects assembled in the building. He and the artists he supervised produced illustrations that publicized these articles as artistic symbols of Russia's past, national memorabilia (dostopamiatnosti). ${ }^{15}$

Olenin then singled out early Russian helmets as objects of antiquity that could lend a distinctly Russian character to neoclassical works, both artistic and literary. He convinced painters and sculptors to depict Russian helmets in what his biographer Victor Faibisovich described as "a Russian empire style." He persuaded the painter O. A. Kiprenskii to include the helmet of Prince M. M. Temkin-Rostovskii, a sixteenth century boiar, in his painting of 1805, "Dmitrii Donskoi on the field of Kulikovo." The helmet, once again based on a sketch of Olenin, also appeared in I. Ivanov's illustration for the frontispiece of the first edition in 1821 of Pushkin's Ruslan and Ludmilla. ${ }^{16}$

A newly discovered helmet thought to belong to Alexander Nevskii brought the exploits of the Vladimir-Novgorod prince into the post-1812 patriotic discourse and became a favorite of illustrators later in the nineteenth century. With Olenin's encouragement, the sculptor Ivan Martos included the helmet in his monument to Kuzma Minin and Prince Pozharskii on Red Square, begun in 1804, but completed in 1818. The two heroes of the Time of Troubles strike grandiloquent classical poses in tunics modified with Russian details. ${ }^{17}$ The Nevskii helmet is to be found under Pozharskii's right arm, visible only from the rear. The helmet, however, proved not to be Nevskii's after all: it was later identified as a work produced in 1621 for Mikhail Fedorovich, the first Romanov tsar. ${ }^{18}$

Olenin's efforts expressed a rising historicist sensibility among the educated public to artifacts of Russia's past. In an article of 1820 about the Kremlin Armory, the artist and travel writer Pavel Svin'in wrote:

\footnotetext{
15 Faibisovich, Aleksei Nikolaevich Olenin, 258-9.

16 Ibid., 270-3.

17 Ibid., 339-42; Janet Kennedy, "The Neoclassical Ideal in Russian Sculpture," in Art and Culture in Nineteenth-Century Russia, ed. Theofanis George Stavrou (Bloomington, IN: Indiana University Press, 1983), 203.

18 Gosudarstvennaia oruzheinaia palata (Moscow: Sovietskii Khudozhnik, 1988), 162-3.
} 
A Russian cannot view the treasures of the Kremlin Armory only with a feeling of astonishment about something fine and valuable.... Each thing also reaffirms the unwavering glory and might of his Fatherland. Each piece of armor may have been stained with the blood of those close to him!19

For Nicholas, such objects demonstrated Russia’s parity with European monarchies, which were enshrining their own medieval traditions. In 1843, when he and the Moscow Metropolitan Filaret were examining the recently discovered frescoes in the Kiev Sofia Cathedral, Filaret voiced doubt about the wisdom of further exposure of the frescoes, which might reveal the practice of current old-believer rituals in Kievan Russia. Nicholas retorted, "You love ancient times (starina), and I love them too. In Europe now the tiniest ancient thing is cherished... Nonsense. Do not contradict me." 20

Antiquities now assumed a sacral status defined as national, hallowed with the term starina, a word uttered reverentially but difficult to translate: olden times, olden things that hearkened back to early Russia and therefore were to be regarded as authentic and eternal signs of Russia's distinctiveness. The same high valuation of the old began to affect the consciousness of the high clergy, who envisioned "the resurrection of ancient religious life." Antiquities were identified as virtual relics: the authenticity of an item as something ancient was sufficient to make it representative of "the spiritual experience of Russia."21 The next step then became to discover these objects and to make them known in Russia and Europe.

Fedor Solntsev came to Olenin's attention as an outstanding student and laureate of the Academy's gold medal in 1824 and 1827. If Olenin excelled in exercising authority effectively to realize cultural goals, Solntsev excelled in obedience to his patron, and did so with a flair that impressed both his mentor and the tsar. After Olenin's death, Nicholas took Solntsev under his

19 P. P. Svin'in, "Oruzheinaia Palata," Otechestvennye zapiski (1822): Part 3, 1. I thank Elena Vishlenkova for this reference. Faibisovich, Aleksei Nikolaevich Olenin, 344-5.

20 Solntsev, Russkaia starina vol. 16 (1876): 290.

21 A. L. Batalov, "Istorizm v tserkovnom soznanii serediny XIX v.," in Pamiatniki arkbtektury $v$ dorevoliutsionnoi Rossii: Ocherki istorii arkbtekturnoi restavratsii (Moscow, 2002), 148-9. 
direct patronage and announced that all future assignments would come from himself, "as imperial commands" (vysochaishie poveleniia). ${ }^{22}$

Solntsev's first major assignment, in 1829, was to depict the "hoard of Riazan," gold and bejeweled items of princely provenance that had been unearthed in the town of Old Riazan in 1822. Next, in 1830, a petition of Olenin prompted a Supreme Command of Nicholas to dispatch Solntsev to the Kremlin Armory in Moscow in order to "depict our ancient (starinnye) customs, dress, weapons, church and imperial paraphernalia, household goods, harness and other items belonging to the categories of historical, archaeological, and ethnographic information." 23 The command went on to specify: "Everything that is worthy of attention and that constitutes historical material or an object of archaeological interest for scholars and artists shall be described in all detail and published." 24

Only six weeks later, Solntsev provided Olenin with nine drawings, several of them watercolors. Olenin was delighted. He wrote to Solntsev of his "great pleasure" in seeing "this new example of your diligence and especially of your art in the faithful and at the same time pleasant depiction of objects that are in essence so dry but at the same time so interesting and useful for the historian, the archaeologist, and, most important, for the artist."25 Solntsev then undertook numerous trips to the sites of early Russian history, such as Vladimir, Iur'ev-Pol'skii, Riazan, and Novgorod, though his major efforts still took place at the Kremlin in Moscow. He completed nearly 5,000 drawings and watercolors, which G. I. Vzdornov described as "a kind of encyclopedia of Russian medieval and national life in its concrete monuments." 26

However, Olenin had more in mind than an encyclopedia. He envisioned a vast project that would use these artifacts to begin an ethnographical study that would integrate a Russian national esthetic into the classical heritage. He began to outline his plans in a small volume, published in 1832, as the

$\overline{22}$ Solntsev wrote of Olenin's "fatherly concern"-watching over his work, giving him instruction and treating him as a member of his family (Solntsev, Russkaia starina vol. 15 [1876]: 311; vol. 16 [1876]: 286).

23 Ibid., vol. 15 (1876): 634; Stuart, Aristocrat-Librarian in Service to the Tsar, 107.

24 A. N. Olenin, Arkheologicheskiia trudy (St. Petersburg: Imperial Academy of Sciences, 1881), 1: xxvii-xxviii.

25 Solntsev, Russkaia Starina vol. 15 (1876): 635.

26 G. I. Vzdornov, Istoriia otkrytiia i izucheniia russkoi srednevekovoi zhivopisi: XIX vek (Moscow: Iskusstvo, 1986), 29. 
first part of a multi-volume work meant to prepare a "course of History, Archaeology and Ethnography," for students at the Academy of Arts. ${ }^{27}$ The volume, the only one published, covered the period "from the time of the Trojans and Russians until the Tatar invasion." It was devoted principally to a description of the clothing of the period and meant as a guide to professor Peter Vasil'evich Basin, who was preparing to paint a scene from 989 of St. Vladimir and the baptism of Rus'. Olenin asserted that "as an enlightened Artist," Basin should "present the principal figures in authentic ancient Russian costume" and commit himself to diligent and precise study of its historical origins. ${ }^{28}$

Dress, like weapons, represented a sign of a people's culture for Olenin. He believed that pagan Russians wore scant attire similar to the primitive peoples of the Americas or the Pacific islands and adorned their skin with tattoos; but with the advent of Norman princes and the conversion to Christianity, Russians adopted items of dress from the Normans and their Byzantine allies. He observed that in all eras, peoples tend to adopt the customs, rites, and fashion of the peoples "dominating by force of arms, trade and enlightenment." To illustrate the extent of the change after the conversion, he referred to a miniature in the Izbornik of 1073, which showed Prince Sviatoslav Iaroslavich, his family, and entourage in Byzantine robes and headdress. ${ }^{29}$

A manuscript version of this volume, inscribed with the date 1834, contains illustrations by Solntsev of pre-Christian Russian princes outfitted as savage warriors and eleventh-century princes and their families in Norman, west Slavic, and Byzantine attire. Olenin concluded that the examples of dress he had found in illustrations of a seventeenth-century khronograf-a history derived from Byzantine sources that placed Russia in a world context-revealed the emergence of a distinctive national style of dress. He asserted that "the clothing of Russian princes, boiars, and boiar wives of the sixteenth century" showed that "the use of epanchi (long and highly decorated mantles and furs with hanging sleeves, otkladnye ruki) became general and a genuine national

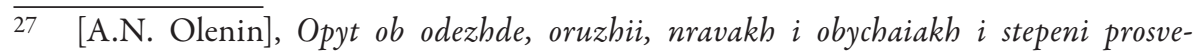
shcheniia slavian ot vremeni Traiana do nashestviia tatar; period pervyi: Pis'ma k G. Akademiku v dolzhnosti Professora Basinu (St. Petersburg: n.p., 1832).

28 Ibid., 2.

29 Ibid., 3-4, 13-19, 71. In the text, Olenin referred to a volume of accompanying illustrations, which I have not been able to locate. 
dress." ${ }^{30} \mathrm{He}$ did not indicate the sources of these items or their relationship to the earlier Byzantine models.

The program of requirements that Olenin drafted in 1835 for Solntsev's promotion to the rank of Academician in the Academy of Arts reflected the director's determination to find and make known examples of a national art that was linked to classical antiquity. The requirements demanded execution in both classical and indigenous styles. In addition to Russian antiquities, armaments, and "especially ancient clothing," Solntsev was to draw classical statues of "Venus Triumphant" and "Weeping Faun," works that had been unearthed on the estate of Princess Belosel'skaia-Belozerskaia. The assignment called for the rendering of all these diverse objects and particularly ancient Russian dress in a single painting. "In order to combine ancient Greek art with our own ancient Russian in a single picture," Solntsev wrote, "I decided to paint a watercolor depicting the meeting of Prince Sviatoslav Igorevich (964972) with the Greek Emperor John I Tzimisces (969-976)."31

Olenin not only dictated the requirements, but also influenced the composition of the painting. ${ }^{32}$ "He helped me with advice and directions, assisting me in any way he could," Solntsev recalled. The watercolor that resulted was a visual expression of his belief in the Byzantine roots of monarchical authority in Russia and his theory that clothing and weapons represented concrete expressions of national identity. (Figure 1) Solntsev places the haughty Emperor John Tzimisces and the half-naked Prince Sviatoslav, whom he defeated in 971, in the same frame, and thus juxtaposes and associates them. The emperor is on horseback in equestrian pose. He wears a crown and shoulder piece and brandishes a scepter. His face, firm and determined, expresses his authority and resolve. The presumably fierce Prince Sviatolav, in simple pagan dress, looks back submissively, chastened by this display of authority. One of the emperor's servitors and a Russian hoist the sail together. The image attached to the lower edge of the proscenium frame, foreshadows the future of Rus'. A copy of the title page of the Izbornik of 1073 shows Prince Sviatoslav Iaroslavich (1073-1076), Sviatoslav Igorevich's great

$\overline{30}$ A. N. Olenin, "Opyt o russkikh odezhdakh i obychaiakh s IX po XVIII stoletiie; Odezhda russkikh, svetskaia i voennaia. Ch. II, Odezhda svetskaia,” Biblioteka Oruzheinoi Palaty, Inv. No. Gr-4441/1-26, 47591 kp. I thank Irina Bogatskaia for recommending this manuscript to me.

31 Solntsev, Russkaia Starina vol. 16 (1876): 269-71.

32 Ibid., 271. 


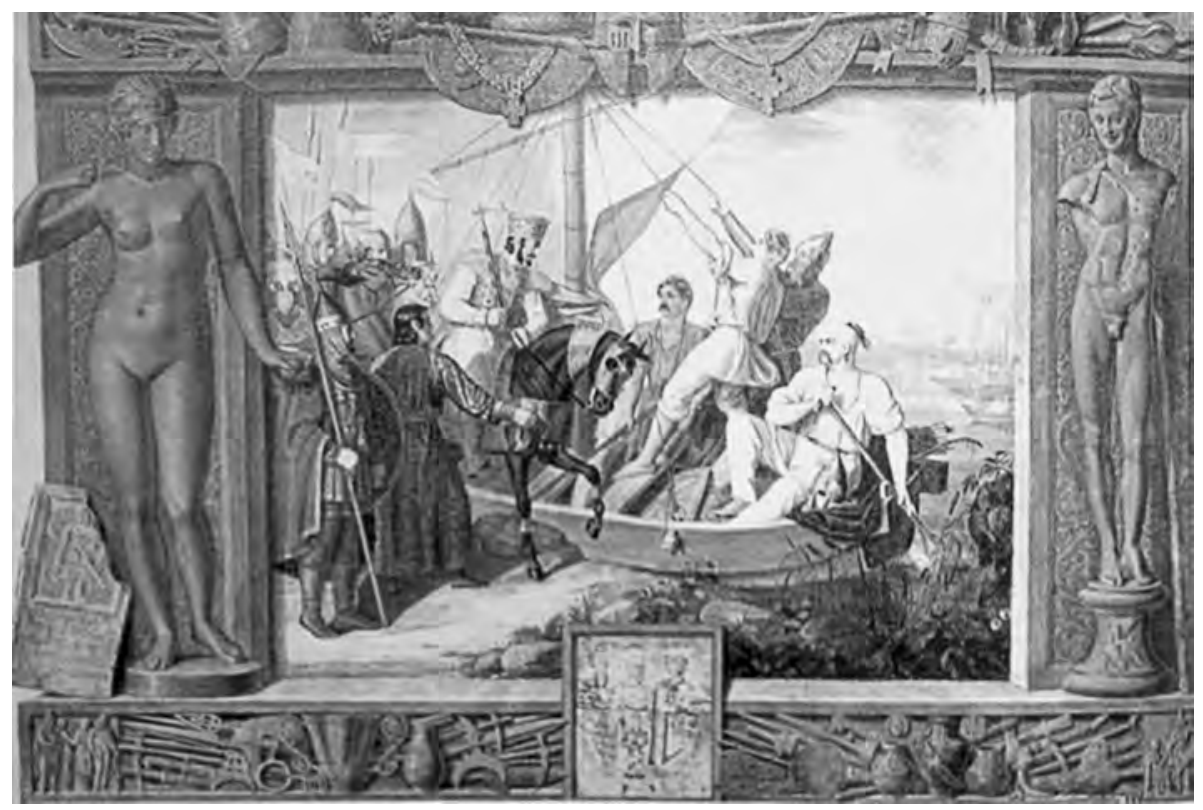

Figure 1-Fedor Solntsev-Meeting of Prince Sviatoslav Igorevich with Byzantine Emperor John I Tzimisces. Copyright (C) 2013, State Russian Museum, St. Petersburg.

grandson, with his retinue, displaying Byzantine type robes, thus demonstrating the adoption of Christian imperial culture by the Kievan dynasty.

The elaborate frame acts as a proscenium enclosing not only a dramatic scene, but also an assemblage of actors with their armaments and dress identifying them with particular periods and their artistic styles. The embellishments on the frame include Russian and Greek articles of attire, weapons, and saddles discovered in previous decades that attest to the diverse traditions of Russia's past. Shoulder crosses hang above the top, making it clear юthat we are viewing the past from a current Christian perspective. The frame is decorated with Scythian and Greek arms, some of them unearthed during recent excavations. The figures of Venus and the faun "from the Belosel'skaia-Belozerskaia estate" stand as if on guard at the sides, symbols of Russia's reception of the classical heritage.

Solntsev's watercolor won him an appointment to the Academy. It also introduced the idiom that identified his most important works-a composite of images and motifs drawn from artifacts that associated them metonymically as an expression of a national artistic tradition. Solntsev was not a creative artist: 
his talent was to reproduce objects exactly, as if a photographer, and to do so with a measure of enhancement of color and design that made them, as Olenin observed, "pleasant" to the eye. ${ }^{33}$ Solntsev applied his techniques in three projects of the 1830s that were intended to advance Nicholas's efforts to make the Moscow Kremlin a principal symbol of Russia's national past: the renovation of the Terem Palace in 1837, the Kremlin Table Service, commissioned in 1837, and the floors and carpets of the New Kremlin Palace in 1838.

The first and most important project was his work on the renovation of the seventeenth century Terem palace. The wall paintings demanded a creative adaptation of old themes since the originals had not survived. Employing motifs from various artifacts, Solntsev tried to capture the spirit of the originals. Solntsev produced this spirit by montage, by bringing together objects of varied provenance and character to associate them with a national historical theme. He borrowed motifs from different sources: decorations from the surviving window frames of the palace (Figure 2), copies of icons, illustrations of regalia, weapons, and other artifacts, and images of lions and imperial eagles. All of these covered red walls that were brightened with gilded interlace and floral designs. Solntsev patterned the dress of the saints he depicted on the walls on colorful miniatures in old manuscripts and carvings on wooden churches and peasant huts, early Russian furniture, and tiled ovens. He covered the entire expanse of the walls with designs, an effect that the art historian Evgenia Kirichenko called "kovrovost"- a carpet-like figuration she traces to Byzantine influences. The vaults and religious paintings of the palace gave the impression of early Russian church interiors, a merging of ecclesiastical and political symbols. ${ }^{34}$ His work evoked what a contemporary critic described as "a poetic mood of the soul, a hypothetical effort to convey [the distinctive features of the building] not only with archaeological exactitude but with the exalted feeling that moved the architect at the moment of creation and gave it the imprint of true beauty and creativity." 35

Nicholas inspected the work and was delighted. That same year, in 1837, he commissioned Solntsev to design the Kremlin dinner service, which

33 As a child, Solntsev had difficulty in school with reading and arithmetic, while he displayed an astounding ability to draw objects with great verisimilitude (Ibid., vol. 15 [1876]: 111).

34 Kirichenko, Russkii stil', 120, 136-8; Solntsev, Russkaia starina vol. 16 (1876): 2724, 279-80.

35 Cited in Kirichenko, Russkii stil', 137. 


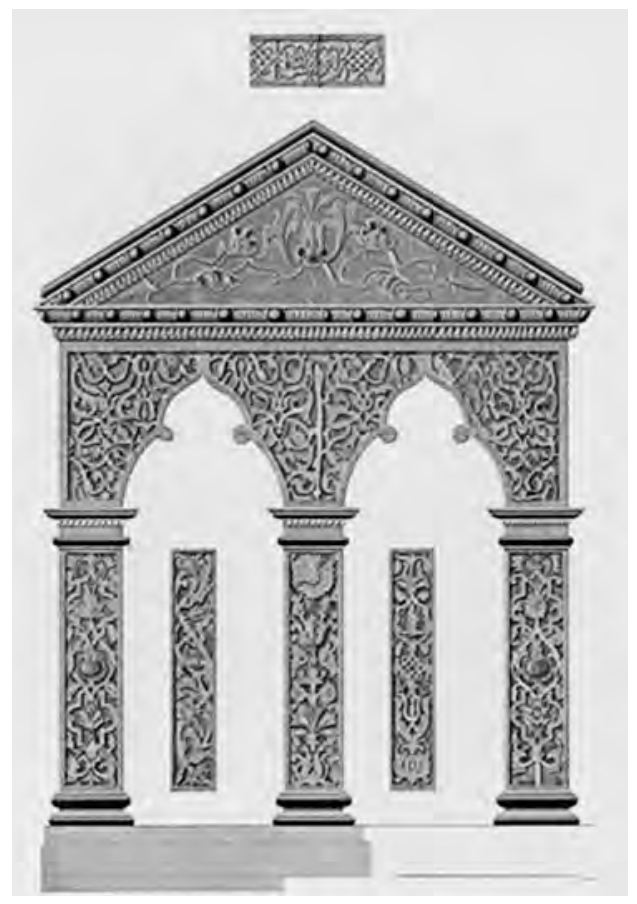

Figure 2-Fedor Solntsev-Window Frame from the Terem Palace. Drevnosti rossiiskago gosudarstva (Moscow: Tipografiia Aleksandra Semena, 1849).

became a mainstay of banquets celebrating important events in Moscow, such as coronations and the Tercentenary of 1913. As Anne Odom has shown, Solntsev used many items from the Kremlin armory as prototypes for the decoration of the service. The rims of the dishes were embellished with interlacing floral patterns from wood and stone carvings, and motifs from metal utensils, embroidery, illuminated manuscripts, and gospel covers. On the dessert plates, floral motifs cover the surface and surround the Russian imperial eagle, producing the effect of kovrovost'. One thousand of these dessert plates were produced for the service, which was completed only in 1847 . Nicholas was also pleased with Solntsev's sketches for the parquet floors and carpets of Thon's New Kremlin Palace. ${ }^{36}$

\footnotetext{
36 Anne Odom, Russian Imperial Porcelain at Hillwood (Washington, D.C.: Hillwood Museum and Gardens, 1999), 57-61; and "Fedor Solntsev, the Kremlin Service, and the Origins of the Russian Style," Hillwood Studies, No 1 (Fall 1991): 1-2; Kirichenko, Russkii stil', 138-9.
} 
The inclination to use art to bring together the diverse, to make the mutually exclusive complementary in the name of nation, culminated in the great compendium of Solntsev's drawings and watercolors, the Antiquities of the Russian State (Drevnosti rossiiskago gosudarstva). Olenin and Nicholas had intended such a publication as early as 1830 , but other projects and technical obstacles delayed the project. In 1841, Olenin submitted a proposal for a publication with broad ethnographical and historical parameters, supplemented with extensive scholarly commentaries. Its title indicated that it was meant "for artists," suggesting that it would also provide models for them to follow in developing a national artistic idiom. ${ }^{37}$

Olenin's vision of a national artistic summa with a scholarly apparatus was not to be realized. He died in 1843, and Nicholas appointed a committee under his own supervision to direct the project, which he supported with a grant of approximately one hundred thousand rubles. The six volumes of Solntsev's illustrations that resulted appeared between 1849 and 1853 in an edition of six hundred copies in both Russian and English. Owing to the emperor's generosity, they were produced with the latest techniques of color lithography. The introduction noted that the committee had abandoned Olenin's plans for "scholarly investigations" and "a purely ethnographic compilation of the antiquities of Slavonic tribes in contact with other peoples." Its members also wanted to publish the illustrations without Solntsev's signature and not to acknowledge his authorship, but Nicholas ruled otherwise. ${ }^{38}$ The introduction acknowledges Solntsev's authorship and many of the illustrations carry his signature. The emphasis of the Drevnosti shifted to ethnographic materials that glorified the ruling house as an incarnation of the national past. The compendium provided proof that due to the efforts of the monarchy, Russia, like European countries, could boast artifacts revealing a native artistic

37 The purpose was "to make known, in all their detail and idiosyncratic aspect our ancient mores, customs, rites, ecclesiastical, military and peasant dress, dwellings and buildings, the level of knowledge or enlightenment, technology, arts, trades, and various objects in our society" (Olenin, Arkheologicheskiia trudy, 1: xxviii; Stuart, Aristocrat-Librarian in Service to the Tsar, 108; Solntsev, Russkaia Starina vol. 16 [1876]: 280-1).

38 Drevnosti rossiiskago gosudarstva (Moscow: Tipografiia Aleksandra Semena, 1849), III. (Separate paginations for several introductory sections of the book); Stuart, Aristocrat-Librarian in Service to the Tsar, 108-9. 
tradition. The change is indicated by the title-Antiquities of the Russian State Published by Imperial Command of Sovereign Emperor Nicholas I (Drevnosti rossiiskago gosudarstva izdannyia po vysochaishemu poveleniiu Gosudaria Imperatora Nikolaia I). The introduction traced the achievements of Catherine the Great in initiating archaeological expeditions and Alexander I in discovering the treasures from the pre-Petrine Great Treasury Chancellery (Prikaz bol'shoi kazny) and creating a repository of antiquities in the Kremlin. It stressed that antiquities had been left to deteriorate across Russia and that "the time of the preservation of monuments began with the accession and the all-embracing solicitude of the reigning Tsar and Emperor Nicholas I."39 Just as the codification and the publication of The Complete Collection of Laws, published by imperial command during the previous decade, brought together and made known laws issued by the Russian monarchy and thus defined a national legal tradition, the Antiquities assembled the artistic works of Russia's past to make known an artistic heritage for the dynasty. ${ }^{40}$

The illustrations are divided by category—religious objects, regalia, weapons, portraits and clothing, artistic versions of household implements, and examples of early Russian architecture-with brief commentaries on the individual items. ${ }^{41}$ The dominating presence throughout is the dynasty and its predecessors. The commentaries invoke legend to set the antiquities in a narrative of dynastic continuity that linked the tsars of Moscow with their Kievan ancestors and the emperors of Byzantium. The members of the committee, Mikhail Zagoskin, Ivan Snegirev, and Alexander Vel'tman, who supervised the work and wrote several of the commentaries, were adepts of Official Nationality and known authorities on early Russian history and archaeology.

The Antiquities restored the Muscovite royal insignia to the dynastic narrative by including numerous renderings of "the regalia of Monomakh"-the

39 Drevnosti rossiiskago gosudarstva, II.

40 See my article, "The Fundamental State Laws of 1832 as Symbolic Act," in F. B. Uspenskii, ed. Miscellanea Slavica: Sbornik statei $k$ 70-letiiu Borisa Andreevicha Uspenskogo (Moscow: Indrik, 2008), 398-408, and Tatiana Borisova, "The Russian National Legal Tradition: Svod versus Ulozhenie in Nineteenth-century Russia," Review of Central and Eastern European Law vol. 33, No. 3 (July 2008): 295-341.

41 The first volume includes religious objects-icons, pectoral crosses, vestments of the clergy, and chrism dishes. The second is devoted to regalia and articles figuring in the sacralization of the tsar, the third to weapons, armor, carriages, and saddles, the fourth to portraits and clothing, the fifth to household items such as cups, wine bowls, and flasks, and the sixth to old Russian architecture. 
Crown or Monomakh Cap, the orb and scepter-which were replaced by Peter the Great at his coronation of Catherine I in 1724. Eight of the watercolors show variants of the Monomakh cap, which, according to the sixteenth century "Legend of Monomakh," had been received by Prince Vladimir Monomakh (1113-1125) from his grandfather, the emperor Constantine Monomakh (1042-1055), who had died long before the reign of his grandson. The original Monomakh Cap, shown in the illustration, is thought to be of fourteenthcentury and possibly Tatar origin ${ }^{42}$ (Figure 3 ). The commentary tried to prove the substance of the "Legend" by contending that Saint Vladimir received a golden "cap" after his conversion in 989 from the Byzantine emperor, and that Constantine Monomakh had made a gift of regalia to the Russian princes. ${ }^{43}$

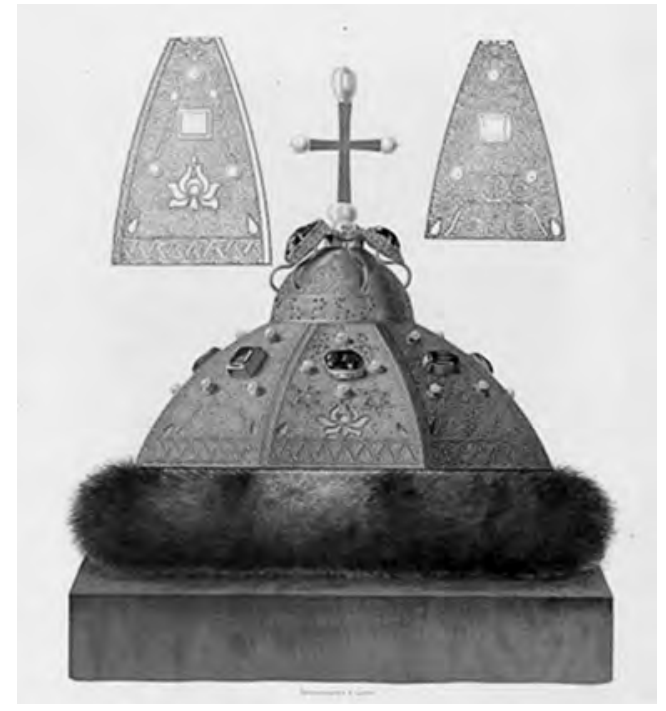

Figure 3-Fedor Solntsev-The "Monomakh Cap." Drevnosti rossiiskago gosudarstva.

After the election of Tsar Mikhail Fedorovich in 1613, new "grand regalia" (bol'shoi nariad) displayed symbolic lineage to the defunct dynasty of Riurik, which had begun with the "invitation to the Varangians" or Vikings in 862,

$\overline{42}$ On the oriental origin of the cap, see G. F. Valeeva-Suleimanova, "Korony russkikh tsarei-pamiatniki tatarskoi kul'tury," in Kazan, Moscow, St. Petersburg: Multiple Faces of Empire, ed.Catherine Evtuhov, Boris Gasparov, Alexander Ospovat, and Mark Von Hagen (Moscow: O.G. I., 1997), 40-52.

43 Drevnosti, viii-ix. 
and ended with the death of the tsarevich Dmitrii in 1598. The Antiquities included pictures of the orb and scepter of Mikhail's regalia, which were fashioned by European craftsmen in the style of the Baroque "treasury art," exhibited in European palaces during in the seventeenth century. However, the authors of the commentary did not know this, and explained the orb and scepter as "Greek work" and "a valuable memento of the tenth century." In 1627, European craftsmen working in the Kremlin produced a Baroque version of the original Monomakh cap. ${ }^{44}$

Solntsev's illustrations accentuate the decorative richness of the individual objects, creating an esthetic unity out of artifacts of diverse character and historical origin. His watercolors highlight the intricate design and vivid color of the individual antiquities, revealing each to be an object of art, and also furthering Olenin's goal to provide a guide for future artists. Solntsev's depiction of the original Crown of Monomakh reveals the intricate floral designs covering the entire gold surface (Figure 3). He includes black and white insets that make clear the intricacy of the decoration. The watercolor captures the gold of the conical form, the brightness of the emeralds and the rubies adorning the sides, and the shades of the pearls at the points of the cross.

Solntsev brings out the rich decoration of "The Grand Regalia" of Tsar Mikhail. The illustration of the scepter provides three views, one in black and white to articulate the design. The artist devotes three separate plates to the orb, a frontal view, copies of the four triangular pictures on the Hebrew kings, and details from the top and the base (Figure 4).

The Antiquities also provide numerous illustrations of weapons and particularly helmets that belonged to Russian princes and tsars. Four illustrations are devoted to views of the purported helmet of Alexander Nevskii ${ }^{5}$ (Figure 5). Two views show the gold engraving of imperial crowns on the surface, the gems, and the enamel figure of the Archangel Michael on the nose piece. The cuirass in the rear, which follows West European examples, is covered with etched interlace of vegetal designs around a figure of Hercules subduing the Hydra of Lernaea. ${ }^{46}$ The breast plate of Alexei Mikhailovich, called "mirror" (zertsalo)

$\overline{44}$ Gosudarstvennaia oruzheinaia palata, 347-9; Drevnosti rossiiskago gosudarstva, Section 2, 34, 51.

45 Faibisovich, Aleksei Nikolaevich Olenin, 296. The commentary refers to the mention of the helmet in a seventeenth-century listing, but links it to Georgian kings. It characterizes the attribution to Nevskii as a "tradition" (Drevnosti, Section 3, No. 7).

Drevnosti, Section 3, 7; Gosudarstvennaia oruzheinaia palata, 162-3. 


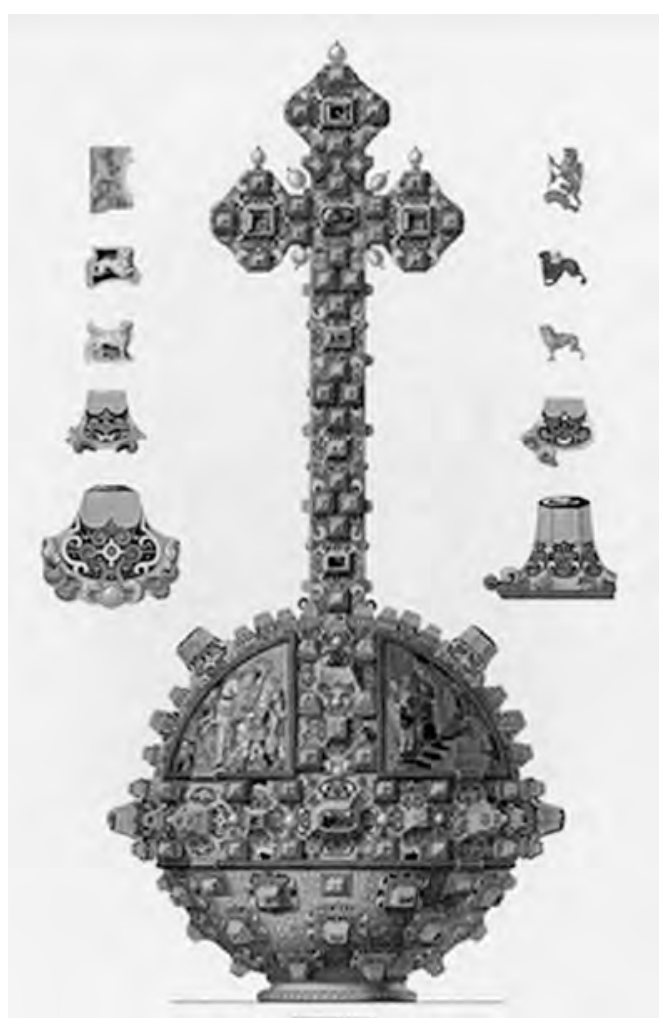

Figure 4-Fedor Solntsev-Orb from the "Grand Regalia" of Tsar Michael. Drevnosti rossiiskago gosudarstva.

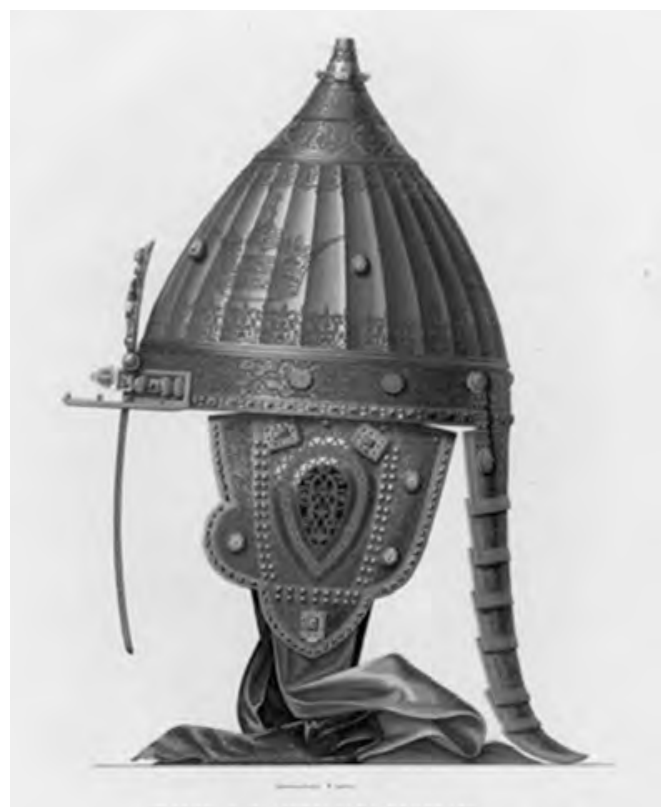

Figure 5-Fedor Solntsev"Helmet of Alexander Nevskii." Drevnosti rossiiskago gosudarstva. 
armor, is made up of shining polished steel with alternating sheets imprinted with gold. Solntsev also provides separate renderings of the details, as he does with the leather bow case and quiver, decorated with enameled gold and gems.

Solntsev pays the same close attention to the lavish embellishment of the household and religious belongings of members of the ruling family. An inkwell of Tsar Michael and Gospel Cover of Natalia Naryshkina, the mother of Peter the Great, are striking examples. The inkwell is studded with great emeralds and rubies and pearls, which are rendered from different views. The gospel cover glitters with diamonds, rubies, and emeralds, interspersed the images of God the Almighty, the Mother of God, John the Baptist and four of the apostles. "The entire surface of the front cover is so lavishly studded with gems that it seems they merge into a single mass," the commentary reads. ${ }^{47}$

Solntsev gave a particularly vivid rendering of an onyx chrism dish - a vessel that contains the sacramental oil for anointment in Eastern Orthodox services. The gold enameled handle in the form of a snake curled in a circle is a symbol of wisdom and health according to the commentary, which cites a legend that it belonged to Augustus Caesar, "whom [Russian rulers] considered an ancestor of Riurik." It emphasized, however, that the name Augustus Caesar was often assumed by Byzantine emperors as well. The commentary also repeated a legend that the dish was among the items that the Emperor Alexis Komnen (10811118) sent to Prince Vladimir Monomakh in 1113.48

Olenin had argued that the sixteenth century marked the appearance of a Russian national dress, and the garments of tsars, boiars, and peasants make up the fourth volume of the compendium. There are four illustrations of the attire of tsars and tsaritsas of the seventeenth century, and eight of boiars, several showing the robes and long loose sleeves that Olenin had singled out as particularly Russian. Twelve of the watercolors depict peasants in folk dress from Torzhok, Tver, and Riazan. These of course were not antiquities, but by appearing in the collection were marked as national and authentic and also associated with the monarchy and state.

The dense and ornate design of the attire shown in the Antiquities establishes a connection between diverse social classes and distant historical periods. The luxurious clothing of the tsars and boiars shares the decorative richness of the holiday costumes of peasant women. Both groups are placed within elaborate interlacing frames reproducing motifs from ancient

\footnotetext{
47 Drevnosti, Section 1, 118-9.

48 Ibid., Section 1, 69-70.
} 
manuscripts. The artistic style overcomes the great social distance imposed by the western dress adopted and imposed by Peter the Great. On the other hand, the scene of Torzhok peasants before a peasant hut, a church with a tent roof in the background, presents them in everyday dress. However, they too are surrounded by interlacing decorative motifs. The exuberant, lush colors recall the decorative vegetation Valerie Kivelson has discerned in early Russian cartography, which derived from folk embroideries, carvings, and icons. ${ }^{49}$

If the Drevnosti demonstrate the ties of nineteenth-century monarchy with Muscovite past, the esthetic idiom of "Russianness" devised by Solntsev brought together everything from a jewel-studded imperial crown to peasant folk costumes in a single visual statement of "Russianness" - a symbol uniting state, monarchy and people. Associating the diverse objects was a style of dense, lush decoration, what William Craft Brumfield has called "Muscovite ornamentalism." 50 The artistic model for all the illustrations remained the surviving window frames of Alexei Mikhailovich's Terem Palace, four of which were reproduced in the Antiquities (Figure 2).

The Russian style promoted by Nicholas I typified the pattern of borrowing by Russian monarchy-the appropriation of a dominant intellectual and artistic mode from the West to enhance its political and cultural standing. The national esthetic complemented but hardly supplanted neoclassicism as an artistic expression of the monarchy. In St. Petersburg, Nicholas favored neoclassicism, as attested by the rows of stately governmental buildings that went up during his reign. He continued to commission table services in other styles, like the Etruscan service he ordered for the empress's Roman pavilion at Peterhof. His imperial scenario, in this respect, as in others, was highly eclectic. The Antiquities and other works of Solntsev focused primarily on Moscow and enhanced Nicholas's credentials as the successor to the Romanov tsars of the seventeenth century and their predecessors in ancient Rus'. St. Petersburg and Peterhof, on the other hand, showed him as heir to the classical traditions of Rome. Olenin's aspiration to unite classical and native traditions had its perhaps unforeseen outcome in Nicholas I's presentation of the Russian monarchy as the paradigm of eastern as well as western Roman imperial heritages.

49 Valerie Kivelson, Cartographies of Tsardom: The Land and Its Meanings in Seventeenth Century Russia (Ithaca, NY: Cornell University Press, 2006), 116.

50 William Craft Brumfield, A History of Russian Architecture (Cambridge: Cambridge University Press, 1993), 149-50. 
Solntsev's work was a Russian expression of a European-wide movement of historicism in art. The distinctive feature of Russian historicism was the prominent role of the monarchy in shaping its subject matter as an elaboration of the mythology and ideology of the state. The works of Solntsev epitomized the eclectic spirit of "Official Nationality": an absolute monarchy purporting to enjoy the love of the people and reflect the idea of nationality (narodnost') while it maintained the tastes and manner of European royalty. The monarch initiated the project of creating a national esthetic and ensured that the dynasty appeared as the principal subject of its art. The dominant role of the monarchy in shaping the historicist esthetic distinguishes the work of Solntsev from such European counterparts as A. W. N. Pugin and Eugène Emmanuel Violletle-Duc, who took their own initiative to discover native artistic traditions in medieval objects of art that would express the spirit of a nation as a whole.

The editor of Russkaia starina, M. I. Semevskii, wrote in a tribute to Solntsev that his works "awakened Russian artists' feeling of national selfconsciousness and respect for models bequeathed to us by our forefathers." 51 Solntsev's resplendent array of intricate and dense multicolored design gained broad appeal as an expression of a distinctively Russian esthetic, which later provided the basis for the emergence of le style russe, the ultimate miniaturization of the Baroque. Only in the last decades of the century, under the influence of Slavophile and other doctrines, did the monarchy begin to escape its earlier ideological and artistic eclecticism and purport to be one spiritually and even ethnically with the Russian people. But that is another story.

During Nicholas's reign, adherents of Schellingian philosophy regarded Solntsev's works as expressions of the "national spirit" they were seeking. One of their number was Mikhail Pogodin-the principal historian of Official Nationality. While witnessing the pageant celebrating the opening of New Kremlin Palace in 1849, Pogodin marveled at the Russian costumes, several of them designed by Solntsev. "Our travelers," he wrote, "were captivated only when the Russian spirit was realized before their eyes, when they saw the way our pretty Russian girls and our fine fellows (molodtsy) were dressed. They appeared before us in their grandfathers' kaftans_staid boiars, majestic boiarins. What delight, what splendor, what variety, what beauty, what poetry!"52

\footnotetext{
51 Cited in G. V. Aksenova, "Fedor Solntsev—sozdatel' arkheologicheskoi zhivopisi," Slovo: pravoslavnyi obrazovatel'nyi portal, www.portal-slovo.ru/rus/history/84/55/.

52 Nikolai Barsukov, Zhizn' i trudy Pogodina (St. Petersburg: M. M. Stasiulevich, 1896), 10: 209.
} 


\section{Cultural Metamorphoses of Imperial Myth under Catherine the Great and Nicholas I}

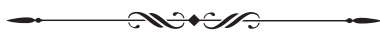

$s$ the papers in this conference have indicated, high culture in the form A of theatrical presentation assumed great importance for the Hapsburg Empire in the eighteenth and nineteenth centuries. ${ }^{1}$ Monarchies took on the role of Kulturträger, bringing civilization to their subjects, encouraging the arts as well as science and literature, and asserting their membership in the community of nations that were heirs to great classical cultures of antiquity. In this way, they legitimized their sovereignty with a cultural genealogy reaching back to Greece and Rome, uplifting their subjects in the name of the general welfare. ${ }^{2}$ Russian monarchs followed the example of the Kulturstaat. However, to a far greater degree they employed the various cultural modes, theater, art and architecture, and music as frames of presentation of the mythology of autocratic power. They served as modes of display of each ruler's scenario, lending his authority cachet and grandeur. This paper focuses on two such examples: Catherine the Great's opera, The Primary Reign of Oleg (Nachal'noe upravlenie Olega) and Nicholas I's publication of the Antiquities of the Russian State (Drevnosti rossiiskogo gosudarstva). Both works furthered institutions of regulation and direction to advance the goal of state monopolization of public representation; both used cultural modes to shape conceptions of the truth of Russia's past as well as its mission.

1 This paper was presented to the Conference "Kulturpolitik in Imperien," Vienna, November 19-20, 2010.

2 See the discussion of the Hapsburg effort in this respect in the paper by Franz Leander Fillafer, "Imperium oder Kulturstaat?" in Kulturpolitik und Theater: Die kontinentalen Imperien in Europa im Vergleich, ed. Philipp Ther (Vienna, Böhlau, 2012), 23-53. 
Impressed with his visit to Versailles in 1717, Peter the Great adorned his newly laid out Summer Garden with more than ninety statues acquired for him by his European ambassadors, including busts of Alexander the Great, the Roman Emperor Trajan, several European kings, and numerous figures of seminude women, symbolizing the secular virtues. Among them stood a statue of Venus, later called the Tauride Venus, which Peter obtained with great effort, to rival Louis XIV's Venus of Arles. Peter's taste was for the practical and technical achievements of the West, not high culture. However, culture was a sign of empire and the power to think, create, and change. The ensemble made clear his determination both to appear as a Western absolute monarch and to mount an affront to Orthodox moral and religious sensibilities. His emblem was the myth of Pygmalion and Galatea: Peter as sculptor creating beauty out of stone.

This display demonstrated to his nobility, at that point defined by service to the tsar and the state, that standing and power would be demonstrated by European appearance, behavior, and culture, which set nobles above the subject population and presented them as inhabitants of a higher world of grace and refinement. They would be known as the "well-born" Russian nobility (blagorodnoe Rossiiskoe dvorianstvo), different in appearance and behavior from the peasants they were destined to rule. Their power derived not from feudal laws or privilege, but their service to the tsar and, as representatives of his authority, their performance as cultivated westernized noblemen that distinguished them from the other estates of the realm.

In this respect, Russia preserved the Baroque form of representation, the "representational culture" explored in the work of Jürgen Habermas and T. C. W. Blanning, a presumed initial stage of public expression that would evolve in the west into a public sphere. Festivities, Habermas wrote, "served not so much the pleasure of the participants as the demonstration of grandeur, that is the grandeur of the host and guests." Aristocratic society "served as a vehicle for the representation of the monarch." 3 For both Habermas and Blanning, Louis XIV's Versailles exemplified Baroque representation. Blanning concludes, "the representational display expressed in palaces, academies, opera houses, hunting establishments, and the like was not pure self-indulgence, nor was it deception; it was a constitutive element of power itself." 4

3 Jürgen Habermas, The Structural Transformation of Public Sphere: An Inquiry into a Category of Bourgeois Society (Cambridge, MA: MIT Press, 1989), 9-10.

4 T. C. W. Blanning, The Culture of Power and the Power of Culture: Old Regime Europe 1660-1789 (Oxford: Oxford University Press, 2002), 59. 
In Russia, culture remained a constitutive element of monarchical power until the demise of the tsarist regime. The adoption of western cultural forms maintained the images of transcendence that ensured the supremacy of the monarchy and the noble elite and the distance between them and the subject population. The act of borrowing and imposing forms of western representation produced what Louis Marin described as a "doubling effect," removing the monarch from his local confines and locating him in a universal sphere of irresistible and efficacious enlightened rule. ${ }^{5}$ The representation of the monarch remained paramount, transcending considerations of law, prudence, or rational argument, and shaping the practices and attitudes of governmental officials to accommodate a culture of power. As a result, rather than give way to an embryonic public sphere, representational culture preserved a dynamic of monopolizing public space and inhibited the spread of public discourse.

Culture was put at the service of myth. Peter's image was that of conquering hero, destroying the old and bringing new into being by acts of power and will. The past was submerged. Peter presented himself as Roman conqueror, an emperor in the images of Julius or Augustus Caesar or Emperor Constantine, though these were metaphors and not grounds of descent or inheritance. His succession law replaced a disposition to hereditary succession with the monarch's own designation, not subject to legal constraint. Indeed, the weakness of a dynastic legal tradition, or dynastic legend after Peter, no matter how fanciful, created a need for new mythical genealogies, attesting to the power of the transcendent monarch to conjure a dynastic national past suitable to absolute rule. ${ }^{6}$ The Hapsburgs' legend, "The Last Descendants of Aeneas," persisted as a backdrop to their claims to imperial dominion. Russian monarchs engaged in an ongoing search for origins, whether in Rome, Byzantium, Ancient Greece, or among invading princes from Scandinavia, to provide renewed historical grounds for dynamic mythical reassertions of the right to absolute rule.

The princes of Moscow had claimed the heritage of the Eastern Roman empire, Byzantium. Symbols and imagery of empire announced their parity with the West, the Holy Roman Empire. To match the seal of the Holy

$5 \quad$ Louis Marin, Le portrait du roi (Paris: Les éditions de minuit, 1981), 10.

6 Richard Wortman, "The Representation of Dynasty and the 'Fundamental Laws' in the Evolution of Russian Monarchy," Kritika vol. 13, No. 2 (Spring 2012): 265300. Article 2 in Russian Monarchy: Representation and Rule. 
Roman Empire-a double-headed eagle-Ivan III introduced his own imperial seal-a crowned Byzantine double-headed eagle, with lowered wings. ${ }^{7}$ Ivan assumed the titles of tsar, from the Greek (tsesar) and autocrat (samoderzhets, from the Greek autocrator), declaring himself a monarch independent of other earthly authorities. From the start, supreme imperial sovereignty represented the only true sovereignty for Russian monarchs. Ivan rejected the crown of king from Holy Roman Emperor Frederick III in 1489, replying that he "had never wanted to be king by anyone, and that he did not wish it." A king's crown signified mediated sovereignty, or in the eyes of Russian rulers and their servitors, no sovereignty at all. ${ }^{8}$ In the sixteenthcentury, Russia adopted rituals of the late Byzantine coronation and devised "the legend of Monomakh," which evoked Vladimir Monomakh's acquisition of the imperial Byzantine regalia from the Byzantine emperor Constantine Monomakh, who in fact had died long before the prince's reign.

Peter the Great's acceptance of the title of emperor (imperator) in 1721 indicated that he had assumed the attributes of a western emperor. He elevated his role as emperor with Baroque allegories and imagery that identified him with emperors of the Roman Empire, Eastern and Western, as well as pagan gods. Peter cast himself as founder, thus consigning the past to oblivion and leaving his successors without an origin tale for imperial authority. ${ }^{9}$ Both Catherine the Great and Nicholas I sought to provide Russian monarchy with narratives that linked Russian Monarchy and the ancient world and present Russia at the forefront of western civilization. They drew on the cultural resources of Russian resources of the monarchy to produce narratives of origin that would define the heritage and mission of empire.

$7 \quad$ Gustave Alef, “The Adoption of the Muscovite Two-Headed Eagle: A Discordant View," in his Rulers and Nobles in Fifteenth-Century Muscovy (London: Variorum Reprints, 1983), Section IX.

8 Dimitri Stremoukhoff, "Moscow the Third Rome: Sources of the Doctrine," in The Structure of Russian History: Interpretive Essays, ed. Michael Cherniavsky (New York: Random House, 1970), 112.

9 Olga Ageeva suggested that at the end of Peter's reign, empire meant little more than a state ruled by a monarch with the status and cultural pretensions of an emperor (O. G. Ageeva, "Imperskii status Rossii: k istorii politicheskogo mentaliteta russkogo obshchestva nachala XVIII veka," in Tsar' i tsarstvo $v$ russkom obshchestvennom soznanii [Moscow: In-t rossiiiskoi istorii RAN, 1999], 123). 


\section{Theatrical Culture and the Greek Project}

Although entrepreneurs, both foreign and Russian, founded many of the first theaters in Russia, the Empresses Elizabeth and Catherine II assumed growing control over theatrical productions and took over or eliminated independent theaters. In 1756, Elizabeth brought the highly successful Iaroslavl company of the merchant and actor Fedor Volkov to Petersburg and amalgamated it with the theater of the Noble Cadets Corps, establishing a Russian Imperial Theater under the direction of the playwright and poet Alexander Sumarokov. A Directorate established in 1766 exercised administrative control over the theaters. By the end of the century, aside from foreign troupes visiting the capital and Moscow, theater in Russia consisted of the Imperial Theater in Petersburg, which performed both for the court and public audiences and estate theaters of wealthy noblemen, their companies made up of serf actors. ${ }^{10}$

Centralization of bureaucratic control continued during the reigns of Paul I and Alexander I, though commercial theaters were permitted in provincial towns. During the 1840s and 1850s, when theatrical events and charitable concerts in gentry, merchant, and artisan clubs of the capital escaped the Directorate's control, Nicholas I issued measures to eliminate these undertakings. A law of 1854 , confirmed in 1862 by Alexander II, gave the Directorate an absolute monopoly of administrative control over theatrical performances. ${ }^{11}$

During the eighteenth and early nineteenth centuries, theater became the cultural medium par excellence of the Russian autocracy and serf-holding nobility, what Richard Stites has described as an "empire of performance." The ethos of performance originating in the Baroque court assumed the character of an imperative. The monarch performed the role of a European monarch as a representation of absolute power. Russian noblemen, proving their status by their western behavior and tastes, reproduced their own images of grandeur and power, what Iurii Lotman described as the "theatricality" of official life in Russia. The Directorate and the estate theaters were closely linked. Stites

10 Murray Frame, School for Citizens: Theatre and Civil Society in Imperial Russia (New Haven, CT: Yale University Press, 2006), 22; Richard Stites, Serfdom, Society and the Arts in Imperial Russia: The Pleasure and the Power (New Haven, CT: Yale University Press, 2005), 132.

11 Frame, School for Citizens, 42-43, 48-50, 79-82; Stites, Serfdom, Society and the Arts in Imperial Russia, 398-9. 
observed: "The Directorate leaders as serf-owners and owners of serf-theaters, tended to transfer the social hierarchies and disciplinary culture of regiment or estate to their serf-like underlings. In an interlock of state and manor house, performers flowed from the seigniorial home to the imperial stage and back again, blurring the distinction between a public and a private sphere."12

Article 6 of Catherine's Instruction (Nakaz) to the codification commission she convened in 1767 proclaimed that "Russia is a European State," and theater became her means to train the Russian nobility in western sociability and ideas. Elise Kimerling Wirtschafter has argued that the theater succeeded in playing an educational role and created a "pre-political literary public sphere" among the Russian nobility. The themes of moral betterment dramatized on the stage led to the appearance of what she describes as a "civic society," devoted to civic engagement, but not "a politically organized 'civil society' independent of the state." The purpose of eighteenth-century theater was not political but didactic, demonstrating common principles of behavior based on reason, reflected in personal virtue, shown to triumph over the snares of the vices, the products of desire. In this way, cultural modes "served an integrative function" and "the shared experience of Russian theater helped to institutionalize civic society." Rather than breed criticism and discontent, the ideas professed in plays reconciled the elite audience with the existing monarchical order. Plays satirized individual greediness and the vanity of fashionable sociability, praised devotion to the patriarchal family, and above all service to the monarch and the fatherland. "The good monarch of the eighteenth century Russian stage displayed not only the uncommon virtue and courage need to justify heroic stature but also the personal shortcomings and emotions of any human being."13

Catherine actively participated in this culture, writing journal articles and plays professing the dominant principles of personal virtue. She also tried her hand at history, composing Notes on History and a history primer. As a playwright, she could project her ideas into the past and create her own origin tales that would substantiate her dreams of imperial expansion and

12 Stites, Serfdom, Society and the Arts in Imperial Russia, 135.

13 Elise Kimerling Wirtschafter, The Play of Ideas in Russian Enlightenment Theater (De Kalb, IL: Northern Illinois University Press, 2003), ix-x, 18, 29-30, 148-9, $172-$ 3, 178-9; on advice literature concerning the good and bad monarch, see Cynthia Hyla Whittaker, Russian Monarchy: Eighteenth Century Rulers and Writers in Political Dialogue (De Kalb, IL: Northern Illinois University Press, 2003), 141-81. 
cultural parity of Russia with Europe. In 1786, after the victories over Turkey, J. J. Eschenburg's German translations of Shakespeare inspired her to write two plays with historical themes, entitled $A$ Historical Performance, Without observing the usual Rules of Theater, from the Life of Riurik: An Imitation of Shakespeare and The Primary Reign of Oleg: An imitation of Shakespeare, Without Observing the Usual Rules of Theater. ${ }^{14}$

Shakespeare's plays emboldened Catherine to ignore the classical unities of time, place, and action. The Life of Riurik recounts the founding episode of the Russian state-the summons by the leaders of Russian tribes to the Varangians from the years 860-862 in the Primary Chronicle, "Our land is great and rich, but there is no order in it. Come to rule over us." Catherine's play glorifies Riurik, the first Russian prince, as a model of decisive action and efficacy. Riurik proves an energetic and able ruler in contrast to the Russian princes, who squabble amongst themselves and seem unable to exercise forceful rule. "Reason and courage overcome difficulties and obstacles," says his stepson, Askold. Riurik replies, "My concern is to rule the land and to administer justice... for that reason I am dispatching the princes accompanying me as authorities to the towns," a step that recalled Catherine's provincial reforms of the previous decades. The plot dramatized the conquest motif of foreign rule according to the "Norman interpretation," advanced by one school of Russian historians at the time in a way that repeated Catherine's own ascent as a foreign ruler, taking power at a moment of political turmoil. The action also substantiated the premise of Peter's Law of Succession: that an heir to the throne should be appointed by the reigning monarch according to qualifications rather than determined by hereditary right. ${ }^{15}$

Riurik was never performed. On the other hand, Catherine took great pride in The Primary Reign of Oleg (Nachal'noe upravlenie Olega). She staged lavish operatic productions with great largesse and flair in 1791 and 1795, and had three editions of the text published in 1787, 1791, and $1793 .{ }^{16}$ The word nachal'noe here carries the connotation of foundational or primary, as in the Primary Chronicle-Nachal'naia letopis'—not "early" as it has

14 Lurana Donnels O'Malley, The Dramatic Works of Catherine the Great: Theatre and Politics in Eighteenth-Century Russia (Aldershot: Ashgate, 2006), 12; Sochineniia Ekateriny II (St. Petersburg: Imperatorskaia Akademiia Nauk, 1901), 2: 219, 259.

15 O'Malley, The Dramatic Works of Catherine the Great, 140-2; Sochineniia Ekateriny II, 2: 232, 241-2.

16 O'Malley, The Dramatic Works of Catherine the Great, 209. 
been translated; indeed, the events described took place in the middle, not the beginning of Oleg's reign (892-922). ${ }^{17}$ Specifically, it presented Prince Oleg's invasion of Constantinople, recorded in the Primary Chronicle under the years 904-907, and the capitulation of the Byzantine Emperor Leo as establishing the foundation of Russian culture in Greece. However, it was not religious Byzantium but pagan Greece that appears in The Primary Reign of Oleg.

Catherine and Potemkin had in mind more than a justification for territorial expansion to the South. They had discovered a new destiny for Russia that they sought to anchor in a re-imagined narrative of Russia's past. The conquest of Constantinople had been on Catherine's mind from the beginning of her reign, encouraged by Voltaire in their correspondence. At first, Catherine had identified Greece and Constantinople with Byzantium, referred to it as Stambul, and had little inclination to favor the religious roots of imperial authority. ${ }^{18}$ By the 1780 s, she had become entranced with Russia's destiny as the heir to the pagan culture of ancient Greece. The Greek city states Sparta and Athens replaced the Byzantine capital as the sources of a Greek heritage for Russia.

As Andrei Zorin has shown, this change reflected the influence of a group of noble poets and playwrights close to the throne, who extolled the civilization of ancient Greece after the initial victories over the Turks. Vasilii Petrov, a friend and protegé of Grigorii Potemkin, greeted Alexei Orlov's naval victory with verse evoking the triumphs of the ancient Spartans, anticipating the revival of their martial virtues, and evoking the worship of Catherine as Pallas in a Greek temple. Petrov's rival, Vasilii Maikov, looked to the restoration of Greece's golden age. Catherine would expel the Muslims, and restore ancient Greece, "Russia shares a faith with Greece, Her laws too shall be the same." The poet and playwright Kheraskov wrote that Russian victories had reawakened the Greeks' dormant valor: "There it seems Achilles and Miltiades arise, Now courage flames in Greek hearts, Greece will see Parnassus renewed.” Pavel

17 The word is also used in article 603 of Catherine's Nakaz, "nachal'nye osnovaniia" translated as "first foundations." Slovar' russkovo iazyka XVIII veka (Leningrad: Nauka, 1984), 14: 101; W. F. Reddaway, Documents of Catherine the Great (New York: Russell and Russell, 1971), 303. I thank Andrei Zorin and Ernest Zitser for their advice on this question.

18 Andrei Zorin, Kormia dvuglavogo orla...: literatura i gosudarstvennaia ideologiia $v$ poslednei treti xviii-pervoi treti xix veka (Moscow: NLO, 2001), 45-8. 
Potemkin, a cousin of Grigorii, presented a similar theme in a verse drama, "Russians in the Archipelago." The Greeks had "endured Christianity," the character of Alexei Orlov pronounces. The Spartan general Bukoval replies, "We, my lord, are the same as the Greeks once were, Your kindness and the heroism of Russian arms, Inspire in us all of our old traits." Zorin suggests the likelihood that Pavel Potemkin's work was known to his cousin, Grigorii, who shaped a political program for the project from the "system of metaphors" devised by these poets. ${ }^{19}$

In this way, a noble literary elite served as cultural interlocutors to channel the western neoclassical topos to the throne to provide the basis for a new mythical configuration. "The Greek Project" not only justified and glorified the expansion to the south: it evoked a mythical landscape that Catherine and Potemkin believed they inhabited and ruled. In 1774, they established a School for Foreign Youths in Petersburg for young Greek men, which in 1777 moved to the newly acquired Kherson on the Black Sea. Sites in the new territories received new names-Khersones, after the Greek, Odessa after Odysseus; Tauris, the Greek name for the district of Crimea. The imperial theme was displayed repeatedly during Catherine's journey through the conquered lands in 1787. The newly-founded city of Ekaterinoslav was to be a counterpart to Petersburg, a perfect imperial city, to show the monarch's creation of a realm of cultivation and political order in Russia's south, a "new Russia." 20 Potemkin began construction on a cathedral that would be a replica of St. Peter's in Rome. He intended to transport a gargantuan statue of Catherine from Berlin. Building materials had been assembled to construct court houses on the model of ancient basilicas, a propylaeum like that of Athens, and twelve factories. He appointed the Italian conductor and composer Giuseppe Sarti the director of a new musical conservatory in Ekaterinoslav. Russia, the bearer of civilization, was going to restore classical culture to the southern steppes.

Catherine envisioned a restored Eastern Roman Empire that would rule the Mediterranean under Russian guidance. The scheme advanced a claim to parity with the Holy Roman Emperor, Joseph II, and lent a historical and sacral aura to the alliance between the two states that made possible the

19 Ibid., 53-9.

20 A. M. Panchenko, “Potemskie derevni' kak kul'turnyi mif,” in XVIII vek (Leningrad: Ak. Nauk SSSR, 1983), 14: 93-104. 
annexation of parts of New Russia and Crimea. ${ }^{21}$ Catherine baptized her two grandsons Alexander after Alexander the Great, and Constantine after the Emperor Constantine, over the objections of their parents. Her expectation was that Alexander would become emperor of Russia and Constantine of a resurrected Greek Empire centered in Constantinople.

The Primary Reign of Oleg was a theatrical confirmation of Catherine's vision of cultural affiliation with ancient Greece. She assured the reader of the historical truth of her play. "In this Historical presentation there is more truth (istina) than invention (vydumka)." She then went on to cite various historical sources at hand that freed her to embroider on the past. ${ }^{22}$ The play gives the struggle in the south and Catherine's appropriation of the heritage of ancient Greek an aura of historical inevitability and therefore of truth.

Catherine portrays Prince Oleg's invasion of Constantinople, recorded in the Primary Chronicle under the years 904-907, as a cordial meeting between prince Oleg of Kiev and Emperor Leo. The play first recounts Oleg's exploits-his alleged founding of Moscow, his marriage to a Kievan Princess, Prekrasa ("most beautiful"), and finally his foray into Constantinople. ${ }^{23}$ Oleg's triumph occasions exultant pagan festivities. The emperor Leo rejoices at his own defeat and welcomes Oleg. "In this capital, with so renowned a guest, only happy celebrations shall occur, joyous exclamations, endless games, singing, dancing, merriment, and gala feasts." Prince Oleg watches martial games in the Hippodrome on a dais next to Emperor Leo and Empress Zoya. Hercules and the Emperor of Festivals appear before the celebrations, which are portrayed in dance and choruses, the music composed by Sarti. A performance of an episode from Euripides, "Alcestis," a Shakespearian play within a play, begins the final scene. King Admetus of Thessaly graciously receives Hercules after the loss of his wife, a generous act of hospitality at a moment of loss, like Leo's reception of Oleg. The play closes with Oleg's leaving the shield of Igor in the Hippodrome for his descendants. The Emperor Leo declares him a wise and courageous prince. The shield of Igor is emblazoned with the iconic figure of St. George killing the dragon-the shield of Moscow that would appear

21 Zorin, Kormia dvuglavogo orla..., 37-8; on the alliance between Catherine and Joseph II see Isabel de Madariaga, Russia in the Age of Catherine the Great (New Haven, CT: Yale University Press, 1981), 387-90.

22 Sochineniia Imperatritsy Ekateriny II, 2: 261.

23 Sochineniia Imperatritsy Ekateriny II, 2: 259-304. 
on the breast of the Russian imperial double-headed eagle in the center of the Imperial Coat-of-Arms. ${ }^{24}$

In 1791, a cast of more than six hundred performed the extravaganza three times at the Hermitage Theater before the court and the public, and again in a $1794 / 5$ revival. The production combined drama, music, and ballet, and, as contemporaries and critics have pointed out, was more of a lavish Baroque pageant than a Shakespearian drama. Heinrich Storch wrote:

The magnificence of the performance far exceeded everything I have ever beheld of this kind in Paris and other capital cities. The sumptuousness of the dresses, all in the ancient Russian costume and all the jewelry genuine, the dazzling luster of the pearls and diamonds, the armorial decorations, implements of war and other properties, the ingenuity displayed in the ever-varying scenery, went far beyond even the boldest expectation. $^{25}$

The Baroque luster asserted the reality of the narrative performed on the stage. Carl Masson admired "the great events of history... introduced as in a picture on the stage." 26 The pastiche of drama, dance, and particularly music permitted a blanket assertion of a common culture linking the ancient Greeks with contemporary Russians. The sumptuousness of the "ancient Russian costume," the overture by Carlo Cannobio based on Russian folk songs, Sarti's score for the Greek choruses reciting verses by Lomonosov and the musical accompaniment to Alceste, all attested to a Russian national culture akin to the Greeks. Before he arrived in Russia, Sarti had served as Kappelmeister in Copenhagen, where he helped to establish the Danish Royal Opera, and he was clearly brought to Russia with a similar assignment in mind. The Primary Reign of Oleg, Maria Maiofis has shown, aspired to be a Russian national opera that would place Petersburg among the great European capitals. ${ }^{27}$

The artist, poet, and folk song collector Nikolai L'vov asserted, in his introduction to Sarti's explanation of his music, that Russians must have borrowed their musical sophistication from the Greeks. "The voice of the

24 Sochineniia Imperatritsy Ekateriny II, 2: 294-304.

25 O'Malley, The Dramatic Works of Catherine the Great, 158.

26 Ibid., 166.

27 Maria Maiofis, "Myzykal'nyi i ideologicheskii kontekst dramy Ekateriny 'Nachal'noe upravlenie Olega," Russkaia filologiia, no. 7 (1996): 66-71; O’ Malley, The Dramatic Works of Catherine the Great, 156. 
passions served our untutored singers instead of knowledge. This notion is only in regard to melody. How without study, guiding themselves only by ear, did they learn Harmony?" This, he explained, could come to them only by imitation. The similarity of these songs to the remnants of Greek music led him to conclude that they were borrowed from the ancient Greeks. "The Primary Reign of Oleg portrays nothing other than the moment of this borrowing-leaving the shield of Igor as a sign of his stay in the Greek capital, Oleg at the same time preserved the memory of everything he saw there, of the Olympic games, the performance of 'Alceste,' and of the music for it." In his accompaniment to Alceste, Sarti sought both to follow Greek harmonic modes and yet to break with tradition in a way to show distinctive Russian variations. Instead of employing the two modes the Greeks required for tragedy, Doric and Phrygian, Sarti utilized all seven that he knew, so that his music would not be "gloomy and sad." 28

Although hardly a lover of music, Catherine admired Russian folk songs and dances, as well as "ancient Russian dress," which demonstrated a cultural identity that could be admired, if not adopted by her multi-national nobility. She often quoted the saying, "A people who sing and dance do no evil." 29 Catherine was proud of the many nationalities of her empire, which substantiated the imperial myth of ruler of savage peoples-what Victor Zhivov describes as the "ethnographic myth" of empire. ${ }^{30}$ Johann Gottlieb Georgi's landmark four-volume Description of All the Peoples Inhabiting the Russian Empire (Opisanie vsekh obitaiushchikh v Rossiiskom gosudarstve narodov), compiled under Catherine's sponsorship, confirmed that the Russian empire was the most diverse of empires. ${ }^{31}$ However, enlightenment would bring

28 Maiofis, "Myzykal'nyi i ideologicheskii kontekst dramy Ekateriny 'Nachal'noe upravlenie Olega', 68-70; O'Malley, The Dramatic Works of Catherine the Great, 154.

29 Maiofis, "Muzykal'nyi i ideologicheskii kontekst dramy Ekateriny 'Nachal'noe upravlenie Olega," 66.

30 "In geographical space the monarch emerges as the hypostatization of Mars, while in ethnographic space, the monarch appears as the hypostatization of Minerva" (V. M. Zhivov, "Gosudarstvennyi mif v epokhu Prosveshcheniia i ego razrushenie v Rossii kontsa XVIII veka," in Vek Prosveshcheniia: Rossiia i Frantsiia; Vipperovskie chteniia [Moscow: GMII im. A. S. Pushkina, 1989], 22: 150).

31 Opisanie vsekh obitaiushchikh v Rossiiskom gosudarstve narodov... (St. Petersburg: Imp. Ak. Nauk, 1799), 4 vols; S. A. Tokarev, Istoriia Russkoi Etnografii (Moscow: Nauka, 1966), 103. 
the elimination of national traits. Those at earlier stages, Georgi wrote, such as the Tungus, the Chukchhi, were ignorant, simple, and possessed a beguiling innocence. It was "the uniformity of State organization" that could transform all nationalities into educated, Europeanized Russians. Catherine admired the illustrations of the varied native costumes in Georgi's books by C. W. Müller, and had them reproduced as porcelain figurines. But the dancers in The Primary Reign of Oleg, wearing only Russian costumes, made clear that it was Russians who would lead the others along the path of civilization. ${ }^{32}$

\section{A National Opera and \\ a Russian National Esthetic}

When Nicholas I ascended the throne in 1825, he openly repudiated the cosmopolitan ethos expressed in Article 6 of Catherine's Instruction and embraced by Alexander I, that Russia was a European state. Nicholas's decrees and ceremonies presented the dynasty as a national institution. His manifesto on the sentencing of the Decembrists announced that the failure of the uprising had demonstrated that the monarchy enjoyed the devotion of the Russian people. Nicholas sought to distinguish Russian monarchy, which he regarded as the supreme example of absolutism from European states that went astray, seduced by liberalism and revolution. He too looked back to the summons to the Varangians as a foundational model of monarchical rule, one that provided popular grounds of absolute monarchy in Russia in response to the doctrines of popular sovereignty introduced by the French revolution. In a lecture, delivered in 1832, the historian Mikhail Pogodin declared, "The Varangians came to us, but voluntarily chosen, at least from the start, not like Western victors and conquerors - the first essential distinction in the kernel, the seed of the Russian State."33 The Russian people had invited their rulers, had obeyed and loved them: autocracy had popular roots. Sergei Uvarov provided this narrative with its ideological formulation of "Official Nationality," expressed in the triad, "Orthodoxy, Autocracy, Nationality."

32 On the different images of "Russianness" in visual sources, see Elena Vishlenkova, "Vizual'noe narodovedenie imperii ili "Yvidet' russkogo dano ne kazhdomu" (Moscow, NLO, 2011).

33 M. P. Pogodin, Istoriko-kriticheskie otryvki (Moscow: A. Semen, 1846), 6-8. 
Nicholas realized Catherine's dream of a national opera glorifying Russian monarchy. The composer Mikhail Glinka had intended to write an operatic version of the patriotic myth of the Russian peasant, who sacrificed his life to save tsar Mikhail Feodorovich's life by leading Polish troops astray. His initial title was Ivan Susanin, a Patriotic Heroic-Tragic Opera. He wanted the opening chorus to express the "strength and carefree fearlessness of the Russian people" and to achieve this sense musically, in "Russian measure and approximations" that were drawn from rural subjects." But Nicholas succeeded in having the librettist, Baron Egor Rosen, reshape the work into a story of personal devotion of the peasant to the tsar. Nicholas took an active interest in the opera and appeared at rehearsals. Instructions came from high circles in the government, probably from Nicholas himself, to change the title from Ivan Susanin to A Life for the Tsar.

Glinka's opera lifts the tale of Susanin from the level of heroic adventure to tragedy. Susanin's noble sacrifice reflects the selflessness of the Russian peasant, passionately devoted to his tsar, according to official ideology. The libretto centers on the peasant's need for a tsar and his feelings of desperation when deprived of one. Though Glinka was hardly the first composer to introduce Russian folk melodies into an opera, he was the first to integrate them successfully into one of European stature. Life for the Tsar opened every season at Imperial Opera Houses and was performed at gala performances during imperial coronation celebrations and other festive occasions. ${ }^{34}$

Nicholas's principal esthetic interests were art and architecture, not theater. As Grand Duke, he showed an interest in early Russian church architecture. In 1817, at age twenty-one, he visited Patriarch Nikon's New Jerusalem Monastery near Moscow, built from 1658 to 1685, and encouraged plans for its restoration. "Once on the throne, he centralized and directed the study and production of art, just as he brought the political police and the work of codification under his personal purview in his chancellery. A decree of February 9, 1829 announced that he was taking the Academy of Arts

34 See Scenarios of Power, 1: 390-5; Richard Taruskin, “M. I. Glinka and the State," in his Defining Russia Musically: Historical and Hermeneutical Essays (Princeton: Princeton University Press, 1997), 25-47. It is interesting that the critic, Vladimir Stasov, detected a similarity between Russian folk melodies and Russian and Greek "medieval plagal cadences" in the famous Slav'sia chorus at the finale, much as L'vov had in Sarti's score. Taruskin dismisses this contention as "pure tendentious invention" (45). 
under his "special most gracious patronage" (osoboe vsemilostiveishee svoe pokrovitel'stvo). The Academy was removed from the Ministry of Education and placed under the authority of the Ministry of the Court, whose Minister reported directly to the emperor. ${ }^{35}$

Like Catherine, Nicholas looked to the Eastern Roman Empire for the cultural origins of Russian autocracy and the derivation of his own myth of foundation. But Byzantium represented for him not the traditions of pagan Greece, but the purest form of absolute monarchy, supported by the Russian Orthodox Church, an alternative to the western political tradition. He too endeavored to construct an esthetic genealogy that would link the Russian state with Byzantium. He sought concrete expressions of such a genealogy in art, specifically in early Russian art and architecture. He hoped to promote a national style of architecture by constructing copies of early Russian churches that incorporated principles of Byzantine architecture. Early Russian churches came in many shapes and sizes, however, and Nicholas lacked a clear idea of which style represented the true national tradition. In 1827, he began to seek designs for St. Catherine's church in Petersburg and for the Christ the Redeemer Cathedral in Moscow, which the architect Alexander Vitberg had planned in neoclassical style for Alexander I. Nicholas asked for a building that "would attest to compatriots as well as to foreigners of the zeal of Russians for the Orthodox faith."

The projects he received were designed in the spirit of neoclassicism. He had only a vague sense of "Russian taste," and most of his architects could not fathom his intent. Although he was considerably more certain in his views than most Russian rulers, he too needed guidance in this sphere. It required an official of high standing, knowledgeable in the arts, but also with insight into the tsar's inclinations and deft in his manner of discourse, an official who could "divine" and influence the imperial will. ${ }^{36}$ The person who had such

35 The first Minister of the Court was Peter Volkonskii, a cousin of Alexei Olenin. Imperatorskaia sanktpeterburgskaia akademiia khudozhestv, 1764-1914: kratkii istoricheskii ocherk (St. Petersburg, 1914), 38; Mary Stuart, Aristocrat-Librarian in Service to the Tsar: Aleksei Nikolaevich Olenin and the Imperial Public Library (Boulder, CO: East European Monographs, 1986), 137.

36 Mikhail Dolbilov has described the practice of "divining the imperial will" (ugadyvat' vysochaishuiu voliu), which all tsar's ministers and advisors endeavored to master in the nineteenth century. "Divining the imperial will" could also involve subtle manipulation, planting ideas in the tsar's mind while making him believe 
talents and shared the tsar's predilections for a national art was the President of the Academy of Arts as well as the Imperial Public Library, Alexei Olenin. ${ }^{37}$

Like the poets and playwrights of Catherine's court, Alexei Olenin served as an interlocutor, providing the cultural idiom to represent monarchical power. As a young man, he had been a fervent adept of the Greek Project and an admirer of the great German historian of ancient Greek art, Johann Winckelmann, so much so that he earned the sobriquet "the Russian Winckelmann." When the discovery of early Russian artifacts in Crimea in the last decades of the eighteenth century provided evidence of direct contact between ancient Greece and early Russian towns, Olenin became engaged in the publication and analysis of these findings. The Tmutorokan stone, discovered in 1792 by Count A. I. Musin-Pushkin, bore an inscription from the year 1036 indicating the proximity of the Russian town of Tmutorokan to "territories of the Greeks." In 1806, Olenin published A Letter to Count A. I. Musin-Pushkin, which confirmed Musin-Pushkin's conclusions with the use of sophisticated comparative materials from chronicles and artifacts such as coins and helmets as well as the "Lay of the Host of Igor," which had also been discovered by Musin-Pushkin. ${ }^{38}$

Olenin pursued his archaeological interests during the first decades of the nineteenth century, when German scholars extended Winckelmann's concept of the range of ancient art to include monuments and everyday objects unearthed during archaeological excavations. ${ }^{39} \mathrm{He}$ looked to articles of clothing to confirm the esthetic link to Greece. In the first decades of the nineteenth century, Olenin seized especially on old Russian helmets as symbols of Russia's past that could lend neoclassical works of literature and art a Russian accent. He introduced helmets into his illustrations for such literary works as the plays of V. A. Ozerov, and the first edition of Pushkin's Ruslan

they were his own (M.D. Dolbilov, "Rozhednie imperatorskikh reshenii: monarkh, sovetnik i 'vysochaishaia volia' v Rossii XIX v.," Istoricheskie zapiski, No. 9 (127) (2006): 5-48.

37 For a more thorough discussion of Olenin and Fedor Solntsev, see Article 5 in this volume.

38 Stuart, Aristocrat-Librarian in Service to the Tsar, 12-19; V. Faibisovich, Aleksei Nikolaevich Olenin: Opyt nauchnoi biografii (St. Petersburg: Rossiiskaia natsional'naia biblioteka, 2006), 246-9.

39 Suzanne L. Marchand, Down From Olympus: Archaeology and Philhellenism in Germany, 1750-1970 (Princeton: Princeton University Press, 1996), 10-11, 40-53. 
and Ludmilla. Olenin convinced painters and sculptors to depict Russian helmets in their works in the classical style, creating what his biographer Victor Faibisovich describes as "a Russian empire style." 40

Olenin's efforts expressed a historicist sensibility that found national meaning in objects retrieved from the nation's past. For Nicholas, such objects demonstrated Russia's parity with European monarchies that enshrined their own medieval traditions. In 1843, when he and the Moscow Metropolitan Filaret were examining the recently discovered frescoes in the Kiev Sofia cathedral, Filaret voiced doubt about the wisdom of further exposure of the frescoes, which might reveal the practice of current oldbeliever rituals in Kievan Russia. Nicholas retorted, "You love ancient times (starina), and I love them too. In Europe now the tiniest ancient thing is cherished... Nonsense. Do not contradict me." 41

Nicholas turned to Olenin for help in finding an architect who could design an early Russian church. Olenin recommended Constantine Ton, whose earlier work had been entirely in the spirit of neoclassicism. Ton too was bewildered by the tsar's instructions. Divining the tsar's vague intentions, Olenin directed him to sketches executed by his protégés, Fedor Solntsev and the architect N. E. Efimov. 42 These served as guides for the plans Ton drafted for the St. Catherine's church and submitted to the tsar in 1830. Nicholas was pleased, and the St. Catherine Church became the exemplar of the "Ton style," which in 1841 would be decreed as the authorized style of Russian church architecture.

Olenin had been consistent in his determination to find a Greek heritage for Russian monarchy and for a Russian art. Now in Nicholas's scenario, he proved adaptable enough to submerge the original vision of the Greek Project to seek the sources of national art in the artistic heritage of the Eastern Orthodox Church. The "Ton style" combined neoclassical structural

$40 \quad$ Faibisovich, Aleksei Nikolaevich Olenin, 270-3, 274-5, 279, 282-6, 339-42; Gosudarstvennaia oruzheinaia palata (Moscow: Sovietskii Khudozhnik, 1988), 162-3.

41 Solntsev, Russkaia Starina vol. 16 (1876): 290.

42 Ton had graduated from the Academy in 1815. His early projects had won Olenin's admiration and he had recommended him for a stipend to travel abroad and study in Italy. Ton's work had been entirely in the spirit of neoclassicism; he was well known for his project to restore the imperial palace on the Palatine hill in Rome (V. G. Lisovskii, "Natsional'nyi stil"” v arkbitekture Rossii [Moscow: Sovpadenie, 2000], 70-1). 
elements with the Russian-Byzantine design, exemplified in the five-cupola structure of the Vladimir and Moscow Assumption Cathedrals. Ton's Christ the Redeemer Cathedral and New Kremlin Palace, both begun in the 1830s, revealed the features of a new eclectic, neo-Byzantine style. The cathedral's proportions and arcades, as well as its cupolas, were typically neoclassical: it was the exterior that asserted its Russian character. The New Kremlin Palace also followed the principles of neoclassical design and proportions. The interlace embellishments around its windows gave it a national touch. The juxtaposition of Western and Russian styles evoked the desired sense of connection Nicholas sought between the westernized monarchy and Russia's distinctive past. ${ }^{43}$

As director of the Academy of Arts, Olenin actively pursued the search for archaeological remnants of Russia's archaeological heritage and the visual presentation as signs of the narrative of descent from Byzantium. He found in Fedor Solntsev, the son of a serf, an artist who could exactly and effectively copy these artifacts. Solntsev's first assignment, in 1829, was to depict the "hoard of Riazan," gold and bejeweled items of princely provenance that had been unearthed in the town of "old Riazan" in 1822. In 1830, a petition of Olenin prompted a Supreme Command of Nicholas, dispatching Solntsev to the Kremlin Armory in Moscow in order to "depict our ancient (starinnye) customs, dress, weapons, church and imperial paraphernalia, household goods, harness and other items belonging to the categories of historical, archaeological, and ethnographic information." ${ }^{4} 4$ The command went on to specify that "everything that is worthy of attention and that constitutes historical material or an object of archaeological interest for scholars and artists be described in all detail and published." 45 Solntsev undertook numerous trips to the sites of early Russian history such as Vladimir, Iur'ev-Pol'skii, Riazan, and Novgorod, though his major efforts took place at the Kremlin in Moscow. He completed nearly 5,000 drawings and watercolors, what G. I. Vzdornov described as "a kind of encyclopedia of Russian medieval and national life in its concrete monuments." 46

\footnotetext{
$43 \quad$ See Scenarios of Power, 1: 381-7.

44 Solntsev, Russskaia Starina vol. 15 (1876): 634; Stuart, Aristocrat-Librarian in Service to the Tsar, 107.

45 A. N. Olenin, Arkheologicheskiia trudy (St. Petersburg: Imperial Academy of Sciences, 1881), 1: xxvii-xxviii.

46 G. I. Vzdornov, Istoriia otkrytiia i izucheniia russkoi srednevekovoi zhivopisi: XIX vek (Moscow: Iskusstvo, 1986), 29.
} 
Olenin had more in mind than an encyclopedia. He envisioned a multivolume work that would use ethnographical materials, especially examples of dress and arms, which would integrate a Russian national esthetic into the classical heritage. He began to outline his plans in a small study, published in 1832, as the first part of a multi-volume work meant to prepare a "course of History, Archaeology and Ethnography," for students at the Academy of Arts. ${ }^{47}$ The volume, the only one published, covered the period "from the time of the Trojans and Russians until the Tatar invasion." It was devoted principally to a description of the clothing of the period. He observed that in all eras, people tend to adopt the customs, rites, and fashion of the peoples "dominating by force of arms, trade and enlightenment." To illustrate the extent of the change after the conversion, he referred to a miniature in the Izbornik of 1073, which showed Prince Sviatoslav Iaroslavovich, his family, and entourage wearing Byzantine robes and headdress. ${ }^{48}$

The inclination to use art to bring together the diverse, to make the mutually exclusive complementary in the name of nation, culminated in the great compendium of Solntsev's drawings and watercolors, the Drevnosti rossiiskogo gosudarstva, or Antiquities of the Russian State. Olenin and Nicholas had intended such a publication as early as 1830 as suggested in the tsar's Supreme Command of May 9, 1830. But other projects and technical obstacles delayed the project. In 1841, Olenin submitted a proposal for a publication with broad ethnographical and historical parameters, supplemented with extensive scholarly commentaries. The title indicated that it was meant "for artists," suggesting that it would also provide models for them to follow in developing a national artistic idiom. ${ }^{49}$

Olenin's vision of a national artistic summa with a scholarly ethnographic commentary was not to be realized. After his death in 1843, Nicholas

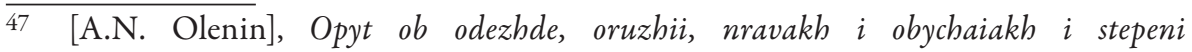
prosveshcheniia slavian ot vremeni Traiana $i$ russkikh do nashestviia tatar; period pervyi: Pis'ma k G. Akademiku v dolzhnosti Professora Basinu (St. Petersburg, 1832).

48 Ibid., 3-4, 13-19, 71.

49 The purpose was "to make known, in all their detail and idiosyncratic aspect our ancient mores, customs, rites, ecclesiastical, military and peasant dress, dwellings and buildings, the level of knowledge or enlightenment, technology, arts, trades, and various objects in our society" (Olenin, Arkheologicheskiia trudy, 1: xxviii; Stuart, Aristocrat-Librarian in Service to the Tsar, 108; Solntsev, Russkaia Starina vol. 16 [1876]: 280-1). 
appointed a committee under his own supervision to direct the project, which he supported with a princely grant of approximately 100,000 rubles. The six volumes of Solntsev's illustrations that resulted appeared between 1849 and 1853, in an edition of six hundred copies in both Russian and English. Owing to the emperor's generosity, they were produced with the latest techniques of color lithography. Just as the codification and the publication of The Complete Collection of Laws, issued by imperial command during the previous decade, brought together and made known laws issued by the Russian monarchy and thus defined a national legal tradition, the Drevnosti assembled the artistic works of Russia’s past to make known the artistic heritage of the dynasty.

However, the work that appeared was not the scholarly study that Olenin had contemplated. The members of the committee, Mikhail Zagoskin, Ivan Snegirev, and Alexander Vel'tman, who supervised the introduction and commentaries of the text, were prominent authorities on early Russian history and archaeology and adepts of the doctrine of Official Nationality. The introduction noted that the committee had abandoned Olenin's plans for "scholarly investigations" and "a purely ethnographic compilation of the antiquities of Slavonic tribes in contact with other peoples." 50 The commentaries resurrected the scheme of the sixteenth-century "Legend of Monomakh"-which according to the legend had been received by Prince Vladimir Monomakh (1113-1125) from his grandfather, the emperor Constantine Monomakh (1042-1055), who had died long before the Prince's reign. (The original Monomakh Cap is thought to be of fourteenth-century and possibly Tatar origin. $)^{51}$ They modified the tale by adducing vague references to gifts of the emperor to Russian princes, thereby setting the paintings of the antiquities in a narrative of dynastic continuity that linked the tsars of Moscow with their Kievan ancestors and the emperors of Byzantium.

The illustrations are divided by category-religious objects, regalia, weapons, portraits and clothing, artistic versions of household implements, and examples of early Russian architecture-with brief commentaries on the

50 Drevnosti rossiiskago gosudarstva (Moscow: Tipografiia Aleksandra Semena, 1849), III. Separate paginations for several introductory sections of the book. Stuart, Aristocrat-Librarian in Service to the Tsar, 108-9.

51 On the oriental origin of the cap, see G. F. Valeeva-Suleimanova, "Korony russkikh tsarei-pamiatniki tatarskoi kul'tury," in Kazan, Moscow, St. Petersburg: Multiple Faces of Empire, ed. Catherine Evtuhov, Boris Gasparov, Alexander Ospovat, and Mark Von Hagen (Moscow: O.G. I., 1997), 40-52. 
individual items. ${ }^{52}$ But the dominant presence throughout is the dynasty and its predecessors. The Drevnosti include numerous renderings of "the regalia of Monomakh" - the Monomakh Cap, the orb and scepter-which were replaced by Peter the Great at his coronation of Catherine I in 1724. Eight of the watercolors show variants of the Monomakh cap (Article 5, Figure 3). The commentary tries to prove the substance of the "Legend" by contending that Saint Vladimir received a golden "cap" after his conversion in 989 from the Byzantine emperor and that Constantine Monomakh had made a gift of regalia to the Russian princes..$^{53}$

After the election of Michael Fedorovich tsar in 1613, new "Grand Regalia" (bol'shoi nariad) displayed symbolic lineage to the defunct dynasty of Riurik, which had begun with the "invitation to the Varangians" in 862, and ended with the death of the tsarevich Dmitrii in 1598. The Drevnosti include pictures of the orb and scepter of Michael's regalia, which were fashioned by European craftsmen in the style of the Baroque "treasury art," exhibited in European palaces during in the seventeenth century (Article 5, Figures 3 and 4). Nonetheless, the authors explained the orb and scepter as "Greek work" and "a valuable memento of the tenth century." In 1627, European craftsmen working in the Kremlin produced a Baroque version of the original Monomakh cap. ${ }^{54}$

Just as Catherine's lush pageantry embellished the tale of Oleg as historical truth, the Baroque extravagance and mixture of classical and national elements impart an esthetic force to the legends of the Byzantine origins of Russian monarchy. The idiom associating the diverse objects was a style of dense, lush decoration, what William Craft Brumfield has called "Muscovite ornamentalism," which owed much in inspiration to the East and Central European Baroque. ${ }^{55}$ As in Catherine's play, the magnificence is expressed

52 The first volume includes religious objects-icons, pectoral crosses, vestments of the clergy, and chrism dishes. The second is devoted to regalia and articles figuring in the sacralization of the tsar, the third to weapons, armor, carriages and saddles, the fourth to portraits and clothing, the fifth to household items such as cups, wine bowls, and flasks, and the sixth to old Russian architecture.

53 Drevnosti, viii-ix.

54 Gosudarstvennaia oruzheinaia palata, 347-9; Drevnosti rossiiskago gosudarstva, Section 2, 34, 51 .

55 William Craft Brumfield, A History of Russian Architecture (Cambridge: Cambridge University Press, 1993), 149-50. 
as artistic profusion or excess. In this respect, excess was not only a prerogative of absolute power: its unapologetic display indicated the power of the ruler to define the culture, the past, and therefore the future of the monarchical state. $^{.56}$

Solntsev's renderings accentuate the decorative richness of the individual objects, creating an esthetic unity out of artifacts of diverse character and historical origin. His watercolors highlight the intricate design and vivid color of the individual antiquities, revealing each to be an object of art, and also furthering Olenin's goal to provide a guide for future artists. Solntsev's depiction of the original Crown of Monomakh reveals the intricate floral designs covering the entire gold surface (Article 5, Figure 3). He includes black and white insets that make clear the decorative details. The watercolor captures the gold of the conical form, the brightness of the emeralds and the rubies adorning the sides, and the shades of the pearls at the points of the cross.

The Drevnosti also provide numerous illustrations of weapons and helmets that belonged Russian princes and tsars. Two views of what was known then as the "helmet of Alexander Nevskii" reveal the gold engraving of imperial crowns on the surface, the gems, and the enamel figure of the Archangel Michael on the nose piece (Article 5, Figure 5).57 The helmet, however, was not Nevskii's: it has been identified as a work produced in 1621 for Mikhail Fedorovich, the first Romanov tsar. ${ }^{58}$ The cuirass in the rear, which follows West European examples, is covered with etched interlace of vegetal designs around a figure of Hercules subduing the Hydra of Lernaea. ${ }^{59}$

From the reign of Peter the Great, westernized culture served as a means to unite the westernized multinational elite of Russia and enhance the power and advance the designs of the absolute monarch as the exercise of a transcendent power dramatized as imperial myth. The nationalities of the empire appeared only as ornaments to the myth, subjects who would

56 See the suggestive remarks on excess in monarchical art in Randolph Starn and Loren Partridge, Arts of Power: Three Halls of State in Italy, 1300-1600 (Berkeley, CA: University of California Press, 1992), 166-74.

57 Faibisovich, Aleksei Nikolaevich Olenin, 296. The commentary refers to the mention of the helmet in a seventeenth-century listing, but links it to Georgian kings. It characterizes the attribution to Nevskii as a "tradition." Drevnosti, Section 3, No. 7.

58 Gosudarstvennaia oruzheinaia palata (Moscow: Sovietskii Khudozhnik, 1988), 162-3.

59 Drevnosti, Section 3, 7; Gosudarstvennaia oruzheinaia palata, 162-3. 
be transformed in the image of European culture advanced by the All-Russian monarch and his nobility. Culture afforded the idioms that lent coherence, stature, and even verisimilitude to myth. Catherine found her medium in eighteenth-century theater; Nicholas in early Russian art and architecture. In this way, their mastery of the esthetic realm enhanced their mastery of the political realm, displaying their transcendence as absolute rulers and maintaining the domination of a public sphere controlled by the state. It is indicative that both the opera of Catherine and the plates of the Drevnosti, though seeking to capture different loci of origin of the monarchy resulted in works adopting the idiom and carrying the magic aura of the European Baroque. Both rulers shaped their scenarios by relying on figures close to the court-cultural interlocutors-poets, artists, architects, who served to inspire and then to shape the form of the imperial myth according to the cultural idiom of the day. Petrov, Maikov, Pavel Potemkin, through his cousin Grigorii, Olenin, and Solntsev provided the sophistication and talent that enabled the monarchy not only to dominate the public sphere, but to do so with conviction and force. 


\section{Myth and Memory — Imperial Evocations of 1812. Alexander I and the Russian People}

or the Russian state and the Russian people, 1812 left ambiguous memories. The victorious struggle against the most powerful army in Europe, led by its seemingly invincible commander, a momentous event giving rise to visions of a glorious if uncertain destiny, was darkened by the fear of defeat and disintegration of the imperial order as Napoleon took Moscow. The greatest battle of the war, Borodino, inflicted colossal losses with an indeterminate outcome. ${ }^{1}$ There were ambiguities about the significance of the ultimate victory and about who brought it about. Was it, as Dominic Lieven has argued, a triumph of the monarchical state and its military elite that proved the resilience of the established order of estates and serfdom in resisting the onslaught of Napoleon's army and destroying his empire? Or was it a victory of national dimensions involving all layers of the Russian population in the cause of liberation?

These ambiguities beset all later evocations of 1812: personal, literary, and artistic. Here, I am concerned with the incorporation of the memory of 1812 into the imperial myth. Political myth abhors ambiguity and reduces memory to fit its own overarching narratives: mythic narratives would change to suit the scenario of each ruler and would shape the evocations to advance his own goals. The evolution of imperial representations of 1812 reveals the interplay between myth and memory, the imperial myth striving to submerge

$1 \quad$ Lieven suggests that the combined Russian losses of the battles of Shevardino and Borodino amounted to between 45,000 and 50,000 men (Dominic Lieven, Russia against Napoleon: The True Story of the Campaigns of War and Peace [New York: Viking, 2009], 209). For a description of the Borodino battle, see ibid., pages 197-210. 
or fashion the wayward memories of the year until it faded into a distant legendary past. ${ }^{2}$

From the beginning of his reign, Alexander I had presented himself in the framework of what I call the European myth, originating in "the representational culture," as T. C. W. Blanning termed it, of the European Baroque and neoclassicism. ${ }^{3}$ The monarch appeared as supreme westernized ruler, above the particular interests of the estates, introducing European culture and rational civic values to the Russian elite and society. Peter the Great's successors presented themselves as mythical heroes, breaking with the previous reign, transcending human limits, and bringing enlightenment and order to the Russian state.

Alexander I took on the persona of an angel, the leitmotif of his scenario. It expressed a refined, otherworldly character that set him above his subjects. His scenario presented him as reformer, implementing the lofty ideals of the enlightenment for the good of Russia. His endearing manner evoked love. While on occasion he allowed himself to receive expressions of affection

2 By myth, I mean an idealization or sacralization that takes the form of a dominant fiction realized in narratives, in this case to elevate the authority of the monarch and his state. Collective memory is a notoriously fuzzy concept, but it suggests the endowment of a significant event in the past by a process of retrieval by a group or a people. "National memory," John R. Gillis writes, "is shared by people who have never seen or heard of one another, yet who regard themselves as having a common history." It was a characteristic of the spread of nationalism following the French Revolution (John R. Gillis, "Memory and Identity: The History of a Relationship," in John R. Gillis, ed., Commemorations: The Politics of National Identity [Princeton: Princeton University Press, 1996], 3-4, 7). Pierre Nora, the father of the recent study of memory characterizes it as a search for the sacred, for eternity, in an increasingly receding and meaningless past experience. "Memory installs remembrance within the sacred; history, always prosaic, releases it again." The retrieval of memory involves a program of institutions and sites. "Museums, archives, cemeteries, festival anniversary, treaties, depositions, monuments, sanctuaries, fraternal orders-these are the boundary stones of another age, illusions of eternity." This is a conscious search. "Lieux de mémoire originate with the sense that there is no spontaneous memory" (Pierre Nora, "Between Memory and History: Les Lieux de Mémoir," Representations 26 [Spring 1989]: 9, 12). In my study, memory figures as an element of myths, created with political animus that highlights events or aspects of events.

3 See T. C. W. Blanning, The Culture of Power and the Power of Culture: Old Regime Europe 1660-1789 (Oxford, Oxford University Press, 2002), 59 and passim; Jürgen Habermas, The Structural Transformation of Public Sphere: An Inquiry into a Category of Bourgeois Society (Cambridge, MA: MIT Press, 1989), 7-10. 
from the elite or the people, he rarely asserted or displayed his love for them. He especially avoided displays that might hint at the popular basis of his sovereign power.

However, the threat of Napoleon's armies made this distant posture untenable and led him to seek popular support and make public appearances. Alexander appointed the conservative, nationalist poet Alexander Shishkov State Secretary to replace Michael Speranskii when invasion threatened. In subsequent months, Shishkov composed manifestos signed by Alexander that appealed to patriotic and religious feelings of the people and called upon them to support the struggle against the invader. When news came of the invasion, in June 1812, Alexander issued a rescript in the name of Field-Marshall Saltykov, concluding with his famous words, "I will not lay down arms while the last enemy soldier remains in my empire." Alexander indicatively referred to the empire as "my" and said nothing about the Russian people. Despite the importuning of his advisors, he felt obliged to play the role of military leader and remained at the front, close to his armies. ${ }^{4}$

Shishkov wrote a letter to the emperor imploring him to leave his armies and to appear in Moscow. His letter was transmitted by Alexander's adjutant, Alexei Arakcheev, who joined his signature to Shishkov's. Shishkov expressed his fear for Alexander's life and advanced arguments that drew sharp distinctions between the tsar's obligations as military leader and as ruler of Russia. He claimed that Alexander's circumstances differed fundamentally from the monarchs he was emulating-Peter the Great, Frederick II of Prussia, and Napoleon, "the first because he was instituting regular military forces, the second because his entire kingdom had, so to speak, been turned into armed forces, the third because it was not birth, but chance and luck that brought him to the throne. None of these circumstances pertain to Alexander the First."5 "The tsar and the Fatherland are the head and the body," he continued. "One without the other cannot be healthy, sound, or safe." Selfless courage in the face of death was reprehensible for a tsar, who, risking death or imprisonment, would leave his state without a head in a time of troubles. Rather, he urged Alexander to rally his subjects, "to summon the nobility and the people for the arming of new forces, who would, under an appointed leader, form a second

4 See Scenarios of Power, 1:217-8.

5 A. S. Shishkov, Zapiski, mneniia i perepiska admirala A. C. Shishkova (Berlin: B. Behr, 1870) 1:140-4. 
defensive force." If he agreed to this, he would "without doubt be met with joyous enthusiasm, and the people, inspired by his presence, would all rise with unprecedented courage."' Alexander yielded to Shish kov's entreaties and in July 1812 traveled to Moscow, where he sought to mobilize the estates to support the war. He addressed the estates separately; as Alexander Martin has observed, Russia lacked an Estates General that could represent a Russian nation. The tsar summoned the nobles to recruit serfs from their estates for the militia and called upon merchants to donate large sums to the war effort. The response in both assemblies was enthusiastic. Shishkov composed an imperial rescript on the forming of a militia, hearkening back to the Time of Troubles of the early seventeenth century and evoking the imagery of a people's war, which had been advanced earlier in the decade by conservative poets and playwrights. His people's war would not jeopardize the social hierarchy: it would be led by the military, merchant, and clerical estates personified in their heroic leaders. His views reflected the ideas of many conservative officials, including Fedor Rostopchin, the Governor General of Moscow. ${ }^{7}$

The foe will meet a Pozharskii in every nobleman, in every clergyman a Palytsin, in every citizen a Minin. Noble gentry estate [blagorodnoe dvorianskoe soslovie]! You at all times were the savior of the Fatherland! Holy Synod and clergy! Your warm prayers always summoned blessing on the head of Russia; Russian people [Narod Russkoi]! Descendants of the brave Slavs! You destroyed the teeth of the lions and tigers advancing on you many times. All should unite: with a cross in your hearts and weapons in your hands, no human force will overcome you. ${ }^{8}$

The image of a united people joining the struggle appeared only in the writings of Sergei Glinka, editor of the journal Ruskoi vestnik and a member of the Moscow militia. Glinka understood the enthusiasm greeting Alexander as the counterpart of the national upsurge of 1613 and the rising of the French

$6 \quad$ Ibid., 1:144-5.

7 Andrei Zorin, Kormia dvuglavogo orla...: literatura i gosudarstvennaia ideologiia $v$ poslednei treti xviii-pervoi treti xix veka (Moscow: NLO, 2001), 158-86, 243-4; Alexander M. Martin, Romantics, Reformers, Reactionaries: Russian Conservative Thought and Politics in the Reign of Alexander I (De Kalb, IL: Northern Illinois University Press, 1997), 127-42.

8 Cited in L. G. Beskrovnyi, Narodnoe opolchenie v otechestvennoi voine 1812 goda; sbornik dokumentov (Moscow: USSR Academy of Sciences, 1962), 14-5. 
nation in the first years of the revolution. His account of Alexander's visit to Moscow, ostensibly written in 1812 and published in 1814, described the tsar's welcome in the Kremlin as an expression of a bond of affection between tsar and people. The rapture (vostorg), the pity, "the love for the gentle tsar," and anger at the enemy inspired the people, creating a "spiritual outpouring." "Lead us Tsar-Sovereign! We will die or destroy the villain!"9

Glinka tried to bring an element of reciprocity into his account, a sign that the tsar recognizes the devotion of the people. To the shouts of enthusiasm, Alexander came out onto the Red Staircase and paused. "For a few minutes, his eyes and heart took in (obtekali) the throngs of his loyal people." There is an intimation of reciprocity, but no more. Alexander stops to consider the spectacle, but his eyes remain dry. Alexander's appearances at the Kremlin represented a milestone, inaugurating imperial visits to Moscow at moments of crisis during the nineteenth century. ${ }^{10}$ However, there was little in the initial ceremonies to present Alexander as leader of a united nation. It was the advance of Napoleon's armies that drove him to appeal to the sentiments of the Russian people as a whole. On September 8, 1812, he signed a manifesto, written by Shishkov, calling upon the Russian people to take up the cause of all peoples united in the struggle against the aggressor. The Russian people, led by the Orthodox Church, were presented for the first time as a force for salvation and liberation.

It is pleasant and characteristic of the good Russian people to repay evil with good! Almighty God! Turn Thy merciful eyes on the Orthodox Church, kneeling in prayer to Thee! Bestow spirit and patience upon Thy faithful people fighting for justice! With this may they triumph over their enemy, overcome them, and, saving themselves, save the freedom and the independence of kings and kingdoms! ${ }^{11}$

On Christmas day, 1812, Alexander issued Shishkov's famous manifesto proclaiming the expulsion of the invader from Russian territory. This began with ringing praise of the Russian people, who had fulfilled the promise

9 S. Glinka, "Vospominanie o Moskovskikh proizshestviiakh v dostopamiatnyi 1812 god, ot 11 iulia do izgnaniia vragov iz drevnei Ruskoi Stolitsy," Ruskoi vestnik 9 (1814): 11-12.

10 Ibid., 12-13, 19.

11 Shishkov, Zapiski, 1: 156-9; V. K. Nadler, Imperator Aleksandr I i ideia sviashchennogo soiuza (Riga, 1886-1892) 2: 54-7. 
not to lay down arms until the foe no longer remained on Russian soil. "We took this promise into Our heart, relying on the powerful valor of the people entrusted to Us by God, and we were not disappointed. What an example of daring, courage, piety, endurance and strength was shown by Russia!" But Alexander, wary of these addresses to the people, was careful to emphasize divine intervention as well. The achievement was so staggering, the decree asserted, as to be beyond human powers. "In this deed we recognize Divine Providence itself." Salvation was to be found in religion, which the enemy had scorned. "We will learn from this great and terrible example to be the mild and humble executor of the laws and will of God, not like those who have fallen away from the faith, those desecrators of the temples of God." Alexander then summoned all to give thanks to God in the cathedrals. On the same day, he issued another decree, vowing to build a Cathedral to be named Christ the Redeemer to show thanks to Divine providence for Russia's salvation. ${ }^{12}$

\section{The Symbolic Inclusion of the Peasantry}

The mention of Providence was scarcely formulaic. The involvement of the people in the symbolic triumph of autocracy was Alexander's answer to Napoleon's claims to represent the French nation. However the circumstances that drove the autocratic monarch into an alliance with the masses confronted him with the dilemma intrinsic to reconciling autocratic rule with a principle of popular sovereignty. First, a problem of representation: the involvement of the people in the imperial scenario threatened the image of the tsar as a superordinate force whose title to power came from beyond or above-from foreign imposition, divine mandate, or the emanations of reason. Secondly, it was impossible to present the people as a historical agent while denying them an independent role so as to defend an estate system based on serfdom. As Dominic Lieven has argued, Alexander used the discipline of the established social and political system to maintain the order, cohesion, and swift movement of his armies that made victory possible. The monarchy "triumphed by exploiting all the potential of old-regime states and military systems to their utmost limits." The authorities carefully avoided mobilizing

12 Polnoe Sobranie Zakonov Rossiiskoi Imperii, Sobranie 1, no. 25,296, December 25, 1812. 
the Russian peasantry as an independent force, or giving any indication that would jeopardize the stability of the serf order. Peasants were recruited into militias and partisan units under the command of noble army officers, and by the end of the war, Lieven points out, most militiamen had been merged into the regular army. ${ }^{13}$

The peasants' participation took the form of verbal and visual representation that brought them within the ambit of the myth. Once the French army abandoned Moscow, a group of intellectuals close to the court, among them Alexei Olenin, Alexander Turgenev, Sergei Uvarov, and Vasilii Zhukovskii, gathered around the Petersburg journal Syn otechestva, founded by N. I. Grech in October 1812, and sought to stir national feeling against the French. To achieve this goal, they composed tales of peasant heroism, which presumably occurred in Moscow and Smolensk province as the foe retreated, and thus substantiated the belief in mass popular participation in the struggle. Alexander Turgenev wrote in October 1812 that the purpose of the journal was "to encourage the people and to acquaint them with themselves"; in other words, Elena Vishlenkova commented, to show the people what Russian character was "and to urge their compatriots to show these qualities." Their tales "were taken as true," Mikhail Dmitriev wrote in his memoirs, "they were believed and produced the desired effect-that is hatred for the people that had wounded our national pride." 14

The episodes were illustrated in the widely acclaimed series of lubki, many of which were republished and would figure in the national memory of 1812, what Stephen Norris in his pioneering study described as "visual nationalism."15 The medium of lubki, originally crude but affecting wood block prints, lent a popular aspect to the appeals of the regime. However, these were works not of peasant craftsmen, but of trained academic artists who put their talents at the service of the national effort. Graduates of the Academy of Arts, Ivan Terebenev, Alexei Venetsianov, and Ivan Ivanov drew upon popular imagery to create scenes ridiculing the enemy and glorifying the shrewdness, power, and

13 Dominic Lieven, "Russia and the Defeat of Napoleon," Kritika vol. 7, No. 2 (Spring 2006): 293-5; Idem, Russia Against Napoleon, 218.

14 Elena Vishlenkova, Vizual'noe narodovedenie imperii, 161-6; M. Dmitriev, Glavy iz vospominanii moei zhizni (Moscow: NLO, 1998), 85.

15 Stephen M. Norris, A War of Images: Russian Popular Prints, Wartime Culture, and National Identity, 1812-1945 (De Kalb, IL: Northern Illinois University Press, 2006). 
heroism of Russian peasants. Lubki gave the impression of peasant participation by characterizing and stereotyping legendary exploits in conventional popular storybook type imagery, without suggesting that the peasantry as a group could be an agent of the struggle. The popular idiom in this way contributed to the image of a nation united against the foe.

Two principal motifs of the lubki issued in 1812 were the evil, effeteness, and ineptitude of the French, particularly Napoleon, and the courage of the peasants and the Cossacks. Several of the lubki drew on upon classical themes, seized upon by the Petersburg writers to identify the peasants with classical examples of valor. Terebenev draws on classical imagery to depict the peasants as a gigantic Hercules. The peasant is a colossal intimidating force, dispatching French soldiers with ease, "driving them into the woods and crushing them like flies," as the caption indicates (Figure 1). Ivanov's "Russian Scaevola" shows a peasant repeating a heroic act of a Roman soldier who placed his hand in a fire when brought before the Etruscan king Porcenna. The Russian peasant captive of Napoleon betters Scaevola, chopping off his own arm, which

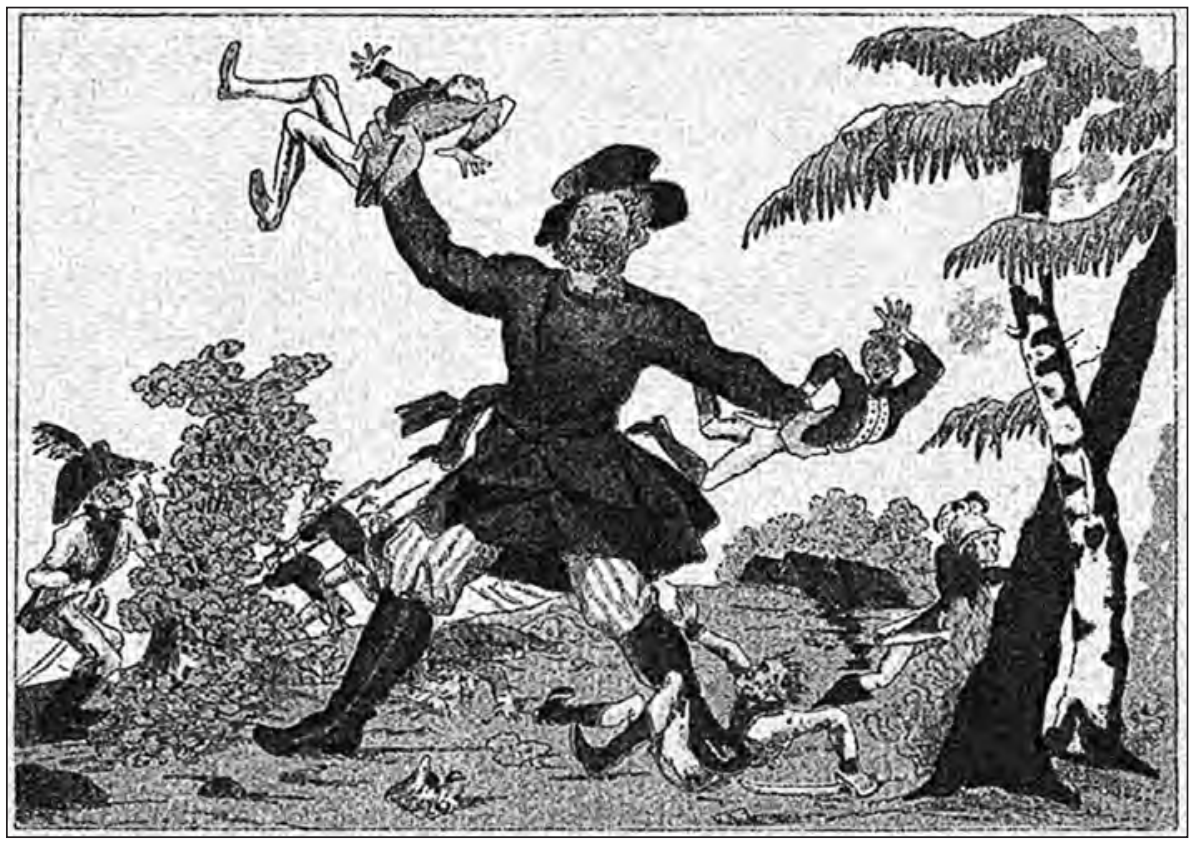

Figure 1-Ivan Terebenev-The Russian Hercules. $1812 v$ karikature

(Moscow: Central Museum of the Great Patriotic War, 1999). 
had been branded with the letter "N"; the French, cast in effete and awkward postures, look on with amazement. ${ }^{16}$

Many of the more vivid images of Terebenev, Ivanov, and Venetsianov were collected in Terebenev's Alphabet of 1812, which was later reprinted many times to instruct and amuse generations of Russian children. $V$ is for Vorona-crow, and the French are "eating crow," so to speak, chewing on the bones: "What a tasty dish is crow! Could I have a leg, please, and why not?" (Figure 2). D is for domoi pora, time to go home, and we see the bedraggled soldiers of the grand armée approaching the Arch of Triumph. "Time to go home! March! March! At last our stay is over. We go with nightcaps whole, but with noses, arms, and legs gone."

Women show no more mercy to the invader. For F, the French are like mice, they are caught in a trap: "I will not free them," the baba cries, "but will burn them up. Fie! I've caught the Frenchmen just like vermin. To rid Russia of their stink I guess we'll just have to burn them" (Figure 3). A gigantic peasant holds Napoleon by the scruff of the neck, Napoleon declaring, "I was a hero, but in the hands of the muzhik, I play the fool." And the Alphabet also took into account Napoleon's real problem with horses: he is shown being pulled on a sleigh by a pig. "There's nothing to be done but to beg the help of swine." Several lubki depict Cossack exploits. One swings his nagaika to cut down the enemy. "A Frenchman has broad shoulders and a good strong back. Well, what do you know, just the thing for my whip."

For all the glorification of peasant heroism and vilification of the foreigner, I would describe this not as "visual nationalism," but "visual patriotism." The lubki sought to mobilize popular sentiment, drawing upon and encouraging antagonism toward the aggressor and everything they represented. They sought to displace the serfs' distress and antagonism onto the image of the foe, the invader. They glorified peasant heroism in legendary space without chancing their mobilization.

Once the invader had been repulsed, lubki no longer portrayed these scenes of violence and ridicule. Rather, they, like official rhetoric, increasingly focused on the tsar and his divine mission. They set the imperial scenario in a popular frame by characterizing the Emperor in the conventional lubok

16 Norris, 20-2; Gosudarstvennyi muzei-zapovednik "Borodinskoe pole" (Moscow: Belyi Gorod, 2007), 45. For a detailed explication and semiotic analysis of the genre see Vishlenkova, Vizual'noe narodovedenie imperii, Chapter 3. 


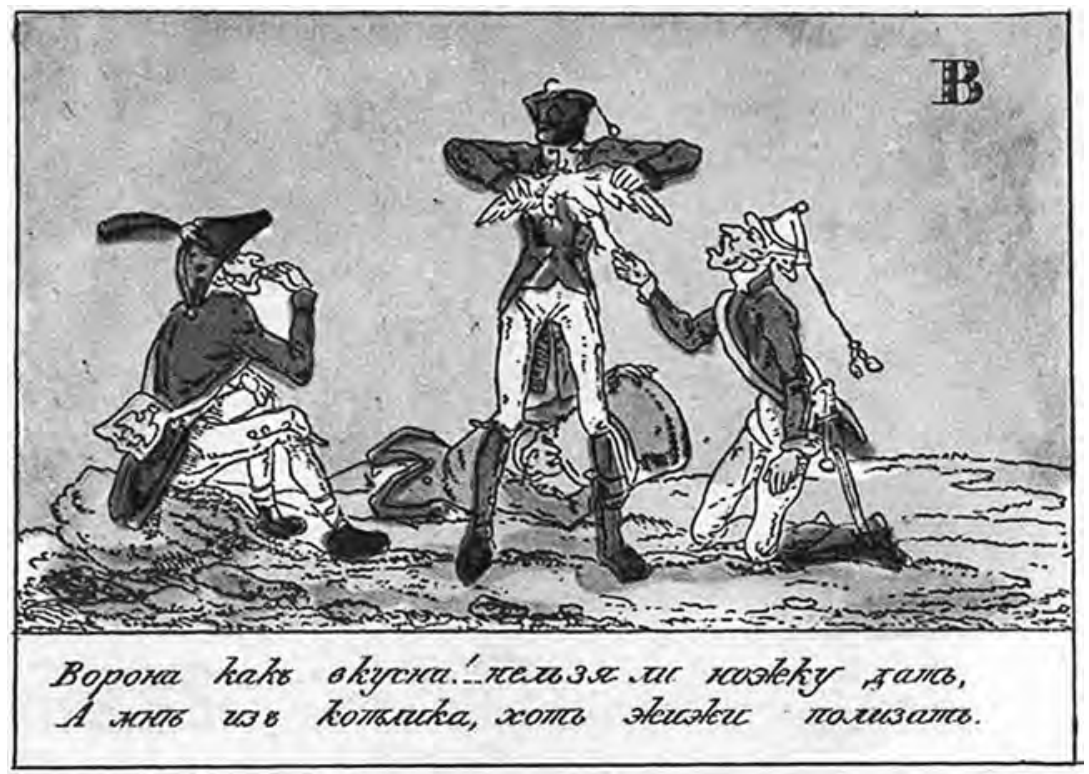

Figure 2-Russkaia Azbuka-Letter "B"-The French Eat Crow. http://www.museum.ru/museum/1812/English/Library/Azbuka/index.html

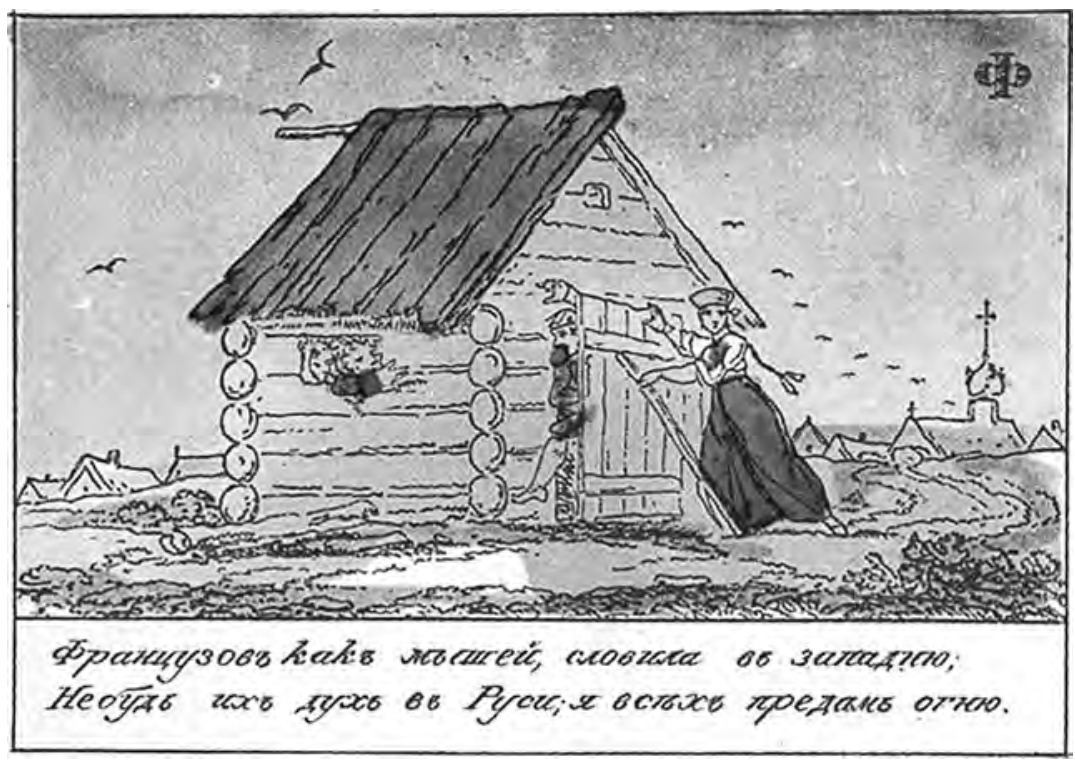

Figure 3-Russkaia Azbuka-Letter "F"-The French like Mice are Caught in a Trap. http://www.museum.ru/museum/1812/English/Library/Azbuka/index.html 
image of military leader on horseback leading his troops. In a depiction of the victory over Napoleon outside Paris on March 18, 1814, Alexander rides in the foreground as if he were commanding. Another shows Alexander's triumphal entry into Paris, the conqueror triumphant (Figure 4).

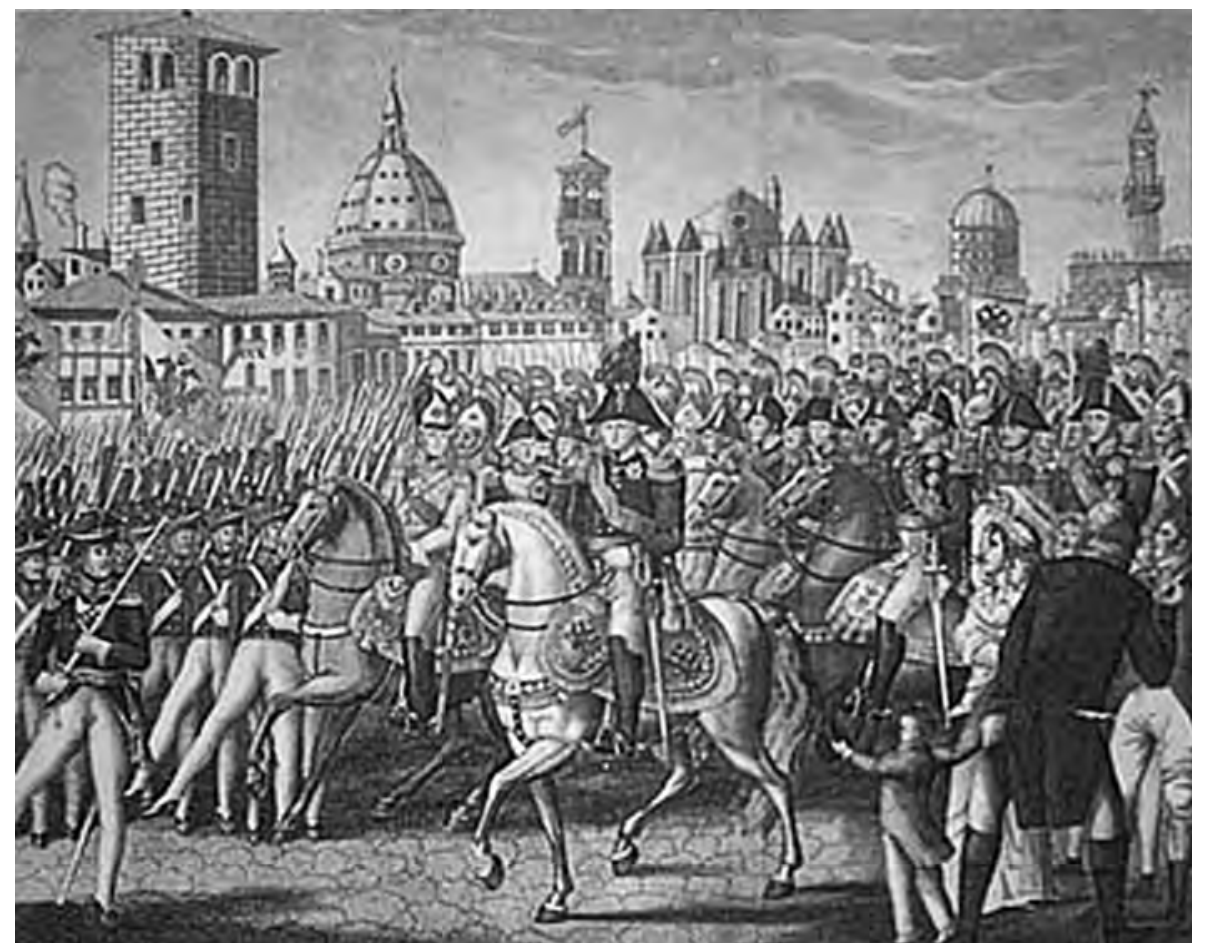

Figure 4-Alexander I's triumphal entry into Paris. Otechestvennaia voina 1812 goda $v$ khudozhestvennykh $i$ istoricheskikh pamiatnikakb iz sobranii Ermitazha (Leningrad: Gos. Ermitazh, 1963).

Alexander continued to view himself as transcendent Western ruler, now governing Russia according to the universal dictates of Christian Providence. He viewed the invasion as punishment for his error of seeking guidance in reason and law. The burning of Moscow was a sign of his transgressions, revealing that his efforts on behalf of mankind had been in vain, and had opened him to knowledge of God. He realized at this point that he lacked the power to transcend his individual interest and attain the general good. The Bible replaced philosophy as the source of the ethical ideas that justified his imperial authority. With his friend Prince A. N. Golitsyn, the Chief 
Procurator of the Holy Synod, Alexander read the ninetieth psalm and experienced a revelation. He listened intently to Admiral Shishkov reading passages from Jeremiah about the downfall of Jerusalem. ${ }^{17}$

Alexander's conception of 1812 and of Russia's destiny did not accord with Shishkov's. Shishkov wrote about the defense of the Fatherland; he did not dream of conquering France and reforming the French. Quite the contrary; along with Kutuzov, he urged Alexander not to cross the Rhine, but to return and devote himself to "the healing of inner wounds and the restoration of broken forces." Unlike most of the war rhetoric, Shishkov's writings did not demonize Napoleon, and he argued that in the event of Russian victory he should be allowed to retain power. Instead, Shishkov demonized the French people as a whole as profligate and incorrigible. "Could Napoleon have instilled the spirit of rage and evil fate in millions of hearts, if the hearts themselves were not corrupt and breathed depravity?" The differences between the two nations were epitomized by the rulers they "elected." In a project of 1814, which he did not publish or share with the emperor, he asserted that a nation, belonging to the divine order, had elected an anointed of God to begin a great dynasty. A nation living by the laws of the devil "places above themselves a tsar, or more accurately an ataman, a commoner born in Corsica, exceeding all in dishonor, perfidy and malice." 18

Alexander rather conceived of himself as redeemer of all mankind as he led Russian armies across Europe. He looked back on 1812 with shame and sought to obliterate the sorry events of that year from his memory as he looked forward to the spiritual liberation of Europe. He could not bear to hear mention of the battle of Borodino with its massive losses, and refused to celebrate its anniversary. To give cultural expression to his vision, Andrei Zorin has shown, he availed himself of the talents of two figures with literary talent, cultural cultural interlocutors: the young and brilliant archimandrite of the Nevsky monastery, Filaret-Drozdov, later the Metropolitan of Moscow, and the poet Vasilii Zhukovskii. Filaret and Zhukovskii gave voice to Alexander's own feelings about the war, the desire to obliterate the memory of the Russian campaign and look forward to the liberation of Europe.

17 N. K. Shil'der, Imperator Aleksandr Pervyi, ego zhizn' i tsarstvovanie (St. Petersburg: A. S. Suvorin, 1897-1898) 3: 117; Nadler, Imperator Aleksandr I, 2: 124-33.

18 Zorin, Kormia dvuglavogo orla..., 250-1 
In 1811, Filaret became a close associate of Prince Golitsyn who had built a church in his home, a "secret temple," where Alexander worshipped. Filaret's sermon at the consecration of the church propounded the doctrine of an inner church, an invisible church. He gave ecclesiastical confirmation to Alexander's narrative of evangelical triumph. The defeat of Napoleon was only the first step to the realization of a Christian order in all of Europe. ${ }^{19}$ Vasilii Zhukovskii found consolation for romantic disappointment by yielding to the dictates of Providence and extolling Alexander in his poems of 1813, "The Bard in the Russian Camp" and "Epistle to Emperor Alexander." Zhukovskii expressed Alexander's own feelings about the war. He devoted only one tenth of the lines of "To Emperor Alexander" to 1812; the rest extolled the emperor's triumphal campaign across the Europe. While twenty lines rhapsodize on the Battle of the Nations at Leipzig, only one is devoted to battle of Borodino. ${ }^{20}$ The burning of Moscow was a prelude to resurrection:

In flames, chains turn to dust, peoples are resurrected!

Your shame and the captivity, Moscow, collapsing was buried,

And from the ashes of vengeance freedom arose to life. ${ }^{21}$

For Alexander, the military victory was a sign of a dawning universal rebirth. He wrote of his conversion, "From that time, I became a different person. The salvation of Europe from ruin became at once my salvation and my liberation." Alexander assumed the role of the leader not of Russia alone but of world Christendom. The office of Russian emperor was filled with appropriate meaning - the instrument of God, the redeemer of humanity, and the defender of the legitimacy of monarchical government throughout Europe. Alexander continued to present himself as an agent of reform, but as redeemer of souls more than as institutional reformer. He understood the success of the Russian armies in terms of his own drama of personal resurrection. His Christian mission now construed "the general welfare" as a spiritual goal. The victorious battles over Napoleon as the Russian armies crossed Europe assumed the meaning of a prelude to a scenario

19 Ibid., 265-6.

20 Ibid., 290-1.

21 V. A. Zhukovskii, Polnoe sobranie sochinenii V. A. Zhukovskogo v 12 tomakh (St. Petersburg: Marks, 1902) 2: 73. 
of redemption, which he performed in grandiose military spectacles staged in France in 1814 and 1815.

The first took place in Paris on Easter Sunday, March 29, 1814, on the square recently renamed Place de la Concorde. With the Prussian king Frederick Wilhelm III and Prince Karl-Philip Schwartzenberg, representing the Hapsburg court, at his side and a large suite, he reviewed 80,000 troops from the allied armies and the Paris National Guard. Seven regimental priests in "rich vestments" stood at an altar erected on the site of Louis XVI's execution to lead the singing of the Te Deum. Alexander knelt at the altar for the prayer service. The French marshals and generals pressed forward to kiss the Russian cross. Then, once a prayer for the long life of the leaders of the alliance was pronounced, salvos sounded and the crowd shouted "Hoorah!"22 A contemporary print showed Alexander at the altar, Louis XVI in the heavens above bestowing his blessing 23 (Figure 5).

Alexander was deeply moved. He felt inspired with the providential mission of absolution of the French for their misdeeds. He recalled, "This moment was both touching (umilitelen) and awesome for me." He was convinced that he had come with his Orthodox army "by the inscrutable will of Providence" to Paris to bring a "purifying and solemn prayer to the Lord." The army now represented the Russian people as the instrument of Providence. He believed that his prayer had achieved its goal and "instilled veneration in the hearts of the French." It had also demonstrated the triumph of Russia as the leader of the alliance. "I strongly sensed the apotheosis of Russian glory among the foreigners, and I myself even won their enthusiasm and forced them to share our national triumph with us." 24

The final events took place on the plains of Champagne near the town of Vertus in August 1815, after the hundred days. With the Prussian king and the Austrian Emperor, Alexander viewed his armies from the hill, Mont Aimé, with admiration. External appearance was indeed the emperor's principal concern, for beauty and symmetry signified order and now the squares formed by the armies gave almost mystical confirmation to the divine source of his power. The displays had been scheduled to include Alexander's name-

\footnotetext{
22 Russkii invalid, August 25, 1814, 243.

23 I am grateful to the art historian Guillaume Nicoud for the identification of the figure of Louis XVI in the bubble.

24 Nadler, Imperator Aleksandr I, 5: 184-6.
} 


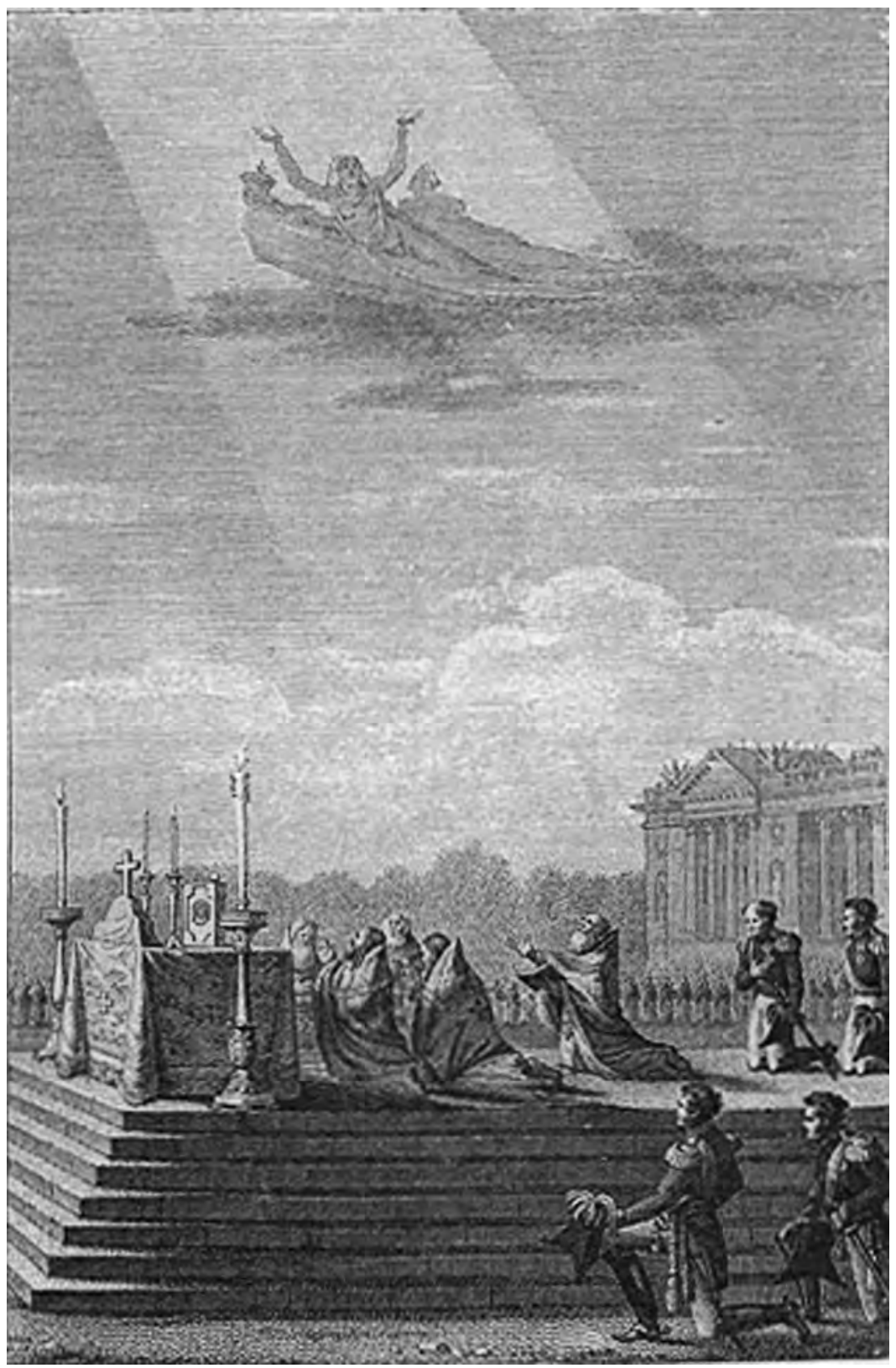

Figure 5-Prayer Service on La Place de la Concorde, March 29, 1814. N. K. Shil'der, Imperator Aleksandr Pervyi, vol. 3 (St. Petersburg: A. S. Suvorin, 1899), 289. 
day, August 30, the feast of Alexander Nevskii and provided the occasion for an immense religious ceremony, held a few miles from the site of the previous day's activity. Prayer services for the monarchs and the generals and the armies proceeded before seven field chapels. The troops, over one-hundred and fifty thousand, lined up without arms in a pattern of open squares pointing toward a nearby promontory, Mont Cormant. Each unit moved in formation toward its altar. The field was silent as the tsar knelt in prayer with the immense army lined up in symmetrical patterns before him. Two days later the Russian armies began their return home. ${ }^{25}$

The Cathedral of Christ the Redeemer, which Alexander had promised to build on Christmas Day, 1812, was to be the principal monument to the spiritual truths he had discovered. The cathedral, designed by Alexander Vitberg, would be a soaring statement of eternal spiritual values, a demonstration that the emperor and the Russian people had conquered the beyond as well as the world. Like Alexander, Vitberg believed that harmonious shapes and classical geometrical forms, realized in the proper mass, could express spiritual truths. He designed the cathedral in three levels, the lowest a square, the middle, a circle, the top, a cupola crowned by a cross. The levels expressed three principles-body, soul and spirit-and moments in the life of Christ: Birth, Transfiguration, Resurrection (Figure 6). However, the cathedral, like Alexander's spiritual vision of a redeemed humanity, was destined to remain unrealized, thwarted by human imperfections and the limits of contemporary technology. The tale of the first attempt to build a Cathedral of Christ the Redeemer encapsulates the sorrowful last years of Alexander's reign. ${ }^{26}$

Alexander I submerged the memory of 1812 in a spiritual affirmation of the universalistic myth of eighteenth century monarchy. It would be his younger brother Nicholas Pavlovich who made the events of 1812 an epic demonstration of the national spirit of the Russian people and their dedication to their westernized ruler and the principle of autocracy. Nicholas's scenario began to take form during the war in the court of the dowager Empress Maria Fedorovna, who gathered and encouraged the advocates of a national monarchy, including not only Shishkov and Sergei

25 Lieutenant-General Khatov, Dva znamenitye smotra voisk vo Frantsii (St. Petersburg, 1843), 50, 58, 61.

26 Scenarios of Power, 1: 236-8. 


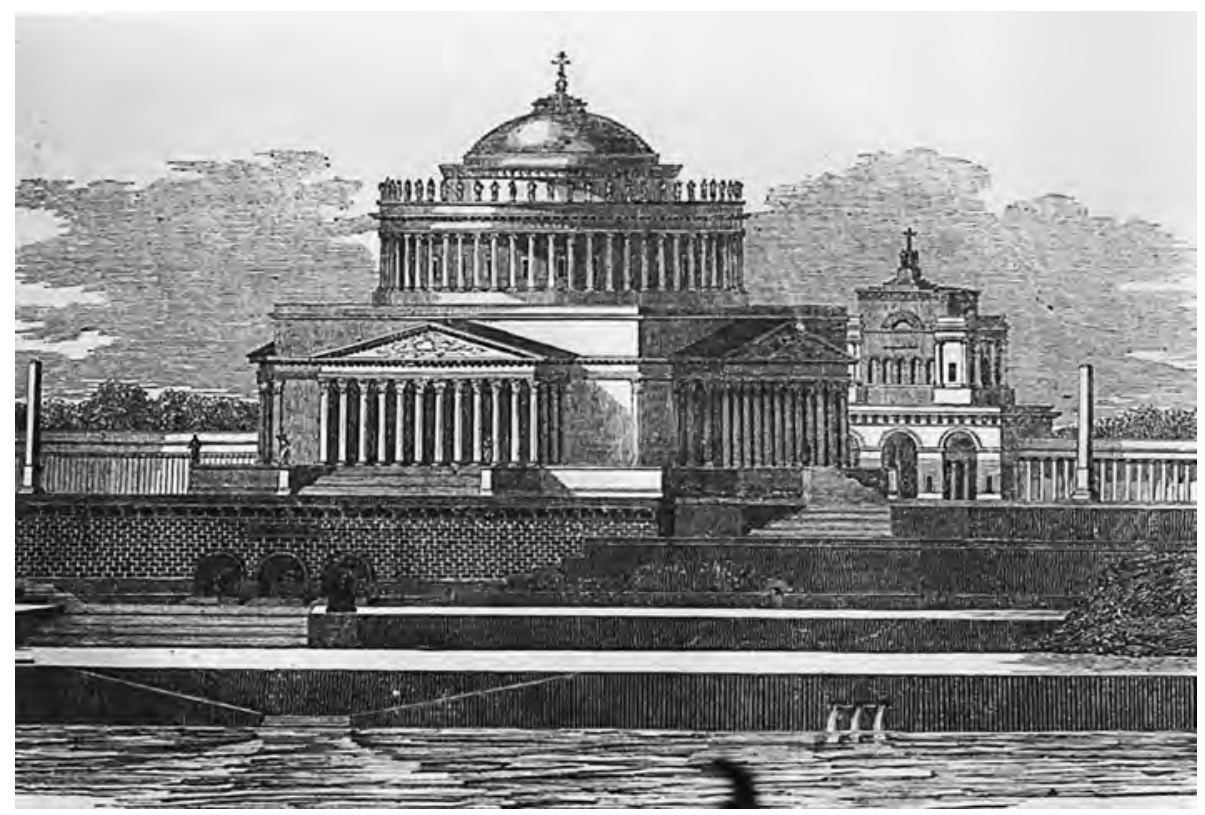

Figure 6-Alexander Vitberg-Project for Cathedral of Christ the Redeemer, Moscow. Zhivopisnoe obozrenie, Vol. 4, 1838.

Glinka, but Nicholas Karamzin, Vasilii Zhukovskii, and Sergei Uvarov, intellectuals who sensed the shifting winds. The key event was Alexander's visit to Moscow in the fall of 1817 and early 1818, timed to coincide with the birth of an heir to the throne, Grand Duke Alexander Nikolaevich, in the Moscow Kremlin, in order to identify the dynasty with a national symbol. Emperor Alexander honored the inhabitants of the city by bowing to them three times from the Red Staircase, the first recorded occurrence of what became a tsarist tradition. But this prefiguring of a national scenario, clearly under the dowager's influence, did not suggest a conversion of Alexander, who in his last years remained aloof and true to his devotion to a universalistic spiritualism. ${ }^{27}$

27 N. N. Mazur, "Iz istorii formirovaniia russkoi natsional'noi ideologii (pervaia tret' XIX v.)," in V. A. Mil'china, A. L. Iurganov, ed., "Tsep’ nepreryvnogo predaniia...": Sbornik pamiati A. G. Tartakovskogo (Moscow: Rossiiskii Gosudarstvennyi Gumanitarnyi Universitet, 2004), 217-9. 


\section{Official Nationality and the Cult of 1812}

If Alexander I wished to consign the memories of 1812 to oblivion as reminders of his fall from grace, transcended by a universal mission to redeem humanity, Nicholas I sought to resurrect the memories of war, and make them part of a scenario of national rebirth, demonstrating the dedication of the Russian people to the system of autocracy, which had saved Russia from revolution and invasion. The ideas of national identity and distinctiveness, emanating from German idealistic philosophy, were now incorporated into a scenario that presented the absolute monarchy as the expression of the will of national feeling and history. 1812 proved that monarchical Russia supported by the devoted Russian people had defeated the forces of liberalism and revolution, which had defiled and weakened the monarchies of the West. The doctrine of "Official Nationality" evolved during the first decade of his reign and was formulated in Sergei Uvarov's triad, "Orthodoxy, Autocracy, and Nationality" (Pravoslavie, Samoderzhavie, Narodnost'), which defined the nation and the Russian people by their historical devotion to monarchy. However great the social, cultural, and ethnic division in the empire, Russians displayed unquestioning obedience to a system of absolute monarchy, ruled and embodied by their tsar. ${ }^{28}$

The theme was introduced in the manifesto announcing the sentencing of the Decembrists, issued on July 13, 1826. The failure of the Decembrist uprising was itself proof of the national character of the monarchy. The Decembrists' design was alien to the Russian people. "Neither in the characteristics nor the ways of the Russian is this design to be found.... The heart of Russia was and will be impervious to it." The manifesto went on "In a state where love for monarchs and devotion to the throne are based on the native characteristics of the people, where there are laws of the fatherland and firmness in administration, all efforts of the evil-intentioned will be in vain and insane." 29

Ceremony, history, and church architecture demonstrated the historic devotion of the Russian people to their westernized conquerors and rulers, setting Russian monarchy apart from its European counterparts. The

$28 \quad$ See Scenarios of Power, 1: 255-95.

29 N. K. Shil'der, Imperator Nikolai Pervyi: ego zhizn' i tsarstvovanie (St. Petersburg: A. S. Suvorin, 1903), 1: 704-6. 
representations of the monarchy showed that the Russian people loved those rulers who had come from outside or appeared to come from outside to govern them. The coronation of Nicholas was exemplary in this respect. ${ }^{30}$ It was the first "national coronation," which presented the people as an active agent of acclamation. The triple bow that Nicholas performed from the Red Staircase before the people gathered on Kremlin square on August 22, 1826 displayed the mutual bond between tsar and people. Pavel Svin' in, the author of official accounts of the coronation rituals and festivities, acclaimed after the explosion of praise, "I will say that this alone would be enough to win the hearts of the good Russian people, if they did not already belong to the Anointed of God."31 It became a ceremony fixed in the tsarist repertoire and regarded as an "ancient Russian tradition” linking nineteenth-century monarchy to the ceremonies of Muscovite Rus'.

The Polish Revolution of 1830 posed a new threat, not to the independence or sovereignty of the monarchy, but to the territorial integrity of the empire. The rapid spread of the insurrection, the difficulties the Russian armies faced in defeating small numbers of Polish resistance, the claims of the revolutionaries to territories reaching into Belorussia and the Ukraine, showed the dangers of bestowing even limited freedoms on a nationality. At the same time, European public opinion, particularly in France, rallied to the Polish cause. In facing the hesitancy of local officials and Russian generals to crush the opposition, Nicholas called upon the memory of the Napoleonic war. He wrote to Field-Marshall Count I. I. Diebich in April, 1831: "For God's sake be firm in your decisions, stop beating around the bush all the time, and try, through some brilliant and daring attack, to prove to Europe that the Russian army is still the same as the one that marched twice to Paris." 32

In 1831, an officially sanctioned brochure, On the Taking of Warsaw, celebrated the victory on August 26, the anniversary of Borodino, with poems by Pushkin and Zhukovskii. Pushkin's “The Anniversary

30 On Nicholas I's coronation, see Scenarios of Power, 1: 279-95.

31 Pavel Svin'in, "Istoricheskoe opisanie Sviashchennogo Koronovaniia i Miropomazaniia ikh Imperatorskikh Velichestv Gosudaria Imperatora Nikolaia Pavlovicha i Gosudaryni Imperatritsy Aleksandry Feodorovny," Otechestvennye zapiski, 31 (1827): 375.

32 W. Bruce Lincoln, Nicholas I: Emperor and Autocrat of All the Russias (Bloomington, IN: Indiana University Press, 1978), 142-3. 
of Borodino" reminded Europe of the fate of those who threatened Russia in 1812: "For them blood of Slavs is heady, but the morning after will be painful." Pushkin's second poem, "To the Slanderers of Russia," responded angrily to the outcry in France in defense of the Poles, as if Poland were a separate nation. Pushkin described the uprising as "a family quarrel" between Slavs and the protests from West expressions of their hatred of Russians. "Won't the Russian Land (russkaia zemlia) arise," he warned. His description of the Russian Land evoked the vast reaches of the empire from Perm to the Crimea, from Finland to Colchis, from the Kremlin to the Chinese border. "So bards send us your embittered sons: there is room for them in the fields of Russia, amongst the graves of their kinsmen." He asked with irony, where Russia should fortify its borders, at the Bug, the Vorsla, the Liman. Who would receive Volynia, the legacy of Bogdan Kmelnitskii? Would Lithuania be torn from them, Kiev? Pushkin extended the heroic defense of the homeland against subjugation in 1812 to the defense of the entire empire against foreign incursion. ${ }^{33}$ The poem, Olga Maiorova wrote, inscribed "the suppression of the Polish rebellion of 1830 and the memory of 1812 into a paradigm of ethnic heroism." 34

After a dearth of publications in the 1820s about the Napoleonic war, a spate of articles appeared in the pages of the newspapers Severnaia pchela, Russkii invalid, and other periodicals. Works of fiction, memoirs, and diaries gave colorful accounts of the war. In the first draft of a letter, Pushkin wrote, "the noise of $1812 \ldots$ the Moscow fire and Napoleon's flight... overshadow and drown out everything." 35 In this setting, Nicholas introduced the ceremonial and symbolic expressions of victory that would consecrate the war against Napoleon in the national memory. During the 1830 s, he marked the events, first by spectacular military reviews, second by beginning the construction of the Christ the Redeemer Cathedral in a "national" style, third with the publication of a massive history of the war, and fourth with the opening of a memorial battlefield at Borodino.

33 A. S. Pushkin, Polnoe sobranie sochinenii (Leningrad: Akademiia Nauk SSSR, 1948), 3: 269-70.

34 Olga Maiorova, From the Shadow of Empire: Defining the Russian Empire through Cultural Mythology, 1855-1870 (Madison, WI: University of Wisconsin Press, 2010), 32-3, 201.

35 A. G. Tartakovskii, 1812 god i russkaia memuaristika (Moscow: Nauka, 1980), 18692. 
It proved not so simple to accommodate the tumultuous memories of 1812 , as significant as they were, to the imperial myth, even in its national scenario. At first, Nicholas avoided the apprehensions and ambiguities of 1812, and like Alexander focused on the triumphal march across Europe from 1813 to 1815. He staged great military ceremonies in the tradition of Vertus, glorifying Alexander as military leader, the agent of Providence. Massive maneuvers and parades celebrated Russia's invincibility at the unveiling of the Alexandrine column in 1834, the meeting of Russian and Prussian armies at Kalish in 1835, the twenty-fifth anniversary of 1812 at Voznesensk in Kherson province in 1837, and the opening of the Borodino monument in 1839. The spectacles confirmed the theme of official nationality by displaying Russia's devotion to the monarch whose leadership brought victory. ${ }^{36}$

The dedication of Auguste Ricard de Montferrand's column to Alexander I was the most lavish and magnificent of these events. On August 30, 1834, Alexander I's name day, 120,000 troops massed on or near Palace Square for a ceremony that marked the column as a votive object in the scenario of a national dynasty. The principal published accounts, a brochure by Ivan Butovskii and an article by Vasilii Zhukovskii, described the spectacle as an epitome of the political order that had lifted Russia to height of power and international prestige. At 11 a.m., Nicholas appeared on the square, cannon salvos sounded, and, at the third blast, columns of troops marched toward him. They quickly covered the entire vast expanse (Figure 7). Zhukovskii presented the parade as an emanation of the sovereign's power:

The heavy measured step, shaking the soul, the calm approach of a force that was at once invincible and obedient. The army poured in thick waves and submerged the square. But there was amazing order in this flood. The eyes beheld an innumerable and immense moving mass, but the most striking thing in this spectacle was something the eyes could not see: the secret presence of a will that moved and directed by a mere nod. ${ }^{37}$

It was in the spirit of monarchical triumphalism that Nicholas conceived the design of his version of the Christ the Redeemer Cathedral in 1832 to memorialize 1812. The architect Constantine Ton provided him with

\footnotetext{
$\overline{36}$ Ibid., 199-210.

37 V. A. Zhukovskii, "Vospominanie o torzhestve 30 avgusta 1814 goda," Severnaia pchela, September 8, 1834, 807.
} 


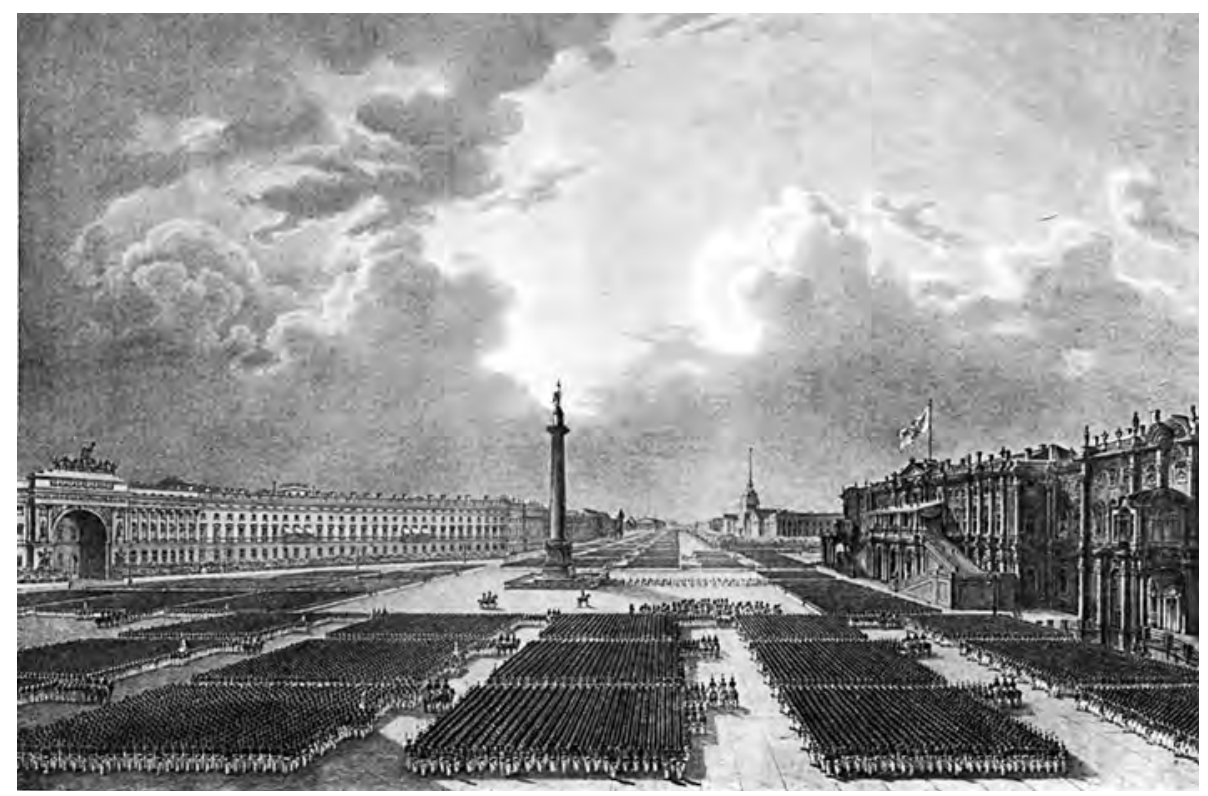

Figure 7-Dedication of Alexandrine Column, August 30, 1834. A. Ricard de Montferrand, Plans et détails du monument consacré à la mémoire de l'Empereur Alexandre (Paris: Thierry, 1838).

a design that realized his vision of a cathedral not expressing universal values, but embodying the spirit of the Russian past and the influence of Byzantium. The cathedral was constructed not at the distant site of the Sparrow Hills, but near the Kremlin.

Nicholas regarded Byzantium as the supreme example of absolute monarchy and Byzantine art and architecture as the true source of Russia's artistic and architectural heritage. He hoped to promote a national style of architecture by constructing facsimiles of early Russian churches that resembled a Byzantine prototype. When he determined to build a Redeemer Cathedral to memorialize 1812, it would not appear as a grandiose neoclassical edifice with symbolic meaning, but as a new Russo-Byzantine style church that attested to Russia's distinctive artistic heritage. The "Ton style" combined neoclassical structural elements with the Russian-Byzantine design, exemplified in the five-cupola structure of the Vladimir and Moscow Assumption Cathedrals. The cathedral's proportions and arcades, as well as its cupolas, were typically neoclassical, while its exterior design asserted its Russian character. (See Article 9, Figure 1.) 
The cathedral assumed the contours of the five-cupola form of the Moscow-Vladimir style, but the resemblance was superficial. The most striking difference was in proportions. Nicholas abandoned Alexander's grandiose dreams of a gigantic temple to dwarf all other buildings. However, he too associated grandeur with size, and as a monument to the 1812 war its proportions had to be monumental. The height from base to the cross was about 340 feet. This meant that it stood over one hundred feet higher than St. Sofia in Constantinople. Ton's neoclassical rendering of a Russian original more than any other building expressed what was meant by "national."

The composition of the initial volumes of the official history of the Napoleonic wars focused on the triumphal march across Europe. Nicholas vested the author, Alexander I's adjutant, Nikolai Mikhailovskii-Danilevskii, with the authority to scour archives in the capitals and provinces for documents relevant to the subject, and even allowed him to consult forbidden foreign books on the subject. The first volume published covered the year 1814, as A. G. Tartakovskii has observed, revealing Nicholas's determination to glorify Alexander I as military leader in the European campaign. ${ }^{38}$ The volume on 1812 appeared only in 1839, and the tsar permitted publication only after closely examining and demanding alterations in the text, eliminating the role of the militias and making sure that Kutuzov did not figure in a favorable light, while generals who served in Nicholas's entourage were singled out for praise. ${ }^{39}$ The work served as the basis for all later writings on 1812, including Tolstoy's War and Peace, which sought to refute the history's premise that the victory was the achievement of the tsar and his generals. MikhailovskiiDanilevskii was hailed as the successor to Karamzin, deserving of the title "historiographer." The author received many honors, was promoted to Lieutenant-General, appointed to the Senate, and designated a member of the Academy in the division of Russian Language and Literature. Criticisms of the work could appear only after Nicholas's death. ${ }^{40}$

38 A. Mikhailovskii-Danilevskii, Opisanie pokhoda vo Frantsiiu v 1814 g. (St. Petersburg: Tipografiia Shtaba Otdiel'nago Korpusa Vnutrennei Strazhi,1836); Tartakovskii, 1812 god i russkaia memuaristika, 203-4.

39 A. I. Mikhailovskii-Danilevskii, Opisanie voiny v 1812 godu po vysochaishemu poveleniiu (St. Petersburg: Tipografiia Shtaba Otdiel'nago Korpusa Vnutrennei Strazhi, 1839); Tartakovskii, 1812 god i russkaia memuaristika, 204-8.

40 Tartakovskii, 1812 god i russkaia memuaristika, 208-12. 
The culmination of the anniversary celebrations took place in 1839, the anniversary of the victory in Europe. On August 26, 1839, Alexander's name day, Nicholas opened the Borodino Battlefield as a site of commemoration, the first such battlefield memorial in history. It was perhaps the most significant act of his dramatization of 1812 , commemorating a battle that was hardly a victory, costing tens of thousands of Russian lives, with a national shrine. The center of the field was marked by a monument, the work of A. U. Adamini. An octagonal column, crowned by a sphere resembling a church cupola below a cross, it appeared as "something between a column and a church bell tower," thus evoking the union of state and Orthodox Church proclaimed by the Official Nationality doctrine. The image of Christ appeared on the front of the octagonal base, with the words "Salvation is in him. The battle of Borodino August 26, 1812." Inscriptions on the seven other sides described the actions of the Russian and French armies. ${ }^{41}$ The Borodino Savior Monastery, founded by the Abbotress Maria Tuchkova, whose husband lost his life during the battle, was built on the field and dedicated at the ceremonies. ${ }^{42}$

The celebrations included a procession of the cross, a parade, and a reenactment of the battle. One-hundred-fifty thousand soldiers stood in three columns on slopes leading down to the new Borodino monument at the scene of what had been the most ferocious clashes. Nicholas was enraptured by the spectacle of battle, but was unhappy with the defensive tactics of the Russian forces and commanded them to "go on the offensive." Afterward, he asked the general at his side, "don't you think that if Field Marshal Kutuzov had acted as we did today, the outcome of the battle would have been different?" Most of the generals remained silent, but someone remarked, "The tsar forgets that today there were no cannon shells or bullets, and that he was not facing Napoleon." 43

\section{The Crimean War and the Memory of 1812}

The Crimean War burst the illusions of 1812. The war itself began under the assumption by Nicholas I and Alexander II of the invincibility of Russian

\footnotetext{
41 K. G. Sokol, Monumenty imperii (Moscow: GEOS, 1999), 120-21.

42 Inokinia Ol'ga (Sergeeva), "Borodino i russkaia sviatost'," in Borodinskoe pole: istoriia, kul'tura, ekologiia, Vyp. 2 (Borodino: Mozhaisk-Terra, 2000), 101-11.

43 Tartakovskii, 1812 god $i$ russkaia memuaristika, 201.
} 
armies when called upon to defend the boundaries of the empire. In February 1854, when Nicholas I announced that Russia was severing relations with France, he evoked the parallel with 1812. "If the enemies attack Russia's borders, we will be ready to meet them with the severity bequeathed us by our ancestors. Are we not the same Russian people whose valor is attested by the memorable events of 1812?" 44 Such claims were repeated in newspaper accounts and sermons during the war. The newspaper Russkii invalid printed an account of the siege of Odessa, noting that "merry souls sang the native legends of the year twelve." Archbishop Inokentii of the Tauride-Kherson interpreted the allies' attack on Crimea as a repeat of Napoleon's 1812 invasion, and warned them that they would confront the great expanses, harsh climate, and wild animals of Russia, suggesting they would seek to advance to the interior. Popular poets took up the theme of Pushkin's "To the Slanderers of Russia," one concluding his verse like Pushkin, "We will lay your bones to rest, among the bones of your kinsmen." After Nicholas realized that the war was going badly, he issued a manifesto, which proved to be his last, on December 25, 1854, the very day that Napoleon's armies had left Russian soil in 1812. The manifesto sought to reinforce determination in the midst of setbacks. He declared "When necessary, we all, tsar and subjectsto repeat the words Emperor Alexander spoke in a time of trial similar to this-stand before the ranks of our enemies with sword in hand and the cross in our hearts to defend the most precious blessings in the world: the defense of the Fatherland." 45

Terebenev's lubki were circulated along with others adapted to the current scene. They showed the bravery of the peasants and Cossacks and presented derisive images of foreigners, especially of the British and Turks. They reproduced the manner of 1812, presenting the conflict in folk characterization to give the conflict a popular resonance. However, the emphases were new. They focus on the army and Cossack units as the bearers of the struggle, rather than on legendary, archetypical evocations of peasant exploits. The emperor does not appear; the struggle is waged by his loyal armies. One lubok depicts a famous encounter between Cossacks and Turks in the Caucasus near Peniak. The Turks replace the French as symbols of cowardice and ineptitude, though they are not demonized as in the

\footnotetext{
44 Maiorova, From the Shadow of Empire, 30-1

45 Ibid., 31-4.
} 
1812 caricatures. There are depictions of the taking of the fortress of Kars and sorties at Sevastopol, the Russian soldiers appearing as mighty figures subduing the craven Turks. Official rhetoric suggested that other nationalities such as Tatars engaged in the battle. Russkii invalid quoted the words of an imam serving as an army chaplain summoning his coreligionists to follow the example of 1812 and defend their homeland "in whose depths reposed...the bones of their fathers." ${ }^{\prime \prime 6}$ A lubok shows Ukrainians joining in defense of what was presumably their homeland as well.

Two innovations, observed by Norris, were scenes of exploits of actual individuals and the appearance of clergymen. A scene of the "podvig (exploit) of ensign (Praporshchik) Shchegolev, later promoted to Staff Captain" showed the ensign heading a battery that scored a hit on an allied ship shelling Odessa, then under siege. In the lubok, "The Praiseworthy Podvig of Ensign Kudriavtsev," an ensign assails Turkish soldiers after they had killed a priest and were about to violate his church. The victory of Father Savinov depicts the tale of a priest bearing a cross during a battle in the Kamchatka campaign and attributes the victory to his intervention. The caption explains that the priest appeared at the moment of a fierce counterattack of the enemy and "raising the cross and singing the troparion 'The Glory of God is with Us,' inspired the troops to victory." Turkish atrocities are shown to result from their Islamic religion, while the Russians' victory is ensured by their Orthodox faith. Orthodoxy is thus incorporated into the struggle, but without the suggestion of a holy war, as would be the case during the Russo-Turkish war of 1876-77.47 It is the defense of homeland and faith, not the struggle against the infidel, that was at stake.

The triumphalist bravado of the propaganda was punctured by the fall of Sevastopol, the major Russian fortress on the Black Sea, at the cost of thousands of lives. The events of 1812 had inflicted a wound to the Russian national psyche, the invader sweeping through Russia and seizing Moscow. Only Borodino provided heroic redemption, though with colossal losses. The wound of 1855 was to the image of Russia as an empire united in defense of the homeland. Alexander Herzen wrote that the landing of foreign troops in Crimea was perceived as a threat to Russian territory, arousing fears that they would advance into the heartland of Russia, which necessitated a defense

\footnotetext{
$46 \quad$ Ibid., 31.

47 Norris, $A$ War of Images, 57-63.
} 
of Russia itself, "saving the wholeness, tselost' (integrity) of the state." 48 Tolstoy's Sevastopol Sketches revealed the horrible suffering and deaths at the scene, the social divisions that emptied the heroic bravado of patriotic meaning for those who were truly heroic, calling into question the unity of the Russian people. "The hero of my tale," Tolstoy wrote in the last lines of one of his sketches, "is Truth."

Even after the fall of Sevastopol, Alexander II remained captive of Nicholas's triumphalist scenario. In September and October 1855, he traveled to Moscow, New Russia, and Crimea. He clearly understood his visit to Moscow as a repeat of Alexander I's in July, 1812. He wrote to General Mikhail Gorchakov, who was commanding troops in the Crimea, "Two years after the Moscow fire our victorious troops were in Paris. We are the same Russians and God is with us!" He sent Gorchakov the icon of St. Sergei carried by the Moscow militia in 1812. Severnaia pchela reported that in Moscow, "where the Russian element is even denser," the feeling of vengeance was even stronger than in St. Petersburg. The correspondent explained how Alexander prayed at the Iberian Chapel, not for himself but for Russia. People of all estates, many of them in Russian costume, swarmed around the tsar, giving him their support. Alexander took the displays of popular enthusiasm as a sign of support for himself and the dynasty. ${ }^{49}$

Despite the seemingly hopeless situation in Crimea and Austria's warning to enter on the side of the England and France, he determined to fight on. His visit to the armies in the Crimea only strengthened this resolve. He helped to formulate campaign plans and expected that disorders among the French lower classes would force France to withdraw from the conflict. At first, he confidently rejected terms proposed by the allies. It was only after Austria issued an ultimatum and even Prussia hinted at intervention that Alexander relented and sued for peace. ${ }^{50}$

At this point, the scenario of invincible union of triumphal monarch and devoted people collapsed, and Alexander, abashed by the terms of the Peace of Paris, began to display humility, broke with his father's narrative

48 Tartakovskii, 1812 god i russkaia memuaristika, 230; on the concept of tselost' see my article "The 'Integrity' (tselost') of the State in Imperial Russian Representation," in Ab Imperio, No. 2 (2011): 20-45. Article 11 in Russian Monarchy: Representation and Rule.

49 See Scenarios of Power, 2: 25.

50 Ibid., 2: 25-6. 
and performed his own scenario, one of mutual love and gratitude between tsar and people. He opened the regime to talk of reform, and demonstrated his generosity to his people, who, he expected would respond with gratitude. He thus perpetuated the official nationality myth, but now on the basis of mutual devotion and sacrifice, rather than reverent submission.

The relaxation of the censorship and the talk of reform permitted the emergence of a popular discourse on 1812. The representation of 1812 as the awakening of a sense of national consciousness apart from the state appeared in educated society, expressed most powerfully in the writings of Alexander Herzen in London. Herzen elaborated a civic tradition, exemplified by the Decembrists and the circles of young intellectuals of the 1840s, the remarkable generation who represented the seeds of a new Russia. For educated society, the misery of war and the suffering of the common soldiers captured by Tolstoy's Sevastopol Sketches, and Ilarion Prianishnikov's "The Year 1812," painted in 1873, a grim realist answer to the merry lubki of 1812.

\section{The Consecration of the Cathedral of THE RedeEmer AND THe Centenary of 1912}

After the Crimean defeat, the memory of 1812 figured little in official presentations. In 1862, the Holy Synod issued a decree barring military ceremonies to commemorate victories other than the battle of Poltava, declaring that those "held significance only for their own times." 51 The field of Borodino fell into neglect until 1885, when Alexander III conducted large-scale maneuvers to mark the battle and ordered repair of many of the monuments. 52

The last official celebration of 1812 in the nineteenth century took place at the consecration of the Christ the Redeemer Church after Alexander III's coronation on May 26, 1883, the Feast of the Ascension. The consecration

51 In 1864, in the wake of the crushing of the Polish rebellion of 1863, Alexander II did stage a parade of the Petersburg guards' regiments in the capital to mark the fiftieth anniversary of the taking of Paris. But Moscow journalists covering the event, while remarking upon Alexander I's role as savior of nations, remarked that the parade glorified only the emperor without taking into account the participation of the Russian people in the struggle against Napoleon (Maiorova, From the Shadow of the Empire, 223, n.86, 114-16).

52 S. A. Malyshkin, "Iz istorii muzeefikatsii Borodinskogo polia, 1839-1911," in Borodinskoe pole: istoriia, kul'tura, ekologiia, 172-3. 
had been intended for the late 1870s, but had been postponed due to the revolutionary movement. The ceremonies recalled 1812 but now presented it less in terms of glorious military triumph, and more of relief at the defeat of the revolutionary movement: the feat of Alexander III, pictured as an ethnic Russian tsar, reflected the force and spirituality of the Russian people. It was an expression of civic peace, as the Russian tsar showed himself in union with the Russian people, represented by the Orthodox Church. ${ }^{53}$

The imperial manifesto on the dedication of the cathedral incorporated the triumph of 1812 into the new national myth evoking an ancient union of tsar and people. In the words of his mentor, Constantine Pobedonostsev, Alexander III had fulfilled Alexander I's vow to build a cathedral as an expression of thanksgiving to God for the salvation of the fatherland. The consecration of the church in the midst of Russians gathered for the coronation attested to "how holy and fast is the centuries old union of love and faith tying the Monarchs of Russia with the loyal people." The monument was to "merciful Divine Providence for Our beloved Fatherland, a monument to peace in the midst of painful trial after cruel combat, undertaken by the humble and pious Alexander (the First) not for conquest, but for the defense of the Fatherland against the foe." 54

Bearing miracle icons, the clergy moved from various churches to the Kremlin and then to the Cathedral of Christ the Redeemer. The processions enacted a succession from the Assumption Cathedral, ancient but miniscule, to the immense and ornate new edifice that could hold nearly 10,000 worshipers and the cupolas of which were visible across Moscow. The succession between churches established the spiritual continuity between Muscovy and Imperial Russia proclaimed in the new national myth.

The clergy then arrayed themselves around the cathedral, the priest of each church facing the building before the gonfalons. At ten, the emperor, wearing a general's uniform and mounted on a white horse, followed by the imperial family in a carriage, made his way from the Kremlin palace to the cathedral.

53 E. I Kirichenko and A. M. Denisov, Khram Kbrista Spasitelia v Moskve: Istoriia proektirovniia i sozdaniia sobora; Stranitsy zhizni, gibeli i vozrozhdeniia, 1813-1997 (Moscow: Planeta, 1997), 140-3.

54 V. Komarov, $V$ pamiat' sviashchennago koronovaniia Gosudaria Imperatora Aleksandra III i Gosudaryni Imperatritsy Marii Fedorovny (St. Petersburg: V. V. Komarov, 1883), 445-6; Polnoe Sobranie Zakonov Rossiiskoi Imperii, Sobranie 3: No. 1602, May 26, 1883. 
The bands along the way played "God Save the Tsar!" other military music, and Tchaikovsky's "1812 Overture," to the accompaniment of cannon salvos and clouds of smoke. It was a ceremony of merger and inclusion, the Muscovite past with the huge revival Cathedral, the military glory of 1812 with the faithful Orthodox Church hierarchy, a statement of the solidarity of a regime threatened within and without.

After the sanctification of the altar, the imperial family, the suite, high officials, and foreign guests joined the clergy in the first procession of the cross around the cathedral, which completed the consecration. The procession moved between the lines of the clergy and the standards of the regiments participating in the event. To the strains of the hymn "Kol' slaven" and the ringing of church bells, the artillery launched into a salvo that continued throughout the procession. As one account observed, the music, the parade, and the cannons recalled that "a cathedral was being consecrated that had been erected in memory of the glorious deeds of the Russian army." 55

The procession then returned to the cathedral for the holding of its first mass. At the conclusion, the emperor kissed the cross, whereupon Bishop Ambrosii of Kharkov declaimed a speech emphasizing that Alexander III had completed the work of his forbears, "who sowed that others may reap." With the coronation, the bishop concluded, Alexander took up his labor of caring for the fate of "the great Russian people." Then, addressing the empress, he characterized the emperor in terms of his scenario, as a tsar at one with his laboring subjects. "The tiller of the soil, working in the field, weary and needing replenishing of his force awaits his food from his home, from his wife: may Your love, with all the treasures of the loving heart, be the bread replenishing the forces of the Most August Toiler of Your Russian land (Avgusteishii Truzhenik zemli Russkoi Tvoei)." 56

Peter Il'ich Tchaikovsky's 1812 Overture, commissioned for the occasion, presented the war against Napoleon in the triumphalist spirit of the resurgent autocracy. Tchaikovsky juxtaposed two national anthems that were not in use in 1812. The rousing, triumphal cadences of "God, Save the Tsar," composed in 1834, play against the fanfares of the Marseillaise, which Napoleon had banned as "a summons to rebellion." Tchaikovsky himself initially had contempt for a work that he had put together in less than a week and considered

55 Komarov, V pamiat' sviashchennago... Aleksandra III, 436-41.

56 Ibid., 441-4. 
"very loud and noisy." 57 Like the Redeemer Cathedral, which he also disliked, it was an eclectic combination of disparate motifs. At the same time, the medley of an Orthodox hymn, tropar', a Russian folk dance, and "God Save the Tsar" in tribute to the memory of 1812 , lifted it into an legendary patriotic space, where faith, nationality, and authority were conjoined in a melodic union that transcended social and intellectual differences and the terrible losses that accompanied 1812 and Russia's later wars.

The final tsarist celebration of 1812, the Borodino centenary of August 1912, took place in a different political and symbolic context. Along with the Poltava bicentenary in 1909 and the tercentenary of the Romanov Dynasty in 1913, it figured as Russia's entry into the rivalry of European monarchs displaying enthusiastic popular consensuses for their regimes. To display the grandeur of the setting and the significance of the event, the government undertook a major transformation of the battlefield. Nicholas I may have constructed the first battlefield museum in history, but decades of neglect had left a sprawling derelict landscape of forest and swamp. A new road provided access to the field. Redoubts and fleches were repaired, dozens of monuments built to mark the location of the position of the regiments. ${ }^{58}$ Of the thirtythree monuments we see on the field today, all but a few arose to celebrate the centenary.

Nicholas II did not seek consensus. Rather, the centenary proved to be an episode in the ongoing political struggle that would culminate in 1917. As I have argued, Russia lacked a legal tradition of dynastic succession, obliging each ruler to justify his power by the representation of heroic acts of transcendence for the defense, expansion, and welfare of the fatherland. 59 The great historical events celebrated the triumph of the dynasty, Poltava and Borodino, and the election of Michael Romanov in 1913. In the aftermath

57 Alexander Poznansky, Tchaikovsky: The Quest for the Inner Man (New York: Schirmer, 1991), 380; Anthony Holden, Tchaikovsky: A Biography (New York: Bantam, 1995), 203-5.

58 G. N. Ul'ianova, "Natsional'nye torzhestva," in Rossiia v nachale XXogo veka: issledovaniia, ed. A. N. Sakharov (Moscow: Novyi Khronograf, 2002), 552-4.

59 See Article 2 in Russian Monarchy: Representation and Rule, or "The Representation of Dynasty and the "Fundamental Laws" in the Evolution of Russian Monarchy," Kritika vol. 13, No. 2 (Spring 2012): 265-300. 
of the revolution of 1905, Nicholas and Alexandra performed the ultimate dynastic scenario in a replica of a seventeenth century village at Peterhof. He envisioned himself as a tsar with divine mandate enjoying a spiritual bond with the masses and leading a recrudescence of Russian monarchy, reenacting its resurgence like the early Romanovs after the Time of Troubles.

Rather than seeking to mobilize consensus, the Borodino Centenary followed a narrative of exclusion, displaying the tsar's personal bond with the peasantry and banishing the elements of the new political classes. The names of the deputies of the Duma were omitted from the guest list on the field of Borodino where the ceremonies took place: Only the chairmen of the Duma and of the State Council could attend. To deepen the insult, members of the half-appointive State Council received invitations to the subsequent events in Moscow, but not the deputies of the Duma. In response, Mikhail Rodzianko, the Chairman of the Duma and a chamberlain of His Majesty's Court, left the celebration after the dedication of a monument and boycotted the Moscow celebrations. ${ }^{60}$

The symbolic continuity of the monarchy of 1812, the sharing in a triumphal union of emperor, state, and the estates, evoked in previous celebrations, now was replaced by an effort to establish association by descent. Evocations of images of Nicholas's and the celebrants' forbears presented him, the army, and people as descendants of the participants in the battle of Borodino, blessed by the Orthodox Church and led by his forefather, Alexander I, whose glory now redounded upon him. The regimental monuments erected across the field honored the ancestors of the members of the regiments.

On August 22, he chatted with several old men who he was told had participated in the events. One of them claimed to be 122 years old. Nicholas wrote to his mother, "Just imagine to be able to speak to a man who remembers everything, describes details of the action, indicates the place where he was wounded etc., etc.! I told them to stand next to us at the tent during the prayer service and watched them. They all were able to kneel with the help of their

60 Rodzianko explained his absence to the the Minister of Interior, Kokovtsev, and the Master of Ceremonies Baron Korff. According to Rodzianko, the latter replied "Members of the Duma do not enjoy the right of access to the Court." Rodzianko retorted, "This is not a Court, but a national celebration. Besides, Russia was saved, not by masters of ceremonies, but by her people" (M. V. Rodzianko, The Reign of Rasputin: An Empire's Collapse [London: A. M. Phillpot, 1927], 65-6). 
canes and then stood up!" Vladimir Dzhunkovskii, the governor of Moscow, described meeting with the old soldiers on August 22 and recalled that they remembered little about the battle, but were accorded special treatment. They rode about in carriages and received the best accommodations and places at the ceremony. One even described Napoleon, as a "fine fellow" with a "beard down to his waist"61 (Figure 8).

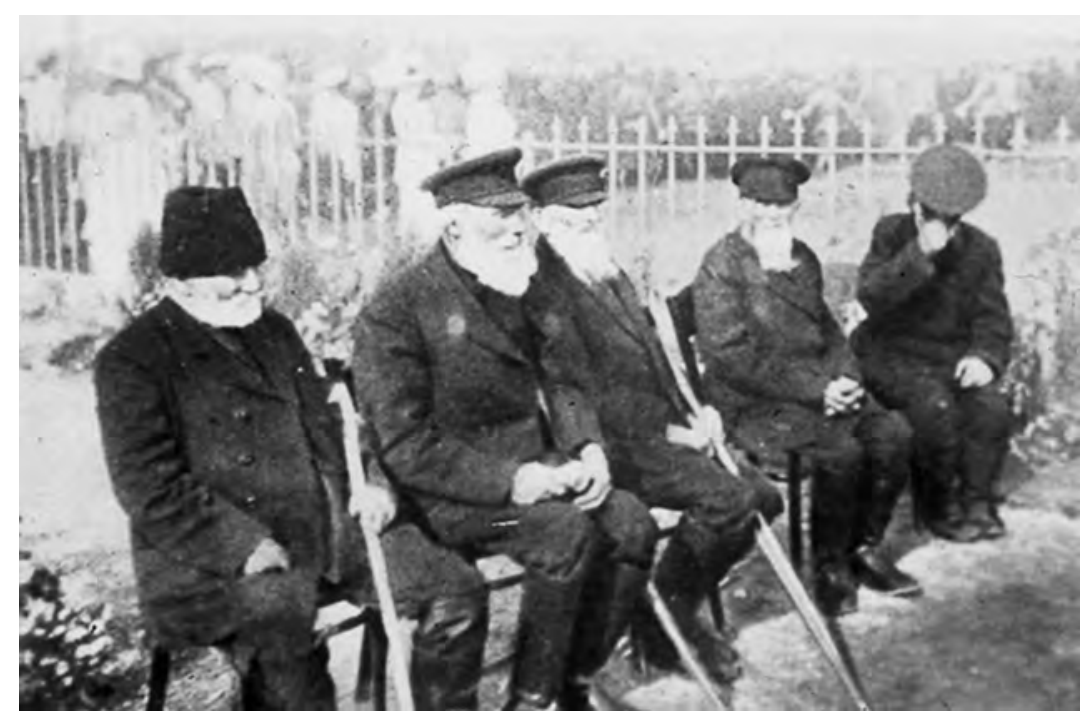

Figure 8- "Veterans of 1812" at the Borodino Centennial. L'Illustration.

On August 25, Nicholas joined a procession of the cross, which had borne the icon of the Smolensk Mother of God that had blessed Kutuzov's army all the way from Smolensk to Borodino, a distance of more than 140 miles. He did not look like a commander: his father had never promoted him to general and he wore the uniform of an officer of the Horse-Guards regiment, a unit that had distinguished itself at Borodino. To the strains of the hymn "Kol' Slaven," he met the procession and followed it to the Campaign Chapel of Alexander I for a prayer service (Figure 9). Then the icon was carried past the lines that extended nearly three miles of those units whose predecessors had fought at Borodino, reenacting a ceremony of 1812 .

61 V. F. Dzhunkovskii, Vospominaniia (Moscow: Izd. Im Sabashnikovyhkh, 1997), 2: 19; Ul'ianova, "Natsional'nye torzhestva," 553-4. 


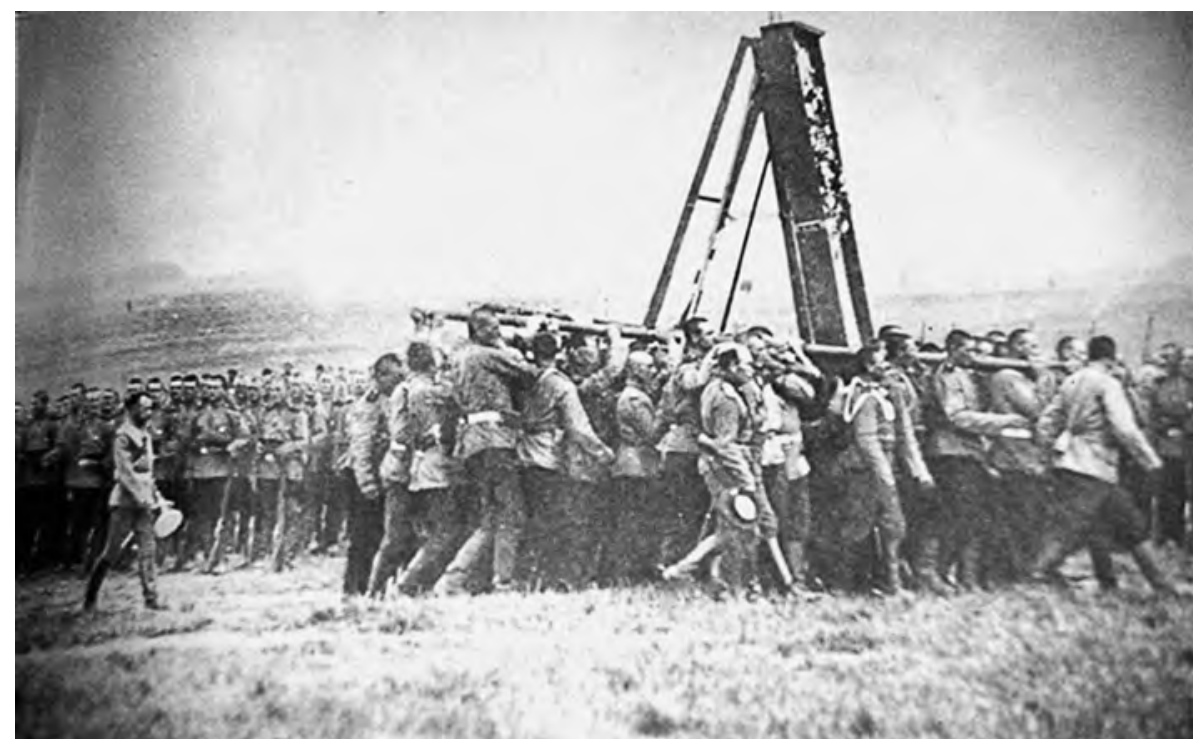

Figure 9-Nicholas II following Procession of the Cross at the Borodino Centennial, August 25, 1912. L'Illustration.

On August 26, the anniversary of the battle, Nicholas addressed 4,550 peasant elders, identifying them with their forbears' feats of heroism. He spoke to them of the battle "where your grandfathers and great-grandfathers fought against the courageous foe and defended the native land with the help of faith in God, devotion to the Tsar and Love for the Native land." 62 The elders represented the peasantry as a whole for Nicholas. The monarchist newspaper Moskovskie vedomosti predicted that their memories of the event would "meet a warm response in all villages and hamlets where they will be transmitted by the fortunate participants in the Borodino festivities."

Liberal opinion did not fail to note that ceremonies focusing on the monarch, the army, the church, and official delegates from the peasantry left out the Russian nation. The centenary did not enjoy the assumptions of the totalizing myth that had informed earlier celebrations. The identification of the sovereign with the state had been thrown into doubt by Alexander III, who asserted the principle of personal rule, a national autocracy centered in the

62 "Dnevnik Nikolaia II," (August 25, 1912- May 6, 1913), GARF, 601-1-259, 3-4; Dzhunkovskii, Vospominaniia, 2: 35-36; Niva, September 8, 1912, 722-3; Moskovskie vedomosti, September 8, 1912, 2. 
Ministry of Interior, obedient to his will and unencumbered by rule and law. Nicholas had extended this distrust to all the institutions of the Russian state, a tendency that became even more pronounced after the creation of the Duma, and extended to the educated elements in Russian society. By this time, a broad swathe of the educated population had come to regard the nation in terms of a Russian state representing the people and 1812 as a struggle of the Russian people, not merely the tsar and his armies. This view was elaborated in an article written by an Ufa school teacher, V. Efremov, entitled "Why is the War of 1812 Called the War for the Fatherland?" which appeared in a brochure, Love for the Fatherland: the Source of National Strength. The united people and the fatherland were the two main components of Russian nationality for Efremov; the emperor was in the background. It was not only the army but "the entire people who defended the freedom, independence and unity of their land." At this time, "the native inhabitants of the Russian state felt immediately that they were Russian, that they formed one people who were ready to sacrifice all for the good of their fatherland." The union was not only between tsar and people but "the close union of all estates" for the purpose of attaining the general welfare." 63 The 1912 centenary put on display not the devotion of the people to the dynasty and the person of the tsar that Nicholas I and his interlocutors had proclaimed but the great chasm between the tsar and his visions and the wishes of the vast majority of the Russian people he claimed the title to rule.

63 V. Efremov, "Otchego voina 1812 goda nazyvaetsia 'Otechestvennoi'?" in V. Efremov and P. D. Zhukov, Liubov' k otechestvu: istochnik sily narodnoi (Ufa, 1912), 11, 20-21. I thank Charles Steinwedel for providing me with a copy of this brochure. 


\section{8. "Glas naroda": Visual Representations of Russian Monarchy in the Era of Emancipation}

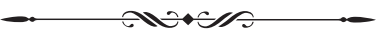

In the months following the emancipation of the serfs in February, 1861, there appeared a number of unusual visual representations of the Russian monarchs, popular prints, lubki, celebrating the emancipation and the dedication of Monument to the Millennium in Novgorod. The lubki were meant to mark the beginning of an era of good feeling and progress to begin with the emancipation of the serfs. Pictures and sculpture expressed the vision of a renewed autocracy united with the Russian people and educated society by bonds of mutual loyalty and devotion and engaged in a common effort to advance Russia along the path of economic and intellectual progress. The vision was also a reaffirmation of the dominant myth of transcendence and dominance that ensured the supremacy of the imperial will-the scenario or contemporary enactment of the myth that elevated the present ruler as the central figure, the hero in a drama of transformation and progress.

Art, as well as rhetoric, sought to reconcile these two divergent goals, intimacy and distance. The iconography of the monarch in the eighteenth and early nineteenth century sought to distance him from the everyday and the people-to project him into what I will refer to as "heroic space," where prodigies of beauty, achievement, and power were wrought. The monarch appeared as warrior, as legislator, as figure in Arcadia, as bearer of the regalia of Russian monarchy. In the first half of the nineteenth century, the relationship between monarch and people required different forms of representation. Responding to the ideas of nationality and popular sovereignty, ceremony and official art were employed to bring the people into the picture, to give the sense of the inclusiveness of monarchy. This tendency 
reached its culmination during the era of emancipation, when official art strove to depict the warm rapport that presumably existed between the emperor and the Russian people.

The word lubok refers to popular prints, originally produced by wood blocks or later copper plates that became widespread in the late eighteenth and early nineteenth centuries. ${ }^{1}$ Lubki were printed on individual sheets that appealed to the common people. Their subject matter varied-religious figures, folklore heroes from byliny, conquerors like Alexander the Great and Ermak, popular generals, as well as satirical and moral tales. ${ }^{2}$ The term also has been used, correctly or incorrectly, to describe pictures produced commercially from more sophisticated techniques, including lithography. All of these works employed simplified forms, techniques partly borrowed from icon painting, partly from primitive folk art. They ostensibly reflected a folk spirit, though some scholars argue that the increasing influence of commercialization and formal art deprived later lubki of their popular character and force. In any case, all of these works strove to produce the effect of the wood-block pictures - to capture the folk spirit and imagination. Iurii Lotman pointed out the playful, theatrical nature of lubok art, viewing it as an aspect of carnival and festival, involving the active participation of the viewer. ${ }^{3}$ M. A. Alekseeva also observed the heroic side of lubok art, which produced a mood of "epic festivity, joyous tranquility" (nastroenie epicheskoi prazdnichnosti, radostnogo spokoistviia). In a world without perspective and

1 On the meanings and development of lubok prints, see M. A. Alekseeva, "Russkaia narodnaia kartinka: Nekotorye osobennosti khudozhesvennogo iavleniia," in Narodnaia kartinka XVII-XIX vekov: materialy $i$ issledovaniia, ed. M. A. Alekseeva and E. A. Mishina (St. Petersburg: Dmitrii Bulanin, 1996), 3-14; E. A. Mishina “Terminy 'lubok'i 'narodnaia kartinka' (k voprosu o proiskhozhdenii i upotreblenii)," in idem, 15-28.

2 For a concise summary of the production and reception of lubok prints in the nineteenth century as well as their dominant themes, see Jeffrey Brooks, When Russia Learned to Read: Literacy and Popular Literature, 1861-1867 (Princeton: Princeton University Press, 1985), 62-7.

3 Iu. Lotman, "Khudozhestvennaia priroda russkikh narodnykh kartinok," in Narodnaia graviura i fol'klor $v$ Rossii XVII-XIX vv. (Moscow: Sov. khudozhnik, 1976), 227-47; See also B. M. Sokolov, Khudozhestvennyi iazyk russkogo lubka (Moscow: Russian Humanities University, 1999). 
great detail, figures were depicted as wondrous or grotesque, and their size was a measure of their greatness, prowess, and standing. ${ }^{4}$

In the eighteenth century, lubki were held in contempt as a lower form of art in official circles, though Catherine the Great circulated several occasionally, for example, to ridicule monks and Old Believers. In the first years of Alexander I's reign, lubki spread knowledge of the horrors of smallpox. ${ }^{5}$ The use by the government of lubki as a means to arouse patriotic sentiment among the people and to represent the emperor as a leader began with Napoleon's invasion in 1812. Prints by formally trained artists, namely Ivan Terebenev, Ivan Ivanov, and Aleksei Venetsianov, borrowed techniques of the lubki to characterize peasants and others routing Napoleon and his troops and subjecting them to comic indignities (See Article 7). ${ }^{6}$

After the victory, popular prints were used, for the first time, to glorify the emperor as heroic leader of the struggle (See Article 7). These prints borrowed several features of the lubok, the standardized characterization of the soldiers, the simplified features of the chief figures. But, retaining perspective and elements of classical iconography, they did not seek to imitate lubok artistic style and composition. A. K. Sakovich described such pictures as "political graphics" (politicheskaia grafika), executed by professional artists. It was a Russian counterpart to European broadsides, "an eclectic pseudo-popular style of pictures for the people," rather than work by the people themselves. These pictures did not breach the emperor's heroic space. Alexander is shown commanding his guardsmen, or flanked by the triumphal leaders led by allegorical figures below. He tolerated expressions of nation and popular support only under the duress of the invasion, and the people did not figure in the scene. At the same time the market in lubki continued to flourish, the subject matter of folk tales and saints' lives remaining dominant without intruding into delicate political matters.

\footnotetext{
$4 \quad$ Alekseeva, "Russkaia narodnaia kartinka," 10.

5 Dmitrii Rovinskii, Russkie narodnye kartinki, vol. 2 (St. Petersburg: R. Golike, 1900), 489-90.

6 See Article 7 and Stephen M. Norris, A War of Images: Russian Popular Prints, Wartime Culture, and National Identity, 1812-1945 (De Kalb, IL: Northern Illinois University Press, 2006), 11-35.

7 A. G. Sakovich, "Moskovskaia narodnaia graviura vtoroi poloviny XIX veka (K probleme krizisa zhanra)," in Narodnaia kartinka XVII-XIX vekov: materialy i issledovania, 139.
} 
This state of equilibrium, however, did not continue through the reign of his successor, his brother Nicholas I. Under the threat of revolution, Nicholas sought a redefinition of the relationship between monarch and people, emphasizing the close national and popular roots of the autocracy. Russian monarchy was presented as the expression of the wishes of a historically obedient and devoted Russian people. The lubki, which had been largely ignored and produced and distributed freely, now represented a sphere of independent and unconstrained creativity that clashed with the presumably monarchist spirit of the population. A decree of 1839 introduced censorship for all prints and print books. The widespread availability of wood blocks and copper plates, however, made it difficult to control the production of $l u b k i$, and during the reaction to the revolution of 1848 , the government instituted more vigorous measures to curb them. The minister of education, Platon Shirinskii-Shikhmatov deplored the "harmful influence... on educated village inhabitants" of lubki, which "quite often concern subjects of spiritual matters." He particularly feared lubki produced by Old Believer communities. The result was a law of January 2, 1851 that codified the rules about the lubki, recommended the destruction of previously existing plates, and placed the production of new ones under government supervision. For the great historian and collector of lubki, Dmitrii Rovinskii, 1839 represented the end of the independent production of folk pictures (narodnye kartinki), and he concluded his massive work on the subject with that year. ${ }^{8}$ Indeed, the policy drove many of the independent cottage artisans out of business and promoted the concentration of the lubok trade in Moscow, where publishing entrepreneurs adopted the new process of lithography. Stephen Norris has shown how the publishing companies reached a modus vivendi with the government, producing lubki of a patriotic character and avoiding serious clashes with the censors. ${ }^{9}$

Popular prints of the emperor began to appear, appropriating the artistic idiom of the lubki and seeking to capture their spirit of the fantastic and otherworldly. They certainly can be described as political graphics, but I shall continue to follow the conventional usage and refer to them as lubki. They depict Nicholas I in various poses during the Danube campaign. One lubok

8 Alekseeva; "Russkaia narodnaia kartinka," 7; Rovinskii, Russkie narodnye kartinki, vol. 1, 82; Norris, $A$ War of Images, 44-8.

9 Norris, $A$ War of Images, 48-50 (54-79.) 
portrays him at the bivouac near a campfire with his suite at his side. In the background, there are other tents and campfires. Nicholas stands in a pose of implacable fortitude, a counterpart of Napoleon, while an adjutant salutes. Others show him reviewing positions with his suite. We see him standing in a boat, his arm outstretched, rowed across the Danube by ten Zaporozhets Cossacks who had just gone over to the Russians. The exaggeration gives him the proportions of a giant, dwarfing the row of the Cossacks' heads, and dominating the landscape in the rear (Figure 1). He carries the allure of the bogatyr', towering over the subjects who have recognized his suzerainty and ascendancy. ${ }^{10}$

Lubki also served to convey the image of the imperial family as symbol of the moral preeminence of the imperial family. ${ }^{11}$ They depicted the heir, Alexander Nikolaevich, striking various poses. He is shown in military uniform at his mother's side, near a bust of Alexander I, proudly holding a rifle, on horseback alone. Lubki published in the first years of Alexander II's reign reproduced the images of the imperial family. The heir, Nicholas Aleksandrovich, joins his father with other Grand Dukes on horseback (Figure 2). He stands with the emperor and the empress in the presence of the regalia after the coronation (Figure 3). Alexander, the empress Maria Aleksandrovna, and the heir, the Grand Duke Nicholas Aleksandrovich pose, framed by a proscenium, which reinforces the sense of distance between viewer and the figures in the scene. The faces are not likenesses, but conventional characterizations, distinguished by particular features, such as Alexander II's mustache. ${ }^{12}$

The lubki of the first years of Alexander II's reign preserved the heroic space of the monarchy, displaying hierarchy and presenting guards regiments in legendary form: the emphasis is on uniformity and order, strict, stiff, and

$\overline{10}$ Stoletie Voennogo Ministerstva: Imperatorskaia glavnaia kvartira; istoriia gosudarevoi svity; tsarstvovanie Imperatora Nikolaia I (St. Petersburg: M. O. Vol'f, 1908), 250-1, 261, 264.

11 See my article "The Imperial Family as Symbol," in Imperial Russia: New Histories for the Empire, ed. Jane Burbank and David L. Ransel (Bloomington, IN: Indiana University Press, 1998), 60-86. Article 5 in Russian Monarchy: Representation and Rule.

12 Imperatorskaia glavnaia kvartira; istoriia gosudarevoi svity; tsarstvovanie Imperatora Aleksandra II (St. Petersburg: R. Golike and A. Vil'borg, 1914), 12, 13, 16, 29, opp. 32; Stoletie Voennogo Ministerstva ... tsarstvovanie Nikolaia I, 217; GARF-678-1027. 


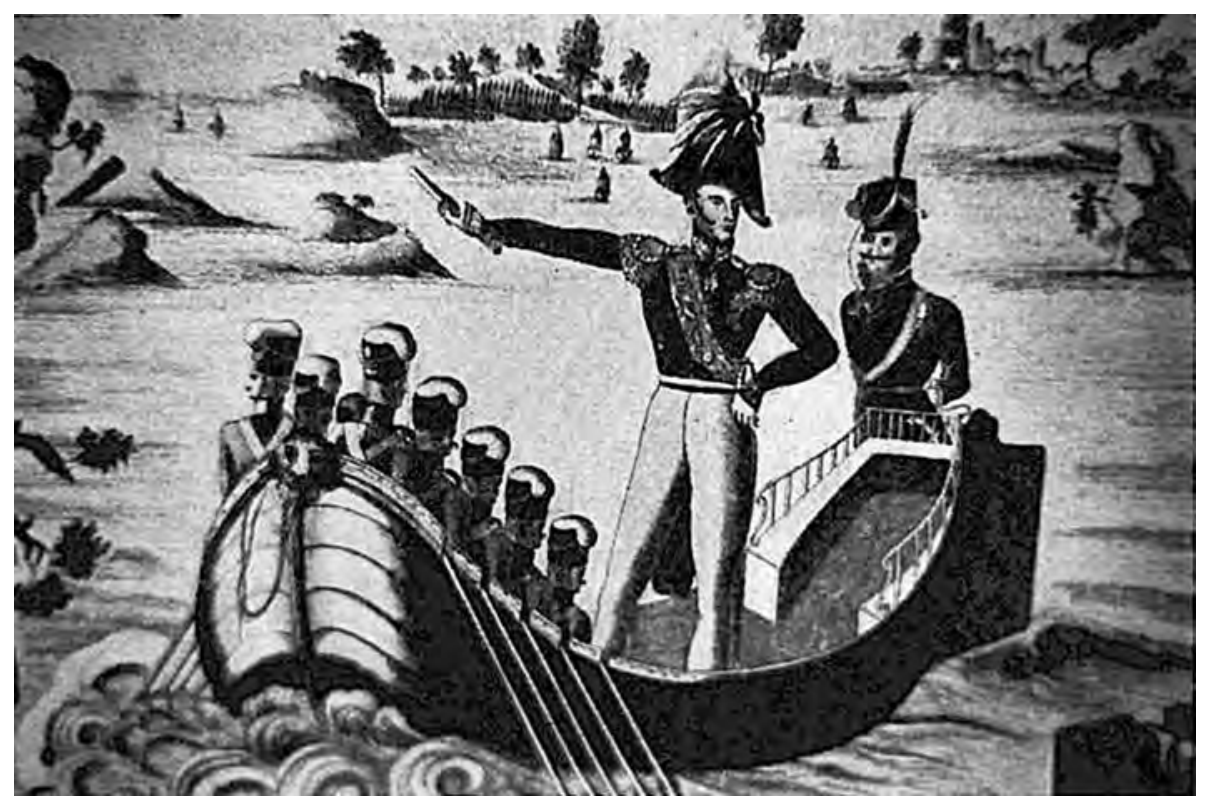

Figure 1-Nicholas I Crossing the Danube. Stoletie Voennogo Ministerstva: Imperatorskaia glavnaia kvartira; istoriia gosudarevoi svity; tsarstvovanie Imperatora Nikolaia I (St. Petersburg: Voennoe Ministerstvo, 1908).

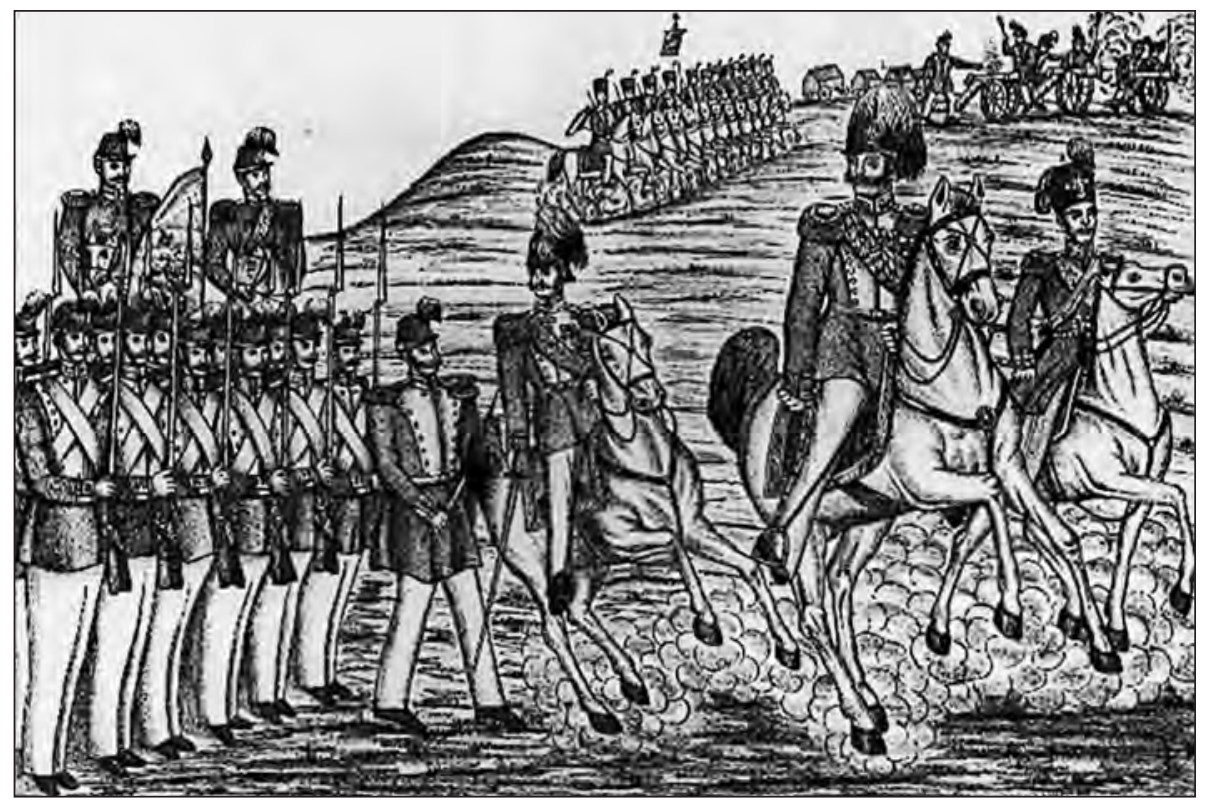

Figure 2-Alexander II followed by Grand Dukes Nicholas Aleksandrovich and Alexander Aleksandrovich. RNB, Print Division. 


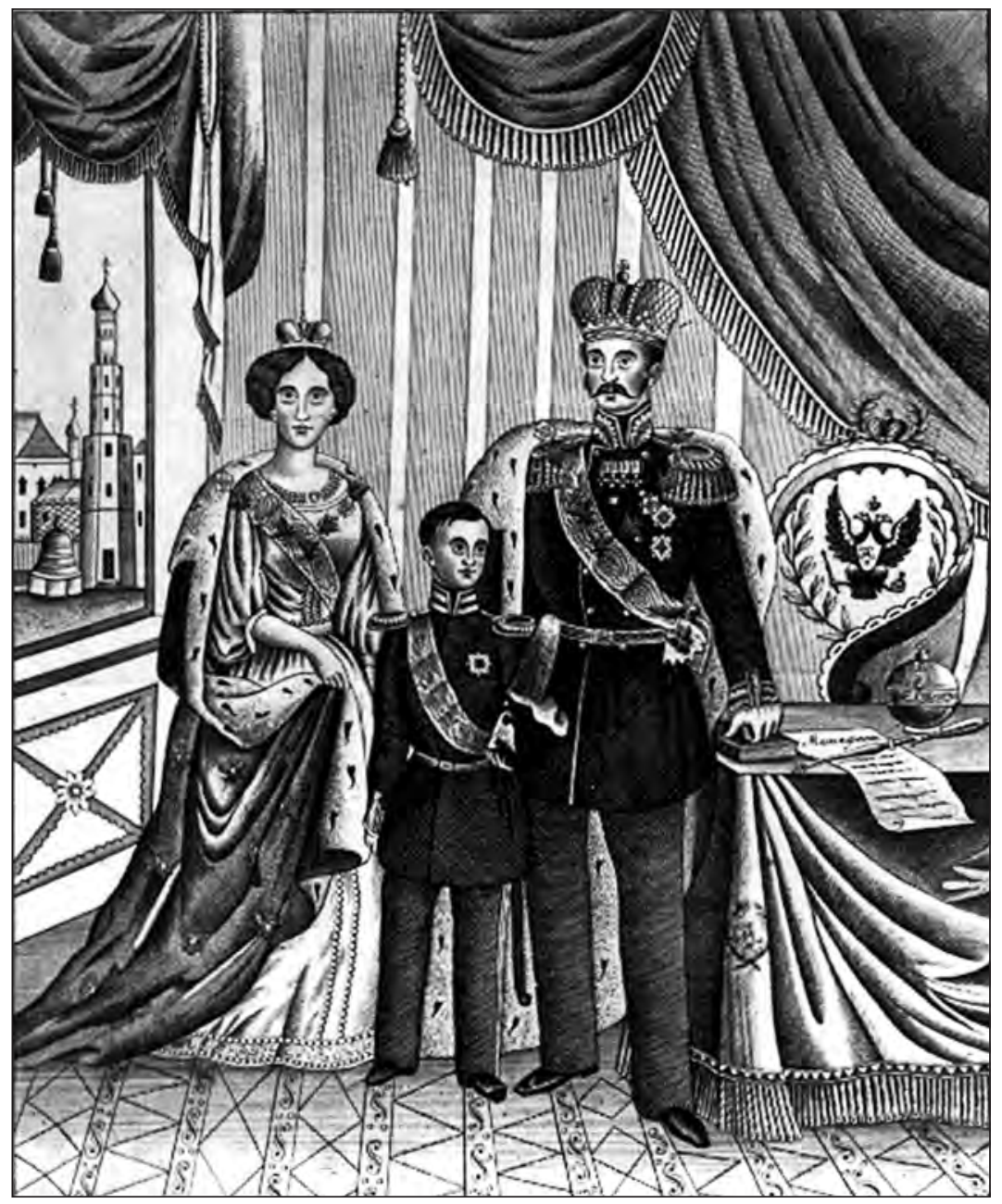

Figure 3-Alexander II, Maria Aleksandrovna, and Grand Duke Nicholas Aleksandrovich. GARF. 
unquestioned. Alexander II shared his father's view that the Russian people were distinguished by a historical devotion to the autocracy. In the aftermath of the Crimean War and era of reform, lubki sought to display a bond with the people, but without suggesting proximity to them. Alexander presented the bond with the people as one more of affection than of awed obedience, a reciprocal affection, shown by the benefactions bestowed on the people by their ruler, which elicited ardent expressions of their gratitude and love. This variant of the Russian monarchical myth was represented in what I have described as a scenario of love-ceremonial demonstrations of the feelings that prompted the emperor to bestow reforms on the people, with the expectation that they would respond to his largesse with gratitude and renewed affection. ${ }^{13}$

It was this expectation of a reciprocity of feeling that enabled Alexander to venture on changes to the social system with a confidence that it would not challenge his prerogatives as absolute monarch or the symbolic distance between ruler and ruled. The fiction that the nobility voluntarily undertook to free their serfs enabled Alexander to include them in their scenario and lent the emancipation a personal and moral, rather than legal character. The fiction dramatized the emancipation as the selfless initiative of the nobility to free their serfs, which the peasants would greet with shows of gratitude to them and the tsar. Feelings of gratitude presumably would prevail over their widespread disappointment with the terms of the emancipation. The Emancipation Manifesto of February 17, 1861, written by the Metropolitan Filaret of Moscow, praised the emancipation as the realization of the tsar's oath "to embrace with our tsarist love and care all our loyal subjects, of every calling and condition, from the noble wielding the sword in defense of the fatherland to the humble person working with the tool of his trade, from one reaching high state service to the person making a furrow on the field with his sokha or plough." On February 17, the Holy Synod despatched a secret circular to rural priests, also the work of Filaret, to summon the peasants to resolve their individual misunderstandings with the landlords "by legal means" and "to instruct their parishioners as much in piety as in good deeds, in both moral and civic relations." 14

Although the announcement of emancipation was met with skepticism and disappointment among the peasantry in many parts of Russia, the Ministry of Interior issued descriptions of peasants gathering to express their joy and

13 See Scenarios of Power, 2: 19-57.

14 P. A. Zaionchkovskii, Otmena krepostnogo prava (Moscow: Prosveshchenie, 1968), 156. 
gratitude. At the instance of the Minister Peter Valuev, the ministry began publishing Severnaia pochta, a newspaper designed to influence public opinion patterned on the French, Moniteur Universel. Its pages evoked the image of a grateful peasantry, adoring of their tsar. The peasants responded with simple, touching prayers: "Attentive eyes could note how great was the love of the tsar in the simple hearts of the people, expressed powerfully in one elegant prayer." 15

The Ministry's rhetoric emphasized the feeling of reciprocity, which was a principal theme of the ceremonies of thanksgiving staged for the emperor in Petersburg and Moscow. Workers, legally still classified as peasants, made up most of the audience. The first took place before the Winter Palace one week after the issuing of the manifesto. Alexander, on his way to his weekly review of the guards, met a crowd of chosen peasants and workers on the Palace Square. A delegation of specially designated artisans and factory workers presented him with bread and salt. Alexander asked them whether they understood what he had done for their "general welfare." They answered obediently, "We thank your imperial majesty with feeling for your great deeds by which you have renewed our life." Alexander replied, "This task had already been started by my parent, but he did not succeed in finishing it during his lifetime." He urged them to thank God and pray for Nicholas's eternal memory, then called upon them to be useful for the well-being of society.

A similar meeting was organized in Moscow in May. A delegation of factory workers approached Alexander with the traditional bread and salt and declared their gratitude. He described the scene and his feelings in a letter to the heir, Nicholas Aleksandrovich. "Nearly four thousand of them gathered and when I went out before them in the courtyard before the palace they fell to their knees and responded to a few words with unceasing hoorahs." When the empress appeared on the balcony, there were more hoorahs. "You understand that it is impossible to look upon such scenes coolly, and inside I thanked God with all my heart for the consolation and reward for our cares." 16 Many of those close to the tsar shared his feelings. Dmitrii Miliutin, then an adjutant-general and assistant minister of war shared Alexander's feelings. "The sensitivity and authenticity of the enthusiasm shown to the Tsar in Moscow, particularly among the common peoples leaves no doubt, though the incorrigible defenders

15 Severnaia pochta, September 16, 1862: 805, September 19, 1862: 813, September 22, 1862: 829.

16 GARF, 665-1-13, 26 (Letter of May 21, 1861). 
of serfdom assure us that all the manifestations of enthusiasm were prepared by the authorities. By the testimony of eyewitnesses that is definitely untrue." A friend wrote to him that "the bringing of bread and salt was the idea of the peasants themselves, not prompted by anyone."17

The visual representations depicting these expressions of mutual love and gratitude sought to publicize these feelings and to generalize them as the response of the Russian people as a whole to emancipation. They appeared over the names of the leading print entrepreneurs of Moscow, Peter Sharapov, A. V. Morozov, and D. A. Rudnev, and all bore the names of the supervising censors. Though I have found no indication of specific directives from the authorities, the entrepreneurs, as Norris suggested, were quite responsive to the wishes of the monarchy, and the depictions of popular love were very much in keeping with official rhetoric. ${ }^{18}$

To depict the love of tsar and people a single frame posed a serious iconographical problem for the artist: how were reciprocal feelings between tsar and people to be depicted without violating the heroic space that had expressed the tsar's distance and supremacy in pictures and statuary? The distinguished art historian E. I. Kirichenko discovered the first such attempt, which signaled a transition to a new iconography-Vasilii Demut-Malinovskii's statue of the peasant Ivan Susanin in Kostroma, which was completed in $1851^{19}$ (Figure 4). Susanin, rendered realistically, kneels in reverence at the base of a long column, upon which rests a neoclassical bust of Tsar Michael Fedorovich. The two figures are not of the same universe. They are separated by distance-the column - and style-the realistic figure of a peasant and the idealized countenance of the tsar. One is the worshipper on earth; the other the worshipped in the heavens.

A second precedent is suggested by the illustrations in Alexander II's coronation album, which sought to incorporate the audience, responding with joy and enthusiasm, into the rites and festivities of the court. The plate

17 D. A. Miliutin, Vospominaniia general-fel'dmarshala grafa Dmitria Alekseevicha Miliutina, 1860-1862, ed. L. G. Zakharova (Moscow: Studiia “TRITE” Nikity Mikhalkova, 1999), 104-5.

18 Norris, $A$ War of Images, 48-53.

19 E. I. Kirichenko, Zapechatlennaia istoriia Rossii (Moscow: Zhiraf, 2001), 2: 279-80. 
PART II. THE IMPERIAL MYTH IN ARTISTIC TEXTS

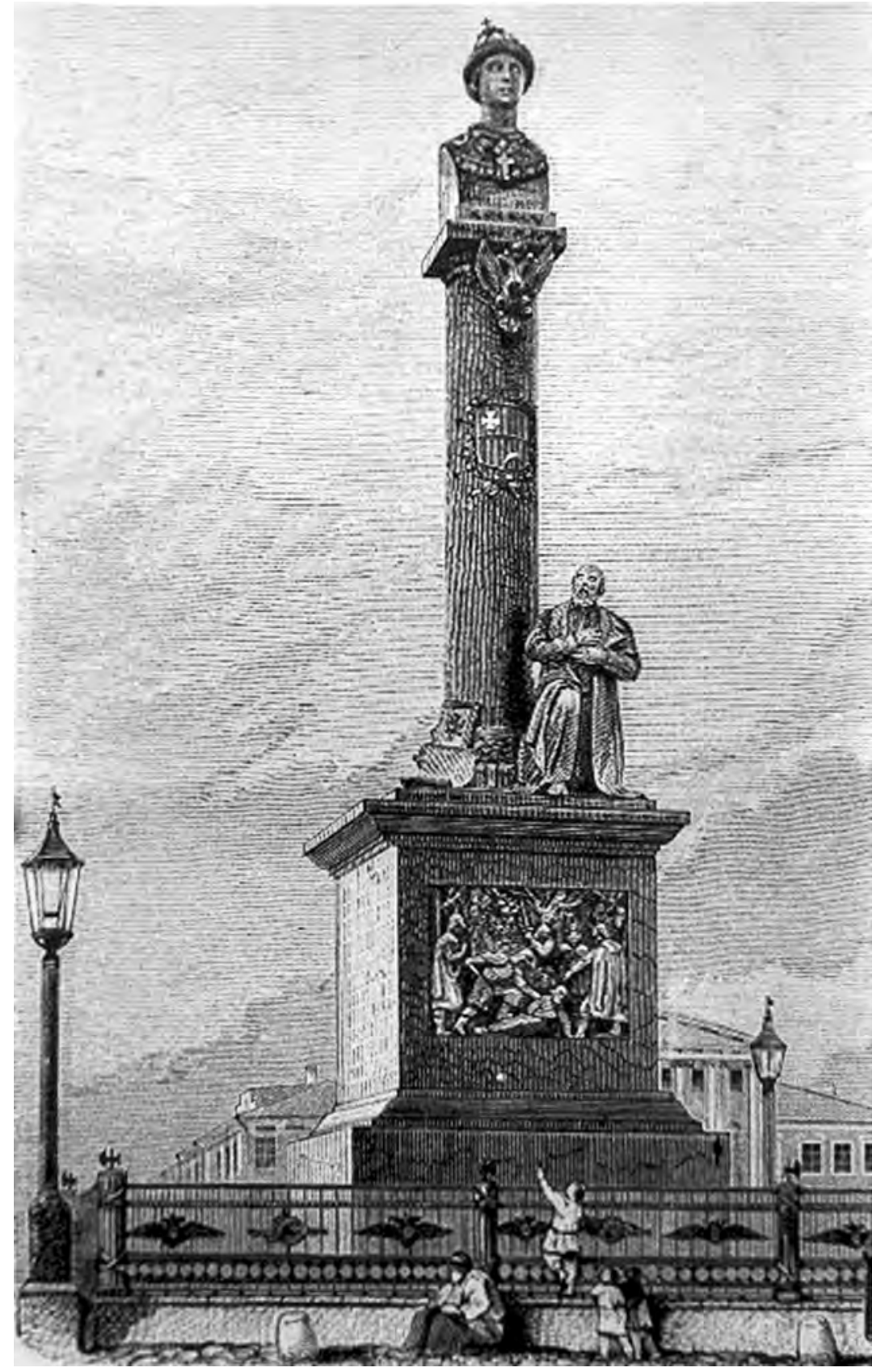

Figure 4-Vasilii Demut-Malinovskii-Ivan Susanin Monument, Kostroma. Vsemirnaia illiustratsiia, No. 2, 1883. 
by the court artist M. A. Zichy of the entry procession to Moscow gives a vivid rendering of the ecstatic welcome of the tsar and the court by the populace (Figure 5). Both educated society and the people are encompassed in the frame. Famous writers, among them Fedor Tiutchev and Ivan Turgenev, welcome him from the grandstand. In the foreground of the scene, a peasant woman in folk dress and a tiara hat faces the tsar, and a man raises his arms in greeting.

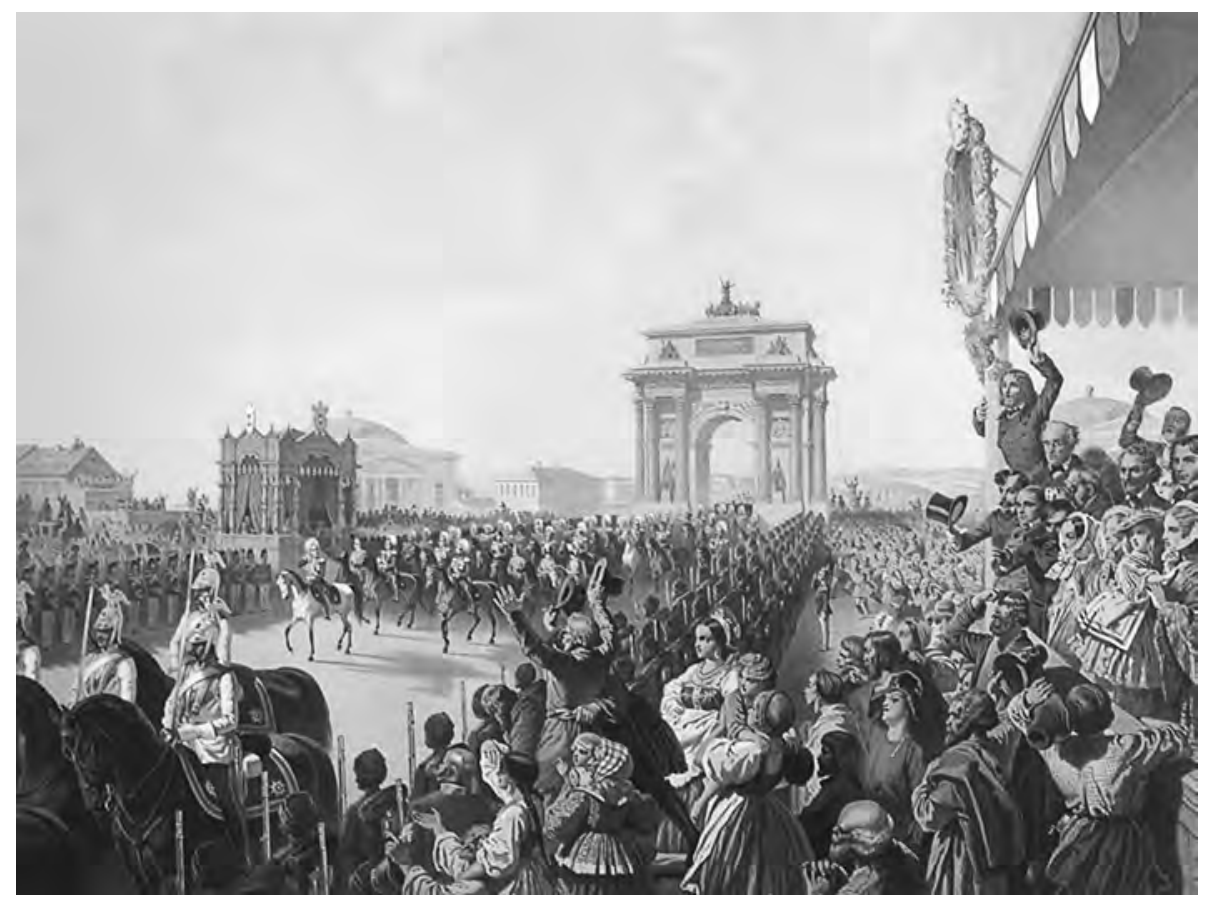

Figure 5-M. A. Zichy-Alexander II's Coronation Entry into Moscow. Alexander II Coronation Album. Opisanie sviashchenneishago koronovaniia ... imperatora Aleksandra Vtorago i imperatritsy Marii Aleksandrovny usei Rossii.

Both the statue and the watercolor preserve the distance between tsar and people, allowing the display of devotion without encroaching on heroic space. The lubki of emancipation preserve heroic space in two ways: rendering the figures of emperor and people in different artistic idioms, and placing them on different planes. First, the tsar appears as an image, a picture in a picture, and therefore not of the ordinary world; further, this image is set above the peasants, who look up at it devoutly. An example of this type of composite, Vasilii Timm's lithograph, "The Emancipation of the Peasants," in Russkii 
khudozhestvennyi listok (Figure 6), makes this relationship explicit, showing a peasant rendered realistically, crossing himself before icons beneath a portrait of Alexander II with the words "February 19, 1861."20

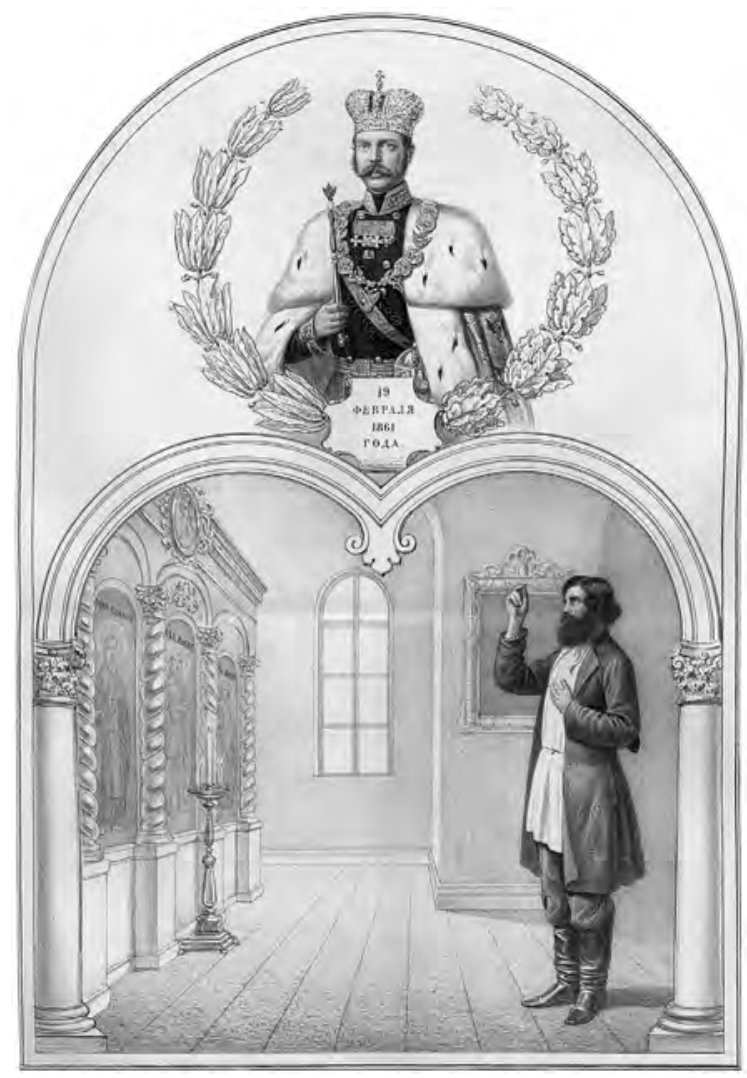

Figure 6-Vasilii Timm- "The Emancipation of the Peasants." Russkii kbudozhestvennyi listok, 1862.

Timm's lithograph is not in lubok style, but the lubki utilize the same devices. "The Voice of the Russian People" (Glas ruskogo naroda) shows the response of the people (Figure 7). The people stand before a raised portrait of Tsar Alexander again in full regalia, but rendered in a simplified lubok manner. The stylized identical peasants gaze upon him with amazement and reverence. The caption places the expected words in peasants' mouths: "We all

$\overline{20}$ Russkii khudozhestvennyi listok, No. 28, September 20, 1862, 108-9. 


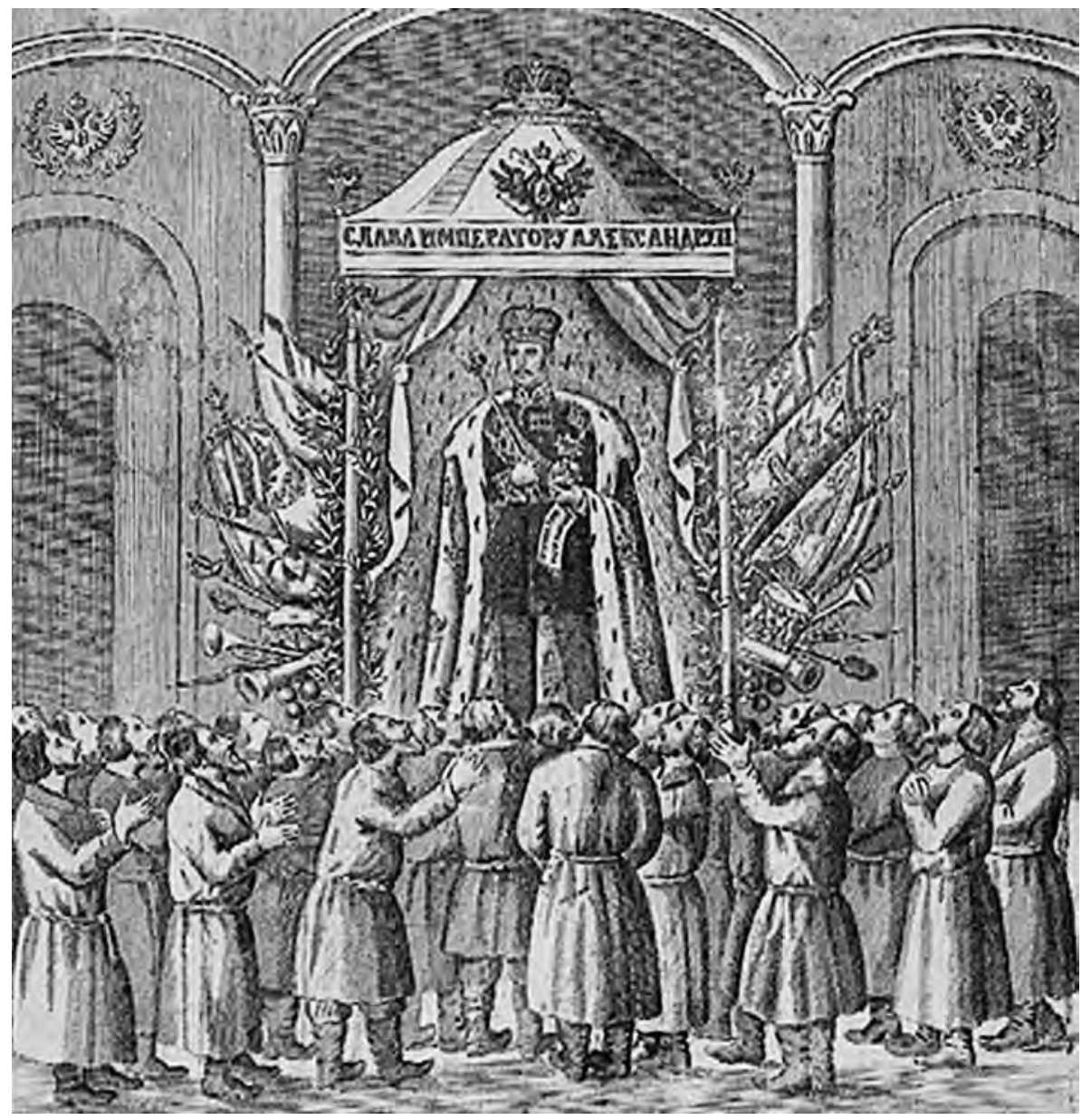

Figure 7- "The Voice of the Russian People." New York Public Library, Miriam and Ira Wallach Division of Arts, Prints, and Photographs. 
appeared before the TSAR, Burning with ardent love for him, Well fellows, it is time, it is time Together, and quite soon, we will shout Hoorah!" The lubok "The Unforgettable day of February 19" (Nezabvennyi den' 19 fevalia 1861 goda) (Figure 8) presents a figure of the tsar on the platform. The tsar appears not as an image in an image, but as the tsar himself. He is shown as an intermediary in the hierarchy between the people and Christ, raising his hands in a blessing. The people fall to their knees worshipping him as they worship Christ. ${ }^{21}$ At Alexander's right are military symbols, on his left other signs of culture and enlightenment, and a scroll with the words "law and justice." The peasant men kneel below, some holding their hands in prayer. The verses below again express the expected feelings of gratitude and devotion. They say that they kneel to praise their "blessed Father" (Otets blagoslovennyi). They call upon him to see their "tears of tenderness" and their joy. "You, our powerful Ruler, have given us a new life."

Two lubki were issued of Alexander's meeting with Moscow workers. Depicting an actual event, they can no longer show the tsar as an image in the midst of the people. Now his figure is brought into the context of the lubok. Distance is expressed by differences of height, dress, and bearing. In the lubok entitled "The Presentation of Bread and Salt to the Tsar and Emperor by Peasants, Factory Workers, and Artisans, about 10,000 Persons” (Figure 9), the emperor stands in guards uniform, towering over the peasants and workers, his face solemn and austere, an expression of strength and authority. The empress looks down on the people from her balcony, more realistic in style, but also more remote. The peasants are lower, kneeling except for their "elected leaders" (vybornye) presenting the bread and salt. They are rendered in conventional lubok form with identical features, except for the starosta, Zakharov. In the second version, "The Solemn Presentation of Bread and Salt" (Torzhestvennoe Podnesenie Khleba-Soli) (Figure 10), the workers kneel humbly while their leaders face the emperor and heir. Both emperor and heir stand stiffly impassive in the lubok style, wearing guards' uniforms, apart from and taller than the workers. The empress, whose figure is suggested in the upper left of the picture, views the scene with a rather detached expression. ${ }^{22}$

The lubki of 1861 were literal realizations of the feelings expressed in the statements and the ceremonies comprised in Alexander II's scenario of love.

$21 \quad$ GARF, 678-1-1027.

22 GARF, 678-1-1027. 


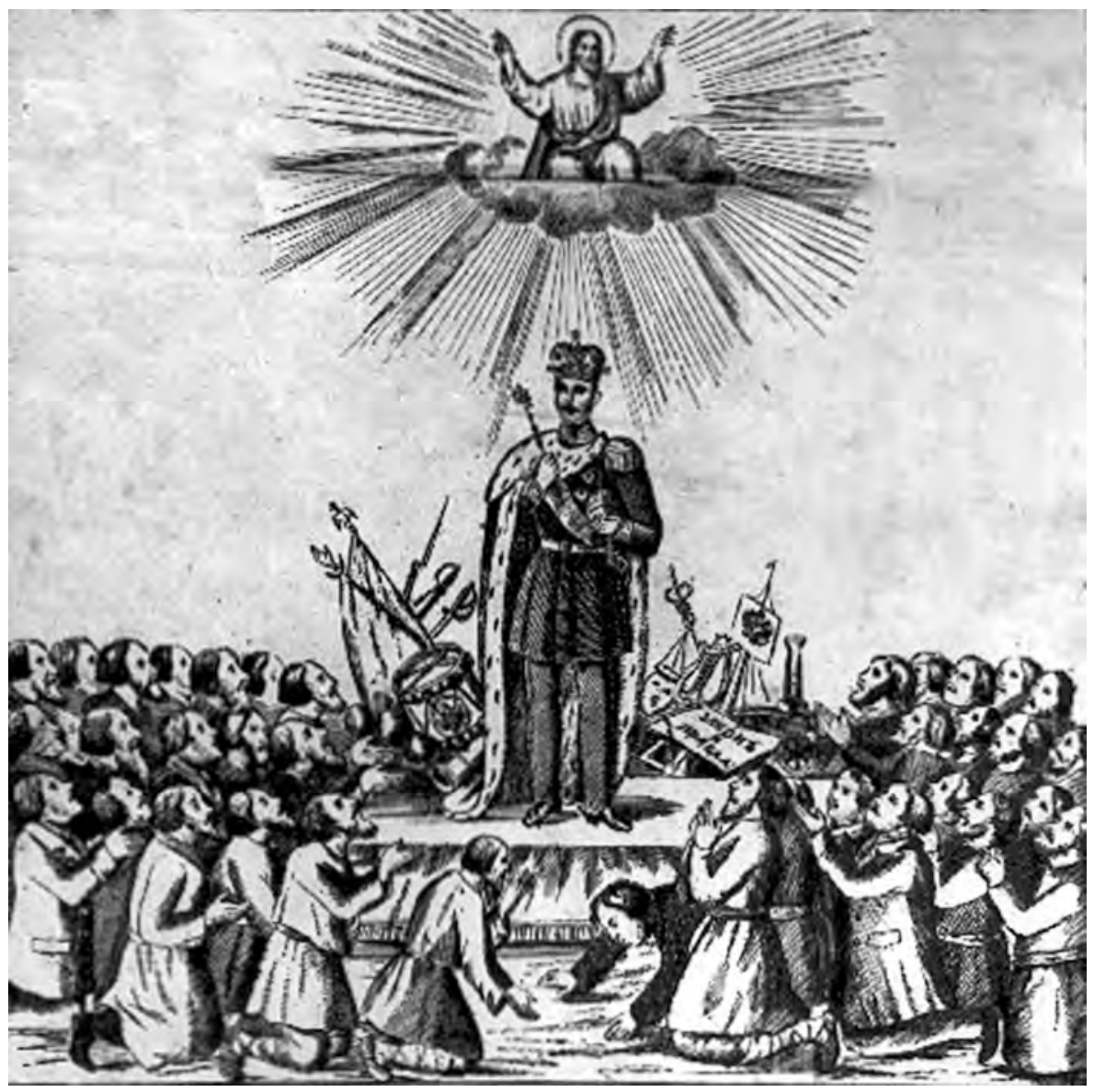

Figure 8-"The Unforgettable Day of February 19, 1861." GARF. 


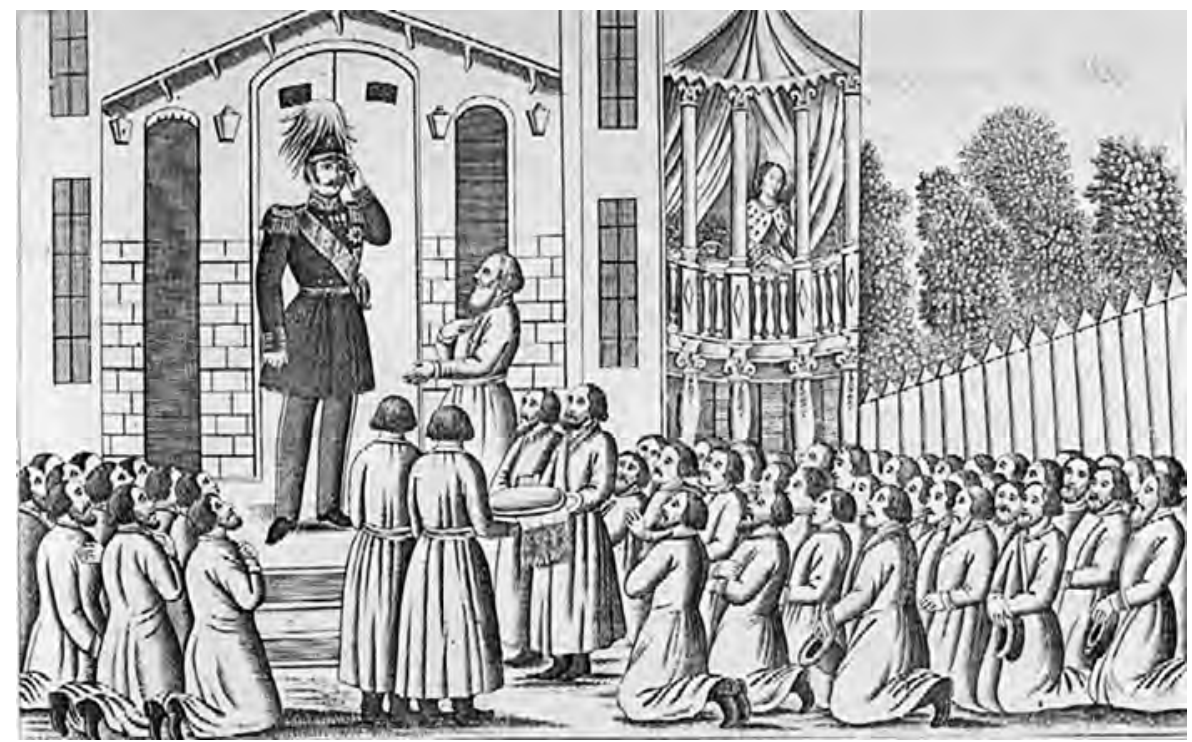

Figure 9- "The Presentation of Bread and Salt to the Tsar." New York Public Library, Miriam and Ira Wallach Division of Arts, Prints, and Photographs.

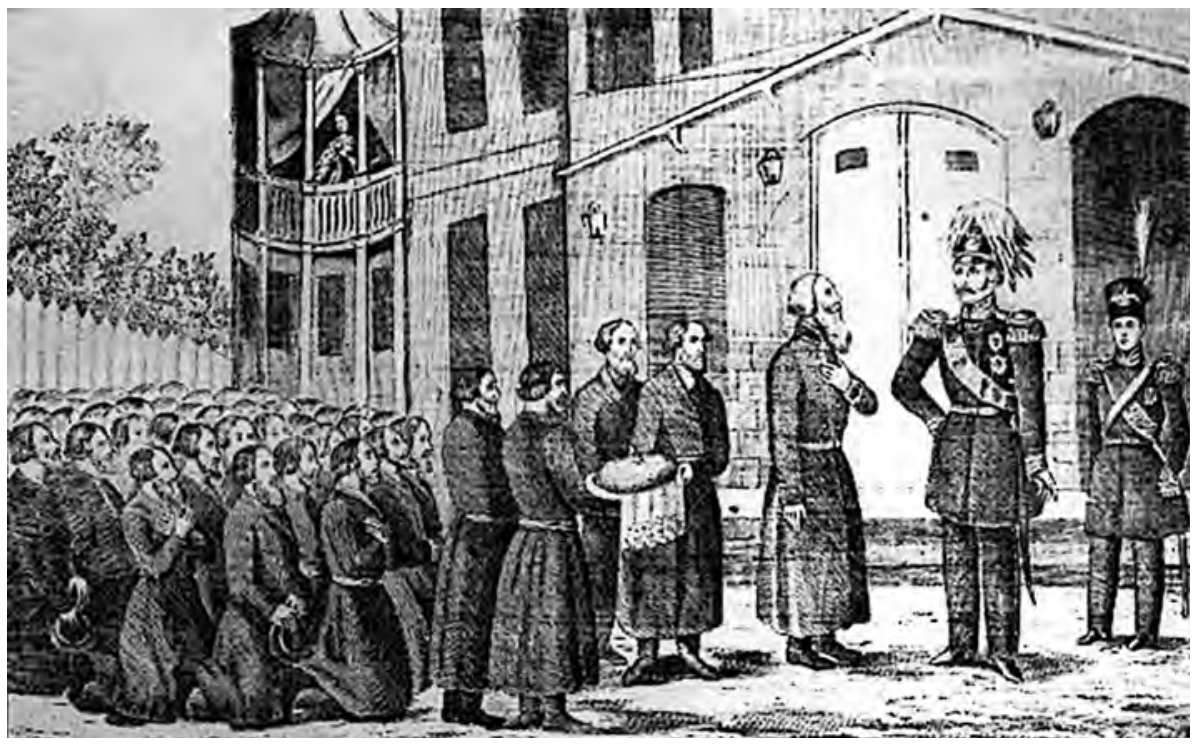

Figure 10_ “The Solemn Presentation (torzhestvennoe podnesenie) of Bread and Salt to the Tsar." GARF. 
The words of the captions repeated official notions of the peasants' appropriate responses. The artists brought tsar and people in the same frame, but kept them apart. The people appear as simple, folk-type images, of obedience and reverence. The ruler remains in his own heroic space, either in the form of "the portrait of the king," or in the rigid, aloof poses attached to figures of authority in the lubok. The renderings give no sense of unity, rather making obvious the incongruity and the artificiality of the composite. The feelings of benevolence and gratitude could not conceal the great distance between sovereign and subject intrinsic to the imagery of Russian monarchy that could be obscured in flights of sentimental rhetoric characteristic of the scenario of love.

The Monument to the Millennium of Rus' in the Novgorod Kremlin and its dedication ceremonies on September 8, 1862 were also meant to convey the sense of an affective unity between the emperor and the Russian people. Alexander took an active part in the preparations and decisions about the monument and the celebration. The monument and the celebration marked the progress of the Russian state under leadership of its monarchs from the date of the legendary founding of Rus', in 862, when the leaders of Novgorod issued an "invitation" to the Varangians come and rule over them and establish order in their land.

The monument was explicitly intended to present not only the monarchs who ruled Russia but the Russian nation as a whole, a unity of all Russians in the march of progress. The initial plans had been merely for a statue of Riurik, which would have expressed the theme of the official nationalitythe Russian people beholden to and devoted to their foreign rulers. But in 1857, the Committee of Ministers decided to build, a "a national (narodnyi) monument to the MILLENNIUM of the Russian state." The terms also specified that the monument clearly depict Orthodoxy "as the principal basis of the moral grandeur of the Russian people." It was to commemorate six principal events of the Russian past: the founding of Rus' in 862, with the figure of Riurik; the conversion of Prince Vladimir, 989; the battle of Kulikovo in 1380; the founding of the unified Russian state by Ivan III; the election of Michael Romanov in 1613; and the reform of Russia and founding of the empire by Peter the Great in $1721 .^{23}$

23 E. N. Maslova, Pamiatnik “Tysiacheletiiu Rossii” (Leningrad: Lenizdat, 1977), 14-17. 
The official description of the monument, written by P. N. Petrov, defined progress as the central force uniting the tsar and people. The monument would reflect the common dedication to progress-"those feelings that the Russian people always shared and will share, in the present case with His Majesty." The winning project interpreted the requirements literally (Figure 11). The painter M. O. Mikeshin won the competition because his design reproduced the six scenes requested by the Committee and provided a pictorial synopsis of the Russian past showing the ruling house as the builders of the Russian state. Mikeshin gave the statue the general shape of a bell. The upper section, above the six scenes, was in the form of an orb, the symbol of monarchical rule. Above the orb, the figure of an angel held a cross, showing the primacy of, and according to Petrov's account, indicating the providential character of the Russian past. The angel blesses an allegorical figure of Russia, and "points to her glorious future under the protection of orthodoxy." 24

The succession of episodes showing the progress of the Russian state, the ensemble of historical scenes blurs the vast differences of the parts of the empire and the sharp discontinuities of Russia's past. Riurik and Vladimir face south to Kiev, Donskoi to the southwest, the Tatar frontier, Ivan III east to Moscow, Minin and Pozharskii to the west against the Polish threat. Peter the Great faces north to Petersburg. He is shown stepping forward into the future; behind him an angel points the way. The monument thus presents a continuous development from the ninth century to the present; shifts of capital, cultural style, and political orientation were encompassed in an overall political unity. The harmonizing of disparity is exemplified by the form of the bell, which could represent either the Novgorod bell, a sign of the town's freedoms until the fifteenth century, or the great Tsar-bell, a sign of central domination by the prince of Moscow. ${ }^{25}$

The theme of the ineluctable progress of the Russian state held great appeal for governmental officials. The Minister of Interior, Peter Valuev, who attended the dedication ceremonies, particularly liked the figures of Riurik and Peter the Great, who he imagined foresaw and created the greatness of Russia. Riurik seemed tranquil and still, to be looking into the distance, and from the distance.

$\overline{24}$ Ibid., 23-9; P. N. Petrov, Pamiatnik tysiacheletiiu gosudarstva rossiiskogo v Novgorode (St. Petersburg: Tip. II Otd. Sobstvennoi E.I.V. Kantseliarii, 1862).

25 See Buslaev's sardonic observations on this ambiguity: Fedor Buslaev, Moi dosugi: sobrannyiia iz periodicheskikh isdanii, melkiia sochineniia Fedora Buslaeva (Moscow: Synod Press, 1886), 2: 208. 


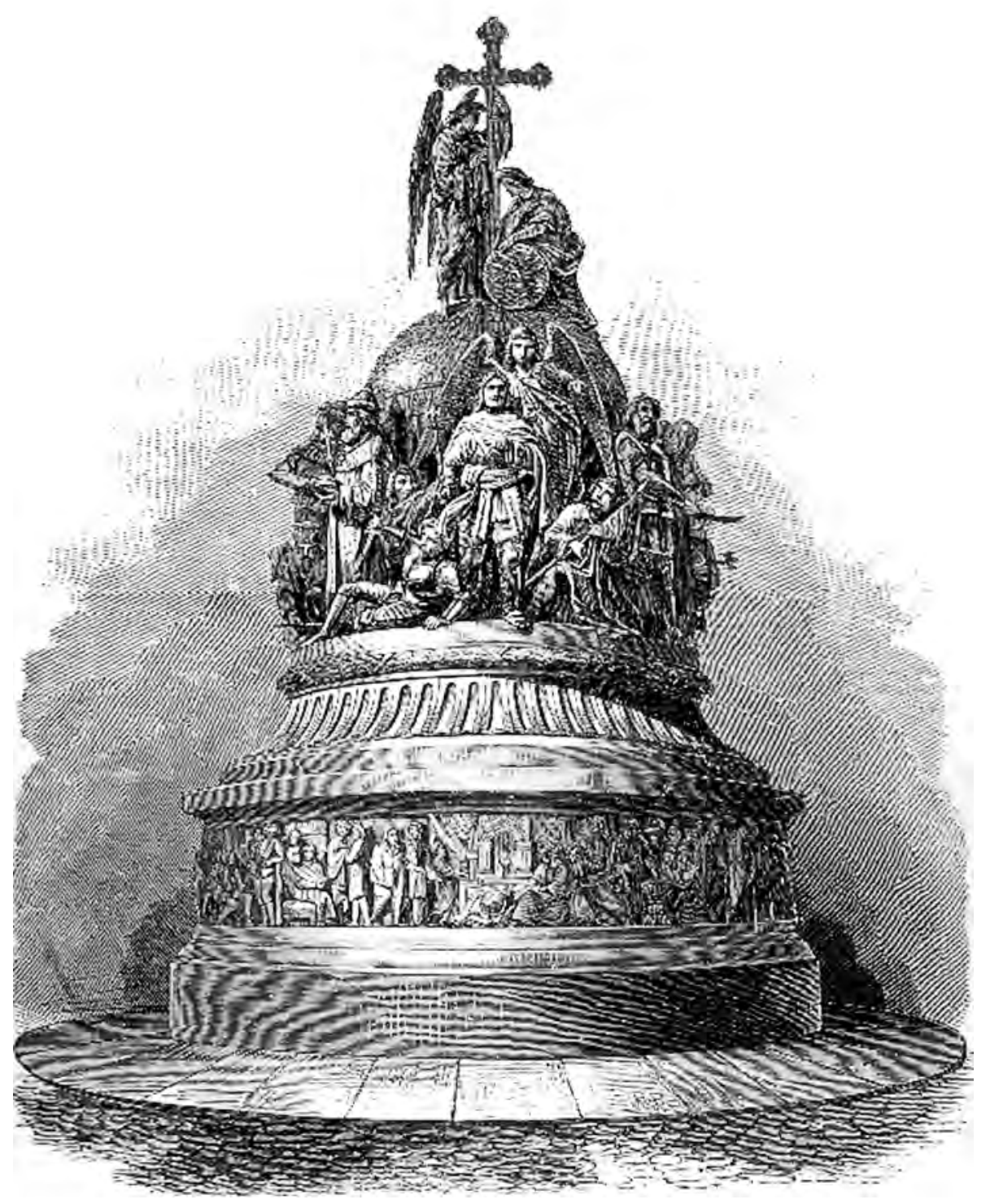

Figure 11-M.O. Mikeshin-Monument to Millennium of Russia, Novgorod. Niva, 1872. 
"Centuries are before him. He personifies the inception, in the cloudy depths of these centuries, of the Rus' that was destined slowly to develop, strengthen, solidify, and expand before Peter." Peter on the other hand was in movement, scepter in hand, representing the triumph of Riurik's vision. He personified "the renewed, transformed Russia, finally subduing her neighbors and together with Peter submissively stepping out onto the terrain of universal history." 26

Like the lubki, the statue distinguishes between heroic and ordinary figures by placing them on different planes, rendering them in different sizes and in different idioms. The grandiloquent poses struck by the almost identical figures sculpted by Shreder give the statue something of the contrived, legendary manner of the lubok; it was no accident that Mikeshin was a painter. The heroes are large and burley; they seem to be in movement. But the statue was supposed to be inclusive and to depict ordinary mortals along with the rulers as part of a Russian nation. All those who contributed to the progress of the Russian state were to appear on the statue, including figures from educated society. If the bond between the emperor and the peasants was shown by pictures of rapt deference of peasants for the tsar, the bond with educated society took the form of the inclusion of "leading figures of the Russian land" (deiateli russkoi zemli) on the bas-relief circling the monument. Among them were writers, composers, artists, and scientists, as well as military leaders, officials, and saints, and Ivan Susanin, the only peasant.

The bas-relief is narrow, and the number of creative figures accounted for only sixteen of one-hundred and nine individuals represented. The space allotted to them beneath the monumental statues of the great rulers is limited, almost grudging. Crowded into one segment of the relief, they serve as minor embellishments to the main narrative, the heroic struggles and achievements of Russian monarchs, who continued to represent the Russian nation. The pretense of representing the nation, moreover, prompted sharp criticisms about why the nation had received such niggardly attention. Writers of a Slavophile persuasion insisted that the Russian people, not the Russian state, represented the nation, and that the monument did not reflect their spirit or desires. When a lithograph of the monument appeared in the official calendar, the Mesiatseslov, for 1862, the philologist Fedor Buslaev wrote an angry critique reflecting some of their views. "This is a monument to the millennium not of Russia in general,

26 P. A. Valuev, “8ogo sentiabria 1862 goda,” Russkaia starina vol. 57 (January 1888): $8-9$. 
but of Russian state life, Russian politics." To be true to the spirit of the era, he asserted, a statue should satisfy the principal demands of the era, which were demands for nationality (narodnost'). Even the figures chosen on the bar-relief, he argued, had advanced only the glory of the Russian state. From the top to the bottom, Buslaev found the monument incomprehensible to the common people and in conflict with Russia's national past. ${ }^{27}$

The ceremony of dedication of the Millennium Monument took place on September 8, 1862, the birthday of the heir, Nicholas Aleksandrovich, and the anniversary of Dmitrii Donskoi's victory over the Tatars on the Don-the symbolic liberation from the Tatars yoke. An article in the official newspaper Russkii invalid in 1859 had emphasized the new significance of the victory. It was presented not as a sign of military power, as in the past, but of liberation, the day "when Russia cast off the last survivals of error, and readied herself by the summons and direction of the worshiped Tsar to move along the path of citizenship (grazhdanstvennost')." Citizenship suggested the appearance of a civil society, of educated individuals, equal under the law, who were taking part in the life of the people. The struggle now was to be waged against "ignorance, and its direct heritage, intolerance and fanaticism." 28 The ceremony was meant to reaffirm the unity of the emperor now with an emergent nation, made up of citizens accepting the benevolent leadership of the monarch.

The political circumstances in Novgorod in the preceding months had not been propitious. Indeed, the atmosphere was tense. The nobility made known their intention to refuse to address the tsar and give a ball in his honor. The Ministry of Interior, apprehensive about the situation, sent ahead the Director of the Department of Police, Dmitrii Tolstoi. But the nobility

27 Buslaev, Moi dosugi, 187-208. Buslaev pointed out that the religious "enlighteners" such as Saint Sergei of Radonezh and Antony and Feodesii of Pechersk were presented as ordinary historical figures, yet the people would not recognize them without their halos, nor would Alexander Nevskii, Dovmont of Pskov, or Michael of Tver be recognized without their crowns. Andrei Rublev and Simon Ushakov were not numbered among the artists; Ivan the Terrible, much admired by the people in their byliny, was not included. For a thorough discussion of the symbolism of the statue and its critics, see Ol'ga Maiorova, "Bessmertnyi Riurik: Prazdnovanie 'Tysiacheletiia Rossii’ v 1862,” Novoe literaturnoe obozrenie vol. 43, No. 3 (2000): 137-65.

Russkii invalid, September 8, 1859, 790-1. 
underwent a strong change of heart when they saw the emperor on board the boat approaching along the Volkhov river. The noblemen awaited the opportunity to express their oppositional sentiment. However, as the tsar's boat approached, their hostility melted, to Tolstoi's great delight. The emperor's appearance brought out what he believed were the true feelings of rapture and devotion of the Russian nobility. "So much for the opposition of our nobility!" he added triumphantly. ${ }^{29}$

The next day, the Novgorod nobility showed their sentiments at a reception before morning mass. The Provincial Marshal, Prince Myshetskii, welcomed Alexander with bread and salt to "the cradle of the Russian tsardom" and declared the Novgorod nobility's "unswerving feelings of warm love and devotion, about which they have always prided themselves and always will pride themselves." The tsar then spoke of the emancipation as "a new sign of the indestructible bond of all the estates of the Russian land with the government, with one goal, the happiness and well-being of our dear fatherland." Alexander thus identified himself with the government and took the feelings for himself as feelings for the government as a whole. ${ }^{30}$

After a service in St. Sofia Cathedral, the clergy and the emperor proceeded to the monument. Before lines of troops and spectators who filled the stands, Isidore, the Metropolitan of Petersburg and Novgorod, blessed the statue with holy water. All present fell to their knees and, in a booming voice, the court deacon, Vereshchagin, delivered thanksgiving and memorial prayers written by the Metropolitan Filaret. At Alexander's request, the prayer expressed the inclusive message of the ceremony. The Metropolitan thanked not only members of the ruling house, but "all chosen sons of Russia" who "over the course of centuries loyally worked for her unity, well-being, and glory, on the fields of piety, enlightenment, government, and victorious defense of the fatherland." He concluded with an allusion to the spirit of rebirth and reform. "May the ancient plant of good not wither and may the new stem of good be grafted onto it and from it grow a new flower of beauty and fruit of perfection."31

29 Graf D. N. Tolstoi, "Zapiski," Russkii arkhiv, 1885, 2: 56-9.

30 S. S. Tatishchev, Imperator Aleksandr II: ego zhizn' i tsarstvovanie (St. Petersburg: S. A. Surovin, 1902), 1: 403-4.

31 N. V. Sushkov, Zapiski o zhizni i vremeni sviatitelia Filareta, Mitropolita Moskovskogo (Moscow: A. I. Mamontov, 1868), Appendix, 88; N. P. Barsukov, Zhizn' i trudy M. P. Pogodina (St. Petersburg: M. M. Stasiulevich, 1905), 19: 268, 275-6; Tatishchev, Imperator Aleksandr II, 1: 404. 
Deeply moved, Alexander wrote to his brother, Constantine, "The reception by all the estates was exceedingly joyous. The dedication of the monument could not have been more marvelous or touching; especially the three prayers, composed specifically for this occasion by Filaret at my instance, which were pronounced so clearly by our Vereshchagin that the words were heard over the whole Kremlin square." 32 In an article in Severnaia pochta, Valuev wrote that he was overcome with emotion. "This prayer breathes such spiritual warmth, such pure heartfelt loving tenderness (umilenie), such deep religious moral feelings that reading it, you unconsciously forget your surroundings and are transported into another world, a celestial world." 33

In the evening, the emperor had heartfelt meetings with peasants. At the gorodishche on the edge of lake Ilmen, where Riurik presumably had lived, according to Severnaia pochta, "the people met their beloved monarch with unbelievable joy and enthusiasm." Since the ground was damp, several peasants spread their caftans on the ground before the tsar's carriage. They called the tsar "heavenly angel." "One might say that the air trembled with the sound of 'Hoorah'." The emperor wrote to his brother Constantine that this joy appeared "unfeigned." “The peasants' zeal deeply touched me," the empress remarked to Count M. V. Tolstoi. ${ }^{34}$

On the next day, another show of affection between emperor and peasants took place. Alexander admonished official deputations from the peasantry about the widespread rumor that the emancipation did not represent the true emancipation. "Do you understand me?" he asked. "We understand," they replied obediently. Valuev described the scene in his newspaper report. "We saw the rapturous tenderness (vostorzhennoe umilenie) of the Russian peasant when he crossed himself at the sight of his tsar. We saw women falling to their knees and kissing the spot where the tsar walked. We heard the following words from old men. 'Just to see our Little Father the Tsar, then I don't mind dying!'”35

32 “Perepiska Aleksandra II s Velikim Kniazem Konstantinom Nikolaevichem," Dela i dni vol. 3 (1920): 82.

33 Severnaia pochta, September 14, 1862, 801.

34 Barsukov, Zhizn' i trudy M. P. Pogodina, 19: 277; Tatishchev, Imperator Aleksandr II, 1: 405; "Perepiska Aleksandra II s Velikim Kniazem Konstantinom Nikolaevichem," 3: 82.

35 "Perepiska Aleksandra II s Velikim Kniazem Konstantinom Nikolaevichem," 3: 82; Severnaia pochta, September 16, 1862: 805. 
Those responsible for the organization deemed the celebration a great triumph. Valuev, who had worried about both the noble sentiment and the threatening weather, wrote that "everything was fine and successful." In Severnaia pochta, he recorded his feelings, the appropriate ones for a loyal official devoted to authority. As the boat disappeared from view to the accompaniment of the tolling of bells and band music, the inhabitants stood on the wharf. "Everyone was deep in tender and warm feelings for the FatherTsar, for his August Family." Novgorod, he believed, would long remember the visit of Alexander, "The Monarch-Emancipator, the Monarch-Benefactor, the Monarch-Friend of Humanity." 36

Those who understood the nation in a broader sense were less happy with the ceremony. Tiutchev found the Millennium celebrations "very beautiful," but admitted that "the one thing that was lacking for me, as for many others, was a religious feeling of the past and only it could give true meaning to this festival. The millennium did not look down upon us from the summit of this monument, otherwise quite successful." In an article titled "Moscow, September, 8," the Slavophile Ivan Aksakov observed that the Millennium had been an official celebration that had excluded the common people. "They do not know our archaeological calculations. They do not share western jubilee sentimentality." Aksakov concluded that the celebration had raised hopes that the state represented more than an external presence and had bonds with the traditions of the Russian people, but these ideas had been expressed neither by the monument nor the dedication ceremony. It is interesting that Alexander himself noted on a copy of Aksakov's article, "Much is just." 37

36 Valuev, "8ogo sentiabria 1862 goda," 1: 12-13; P. A. Valuev, "Pis'ma k A. G. Troinitskomu,” Russkaia starina vol. 2 (1898): 212-13; Severnaia pochta, September 18, 1862: 808 .

37 "Lettres de Th. I. Tjutsheff a sa seconde épouse nee Baronne de Pfeffel," Starina i novizna, XXI (1916): 197; Barsukov, Zhizn' i trudy M.P. Pogodina, 19: 2804; Aksakov's remarks correspond to those of the anonymous correspondent from Moskovskie vedomosti, No. 199 (September 12, 1862), 1597, who concluded that the peasants understood nothing about the celebration except the immensity of the number 1,000, when indicating the longevity of the Russian state. 
Two lubki of the celebration in 1866 and 1867, hardly confirm Valuev's sense of the ceremony. Again the monarchy is placed in the same frame as the spectators, suggesting that there should be interaction or some kind of bond, but these scenes make clear rather the absence of reciprocity and unity. In the first (Figure 12), we see not a ceremony with a rapt audience, but a parade displaying order and solemnity (torzhestvennost'). Alexander on a white horse leads members of the suite and guardsmen with scant attention from the spectators. However, the parade seems to proceed with scant attention from spectators. A crowd of townspeople mills in the foreground, some looking at the monument, others ignoring it, engaging in conversation or going about their business. Members of the clergy do not appear at all. The feeling is one of disconnection.

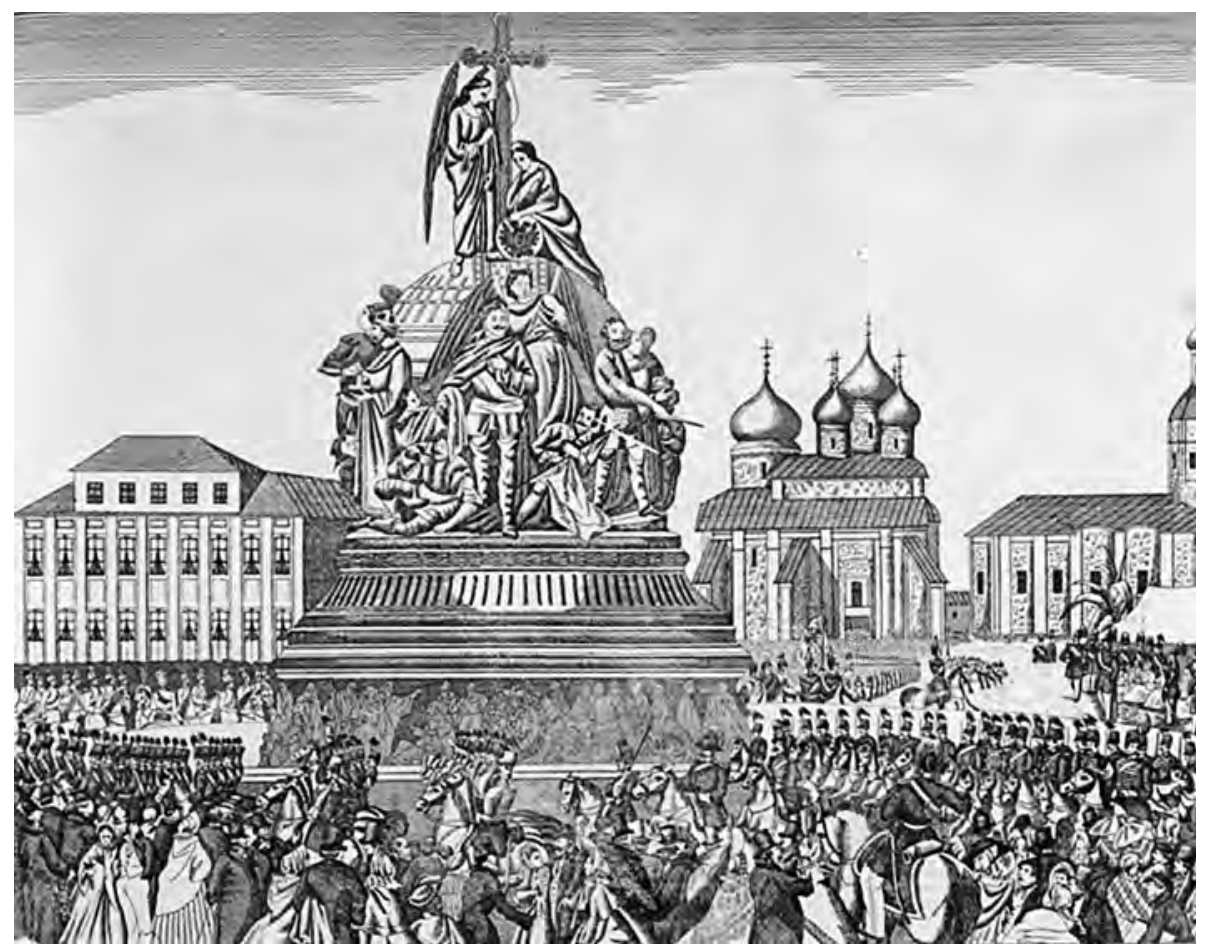

Figure 12_ “The Dedication of the Millennium Monument." New York Public Library, Miriam and Ira Wallach Division of Arts,

Prints, and Photographs. 
Most notably, the figure of Peter the Great is set above the melee of the celebration. Peter's gaze is fixed ahead with the angel behind, pointing to the future. The artist working in the atmosphere of the second half of the 1860s, when the spirit of reform had ebbed, now exaggerates the incongruity between tsar and people that we have seen in the earlier lubki and produces a representation that verges on parody. The statue, the ceremony, the townspeople seem to have nothing to do with one another. Instead of reverence for Peter and the glorious past of Russian monarchy, and love for the sovereign, there is indifference, each group focused on its own concerns. Instead of unity, there is a a sense of disconnection, and Peter's heroic stance seems a stage posture.

The second lubok (Figure 13) turns the parody into a social critique of the celebration. Issued in 1864 by the house of Rudnev, it seems to have slipped

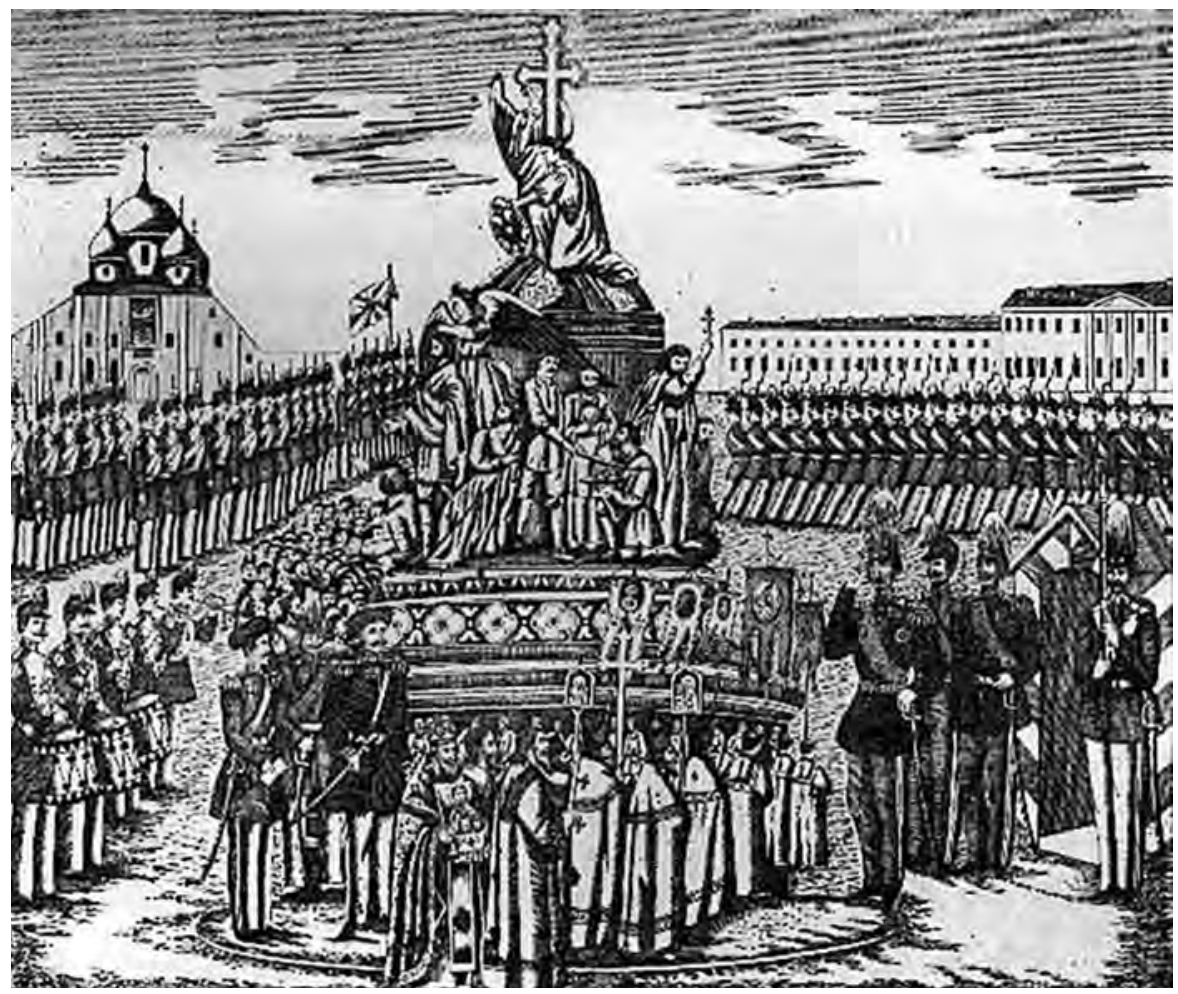

Figure 13- “The Festive Dedication of the Millennium Monument." New York Public Library, Miriam and Ira Wallach Division of Arts, Prints, and Photographs. 
by the censor. The view is from the west side of the stature, where Minin offers the crown to Michael, thus indicating a focus on the pre-Petrine origins of the monarchy. In the foreground, the emperor stands tall, saluting; behind him are Grand Dukes of almost the same height. The guardsmen parading in the rear are somewhat shorter. The clergy, marching in the procession of the cross before the emperor, are dwarflike. The people, miniscule figures, are crowded to the left of the monument that overshadows them, which they strain to see. The anonymous artist thus represents the hierarchy of the celebration in a grotesque visual hierarchy of size, making clear the predominance of the ruler and the military elite, and the insignificance of the people, the nation, who presumably were to be included in the celebration. ${ }^{38}$

The lubki of emancipation and the Millennium celebration and monument sought to express a bond between of the Russian people and their ruler-achieving civic progress without the encumbrance of representative institutions. In the eyes of the monarch and officials at the head of the government, these works confirmed the success of the reforms and the realization of the image of a people united with their monarch by bonds of gratitude and love. However, lubok and sculpture proved less yielding to the demands of the tsar's scenario than sentimental rhetoric. The artistic representations of a mythical nation only made clear the distance between the monarchy and the people, and between the monarchy and educated society: they brought out the incongruities estranging a majestic ruler from his abject subjects. The Millennium monument meant to include the nation expressed the domination of the people by the monarchy, and the responses to the monument and celebration made clear that the monarchy had not accepted the existence of a separate Russian nation. Nonetheless, this scenario, reflected in visual expressions and in future policies, dominated the mentality and policies of high Russian officials until the end of the 1870s. It continued to close out the realities of peasant attitudes and the demands in educated society for a nation with political rights.

38 Print and Photograph Division of the New York Public Library, MEWG, 143. 


\section{The "Russian Style" in Church Architecture as Imperial Symbol after 1881}

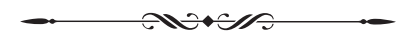

$\int$ everal chapters in this volume ${ }^{1}$ (those by Michael Flier, Dan Rowland, and Dimitryi Shvidkovskyi, and James Cracraft's study of Petrine architecture), have made clear the clear the declaratory role of architecture in the representation of Russian monarchy. The style and magnificence of thrones, buildings, and parks were meant not only to awe the population and foreign dignitaries, but also to give each reign its own characteristic aspect, to set each ruler apart as a distinctive ruling presence embodying specific transcendent attributes of power. Ivan the Terrible, Boris Godunov, Peter the Great, and Catherine the Great sought to create their own landscapes, which provided settings for the presentation of their political personae, what I have called their scenarios of power. From 1881, church architecture in "the Russian style" became an important means to display a national identity for Russian monarchy that distinguished it from the goals and practices of the previous reign.

A national style in church architecture first appeared during the reign of Nicholas I (1825-1855) as an expression of Nicholas's doctrine of "Official Nationality," which located national distinctiveness in the Russian people's devotion to their rulers, to the Westernized absolutism that ruled since Peter the Great. Nicholas sought an architecture that would set Russia apart from the contemporary West, which he believed had fallen prey to constitutionalism and revolution. He wished to show the Russian people's piety and loyalty, without denying the universalistic, Western character of Russian absolutism. He found the answer in a Byzantine cultural tradition that glorified Russia as the highest realization of the principle of absolute monarchy. Architectural

The volume is Architectures of Russian Identity: 1500 to the Present, ed. James Cracraft and Dan Rowland (Ithaca, NY: Cornell University Press, 2003). 
design, the Russian art historian E. A. Borisova has pointed out, became a narrative medium, displaying motifs that recalled particular themes of Russia's historical development. ${ }^{2}$

The architect who divined the emperor's intentions and found the appropriate architectural idiom was Constantine Ton. Ton's project for the St. Catherine's Church in Petersburg (1830) presented a five-cupola design whose exterior recalled the Moscow-Byzantine style of the Dormition Cathedrals of Vladimir (1158-61) and Moscow (1475-79). His design, grafting the fivecupola form onto a nineteenth-century neoclassical structure, typified the eclectic spirit of Nicholas's "Official Nationality" doctrine, which, while claiming national distinctiveness, sought to defend the Petrine cultural and institutional heritage. ${ }^{3}$ Its most prominent example was the immense Cathedral of Christ the Redeemer in Moscow (1837-1882), which has recently been reconstructed ${ }^{4}$ (Figure 1).

While the proportions, the arcades, and the structure of the cupolas of the cathedral were typically neoclassical, the exterior decorative elements asserted the building's Russian character. The five-cupola silhouette, like the tracery and icons on the facade, identified a Russian church. ${ }^{5}$ The Redeemer Cathedral set the pattern for similar churches that would provide specific visual references both to the national past of autocracy and to the universalistic context of empire derived from Byzantium. Published explanations of the buildings spelled out these references, disclosing the meaning of Russia's architectural heritage to all. Nicholas made "the Ton style" official. A decree of March 25, 1841 ordained that "the taste of ancient Byzantine architecture should be preserved, by preference and as far as is possible" in the construction of Orthodox churches. "The drawings of Professor Constantine Ton composed for the construction of Orthodox churches may prove useful in this regard."6

$\overline{2}$ E. A. Borisova, Russkaia arkhitektura vtoroi poloviny XIX veka, 174-75. (Cited in earlier article).

3 Ibid., 100, 101; Konstantin Ton, Tserkvi, sochinennye arkhitektorom Ego Imperatorskogo Velichestva Professorom Arkbtektury Imperatorskoi Akademii Khudozhestv i chlenom raznykh akademii Konstantinom Tonom (St. Petersburg: n.p., 1838).

4 The most thorough treatment of the history of the building is E. Kirichenko, Khram Khrista Spasitelia v Moskve (Moscow: Planeta, 1997).

5 Ibid., 61-3; Borisova, Russkaia arkbitektura vtoroi poloviny XIX veka, 106-9.

6 Svod Zakonov Rossiiskoi Imperii (St. Petersburg: Tip. II Otd. Sobstvennoi E. I. V. Kantseliarii, 1857), 12: 49. The provision is article 218 of the Stroitel'nyi ustav. 


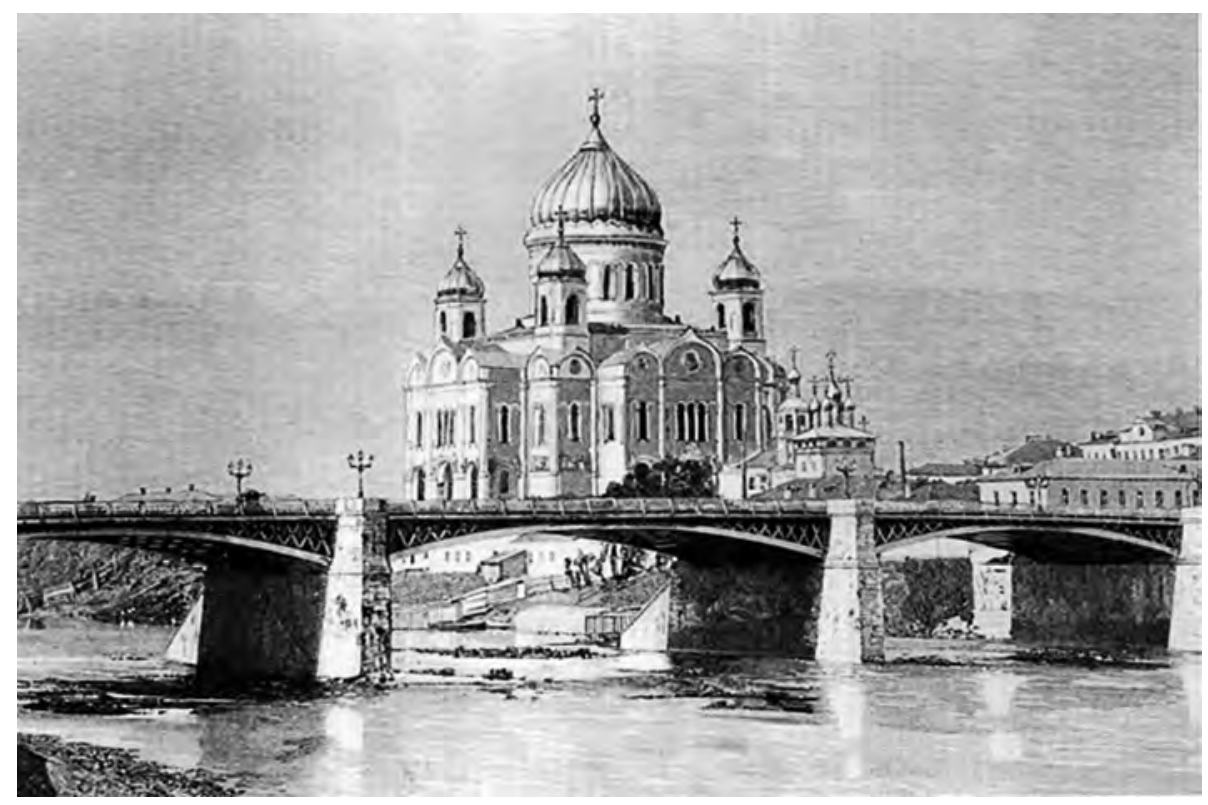

Figure 1-Constantine Thon-Cathedral of Christ the Redeemer, Moscow. Vsemirnaia Illiustratsiia, 1879.

The national myth introduced by Alexander III in 1881 revealed images of the nature and past of Russian autocracy that were quite different from those of "Official Nationality." The national myth evoked a religious and ethnic bond between the tsar and the Russian people, who had presumably survived the processes of Westernization and provided the basic foundations of Russian monarchy and state. The Russian tsar strove to embody not the existing state, contaminated by Westernized accretions, the reformed courts, and zemstva, but the ancient traditions persisting after the Petrine reforms in the people and the Orthodox Church. The Orthodox Church preserved the faith of the Russian people that permitted a union of tsar and people. The churches

$7 \quad$ For a discussion of the differences, see my articles, "National Narrative in the Representation of Nineteenth-Century Russian Monarchy," in Extending the Borders of Russian History: Essays in Honor of Alfred A. Rieber, ed. Marsha Siefert (Budapest and New York, Central European University Press, 2003), 51-64. Article 7 in Russian Monarchy: Representation and Rule and N. N. Mazur, ed., Rossiia/Russia: kul'turnye praktiki v ideologicheskoi perspektive, Rossiia, XVII—nachalo XX veka No. 4 [11] (1999): 233-44. 
erected in this period were meant to be concrete expressions of this union, evoking not Byzantine architecture, but an idealized seventeenth century that would replace the reign of Peter the Great as the mythical founding period of the Russian state. Churches would be monuments to the historical past, which demonstrated the persistence of the culture of seventeenth-century Rus'. Church construction intensified, and architects were expected to build thoes resembling those of early Russia: they were to recreate Muscovite scenes in Russia, particularly in Petersburg, to resurrect the national past by designing artifacts attesting to its persistence. ${ }^{8}$

The church architecture of Alexander III's reign sought to capture a culture rooted in the people that reflected a national spirit, rather than to display the Byzantine roots of Russian culture. For this purpose, it drew on the architectural theories of the 1860s and 1870s, which advocated a democratic national style in opposition to both neoclassicism and the Ton churches. Champions of a popular national Russian architecture, such as Lev Dal', Victor Butovskii, Ivan Zabelin, Vladimir Shervud, sought an architecture that would organically unite form and function in ways that reflected indigenous traditions and climatic conditions. Like A. W. N. Pugin in England and Eugène Emmanuel Viollet-le-Duc in France, they used the "realist" principle in architecture to interpret popular forms as structures that answered the practical needs of the people. The peasant hut, pre-Petrine wooden churches, and churches that reflected popular tendencies of innovation and ornamentation provided possible sources for a Russian national style. ${ }^{9}$ In the 1870 s and the 1880 s, the national style gained popularity, particularly among merchants, who favored old Russian motifs in their churches. ${ }^{10}$

8 From 1881-1894, the number of churches rose from 41,500 to 46,000. A. Iu. Polunov, Pod vlast'iu ober-prokurora: gosudarstvo i tserkov'v epokbu Aleksandra III (Moscow: AIRO-XX, 1996), 52; from 1870-1890, the number of churches increased from 38,613 to 45,037 and the number of chapels from 13,228 to 18,979. The figure for churches for 1898 is 46,000. Igor Smolitsch, Geschichte der russischen Kirche, 1700-1917 (Leiden: E. J. Brill, 1964), 1: 709.

9 On the architectural theorists of the 1870s, see E. I. Kirichenko, Arkbitekturnye teorii XIX veka $v$ Rossii (Moscow: 1986), 152-278; on Pugin and architectural realism, see Robert Macleod, Style and Society: Architectural Ideology in Britain, 1835-1914 (London: RIBA, 1971), 9-12; also Catherine Cooke, "Russian Perspectives," in Eugène Emmanuel Viollet-le Duc, 1814-1879 (London: Academy Editions, 1980), 60-3.

10 B. M. Kirikov, "Khram Voskreseniia Khristova (k istorii russkogo stilia v Peterburge)," Nevskii arkhiv: istoriko-kraevedcheskii sbornik 1 (1993): 216-7. 
Butovskii and others sharing his views succeeded in convincing Violletle-Duc to write a study of Russian art. Viollet's L'Art russe expressed many of the principles of the national school in terms of his own general theories of architectural development. The author, who had never visited Russia, marveled over the corbelled vaults and tent roofs of sixteenth and seventeenthcentury Russian churches, which he thought were structurally well-adapted to lavish ornamentation reflecting popular tastes. As Lauren O'Connell has shown, Viollet's notion of Asiatic influence and his sometimes fanciful explanations of the structure of old Russian buildings prompted angry recriminations from many Russian art critics. However, his book gave the confirmation of a renowned authority to the belief that the sixteenth and seventeenth centuries were the true period of national creativity in Russian architecture. ${ }^{11}$ Russians, Viollet asserted, had to restore the link with this time broken by Peter the Great and "to repossess the national art dominated for so long by Western arts!" The "reinstallation of Russian art in Russia ... would be met with favor by the immense majority of the nation and would become the corollary of the emancipation of the serfs." 12 The monarchy appropriated this cultural idiom and invested it with specific political meaning. It utilized revival architecture, as it had been conceived in nineteenth century Europe, as a means to shape attitudes. Visual imagery could restore a lost purity, change attitudes, and reshape society. ${ }^{13}$ After 1881 , this type of thinking encouraged a kind of inverted archaeology: monuments were constructed to resurrect an invisible national past, particularly in regions deemed in need of admonition and edification.

The building announcing the new official national style was the Resurrection Cathedral erected on the site of Alexander II's assassination-in

11 On Viollet and the controversy around his books, see Lauren M. O'Connell, "A Rational, National Architecture: Viollet-le-Duc's Modest Proposal for Russia," Journal of the Society of Architectural Historians vol. 52, No. 4 (December 1993): 436-52; Idem, "Viollet-le-Duc and Russian Architecture: The Politics of an Asiatic Past," in Architectures of Russian Identity, 101-16; E. Viollet-le-Duc, L'Art Russe (Paris: Ve A. Morel, 1877), 164-71, 178.

12 Viollet-le-Duc, L'Art Russe, 8, 148-9.

13 See, for example, Margaret Belcher, "Pugin Writing," in Pugin: A Gothic Passion, ed. Paul Atterbury and Clive Wainwright (New Haven, CT: Yale University Press, 1994), 115-6; Thomas R. Metcalf, An Imperial Vision: Indian Architecture and Britain's Raj (Berkeley, CA: University of California Press, 1989), 139-40. 
popular parlance, "the Savior on the Blood."14 The initiative for the church belonged to the St. Petersburg City Duma, which opened a public subscription for the structure. The decision on the plans was quickly taken over by the tsar, and most of the cost was assumed by the treasury. Again the architect was chosen for his ability to conform to the image in the mind of the emperor, an image which Alexander III, like Nicholas I, did not trouble to make clear.

The first competition, completed in April of 1882, yielded projects in the Ton style decreed by Nicholas I in his Construction Statute, which continued to regulate the building of Orthodox churches. But the emperor found none to his liking. A report in Moskovskie vedomosti on April 9, 1882 stated that Alexander III believed that the best eight projects in the competition did not suit the taste of "Russian church architecture." He indicated to various individuals that he wanted the church to be in "Russian style," and "in the style of the time of the Muscovite tsars of the seventeenth century." 15 The journal Nedelia stroitelia reported that he announced that he wished a "purely Russian style of the seventeenth century." A comment added that models of these were to be found "in Iaroslavl." 16

Architects groped for designs in the new style. The submissions for the second competition, completed only five weeks after the first, incorporated a great variety of pre-Petrine church motifs, none of which seem to have pleased Alexander. He preferred a submission not from a distinguished architect, but from a person close to the court. The hegumen of the Trinity-

14 Three recent studies have provided excellent discussions of the church's architecture and significance: Kirikov's article cited in footnote 6 and two articles focusing on the history and the iconography of the church by Michael S. Flier: "The Church of the Savior on the Blood: Projection, Rejection, Resurrection," in Christianity and the Eastern Slavs, ed. Robert P. Hughes and Irina Paperno (Berkeley, CA: University of California, 1994), 2: 25-48; Idem, "At Daggers Drawn: the Competition for the Church of the Savior on the Blood," in For SK: In Celebration of the Life and Career of Simon Karlinsky, ed. Michael S. Flier and Robert P. Hughes (Berkeley, CA: University of California Press, 1994), 97-115.

15 In April 1882, the mayor of St. Petersburg informed the City Duma that he had received a notification from the St. Petersburg Governor of the tsar's wish, conveyed by the Minister of the Interior, that the cathedral be built "in Russian style" (Moskovskie vedomosti, April 9, 1882); A. A. Parland, Khram Voskreseniia Khristova sooruzhennyi na meste smertel'nogo poraneniia $v$ Boze pochivshego Imperatora Aleksandra II na Ekaterininskom kanale v S-Peterburge (St. Petersburg: R. Golike and S. Vil'borg, 1909), 2.

16 Flier, "The Church of the Savior on the Blood," 27; Flier, "At Daggers Drawn," 98. 
Sergius Hermitage near Peterhof, Arkhimandrite Ignatii Makarov, contributed a project at the instance of the tsar's cousin, Grand Duchess Ekaterina Mikhailovna. Makarov had drawn the sketch of a church, he claimed, "almost automatically," on the day of Annunciation. After considerable reworking by the architect Alfred Parland, the project, submitted after the deadline of the competition, received the emperor's approval. The final form of the cathedral, Michael Flier has shown, was a composite of the plans of the many architects who were struggling to find a seventeenth-century national style that suited the emperor's taste. ${ }^{17}$

At first sight, Parland's cathedral recalls the kaleidoscopic forms of Vasilii the Blessed on Moscow's Red Square. Parland himself noted the resemblance (Figure 2). The flamboyant decorations, the tent roof, the onion cupolas became signatures distinguishing the building from the Ton model. However, as B.M. Kirikov has convincingly argued, the resemblance is deceptive. The new church's five-cupola cruciform structure, with a large central basilica-like hall, has little in common with the intricate warren of Vasilii the Blessed. The external devices-the tracery, kokoshniki, and shirinki-borrow from a great number of seventeenth-century churches in the Moscow-Iaroslavl style. ${ }^{18}$ Although the cathedral was not consecrated until 1907, its amalgam of the fivecupola form with pre-Petrine ornamentation became the dominant model for church design in the official Russian style from 1881 to 1905 . The new national churches provided a backdrop for the "union of tsar and people" extolled in official statements after March 1. The monarchy, claiming popular national roots, now took up the same undisciplined and flamboyant decorative forms that had been condemned by Nikon and other members of the seventeenthcentury church hierarchy.

The "Savior on the Blood" was one of five Resurrection churches erected after 1881 in St. Petersburg. Flier has given a close analysis of its iconology of Resurrection. The theme of Resurrection is elaborated on the exterior

17 For the projects of the second competition, see the volume of Zodchii for 1884 . Ignatii's account is cited in Zhizneopisanie arkhimandrita Ignatiia (Malysheva), byvshego nastoiatelia Troitse-Sergievoi pystyni (St. Petersburg: V. V. Komarov, 1899), 84.

18 Kirikov, "Khram Voskreseniia Khristova," 230-3; I. Grabar', Istoriia Russkogo Iskusstva, vol. 9, Book 2 (Moscow: Ak. Nauk SSR, 1965), 269. Kokoshniki are decorative arches that resemble the Russian woman's hat, the kokoshnik. Shirinki are oblong panels recessed in exterior walls. 
9. THE "RUSSIAN STYLE" IN CHURCH ARCHITECTURE ...

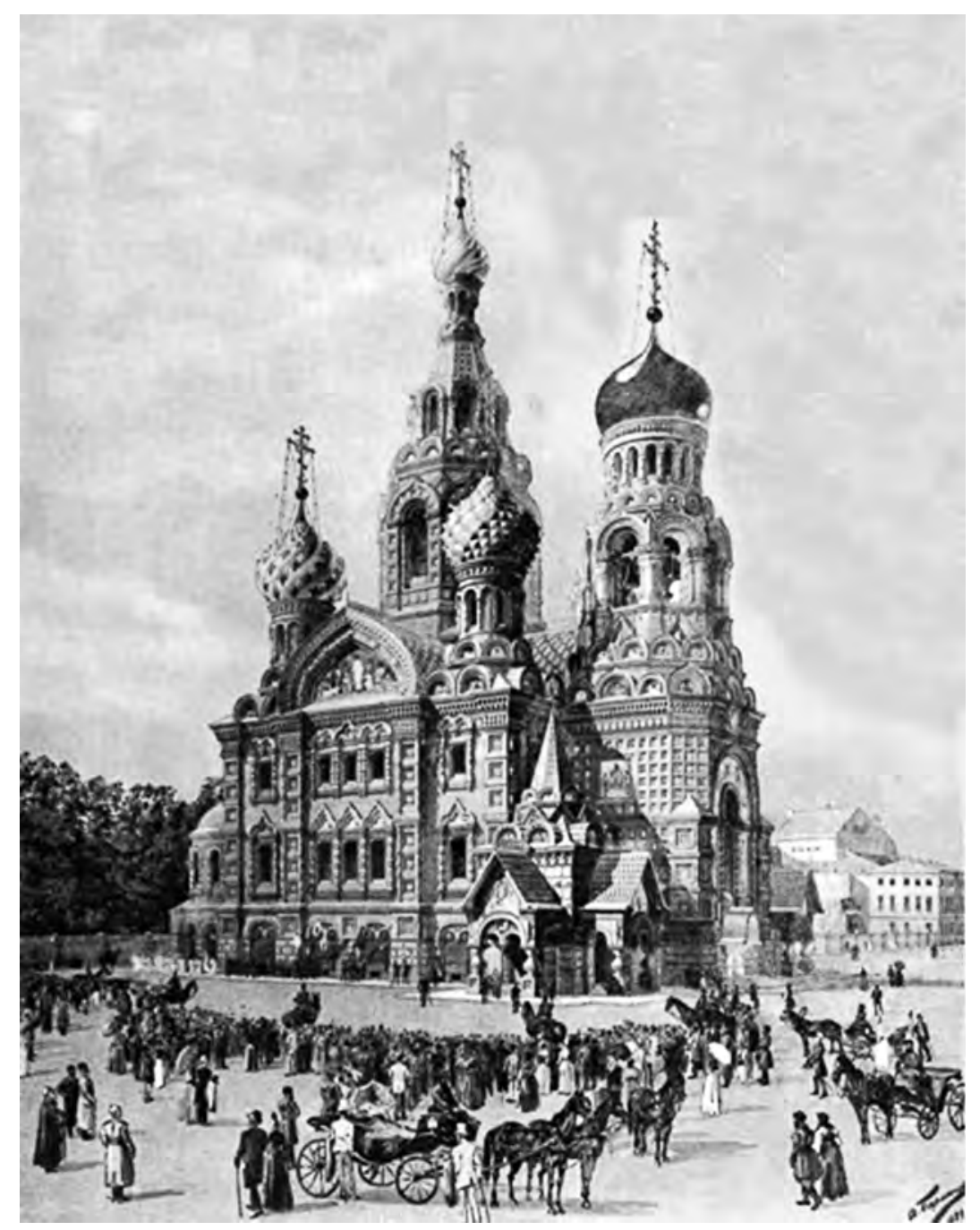

Figure 2-Alfred Parland-The Cathedral of the Resurrection (Christ on the Blood), St. Petersburg. A. A. Parland, Khram Voskreseniia Khristova (St. Petersburg: R. Golike and S. Vil'borg, 1909). 
mosaics, which represent Christ carrying the cross, the Crucifixion, the Deposition, the Descent into Hell, and, on the southern pediment, the Resurrection itself. "Resurrection" referred not only to the Savior; it signified the rebirth of a political and religious heritage long moribund and the repudiation of the symbolic traditions of the previous reigns. The central theme of the church's interior, Flier shows, displaced the mythological point of origin from Rome to Jerusalem. The model for the layout of the cathedral was the Church of the Holy Sepulcher in Jerusalem, also named for the Resurrection. ${ }^{19}$

The interior presents Russia's beginnings not in the Roman Empire-as in the legends of Andrew the First-Called-or Byzantium, as claimed in the legend of Monomakh. Rather, the origins are set at Golgotha itself, now transposed to Russia, with national and messianic implications. The symbolism has a negative thrust-one of rejecting, of clearing away the previous historical narrative, of removing Rome and even Byzantium as forerunners of Russia. The cathedral expresses the determination to do away with foreign mediation of the divine, to overcome the derivative character of Russian religious doctrine and to identify Russia with the source of Christianity itself. The true Russian spirituality could be manifested only after Russia had thrown off some of its Byzantine trappings, but before it had fallen under the domination of western culture in the eighteenth century-as the national school, echoed by Viollet, had suggested.

The references to Jerusalem, like the popular Resurrection motifs on the exterior, were signs of a new state mythology that conveyed a powerful admonition regarding the evils supposedly besetting Russia. The building of the cathedral was to be seen as an act of expiation to atone for the assassination of Alexander II, the shame of which branded the entire people. ${ }^{20}$ Thus, Parland placed "the prayer of Vasilii the Blessed" beneath the central cupola. The prayer

19 Flier, "The Church of the Savior on the Blood," 32-43.

20 This theme was made explicit in sermons and official statements in the months after assassination. For example, Father Ignatii, in an appeal for contributions for the building of the church, emphasized that the entire people bore the shame, and to a large degree the responsibility, for the death (Zhizneopisanie arkbimandrita Ignatiia, 92). When betrayed by the Jews, Ignatii explained, Christ cried out, asking what the people had done. "Alexander's blood also cried out, My people what have you done? For my whole life, I have cared for you and your well-being, and you condemned me to death. My thoughts and heart were devoted to you... I made the expiatory sacrifice - the body and blood of Christ cleansing every sin, and you murdered me." 
begged God to forgive the people for their sins. The many icons of Ss. Boris and Gleb, the Kievan princes who had died passively to expiate the sins of the Russian land, recalled others martyred for their fatherland's transgressions. ${ }^{21}$ The sins comprised more than the mere act of assassination; they included the weakness, the tolerance, and the laxity presumably responsible for the murder. The cathedral was an act of repentance for Western culture, and the mosaic icons on the exterior were meant to remind Petersburg of its shame. The final lines of Fet's "March 1, 1881" pronounced the transformation of the blood into a shrine. ${ }^{22}$

Nicholas I's 1841 decree encouraging Byzantine-style churches remained on the books, and such churches continued to be built, mainly in non-Russian regions. ${ }^{23}$ Most official churches erected after 1881 incorporated the national motifs of the Savior on the Blood, seeking to evoke the spirit of the seventeenth century. ${ }^{24}$ The abundance of bulbous onion domes and floral kokoshniki, girki, and shirinki particularly distinguished new churches based on the

$21 \quad$ Apollon Maikov's poem, "March 3, 1881," published in Moskovskie vedomosti_(March 12, 1881), 3, also expresses a sense of collective shame.

Oh beloved Tsar! Ob remain after death

Our protector!

May Your bloody image show us our emptiness

Our vacillating and weakness for all time!

A. A. Parland, "Khram Voskreseniia Khristova," Zodchii (1907): 375-6; Parland, Khram Voskreseniia Khristova, 3; Flier, "The Church of the Savior on the Blood," 43-5; George P. Fedotov, The Russian Religious Mind (Belmont, MA: Nordland, 1975) 2: 110 .

22 A. A. Fet, Polnoe sobranie stikhotvorenii (St. Petersburg: Marks, 1912), 397.

The snares of the Pharisee are powerless,

What was blood, has become a cathedral,

And the site of the horrible crime,

Has become our eternal shrine!

23 For example, The Cathedral of the Transfiguration, built in 1888 in Tashkent, most Orthodox Churches in Poland, and Fedor Shekhtel's 1898 Church of the Savior in Ivanovo-Voznesensk.

24 A. I. Vlasiuk has shown that architectural practice in the second half of the nineteenth century developed its own momentum and was hardly constrained by the 1841 Construction Statute (Vlasiuk, "Evoliutsiia stroitel'nogo zakonodatel'stva Rossii v 1830-e-1910 gody," in Pamiatniki russkoi arkbitektury i monumental'nogo isskustva [Moscow: n.p., 1985], 226-46). 
Moscow-Iaroslavl style. These included the Petersburg church named after its miracle icon, The Mother-of-God of the Joy of All the Grieving (Materi vsekh skorbiashchikh radosti), designed by Alexander Gogen and A. V. Ivanov, and erected from 1894 to 1898, and M. Preobrazhenskii's Alexander Nevskii Cathedral in Reval (Figure 3). ${ }^{25}$ Viollet had emphasized that the type of corbelled vaulting of seventeenth-century Russian churches lent them to elaborate decoration of the kokoshnik type; he especially admired the famous Moscow church at Putynki with its profusion of tent and kokoshnik forms. ${ }^{26}$

The architect Nikolai Sultanov, the translator of L'Art russe and an exponent of the new official style, declared Moscow-Iaroslavl churches to be exemplary of seventeenth century church architecture as a whole. He singled out the Church of the Icon of the Georgian Mother of God in Moscow and the Church of the Trinity in nearby Ostankino as the highest achievements of the type, and based his submission for the second competition for the Resurrection Church on them. Sultanov also did considerable archaeological work on the Trinity Church and assisted in its restoration. ${ }^{27}$ His Peter-Paul Cathedral at Peterhof, completed in the late 1890s, brought the images of the Resurrection Cathedral to the playground of the court. Set on a pond, it reproduced the tent forms and kokoshniki of the seventeenth century in brick, which Sultanov considered the building material most suitable for Russian churches. The church provided a stark contrast to the Rococo elegance of the palaces of Peterhof.

The new churches were acts of visual provocation-flagrant repudiations of the esthetic, and by implication, the political and spiritual, premises of Russian autocracy before 1881. The organic motifs of these churches, springing mushroom-like from their surface, defy the order and restraint of neoclassicism and even the eclecticism that had succeeded it, the entwining designs verging on the lushness of Art Nouveau. ${ }^{28}$ The profusion of decoration exemplifies what Randolph Starn and Loren Partridge have identified as the

25 S. Shul'ts, Khramy Sankt-Peterburga: istoriia i sovremennost' (St. Petersburg: Glagol, 1994), 177-8; M. Preobrazhenskii, Revel'skii Pravoslavnyi Aleksandro-Nevskii Sobor (St. Petersburg; A. E. Vineke, 1902).

26 Viollet-le-Duc, L'Art Russe, 115-17.

27 N. Sultanov, "Vozrozhdenie russkogo iskusstva," Zodchii 2 (1881): 9; Borisova, Russkaia arkhitektura vtoroi poloviny XIX veka, 308.

28 Iu. V. Trubinov notes this resemblance; Khram Voskreseniia Khristova (Spas na Krovi) (St. Petersburg: Beloe i chernoe, 1997), 40-1. 
9. THE “RUSSIAN STYLE” IN CHURCH ARCHITECTURE . . .

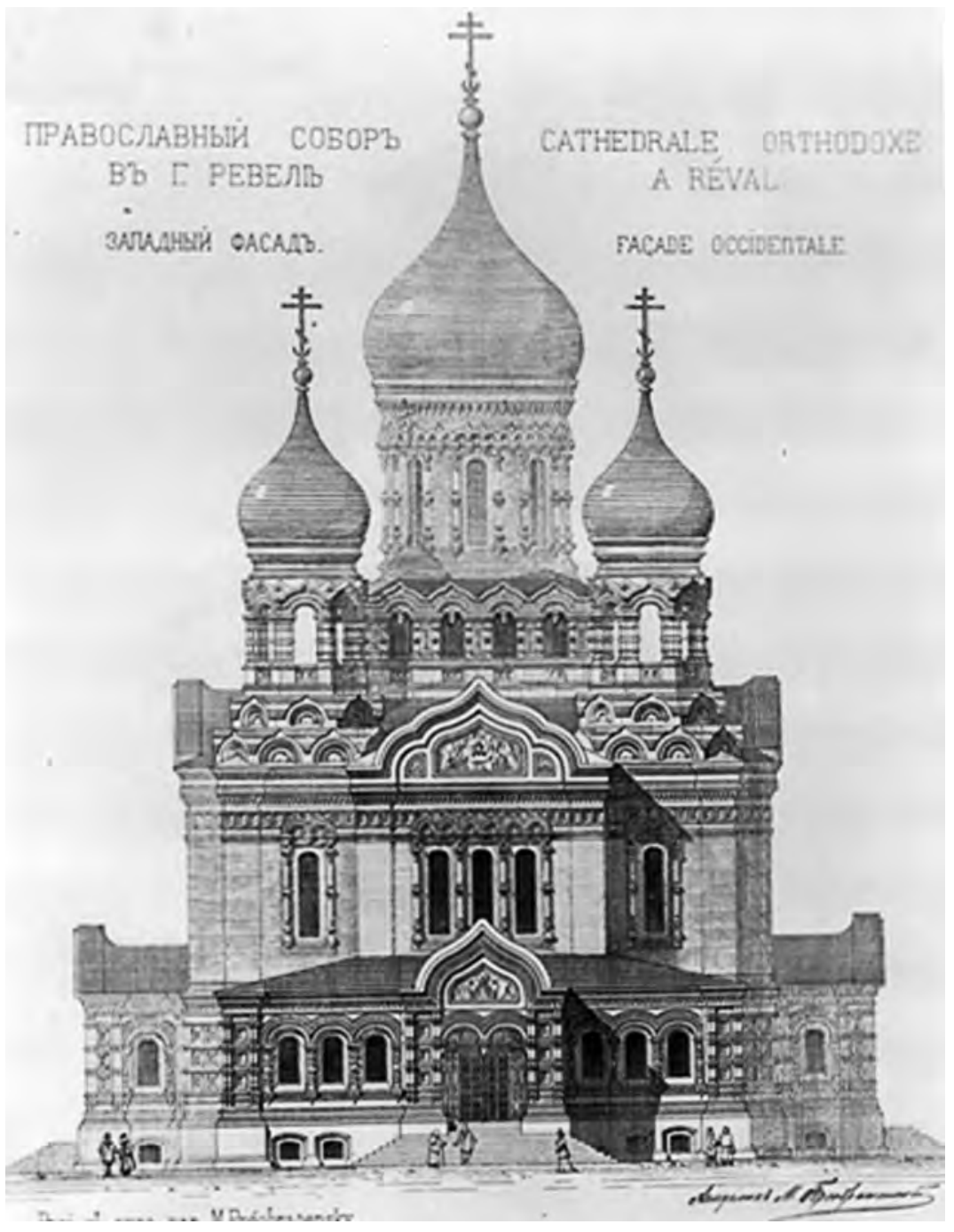

Figure 3-M. Preobrazhenskii-Alexander Nevskii Cathedral, Reval. M. Preobrazhenskii, Revel'skii Pravoslavnyi Aleksandro-Nevskii Sobor (St. Petersburg: A. E. Vineke, 1902). 
use of redundancy to enhance the totality and expressiveness of monumental architecture: excess as a prerogative of absolute power. ${ }^{29}$ The excess was made conspicuous at prominent places so as to admonish the population. Expressing the autocrat's growing dissatisfaction with the western imperial capital, these churches administered an open rebuke to the city itself, constituting an effort to Muscovitize St. Petersburg. ${ }^{30}$

The Resurrection Cathedral, built on the site of Alexander II's assassination on Catherine Canal, is easily visible from Nevskii Prospect. There is nothing understated in its appearance; it is a declaration of contempt for the order and symmetry of the capital, producing what Louis Réau, the noted French student of Russian art history, described as "a troubling dissonance." A prominent building in Moscow style set in the middle of classical Petersburg was meant to express this rejection. It was, Flier writes, "old Muscovy plunged into the heart of European Petersburg." 31 More than twenty official Russianstyle churches went up in St. Petersburg from 1881-1914. At least eighteen of these were demolished or transformed beyond recognition after the revolution. Constantine Pobedonostsev reported that eight such churches were consecrated in the years 1893-95 alone. ${ }^{32}$ The Assumption Cathedral of the St. Petersburg branch of the Kiev Monastery of the Caves (1895-1900) looks out over the Neva from the Nikolaevskii embankment, a five-cupola church with elaborate seventeenth-century decoration. The Resurrection Cathedral on the Obvodnyi Canal (1904-08), within view of the Warsaw Railroad Station, combines a Byzantine central basilica with kokoshniki and a tent belfry. 33

29 See the suggestive remarks on inflation and copiousness in the art of monarchy in Randolph Starn and Loren Partridge, Arts of Power: Three Halls of State in Italy, 1300-1600 (Berkeley, CA: University of California Press, 1992), 166-74.

30 L. N. Benois wrote that during Alexander III's reign, "Petersburg, Peterhof, Warsaw, etc., were graced with new churches, the lack of which was felt acutely, especially in the capital" ("Zodchestvo v tsarstvovanie Imperatora Aleksandra III," Nedelia stroitelia, November 27, 1894, No.48: 245). On the increased emphasis on Moscow as the political center of autocracy, see Article 8 in Russian Monarchy: Representation and Rule.

31 Louis Réau, Saint Petersburg (Paris: H. Laurens, 1913), 67-8; Flier, “The Church of the Savior on the Blood," 30.

32 Utrachennye pamiatniki arkhitektury Peterburga-Leningrada; katalog vystavki (Leningrad: Khudozhnik RSFSR, 1988), 31-9; Shul'ts, Khramy Sankt-Peterburga, 52, 79-82, 104, 106, 119-21, 173-4, 177-80, 200, 203-4, 212, 218; Polunov, Pod vlast' iu ober-prokurora, 76.

33 Shul'ts, Khramy Sankt-Peterburga, 81-2, 120-1. 
By bringing forth a forgotten national past, the new Russian style churches of the late Imperial period sought to exert an edifying influence on the masses. Since the 1870s, the Orthodox Church had been engaged in a campaign to broaden its moral influence by adopting Protestant and Catholic practices of addressing the people through sermons, lectures, and literature. ${ }^{34}$ Churches were built to accommodate large numbers of worshipers and to provide amenities needed to attract a contemporary population. The celebratory literature about the churches dwelled on their size, convenience, and comfort. The Savior on the Blood held 1,600 people. Parland boasted that he used modern technology to light and heat his cathedral. Large stained glass windows, white at the bottom and rising to light blue at the top, allowed natural light to bring out the colors of the mosaics. His design thus was remote from the appearance of early Russian orthodox churches, whose thick walls with few, small windows kept out the light and turned the interior into a sanctum separate from the outside world. In the evening, the great expanse of Parland's church was lit by 1589 electric lights, creating a magical effect. He wrote, "Whatever the weather, whatever the color of the sky, cloudy or threatening, it seems blue in the cathedral, clear, bright, harmonizing with the mood of prayer." The light from the chandeliers flooded the walls "as if bringing to life the severe physiognomies of the saints, as if filling the air of the cathedral to its top." The cathedral was also equipped with steam heat. ${ }^{35}$ The attempt to return to the simple spirit of early Russia had resulted in splendor and show: in Réau's words, it "surpasses all the churches of Petersburg in its sumptuousness." The Resurrection Church on Obvodnyi Canal could hold 4,000 worshippers under its large central dome of reinforced concrete. ${ }^{36}$

Combining function and amenities with beauty was presented as a confirmation of the principle of "realism" in Russian national architecture.

$\overline{34}$ See Nadieszda Kizenko, The Making of a Modern Saint: Father John of Kronstadt and the Russian People (University Park, PA: Pennsylvania State University Press, 2000); Simon Dixon, "The Church's Social Role in St. Petersburg," in Church, Nation and State in Russia and Ukraine, ed. Geoffrey A. Hosking (London: St. Martin's Press, 1991), 167-92; Jeffrey Brooks, When Russia Learned to Read: Literacy and Popular Literature, 1861-1917 (Princeton: Princeton University Press, 1985), 300-1, 306-11.

35 Parland, Khram Voskreseniia Khristova, 14; Grigorii Moskvich, Petrograd i ego okrestnosti (Petrograd: G. Moskvich, 1915), 62-3.

36 Réau, Saint Petersburg, 68; Shul'ts, Khramy Sankt-Peterburga, 121. 
Nikolai Sultanov lauded the comfort and convenience of his Peter-Paul Cathedral in Peterhof, which had room for 800 worshipers. He observed that many members of the propertied classes avoided parish churches and prayed at home because they had to wear coats indoors, or because the churches became crowded and overheated. His church, on the contrary, was spacious, and provided good ventilation, cloak rooms, and seats for the old and infirm. A gallery outside was to protect processions of the cross from inclement weather. Indeed, the official Slavic-revival churches were monumental buildings full of light and comfort that had little in common with the smaller, darker, and colder churches of early Russia. ${ }^{37}$

Like the Savior on the Blood, other churches were placed at sites for demonstrations of spiritual purification and contrition. ${ }^{38} \mathrm{~A}$ fanciful singledomed Church of the Savior covered with kokoshniki and other decorations, accompanied by a tent-shaped bell tower, went up at Borki near Kharkov, the site of the wreck of the emperor's train in 1888 , as a sign of miraculous salvation ${ }^{39}$ (Figure 4). Churches built near factories promoted efforts by the government

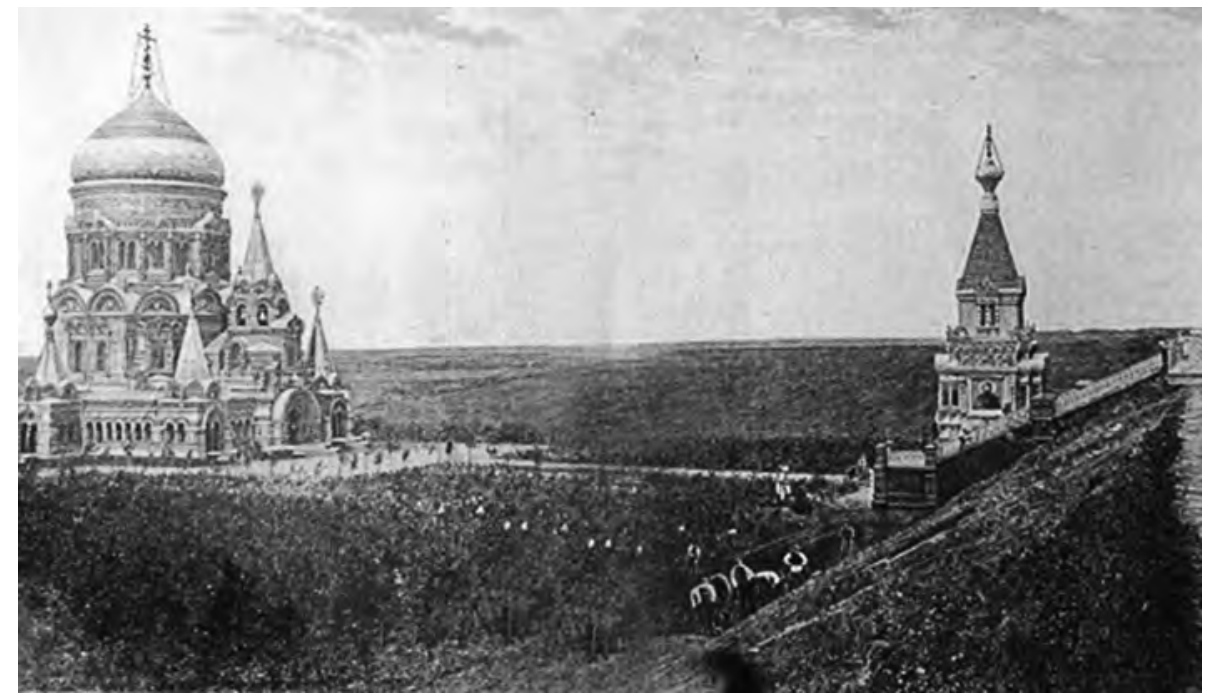

Figure 4-Church and Bell Tower, Borki. Niva, 1894.

37 Stroitel' (1896): 559-66, 667-95; Kirichenko, Arkbitekturnye teorii XIX veka v Rossii, 254-5.

38 These edifices as well as others in the national style are discussed in V. G. Lisovskii, "Natsional'nyi stil"” $v$ arkhitekture Rossii (Moscow: Sovpadenie, 2000), 197-211.

39 Niva 24 (1894): 569. 
and church to awaken the religious faith of industrial workers. At the beginning of the 1890s, Leontii Benois designed a church for 2,000 people near the textile factory of the Hof-meister, N.C. Nechaev-Maltsov, in the town of Gusev, near Vladimir (Figure 5). This massive edifice was surmounted by a great tent roof and bell tower at one end, and by cupolas and kokoshniki in the Iaroslavl style at the other. The mosaic of St. George, the patron saint of Moscow, placed over the portal was probably the work of Victor Vasnetsov, who executed the paintings on the interior walls. From 1901 to 1907, a two-story church erected at the Putilov Factory in St. Petersburg was funded by workers' "contributions" as a memorial to the plant's founder, N. I. Putilov. A drawing of this church, which has since been destroyed, recalls the tent and cupola forms of Vasilii the Blessed. Fedor Shekhtel's large Church of the Savior in the textile center at Ivanovo-Voznesensk, completed in 1898, was built in neo-Byzantine style. ${ }^{40}$

Officials and noblemen close to the court built Russian-style churches on their estates. In the 1880s, Sultanov designed a Moscow-Iaroslavl church with a brick exterior for I. I. Vorontsov-Dashkov's estate at Novotomnikov in Tambov guberniia. Vorontsov-Dashkov helped shape the national myth and governmental policy at the beginning of Alexander III's reign and served as the head of his palace guard and Minister of the Court. ${ }^{41}$ Leontii Benois' church on the estate of A. D. Sheremet'ev, the prominent choral director and composer, in Smolensk guberniia, was also in Moscow-Iaroslavl style with a tent bell tower. A flamboyant Moscow-Iaroslavl church with four altars was built from 1886 to 1892 on Sheremet'ev's tract near Peterhof. 42

The specific means by which the new style was suggested or imposed by the Imperial government are difficult to determine from the available sources. It seems evident that the procedures for state approval of official projects ultimately required the consent of those close to the emperor, or of

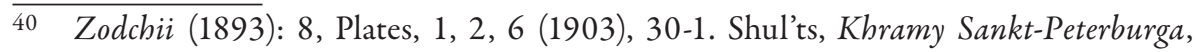
180. William Craft Brumfield, The Origins of Modernism in Russian Architecture (Berkeley, CA: University of California Press, 1991), 129.

41 Zodchii (1889): 74-7; On Vorontsov-Dashkov, see B. V. Anan'ich and R. Sh. Ganelin, "Aleksandr III i naslednik nakanune 1 marta 1881 g.," in Dom Romanovykh v Rossii: istoricheskii opyt russkogo naroda i sovremennost', 2 (St. Petersburg: St. Petersburg University Press, 1995), 205.

42 Zodchii (1893): Plates 21-23; Shul'ts, Kbramy Sankt-Peterburga, 173-4. I thank Priscilla Roosevelt for drawing my attention to the nobility's reproduction of the official Russian style on their estates. 


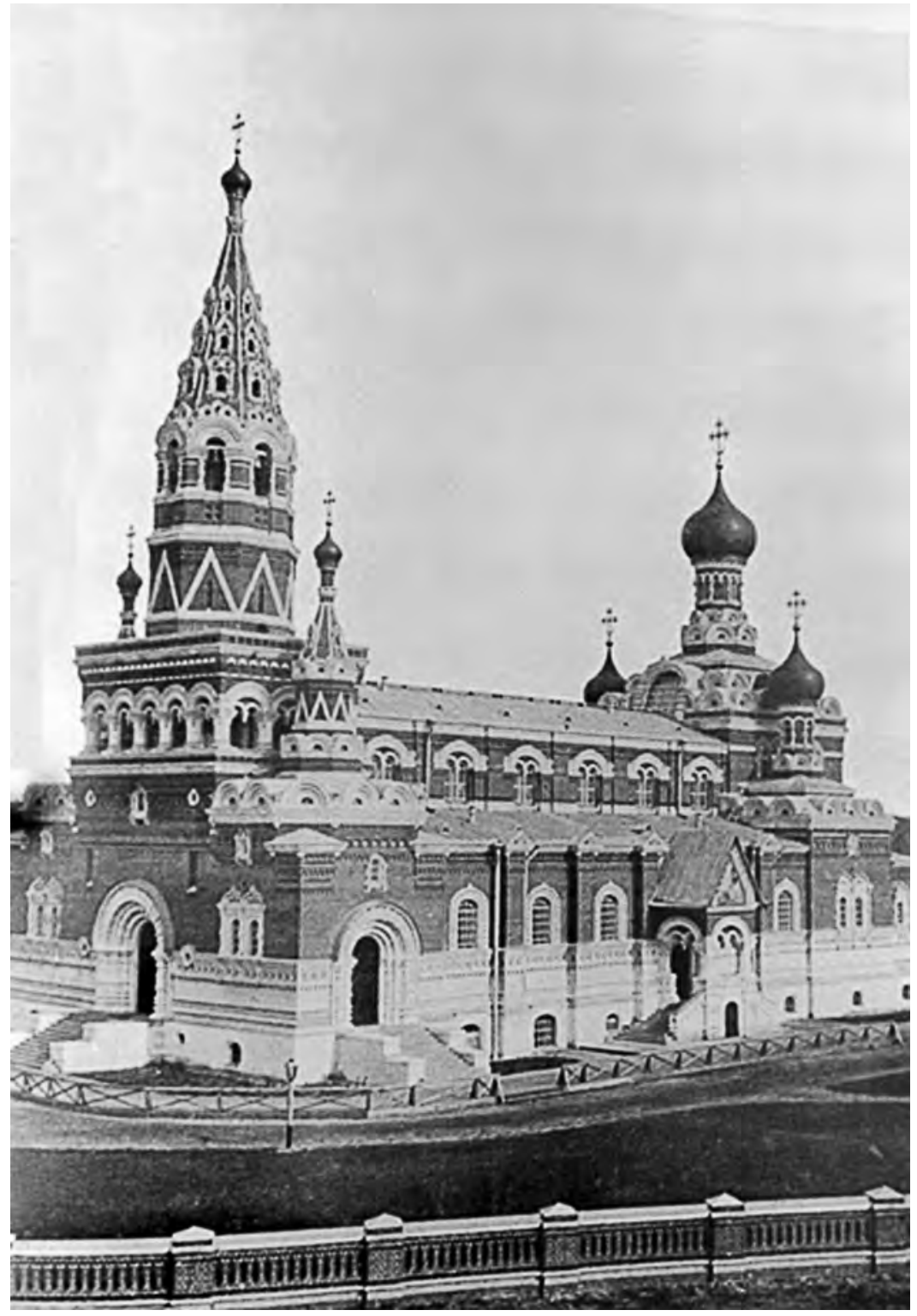

Figure 5-Leontii Benois, Church for 2000 people, Gusev. Zodchii, 1893. 
the emperor himself, creating a disposition to conform with their tastes. The construction of Orthodox churches, for instance, required the permission of either the Holy Synod or the local diocese. In St. Petersburg, initiatives from monasteries, religious societies, or even institutions of the government were submitted to the Synod, which was of course dominated by its chiefprocurator, Constantine Pobedonostsev. Many churches were dedicated to events in the lives of members of the Imperial family, an act that both required the emperor's approval and won his favor. The church built to house the icon, The Mother-of-God of the Joy of All the Grieving, at the Imperial St. Petersburg Glass Factory commemorated the tenth anniversary of the emperor's survival of the Borki disaster. The proposal came to the Synod from the Minister of the Interior. The 1904 church built on the Obvodnyi Canal was sponsored by the St. Petersburg Temperance Brotherhood to commemorate the birth of an heir to Nicholas II. The Brotherhood's proposal, submitted by the St. Petersburg Metropolitan, received the approval of the Synod and the emperor. ${ }^{43}$

Churches built in the national style symbolized Russian domination of regions that retained elements of religious and political autonomy. ${ }^{44}$ In the Baltic provinces and Poland, new churches and cathedrals ensured that the inhabitants would not forget who ruled their land. Cathedrals in Riga and Warsaw carried the name of Alexander Nevskii, Alexander III's namesake, and the traditional defender of Russia against Western Christendom. Publications celebrated their construction, providing conspicuous statements

43 The requirements are indicated in articles 205 and 206 of the "Stroitel'nyi Ustav." Svod Zakonov Rossiiskoi Imperii (St. Petersburg: Tip. II Otd. Sobstvennoi E.I.V. Kantseliarii, 1857), 12: 47. The procedures are suggested in the memoranda: "Po otnosheniiu Ministerstva Vnutrennikh Del o postroike tserkvi vo imia Skorbiashchei Bozhiei Materi v selenie Imperatorskogo steklannogo zavoda na naberezhnoi r. Bol'shoi Nevy," RGIA, 797-63-225; and "O postroike kamennoi tserkvi na naberezhnoi Obvodnogo kanala bliz Varshavskogo Voksala v S-Petersburge,” RGIA, 799-25-1289 (1903). The first church on the Obvodnyi Canal, completed in 1894, was dedicated to the marriage of Nicholas and Alexandra; the present church, begun in 1904, marked the birth of Tsarevich Aleksei (Shul'ts, Khramy Sankt-Peterburga, 121).

44 The most comprehensive study of the use of church architecture to express Russian imperial dominion is Piotr Paszkiewicz, W sluzbie Imperium Rosyjskiego 17211917: funkcje i tresci ideowe rosyjskiej architektury sakralnej na zachodnich rubiezach Cesarstwa i poza jego granicami (Warsaw: Inst. of Art, Polish Academy of Sciences, 1999). 
of domination. A large orthodox cathedral in Russian-Byzantine style had been built in the center of Riga from 1876-1884. In 1888, the Imperial government commemorated the Borki disaster there with an elaborate Russian-style votive chapel of marble shaped in tent form, its surface covered with innumerable icons and mosaics, placed on the square before the city's railway station. ${ }^{45}$

Church construction in Estland guberniia was actively promoted by its governor, S. V. Shakhovskoi, an ally of Pobedonostsev and active supporter of Russification. Shakhovskoi won central government support for the spread of Russian Orthodox religion and education among the population. ${ }^{46} \mathrm{His}$ pride was the massive Alexander Nevskii Cathedral (1894-1900) designed in Moscow-Iaroslavl style, which its architect M. Preobrazhenskii described as "the most characteristic of Russian church architecture" (Figure 3). It was placed, Preobrazhenskii wrote in the dedicatory volume, at the "best site," which allowed the cathedral on its commanding heights "to dominate the city." This was Reval's most prominent square, the Domberg, called by Toivo Raun "the traditional bastion of the Baltic German elite." ${ }^{\prime \prime} 7$

The acquisition of the property adjacent to the cathedral involved the confiscation of private lands and required considerable pressure from Petersburg authorities and the emperor himself. A recommendation by a committee chaired by the deputy Minister of the Interior, Viacheslav Plehve, prompted a lengthy inter-ministerial correspondence. The Minister of Justice, Nikolai Manasein, considered the legal grounds for seizure weak, but he concluded that the alternative-building the church at another, lower site, where it would stand beneath Lutheran churches-was inadmissible. Laws, however troublesome, could not deter the symbolic solution: "an Orthodox cathedral, rising above numerous Lutheran churches, will occupy a beautiful, dominating location that is suitable for an Orthodox shrine in a Russian state." 48

Parish churches constructed between 1887 and 1889 in Estland displayed the motifs of Muscovite architecture. They fit a standard plan: a tent-form

\footnotetext{
45 Riga und seine Bauten (Riga: P. Kerkovius, 1903), 181-4.

46 Edward Thaden, "The Russian Government," in Russification in the Baltic Provinces and Finland, 1855-1914, ed. Edward Thaden (Princeton: Princeton University Press, 1981), 67-70; Toivo U. Raun, “The Estonians," in idem, 323-5.

47 Preobrazhenskii, Revel'skii Pravoslavnyi Aleksandro-Nevskii Sobor, 3-4; Raun, "The Estonians," 325.

48 "Po voprosu o postroike sobora v g. Revele, Estliandskoi gubernii," RGIA, 797-91-6.
} 
belfry beneath an onion cupola was attached by a passageway to the main cubiform church corpus, itself surmounted by a central onion cupola and with four small cupolas at the corners. Kokoshniki decorated the bases of the central cupola, and, in several churches, the tent roofs themselves (Figure 6). A luxury album containing photographs of seven of the churches celebrated the achievement. The album was issued by the commission supervising the construction, which was chaired by a member of the Provincial Bureau (gubernskoe pravlenie), A. A. Shirinskii-Shikhmatov, and consisted of Russian officials and priests. ${ }^{49}$

The use of ecclesiastical architecture as a statement of symbolic conquest was most apparent in Warsaw, where almost twenty Russian-style Orthodox churches were built in the 1890s. In Warsaw, as in Riga, the Moscow-Byzantine style remained prevalent, signifying imperial domination. The principal cathedral, Leontii Benois' immense Alexander Nevskii Cathedral (1894-1912), combined the classical Moscow-Byzantine form with abundant kokoshniki on the roof affirming the national character of imperial rule. Its 70-meter bell tower made known the Russian presence by dwarfing surrounding buildings. It became "the most conspicuous accent of the city skyline," prompting lewd comparisons from the city's residents. 50 Initiative belonged to the GovernorGeneral, I. V. Gurko, who solicited contributions from Russian donors. The chancellery of the Governor-General appealed to residents of Moscow: "By its very presence ... the Russian Church declares to the world ... that in the western terrains along the Vistula, mighty Orthodox rule has taken root ... the appearance of a new ... church in Warsaw as a boundary and pillar of Orthodox Russia will animate the hopes of the Orthodox Slavs for unification under the Orthodox cross." The journal of the Warsaw Eparchy boasted in 1912, "Under the dome of this magic temple, we find ourselves as if on Russian soil." 51

49 Al'bom vidov tserkvei Estliandskoi gubernii, sooruzhennykh pod vedeniem Revel'skogo nabliudatel'nogo komiteta po postroike tserkvei, prichtovykh i shkol'nykh zdanii (Reval: n.p., 1889?); Adres-kalendar' na 1889 g. (St. Petersburg, 1889), 285. Shirinskii-Shikhmatov later rose to the positions of provincial governor, member of the State Council, official in Nicholas II Court, and Chief-Procurator of the Holy Synod (A. A. Mosolov, Pri dvore poslednego Rossiiskogo imperatora [Moscow: Ankor, 1993], 244, 273).

50 Piotr Paszkiewicz, "The Russian Orthodox Cathedral of Saint Alexander Nevsky in Warsaw," Polish Art Studies vol. 14 (1992): 64-5, 67.

51 Ibid., 65-6. 
PART II. THE IMPERIAL MYTH IN ARTISTIC TEXTS

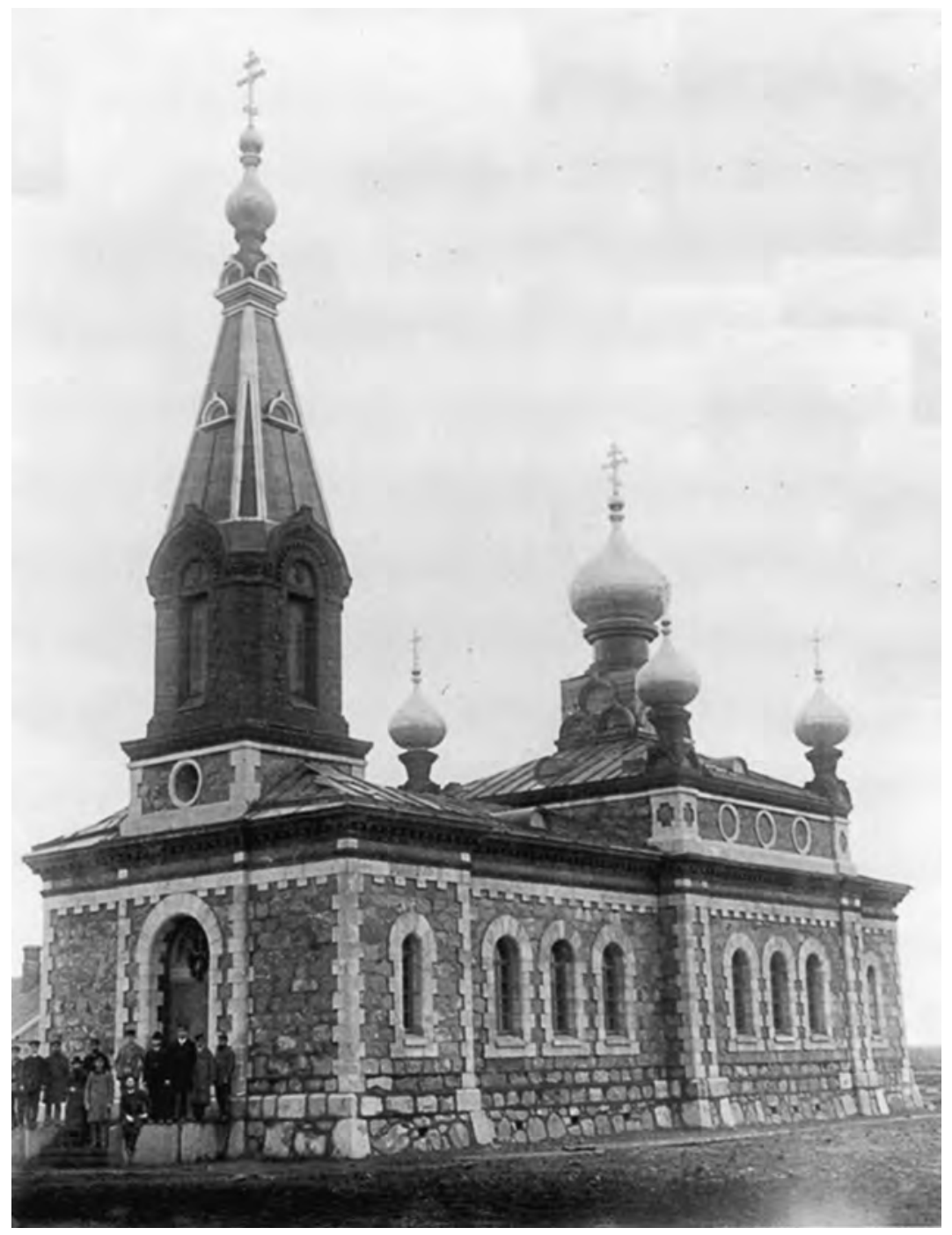

Figure 6-Parish Church, Estland. Al'bom vidov tserkvei Estliandskoi gubernii, sooruzhennykh pod vedeniem Revel'skogo nabliudatel'nogo komiteta po postroike tserkvei, prichtovykh i shkol'nykh zdanii. (Reval: n. p., n.d.) 
Imposing Orthodox churches also announced imperial rule over Central Asia. The Cathedral of the Transfiguration, a large neo-Byzantine church completed in 1888, towered over the governor's house on the principal square of Tashkent. It was the most prominent building in the center of the new Russian city, which Robert Crews has analyzed as an expression of the imperialist and colonial mentality of late nineteenth-century Russian expansion. The Teachers' Seminary, on the other hand, was designed in the 1880s in Muscovite style. In 1898, a tall five-cupola tent-style brick church, designed by A. L. Benois, was built into the walls of the seminary compound, signifying the particular national and ethnic character of the Russian presence in Tashkent. ${ }^{52}$ A similar tent-style church went up in Baku in the 1880s. ${ }^{53}$ Russian missionaries and officials in the Caucasus pointed out the symbolic role of Orthodox churches in the religious guidance of mountain peoples. The Viceroy of the Caucasus, Prince Alexander Dondukov-Korsakov, wrote that the "external" aspects of the faith were most important for "Eastern peoples." 54

Russian-style churches carried the image of Orthodox autocracy abroad. 55 Construction of a Russian cathedral in Port Arthur, designed by Alexander Gogen, began in 1902. Its character, announcing Russian ambitions in the Far East, was to be "purely Muscovite, without admixture of Byzantine or other style." The architect gave the cathedral the form of a ship, appropriate for a naval base, with seven gilded cupolas and a high, tent-shaped bell tower. He placed it high above the city so that the cupolas would impress those viewing from the sea $^{56}$ (Figure 7). Similar churches were built in Carlsbad, Vienna, and Copenhagen. ${ }^{57}$ The spiritual significance of the new national myth was announced by the church of Maria Magdalena, which Alexander III

52 Robert D. Crews, "Civilization in the City: Architecture, Urbanism, and the Colonization of Tashkent," in Architectures of Russian Identity, 123; V. A. Nil'sen, $U$ istokov sovremennogo gradostroitel'stva Uzbekistana: xix-nachalo xx vekov, 49-52, 64-5; Robert Crews, "Civilization in the City," conference paper, 5.

53 Zodchii (1889): Plates 35-38.

54 Austin Jersild, "From Frontier to Empire: The Russification of the Causasus, 18451917," unpublished mss.,Chapter 12, 493 note 124.

55 On Russian national churches abroad see Piotr Paszkiewicz, $W$ sluzbie Imperium Rosyjskiego 1721-1917, passim.

56 Stroitel' (1900): 536.

57 Podvor'e russkoi pravoslavnoi tserkvi v Karlovykh Varakh (Prague: Ústrědní církevní nakladatelství, 1987); Zodchii (1881): 21, Plates 49-50. 


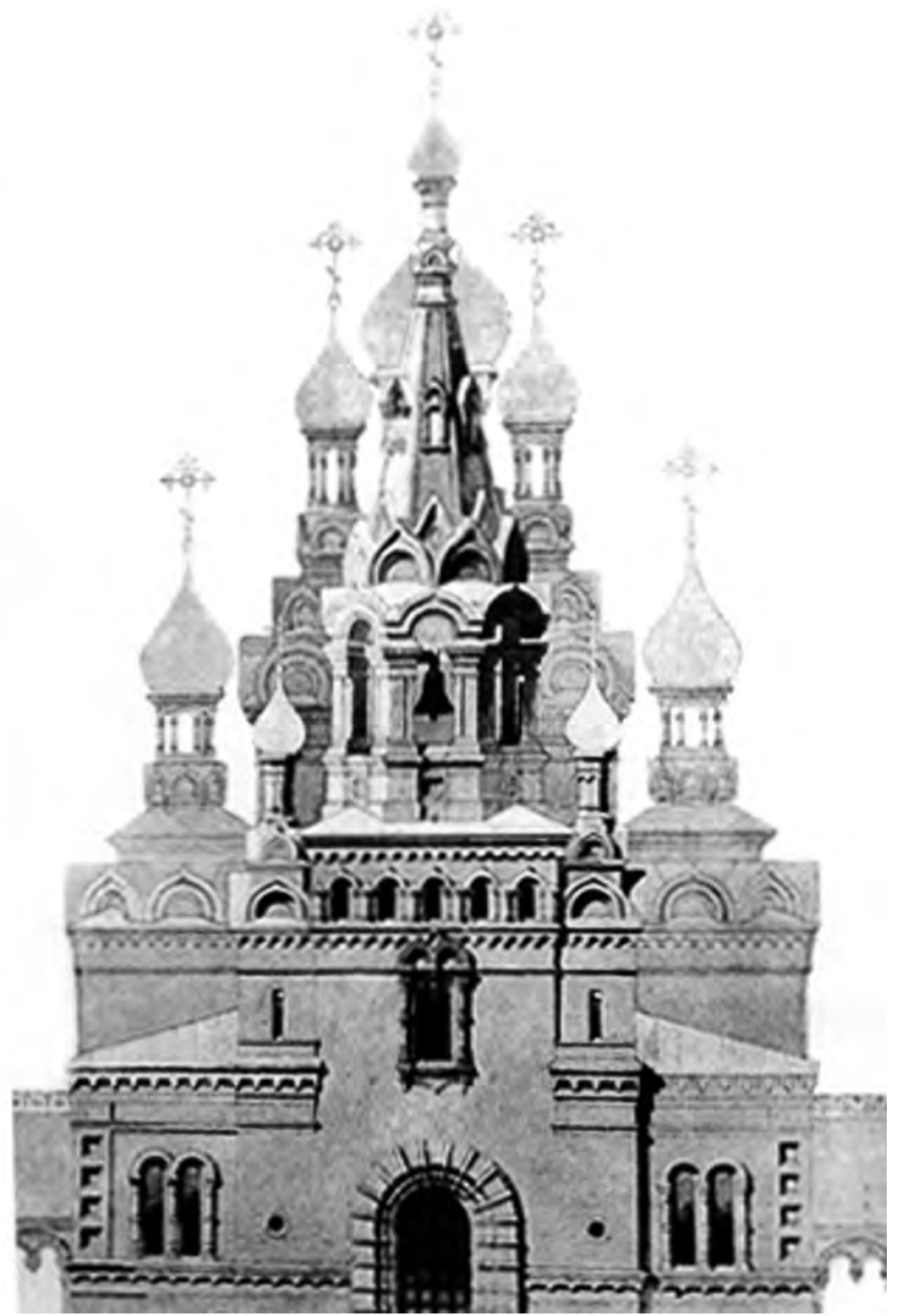

Figure 7-Alexander Gogen-Orthodox Church, Port Arthur. Stroitel', 1902 
commissioned in 1883, set prominently on the Mount of Olives at the Orthodox Gethsemane. The kokoshnik decoration and tent-shaped bell tower are visible from afar, identifying old Russian imagery and Orthodoxy for all to see across Jerusalem.

The new official style of church architecture repeated the pattern of earlier reigns, using buildings as imposing declarations of visions of change contemplated by the emperor and his entourage. The symbolic break with the past, however, was now sharper and more thoroughgoing, repudiating the Western cultural tradition that had elevated monarchs since Peter the Great and giving the autocracy a specific ethnic identity. It was an architecture alien to compromise, stating the absolute truth of the new myth. The flamboyance of the buildings, their redundancy of forms, their siting, and the proud and self-congratulatory texts that accompanied many of them indicated that the style was a celebration of power, showing the efficacy of the state in shaping the spiritual and cultural life of the nation. The writings that surrounded the design and construction of the churches set them in an ongoing narrative of power. They demonstrated the reality of the myth, the government's capacity to embody the spirit of the nation as enshrined in a particular architectural design.

The buildings themselves announced the resurrection of purportedly forgotten traditions. Manasein's description of the Reval Alexander Nevskii Cathedral as "an Orthodox shrine in a Russian state" characterizes the thinking of the officials sponsoring the new national-style churches. Architecture could resurrect the past and shape attitudes. A shrine, sviatynia, a sacred object, designated not a revelatory religious event or person, but an immanent national identity, made into a dominating visual presence. The symbols of Muscovy would command the belief in state and Orthodoxy that officials believed would make Estland part of a Russian state.

The appeal to nationality in architecture represented a reaffirmation of the preeminence of state and empire. To be sure, the new official style responded to the search for native artistic expression of the democratically inspired revival architecture of the 1860s and 1870s. But this style was an official construction, a created architecture - the attempt of an imperial regime to find a grounding in the ruled population by claiming their history. In this respect, it resembles the British colonial administration's creation of a national revival style in India, 
the Indo-Saracenic style. Like the Russian official national style, introduced after the terrorists' assassination of a tsar, the "Indo-Saracenic" style was invented after a traumatic revolutionary event-the Sepoy mutiny of 1857which had thrown the premises of imperial rule into doubt. ${ }^{58}$ In both cases, the ruling elites claimed the spirit of the nation by using architecture to assert mastery over its past.

The Russian emperor was asserting a claim to an ethnic Russian past, one that previous monarchs had avoided. He evoked a solidarity between rulers and ruled in the Russian provinces and claimed a national mission in non-Russian territories. In this respect, the new official style enjoyed somewhat greater popular appeal than did the Indo-Saracenic in India, which apparently was ignored by the native population. "Society," particularly conservative officials, noblemen, and merchants, liked the elaborate decorations on old Russian churches. However, with the revolution of 1905, critical voices, especially among the architects themselves, pointed out the flaws and anomalies in the style. Writing in 1905, V. Kurbatov lamented the transformation of churches into "a kind of architectural museum." "In the construction of nearly all contemporary churches, the Russian style has become the unavoidable requirement. One cannot say, though, that this requirement has been successfully fulfilled anywhere." It was based on the erroneous notion that before Peter a single style had prevailed, "all the forms of which could be realized within a single building." 59

Andrei Aplaksin, an architect attached to the St. Petersburg eparchy, deplored the triteness of national church architecture in a speech delivered to the Fourth Congress of Russian Architects in January 1911. The imperative to follow the prescribed style, Aplaksin declared, cost the architect his professional integrity. "The role of the architect, being reduced to a minimum, amounts to composing a rough draft in the process of planning." He blamed this situation on government restrictions and public taste, but above all on the architects themselves, whom he called upon to go beyond the "crude tastes of the crowd" to study the architecture of the past and struggle against the

58 Metcalf, An Imperial Vision, 24, 57, 86-8, 113-15, 128, 140, 245, 249-50. It is interesting to note that the favorite building style of the indigenous merchant elite in Bombay was the English Gothic, which they thought would bring them closer to their colonial rulers (Ibid., 90-98).

59 Zodchii (1905): 497-8. 
ignorance of the clergy. Aplaksin observed that some architects had already begun to work creatively with historical forms and to allow more play to their imagination. This "neo-Russian" style, which Aplaksin himself practiced, resulted in innovation and imaginative and tasteful use of the national forms, several of them in churches beyond the jurisdiction of official Orthodoxy. ${ }^{60}$

Many of these churches continued to promote the national mission of Russia in the borderlands. Aleksei Shchusev's striking Trinity Cathedral, at the Pochaev Monastery in Kremenets in the Ukraine, followed the prototype of the twelfth century Iur'ev monastery, with its spare white walls, prominent lesenes that articulate the internal structure of the church, and a central dome with a helmet cupola. The Pochaev Monastery was an outpost of Orthodoxy and empire in Volynia province, about five miles from the Austrian border. It was known both for the Pochaev Miracle Icon, which attracted many pilgrims, and the anti-Duma, anti-Semitic weekly, Pochaevskii listok, edited there by the monk, Iliodor. The Trinity Cathedral was an esthetic national riposte to the eighteenth-century Baroque Dormition Cathedral in the monastery. ${ }^{61}$

The seventeenth century remained a model for churches associated with autocracy especially in and around St. Petersburg. Stepan Krichinskii's "Tercentenary Church" was built to mark the 1913 celebration of the threehundredth anniversary of the beginning of the Romanov dynasty (Figure 8). The initiative had been taken by the Fedorovskii Gorodetskii Monastery in Nizhegorodskii guberniia. The monastery's hegumen, the Arkhimandrite Aleksii, had worked actively to turn the monastery's small chapel in the Nikolaevskii (Moscow) Railroad Station into a church. He succeeded in gaining the patronage of Grand Duke Michael Aleksandrovich and secured

60 Ibid. (1911): 23-4; William Craft Brumfield, "The 'New Style' and the Revival of Orthodox Church Architecture, 1900-1914," in William C. Brumfield and Milos M. Velimirovic, Christianity and the Arts in Russia (Cambridge: Cambridge University Press, 1991), 105-23; Brumfield, The Origins of Modernism, particularly Chapters 4 and 6; one of Aplaksin's neo-Russian churches is shown in Shul'ts, Khramy SanktPeterburga, 106-7; two are mentioned in Utrachennye pamiatniki..., 36.

61 The monastery had been a center of the Uniate faith. In 1831, after the monks had joined the Polish insurgents, Nicholas I had placed it under the "Orthodox Church administration" (Brumfield, The Origins of Modernism, 105-7); Entsiklopedicheskii Slovar' Brokgauza-Efrona (St. Petersburg: I. A, Efron, 1898), 48: 767; John Curtiss, Church and State in Russia: The Last Years of the Empire (New York: Octagon, 1940), 255. 


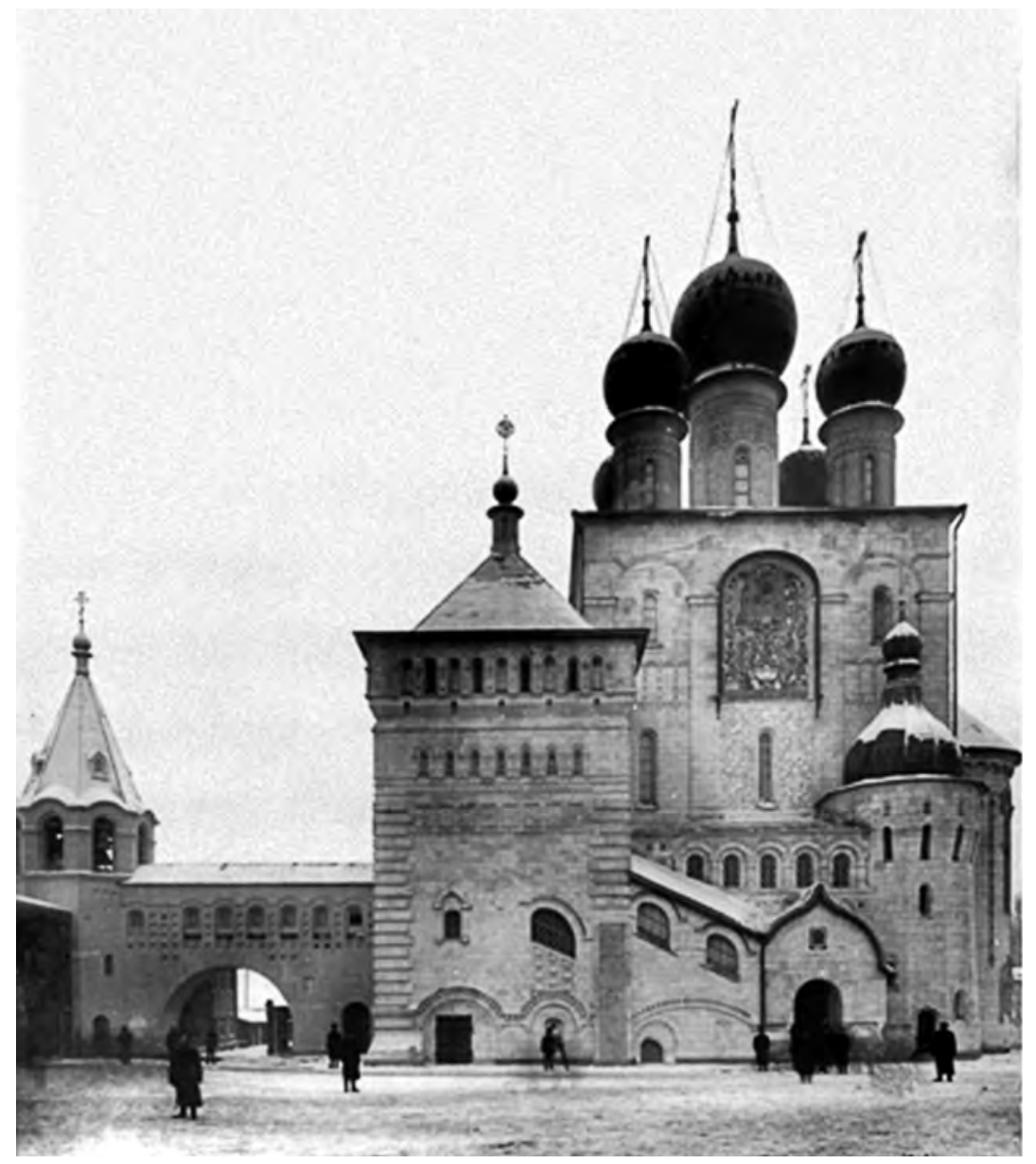

Figure 8-Stepan Krichinskii-Tercentenary Church, St. Petersburg. GARF, fond 601 . 
funds from a national subscription, the St. Petersburg City Duma, church and governmental institutions, and from the emperor himself. ${ }^{62}$

The Tercentenary Church was an exact copy of Rostov wall churches of the seventeenth century, which, Krichinskii asserted, exemplified the true Russian style. It was considerably more elaborate-built in reinforced concrete-larger, nearly as high as Kazan Cathedral, and accommodated over 4,000 worshipers. When completed in 1914, it cost one million rubles, several times the original estimate. The north wall had a large majolica icon of the Fedorov Mother of God, based on Iaroslavl frescoes and a genealogical tree of the Romanov house. The church bells were cast with reliefs of members of the ruling family and their patron saints. A kremlin was to be built around the church. "The idea was to create an entire corner of the seventeenth century," Krichinskii wrote. It would transplant a bit of Muscovy to St. Petersburg, where many, including the art critic George Lukomskii, believed it did not belong. ${ }^{63}$

Krichinskii's design answered the needs of an era in which religion retreated from public view to sequestered spaces behind the walls of monasteries, to provide a model of the spiritual life. The purpose of the new buildings was exemplary, rather than admonitory, showing the persistence and revival of old-Russian piety among those forswearing the contestation and distraction of contemporary society. Among these were the emperor and empress, who created their own replica of seventeenth-century spirituality at the Fedorov village at Tsarskoe Selo, which was built for the tsar's Convoy and His Majesty's Rifles. The village was to provide a spiritual model shaped by the tsar of a reborn autocratic nation. Krichinskii designed a kremlin wall of elaborately decorated white Staritskii limestone to surround the village. ${ }^{64}$

62 Istoriia Fedorovskogo Gorodetskogo monastyria (Nizhegorodskaia guberniia) i postroenie $v$ S-Peterburge khrama v pamiat' 300 iubileiia tsarstvovaniia imperatorskogo Doma Romanovykh (St. Petersburg, 1913), 113-24.

63 S. Krichinskii, "Khram v pamiat' 300-letia doma Romanovykh," Zodchii (1914): 122-3; Niva 5 (1914): 97; “Snimki vidov tserkvi postroennoi v pamiat' 300-letiia tsarstvovaniia Romanovykh," GARF, 601-1-1841; Georgii Lukomskii, "Khram v pamiat' 300-letia tsarstvovaniia goma Romanovykh," Appolon 5 (1914): 47-9; "Zhurnaly komiteta dlia ustroistva prazdnovaniia trekhsotletiia Doma Romanovykh," RGIA, 1320-1-30, 5-6, 43-5.

64 Pamiatniki arkhitektury prigorodov Leningrada (Leningrad: Stroiizdat', 1983), 1269. Vladimir Pokrovskii's unrealized project for a Military-Historical Museum in St. Petersburg is an example of this (Ekaterina Abrosova, "Arkhitektor Vysochaishego 
The centerpiece was the Fedorov Cathedral (1908-1912), dedicated to the protectress of the dynasty, the Fedorov Mother-of-God. The architect Vladimir Pokrovskii took the model of the fifteenth-century Annunciation Cathedral in the Moscow Kremlin, which had served as the private chapel for the tsar's family before Peter the Great, but he added seventeenth-century elementstent-shaped roofs over the main entrance and covered vestibules. He also drew on Novgorod motifs for the bell tower. ${ }^{65}$

The cathedral was intended as a museum of early-Russian religious art that would attest to the rebirth of a national religious esthetic and hold numerous icons and other religious treasures. ${ }^{66}$ For Alexandra, Pokrovskii's assistant, Vladimir Maksimov, constructed a "cave church" in honor of Serafim Sarov below the cathedral, where the imperial family could worship before communion. ${ }^{67}$ The walls were painted with motifs from the terems, the chambers where women had been kept sequestered in old Russia. The vestibules were decorated with scenes of Hell and Paradise and above, the fortress of heaven. The chapel held a pitcher of water from the stream at Sarov, in which the imperial family had bathed, an icon of Serafim, a box with a relic, and a copy of the "Tenderness" icon, which Serafim had kept in his cell, and

Dvora Vladimir Aleksandrovich Pokrovskii," in Tsar'ino: Pravoslavnyi istorikokraevedcheskii almanakh, vol. 98, Vyp. 4: 44-46). Also see Vladimir Maksimov's unrealized projects for the building complex of the Railroad Guards' regiment and a hotel complex at Tsarskoe Selo (Arkadii Krasheninnikov, "Russkii zodchii Vladimir Nikolaevich Maksimov, [1882-1942]," Tsar'ino: Pravoslavnyi istorikokraevedcheskii almanakh, vol. 98, Vyp. 4, 74).

65 Kirichenko, Russkii stil', 305-8, 310-1, 366-8.

66 Abrosova, "Arkhitektor Vysochaishego Dvora Vladimir Aleksandrovich Pokrovskii," 55-6; One of the principal sponsors of the church was the chief of the Tsarskoe Selo Palace Administration, Mikhail Putiatin, a former officer of the Preobrazhenskii Guards and Marshal of the Court. Putiatin was a lover of Russian antiquities, who had helped organize the tsar's visit to Sarov and had designed the shrine for the saint's remains. He closely supervised the decoration of the church and insisted that the iconostasis be in Old Russian style. The church warden was Captain N. Loman, the author of the popular account of Nicholas II's coronation and a popular biography of Alexander II, and an associate of Rasputin (Général Alexandre Spiridovitch, Les dernières années de la cour de Tsarskoe-Selo [Paris: Payot, 1928-1929], 1: 352, 2: 253-62); Mosolov, Pri dvore poslednego Rossiiskogo imperatora, 28, 118.

67 On Maksimov, his buildings, and his tragic fate under Stalin see Krasheninnikov, "Russkii zodchii Vladimir Nikolaevich Maksimov (1882-1942)," 63-83. 
his pectoral cross. ${ }^{68}$ The cathedral thus incorporated the symbols of popular charismatic religion into the artistic motifs of early Russia.

The town was to represent a spiritual model of a monarchist nation taken from Russia's distant past. The officers and soldiers of the Convoy and Sharpshooter Regiments worshiped in the church and lived in the old-Russianstyle barracks. Dressed in Russian costumes resembling early prototypes, designed by Victor Vasnetsov, they enacted an imagined seventeenth century, on a stage set of early Russia, to set the military-religious entourage of the imperial family apart from the court, state, and Orthodox Church. ${ }^{69}$

The revival of seventeenth-century architectural forms by the monarchy both expressed and sustained a myth that set Russian autocracy apart from the monarchies of the West and gave the Russian emperor a religious mandate for the preservation of his absolute power. The building of revival churches after 1881 sought to demonstrate the vitality of the historical spirit of Muscovite Rus' and affirm the autocrat's title to the national past. After the revolution of 1905 , the recreation of the past withdrew behind monastery walls to sustain illusions of omnipotence and mass support that allowed Nicholas II to believe that he still represented and spoke for a Russian nation.

68 Fedorovskii gosudarev sobor $v$ Tsarskom Sele: Vyp. I, Peshchernyi Khram vo imia prepodobnogo Serafima sarovskogo (Moscow: A. A. Levenson, 1915); Rodina, September 16, 1912, 538; Spiridovitch, Les dernières années de la cour de TsarskoeSelo, 2: 253-60; Maurice Paléologue, Alexandra-Féodorowna, impératrice de Russie (Paris: Plon, 1932), 51-2; A. N. Naumov, Iz utselevshikh vospominanii, 1868-1917 (New York: A. K. Naumova and O. A. Kusevitskaia, 1954-1955), 2: 226.

69 S. Ia. Ofromisova, "Tsarkaia sem'ia (iz detskikh vospominanii)," Russkaia Letopis' (Paris, 1925), 7: 240-1; I. M. Shadrin, "Pridvornaia Pevcheskaia Kapella i Imperatorskii Dvor do Velikoi Voiny 1914-1917 gg.," Bakhmeteff Arhive, Columbia University, Shadrin Collection, 55. On the theatricalization of church architecture in the neo-Russian style and particularly in Pokrovskii's Fedorov Sobor, see A. V. Ikonnikov, Istorizm v arkbitekture (Moscow: Stroiizdat, 1997), 304, 310. 


\section{St. Petersburg the Imperial City and Peter Tchaikovsky ${ }^{1}$}

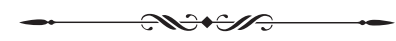

$\mathrm{U}$ pon his death in 1893, Peter Tchaikovsky's Moscow friends and admirers argued that he should be buried in Moscow, where he had lived and taught for many years. His brother Modest insisted that he be laid to rest in Petersburg: "He received his education here, first at the School of Jurisprudence, then at the conservatory. Here his operas and symphonies enjoyed their first successes, here he had so many artistic attachments!" 2 We can understand the dilemma. Peter Tchaikovsky had no real home, not Moscow, not Petersburg. I will return to this question later. But St. Petersburg was Tchaikovsky's city in many ways. He was a product of Petersburg society and the rich cultural life that had evolved in the capital. Most important, his music captures the spirit of Petersburg the imperial city, its mystique, aura, power, and pervasive sadness.

Imperial Petersburg was a symbol of the westernized Russian monarchy of Peter the Great, displaying the irresistible power of his will, creating beauty out of nothingness. St. Petersburg would be a demonstration that Russia was a European state. Not only would Petersburg be a European city; it would be the most European of cities. Petersburg rivaled European cities by incorporating variations on western architectural styles: from the mansions and gardens of Amsterdam, the palaces and gardens of Versailles, the canals of Venice, and the vast neoclassical squares of Napoleonic Paris.

Petersburg is a European city, but its appearance is strikingly Russian. The size, the variety, and the flamboyance of the borrowed forms give it a particularly Russian look. By the middle of the nineteenth century, the

1 Keynote Address, Carnegie Hall Tchaikovsky Festival, October 15, 2012.

2 Alexander Poznansky, Tchaikovsky: the Quest for the Inner Man (New York: Schirmer, 1991), 594. 
capital had become a city so western that it was not western at all, a distillation, an ideal western city. Alexander Herzen wrote in 1842, "St. Petersburg is different from all European cities in that it resembles them all." 3

The palaces and drill fields of Petersburg provided a setting for performances of the ceremonies of the westernized absolute monarchy, the most absolute of absolute monarchies. It preserved the representational culture of early modern absolutism long after that had declined in most of Europe. Processions and balls in the palaces and massive reviews on the Palace Square and Field of Mars displayed again and again the preeminence and power of the ruler and his elite. St. Petersburg was also the center of the vast tsarist administration, and leading officials - ministers and state secretaries, as well as the tsar's suite-joined in the presentations of the Russian imperial court.

Petersburg was the setting where the tsar and the most prominent figures in the Russian court performed their roles in the drama of autocratic power. In many respects, Russian monarchy accords with Clifford Geertz's model of the "theater state" and the "theatricality" teatral'nost' that characterized the political culture of Russian monarchy until its demise. ${ }^{4}$ In St. Petersburg, the monarch brandished the symbols of power to produce the effects of what was described by the word torzhestvennost', the solemn festivities of power that exalted the monarch before his subjects. (See the introductory essay to this volume.)

The vast palace square, with the monumental buildings enclosing it epitomized the spirit of torzhestvennost' (Figure 1). The immense rococo Winter Palace, the work of Bartollommeo Rastrelli, symbolized the expanse and power of the autocracy. The architectural historian John Summerson described the Winter Palace as "a brutally literal Bilbiena stage design," which could be tolerated only in Russia, where it gave "an effect of absolute, grim, and careless dominion." 5

3 A. I. Gertsen, Polnoe sobranie sochinenii i pisem (Petrograd: Literaturno-izdatel'skii otdel Komissariata po prosveshcheniu, 1919), 3: 11; see also Iu. M. Lotman, "Simvolika Peterburga i problemy semiotiki goroda," in Semiotika goroda i gorodskoi kul'tury Peterburga, Trudy po znakovym sistemam XVIII (Tartu: Tartu University Press, 1984), 31-5.

4 On the theater state, see Clifford Geertz, Negara: The Theatre State in NineteenthCentury Bali (Princeton: Princeton University Press, 1980), 121-36; On the theatricality of Petersburg, see Lotman, "Simvolika Peterburga," 37-41.

5 John Summerson, The Architecture of the Eighteenth Century (London: Thames and Hudson, 1986), 34. 


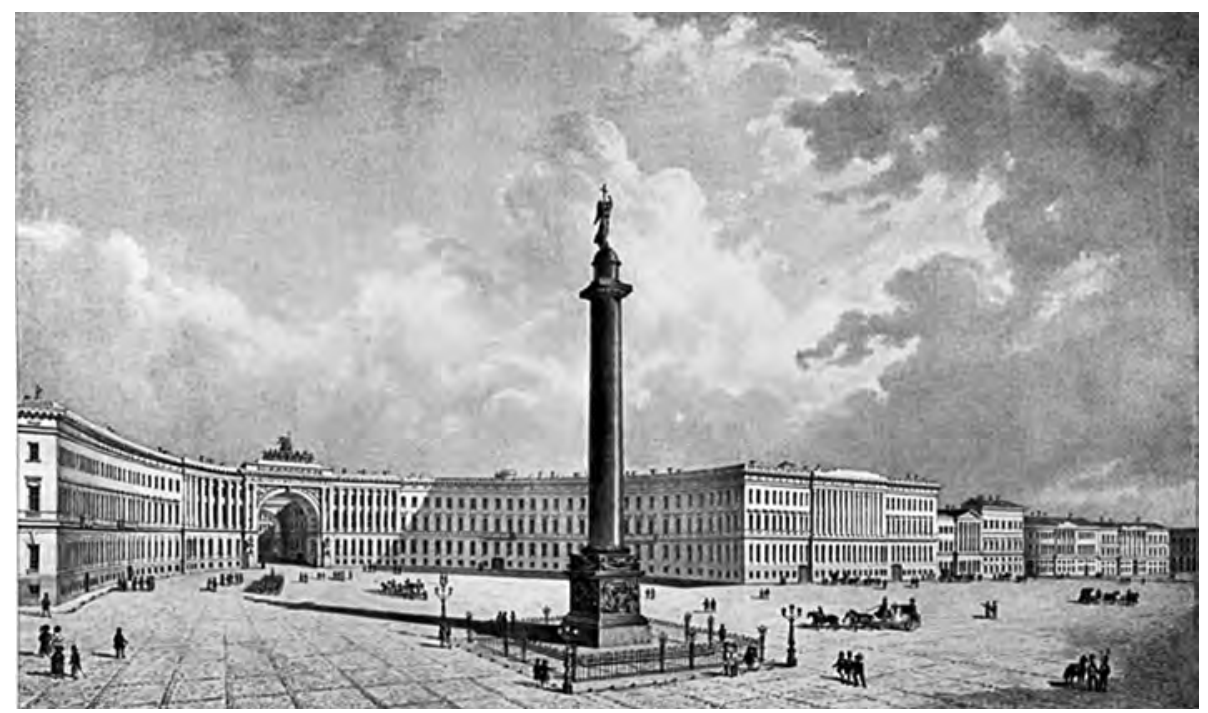

Figure 1-A. Ricard de Montferrand-The Alexandrine Column on Palace Square, St. Petersburg. Montferrand, Plans et détails du monument consacré à la mémoire de l'Empereur Alexandre (Paris: Thierry, 1838).

In the center of the square stands the Alexandrine column, dedicated in 1834 , which served as "one of the primary visual foci of the classical center of the city." 6 The column memorialized the triumphs of the reign of Alexander I. Designed by the architect Auguste Montferrand, it incorporated the models of the Trajan Column in Rome and the Vendôme column in Paris, but, as Montferrand boasted, was taller than either. The figure of the angel hovers over the square. Its face, almost invisible from the ground, is that of Tsar Alexander (Figure 2). However, Alexander is a militant, not a gentle and endearing angel, the instrument of Providence in defeating Napoleon, a symbol of power and destiny. The reliefs on the base celebrate his military victories. Garlands, eagles, and laurel wreathes resemble those on the Trajan column. Russian military insignia included helmets that at the time were thought to belong to the princes Oleg and Alexander Nevskii.

The great arc enclosing the square by Carlo Rossi took form during the 1820s (1819-1828). The headquarters of the Russian General Staff and the center is flanked by the buildings of the former Ministry of Finances and

6 George Heard Hamilton, The Art and Architecture of Russia (Hammondsworth: Penguin, 1983), 333. 


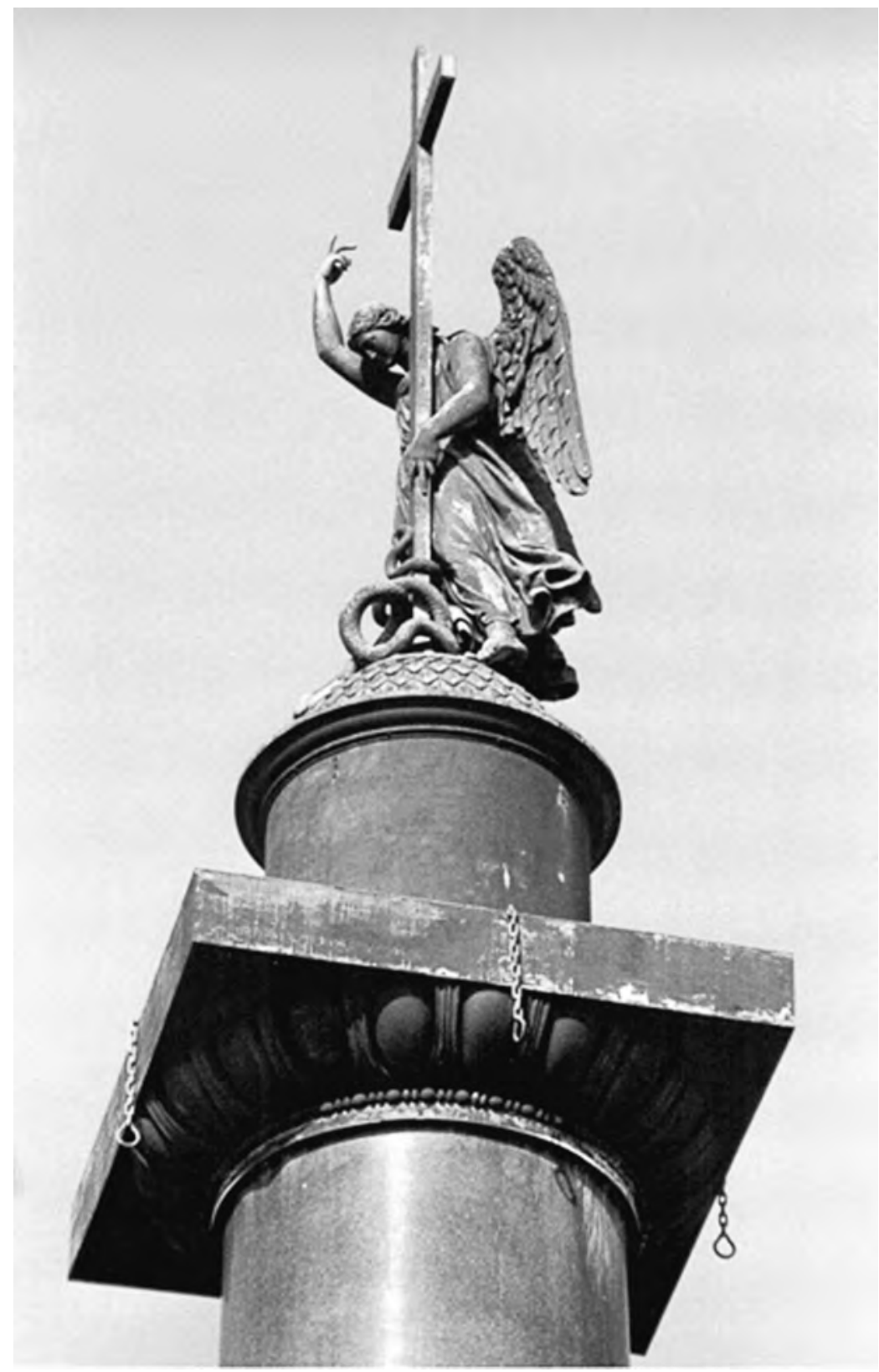

Figure 2-Boris Orlovskii-Statue of Alexander I. Author's photograph. 
Foreign Affairs, both of which Alexander I had established during the first years of the nineteenth century. Atop the arch is a chariot, the classical ensemble of a chariot driven by the figure of winged victory (Figure 3). It is clearly patterned on the models of the Brandenburg Gate in Berlin (1791) and L'Arc de Triomphe du Carrousel in Paris (1808), though its chariot is drawn by six horses rather than the classical quadriga. The square provided the setting for massive reviews of brightly dressed guardsmen marching in unison to their commander's will.

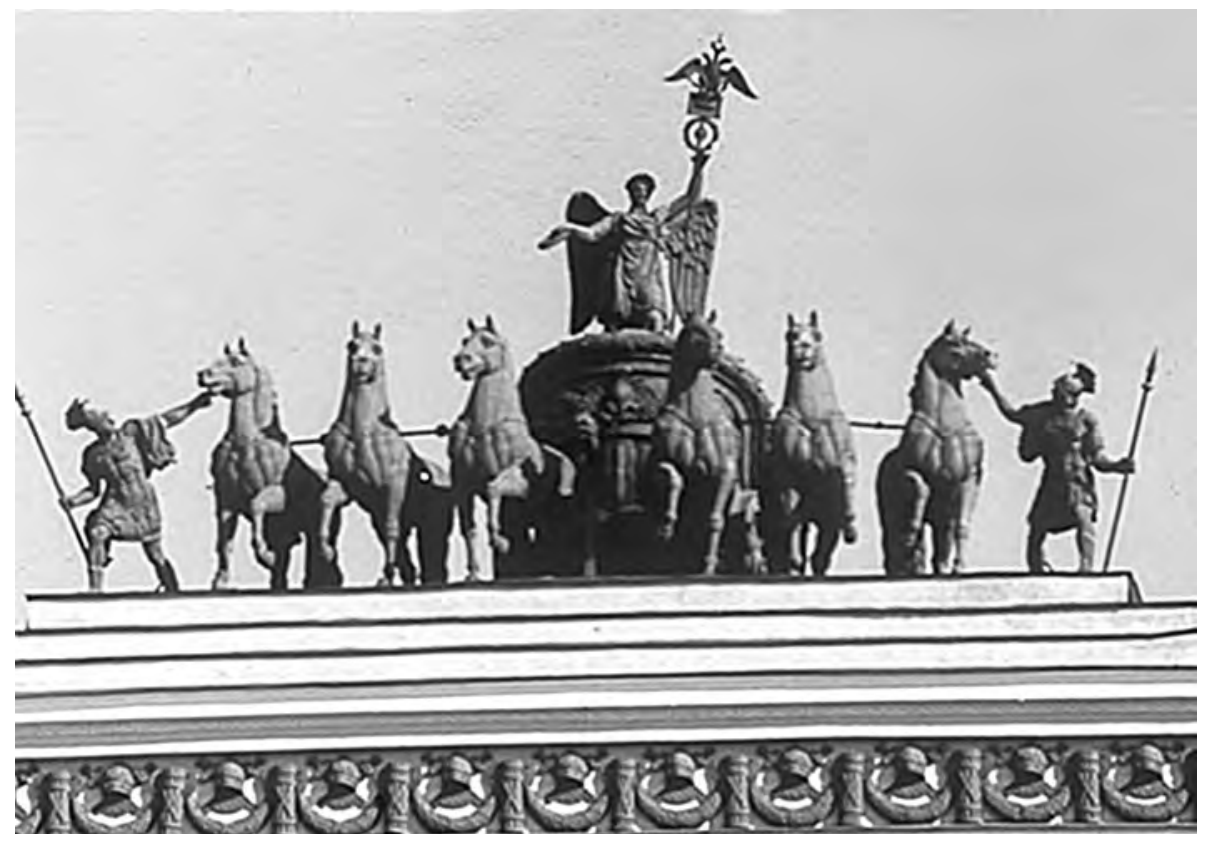

Figure 3-Chariot with Figure of Winged Victory. Author's photograph.

The celebration of the dedication of the column in 1834 gives a sense of the grandeur and sweep of tsarist ceremony. Nicholas I, his brother-in-law, Prince William of Prussia, at his side, prayed together with his entire army. "A spectacle that was at once touching and instructive," Ivan Butovskii wrote in a brochure describing the spectacle. Nicholas fell to his knees, followed by the entire army. When the Protodeacon uttered the prayer of Eternal Memory, the cloth fell, bearing the column to public view. Nicholas then took command of the guard, and saluted the monument to the strains of band music, with loud shouts of "Hoorah" from the crowd. The thunderous 248 
gun salute that followed, accompanied by blaring music, struck Butovskii as a "frightening dream." The people crossed themselves and shed tears of tender pity (umilenie) while they gazed intently at the monument and Nicholas I standing before the column with lowered sword. ${ }^{7}$

The poet Vasilii Zhukovskii was struck dumb by the scene:

The miraculous fusion of earthly power reduced to dust, with the mysterious power of the cross, rising above it and the invisible presence of that without name, expressing everything that is dear to us, something whispering to the soul, "Russia, your past glory is your future glory" and finally the touching word eternal memory and the name ALEXANDER, whereupon the drape fell from the column, followed by a thunderous prolonged Hoorah, combined with sound of five hundred cannons, from which the air was transformed into a festive storm of glory ... For the depiction of such moments there are no words and the very recollection of them destroys the gift of the one who describes. ${ }^{8}$

Tchaikovsky was an imperial composer in several respects. First, he shared the imperial mystique, and many of his compositions shared an imperial idiom epitomized by St. Petersburg with its characteristic modes of expression. Like the architects of Petersburg, Tchaikovsky engaged in a process of incorporation, by introducing into his compositions Russian folk themes, or melodies of his own creation that recalled folk themes, into western, German, formal structures. His genius for doing so was astonishing. Rather than lowering orchestral genres to level of the popular tunes, he lifted the popular to the stature of the symphonic. He was considered the most European of the Russian composers of the late nineteenth century and endured the obloquy of critics who favored reproducing indigenous national themes and modes.

Tchaikovsky's manner of incorporation was the counterpart to the doctrine of Official Nationality that prevailed during most of his life. The doctrine proclaimed a unity of the many nationalities in the all-Russian multinational empire, the Rossiiskaia Imperiia whose westernized noble elites,

Ivan Butovskii, Ob otkrytii pamiatnika Imperatoru Aleksandru Pervomu (St. Petersburg, 1834), 21-3.

8 Vasilii Zhukovskii, "Vospominanie o torzhestve 30ogo avgusta 1834 goda," Severnaia pchela, September 8, 1834: 807. 
and by extension their peasant populations, were devoted to the Russian Emperor, Rossiiskii Imperator, who served himself as symbol of European statehood. Ukraine, termed "Little Russia," was regarded as part of Great Russia, its inhabitants as Little Russians, and the Ukrainian language as a dialect of Russian. Tchaikovsky's music expressed the "Little Russian" assumptions of state ideology. Many of his compositions, such as his First Piano Concerto and his Little Russian Symphony, Number Two, incorporated renditions of three Ukrainian melodies into the European symphonic idiom. His operas, Cherevichki (The Slippers) and Mazeppa, drew upon Ukrainian folk songs. Mazeppa, based on Pushkin's poem Poltava, portrayed the horrific fate of a Cossack leader who betrayed the Emperor Peter the Great by seeking independence for Ukraine.

Other orchestral works combined official and folk motifs in an eclectic mix that expressed the nationality of the westernized empire. The 1812 overture incorporates an Orthodox hymn, a Russian folk dance, and of course the national anthem, "God Save the Tsar." Marche Slav combines Serbian and Russian folk melodies with the national anthem. It is a musical statement of an envisioned pan-Slavist empire. "God Save the Tsar," written by Prince Alexei L'vov in 1834, when the doctrine of Official Nationality was dominant, concludes six of Tchaikovsky's compositions, and represents perhaps the most powerful musical expression of the spirit of torzhestvennost'.

Valery Gergiev has remarked that Tchaikovsky's symphonic works, like his music for opera and ballet, were written for theatrical performance. They evoke a sense of theatricality, you can almost see the stage while listening. They ring with the exalted grandeur of Petersburg; they overwhelm and enthrall, elevating and romanticizing authority, so much so that they won the admiration of Tsar Alexander III, who helped Tchaikovsky with grants of money and a pension and even attended his funeral accompanied by the imperial family. But it would not be accurate to describe Tchaikovsky as a court or even as an official composer. He was officially honored only in the last decade of his life and was never in attendance at court. In this respect, he remained independent, on his own, but always dependent on patronage, most notably on the part of Madame von Meck. Tchaikovsky's music expresses, at once, the mystique of imperial grandeur and his apartness from that grandeur: his characteristic sadness, a melancholy longing for something closer, human, and permanent, alternates with resounding moments of the solemn and festive. 
Tchaikovsky's relationship to the state and his personal identity were largely. defined by his social background. $\mathrm{He}$ and his forebears belonged to the service nobility established by Peter the Great in the first decades of the eighteenth century. Two imperatives defined membership in the Russian nobility: an imperative of service to the throne, at first obligatory for life, after the emancipation of the nobility from service in 1762, an ethos governing the nobleman's life. The second imperative involved the nobility's adoption of the forms of European conduct and culture, a western identity that distinguished them from the serfs and other estates. To display their status, they wore European dress, learned European polite conduct, and acquired a taste for the culture of the west, particularly literature and theater, which created the basis for the illustrious Russian literary heritage we know today.

Agents of the centralized state, many of the noblemen lacked local attachments and a sense of home, which gave rise, Marc Raeff has written, to feelings of "alienation and rootlessness," expressed most eloquently in Peter Chaadaev's "Philosophical Letter," published in 1836.9 Chaadaev wrote:

Look around you. Everyone seems to have one foot in the air. You would say we are all travelers on the move. No one has a fixed sphere of existence; there are no good habits, no rules that govern anything. We do not even have homes; we have nothing that binds, nothing that awakens our sympathies and affections, nothing that endures, nothing that remains. Everything passes, flows away, leaving no trace either outside or within us. We seem to camp in our houses, behave like strangers in our families; and in our cities we appear to be nomads, more so than the real nomads who graze their flocks in our steppes, for they are more attached to their desert than we are to our towns. ${ }^{10}$

In many ways, Peter Tchaikovsky's life conformed to this pattern. His father, Ilia, was educated as an engineer and served as the manager of an ironworks at the town of Votkinsk in the Ural Mountains, where Peter

9 Marc Raeff, Origins of the Russian Intelligentsia: The Eighteenth-Century Nobility (San Diego, CA: Harcourt Brace Jovanovich, 1966), 79-80 and passim.

10 Peter Iakovlevich Chaadaev, "Letters on the Philosophy of History: First Letter," in Marc Raeff, Russian Intellectual History: An Anthology (New Jersey: Humanities Press, 1978), 162-3. 
was born. Later Ilia would be appointed director of the St. Petersburg Technological Institute. Peter attended a private boarding school in Petersburg, then the elite Imperial School of Jurisprudence, where his two younger brothers, the twins Modest and Anatole, later studied. Modest became a collaborator on the librettos of several of Peter's operas and his brother's first biographer. Anatole went on to a career in the judicial administration, serving as a prosecutor in Tbilisi and later a member of the Senate. The family did not own a hereditary estate.

Tchaikovsky served as an official in the central apparatus of the Ministry of Justice in Petersburg for four years (1859-1863). Alexander Poznansky, Tchaikovsky's biographer, suggests that only after a disappointment over the loss of a promotion and a fortuitous meeting did he decide to devote himself to music. ${ }^{11}$ The promotion may have qualified him for advancement from the ninth rank in civil service to eighth, from tituliarnyi sovetnik to kollezbskii assessor. The eighth brought membership in the hereditary nobility, which Tchaikovsky of course already enjoyed, but it also represented a symbolic divide between the higher and lower levels of administration. The choice, in any case, was not predetermined or easy. Music was not regarded as a respectable occupation for a member of the Russian nobility. The St. Petersburg Conservatory of Music had been established only in 1858. Anton Rubinstein, its first director, wrote, "It was obvious that in Russia the profession of musical artist, a profession that defined the position in society of a person who has devoted his whole life to his art and music did not exist." 12 Tchaikovsky belonged to that brilliant first generation of dedicated Russian composers whose works we know today. He began serious study of music in 1863 and his progress was amazing. By 1866, he had completed his beautiful First Symphony, "Winter Dreams."

In 1861, Tchaikovsky took the first of many European tours. Indeed, he was nearly always on the go; Poznansky writes of his "nomadic wandering." 13 Whether in Russia, Europe, or the United States, he could never stay long in one place, and only late in life (1885) did he establish a more or less permanent home at Klin, near Moscow. Tchaikovsky felt that

\footnotetext{
11 Poznansky, Tchaikovsky, 50-66.

12 James Loeffler, The Most Musical Nation: Jews and Culture in the Late Russian Empire (New Haven, CT: Yale University Press, 2010), 27.

13 Poznansky, Tchaikovsky, 357.
} 
sense of rootlessness expressed in the poignant strains of his music. I suggest that much of the haunting quality of Tchaikovsky's music results from the interplay of official, monarchical grandeur embodied in Petersburg with his drama of the wandering, yearning soul, all of this sublimated in the realm of performance. This interplay often comes about through the device of what Richard Taruskin has called the "triumphal polonaise," which injects the element of torzhestvennost' into the performance. Taruskin writes that "Tchaikovsky's 'imperial style' was virtually defined by the polonaise." 14

The Russian court appropriated the triumphal polonaise at the end of Catherine the Great's reign, signaling the conquest of Poland lands and their incorporation into the empire. After Catherine's death, the dance accompanied stately processions through the halls of the imperial palace. Taruskin has shown how Tchaikovsky's polonaises brought the element of official grandeur into orchestral works such as the fourth movement of the Third Orchestral Suite, the fourth movement of the Third "the Polish" Symphony, and the first movement of the Fourth Symphony. ${ }^{15}$

It is in Tchaikovsky's operas that polonaises create their most striking psychological effect, particularly in Eugene Onegin and the Queen of Spades. The eighth chapter of Pushkin's novel, Eugene Onegin, takes place in a Petersburg mansion, where Onegin sees Tatiana. She is no longer the rural maiden he had rebuffed, but a grand dame married to a general. Pushkin's text only vaguely suggests the setting of the action. However, in Act 3 of the opera, Tchaikovsky seizes the opportunity to introduce torzhestvennost'. The scene takes place in the lavish mansion of Tatiana and her eminent husband, Prince Gremin, whose character the composer introduces into the drama.

The Act opens with the slow beats and mounting strains of the polonaise, evoking the grandeur and majesty of power. Then Prince Gremin, the imposing "grey headed warrior," sings his aria, assuring us that old men too can experience love. Taruskin notes the contrast between the solemn polonaise and the cheerful waltz that had been performed in the Larin's country house in Act 2 ; the waltz, the lower form, here is the melody of the provincial picturesque. ${ }^{16}$

$14 \quad$ Richard Taruskin, Defining Russia Musically: Historical and Hermeneutical Essays (Princeton: Princeton University Press, 1997), 286.

15 Natalia Ogarkova, Tseremonii, prazdnestva, muzyka russkogo dvora XVIII-nachala XIX veka (St. Petersburg: Rossiiskii Institut istorii iskusstv, Dmitrii Bulanin, 2004); Taruskin, Defining Russia Musically, 278-84, 290.

16 Taruskin, Defining Russia Musically, 287-90. 
It is not only the humiliation of love rebuffed that the hapless, nomadic Onegin suffers: it is a social indignity inflicted by the majesty of power, discomfiting a person whose bravado concealed the inner weakness of the superfluous man, which Boris Gasparov has shown was central to the composer's rewrite of Pushkin, and quite remote from the Onegin Pushkin had in mind. ${ }^{17}$ It is no wonder that Onegin was the favorite opera of Tsar Alexander III. In a recent production at the Metropolitan Opera, with Renée Fleming and Dmitrii Khvorovstovskii the polonaise was reduced almost to background music at the beginning of the act, as Onegin, the dandy, dresses himself and prepares his toilet with the aid of valets. The focus is heavily on the tragic love story, appealing to our own reflexive impulses, but dispelling the dramatic tension between the official and the personal.

Tchaikovsky's fascination with the torzhestvennost' and éclat of the reign of Catherine the Great is evident in two other operas: The Slippers (Cherevichki) and, most notably, in the ball scene of Act 2 of Queen of Spades. Pushkin's short story about Ghermann, a guards' officer obsessed with the goal of a big win at cards, takes place presumably in the 1830s. For Tchaikovsky, it provided an opportunity to call forth the grandeur of Catherine's court in the 1790s. Gasparov has observed the hallucinatory effects of the changing chronotopes, prefiguring the devices of modernism. The polonaise motif pursues Ghermann, alien both in name and social standing to the illustrious milieu, throughout the opera and rises to its culmination at the end of the ball scene. ${ }^{18}$

The climax of the scene is the polonaise by Josef Kozlovskii, set to Gavriil Derzhavin's verse "Thunder of Victory, Resound," and the singing of "Glory to Catherine" in preparation for the expected arrival of the empress herself, who, depending on the performance, appears or is even more present by her absence. The majestic polonaise dwarfs the wretched hero, punishment as it were for his amorality and love of one above his station (the romantic theme was added by Tchaikovsky). Like Onegin, Ghermann is cast down and perishes, a pitiful figure unworthy of the transcendent presence of the imperial order. Tchaikovsky thus evoked the emanations of St. Petersburg, the city of Peter the Great and his successors, who strove to live up to his example.

\footnotetext{
17 Boris Gasparov, Five Operas and a Symphony: Word and Music in Russian Culture (New Haven, CT: Yale University Press, 2005), 58-94.

18 Ibid., 156-60.
} 
The city at once exalted its servitors as emanations of sovereign power and crushed those willful and reckless with brutal indifference, demonstrating the distance between the majesty of power and the hapless individual.

The sacred aura of the imperial city had begun to dim even in Tchaikovsky's lifetime. Petersburg, and all it represented, increasingly became witness to scenes of the vulnerability and even helplessness of the monarchy. The assassination of Alexander II on March 1, 1881 revealed the inability of the Russian state to protect its sovereigns. It attested to the penetration of St. Petersburg by foreign elements alien to the Russian people who presumably loved their tsars. An article appearing in a Petersburg newspaper a few days after the assassination described St. Petersburg as a nest of "foreigners thirsting for the disintegration of Russia.... In St. Petersburg, you meet many people who seem to be Russians but think like enemies of their native land, like traitors to their people."19

The assassination brought forth a new myth of autocracy, a neo-Slavophile myth that looked back to Muscovy, rather than to Petersburg, as the founding period of a Russia in which the Russian people were united with their tsar in faith and feeling. Alexander III appeared as little as possible in Petersburg, living instead at the suburban estate at Gatchina. Nicholas II shared his father's aversion for the capital. In the first years of his reign, he resided there, but the revolutionary events of the early twentieth century forced him to retreat to Tsarskoe Selo.

The imperial city itself changed with the economic development of the late nineteenth and early twentieth century. St. Petersburg grew from a population of a half million in 1856 to one and one half million in 1910. It was the largest city in the empire. Many of the new urban dwellers were peasants, fresh off the land, and not used to urban life, experienced it as alien and traumatic. The Russian working class was small compared to that of other European countries, but more concentrated in large factory towns and cities, which at moments of political and social crisis this created an explosive mix. Most national capitals were not also major centers of heavy industry. The squares and boulevards of Petersburg became scenes of open confrontations between the monarchy and a disgruntled working class. In the pages of the increasingly assertive periodical press, Russian and foreign readers followed the challenges to the autocracy and the defiling of the imperial city.

19 Moskovskie vedomosti, March 11, 1881, 3. 
On January 6, 1905, the Blessing of the Waters took place, the most important public religious ritual for the Petersburg court, on the Neva before the Winter Palace. During the ceremony, a gunshot rang out, shattering several of the panes of the windows of the Winter Palace where the members of court stood viewing the ceremonies. The shooting was not explained, but remained an omen of things to come. Three days later, Father Gapon, the leader of a "police union" originally sponsored by the government, led a peaceful movement of workers to the Winter Palace to petition for the rectification of grievances and for a constitution. The troops confronting them on Palace Square opened fire, killing hundreds.

The result was a desecration of power, of authority. Bloody Sunday undermined the myth of the benevolent tsar in the eyes of many workers and peasants-their fundamental faith in the monarchical order. Gapon himself, it is said, cried out "There is no God any longer! There is no Tsar!"20 It discredited Nicholas II in the eyes of educated opinion, both in Russia and Europe, where the tsar struggled to be seen as one of the leaders of civilized states of the west. It marked the beginning of the Revolution of 1905.

In first years of the twentieth century, St. Petersburg would provide a backdrop for events that revealed the helplessness and desperation of the monarchy-a city that had lost its meaning, a signifier without a signified, its austere beauty a phantasmic presence conjured by the poets of the silver age. In subsequent decades, the capital provided the setting for a new myth of revolutionary Petrograd, Leningrad, a myth elaborated in speeches, the press, and most vividly in film. Today, St. Petersburg appears as a magnificent relic, a monument to the somber course of Russia's broken history.

20 Abraham Ascher, The Revolution of 1905: Russia in Disarray (Stanford, CA: Stanford University Press, 1988) 1: 91. 
Part III

Explorations and Empire

cof 



\section{Texts of Exploration and Russia’s European Identity}

"Russian Christopher Columbuses, scorning dismal fate, Will open a new route through the ice to the East, And our Mighty Power shall reach America, But now wars urge another glory.” -Michael Lomonosov, Verse from "Peter the Great," $1761^{1}$

\section{Russia as Outpost of the European ENLIGHTENMENT}

In 1721, at the celebration of the Treaty of Nystadt ending the Northern War with Sweden, Peter the Great accepted the title of emperor (imperator). Chancellor Gavriil Golovkin made clear the symbolic meaning of the change in a speech to the Senate. Peter, he intoned, had taken Russia "from the darkness of ignorance into the Theater of the World, so to speak from nothingness into being, to one of the political peoples of the world."2 The adoption of a western, Roman image of secular rule was expressed in the imagery of emergence, showing movement from ignorance and superstition to the promotion of science, which was cultivated by "political peoples of the world," who had embarked on explorations and extended their realms as they ventured into the unknown.

In other words, a sign of Russia's emergence onto the "theater of the world" was its engagement in the European project of world exploration and its scientific pursuits. In the late seventeenth century, Siberia had become the focal point of interest for western scholars and explorers interested in pathways to China. Dutch and German scholars began to publish descriptions of the region. During Peter's reign, Russia participated in this effort. An expedition

1 M. V. Lomonosov, Polnoe sobranie sochinenii (Moscow-Leningrad: Izd. Ak. Nauk SSSR, 1959), 8: 703.

2 S. M. Solov'ev, Istoriia Rossii s drevneishikh vremen (Moscow: Social-Economic Literature, 1963), 9, 321. 
of Cossacks led by V. V. Atlasov explored Kamchatka. D. Y. Antsyferov and Ivan Kozyrevskii conducted explorations of the Kurile Islands. ${ }^{3}$ Peter also sought to bring Russia into the European scientific endeavor. In his correspondence with Peter, the famed German philosopher Leibniz had wondered whether Asia was joined by land to North America, and the emperor was determined to find the answer. He instructed two surveyors, Ivan Evreinov and Fedor Luzhin: "Go to Tobolsk, and from Tobolsk, with guides, travel to Kamchatka and beyond, wherever you are shown, and describe these areas to find out whether America is joined to Asia. This is to be done with great care."4 The surveyors provided him only with a map of the Kurile Islands. Disappointed and on his deathbed, Peter entrusted the undertaking to a Dane in Russian service, Vitus Bering. The Bering explorations showed what the simple instructions to Evreinov and Luzhin entailed. It took the explorer three years just to reach the Pacific by land. Once there at Okhotsk, he built his ship, the St. Gabriel, but the results of his first expedition proved unsatisfactory, as he failed to reach America.

The Academy of Sciences, established by Peter in 1724, sponsored Bering's second expedition, from 1733 to 1743 . One part consisted of a sea expedition to the coast of America; the other, a land expedition, was charged with a multifaceted description of Siberia. The sea expedition was grandiose and arduous. Moving the equipment and supplies from Tobolsk to Okhotsk, where the ships were built, took hundreds of sledges and lasted eight years. Bering finally discovered the coast of North America, but died in a sea accident on the return voyage. The land expedition was led by a team of scholars under the direction of the historian Gerhard Friedrich Müller, a Westphalian, who had come to study at the newly opened Academy in Petersburg and the naturalist, Johann-Georg Gmelin. The team conducted a vast survey of Siberia, including geography, flora, and fauna, Siberian peoples and their languages. Müller brought back copies of hundreds of documents from local archives, which provided the basis for his classic History of Siberia. Gmelin's four-volume Voyage through Siberia, published in Göttingen in 1751, also focused on flora and fauna but included extensive descriptions of Siberian people. Other naturalists, Stepan Krasheninnikov and Georg Wilhelm

3 Eric Donnert, Russia in the Age of the Enlightenment (Leipzig: Edition Leipzin, 1986), 95-6.

4 Solov'ev, Istoriia Rossii, 9: 532. 
Steller, wrote accounts of an encyclopedic character on Kamchatka. All in all, the expedition's maps, as well as collections of materials, provided the basis for future ethnographical, historical, botanical and zoological studies of the regions. 5

The scholarly texts of the "great Northern expedition," as it was often called, were potent symbols of Russia's European character. Written in or quickly translated into European languages and accompanied by elaborate illustrations, they showed Russia participating in European explorations of Russia. The paradoxical character of this relationship was concealed by defining Siberia as a colony, similar to those of the west. In the 1730s, the historian and geographer Vasilii Tatishchev drew a line between Europe and Asia at the Urals, which soon gained general acceptance. As Mark Bassin wrote, "In one stroke, Siberia was transformed into an Asiatic realm cleanly set off from a newly identified 'European Russia." Russians began to call Siberia "Great Tatary," which Europeans had often used to refer to Russia in general. ${ }^{6}$ The relationship was also concealed by defining the expeditions as Russian, regardless of the nationality of the leaders or the authors of the texts. For instance, Müller wrote of a "summary of the voyages made by Russians on the Frozen Sea, in search of a north east passage," and Vitus Bering came to be known as the "first Russian sea-farer." The designation "Russian" came to be applied to anyone serving the westernized Russian state.

Another sign of Russia's European identity was the production of maps indicating the extent and the features of the empire ruled by the Russian state. Following the example of western monarchies, Peter used maps to define Russia as a discrete territory, initiating what James Cracraft has called the "visual conquest of Russia." After Peter's Great Embassy of 1697-98,

5 Donnert, Russia in the Age of the Enlightenment, 99-100; S. A. Tokarev, Istoriia russkoi etnografii: dooktiabr'skii period (Moscow: Nauka, 1966), 82-5, 87-93; Gert Robel, "German Travel Reports on Russia and their Function in the Eighteenth Century," Deutsch-Russische Beziehungen im 18. Jarbrhundert: Kultur, Wissenschaft und Diplomatie, ed. Conrad Grau, Serguëi Karp, and Jürgen Voss (Wiesbaden: Harrassowitz, 1997), 276-8.

6 Mark Bassin, "Inventing Siberia: Visions of the Russian East in the Early Nineteenth Century," American Historical Review vol. 6, No. 3 (June 1991): 767-70.

7 Müller's book appeared in 1764 in English and 1766 in French. Gerhard Friedrich Miller, Voyages From Asia to America: For Completing the Discoveries of the North west Coast of America (London: Thomas Jefferys, 1764). See the entry for Bering in Entsiklopedicheskii slovar' Brogauza i Efrona (St. Petersburg: I. A. Efron, 1892), 6: 534. 
he commissioned maps of southern Russia, including his recent conquest of Azov, from his officers Jacob Bruce and Georg Mengden. In 1719, the tsar founded a Cartography Department, where the French astronomer JosephNicolas Delisle collaborated with the Russian cartographer, Ivan Kirilov. Although Kirilov's Atlas Vserossiiskoi and the Academy's Atlas Rossiiskoi did not attain the accuracy of contemporary European atlases, they represented the first efforts of the Russian state to mark the extent and boundaries of the empire. ${ }^{8}$ By the end of the century, Russians were developing what Willard Sunderland describes as a "territorial consciousness" that identified Russia with the land belonging to the empire as well as with the westernized monarchy that created the empire.?

In 1767, Catherine the Great's Instruction to the Legislative Commission, assigned to codify Russian laws, announced the European character of the Russian state as an apodictic truth, demonstrated by the success of Peter's reforms. The rapid expansion of the empire during Catherine's reign later afforded another indication of the success of the westernized Russian state. The empire grew in the south and the west to encompass the littorals of the Caspian and Black Seas, as well as the lands that came to Russia with the partitions of Poland. Russia now seemed not only to equal but also to excel its western rivals as the most imperial of nations, comprising more peoples than any other. By 1797, the economist Heinrich Storch could write, "no other state contains such a mixed and diverse population. Russian and Tatars, Germans and Mongols, Finns and members of the Tungusic tribes live here separated by vast distances and in the most varied regions as citizens of a single state, joined together by their political order..." He went on to

8 James Cracraft, The Petrine Revolution in Russian Imagery (Chicago: University of Chicago Press, 1997), 272-81; Larry Wolff, Inventing Eastern Europe: The Map of Civilization in the Mind of the Enlightenment (Stanford: Stanford University Press, 1994), 144-6; Mark Bassin, "Russia Between Europe and Asia," Slavic Review vol. 50, No. 1 ( Spring 1991): 7-9.

9 This tendency in Russian statecraft is analyzed in depth in the innovative article by Willard Sunderland, "Imperial Space: Territorial Thought and Practice in the Eighteenth Century," in Russian Empire: Space, People, Power, 1700-1930, ed. Jane Burbank, Mark von Hagen, and Anatolyi Remnev (Bloomington, IN: Indiana University Press, 2007), 37-55. 
conclude that to see so many different people united in one state "is a most rare occurrence, a second example of which we look for in vain in the history of the world." The empress favored comparisons with Rome. One poet opined that Russia has "soared with greatness like Rome in its flourishing days and extending the limits of its territories has given laws to all and amazed the entire world." 10

However, Russia's European character did not remain undisputed. Chappe d'Auteroche's derogatory account of the journey in Voyage en Sibirie, published in 1768 , challenged Russia's claim to belong to the enlightened peoples of Europe. The book deplored the bondage and ignorance of the Russian people, as well as their lack of genius and imagination, which he ascribed to the climate and the atmosphere of despotism that, he claimed, poisoned Russian arts and manufacturing. The illustrations of the book by Jean Le Prince reinforced this impression, showing such scenes as dirty hovels and brutal punishment by the knout. ${ }^{11}$

In reply, Catherine wrote her famous Antidote, affirming the enlightenment beliefs in the universality of human nature and the perfectibility of all peoples. To substantiate her views, she launched a massive survey of the regions of Russia under the direction of the Academy of Sciences. The "Academy Expedition" assembled an impressive array of German scholars, who for six years undertook detailed and extensive studies of various parts of the empire and produced works describing the economic, geographical characteristic of particular regions, as well as the variety of its human subjects. Perhaps the most important contribution was made by Peter Simon Pallas. Pallas traveled through the Urals, Altai, and Trans-Caucasus region, and his work was published in German, English, French, and Russian editions. His account included observations of the mining resources, animal and plant life, as well as the manners and traditions of the peoples he encountered. ${ }^{12} \mathrm{His}$

10 Andreas Kappeler, The Russian Empire: A Multiethnic History (Harlow: England, 2001), 141; Stephen Baehr, "From History to National Myth: Translatio imperii in Eighteenth Century Russia," The Russian Review vol. 37, no. 1 (January 1978): 10-12.

11 Isabel De Madariaga, Russia in the Age of Catherine the Great (New Haven, CT: Yale University Press, 1981), 337-8; Hans Rogger, National Consciousness in Eighteenth Century Russia (Cambridge, MA: Harvard University Press, 1960), 263-5; Wolff, Inventing Eastern Europe, 36, 76-7.

12 Robel, "German Travel Reports on Russia and their Function in the Eighteenth Century," 278-9; Donnert, Russia in the Age of the Enlightenment, 110-11. 
exquisitely illustrated study of Russian plants, compiled on the basis of the trip, was a landmark of eighteenth-century botany.

Another member of the expedition, Johann Georgi, in the late 1770s published German, French, and Russian versions of a monumental fourvolume Description of all Nations of the Russian Empire, their Way of Life, Religion, Customs, Dwellings, Clothing and other Characteristics. The study was based on his own observations during his participation in the "physical" expedition as well as on the works of Müller, Gmelin, Krasheninnikov, and Pallas. ${ }^{13}$ Georgi applied the methodology of natural science formulated by Linnaeus to create a taxonomy of the nationalities of the empire. Language was his principal determinant of classification, and he placed groups speaking the same language in the same nationality. ${ }^{14}$ The text Georgi produced confirmed that the Russian empire was the most diverse of empires. "Hardly any other state in the world possesses such a great variety of different nations, survivals of peoples, and colonies as the Russian state." 15

Georgi and other scholars of the Academy Expedition shared Catherine's enlightenment faith that human nature was uniform. They believed that all peoples possessed reason; however, that reason developed only through education, which would be imposed from above and eventually would bring about the elimination of national traits. Those at earlier stages, for instance, the Tungus and the Chukchhi, were ignorant, simple, and possessed a beguiling innocence, but "the uniformity of State organization" could transform all nationalities, including ethnic Russians, into educated, Europeanized Russians. The state, Georgi concluded, was "leading our rude Peoples by giant steps toward the common goal of general enlightenment in Russia, of a wonderful fusion of all into a single body and soul, and of creating, as it were, an unshakable Giant that will stand for hundreds of centuries."16

13 Tokarev, Istoriia russkoi etnografii, 103-110.

14 Nathaniel Knight, "Constructing the Science of Nationality: Ethnography in MidNineteenth Century Russia” (Doctoral Dissertation, Columbia University, 1995), 32-40.

15 Tokarev, Istoriia russkoi etnografii, 103.

16 Yury Slezkine, "Naturalists versus Nations: Eighteenth-Century Russian Scholars Confront Ethnic Diversity," in Russia's Orient: Imperial Borderlands and Peoples, 1800-1917, ed. Daniel R. Brower and Edward J. Lazzerini (Bloomington, IN: Indiana University Press, 1997), 38-9; Knight, "Constructing the Science of Nationality," 36-7. 


\section{"Russian Christopher Columbuses" AND Their TeXts}

The great Russian polymath and academician Michael Lomonosov insisted on a different measure of Russia's European identity. The Russian state could achieve glory equal to that of other states only if it developed sea power and extensive commerce with foreign nations, particularly in Asia. His poem of 1761, "Peter the Great," put his own hopes for future "Russian Christopher Columbuses" in Peter's mouth. In 1762, his memorandum, composed for the tsarevich Paul, "A Brief Description of Various Voyages in Northern Seas and An Indication of a Possible Passage through the Siberian Ocean to East India," asserted that Russia had lagged behind other states in the development of foreign trade because they had greater access to sea routes, and therefore "from ancient times had learned sea-faring and the art of building ships for long voyages." As a result, Russia had enjoyed little success in trading with Eastern peoples.

Lomonosov looked forward to the appearance of Russian seamen and shipbuilders. His immediate concern, however, was to discover and open a Northeast passage that would make it possible for Russian ships to sail across the Arctic Sea into the Pacific. He argued that such a voyage was feasible. He claimed that though Arctic voyages faced the hardships of ice and cold, these challenges did not compare with the terrible storms, savage people, illnesses, and the extremes of weather, faced by Portugese explorers on their way to the East Indies. The last sections of the memorandum set forth a scientific analysis of the waters and the ice flows of the Arctic Sea, leading to the conclusion that "according to natural laws and information concordant with them," such a voyage would fare well. ${ }^{17}$ Lomonosov succeeded in convincing the Admiralty College to launch two expeditions under Vasilii Chichagov in 1765 and 1766, but his ships could not find their way through the ice and heavy fog, and turned back less than one-third of the way from the port of Kola to the Bering Straits.

In the last decades of the eighteenth century, Catherine began to follow Lomonosov's suggestions and took measures to enhance Russia's sea power and presence in the North Pacific. The quickening of her interest was in response to the changed situation in the Pacific. James Cook's third voyage (1776-79)

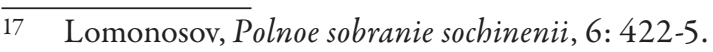


made known the abundance of furred animals in the North Pacific and spurred British merchants to develop an extensive trade, particularly with China. ${ }^{18}$ Cook's example was important in another respect; unlike previous explorers, he published his journals. ${ }^{19}$ Cook's journals represented at once scientific documents, charting new waters and islands, and cultural statements, recasting the relationship between Europeans and the Pacific peoples he encountered. The three volumes of his journals appeared in Russian translation from 17801805, and wielded considerable influence. The government promoted the publication of two Russian accounts of sea explorations, Grigorii Shelekhov's description of his colonization of Kodiak Island, and Grigorii Sarychev's account of his voyage to Siberia and study of the Siberian coastline.

Shelekhov, often called "the Russian Christopher Columbus," was a merchant who came from Ukraine to make his way in the rough and tumble frontier of Okhotsk. In Okhotsk, he organized a group of merchants and hunters to mount an expedition to the shore of Kodiak Island off the southern coast of Alaska. With the support of the Russian government and a loan of 50,000 rubles from the wealthy Ural mine owner, N. Demidov, Shelekhov sailed with three ships from a port near Okhotsk in 1783. After a year's journey, he reached Kodiak Island, where he built the first Russian settlement in America, which would become the center of the Russian fur trade in Alaska. ${ }^{20}$ Shelekhov also tried to organize the competing merchants into a monopoly under government protection, an effort that succeeded only after his death with the establishment of the Russian-American Company in 1799. Shelekhov's account of his achievements was not a seaman's journal but an official report submitted to the governor-general of Siberia, published in $1791 .^{21}$ Unlike Cook, Shelekhov made little effort to record the truth. $\mathrm{He}$ cast himself as a benevolent conquistador, subduing the natives

18 In the preface to his account of his voyage, Adam Johann von Krusenstern gives a vivid description of the backwardness of Russian merchants and seafaring (Captain A. J. Von Krusenstern, Voyage Round the World in the Years, 1802, 1804, 1805, \& 1806 [London: C. Rowerth for J. Murray, 1813], xxi-xxii).

19 Bernard Smith, Imagining the Pacific in the Wake of the Cook Voyages (New Haven, CT: Yale University Press, 1992), 231.

20 See the Introduction by Richard A. Pierce to Grigorii I. Shelekhov, A Voyage to America, 1783-1786 (Kingston, ON: Limestone Press, 1981), 1-15.

21 For a list of the editions of Shelekhov journey, see Avrahm Yarmolinsky, Shelekhov's Voyage to Alaska: A Bibliographical Note (New York: New York Public Library, 1932), 5-8. 
with minimal force and winning their admiration and obedience. The frontispiece set Shelekhov's achievement in the frame of myth. The rather crude illustration depicted a merchant, presumably Shelekhov, standing on a shoreline, receiving a seal skin from a native. The figure of Mercury hovers in the clouds, announcing the benevolence of the gods. Various animals-an otter, and sea lions-sit gazing out innocently. The caption below repeats the first three lines of Lomonosov's verse. Lomonosov's fourth line was replaced with the words, "And glory comes to Russians everywhere."22

The stately peacefulness of the scene was consistent with the heroic tale that Shelekhov contrived. He described how he subdued the "savages" (whose numbers he greatly exaggerated) by ordering his men to open fire with cannons. He then told the natives of the "tranquillity, grandeur, power, and beauty of everything in Russia," and extolled the empress's mercy. They were astonished at the speed with which he built houses. He promised to instruct them, showed them Catherine's portrait and some books, and then announced how fortunate they were to live under laws. He also claimed that he had taught them the bases of Christianity. As Richard Pierce has shown, Shelekhov's claims were refuted by all later accounts. Like earlier conquistadors, he massacred hundreds, treated those who survived brutally; the houses and education were fabrications. It would be many years before the natives on the island adopted Christianity. His abuses became notorious, and were perpetuated in the practices of the Russian-American Company at the beginning of the nineteenth century. ${ }^{23}$

In 1785, Catherine the Great sponsored a voyage to explore Russian holdings in the North Pacific and to take possession of areas not formally incorporated into the Russian empire. She appointed Captain Joseph Billings to lead the expedition. Billings had accompanied Cook on his third expedition and entered Russian service in 1783 . He captained the lead ship, the Pallas, and a Russian naval officer Gavriil Sarychev, the second, The Glory of Russia. The expedition undertook the arduous trip to Okhotsk, where the ships were built, and finally set sail in 1787 . The explorers tried but failed

22 The illustrations is available in the original publication, Russia Engages the World, 1453-1825, edited by Cynthia Hyla Whittaker, 100.

23 Puteshestvie G. Shelekhovas 1783 po 1790 god uz Okhotska po Vostochnomu Okeanu $k$ Amerikanskim beregam, i vozvrashenie ego $v$ Rossiiu (St. Petersburg: Tipografiia Gubernskogo Pravleniia, 1812), 15-21, 29-36; Pierce, Introduction to Shelekhov, $A$ Voyage to America, 8, 10, 12-13. 
to reach the Kolyma river in Northern Siberia, then sailed for America. It is clear that Sarychev took the tasks of the expedition far more seriously than the Englishman. He carefully mapped the shorelines of the Sea of Okhotsk and the Aleutian Islands. ${ }^{24}$

Sarychev kept a journal, but without intention to publish. Loggin Golenishchev-Kutuzov, a noble naval officer, working on the translation of Cook's journals, then prevailed on him to put his entries in order and "compose a connected narrative from them." The author became convinced of both the benefit of such a publication to seafaring and the pleasure that it would bring to the reading public. ${ }^{25}$ Sarychev's account was the first Russian explorer's journal in the Cook tradition, but the least sophisticated and comprehensive. Like other seamen publishing journals, he took care to apologize for his unpolished writing. "I have not tried like some explorers to embellish my tale with attractive, extraordinary and diverting, but invented adventures, but have followed the exact truth, describing real events, and in places, made my own remarks." The text is written in simple conversational style. Captain Cook, he claimed, had been limited by his dependence on large vessels meant to traverse the seas and, as a result, had often taken islands for the mainland and clouds for islands. Sarychev used baidars - the native Siberian canoes-and rowboats to investigate the shoreline. Another purpose of his visit, he understood, was to assert the sovereignty of the Russian empress in Siberia-to give "an effusive expression of [Her Majesty's] benevolence and to announce Her protection to the savage people in the countries subject to Her." ${ }^{26}$ His descriptions of the native peoples, particularly the Iakuts, are sympathetic, but extremely critical of their superstitions, especially the way the shamans exploited the natives' credulity. Sarychev provides a lengthy, astonished description of a shaman, screaming and writhing as he evokes the evil spirits that presumably had inflicted illness on a Yakut. A print shows the shaman's presumed loss of control as he takes the spirit into himself. Other illustrations depict inhabitants of Unalashka, and a group of Iakuts.

$\overline{24}$ Donnert, Russia in the Age of the Enlightenment, 112-14; Krusenstern, Voyage Round the World, xviii.

25 Puteshestvie flota-kapitana Sarycheva po Severovostochnoi chasti Sibiri, Ledovitomy Moriu i Vostochnomu Okeanu (St. Petersburg, 1802), viii; the volume was published in 1802 with a dedication to Emperor Alexander I and translated into English in 1806.

26 Ibid., n. p., iv-vi, xii. 
Like those accompanying Cook's later journals, they favor science over art, eschewing invention in order to inform. ${ }^{27}$

\section{Russians AS EUROPEANS}

Shelekhov and Sarychev wrote their accounts without intending to publish them. The descriptions of sea expeditions during the reign of Alexander I (1801-25) were statements of their authors' achievements as events in the history of world exploration. Educated in elite naval institutions, they familiarized themselves with western thought and literature, and, as Ilya Vinkovetsky has shown, "considered themselves engaged in active dialogue with general European culture." 28 Several of them took advantage of opportunities, to train in the British navy. Indeed, the four captains of major sea explorations of the first quarter of the nineteenth centuryAdam Johann von Krusenstern, Iurii Lisianskii, Vasilii Golovnin, and Mikhail Lazarev-served as officers and saw combat with the British navy, an interchange initiated by Catherine II. They came to believe that Russia would show its European character by extending its sea power, like Britain, into the Pacific and developing trade and colonies. They had little interest in Siberia, which had come to be regarded as a barren, forbidding land, a bleak place of exile that was, for better or worse, a part of Russia. ${ }^{29}$

For the explorers of Alexander's day, the model was not Christopher Columbus, but James Cook, and the composition of a journal was the demonstration of both their achievement and their European character. They aspired to Cook's professional competence and integrity, as well as his determination to combine exploration, the expansion of trade, and the advancement of science. Like Cook, they took naturalists, astronomers, and artists on board, leaving a scientific and artistic as well as a verbal record of the journeys. They adopted Cook's sympathetic and inquisitive manner toward native peoples. Their journals revealed a new conception of Russian seamen as European explorers-to use Marc Raeff's phrase, full partners in the project of world exploration.

$\overline{27 \quad \text { Sarychev, 29-31 }}$; Smith, 1-4, 20-8, 36-7.

28 Ilya Vinkovetsky, "Circumnavigation, Empire, Modernity, Race: The Impact of Round-the-World Voyages on Russia's Imperial Consciousness," Ab Imperio, 1-2 (2001): 198-201.

29 Bassin, "Inventing Siberia," 770-5. 
Cook had shown the possibilities of extended sea voyages. Taking up an idea of Catherine's, these explorers reached the Pacific by sea, thus avoiding the overland trek to Okhotsk. They now embarked on "round-the-world" voyages, beginning at Kronstadt, crossing the Atlantic with stops in the Canary Islands and Brazil, rounding Cape Horn to the west coast of South America and to explore the myriad islands of the Pacific, before heading north to Siberia and Alaska. The voyages returned by the China Sea, the Indian Ocean, and the Cape of Good Hope. They sailed in modern ships built in London or the Baltic ports, rather than the ramshackle vessels put together in Okhotsk. The first to embark on this route was Adam Johann von Krusenstern, a Baltic German nobleman from Estland educated at the Naval Cadets Corps, who took part in naval battles against Sweden in 1789-90. He served in the British navy from 1793 to 1799, when he saw combat against French warships and witnessed the vigorous British trade in the Far East. He returned with a determination to reform the Russian navy and to extend its reach in the Pacific.

Krusenstern's journal, published in four volumes (1809-11) opened with a virtual manifesto about the future of Russian naval exploration. He recalled his chagrin when he observed an English trading vessel in Canton, which, after being fitted out in Macao, had reached the northwest coast of America in less than five months. Russians customarily brought their furs to Okhotsk, then to Kiakhta, and then to Canton-a two year trek. He reasoned that if Russia had good ships and sailors, the journey could be made directly and the return trip could bring Russia goods from Canton and other ports along the way. The empire then could also avoid the payments to England, Sweden, and Denmark for East European and Chinese goods, and could even undersell these nations in the north German market. He proposed to augment the Naval Cadets Corps with six hundred young noblemen and one hundred commoners, the latter to be trained for the merchant service and "on the same liberal footing as the nobles." "In this manner a most useful body of men might be created for the service of their country; nor would Cook, Bougainville, or Nelson have ever been what they proved to [their countries], if attention had only been paid to birth."30

Krusenstern envisioned a sweeping governmental program that would extend Russian sea power and establish a merchant marine and an assertive

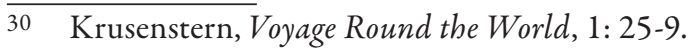


and enterprising merchantry in the Far East. His proposals made little headway during the reign of Paul I (1796-1801), who showed little inclination to further Catherine's policies. Reversing his father's despotic measures, Alexander I was sympathetic to efforts to show Russia's support for science and exploration. Two high officials of the beginning of Alexander's reignCount Nikolai Mordvinov and the Minister of Commerce, Count Rumiantsev-promoted the project; both remained forceful proponents of sea explorations throughout the epoch. In addition, resources provided by the Russian-American Company made it possible to purchase the latest ships and equipment in London. Krusenstern captained the first ship, the Nadezhda (Hope), and his protegé, Iurii Lisianskii, the second, the Neva, which followed a somewhat different route. Two naturalists, George Heinrich von Langsdorff and Wilhelm Gottfried Tilesius traveled on the trip, along with the astronomer Johann Kaspar Horner. Krusenstern also agreed to take along Otto and Moritz von Kotzebue, two sons of Auguste von Kotzebue, the conservative German playwright who was in Russian service, and a special embassy to Japan, headed by the ambassador, Nikolai Rezanov. ${ }^{31}$

Alexander I brought the project of Pacific exploration into his scenario of friendship, kindness, and sympathy, making it an expression of his image of wise and enlightenment monarch. ${ }^{32}$ Krusenstern described how the emperor carefully inspected the two ships: "He noticed everything with the greatest attention, and expressed his satisfaction," with the ships and the new equipment acquired in England. He spoke with the commanders and "attended with some pleasure the work that was going on board the ship." Alexander also bestowed the revenues of an estate, 1,500 rubles for twelve years, on Krusenstern's wife, to set his mind at ease. ${ }^{33}$ Alexander accorded similar attention to Lisiasnkii on the Neva upon its return. ${ }^{34}$

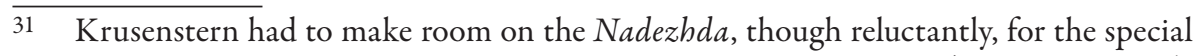
embassy, headed by Rezanov, who was Shelekhov's son-in-law (Ibid., 1: 5, 17-8). The voyage was marred by conflicts between Rezanov, a high official and courtier who outranked Krusenstern. See Victoria Joan Moessner, "Introduction," in George Heinrich von Langsdorff, A Voyage Around the World From 1803 to 1807 (Kingston, ON: Limestone Press, 1993), xiii-xvi.

32 Scenarios of Power, 1: 195-201.

33 Krusenstern, Voyage Round the World, 1: 6-7.

34 Urey Lisianskii, Voyage Around the World in the Years, 1803, 1804, 1805, 1806 (London: J. Booth, etc., 1814), 316-17. 
Krusenstern's voyage originated the genre of Russian ship journal as a sign of Russia's advancement and sophistication; it was taken up by the others who left accounts of this voyage: Lisianskii, Langsdorff, Rezanov, and the clerk of the Russian-American Company, Fedor Shemelin, who accompanied Rezanov's embassy. Krusenstern's journal appeared almost simultaneously in Russian, German, and English, Lisianskii's in Russian and his own English translation, and Langsdorff's in German and English. The volumes included maps of the discoveries, scientific reports, illustrations of scenes of the voyage, plant and animal life, and portraits of the native peoples the authors met and described. They announced to the world Russian seafarers' active involvement in the exploration of the Pacific.

In the Alexandrine era, Russia's American settlements replaced Siberia as the indication of imperial status and prestige. The explorers' descriptions of their encounters with native peoples reflected the sympathetic, inquiring attitude of those striving to understand human beings remote from their own experience. While the eighteenth-century faith in education and progress persisted, it receded into the background at the sight of individuals bizarre in appearance, dress, and conduct. The evidence of the corruption and abuses of the Russian-American Company belied the easy identification of civilization and progress, while the Rousseauist image of primal innocence lingered to produce feelings of guilt and uncertainty in the confrontation with people who did not conform to their notions of humanity.

The accounts of native people on this first circumnavigation were varied, reflecting the authors' efforts to make sense of their perceptions while maintaining their role as detached scientific observer. They were particularly nonplussed by the inhabitants of Nukahiwa, an island in the Marquesan chain in the South Pacific. On the surface, the Nukahiwers fit the conception of the innocent savage, handsome, friendly, peaceful, and honest. The men were large and striking, and many covered their bodies with tattoos, a frequent subject of illustrations in all the journals showing the distance of these natives from European society. However, Krusenstern and his comrades learned of the dark side of the Nukahiwers from a runaway British seaman, Edward Roberts, who told them of their brutality, and frequent episodes of cannibalism.

Krusenstern was struck by the absence of institutions and morality in their midst. The king possessed no power, and as a result there was no justice; theft was regarded as "a particular merit in those who evince 
adroitness." Men took connubial vows, but adultery was general, and he learned of husbands consuming their wives and children during famines. He held their religion in particular contempt. There were priests among them, but from Nukahiwers' "moral character," he concluded that the religion had done nothing to ameliorate it. The Nukahiwers had all the marks of children of nature, but of a nature that was violent, brutish, and profligate. 35

Iurii Lisianskii was somewhat more sympathetic. He believed that they regarded their marital vows as sacred. Following the logic of eighteenthcentury ethnographers, he attributed their violence and brutality to instinct and ignorance, which led them to believe in superstitions and magic. ${ }^{36}$ Langsdorff expressed a Hobbesian conception of human nature. Everything he saw in Nukahiwa seemed to support his notion that "there is no creature on earth in all zones and climates that rages against its own species as much as man .... Among savages as well as civilized peoples, man eternally seeks to destroy his species." The depravity of the Nukahiwers, however, demonstrated the beneficial effects of civilization. "I have, unfortunately, seldom observed the gentle tender feelings of affection and love, of friendship and attachment, even of parents for children and vice versa among brutal uncivilized nations." 37

The Aleutians and the inhabitants of Kodiak Island off the south coast of Alaska evoked the same feelings of offence and disapproval from Lisianskii and Langsdorff (Krusenstern did not describe these peoples). Lisianskii was contemptuous of their lengthy mourning rites and their fantastic myths of origins. He considered the Toyons' practice of keeping male concubines especially repulsive. He found the inhabitants of Kodiak Island incapable of conversation: "a stupid silence reigns amongst them... I am persuaded that the simplicity of their character exceeds that of any other people, and that a long time must elapse before it will undergo any very perceptible change." On occasion they did not fear to appear before him in the nude, though they considered him "the greatest personage on the island." But he was most disgusted by their filth: "They have not the least sense of cleanliness. They will not go a step out of their way for the most

\footnotetext{
35 Krusenstern, Voyage Round the World, 1: 152-84.

36 Lisianskii, Voyage Around the World in the Years, 1803, 1804, 1805, 1806, 79-90.

37 Langsdorff, A Voyage Around the World From 1803 to 1807, 1: 91.
} 
necessary purposes of nature." They used urine to launder their clothing and even to wash themselves. ${ }^{38}$

Both Lisianskii and Langsdorff were critical of the Russian-American Company for its cruel and irresponsible treatment of the natives subject to their authority, and their accounts bear what Vinkovetsky describes as "the mark of condescending paternalism." Lisianskii criticized the company for setting prices on agricultural implements that the natives could not afford. Langsdorff was more sweeping in his condemnation. The Company's agents were hunters, many of them former convicts from Siberia, who wielded despotic power over the natives. "They have tortured those defenseless creatures to death in the cruelest manner and gone unpunished. That is why the natives hate the Russians, including their wives and children, and kill them whenever the opportunity presents itself." They had lost all their possessions and "own barely more than the clothing on their backs." 39

Krusenstern's expedition was the first of thirty-three sea voyages to the North Pacific from 1803 to 1833, many of which were described in journals. Two notable expeditions were led by Otto von Kotzebue, who as a boy had sailed with Krusenstern from 1803 to 1807 . His first expedition, from 1815 to 1818 , financed by Count Nikolai Rumiantsev, received the sympathetic attention of Alexander I, who allowed the ship, the Riurik, to fly the Russian military flag, along with the commercial flag, in order to protect it from international incidents. Kotzebue's voyage was another effort to find a Northeast passage and Krusenstern prefaced Kotzebue's account with a plea for such a voyage. ${ }^{40}$ Kotzebue did not in fact attempt to find a passage, but reached Kamchatka and the Bering Straits and claimed to discover over threehundred islands. His account of his voyage appeared in German, English, and Russian. Remarkable illustrations by Ludovik Choris, an artist of RussianGerman parentage, were published in a separate volume in Paris in 1822.41 Kotzebue's second voyage around the world from 1823-26 also resulted in a multi-volume publication in Russian and English.

38 Lisianskii, Voyage Around the World in the Years, 1803, 1804, 1805, 1806, 179, 1823, 214-5.

39 Langsdorff, $A$ Voyage Around the World From 1803 to 1807, 2: 21-2, 36-8.

40 Flot-kapitan Kotzebue, Puteshestvie v iuzhnyi okean...1815-1818 (St. Petersburg: N. Grech, 1821), iii-v.

41 Louis Choris, Vues et paysages des régions équinoxales recuillis dans un voyage autour du monde (Paris: Didot, 1826). 
Another notable explorer, Vasilii Golovnin, authored Around the World on the Kamchatka, 1817-1819, a volume that expresses the viewpoint of a talented and educated naval officer who was determined to defend and extend Russia's possessions in the Pacific. Golovnin was educated at the Naval Military Academy at Kronstadt and read extensively in the history of sea exploration and philosophy as well as the works of the philosophes. From 1802 to 1805 , he served in the British navy, and saw combat under Admiral Nelson. In 1807, he undertook a voyage on the Diana to conduct a survey of the Northern Pacific regions. Despite numerous mishaps-including being taken captive in South America and Japan-he completed a survey of Russian possessions along the coast of Alaska. Upon his return, he wrote an account of Japan that enjoyed great popularity and became a classic text on the subject. Golovnin served as the model for the cosmopolitan, professionally trained naval officer for future generations. Three explorersFedor Litke, Ferdinand Wrangel, and Fedor Matiushkin-served under him on the Kamchatka and praised the strict and rigorous training they received in the "Golovnin school."

Golovnin's trip had several objectives: to deliver supplies to Kamchatka; to survey islands in Russian possession not already surveyed as well as a stretch of the Northwest Coast not approached by Cook; and to inquire into the treatment of natives by the Russian-American Company. ${ }^{42} \mathrm{He}$ confined most of his criticisms of the company to a confidential report he wrote for the government. He approached the natives without the sense of righteous superiority displayed by his predecessors. Describing the Kodiak islanders, Golovnin observed the survivals of idolatry; although they professed Orthodoxy, the natives refused to talk about the subject, "because the first Russian settlers...made fun of and expressed scorn at the various myths which they heard about the creation of the world and man." The Sandwich or Hawaiian islanders stole, but "at least along with all the other European 'arts' they have learned to steal like civilized people"-that is, they did not take things that they did not need. He believed that the introduction of Christianity and the art of writing to the Sandwich Islanders would enable them to reach a stage of development "unparalleled in history." "But it is not

42 V. M. Golovnin, Around the World on the Kamchatka, 1817-1819, 7 (Honolulu, HI: Hawaiian Historical Society, 1979), 7; L. A. Shur, K beregam Novogo Sveta (Moscow: Nauka, 1971), 89-90. 
easy to introduce a foreign religion to a free and vigorous people!" Conquered peoples outwardly accepted the faith of their conquerors, but free people had to be persuaded, and it would take a long time to accomplish that. ${ }^{43}$

In general, Golovnin shared Krusenstern's vision for an expansion of Russian initiatives in the Pacific and demanded a rebuff to merchants from the United States, who had been encroaching on the Russian fur trade in Alaska. He inspected the small Russian settlement at Fort Ross in California, which had been established in 1812; he found that it was thriving and enjoyed the friendship of the local Indian tribes. Hi gave an eloquent defense of Russia's rights to the fort and the adjacent land. ${ }^{44}$ However, in the last years of his reign, Alexander I abandoned his aims in the Pacific. The triumphalist mood that set in after the victory over Napoleon was sufficient to display Russia's parity with or even moral superiority to Europe. The development of Russian naval power was no longer necessary to elevate Russia's prestige. The beginning of the Greek war of independence in 1821 convinced Alexander that it was necessary to avoid offending the British in the Pacific. Golovnin watched in dismay as the attention to the fleet began to wane, a tendency that would continue during the reign of Nicholas I. ${ }^{45}$

The final text of this rich period of naval explorations was Captain Fedor Petrovich Litke's A Voyage Around the World, 1826-1829. Litke, a product of the Golovnin school, came from a Russified German family, the Lütkes. His father served in the Customs administration and the imperial court. He joined the navy in 1812, and in 1817 gained a place on Golovnin's Kamchatka expedition. Litke understood his role more as a scientist than a representative of Russian sea power. He contemplated the difficulties awaiting him on the voyage of the Kamchatka but was inspired with the determination "to see much that is new that cannot be learned in the fatherland, and the hope that our voyage will not be without benefit for the enlightened world and will not remain without reward from the monarch." 46

From 1821 to 1824 , he led an expedition to study the island of Novaia Zemlia in the Arctic Ocean. In 1826, he was assigned to captain a voyage

\footnotetext{
43 Golovnin, Around the World on the Kamchatka, xxviii-xxx, 116, 122-3, 202, 206-7.

44 Ibid., 127-31,162-6.

45 See the "Forward" to Golovnin by John J. Stephan, xiiii-xiv.

46 Shur, K beregam Novogo Sveta, 89.
} 
on the Seniavin to the Pacific to the North East coast of Asia and the Northwest coast of America, which would be the subject of his Voyage. In the introduction, Litke emphasized that the principal goals of his expedition were scientific, unlike the expeditions of the previous fifteen years, which "were destined to carry cargoes to Okhotsk and Kamchatka, and to cruise around the colonies of the Russian-American companies" and produced few scientific results. In addition to surveying shores of the Bering Sea and Pacific islands, Litke undertook scientific investigations with the pendulum on the curvature of the earth; with a magnetic needle on the theory of gravity; and with a barometer on climatic phenomena. The naturalists on the voyage, Alexander Postels and Karl Heinrich Mertens, collected hundreds of specimens of flora and fauna. Postels also collected ethnographic materials, costumes, arms, utensils, and ornaments. The two naturalists and Friedrich Heinrich Kittlitz, the accompanying artist, compiled a portfolio of 1,250 sketches, some of which were published as illustrations to Litke's text. ${ }^{47}$ Litke's scientific work gained him world renown: his survey of the Bering Sea revealed unknown shorelines and islands; his conclusions about the curvature of the earth were considered major scientific contributions; and his findings with the magnetic needle provided material for important works of other scholars.

Litke's Voyage around the World, written in Russian and published simultaneously in Russian and French, marked a new stage in the evolution of the genre of texts of exploration. The effacing mode of the humble ship captain, not given to verbal expression, disappears. Litke does not contain his authorial voice and shapes his material to express his own personal feelings and views, for instance, describing the beauty of a sunset, or recalling the problems of perception, when the last port-of-call remains in the sailor's mind. The confidence and authority in his writing and his eloquence of expression give his account the flow and evocative power of a literary text. A review of the first two parts of his study greeted Voyage as a "European book." "The appearance of a European book in our literature is an event like the appearance of a comet." The reviewer perceived that the European persona of the author was expressed in the quality of his writing, the vividness of his perceptions, and the nobility of his attitude toward native peoples. ${ }^{48}$

$47 \quad$ Frederic Litke, $A$ Voyage Around the World, 1826-1829 (Kingston, ON: Limestone Press, 1987), i, viii-xi.

48 "Puteshestvie vokrug sveta," Biblioteka Dlia Chteniia vol. 9 (1835): Part 5, 1-32. 
Concerning the last encomium, Litke describes the native peoples encountered with ease and confidence: there is no sense of discomfort at the crude customs and the squalor of native life. He respects their myths of origin, such as a tale of a legendary flood told by the Kaloshes of Sitka. He notes that they resembled the myths of other peoples, including those of the ancient Greeks: "the childhood dreams of the human spirit are the same under the beautiful sky of Greece as in the wild forests of America." ${ }^{4}$ The Kaloshes' sacrifice of slaves and their brutal warfare evince "the same bloodthirsty vengeance that we find with the Bedouins and our own mountain people." "The customs of the Kaloches," he concluded, "differ very little from those of other peoples who live in wild independence. They are cruel to their enemies, and all strangers are enemies. They are suspicious and cunning." These qualities designated a people "who have neither civilization nor any religion based on the love of one's fellow man. But they do not render them unworthy of being human beings, as would infer a very recent traveler, in which case one would have to similarly discard a major part of the peoples who inhabit the earth." He then went on to describe their positive qualities: their love for their children, who were obedient; the absence of poverty in their midst; their attention to their physical condition; and their love for life, proven by the absence among them of suicide. ${ }^{50}$

Litke found that the administration of the Russian-American Company had greatly improved. The company had reached a fair arrangement with the Aleutians, who were exempted from paying tribute, either in skins or currency, as long as they agreed to supply half their manpower to hunting sea animals when the company demanded it. ${ }^{51} \mathrm{He}$ concluded that the condition of the Aleutians on the island of Unalashka had changed greatly for the better. They had adopted the habits of the Russians and their way of life and dress. They had become true converts to Orthodoxy: they had begun to adopt Christian beliefs; attended church diligently; made the sign of the cross when boarding ship; and sent their children to the school founded for them. ${ }^{52}$

Litke's text expresses the confidence of a seaman, born and educated in Russia, who serves the Russian emperor and expresses his western identity

\footnotetext{
49 Litke, $A$ Voyage around the World, 83-4.

50 Ibid., 88-9.

51 Ibid., 72-8.

52 Ibid., 101-2.
} 
in his scientific contributions and literary sophistication. However, Russia's Pacific empire was losing its political significance by the time the book was published, and the new emperor, Nicholas I, boasted of Russia's superiority to the west because of its defense of monarchy and religion, as evidenced by the victory over Napoleon and Russia's military might. The doctrine of Official Nationality proclaimed the national character of the westernized monarchy and the distinctiveness of its institutions. ${ }^{53}$ In this setting, exploration took new directions. Litke remained a respected and influential figure in Russian government and cultural life-he was a founder and first vice-president of the Russian Geographical Society, which organized geographical and ethnographic expeditions in the last decade of Nicholas's reign. These expeditions, however, focused not on the exotic world beyond, but on Russia itself. They sought not so much an engagement with the world and fostering Russian Europeans, as answers to the question of Russia's distinctive national identity. ${ }^{54}$

53 Scenarios of Power, 1: 275-8, 298-9, 379-81.

54 On Litke and the Geographical Society, see Nathaniel Knight, "Science, Empire and Nationality: Ethnography in the Russian Geographical Society, 1845-1855," in Imperial Russia: New Histories for the Empire, ed. Jane Burbank and David L. Ransel (Bloomington, IN: Indiana University Press, 1998), 108-47. 


\section{Russian Noble Officers and the Ethos of Exploration}

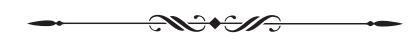

D uring the nineteenth century, Russian noble officers led extraordinary expeditions to the Pacific, the Russian Far East, and Central Asia. The first generation of noble explorers undertook maritime explorations of the Northern Pacific. Later in the century, army officers organized expeditions to the distant reaches and borderlands of Russia. Inspired by their readings and the examples of European and Russian explorers, both generations were driven by a powerful personal desire to venture into the unknown. By embarking on organized expeditions of discovery and scientific investigation, they sought both to realize these aspirations and to fulfill the obligation of service to emperor and Russia borne by Russian noblemen since the reign of Peter the Great. Their determination to embark on difficult and perilous expeditions reflects what I call an ethos of exploration, which they expressed in accounts of their voyages as well as in scholarly and personal writings. These writings defined their personal identities both as Russians and as European explorers and scientists. This article will trace the emergence of the ethos and its transformation in response to changing conceptions of the Russian nation and its imperial destiny during the nineteenth century.

The training of Russian noblemen to lead maritime expeditions began in the last decades of the reign of Catherine the Great. In response to Captain James Cook's discovery of an abundant sea otter population in the North Pacific on his last voyage (1776-1779), Catherine assigned young officers from the Naval Academy and the Naval Cadets Corps to serve apprenticeships in the British navy, a practice followed also by Alexander I. Four of these officers, Adam Johann von Krusenstern, Vasilii Golovnin, Iurii Lisianskii, and Mikhail Lazarev, served and saw combat on British ships. Their model of professional dedication and integrity was Captain Cook- 
a seaman who combined the goals of maritime exploration, the expansion of trade, and the advancement of science. ${ }^{1}$

The first contingents of noble naval explorers embarked on circumnavigations of the globe that took to them to the North Pacific and to Russia's recent Pacific acquisitions. Following a route proposed by Catherine's War Cabinet, they avoided the difficult overland trek from Petersburg to Okhotsk, which took at least two years. ${ }^{2}$ They started out at Kronstadt, crossed the Atlantic with stops in the Canary Islands and Brazil, rounded Cape Horn to the west coast of South America, and then explored myriad islands in the Pacific before heading north to Siberia and Alaska. They returned via the China Sea, the Indian Ocean, and the Cape of Good Hope. They captained modern ships built in London or the Baltic ports, rather than the ramshackle vessels put together in Okhotsk. Like Cook, they took aboard naturalists, astronomers, and artists, leaving scientific and artistic as well as verbal records of their journeys. Like him, they charted unknown areas and composed literate and detailed diaries, intended for publication and translation.

Beginning with Krusenstern's voyage of 1803-06, Russian seamen completed thirty-three circumnavigations by 1833 . A Baltic German nobleman from Estland, Krusenstern was an active proponent of Russian exploration in the North Pacific. He had served with the British fleet from 1793-99 and observed the vigorous British trade in the Far East. Krusenstern envisioned an ambitious governmental program that would extend Russian sea power, establish a merchant marine, and develop an assertive and enterprising merchantry to engage in trade with China. He received little encouragement from Emperor Paul I (1796-1801), but when Alexander I ascended the throne, he welcomed Krusenstern's initiative. ${ }^{3}$ Krusenstern, who commanded the

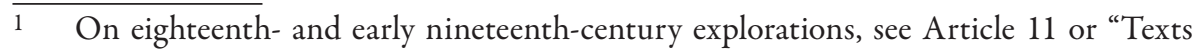
of Exploration and Russia's European Identity," in Russia Engages the World, 1453-1825, ed. Cynthia Hyla Whittaker (Cambridge, MA: Harvard University Press, 2003). Article 11 in this volume. "Zapiski o puteshestviiakh i evropeiskaia identichnost' Rossii," in Rossiiskaia imperiia: strategii stabilizatsii i opyty obnoveleniia, eds. M. D. Karpachev, M. D. Dolbilov, A. Iu. Minakova (Voronezh: Izdatel'stvo VGU, 2004).

2 Ryan Jones, Empire of Extinction: Nature and Natural History in the Russian North Pacific, 1739-1799 (PhD dissertation, Columbia University, 2008), Chapter 6.

3 A. J. von Krusenstern, Voyage Round the World in the Years, 1802, 1804, 1805, 1806 (Cambridge, MA: Da Capo Press, 1968), 1: 6-7. Reprint of the original London edition of 1813 . 
Hope and his comrade Iurii Lisianskii, in charge of the Neva, the second ship on the voyage, publicized their exploits. Five of the participants left accounts: Krusenstern, Lisianskii, George Heinrich von Langsdorff, Nicholas Rezanov, and the clerk of the Russian-American Company, Fedor Shemelin. ${ }^{4}$

Vasilii Golovnin was the most influential exemplar of the ethos of sea exploration. Born into an old Russian family, he was orphaned at the age of nine in 1785 . His relatives, lacking means, sent him to the Cadets Corps of the Kronstadt Naval Academy, where from 1785 to 1793, he was educated at governmental expense. In 1802, Alexander I sent him to train in the British navy, where he served until 1805 and saw combat under Admiral Nelson. In 1807, he undertook a voyage, on the ship Diana, to conduct a survey of the Northern Pacific regions. Despite numerous mishaps, among them being taken into captivity in South America and Japan, he completed a survey of Russian possessions along the coast of Alaska. Upon his return, he wrote an account of Japan, which enjoyed great popularity and became a classic text on the subject. ${ }^{5}$

Golovnin's second major trip was the subject of his widely read account, Around the World on the Kamchatka, 1817-1819. His assignment was to supply the island of Kamchatka, to survey islands in Russian possession as well as a stretch of the Northwest Coast not approached by Cook, and to investigate the treatment of natives by the Russian-American Company. $\mathrm{He}$ also visited Fort Ross, the Russian settlement in Northern California. Golovnin provided a Spartan model of dedicated captain-explorer. Rigid but principled, he instilled a sense of the importance of discipline and obedience in his officers and disregarded cosmetic matters of cleanliness and show, which were popular at the time and became a virtual obsession for Nicholas I. At sea, he remained in his uniform at all times, even when he slept.

Three renowned explorers-Fedor Litke, Ferdinand Wrangel, and Fedor Matiushkin-served under Golovnin on the Kamchatka. Litke admired him and praised the strict and rigorous training of "the Golovnin

$4 \quad$ Urey Lisianskii, Voyage Around the World in the Years, 1803, 1804, 1805, 1806 (London: J. Booth, 1814); George Heinrich von Langsdorff, A Voyage Around the World From 1803 to 1807 (Kingston, ON: Limestone Press, 1993); Nicholas Rezanov, Rezanov Reconnoiters California (San Francisco: Book Club of California, 1972); F. Shemelin, Izvlechenie iz "Zhurnala pervago puteshestviia rossian vokrug zemnago shara" (n.p., 1818). Pamphlet volume in New York Public Library.

5 See Ella Lury Wisell, "Introduction," V. M. Golovnin, Around the World on the Kamchatka, 1817-1819 (Honolulu, HI: The Hawaiian Historical Society and the University Press of Hawaii, 1979), xix-xxiii. 
school,"6 but he nurtured no warm feelings for him. Golovnin showed his subordinates no kindness, no human feeling. They, like Litke, revered him for his "feeling of duty, honor, and nobility." 7 Golovnin recognized their talent. He recommended Wrangel and Litke to lead expeditions-Wrangel to chart the Arctic coast of Siberia, Litke to chart Novaia Zemlia, which he undertook in 1821 , at the age of twenty-four.

The seamen who led these voyages saw themselves as European explorers, helping to advance Russia as a sea power in emulation of Britain and other seafaring nations. They had been educated in elite naval institutions, where they learned about western thought and literature, and, as Ilya Vinkovetsky observed, "considered themselves engaged in active dialogue with general European culture." ${ }^{\circ}$ They represented an enclave of young officers who were markedly different from other members of the noble officer corps in the navy-extreme variants of the type of noble servitor cut off from estate and family ties, completely devoted to serving the goals of a dynamic westernizing autocracy. ${ }^{9}$ The names of several of them-Krusenstern, Litke, Wrangel, Anzhu (Anjou)-indicate Baltic or European ancestry that itself set them apart in a special category. Several were orphans-Vasilii Golovnin, Fedor Litke, Ferdinand Wrangel-who were sent to Petersburg as boys and found their true home in the naval officers' corps.

The memoirs of Fedor Litke tell how a young Russian nobleman was drawn to seafaring and emerged as a prominent figure in the naval and scientific establishment during the reign of Nicholas I. Litke's family, the Lütkes, were among those recruited by the Russian monarchy to put their scholarly knowledge and skills to the service of the Russian state and nobility. His grandfather arrived from Germany with a Masters of Philosophy to serve as Assistant Rector of the gymnasium under the Academy of Science. He wrote on the physical sciences, chemistry, and theology. Litke's father was

6 Graf F. P. Litke, "Avtobiografiia," in V. P. Bezobrazov, Graf Fedor Petrovich Litke (St. Petersburg: Imperatorskaia Akademiia Nauk,1888), 1: 88-95

7 Ibid., 1: 88 .

8 Ilya Vinkovetsky, "Circumnavigation, Empire, Modernity, Race: The Impact of Round-the-World Voyages on Russia’s Imperial Consciousness," Ab Imperio 1-2 (2001): 198-201.

9 See Marc Raeff, Origins of the Russian Intelligentsia (San Diego: Harcourt Brace Jovanovich, 1966), 122-9. 
associated with the Martinist sect of the Masonic movement and wrote essays of a mystical character. He served as the manager of the estates of Prince Repin, but due to the failure of a vitriol factory he received from Repin, had to move to Petersburg, where he began service in the Petersburg Fiscal Chamber and the Commerce College.

Litke's memoirs begin with a tale of early tragedy. His mother died two hours after his birth. "On September 17, 1797," he wrote, "I became my mother's murderer." The blow of her death led his father to contemplate suicide and left him unable to care for Litke or his siblings. The boy was sent to relatives with "coarse morals," who indulged in debauchery and regarded him as little more than a nuisance. "Childhood did not leave me with a single pleasant memory." At school, he recalled only the rod. He was the youngest in class, played no games, and was physically undeveloped. When he was eleven years old, his father died, leaving his son and second wife completely bereft. Two months later, his grandmother died. He was placed under the tutelage of a hated uncle, who ignored him completely. In these years he began to find solace in his reading, particularly Karamzin's Letters of a Russian Traveler and occasional issues of the journal Priatnoe chtenie. ${ }^{10}$

Litke experienced his intellectual and social awakening during the summer of 1811, when he visited his sister and her husband in Kronstadt. There he fell into the company of young naval officers and began to share their love for the sea. One of them, Dmitrii Golovnin, the brother of Vasilii Golovnin, took him under his wing and taught him Arithmetic and Geography. A book about explorations awakened dreams of sea voyages. He paid close attention to the events of 1812, keeping a diary of everything he heard. In 1813, he merited distinction in the naval bombardment of Danzig. ${ }^{11}$

Serving in the Naval Cadet Corps, he participated in the lively social life of the capital. He devoted himself to the study of navigation and sailed whenever the occasion arose. His efforts were well rewarded. In 1814, he received the invitation to sail with Vasilii Golovnin on the Kamchatka, which immediately appealed to his urge "to plunge into the unknown." $\mathrm{He}$ read the published journals of Krusenstern, Lisianskii, Sarychev, Cook, and Anson, and "lived in the future." When he returned from the voyage, he felt himself "a sailor of the school of Golovnin." That meant "thinking of the essence of the matter, not paying any attention to its appearance." 12

\footnotetext{
10 Litke, “Avtobiografiia," 1: 33-40, 45.

11 Ibid., 1: 58-63.

12 Ibid., 1: 87, 94.
} 
Litke followed these principles when he captained his own circumnavigation, which he described in his celebrated A Voyage Around the World, 1826-1829. The voyage clearly was planned at the end of Alexander's reign, without the earlier determination to assert Russia's maritime power. Litke understood his principal role as a representative of Russian science. In the introduction to his account, he emphasized that the principal goals of his expedition were scientific, unlike the expeditions of the previous fifteen years, which "were destined to carry cargoes to Okhotsk and Kamchatka, and to cruise around the colonies of the Russian-American companies." In addition to surveying the shores of the Bering Sea and Pacific islands, Litke undertook various experiments, with the pendulum on the curvature of the earth, with a magnetic needle on the theory of gravity, and with a barometer on climatic phenomena. Litke's scientific work gained him worldwide renown. His survey of the Bering Sea revealed unknown shorelines and islands. His conclusions about the curvature of the earth earned praise as major contributions to science. His findings with the magnetic needle provided a basis for future scientific discoveries. ${ }^{13}$

Both Litke and Wrangel saw their achievements as Russian contributions to a European scientific and cultural project. Many educated Russians took their discoveries and accounts as evidence that Russians had established themselves as true Europeans. For example, in 1835, an anonymous review of the first two sections of Litke's account praised the work as a "European book." "The appearance of a European book in our literature is an event like the appearance of a comet." The author observed that Litke's European identity was evident in the quality of his writing, the sharpness of his perceptions, and the nobility of his attitude to native peoples. ${ }^{14}$

In the last years of his life, Alexander I's interest in explorations and expansion in the Pacific waned. The triumphalist mood that set in after the victory over Napoleon was sufficient to display Russia's parity with or even moral superiority to Europe. In addition, the beginning of the Greek war of independence in 1821 convinced him that it was necessary to avoid offending the British in the Pacific. ${ }^{15}$ When Nicholas I ascended the throne at the end

13 Frederic Litke, $A$ Voyage Around the World, 1826-1829 (Kingston, ON: Limestone Press, 1987), i, viii-xi.

14 "Puteshestvie vokrug sveta," Biblioteka dlia chteniia 9 (1835): pt. 5, 1-32.

15 See John F. Stephan, "Forward" to Golovnin, Around the World on the Kamchatka, xiiii-xiv. 
of 1825 , he gave a national orientation to Russian science and exploration, which now increasingly focused on continental Russia. He brought leading figures to the Academy of Sciences, many of them seeking new fields of study in the geology, the flora and fauna, and ethnographical groups of Russia. In 1832, Nicholas placed Litke in charge of the education of Grand Duke Constantine, establishing him as a person of influence in matters relating to science and exploration.

Another Baltic nobleman, Alexander Middendorf, a professor at Kiev University, took the initiative in opening new regions to exploration. ${ }^{16}$ In 1843, he embarked on an expedition to northern and Eastern Siberia to investigate the effects of permafrost on the animals of the region. ${ }^{17}$ However, Middendorf exceeded his assignment and traveled south to the Amur River, which connected eastern Siberia to the sea, and which he believed would bring great economic benefits to Russia. The Amur region, according to the treaty of Nerchinsk of 1689 , belonged to China, and it was official policy to respect Chinese rights to the area. Middendorf found that Chinese boundary markers were inaccurate, and concluded that Russia was entitled to far more of the territory than the authorities believed. He returned not to reprimands and penalties, but to a hero's welcome, banquets, and acclaim from the nascent Russian Geographical Society. Most important, Nicholas received him sympathetically and, Middendorf wrote, "wished to learn from me the circumstances in the Amur lands." 18 Nicholas had been aware of the importance of Siberia to Russia and had made sure that western Siberia was included on the heir's tour of the empire in 1837.

Middendorf displayed the new sense of mission and entitlement that would characterize Russian explorers from the 1840s. Wishing to trespass the established borders of Russia, the explorers were denied official approval, for fear of antagonizing Russia's neighbors and the Great Powers, but gained tacit support from powerful figures and eventually approval from the throne. One of these supporters was a naval officer, G. I. Nevel'skoi, who had long cherished

16 Alexander Vucinich, Science in Russian Culture: A History to 1860 (Stanford: Stanford University Press, 1963), 304-6.

17 A. F. Middendorf, Puteshestvie na sever i vostok Sibiri, 2 vols. (St. Petersburg: Imp. Ak. Nauk, 1860-1877).

18 Mark Bassin, Imperial Visions: Nationalist Imagination and Geographical Expansion in the Russian Far East (Cambridge: Cambridge University Press, 1999), 78-84; Middendorf, Puteshestvie na sever i vostok Sibiri, 1: 187. 
the notion of exploring the Amur in order to debunk the official wisdom that the river was inaccessible by ships from the sea. Nevel'skoi had come in contact with the imperial family by serving as instructor to the Grand Duke Constantine in naval science, who also accompanied him as a companion on sea voyages. ${ }^{19}$

Despite official resistance, Nevel'skoi mounted an expedition in 1848 and 1849 under the pretext of carrying supplies to Kamchatka and various settlements on the shore of Okhotsk. With the support of Governor General Nikolai Murav'ev (later called Murav'ev-Amurskii) and the encouragement of the heir, Grand Duke Alexander Nikolaevich, Nevel'skoi ventured to the mouth of the Amur and declared that it was open and navigable. When he returned, he met bitter rebukes from many of Nicholas's ministers and a committee chaired by the Foreign Minister Nesselrode. Again Nicholas took the side of an explorer who had ignored formal constraints. He called Nevel'skoi's achievement "dashing (molodetskii), noble, and patriotic," awarded him the Order of Vladimir, fourth level, and declared, according to Nevel'skoi, "Where the Russian flag has been hoisted, it should never be taken down."20 Nevel'skoi later shared his experiences and his ideas with young officers like Mikhail Veniukov. His account of his voyage, The Heroic Exploits of Russian Naval Officers in the Far East of Russia, written shortly before his death in 1876, was a vigorous statement of the explorer ethos. ${ }^{21}$

The economic advantages that were supposed to accrue to Russia with the opening of the Amur not only failed to materialize, but became a secondary concern. The gaze of Nevel'skoi and the other naval officers soon turned south to the Ussuri valley, which promised access to the markets of Manchuria and China. The Amur was only a first step toward annexing the entire region,

19 G. I. Nevel'skoi, Podvigi russkikh morskikh ofitserov na krainem vostoke Rossii, 1849 1855 (St. Petersburg: A. S. Suvorin, 1897), v-vi; Bassin, Imperial Visions, 127n.

20 Bassin, Imperial Visions, 127-29; Nevel'skoi, Podvigi russkikh morskikh ofitserov na krainem vostoke Rossii, 112.

21 In it, Nevel'skoi stated his conviction that it was not obedience or discipline that opened the Amur, but the officers' daring acts, "outside the order of command" (vne povelenii). It was "solely at their own discretion (po svoemu usmotreniiu)" that "they had ventured to give this minor commercial expedition state direction and had occupied the mouth of the Amur river and in the name of the Russian government announced to natives, Manchurians and to foreign vessels in the vicinity of the Amur estuary, that Russia had always regarded this area as its possession...." (italics in original) (Nevel'skoi, Podvigi, 57, 412). 
including the Ussuri basin. In this respect, Middendorf's and Nevel'skoi's Amur adventures marked a transition from the goal of a maritime empire to a continental empire, whose exploration and expansion would center in Asia. ${ }^{22}$ At the same time, it portended a disregard for international borders, with the monarch's tacit approval.

The backing for Nikolai Murav'ev's and Nevel'skoi's ventures came from the members of the Russian Geographical Society. ${ }^{23}$ The Society had been established at the initiative of Litke and the eminent botanist and geographer Karl von Baer, under the aegis of the Grand Duke Constantine Nikolaevich, and remained a favored institution under the monarchy that pursued a scientific agenda focused on the territory of Russia. In his inaugural address as vice president, the de facto head of the society, Litke emphasized that Russia was "part of the earth that has been studied very little" and had "unique variations in climate, geognosy, in flora, and fauna, with numerous peoples and so forth." 24

The ethos of exploration now evoked new goals and a new type of explorer. If the professional sailor Captain Cook provided the model for the previous generation of noble seamen, the model for Russian explorers became the explorer-scholar, whose focus was not the sea, but the vast lands of Asia adjacent to Russia. The works of two world-renowned German scholars, Karl Ritter and Alexander von Humboldt, turned the attention of young Russian officers to these lands. Ritter's nine-volume study of physical geography, Die Erdkunde, published from 1832 to 1859 , was devoted predominantly to Asia. Alexander von Humboldt, the nobleman, explorer, and polymath, visited parts of Central Asia in 1829 and in 1843 published a three-volume account of his experiences and findings. His conclusions about the mountain ranges of Central Asia inspired Russian explorers to plan their own expeditions. ${ }^{25}$

Litke's passion for exploration was prompted by the curiosity of the scientist. The young members of the Geographical Society, however, regarded

22 Bassin, Imperial Visions, 211-12.

23 Ibid., 100, 128.

24 Cited in Nathaniel Knight, "Science, Empire, and Nationality: Ethnography in the Russian Geographical Society, 1844-1855," in Imperial Russia: New Histories for the Empire, ed. Jane Burbank and David L. Ransel (Bloomington, IN: Indiana University Press, 1998), 110.

25 V. A. Esakov, Aleksandr Gumbol'dt v Rossii (Moscow: Akademiia Nauk SSSR, 1960), 77-9. 
geography as conveying something more-namely a means to understanding the nation and the people through their land. Alexander Golovnin, the secretary of the Society and the son of Vasilii Golovnin, made a special effort to recruit talented and progressive young noblemen into the society. Between 1848 and 1850, a rift opened in the Russian Geographical Society between the founders of the society, Litke and von Baer, and the younger members, who sought to take a more "national approach" to science-to direct the society to the more "practical" goals of Russian geography and ethnography. The younger members rallied behind Mikhail Murav'ev, a wealthy nobleman and powerful official with a Russian surname. ${ }^{26}$

In 1850, to Litke's chagrin, Mikhail Murav'ev defeated him in the election for Vice-President of the society he had helped to found. Litke was shocked and bemused by this show of national consciousness. He had perceived no contradiction between his European ancestry, his scientific work, his service to the emperor, and his sense of himself as Russian. Reflecting on the his father's life from the perspective of the 1860s, Litke wrote, "He was in his soul a Russian (russkii) and considered himself a Muscovite and it didn't occur to anyone to call him a German.... For such an outrage one had to be destined to live in our enlightened century." 27

The next generation of explorers, exemplified by Peter Semenov and Mikhail Veniukov, although inspired by the examples of Krusenstern, Golovnin, and Litke, were scientists and army officers who sought to infuse imperial exploration with a national purpose. For them, science became a means to shape their own sense of nation. Semenov, who served as secretary for the Society from 1849, translated the first volume of Karl Ritter's Die Erdkunde von Asien. In the introduction, he described science as "'selfknowledge' (samopoznanie), that is as the recognition of the objects and forces of Nature and the ability to subject them to our own power, to use them for our needs and demands... the desire to introduce the treasures [of human knowledge] into the life of the nation." 28 The treasures that Semenov had in mind comprised knowledge of the geography of the nation.

26 On the foundation of the Geographical Society and the involvement involvement of the "enlightened bureaucrats" in its work see W. Bruce Lincoln, In the Vanguard of Reform: Russia's Enlightened Bureaucrats 1825-1861 (De Kalb, IL: Northern Illinois University Press, 1982), 91-101; Knight, “Science, Empire, and Nationality," 110-14.

27 Litke, “Avtobiografiia," 13.

28 Cited in Bassin, Imperial Visions, 97. 
This knowledge represented for Semenov not merely a contribution to science, but also means to advance Russia's interests by extending its territorial sway. In an article of 1855 devoted to a description and analysis of the geography of the Amur region, Semenov observed that the explorations of the previous thirty years had shown that "Russia moves forward, as Providence itself has ordained, in the general interests of humanity: the civilizing of Asia." He envisioned a future in which Russians would not annihilate native populations as the Spanish had in South America and the British in North America. "Rather, they gradually assimilate [the half-wild tribes of Central Asia and the Far East] to their civilization, to their social life and their nationality." 29

Semenov and Veniukov were representatives of a new type of noble explorer as army officer. Like Golovnin, Litke, and Wrangel, they had limited means and had to depend on their service for their livelihood. However, unlike them, they came from old noble families of Riazan province and retained a sense of attachment to their estates and their families. Most important, unlike their predecessors they engaged in formal study of geography and the natural sciences, at St. Petersburg University. They emerged trained scientists, and during their careers regarded themselves as geographers, rather than officers.

While Litke's memoirs focused on his service to the emperor and to the Russian state, those of Semenov and Veniukov expressed a new sense of concern for the Russian land and people. Their life stories follow the pattern of romantic noble memoirs of mid-century and begin with affectionate memories of life on the family estate. Unlike Litke, whose arrival in Petersburg was his entry into a new world of science and dignity, theirs was a traumatic break from a cultured and sympathetic family life close to nature. Both found in the realm of Natural Science a means to fulfill the imperative of state service and to link their lives with the Russian people and the Russian land.

Semenov's father had fought at Borodino in the Izmailov Guard's Regiment. His mother came from a French family that had arrived in Russia in the eighteenth century. Both parents followed the literature and thought of the first decades of the nineteenth century, and their estate became a cultural center for the local nobility. Semenov recalled a life that was "open and hospitable." ${ }^{30}$ In 1843, at age sixteen, circumstances abruptly changed.

29 Ibid., 203-4.

30 P. P. Semenov-Tian-Shanskii, Memuary (Petrograd: Izdanie sem'i, 1915), 1: 50. 
His father died, and his mother began to suffer mental illness. He was shortly enrolled in the Lycée at Tsarskoe Selo.

Semenov learned much from the teachers at the School, but his heart and his interests remained with his estate in Riazan province, where he spent five months each year indulging his love for "nature and freedom." Fascinated first by gardens, he read the books on the subject from the estate library, memorized the Latin names of plants and trees by heart, and began to collect specimens. A German tutor acquainted him with the science of botany, which remained his first love throughout his life, and he mastered the principles of the Linnaean system. He hunted fauna on the estate as well, particularly insects and river crabs. "Every day and from each excursion I brought back something new and interesting." In the winter time, he read his father's atlases, works on geography, Russian classics, Karamzin's history, French plays, Sir Walter Scott, and especially Shakespeare. He was indifferent to children's books, except for Robinson Crusoe, which he found in three languages in his father's library. 31

Semenov yearned to attend the university, but his mother could not afford the cost. Instead, he was placed at the elite School of Guards' Ensigns and Cavalry Ensigns. In 1845, he took the opportunity to attend university courses. He studied the natural and physical sciences and formed friendships with the botanist Andrei Beketov and the biologist and later pan-Slavist Nicholas Danilevskii. In 1855, after Alexander II had ascended the throne, Semenov traveled abroad to study Geography in Berlin. His young wife had just passed away. Shaken by the tragedy, he vowed to overcome his grief by beginning a new life and devoting his energies to "exploits (podvigi) that were difficult but beneficial for my fatherland." The first exploit he envisioned was to climb the heights of the Tian-Shan mountain range, which no European had reached, and bring back samples of rock to test Humboldt's hypothesis that the mountain had been volcanic. The second was to work for the emancipation of Russian serfs. ${ }^{32}$

In Berlin, Semenov prepared himself for the first of these tasks by studying meteorology with Heinrich Wilhelm Dové, mineralogy and geology with Gustav Rosé, who had accompanied Humboldt on his Central Asian trip, and, most important, geography with Karl Ritter. He declared that his journey to the Tian-Shan region, sponsored by the Geographical

\footnotetext{
$31 \quad$ Ibid., 1: 137-44.

32 Ibid., 1: 238-9.
} 
Society, would be devoted to the greater understanding of Russia. ${ }^{33}$ Enjoying the cachet of the Society, Semenov felt empowered to flout rules and restrictions. To reach the Tian-Shan mountains he had to cross the border of Russia and enter China, which would violate a prohibition of private expeditions into neighboring countries. As a result, he omitted mention of his goal in his application to the Ministry of Foreign Affairs and described the purpose of his trip as the exploration of the Altai and the Kirghiz steppes. By concealing his goal, the Tian-Shan mountains, from the authorities, he gained the necessary escorts and papers to enter the region. He made numerous important scientific discoveries. Along the way to Lake Issyk Kul, he disproved the assumptions of Ritter and Humboldt that it was the source of the river Chu. His observations about the geology and geography of the region threw doubt on Humboldt's hypothesis that the mountains had a volcanic origin. He discovered and described five glaciers.

Semenov also saw his expedition as a means to promote Russian expansion and colonization in the region. With the favor of Mikhail Murav'ev and the Geographical Society, he succeeded during the first months of 1857 in strengthening the resolve of the Governor of Western Siberia, General G. I. Gasfort, to defy the authorities and occupy the adjacent Zailiisk region. He argued that this would "firmly secure peaceful Russian colonization, would make it become one of the pearls of Russian power in Asia." He argued for moving Russian administrative centers further into Central Asia. ${ }^{34}$ Semenov returned to Petersburg to work behind the scenes to influence the decisions leading to the emancipation of the Russian serfs. He remained a lifelong champion of Russian colonization, which he described in 1892 as "part of the great colonizing movement of the European race," comparable to the overseas colonization of Spain, France and England. ${ }^{35} \mathrm{He}$ went on to initiate numerous geographical and statistical studies of the empire and later served as Vice-President of Russian Geographical Society. While critical of much in Russian government,

33 W. Bruce Lincoln, Petr Petrovich Semenov-Tian-Shanskii: The Life of a Russian Geographer (Newtonville, MA: Oriental Research Partners, 1980), 21. Lincoln provides an excellent critical account of the journey.

34 Ibid., 23, 25, 28-9, 31-4.

35 Cited in Uillard Sanderlend (Willard Sunderland), "Imperiia bez imperializma?" in Novaia imperskaia istoriia post-sovetskogo prostranstva, ed. I. Gerasimov, et al. (Kazan: Tsentr issledovanii natsionalizma i imperii, 2004), 463. 
he remained devoted to the monarchy and was awarded the hereditary title Tian-Shanskii by Nicholas II in 1906.

Mikhail Veniukov, also an eminent geographer, served under Semenov in the Society. In 1873, he was appointed editor of its journal, and began work on an ethnographic map of European Russia. In contrast to Semenov, Veniukov regarded the monarchy as the source of Russia's social and economic problems and the major deterrent to the formation of a Russian nation-state. ${ }^{36}$ Like Semenov, Veniukov grew up on a small estate in Riazan province and his memoirs describe his strong attachments not only to his grandmother and father, but to the local priest and peasants, who were whipped before his eyes, causing him to weep. Like other gentry memoirs at the time, his portrayed an idyllic childhood. ${ }^{37} \mathrm{He}$ described the estate as his "paradise" where, as an only child, he was doted on by the adults, especially women.

Veniukov's father was a small landlord, from an old family, and served in minor local positions such as town head (gorodnichii). He conveyed to his son the feelings of patriotism, sacrifice, and courage that he had felt during the Napoleonic wars. He stirred his son's imagination with tales about Bagration and Kutuzov, whose lithographed portrait hung on the wall. Before he could read, Veniukov could recite Vasilii Zhukovskii's "Bard in the Camp of Russian Warriors" by heart. He learned to read from his grandmother, and was fascinated by an old book on navigation. "I learned that on earth there were places such as London, Paris, and Kronstadt."38

In 1845, at age thirteen, Veniukov was sent off to Petersburg to prepare for the officer corps in the Noble Regiment (Dvorianskii polk), under the Second Cadets Corps. He compared the experience with being committed to prison for ten years. He received a "barrack education" of parades and discipline enforced by the rod and survived on niggardly rations. Only the friendships he developed among the students made the experience tolerable, and readings in geography and natural history provided his only intellectual substance. He read Humboldt's Cosmos, and works on zoology, botany, and land

36 I am indebted to Seymour Becker for making available his brief but incisive unpublished essay on Veniukov, "Mikhail Ivanovich Veniukov (1832-1901) Liberal Proponent of Empire."

37 M. I. Veniukov, Iz vospominanii: kniga pervaia: 1832-1867 (Amsterdam: n.p., 1895).

38 Ibid., 1-6, 30-1, 34-5. 
surveying. In his last year he devoted himself to mineralogy and meteorology as well as to the reading of Liebig's "History of Chemistry." 39

Veniukov had hoped to study at the Mining Institute, but to his disappointment he was assigned in 1850 to serve as an artillery officer in the provincial town of Serphukov in Moscow Province. There he found diversion in his readings-Liebig's Letters on Chemistry, Herzen's Letters on the Study of Nature, Humboldt's Pictures of Nature, and Litke's Voyage. He claimed that he liberated himself "thanks to science, physics, chemistry, and zoology from absurd ideas about the heavenly origin of earthly things, about some good-fornothing everlasting creator of an eternal world."

In this period he also turned his attention to current social problems, particularly to the ideas of freedom and equality as the basis for human happiness. Herzen's novel, Who Is to Blame?, made him aware of the absence of "luminaries" (svetlye lichnosti) who could spread light in the darkness." Like the hero of Herzen's novel, he felt isolated in provincial society, far from the universities where he yearned to study. It was at this time, he recalled, that he developed a strong aversion to the principle of command and authority that dominated Russian life under Nicholas I. ${ }^{40}$

In 1853, Veniukov returned to Petersburg, where he led a penurious existence, selling his pocket watch and all of his books except Humboldt's Cosmos in order to survive. He began a course of study at the university and dreamed of achieving the rank of academician and also of becoming an explorer, like Peter Simon Pallas and Humboldt. ${ }^{41} \mathrm{He}$ studied at the General Staff Academy, where he learned cartography, surveying, and tactics, all of which made clear to him the incompetence of the generals in the Crimean War, who lacked a plan. None of the battles of the war, however, had been explained to them at the Institute, because of fear of "the spirit of criticism." 42

After graduating from the Academy in 1856, he was appointed adjutant to Nikolai Murav'ev and assigned at the age of twenty-four to lead an expedition to find the source of the Ussuri river. In Petersburg he had made the acquaintance of Nevel'skoi, who visited him in his apartment and held forth in detail about the Amur and Ussuri regions. Veniukov felt himself following

\footnotetext{
39 Ibid., 55-62, 72-7, 97-101.

40 Ibid., 125-9.

41 Ibid., 140, 151-2.

42 Ibid., 181-2.
} 
the examples of the great explorers of the past, the discoverers of America described in the accounts of Washington Irving and Walter Prescott, which, he indicated, all educated young people read in the 1840s and 1850s. They also read Humboldt's descriptions of his travels in South America. "It is no wonder that those of us who first saw the Amur experienced the sense felt by Balboa when he first beheld the Pacific from the heights of the isthmus of Panama." 43

Veniukov's response to the Amur land was different from Nevel'skoi's, who saw the region as one inhabited by natives, whom Russians could instruct. Instead, he saw the Amur as a land already inhabited by Russians. These inhabitants were principally Cossacks, the advance guard of Russian colonization, leading the process of the conquest of the new territories. He felt a sense of kinship with them-that they were all "members of one great Russian family." The region, he recalled, was already Russian, "undoubtedly Russian." ${ }^{44}$ He felt the prevalent hopes for the Amur region-that the Pacific Ocean was to become the new Mediterranean and the rivers flowing into it, like the Amur, possible routes for trade. ${ }^{45}$

The colonization, however, was unsuccessful, and Veniukov experienced the general disappointment with the prospects of the Amur region after its discovery. ${ }^{46}$ His explanation followed from his belief in the arbitrariness and incompetence of the authorities. ${ }^{47}$ Veniukov continued his work as a geographer in the Central Asian borderland and the northwest Caucasus. His work in the Caucasus from 1861 to 1863 again allowed him to observe the process of Russian resettlement, which seemed to open great possibilities after the Emancipation. The Don territories and the Kuban region also seemed to offer plentiful land. This movement, together with what he witnessed in Siberia and Turkestan, he wrote, showed "the great rise of historical pulse in Russia" and promised a brilliant future for the new Russian colonies. ${ }^{48}$

Although Veniukov continued to criticize the tsarist administration, he was enthusiastic about the conquest of the Caucasus and the possibilities it opened for further Russian colonization. A speech of 1873, which he cited in his memoirs, described the conquest as the forward march of civilization. Its true

\footnotetext{
43 Ibid., 213-4.

44 Ibid., 218.

45 Ibid., 225-6; Bassin, Imperial Visions, 269.

46 See Bassin, Imperial Visions, 233-60.

47 Veniukov, Iz vospominanii: kniga pervaia, 228-39.

48 Ibid., 283-4.
} 
conquerors were not the generals, but the Russian soldiers, whose endurance and courage not only defeated the native peoples, but ensured that "the Caucasus became Russian land." They triumphed in a region where "without the arrival of Russians barbarism would rule forever." 49 Veniukov believed that Russian settlements could provide these peoples with models of civilized life and thought that this was already beginning to take place. In this way, Russia could follow the example of the United States, France, and England, imperial polities that incorporated various nationalities into nation states. ${ }^{50}$

Russia's most illustrious explorer of the nineteenth century, Nikolai Przheval'skii, was also the most consistent and impassioned devotee of an explorer ethos. A nobleman who felt uncomfortable in civilized and official settings, he loved the thrill of conquest of difficult and exotic realms, the feeling of confronting danger alone in nature. As a young man he read about the accounts of Russian explorers. He served as a non-commissioned officer in an infantry regiment, then began to study at the General Staff Academy. There he wrote a well-received scientific study of the Amur region, and dreamed of seeing the Amur. For several years he taught at a gymnasium in Warsaw, and then, to his great delight, was assigned to the Amur region. Siberia and the Amur enchanted him: "I was delighted by everything-the ferocity, the expanse." 51 After a mostly self-financed expedition to the Ussuri region in 1866-67, Przheval'skii launched the first of four forays to the lands of Central Asia, Turkestan, and beyond, areas under Chinese suzerainty that had not been explored or charted, and to Tibet. These explorations were financed largely by the Russian Geographical Society under the aegis of Peter Semenov.

Przheval'skii shared the earlier explorers' interest in natural science and geology, and their determination to penetrate the unknown reaches of the empire and beyond, but he, more than they, experienced the uplift and thrill of venturing into wild and dangerous regions. His memoirs recall his early joy in solitary wandering in "the wild woods" on his Smolensk estate. "I grew up in the country as a savage," he wrote. He dwelled on his early love for hunting,

\footnotetext{
49 Ibid., 336-8.

50 Becker, "Russia Between East and West: The Intelligentsia, Russian National Identity and the Asian Borderlands," Central Asian Survey vol. 10, no. 4 (1991): 4-7.

51 "Nicholas Mikhailovich Przheval'skii," Russkaia Starina 60 (1888): 536.
} 
fishing, and horseback riding. ${ }^{52}$ Later, he felt not a sentimental attachment for the quiet and beauty of nature, but exhilaration with wilderness and delight in the hunt-the stalking and the kill. Inspired by a novel, $A$ Warrior without Fear, in 1855, at age sixteen, he began to serve in an infantry regiment, convinced that "only in this way could one do good." However, he was revolted by the coarse and dissolute ways of the "rabble" of the officer corps and the dreadful food, especially the foul cabbage soup (shchi). He had higher goals in mind, and successfully passed the entry examination for the General Staff Academy, where he first attained distinction with the publication of his study of the Amur region. ${ }^{53}$

Although Przheval'skii did not attend the university, he read extensively in history, natural sciences, and geology. His favorite books were Humboldt's Pictures of Nature and Ritter's massive study of Asia. Scientific discoveries were among the explicit objectives of all expeditions, where he collected thousands of specimens of the geology, and flora and fauna of the lands he explored. ${ }^{54}$ But after his initial work on the Amur, he did not devote himself to lengthy scientific studies. He sought to emulate the explorers of Africa he had read about as a boy, and David Livingstone, whose memoirs appeared in Russian in the $1860 s .{ }^{55}$ His passion was for exploration itself, for steeling his muscles and will to plunge into new wild areas, to endure difficult, dire physical tests in order to discover the unknown and exotic. In the introduction to the account of his fourth and last exploration to China and Tibet, he laid out the requirements for individuals participating in a successful expedition, among them "flourishing healthy muscles," scientific preparation and a disposition unspoiled by civilization and demanding hard, dirty work. The members of the expedition had to be organized as a "military detachment," subject to "inexorable discipline" along with "brotherly relations" between the commander and his subordinates. He preferred those "inexperienced in life, who are always more energetic, honest, selfless, and more enthusiastic about the matter. They live more amicably with one another, don't become homesick."

52 Ibid., 529-30; N. F. Dubrovin, Nikolai Mikhailovich Przheval'skii: biograficheskii ocherk (St. Petersburg: Voennaia tipografiia, 1890), 9-18.

53 "Nikolai Mikhailovich Przheval'skii," 531-4; Dubrovin, 21-7.

54 On Przheval'skii's devotion to science and positivist conception of progress, see Daniel Brower, "Imperial Russia and Its Orient: The Renown of Nikolai Przhevalsky," The Russian Review vol. 53, no. 3 (July 1994): 370-1.

55 Dubrovin, Nikolai Mikhailovich Przheval'skii, 33-5, 41-2. 
The best suited were boys from rural areas, far from railroads and very poor, those who served as soldiers and especially Cossacks, who were bold and sturdy, not given to whining, and could be easily disciplined, and of course subject to his will. ${ }^{56} \mathrm{He}$ succeeded, he asserted, "in studying a region where no European has ever set foot and to become acquainted with a people that had been unknown until that time and that had very interesting features from an anthropological view point." 57

This statement expressed the belief that he, a Russian explorer and scientist, had achieved a feat that equaled or surpassed his European counterparts. Like his predecessors, Przheval'skii asserted his national identity by emulating European examples of heroic explorers bringing civilization to the Far East, thereby placing a Russian in their number. Przheval'skii's aims for exploration and the extension of Russia's power were more far-reaching and ambitious than Semenov's and Veniukov's. They had promoted exploration and colonization of the borderlands and adjacent areas of Russian empire. Przheval'skii entertained an explicitly imperialist vision. He foresaw Russia's might and influence advancing far beyond Russia's borders into China and Tibet, thus entering Russia into Great-Power rivalry, particularly with Britain. After his first Central Asian expeditions in the 1870s, he was received as a national hero, acclaimed at public lectures, where he declared that historical circumstances had compelled Russia to take on the task of bringing civilization to Asian peoples beyond the Russian empire. ${ }^{58}$

He presented himself as a liberator of Chinese subjects from "the yoke of Chinese power," who, as agent of the Russian monarch, would introduce legality "in countries so recently being the arena of the broadest despotism of their rulers." He wrote that the "nomadic Mongols, the Muslim Chinese, and inhabitants of East Turkestan all yearn to become subjects of the White Tsar, whose name like the Dalai Lama's appears in the eyes of the Asiatic Masses in a halo of mystic light." 59 By 1886, Semenov, a revered figure, a Senator and chair of the Statistical Council of the Geographical Society, had been enthralled by Przheval'skii's achievements and designs, praising

\footnotetext{
56 N. M. Przheval'skii, Ot Kiakhty na istoki zheltoi reki (St. Petersburg: V. S. Balashov, 1888), 2-7.

57 "Nicholas Mikhailovich Przheval'skii," 540.

58 On Przheval'skii's as national hero, see Brower, "Imperial Russia and Its Orient," 372-4.

59 Przheval'skii, 509-10.
} 
him as "a pioneer gathering the scientific material that is necessary for the definitive conquest of these [Asian] lands for culture and civilization."60

The Russian naval officers who ventured to the Pacific, the Amur, and Central Asia in the nineteenth century shared an ethos that moved them to devote themselves to science and exploration in the service of the Russian monarch, state, and nation. Their expeditions and scientific discoveries defined their identities, both as noble servitors of the throne and as European explorers, asserting Russia's international significance and national destiny. Krusenstern, Golovnin, and Litke asserted their European identity by organizing sea explorations and scientific investigation in the northern Pacific. Taking Captain Cook as their model, they explored the islands of the Pacific and established settlements in North America. They thus played their role in the scenarios of Catherine the Great and Alexander I, which portrayed Russia as a European Empire ruled by emperors and noblemen equal in their achievement to their western counterparts.

Semenov and Veniukov understood exploration as service to the Russian nation. They responded to the national orientation of Nicholas I's scenario by pursuing the study of Russia itself. Their exemplar was the noble scientistexplorer, Alexander von Humboldt. The science of geography promised answers to the problem of national identity posed by Nicholas's scenario and the dominant German philosophies of the day. Cherishing attachments to family estates, they felt a bond with the land, and geography for them was an act of discovery of the nature and true extent of the Russian land. They pursued exploration as a means to learn about the Far East and Asian borderlands of Russia, lands that could become the object of colonization by the Russian people. "Asian borderlands," Seymour Becker wrote, "were perceived by the intelligentsia not as a threat to Russia's European identity but rather as an opportunity to prove that identity." ${ }^{1}$ For Semenov and Veniukov, exploration asserted their identity as Russians and Europeans. In their eyes, the expansion of the empire, through science and the force of arms, was the expansion of the nation. They conflated the land with the people and the Russian nation with the Russian empire-Semenov with the existing empire, Veniukov with an empire envisioned as a nascent, liberal nation state. They

60 Brower, "Imperial Russia and Its Orient," 378.

61 Seymour Becker, "Russia Between East and West," 61. 
asserted their European identity by proving the belonging or desire to belong to a state expressing the interests of its people. ${ }^{62}$

Both Semenov and Veniukov sought to extend Russia's borders in Asia for the purpose of colonization by Russians. They assumed that their explorations would be limited to areas adjacent to the empire, where boundaries were vague, which could reasonably be incorporated into a Russian imperial nation. Przheval'skii was inspired by European explorers of Africa, whose courage, knowledge, and will made possible the subjugation of distant native peoples by dint of their superior knowledge and power. His gaze fixed on lands of Asia beyond the borders of Russia, regions not contiguous to and not contemplated as borderlands of the Russian empire. The audacious disdain for borders and determination to extend Russia's influence displayed by earlier explorers now took the form of an imperialistic drive for domination, arrogant and boundless, what David Schimmelpenninck has aptly described as "conquistador imperialism."63 "No matter what," Przheval'skii wrote "we will have to settle old accounts and give tangible proof to our haughty neighbor [China] that the Russian spirit and Russian bravery are equally powerful in Great Russia and in the far east of Asia." ${ }^{4}$ He impressed this notion of Russia's proud destiny in the East on the young tsarevich, Nicholas Aleksandrovich, the future Nicholas II. "In lessons he gave Nicholas on Central Asia, and vivid reports shown to him on his experiences during his fourth expedition to the East, Prezheval'skii conveyed a sense of native invincibility and courage that could enable Russia to join other Great Powers in subjecting the remote reaches of Asia. The ethos of exploration had modulated into an ethos of conquest that would prepare the way for the disastrous confrontation with Japan in the first years of the twentieth century. ${ }^{65}$

62 On the tendency to imagine the Russian Empire as a nation state, see Vera Tolz, Russia: Inventing the Nation (London: Arnold, 2001), Chapter 5.

63 David Schimmelpenninck Van Der Oye, Toward the Rising Sun: Russian Ideologies of Empire and the Path to War with Japan (De Kalb, IL: Northern Illinois University Press, 2006), 24-41.

64 Przheval'skii, Ot Kiakhty na istoki zheltoi reki, 536.

65 Schimmelpenninck Van Der Oye, Toward the Rising Sun, 38-9, 196-201; Scenarios of Power, 2: 323-4, 366-7, 390-1. 
Part IV

Intellectual

History

cof́s? 



\section{Koshelev, Samarin, and Cherkasskii and the Fate of Liberal Slarophilism}

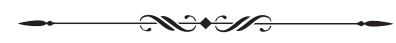

In the historiography of the Russian intelligentsia, liberal Slavophilism has suffered a sad neglect. Whereas Marxist and Populist historians alike have hallowed the radical Westernizers, the liberal Slavophiles have been relegated to a minor position and Slavophilism presented as an ideology of obscurantist conservatism. In one respect this is understandable: the liberal Slavophiles were above all moderates, and did not offer the violent expressions of resentment against the existing order that appealed so much to the revolutionary mentality. Although moderate, Slavophilism in the forties and fifties was a powerful progressive force, instrumental in bringing about the Great Reforms. In their concrete notions of reform and their determination and ability to carry them out, the liberal Slavophiles far surpassed the Westernizers, who in the forties were still groping in the labyrinth of Hegelian philosophy, and in the fifties were disoriented by the failure of the revolution of 1848 . The Slavophile circles were the only forums where the social problems of Russia could be aired in the forties. Impelled by their devotion to the narod-the people-and their desire to rid their nation of its faults, the liberal Slavophiles went beyond theoretical considerations of reform to work out practical proposals for its execution. ${ }^{1}$

They also outstripped the westernizers in their understanding of the technical problems facing emancipation. The most talented and active members of the group, Alexander Ivanovich Koshelev, Vladimir Aleksandrovich Cherkasskii, and Iurii Fedorovich Samarin, had closely studied local

$\overline{1}$ Pavel Annenkov, Literaturnye vospominaniia (Leningrad: Academia, 1928), 462-3. 
conditions, and Koshelev and Cherkasskii had pressed for the first steps of emancipation in their districts (uezdy). ${ }^{2}$ After the Crimean War, they took the lead in pressing the government for reform and providing it with informed advice. Iurii Samarin's memorandum on serf reform ("On the Serf Status and the Transition to Citizenship"), the first major statement of the need for emancipation, circulated through society after the war and produced a strong effect in government circles. In the pages of the new Slavophile journal Russkaia beseda all three campaigned for reform, and Koshelev opened an adjunct publication, Sel'skoe blagoustroistvo, devoted to enlisting the landlords' support for emancipation and instructing them in its technical intricacies. When the government requested projects from society in 1857 , only those of Koshelev, Samarin, and Cherkasskii were seriously examined. ${ }^{3}$ In 1858 , they were chosen as government representatives in their respective gentry committees to defend the reform against the local nobility. Their threeway correspondence during this trying period is a poignant testimony to the resistance they encountered from hostile majorities and the common ideals that made them persist against great odds.

Three years later, the progressive influence of the Slavophiles had all but disappeared. Each continued to work for further reform, but they followed different paths and their efforts were isolated and ineffectual. In spite of their fruitful activity, the liberal Slavophiles left no tradition behind them, as had the radical Westernizers, for by the early 1860s they themselves were seeking new allegiances. The ideas that had been associated with Slavophilism became increasingly associated with reaction, and later moderate progressives identified themselves with other causes.

Liberal Slavophilism failed to endure because of changed historical conditions. The liberal Slavophiles' devotion to the narod was the basis of their united stand on the need for emancipation, but once the work on serf reform had begun, other questions arose for which devotion to the people provided no simple answer. The most pressing of these was the

$2 \quad$ Aleksandr Koshelev, Zapiski, 1812-1883 (Berlin: B. Behr, 1884), Appendix, 7-14; Ol'ga Trubetskaia, Materialy dlia biografii V. A. Cherkasskogo: Cherkasskii i ego uchastie $v$ razreshenii krest'ianskogo voprosa (Moscow: G. Lissner and A. Geshel', 1901, 1904), 1: 11-20.

3 Aleksandr Kornilov, Obshchestvennoe dvizhenie pri Aleksandre II, 1855-1881 (Paris: Russkaia Mysl', 1905), 31-2. 
political problem: the question of who was to rule Russia and how Russia was to be ruled. When the form emancipation would take became known, groups in society that had been dormant awakened to challenge the terms of the reform and insist on a part in its enactment. How the political claims of the various groups could be satisfied and fitted into the traditional Russian system had not been considered by the liberal Slavophiles, for they had all placed implicit faith in a reforming autocracy. Once they realized the shortcomings of the autocracy's policies, they were forced to consider the insistent political demands of the array of newly awakened social forces and to evolve and clarify their own political views. In this endeavor, their Slavophile ideas were of little help. The Slavophiles believed the narod to be the only pure, uncorrupted Russian element in the land, but their doctrine was not at all democratic, and they were anything but democrats. Their idealization of the people never brought these landlords to believe that uneducated peasants could suddenly rise to positions of power and responsibility. The only other institution unstained by Western influence was the autocracy, and the Slavophiles' ideal was a fusing of tsar and people-the tsar should slit'sia s narodom ("merge with the people"). How this was to be accomplished was unclear, as nobility and bureaucracy alike appeared alien and venal. The only political programs Slavophilism could offer were schemes of idealized peasant anarchism under a benevolent tsar or glorifications of a romanticized version of the ancient zemskii sobor, notions too remote from mid-nineteenth-century Russia to appeal to practical-minded men like Samarin, Koshelev, and Cherkasskii.

Slavophilism was an ideology of the forties, conceived in dreamlike ideals; and though such a mode of thought might well befit a revolutionary bent on destroying the existing order, it offered little help to those seeking to accommodate prevailing arrangements to newly arisen needs. Koshelev, Samarin, and Cherkasskii had never held common political ideals, but had not realized their differences, since the political problem had been dormant in the forties, and their views on the political destiny of Russia, however deeply rooted, remained vague and unformulated. As their political ideas developed, the force of their common devotion to the narod flagged; they formed new loyalties and forsook their allegiance to the group of Slavophile reformers. Thus, while its adherents continued to work for reform, progressive Slavophilism ceased to be an influence of moment. 
The evolution of a set of political and social ideals distinct from Slavophilism, though set in a Slavophile world view and expressed in Slavophile terminology, is strikingly displayed in the life and activity of Alexander Koshelev. A Riazan landlord of the generation of Ivan Kireevskii, Koshelev had close ties with the countryside and had acquired an authoritative knowledge of rural conditions. As a leading member of the Riazan nobility, he had pressed unsuccessfully in the provincial government for the introduction of a measure emancipating the province's serfs. ${ }^{4}$ His disappointments turned him away from the gentry and led him to seek support for reform in the Slavophile circles, where he acted as a mentor and inspirer of younger members, among them Samarin and Cherkasskii. ${ }^{5} \mathrm{His}$ faith that the nobility would ultimately favor ideas of emancipation never disappeared. ${ }^{6}$ A landlord conversant with estate management, he respected the expertise of those close to agricultural life and was disinclined to trust the judgments of those far from the scene. After the initial defeats in the Crimean War, he addressed a memorandum to the tsar, requesting him to resurrect the old zemskii sobor, to summon the leading men of the land to inform him of local conditions and to rally the nation behind the war. In the zemskii sobor, Koshelev saw the consummation of the Slavophile "fusion with the people," though the people themselves were to have little to do with the institution, composed as it was of the "leading men of the realm." 7 Koshelev's journal, Sel'skoe blagoustroistvo, published in 1858, sought to arouse reform sentiment among rural nobility and to instruct them in the complexities of reform, so that they could participate in a national assembly to consider emancipation. ${ }^{8}$ However, in 1858 , Koshelev's favorable attitude toward the gentry was more a hope of what they might become than a statement of their actual capacities. Until 1859, moreover, he could consider his scheme for national participation in government at least partly realized, since the tsar had requested projects from the gentry, convened local committees, and listened attentively to the views of leading men, Koshelev's included.

\footnotetext{
Koshelev, Zapiski, Appendix, 7-17.

Boris Nol'de, Iurii Samarin i ego vremia (Paris: n. p. 1926), 54.

Kornilov, Obshchestvennoe dvizhenie pri Aleksandre II, 10.

A. I. Koshelev, “Ot izdatelia," Sel'skoe blagoustroistvo, No. 1 (1858): i-ii.

Koshelev, Zapiski, Appendix, 45; Trubetskaia, Materialy dlia biografii V. A. Cherkasskogo, 1: 109.
} 
Whereas Koshelev adapted Slavophilism to his faith in the wisdom of the Russian noble, Iurii Samarin, the most brilliant of the younger generation of Slavophiles, looked upon the state as the mainstay of reform, and the gentry as its chief foe. Bred and educated in an old and distinguished family with strong personal bonds with the tsar, Samarin deeply venerated the Russian autocracy. ${ }^{9}$ This feeling was reinforced during his initial government service, when he acted as an agent of the reforming autocracy in Riga, opposing an intransigent Baltic nobility seeking to prolong its sway over the peasants after the abortive revolt of 1840 . His frustrating experience in Riga also served to instill in him a distrust of the nobility, which was sharpened by his later observations of landlord-peasant relations in the Ukraine. ${ }^{10}$ In 1853 , he sat down to compose the memorandum that was to prove so influential after the climate in society had changed. Bearing the imprint of his injured sense of social justice and his reverence for the autocracy, Samarin's plans for reform insisted on the primacy of government action. They stressed the need for firmness and vigor to counter the powerful resistance of the local gentry:

The decree should clearly express the government's conviction of the urgent necessity of the abolition of the arbitrary facets of serfdom. It should provide for the introduction of the obligatory statute, if this statement is not echoed: for until the government's views on the serf question are promulgated for all to hear, until its intentions and the advantage of the majority are no longer matters of doubt, until the bitter foes of all measures for the alleviation of the lot of the serfs can no longer pose as political conservatives, until all this happens, there is no doubt that no landlord will be affected. ${ }^{11}$

For Samarin, emancipation was but the first step in the slow emergence of the masses from servitude to civic freedom. He looked forward to the distant future, when the peasantry would replace the nobility as the mainstay of the autocracy and make possible a real fusing of tsar and people. Vladimir Cherkasskii, another member of the younger generation of Slavophiles, also favored government enactment of the reform, but he did not share Samarin's

\footnotetext{
$9 \quad$ Nol'de, Iurii Samarin i ego vremia, 8.

10 Ibid., 37-43, 56-9; Iurii Samarin, Sochineniia (Moscow: D. Samarin, 1877-1896), 7: ii-iii, xxxvi-xxxvii.

11 Ibid., 1: 294, Appendix, 1-2.
} 
strong feelings for the autocracy and against the nobility. He simply believed that the government could execute emancipation more efficiently if it were free from gentry intervention. Certain that most noblemen would oppose the reform, he suggested that the government establish central committees that would assure tranquility by standing firm before gentry attacks. ${ }^{12}$ While Samarin distrusted the nobility alone, Cherkasskii's more skeptical temperament led him to be wary of the bureaucracy as well, and he thought that the nobility, when it had come of age, would constitute the government's most reliable basis of support and the peasants' firmest safeguard against administrative excess. ${ }^{13}$

Koshelev, Samarin, and Cherkasskii became aware of the importance of the political problem but began to articulate and enunciate their views on the subject only after they had become disenchanted with the policy of the government and realized that the political problem could not be overlooked in the endeavor for social reform. The first to experience this change of attitude was Koshelev. All three had looked forward to being chosen as members of the Editing Commission, the body charged with the major task of drafting the reform. However, when the members were selected in the first months of 1859, Koshelev found that he had been passed over in favor of both Samarin and Cherkasskii, men respectively fifteen and nineteen years his junior, whom he had instructed in matters of rural economy. And these men were now going to build the new rural economy of Russia. Almost simultaneously, the tightening of censorship restrictions forced the closing of Sel'skoe blagoustroistvo. Koshelev's work for society seemed to have been in vain. Disoriented, without means to fulfill the obligations he thought were incumbent upon him, he feigned indifference and set off to Europe. ${ }^{14}$

Koshelev's withdrawal from public life was short-lived. When after a year abroad he returned to participate in the first summons of the provincial gentry, he found the mood of the gentry had changed. When their interests were threatened, the nobility's apathy vanished, and they began to demand a voice in the resolution of the reform. Uninvited members of the provincial nobility streamed to St. Petersburg, hoping by a show of zeal to divert the

\footnotetext{
12 Trubetskaia, Materialy dlia biografii V. A. Cherkasskogo, 1: Appendix, 84, 88-90.

13 Ibid., 1: 294, Appendix, 1-2.

14 Ibid., 2: 1-10.
} 
reform to their own benefit. They had their own ideas on how emancipation should be executed, and these corresponded little with those in the minds of the leaders of the Editing Commission. Circles were formed to oppose the government's policy, the most notable of which gathered around the Senator A. M. Bezobrazov and his two sons. The Bezobrazov circle drew up and circulated an address rebuking the central government for its bureaucratic approach and warning that unless an assembly of the nobility with direct access to the tsar was summoned, a general cataclysm would ensue. A similar address came from the pen of the wealthy aristocrat Count V. P. Orlov-Davydov, charging that the government was aiding the peasantry to the detriment of the upper classes and calling for a gentry-dominated constitutional system. ${ }^{15}$

A fear that the Editing Commission was intent on destroying the Russian gentry was taking hold of the delegates in Petersburg when Alexander Koshelev, his wounds from his exclusion from the commission still fresh, arrived from abroad. ${ }^{16}$ Now the situation in society seemed to resemble what he had been seeking since the forties: the Russian gentry were showing signs of revival. They were supporting the serf reform and demanding a role in central government. Koshelev entered into friendly relations with his former enemies among the Riazan gentry and, at the same time, began to sense a certain coolness in his contacts with his friends on the commission. ${ }^{17}$

The Editing Commission did not remain silent in the face of the charges leveled by the gentry. Its dominant figure, Nicholas Miliutin dispatched a memorandum to the tsar that portrayed the gentry representatives as the chief obstacle to the success of the reform. ${ }^{18} \mathrm{Up}$ to this point, the delegates' powers had remained undetermined. In August 1859, Miliutin placed the question of the gentry delegates before a special committee, which included Samarin and Cherkasskii. Miliutin posed the question, "Can the merging of the two committees [the gentry assembly and the Editing Commission] take

15 N. I. Iordanskii, Konstitutsionnoe dvizhenie (St. Petersburg: Obshchestvennaia Pol'za, 1906), 36-9; D. I. Khrushchev, Materialy dlia istorii uprazdneniia krepostnogo sostoianiia pomeshchish'ikh krest'ian $v$ Rossii $v$ tsarstvovanie imperatora Aleksandra II (Berlin: F. Schneider, 1860-1862), 2: 93-112.

16 Ibid., 2: 139-40.

17 Koshelev, Zapiski, 117.

18 M. A. Miliutin, "Iz zapisok Marii Aggeevny Miliutinoi," Russkaia Starina No. 4 (1899): 106-8. 
place?" The committee voted unanimously in the negative. Miliutin then asked whether the deputies should be allowed to discuss all questions, or whether some-those on which the government would not permit retreat-should be shelved. On this question there was much discussion, but a compromise was reached that virtually gave Miliutin the power to determine which questions should be considered. On the final issue-whether the deputies should be permitted to assemble and present common opinions-there was open disagreement. Samarin, in the minority, upheld freedom of speech, since he did not believe that the nobility could organize effective opposition to the commission. The majority, including Cherkasskii, thought otherwise, and the delegates were silenced. ${ }^{19}$

Samarin's attitude toward the delegates stemmed from his low estimation of the political capabilities of the Russian gentry. At the first meeting of the summons, the delegates listened in silence to the rules that were to govern their future sessions, and their enthusiasm quickly turned to confusion and indignation. Samarin, however, regarded their response as ludicrous. Emancipation was his overriding interest: that the deputies had been summoned was but a great nuisance for him, and he never dreamed for a moment that they would be able to disrupt the business of reform. He described the opening meeting, in which a table was placed between the members of the commission and the gentry deputies thus:

Such an arrangement fulfilled a dual purpose. First, the warring camps of the deputies and the members of the commission were divided from each other by an insuperable obstacle-a table: thus clashes were prevented. Second, only the back of the head of our leader [Ia. I. Rostovtsev] was visible to us, and we could not see his face, upon which signs of reddening and vexation were displayed. When all were in their seats, a magnificent spectacle began. Our first rank was radiant. On all the dress shone stars, while the back row, of course, was marked by an absence of all ornaments .... Do you remember the scene in Dead Souls, when the male half of the town was divided into fat and thin men? Surveying the deputies, I was convinced that a better means for sorting them could not be found. ${ }^{20}$

19 P. P. Semenov, Osvobozhdenie krest'ian v tsarstvovanie imperatora Aleksandra II (St. Petersburg: M. E. Komarov, 1889-1892), 1: 610-13.

20 Trubetskaia, Materialy dlia biografii V. A. Cherkasskogo, 2: 83. 
A few days later, he attended a dinner with Cherkasskii, Koshelev, Miliutin, and Bezobrazov. "All are extremely discontented with the instructions," he wrote, "but at the same time all felt a certain malevolent glee at the puzzlement of the others. One must not expect any unity of action at all."21

Cherkasskii took the pretensions of the nobility far more seriously than Samarin. He was convinced that some of them were capable of damaging and others of aiding the reform. In a memorandum to the tsar he stated that even though the government had never before requested the assistance of society with such faith, the majority of gentry representatives were unsympathetic to reform. The landlords were reared in conditions of bondage and were alien to the conviction "that at present the state power is founded above all on the welfare of the mass of the people and on the firm security of the farming class." Unlike Samarin, Cherkasskii regarded the small landowners, many of whom wanted to liquidate their holdings for cash, as potential support for the reform. ${ }^{22}$

The deputies were stung by the tenor of the rules, and Koshelev was among the most voluble. With A. M. Unkovskii and Prince Gagarin, he drafted an address of protest, which was accepted by the majority of the deputies. Charging that the Editing Commission was incapable of coping with the local needs of the entire country, the address asserted that the Commission had to secure the help of the gentry through a conference of gentry delegates and members of the Commission. ${ }^{23}$ The rules, however, were left unaltered.

These basic differences of view on how the reform was to be considered laid the groundwork for the division of opinion on Russia's political future that spelled the doom of liberal Slavophilism. Each had already fallen under the influence of a particular group: Koshelev was becoming a part of the revivified forces of the gentry, Samarin and Cherkasskii officials in a vigorous organ of the bureaucracy. As the conflict between these forces sharpened, Samarin, Cherkasskii, and Koshelev were drawn into closer identification with them, and their association with each other became increasingly tenuous. Frustrated by the Commission's restrictions of delegates and enraged by the

$21 \quad$ Ibid., 2: 84 .

22 Ibid., Appendix, 36-45.

23 Koshelev, Zapiski, Appendix, 172-6. 
smugness of its members, Koshelev became more violent in his recriminations. The committee took little notice of his statements. Cherkasskii labeled them a "pasquinade." The result was to drive Koshelev even further into the opposition. He attacked the commission for blindly trying to apply the Complete Collection of Laws to peasant conditions that they knew little about, disrupting, as a result, the course of peasant life. ${ }^{24}$ Most important, he took up a theme he had acquired from the gentry constitutionalists, which would become increasingly prominent in his later writings: the indictment of the bureaucracy for all Russia's failings and the glorification of the nobility as a protection against the administrative menace. He feared that if power over the countryside slipped from the hands of the gentry, it would pass to the local bureaucracy and render the police all-powerful. ${ }^{25}$ It was the gentry who were the true standard-bearers of reform. ${ }^{26}$

At the same time, Koshelev hoped to maintain his agreement with his Slavophile friends. He wrote to Cherkasskii:

From the words of the Princess [Elena Pavlovna] and from your jokes I conclude that you think that I am caballing against the Editing Commission. We may hold different opinions superficially, but essentially we want the same thing and we cannot really differ. Agreeing on much with the Editing Commission, I really differ from it in a few essential points. This I do not conceal. But I will never cabal. First, this is not a part of my character. Second, I know that if the work of the commission were eliminated, we could, in another case, receive a project which is incomparably worse. ${ }^{27}$

Cherkasskii did not respond kindly to Koshelev's weaseling. He wrote:

In general, I do not think that you caballed against the commission, but I think, and I hold, not without basis, that you were carried far beyond the bounds of what you first proposed by the spirit of critical opposition, and that you exploited our opponents with particular success. In this

$\overline{24}$ Aleksandr Skrebitskii, Krest'ianskoe delo v tsarstvovanie imperatora Aleksandra II: Materialy dlia istorii osvobozhdeniia krest' ian (Bonn: F. Kriuger, 1862-1868), 1: 19-20.

25 Ibid., 1: 780-2.

26 Koshelev, Zapiski, Appendix, 195.

27 Trubetskaia, Materialy dlia biografii V. A. Cherkasskogo, 2: 95. 
respect you simply fell in with the general law and proved that it is hard to stand opposed to the influence of the surrounding milieu. ... I will repeat to you what you cogently said yourself two months ago: sometimes we must remove ourselves to a point of view far away from our present quarrels and view things from the standpoint from which we will see them in two years, when the passion has died down. Think of what influence your views will have in two years among the rubbish that will surround them. ${ }^{28}$

Thinking the agreement that had existed between the Slavophiles still existed, Cherkasskii misunderstood Koshelev's motives. He did not realize that Koshelev's primary attachment was to the nobility and not to the Slavophiles, and that the next two years would bring not the modification but the crystallization of Koshelev's views. Koshelev, however, nourished similar illusions about Cherkasskii. He accused Cherkasskii of not understanding the iniquitous influence of the bureaucracy because he had fallen under the deception of state power. ${ }^{29}$ Koshelev, however, had deceived himself: Cherkasskii had always stood for the ascendancy of the bureaucracy, and his actions and ideas were not inconsistent. The illusion of possible solidarity remained, though the reality had passed.

The clamor of the first summons was soon silenced. Heeding Miliutin's warnings, the tsar disbanded the assembly and announced that the deputies would be informed of the outcome by their local governor. When the deputies arrived home, they were further disappointed to learn that discussions and petitions on emancipation were henceforth prohibited. ${ }^{30}$ Infuriated by the government's action, Koshelev addressed an open letter to the deputies of the second summons, calling upon them to persuade the tsar to make the state unite with the people and stand at their head by making local officials responsible to a local elective government dominated by the local nobility. ${ }^{31}$ The interdiction of discussion of the serf reform seemed to provide a fertile field for the spread of Koshelev's ideas. The gentry committees

\footnotetext{
28 Ibid., 95.

29 Ibid., 139-42.

30 Miliutin, “Iz zapisok Marii Aggeevny Miliutinoi," 113-7; Koshelev, Zapiski, Appendix, 1868.

31 Khrushchev, Materialy dlia istorii..., 2: 415-26.
} 
in several northern provinces responded indignantly to the tsar's action. In Tver Province, A. M. Unkovskii, the young marshal of the nobility, lost his post because of his protest against the decree. Mikhail Bezobrazov and D. N. Shidlovskii, a delegate from Simbirsk, drafted addresses appealing for an oligarchic constitution, which won considerable support among wealthy landlords. These movements among the gentry perturbed Samarin, and the fact that Koshelev, one of his confreres, was leading the forces he least trusted, he judged perfidious and irresponsible:

You still haven't tired of writing addresses, brochures, and letters, and you are spoiling the matters with which you sympathize as much as anyone. I hear from Galagin that you are preparing some sort of a manifesto from the name of the almshouse called rural economy. When will you give up? This is simply bothersome. Even if you were right a thousand times in your attacks against us, as you would like to believe, the mood at the moment is such that each word uttered against the Editing Commission will be seized upon with joy and turned into a weapon against the emancipation of the serfs with land. ${ }^{32}$

The tumult momentarily subsided. The second summons of deputies hardly took notice of Koshelev's letter and instead concentrated on the material concessions they sought. However, with the promulgation of the decree of Emancipation in February 1861, it revived again, and those who had expected more from the reform than it had provided as well as those who had expected to turn it more to their own advantage raised their voices in protest. Koshelev, seeing his apprehensions justified in the eyes of society, journeyed to Leipzig, where he published two pamphlets setting forth his plans for Russia's political renovation. These writings mark the end of Koshelev's attachment to the group of Slavophile reformers and the beginning of his campaign, to last the rest of his life, for a permanent, elected legislative body. Again, Koshelev called for an assembly of representatives of the land, which, like the zemskii sobor, would unite tsar and people. He no longer looked upon the political problem as one aspect of the greater issue of reform; now it occupied the center of the stage-the political system was the source of all evil in the country. Koshelev placed the responsibility for Russia's lamentable

32 Trubetskaia, Materialy dlia biografii V. A. Cherkasskogo, 2: 160-1. 
situation on the bureaucracy. Once the existing bureaucratic machine had been abolished and replaced by a hierarchy of elected assemblies, the troubles of the land would soon disappear. ${ }^{33}$

Russia was not backward but poorly organized. Koshelev did not believe that there should be a long period of education in the institutions of local government before the Russian people participated in national politics, for he was certain that local government would remain impotent as long as the bureaucracy could arbitrarily interfere in its activity. ${ }^{34}$ The talented men that Cherkasskii and Samarin claimed were lacking in Russia were merely in seclusion, shunning the noxious influence of the bureaucracy. ${ }^{35} \mathrm{~A}$ system of representative government could be established only by a sweeping decree of the tsar. ${ }^{36}$

Again, Koshelev's program was but a masked version of the political claims of the gentry, and his defense of the political maturity of the Russian people was no more than a declaration of the gentry's political capacities. Not only were they to occupy the chief positions in the new assembly; they were also to strengthen their control over the countryside and maintain their tutelage over the peasantry:

The most natural, most convenient, and above all, the most welldisposed intermediaries [for the peasants] will be the best people of the rural population, i.e., the landlords. The peasants cannot find better representatives, defenders, teachers, managers, and high judges than the landlords. ${ }^{37}$

The tsar, in fact, was to fuse not with the people but with the gentry. Koshelev's championing of the gentry had now passed the stage when it was only part of his world view; now it represented his total world view. Russia was in dire straits, and only the gentry could save it. Koshelev was to be committed in the future to gentry constitutionalism. As a leading

33 A. I. Koshelev, Kakoi iskhod dlia Rossii iz nyneshnogo eia polozheniia? (Leipzig: F. Vagner, 1862), 5-39.

34 A. I. Koshelev, Konstitutsiia, samoderzhavie i zemskaia duma (Leipzig: F. Vagner, 1862), 36-41.

35 Ibid., $42-6$.

36 Ibid., 22-4.

37 Koshelev, Kakoi iskhod, 62-3. 
spokesman of the constitutional movement of the early sixties, he became the progenitor of the later gentry "Slavophile" constitutionalism of D. N. Shipov and N. A. Khomiakov. However, the links between him and his Slavophile associates had now all but disappeared. Nevertheless, after the publication of the first of his two pamphlets, he entertained the hope that his friends would accept his position. He wrote to Cherkasskii:

Samarin curses and says that only the introduction is good ... that the rest is the product of an itch. This confused me.... I wish very much to know your opinion. Are you of the same mind as Samarin: I cannot believe that. But that would not prove the erroneousness of my point of view. The more I scrutinize what is happening in St. Petersburg, the more I become convinced that matters cannot continue in this manner. Maybe we will not be granted a duma, but we must demand a summons of deputies from all classes. Beyond this there is no solution. ${ }^{38}$

Koshelev then spelled out his differences with Samarin and attacked Samarin's insistence that long schooling in local government should precede the introduction of a national legislative assembly:

Samarin says that it is necessary to begin the construction of the building from the bottom, from the basis, local society. But how can local society develop when the bureaucracy doesn't even permit it to meet for common consultations? And under a bureaucracy you cannot say that local life will develop. What are we to do? Everything here occurs not gradually but by leaps. That is our faith. You have many practical sensibilities, and so I cannot believe that you are not in agreement with the ideas which I am proposing and defending. 39

In short, Koshelev was asking a former member of the Editing Commission who had viewed the gentry's political pretensions with alarm to support a new gentry-dominated governmental structure. Cherkasskii replied:

In many respects, and in the real essentials I wholly share Samarin's opinion. Thus I do not see the gain in convening a Zemskaia Duma at the present time, and I am convinced that now that time should be devoted

38 Trubetskaia, Materialy dlia biografii V. A. Cherkasskogo, 2: 351-2.

39 Ibid., 2: 352 . 
to more essential and beneficial concerns, though ones that would perhaps be less flattering to the conceit of society. I repeat with Samarin from deep conviction: if Russia wants to be happy, she must begin by placing beneath her a firm foundation of local institutions, and then, later, think of the luxury of public life and the consolidation and ornamentation of political forms. In the correct order of historical development we are not destined to see the latter. ${ }^{40}$

"For us it is fated to build not from the foundation, but from the roof," Koshelev replied, and repeated his insistence on the priority of a national duma before local institutions. ${ }^{41}$ The bureaucracy was encroaching on the independence of local assemblies, he claimed, and there was a growing tendency in the Ministry of Interior to augment the powers of governorgenerals at the expense of local government. ${ }^{42}$ In reply, after the promulgation of emancipation in February 1861, Cherkasskii cautioned Koshelev about his faith in the nobility:

Gentry society has become embittered and, as a result, has been compelled to become thoughtful and wise. But it has not advanced far enough to overstep the negative types of reasoning. [The gentry] has learned to criticize precisely, but hardly are they capable of a peaceful attitude toward the more important social matters in prospect, so that we might expect something more from them than systematic, juvenile, and silly opposition.... I tell you frankly that even you ... as you now play the liberal in the hands of the nobility, will hardly receive expiation of your old sins-which are "liberal" but not in the gentry sense. For all I know, when the Zemskaia Duma opens, we may have to be off to Berlin. ${ }^{43}$

Cherkasskii's own proposals for political reform, however, remained ambivalent and contradictory. Like Koshelev, he distrusted the bureaucracy because he feared it would tyrannize the peasantry. Hence, during the months following emancipation, in his plans for local government he upheld the establishment of an "all-class" assembly to restrain the excesses of the administration. He considered the nobility the only class in the countryside

\footnotetext{
40 Ibid., 2: 352-3.

41 Ibid., 2: 357.

42 Ibid., 2: 358 .

43 Ibid., 2: 358-60.
} 
capable of directing the operations of government, and hoped they would gain control of the assembly by winning the backing of other classes too busy to serve. He also believed the nobility to be the principal force striving to contain the reforming autocracy. Consequently, he wanted the government to circumvent the nobility by "fusing with the people," and though he wished to see the nobility endowed with considerable power in local government, he wished to see the bureaucracy invested with even more. It was not the body of deputies in the assembly who were to govern the affairs of the locality, in his plans, but an enlightened elite who could be trusted to safeguard the reforms. By directing the voting of the bourgeoisie and peasantry, removing refractory individuals from the area, and designating the assembly's chairman, the bureaucracy would ensure the elite's continued enjoyment of power. Watching benevolently over local government with sage fermeté, the Minister of Interior, meanwhile, would guard against the peril of constitutionalism. The nobility was to become the administrative lackey of the central government. ${ }^{44}$

Cherkasskii was soon forced to face the political problem and clarify his ideas, for he too was slowly becoming disillusioned by the consequences of the reform and the conduct of government. When in the summer and fall of 1862 landlord-peasant relations in Tula took a turn for the worse, he began to voice criticisms of the provisions of emancipation. The functioning of local government disappointed him. He feared that the financial problem and the Polish revolution might force the calling of a Zemskaia Duma. In the spring of 1863, he visited St. Petersburg, but once there, he felt himself in an awkward position. He expected, he wrote, that he might be asked to re-enter the service, and he was afraid to refuse and loath to accept. There was no cause for worry, however, for he was not asked. He wrote to Samarin,

To my shame, I must confess that this result actually made me happy. It delivered me from the false position I had feared. Nevertheless, it also surprised me a little, for personal pride and a few memories of the place our commission occupied in the administration, combined with a not too high opinion of what comprises this world at present, led me to an erroneous judgment of the degree of importance which the government attached to the few members of our commission who had returned to private life. All this, I repeat, appeared to me as nothing but

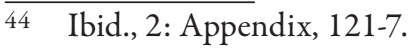


error, and from the trip to Petersburg, I have derived a double benefit for myself: first I not only preserved my complete personal freedom, but as if by act of government itself, I was, so to say, retired from all obligatory moral relations, and from all the solidarity which willy-nilly bound all members of the commission to it. In the second place, I derived a personal moral gain, a few lessons in humility, which, without doubt, also did not pass in vain. ${ }^{45}$

Beneath the equivocation, it is evident that Cherkasskii had sustained no less a blow than had Koshelev when he was excluded from the Editing Commission. Cherkasskii had gone to the capital to secure a high administrative position. Four years before, he had been lionized in St. Petersburg society; now he was received coldly, if at all. 46 The man who had been instrumental in the successful culmination of the work of the Editing Commission had now been forgotten. New men were now in charge of the administration, and different reformers were undertaking the transformation of Russia. The tsar did not rely upon one group to carry through all the reforms, but upon new figures for each. Consequently, no firm cadre was formed that supported all the innovations, and many reformers, renouncing responsibility for the reforms as a whole, were inclined to attack those in which they had no part. Cherkasskii learned a lesson of humility in St. Petersburg, but lessons of humility often leave wounds that make the bearer resentful as well as humble. Cherkasskii's renunciation of solidarity with the Editing Commission was more than a severing of sentimental ties: it was a repudiation of his faith in the central government's capacity to prosecute the reforms. With his change in orientation, his view of conditions altered radically. A week after the letter quoted above, he wrote to Samarin,

Speaking in general, the position of society and the general state of mind have improved significantly... The reasons for these changes are known to you as well as to me. Among them, the incontestable success of the serf reform has played a not unimportant role. Its progress has even quieted down the nobility. The Petersburg fires also have contributed to the general sobering of minds. The general crisis has passed. ${ }^{47}$

\footnotetext{
45 Ibid., 2: 428-9.

46 Ibid., 2: 430.

47 Ibid., 2: 431-2.
} 
Just as society began to appear more mature and competent to Cherkasskii, the government began to seem more obtuse and inept:

Is this situation firm? A sinful man, I am ready to believe that while such a mood prevails in society, in higher spheres they either drift off into autocratic dreams or wonder whether to go further and up to what limit. Generally it seems to me that the government has lost the understanding of what society wants, what it rightly and insistently expects, and what it should be given. Before, the necessity of the abolition of serfdom stood before all and was denied by none. Now, with the abolition of this great evil and the rise of versatility and diversity in the life of society, a multitude of secondary problems which are both important and difficult have been summoned forth. We need a more refined feeling of discernment, so that the real and urgent demands may be distinguished from those which are illusory or not so pressing. But such a feeling has not grown stronger, and meanwhile the worst possible enemy is well entrenched in the government-the feeling of true fear. Reitern and Melnikov are not building railroads, much as the nation clamors. In spite of the tsar's persistent demands, the zemstvo project is being worked out slowly and uncertainly and promises little that is good, while public opinion has already outstripped it in its demands and will not be content with it. The project on publication is veiled in semi-darkness. The new judicial project is now being worked out; from the early handiwork we can only conclude that it is unsatisfactory. 48

Cherkasskii's attitudes toward the government had always been provisional and pragmatic. When the autocracy appeared to show little promise of enlightened leadership, and was cold to him to boot, he simply realigned his views. He now was convinced that society was ready to participate in central government, and that the emperor had become dependent upon it for information on the condition of the nation. By the spring of 1863, Cherkasskii had come around to Koshelev's conviction of the necessity of a legislative assembly:

I must confess that all the above circumstances, especially the unexpected development of the Polish question, have significantly changed my thoughts on the necessity of national representation and have forced

$\overline{48}$ Ibid., 2: 432-3. 
me, in this respect, to advance a great deal since I saw you over a year ago. In other words, I am convinced that the autocracy is dealing with the Polish question weakly and that Lithuania and Kiev can remain part of Russia only if an all-Russian assembly is summoned. ${ }^{49}$

But Cherkasskii was now confronted with a dilemma. Koshelev could turn away from the government to embrace the aspirations of the Russian nobility, with whom he already felt a deep affinity. But Cherkasskii was too realistic to believe in a sudden change of motives and was still wary of those who had opposed his reforming efforts. Rebuffed by the government and hostile to the political program of his own class, Cherkasskii sought solace in the rhetoric of Slavophilism and based his hopes on the people. His assembly was to be a democratic one:

With the present mood in society, when civic spirit is penetrating everywhere and is even being felt in Russia, the old absolutist forms of government are becoming outmoded. It is necessary, in the interests of the government itself, to adopt a different system, different forms, to seek new forces and combinations upon which we can depend more surely. The democratic element of society seems to afford such support.... The government can rely upon it only after it has granted free institutions to the country. Its power will be decreased but little.... Its actual strength will be multiplied tenfold. ${ }^{50}$

In the scheme contemplated by Cherkasskii, the fusing with "the people" was actually to take place. But his reliance on "the people" was merely an intellectual artifice that enabled him to sidestep his dilemma; for Cherkasskii felt no kinship with the masses of the people, who would dominate his new institution:

Service for me in any circumstances is impossible. Local government remains closed to me because of the local gentry's persistent enmity. I find no counterweight to this in the lower classes. Moreover, I have not sought such support and I hardly intend to seek it. ${ }^{51}$

\footnotetext{
49 Ibid., 2: 433-4.

50 Ibid., 2: 435.

51 Ibid., 2: 426.
} 
Like the Slavophilism it derived from, Cherkasskii's constitutionalism was entirely theoretical. In reality there was nowhere for him to turn. Disappointed in the autocracy, he was unable to find any group in society capable of replacing it at the head of the movement for reform. Again, as in the forties, Cherkasskii was a man with ideals and the capacity and energy to assist in their enactment, but deprived of the opportunity to use his abilities. "At the age of forty I am in the position of a completely superfluous man," he wrote. 52 His situation was immeasurably worse than it had been in the forties, for now he lacked the companionship and common devotion to social ideals that had linked the Slavophiles in friendship and action. While Koshelev reposed his hopes in the nobility and Samarin in the autocracy, Cherkasskii sought futilely for a nonexistent fountainhead of reform. Now he was alone, and his ideals and fantasies were incapable of being realized.

Samarin too was disappointed in the conduct of government after the Emancipation decree, and he too was forced to consider the political problem more seriously. While visiting St. Petersburg, he wrote to Cherkasskii that the mood depressed him; that a complacent, faithless cynicism prevailed there, and that there was no solidarity among those serving the government. The zemstvo reforms were emerging "ugly and emaciated." 53 Samarin had trusted in the state and had expected the reforms to bring about a general improvement in its personnel. Now it seemed that the new governmental order was worse than the old. "The old self-confident bearing, which displayed great energy despite all the attendant stupidity, is gone, never to return," he wrote. "The old processes of government have been rejected, and conditions have brought forth nothing to replace them." 54

Despite his loss of faith in the government, Samarin was even more distrustful, even frightened, of the forces at work in society. Koshelev and Cherkasskii could turn away from the state, but Samarin could not because he suspected the motives of the gentry and feared the power of the uneducated peasantry. The dread of a cataclysm which would obliterate all Russian culture, all the values he cherished, tormented him:

\footnotetext{
52 Ibid.

53 Ibid., 2: 110-11.

54 Anatole Leroy-Beaulieu, Un homme d'État russe (Nicolas Milutine) d'après sa correspondence inédite (Paris: Hachette, 1884), 110.
} 
On the part of society there is only weakness, chronic laziness, an absence of all initiative and a desire to antagonize authority, which has become more marked from day to day. Today, just as two hundred years ago, there are only two living forces in all of Russia-the autocracy at the top, and the rural commune at the opposite extreme. These forces, however, are not united, but are separated by all those intermediary layers, which, deprived of any root, have clutched to the summit during the course of centuries. These layers are now pretending to be courageous and are starting to defy their single support ... for nothing. The tsar recoils, makes concession upon concession, without any profit to the part of society which irritates for the pleasure of irritating. But this will not last long. Otherwise, the meeting of the two extremes cannot be avoided, a meeting in which everything in between will be flattened and pulverized. What is in between includes all of literate Russia, all our culture. A fine future indeed. 55

Above all, Samarin feared that constitutionalism would bring on such a calamity. In an article written originally for Aksakov's Den', but published in 1881, Samarin insisted that no existing political force was powerful enough to curb the autocracy, except the people, who recognized "their personification and external embodiment" in the tsar and were unwilling to brook the interference of other classes. That the people themselves could not be an agent in a constitutional system was obvious. "The illiterate people, the people estranged from other classes, thrown from the path of historical development by Peter's reform-these people are incapable of taking part in the working of governmental institutions." 56 Only the tsar could govern Russia and satisfy the needs of the people: "toleration, an end to police homilies against the schism, an open and independent judiciary, free printing as a simple means to bring to light all the contaminating juices poisoning our literature ... a simplification of local administration, reform of taxes, freely accessible education, restriction of unproductive expenses." 57 Samarin's image of Russia as a backward nation, whose most advanced members were peccant and unreliable, remained unshaken by his disappointments in the autocracy.

\footnotetext{
55 Ibid., 110-11.

56 Iu. F. Samarin, "Po povodu tolkov o konstitutsii," First published in Rus', No. 29 (1881): 14 .

57 Ibid.
} 
Adhering to his belief in education and slow development, he continued to insist that only the tsar could uplift the masses and introduce a Rechtsstaat.

Samarin's reassertion of faith in the autocracy did not dispel his misgivings about the men then running the government and the policies they were introducing. In local government-the mainspring of his new society, the school of the future leaders of the nation-he found only indolence and indifference, and he concluded that under prevalent conditions, liberal ideas amounted to no more than connivance in the ascendancy of the strongest. ${ }^{58}$ As before 1855, he was tormented by the tension between his belief in social reform and his loyalty to the autocracy. Again he resigned himself to an indefinite period of waiting for a reforming autocracy. However, now his friends did not share his conviction that the autocracy was the only force able to provide enlightened government. Now he was alone, possessed by a feeling of isolation and cut off from all constructive movement in Russian society. "I have come to a sad conclusion," he wrote, "nothing is possible except isolated, individual action in the limited circle of our private influence-the work of a missionary. Besides this, nothing takes."59

Once the serfs had been freed, the liberal Slavophiles, who had accomplished so much to inspire the reform and assist in its execution, ceased to exert a significant influence in Russian society. The turmoil the emancipation produced, coupled with the Slavophiles' rapid descent from positions of prominence and power to embittered solitude, led them to seek an answer to the question of how Russia was to be ruled and who was to rule it. Finding no solution in their old framework of ideas, they developed their political views independently and moved further and further apart. Thus, Koshelev's sympathy with the gentry class impelled him to assign a major role in Russia's future development to the nobility, and he advanced a program of gentry constitutionalism. In terms of his Slavophile ideology, this meant the summoning of a Zemskaia Duma and the achievement of the hoped-for union between tsar and people. Aside from terminology, however, his view had little in common with Samarin's and Cherkasskii's. Cherkasskii, who was firmly committed neither to gentry nor to autocratic rule, finally rejected both and demanded a literal realization of the formula, "fusing with the people."

58 Trubetskaia, Materialy dlia biografii V. A. Cherkasskogo, 2: 420.

59 Ibid., 2: 426. 
Lacking democratic inclinations, he despaired of this course and was left without a political and social mission. Samarin alone remained faithful to the autocracy, for the reverence instilled in him as a child and his dread of other elements in society deterred him from looking elsewhere for a palladium of reform, despite his disillusionment with the government's conduct of affairs. Terrified at the thought of a mass peasant revolution brought on by the constitutionalism that Koshelev advocated, he maintained his faith in the autocracy and awaited another change of heart. Seeking the elusive source of reform, Koshelev, Samarin, and Cherkasskii sundered their common bonds and brought to an end the group that had done so much to inspire the progressive changes of past years. 


\section{Tolstoy and the Perception of Poverty: Tolstoys' "What Then Must We Do?"1}

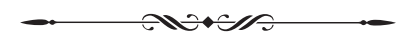

"What Then Must We Do?" ("Tak chto zhe nam nuzhno delat'?") presents Tolstoy's answer to the problem of poverty. It is a sprawling, disorganized essay that approaches the problem in many varied ways. It presents the scenes of want and suffering that Tolstoy witnessed in Moscow in the early 1880s. It recounts his personal responses to sights of poverty and his desperate attempts to remedy it. Finally, it contains his lengthy and highly repetitious critiques of contemporary philosophy and economics. Above all, it is a long autobiographical essay about Tolstoy's confrontation with poverty, especially urban poverty.

The work is actually a series of fragments related to Tolstoy's experiences in Moscow from 1882 to 1884 , when he assembled and shaped the final essay. In his illuminating commentaries on the text, published in the complete collection of Tolstoy's works in 1937, N. K. Gudzii identifies the numerous drafts he left. He also describes the difficulties that he and Sofia Andreevna encountered with the censors, particular those in the Holy Synod, headed by Alexander III's éminence grise, Constantine Pobedonostsev. A complete and accurate version appeared only in England in 1902, under the auspices of his disciple, Vladimir Chertkov. ${ }^{2}$

$1 \quad$ I am much obliged to Dr. George Moraitis for the many informative and illuminating discussions we had about this and many other works of Tolstoi in the past several years.

2 L. N. Tolstoy, "Chto zhe nam nuzhno delat'," in Polnoe sobranie sochinenii (Henceforth PSS), vol. 25 (Moscow: Khudozhestvennaia Literatura, 1937), 182412; N. K. Gudzii, “Kommentarii,” 740-839. 
The solution Tolstoy prescribed was the renunciation of wealth and the simple life of the peasant in the countryside. He called upon educated individuals to throw off civilized habits and tastes, and to work, as he did, on the land. Such a solution, of course, was hardly extraordinary or novel at the time. Writers like Alexander Engel'gardt and Sergei Krivenko had praised a life of physical labor, and Engel'gardt had written of his commune of young intelligenty who lived like peasants and tilled the land. ${ }^{3}$ Tolstoy admired these writers and was particularly impressed with the peasant Siutaev, who preached Christian pacifism and love and a life of work on the land. Tolstoy met Siutaev in 1881 and describes an early conversation with him in "What Then Must We Do?"4

"What Then Must We Do?" is revealing not in the depth of its philosophy or the originality of its solution, but in the distinctive way Tolstoy sought his answers. As always, he did not merely embrace current ideas of the intelligentsia. The work described his own existential search prompted by scenes of urban poverty. He struggled toward his own solution through introspection, thought, and reading, recorded in the fragments that made up the whole, as well as his letters, which give his responses a sense of immediacy. Dominating the problem of poverty is the story of Tolstoy's war with himself.

In the early 1880 s, Tolstoy found a focus for his personal experience and quandaries in the indigence that surrounded him in Moscow. He went out to see the poor and began to dwell on their suffering. He used his writing to transmit his experience to others, hoping that they too would suddenly perceive poverty and that their perceptions would lead them to renounce their comfortable lives. Underlying this hope was a belief that other people differed little from himself.

I am the same as everyone else, and if I differ in some way from the average person it is only because I, more than the average person, have served and pandered to the false teaching of our world, received more approval from people supporting the prevalent doctrine, and therefore corrupted and led more people astray. ${ }^{5}$

3 On Tolstoy's debt to the intelligentsia in this period see D. N. Ovsianiko-Kulikovskii, Sobranie sochinenii (St. Petersburg: Prometei, 1911), vol. 9: 129-33; On Engel'gardt see my Crisis of Russian Populism (Cambridge: Cambridge University Press, 1967), 35-60.

4 PSS, 25: 233-8, 834-6.

5 Ibid., 376. 
Tolstoy assumed that perception required little more than opening one's eyes to reality. However, his perception of the poor was not a mere passive act of witnessing. His was a complex process that began with intense feelings for those he saw and ended with emotional involvement with them. The main objects of his perception were destitute and suffering women, and encountering them awakened in him the troubled feelings he felt towards women in general. For Tolstoy, perception was an emotional act.

Tolstoy's preoccupation with the problem of poverty began during a difficult spell in his personal life during the fall and winter of 1881, when he began to spend part of the year in Moscow. Moscow sojourns were oppressive to him and arranged against his judgment. Sofia Andreevna insisted upon them in order to introduce their daughter Tatiana to Moscow society and allow their son Sergei to attend the university: to educate the children in a manner Tolstoy himself found absolutely abhorrent. As a result, constant family altercations ensued, and Tolstoy began to feel that his wife had never loved him. His letters and his diaries mention a loss of faith in himself and a loss of a desire to live. He described his first month in Moscow as "the most excruciating in my life." ${ }^{\circ} \mathrm{He}$ felt powerless to live in a manner consonant with the Christian principles he had embraced.

He now felt unable to cope with the sights of poverty and depravity he saw everywhere in Moscow. Urban poverty affronted his senses. It seemed different from the poverty of the countryside. The poor were deceitful and more numerous and visible than they were in the countryside. "Stench, stones, luxury, poverty, debauchery...." he wrote in his diary. ${ }^{7}$ They somehow had to retrieve the money plundered from them. He could not look indifferently upon such suffering. It seemed his responsibility, and yet he felt his helplessness to do anything about it. "Everything that is repellent to me now is the fruit of my own mistakes," he wrote to a friend in September $1881 .^{8}$

The problem of poverty seemed to exceed his powers and add to his sense of helplessness. The individualistic ethical principles he had presented in The Confession and subsequent religious essays did little to help in dealing with a social problem like poverty. His first attempt to act resembled the usual religious approach to the poor. He tried to go among them and give them alms.

$6 \quad$ PSS, vol. 49 (Moscow: Khudozhestvennaia Literatura, 1952), 48.

7 Ibid.

8 PSS, vol. 63 (Moscow: Khudozhestvennaia Literatura, 1937), 76. 
The remoteness he felt from the poor could be overcome by associating with them. For this reason, he joined the work on the Moscow census of 1882, which in his article, "On the Census in Moscow," he described as an opportunity to observe the poor and learn about them directly rather than from numbers or sociological abstractions. The census counters had to see the poor directly and not "allow other considerations to hide this most important matter of our life." The census would raise the "curtain" on the poor: "all the sores of society, the sores of poverty, debauchery, ignorance, all will be exposed." The goal of the census should not be primarily scientific, giving society a glimpse of itself, but rather present an opportunity for introspection. "To go on the census, as thousands of people are doing now, is to look closely at oneself in the mirror."

It was a bestowal of love that would eliminate the distance between rich and poor, as the poor, no longer alien and different, would appear as mirror images of the privileged. The great goal of the census should be "the affectionate socializing of people with the people and the destruction of those barriers that the people have erected between themselves, so that the joy of the rich man is not broken by the wild howls of people become cattle and the groans of helpless hunger, cold and illness." 10

The census would help Tolstoy find a common humanity in the city and he would join with them in "fraternal socializing." Then the rich could help the poor. By this time, he had little confidence in charitable contributions from the rich, though he continued to solicit them, but he thought that this socializing and contact could create the common sense of humanity that could lead to continued help to the poor by doing good. "Doing good is not giving money but the affectionate relations between people. That alone is needed." 11

These hopes soon appeared excessive, and Tolstoy began to feel acute embarrassment about his activity before and during the census. The first fragment of "What Then Must We Do?" was written shortly after the census in 1882 and reveals his dissatisfaction with his efforts. He found the poor, even before the census, difficult to mingle with and difficult to love. The urban poor were not the rural poor. When beggars approached him in Moscow, they did so in order to deceive. In the Khitrov market region of Moscow, he saw many

\footnotetext{
9 PSS, 25: 174-6.

10 Ibid., 178.

11 Ibid., 179.
} 
poor living in great need, but he encountered many others who were getting along and enjoying life.

In a fragment of 1882, Tolstoy describes the feelings the poverty of Moscow prompted in him, but without assessing their meaning. At first, he realized that urban poverty could not be remedied since it exceeded his powers. Rural poverty could be ameliorated; it was a result of the shortage of land, and individuals like himself could and did assist the poor. The urban poor, however, were needy because they avoided work, even when it was available. At first, he became angry and cold to them. When he tried to give alms in the environs of the Khitrov market, he was mobbed. He felt helpless and futile, and yet responsible - an accomplice in a terrible crime. He recalled watching an execution twenty-five years earlier and feeling the same complicity; he should have cried out, and by remaining silent he had become a participant. The horror of the situation tormented him; he could neither eat nor drink. ${ }^{12}$ His visit to the Rzhanov House for the Poor, however, left quite different impressions. The poor there seemed lighthearted and indifferent to him-not needy of his help. ${ }^{13} \mathrm{He}$ blamed his failure on his mistakes, "I erred because I forgot something I know very well: that one cannot begin an enterprise in the middle, that you can't bake bread without having mixed the dough, nor do good without preparing for it." 14

By the time Tolstoy returned to this subject in 1884 , he had discovered the source of his error and was writing about himself with considerable distance. He had reached the conclusion that nothing less than a complete rejection of his civilized self and the acceptance of life of physical labor would enable him to cope with the problem of poverty. The Tolstoy of $1884-85$ jeers at the Tolstoy of 1882 . He had been praised for his sensitivity and goodness and been told that he had reacted so strongly to poverty because he was so kind and good. He had begun to believe this. "Hardly had I turned around, when, instead of the feeling of reproach and repentance that I had first experienced, there was already in me a feeling of satisfaction with my virtue and a wish to explain it to people." $15 \mathrm{He}$ was feeling embarrassed by soliciting contributions from the rich, he claims, but asserted himself all the more vociferously because he knew

\footnotetext{
12 Ibid., 618.

13 Ibid., 620.

14 Ibid., 618.

15 Ibid., 192.
} 
himself to be in the wrong. He went to bed in the evening after the appeal for contributions "not only with a premonition that nothing would come out of my ideas, but with shame and an awareness that I had been doing something vile and shameful the whole day." 16

Tolstoy looks upon his efforts with shame, and ascribes feelings of shame to his earlier self. Shame is the modal feeling of the final version of "What Then Must We Do?” and more than guilt, which Tolstoy also feels, expresses his own relationship to the poor. Shame is a matter of display. It is a public failure to live up to an ideal, unlike guilt, which connotes an inner sense of wrongdoing. The failure may involve the violation of a norm and bring forth censure from society. Or it may be a failure to live up to an ideal of self projected onto a fantasy audience. It is the latter type of shame that characterizes Tolstoy's writing, since Tolstoy is very much his own audience. He watches and condemns himself on the basis of his new ideal of life, though sometimes he sees his own censure reflected as well in the eyes of the poor. ${ }^{17}$

The occasion for shame in "What Then Must We Do?" is usually sexual. The disgust for sex or sexual impulses is an important source of shame. Freud used the word shame only in this sense: to refer to tension associated with exposure of the body. ${ }^{18}$ Shame can refer also to a sudden loathing for one's animality, arising from a failure to live up to an ideal of human conduct. The condemnation of self that fills the final version of "What Then Must We Do?" is closely connected with the troubled feelings about women that awakened in Tolstoy in early 1884, when the problem of poverty again began to torment him, and he resumed work on the text.

In 1884, he was assailed by feelings of loneliness and worthlessness. He resumed entries in his diaries, which he had left off in the spring of 1881, and again began to enumerate his shortcomings and sins. "It is painful for me. I am a negligible, pitiful, useless creature, and still concerned with myself," he wrote. "The one good thing is that I want to die." He complained about the power of the flesh, felt desolate, and explained his misery by the lack of a loving wife. ${ }^{19}$ In "What Then Must We Do?" Tolstoy describes three incidents

\footnotetext{
16 Ibid., 193.

17 See Gerhardt Piers and Milton Singer, Shame and Guilt: A Psychoanalytic and Cultural Study (Springfield, IL: Thomas, 1953).

18 Ibid., 7-8.

19 N. N. Gusev, Letopis' zhizni I tvorchestva L'va Nikolaevicha Tolstogo (Moscow: Khudozhestvennaia Literatura, 1958), 573-4; PSS, 49: 67, 74-5, 89-90, 97-8.
} 
from this period, all of them involving women who aroused confused feelings of compassion, affection, and shame in him.

The first was a relatively trivial episode that took place on his estate. He had borrowed twenty kopeks from his cook to give as alms. The next day, he returned it to the cook's wife, but he had only a ruble. She not knowing what was for, mistook it for a gift, and bent forward to kiss his hand. "I was ashamed, excruciatingly ashamed as hadn't happened for a long time. I writhed, I felt myself making grimaces, and groaned from shame, running from the kitchen." 20 Tolstoy, for the first time in the text, describes himself as completely aware of his shame at the time of the happening, and then seeking explanations. He gives two. First, he realizes the tiny part of his income that the gift represents. The second, however, reveals something of the sadistic feelings that he felt were shameful. He now saw giving as an amusement that involved no deprivation but represented only giving back a small part of what he and others had taken from the poor. The poor looked upon this not as real money, not as money gained by work, but "fools money" (durashnye den'gi) which he returned as a kind of diversion (potekha). It was the cook's wife who seemed to be thinking this: but it was in fact his own view of himself, a view "which she and other poor people should have of me." Tolstoy now perceives the eyes of the poor people, "whom I toy with," upon him, expressing condemnation and disdain. "That is the way everyone looks upon me." He had to escape from evil if he was to do good. "But then all my life is evil." 21 The incidence of Tolstoy's shame in this case has clear sexual connotations. The cook's wife, who had come to the estate only recently, was about to kiss his hand, to give loving gratitude for the gift when he ran from the kitchen. He felt himself buying affection, and the recurrence of an intensity of shame that he had not felt for a long time seems to have recalled memories of the feelings he had had as a youth after frequenting prostitutes. ${ }^{22}$

The two other episodes occurred in the course of less than a day in March 1884. He described them in Section 24 of the text, in a letter to V. G. Chertkov, and in his diary. First, he saw a fifteen-year-old prostitute as she was being apprehended by the police. Approaching her, he noticed that she was prematurely old; she looked thirty. "The dirty color of her face, small,

\footnotetext{
20 PSS, 25: 240.

21 Ibid., 242.

22 PSS, 46: 59-64.
} 
cloudy, drunken eyes, a button nose, twisted dribbling lips, drooping at the corners, and short pleat of dried hair sticking out of her kerchief." He asked her if she had parents. She grinned with an expression that seemed to say, "Just think what he is asking!" When he returned home, he learned that his daughters had enjoyed themselves at a party and were already asleep. The next day, he visited the station and found that the girl had already been taken away. The police officer casually remarked that "there were twelve-year-old prostitutes too, and fourteen- and fifteen-year-olds were everywhere." 23

The encounter is related in matter-of-fact terms in the text without explicit mention of Tolstoy's own feelings. In his diary, however, he remarked despairingly, "I didn't know what to do." He wrote to Chertkov that he was too sensitive to the life around him, and that "life is repulsive." He was disturbed not only by the sight of the child prostitute, but also by his own failure to help her. “They took her away, and I didn't take her to my home, did not invite her to my home, didn't take her in at all—and I had begun to love her (Ia poliubil ee)." 24 He felt his inability to help one he loved. The second episode occurred the next morning. He learned that a laundress of about thirty years old, ailing and near death, had been driven out of the Rzhanov House because she had no money. A policeman had evicted her, but with no other place to go she returned and died at the entrance. He went to the house to see the corpse, and marveled at its beauty. "All the deceased are beautiful but this one was especially beautiful and touching in her coffin." She had a pure pale face, protruding eyes, sunken cheeks, and soft red hair over a high forehead; "a tired face, kind and not sad, but surprised. And in fact if the living don't see, then the dead are surprised." 25

Again, the text does not reveal Tolstoy's feelings mentioned in his letter to Chertkov. He condemns his own motives, condemns his failure to act. "I came out of curiosity. I am ashamed to write that, ashamed to live." At home, sturgeon was served, and people could not understand why he bothered about something he could do nothing about. He began to-pray, "My God, teach me how to be, how I should live, so my life will not be vile. I am waiting for Him to teach me." 26

23 PSS, 25: 297-8.

24 PSS, 49: 73-4.

25 PSS, 25: 298-301.

26 PSS, vol. 85 (Moscow: Khudozhestvennaia Literatura, 1935), 43. 
Unable to help women for whom he felt strong feelings of affection and compassion, Tolstoy felt ashamed of his own weakness. These feelings enabled him to make contact with the world of the poor and to see its horrors. But others didn't see. "If the living don't see, then the dead are surprised." The task was to make the living see, by awakening their dormant sense of shame. Tolstoy now tried to generalize his shame, to make the privileged aware of the bestiality of their lives and teach them how to see.

His means to do this was first to expose his earlier self and his efforts during the census. Though expressing Tolstoy's own feelings and experiences, much of the final text of "What Then Must We Do?" is virtually a third person description of himself. The description of his experiences at Khitrov market, in the final version, stresses his feelings of alienation from the scene. He listens as two women, one young, one old, both dressed in grey and tattered clothing, are seriously discussing something. "After each necessary word, they uttered one or two unnecessary indecent words." Yet the men nearby paid no attention to this talk that he found so repellent. The men waiting to be admitted to the flop houses looked upon him with the same uncomprehending gaze, asking the questions "What are you here for?" (Zachem ty?), "Who are you?" "Are you a self-satisfied rich man who wants to enjoy our need, to divert himself from his boredom and torment us some more, or are you what does not and cannot exist—a person who pities us?" 27

Tolstoy senses this question in the eyes of the poor; in fact none of the poor appear to care who he is, though his presence there surprises them. Tolstoy talks to them, and gives them hot drinks and money. He then goes into the house and sees one of the men whom he had given money. "Seeing him, I became horribly ashamed, and I hurried to leave." He returns home, and has a five course meal. The feelings of culpability and the recollection of the execution first set forth in 1882 are described at this point. ${ }^{28}$

In the following sections of the text, he writes that giving money makes him feel ashamed. As he confronts each group of poor, he feels himself a person from another world, and feels prompted to help them in some way. The only way he knows is to give money, and yet once he gives money he feels ashamed. The same pattern is repeated in the description of Tolstoy's visit to the Rzhanov House during the census: he feels alien and inferior, gives money, is filled

\footnotetext{
27 PSS, 25: 187-8.

28 Ibid., 188-9.
} 
with shame. Entering the courtyard, he is overcome by the "revolting stench" and finds it "horribly ugly." He hears someone running. It is a thin woman, her sleeves rolled up, chased by a ragged man in a red shirt, trousers as broad as skirts and galoshes. The man grabs her and, laughing, says, "You won't get away!" "Oh, you squint-eyed devil!" she retorts, flattered by the attention. Then she turns to Tolstoy and shouts maliciously "Who do you want?"

"Since I didn't want anyone, I became confused and went away." The woman preferred the ragged lecher to the well-wishing Count. There was nothing surprising in what he saw, Tolstoy acknowledged, but it made him look at the enterprise he was undertaking in a new light. At this point, he sees himself realizing that these were human beings, with the same emotions as he, who lived a complete life that he had not considered. He understood that "each of these thousand people is the same person, with the same past, the same passions, temptations, errors, with the same thoughts, the same questions, the same kind of person as I." But this gave him little comfort. The enterprise of helping the poor now seemed so hard, "that I felt my helplessness."29

Looking back upon his experience in the Rzhanov House, Tolstoy identified a common flaw that linked him to the inhabitants. At the time, he had been "bedimmed" by pride in his virtues, which he had not recognized. While talking with impoverished noblemen in the house, he recalled, he saw his own failing in them "as in a mirror." 30 The people in the house needed not money, he concluded from his new vantage, but a change in their world view (mirosozertsanie), for like him the very poor had adopted the general view that work was burdensome, and if possible to be avoided. The tract then elaborates on this theme, showing how this mistaken view was held by prostitutes and children as well, creating their plight. Prostitutes merely imitated the ways of society ladies who tried to live without carrying out their role as mothers. The children in the Rzhanov House followed the example of rich children. Tolstoy even took an urchin from House into his own home to work in the kitchen, where the boy only got in the way of the servants. He then found him work in the countryside, but the boy then returned to Moscow to join an animal act. Tolstoy writes that he had thought himself kind and good at the time, though he had paid little attention to the boy who in Tolstoy's

\footnotetext{
29 Ibid., 198-9.

30 Ibid., 207.
} 
home had seen only how the children lived by making work for others but not by working themselves:

I might have understood how absurd it was for me, training my children for complete idleness and luxury, to correct other people and their children, who were perishing from idleness in what I have called the Rzhanov den, where three-quarters of the people, nonetheless work for themselves and others. But I understood nothing at all of this. ${ }^{31}$

Much of Tolstoy's exposé was directed at the members of his own family, whom he saw binding him to a cruel and immoral life. The specific references to his daughters and sons, however, were removed at Sofia Andreevna's instance. He described a ball where lavishly dressed women (his daughters) wore perfume, rode in carriages, and bared their chests before men they did not know. All of this took place near his home, which was located in the midst of a factory area that produced fancy goods for balls. There, impoverished workers could be seen collapsing and dying from starvation. His son (in the final draft called "a friend") hired a consumptive woman and a girl to make cigarettes and then awoke at noon to spend his life pursuing pleasure. His son remained oblivious. The woman complained of pains in her chest. However, Tolstoy wrote, she didn't have to complain: "It was enough to take a look at the girl. She has been working at this for three years, but anyone seeing her at this work would say that this was a strong organism that was already being destroyed." By insisting on changing his shirt twice a day, Tolstoy felt he shared responsibility for working laundresses to death. ${ }^{32}$

Tolstoy hoped to convey this sense of responsibility for poverty to other members of the privileged classes. They had erred, he felt, by trying to escape the struggle for survival. They tried to avoid work, indulged in luxury and excess, and thus forced the poor to toil to support them in their ease. He wanted them to renounce their privileged life and habits and produce for themselves, with their own hands, rather than enslave the poor. But like him, they had first to see that the poverty that existed right before their eyes was the result of their easy life. "We do not want to see that if our idle luxurious and dissolute life did not exist, there also would not be that backbreaking

\footnotetext{
$31 \quad$ Ibid., 213-14.

32 Ibid., 303-6, 803.
} 
labor, and without this backbreaking labor we would not have our life." 33 The privileged could not see, he stated and repeated. "We see nothing, because this surprising effort is taking place beyond us: we do not hear, we do not see, we do not reason with our hearts." 34

Tolstoy attributed their blindness, in true Rousseauist fashion, to the products of the intellect. They could not see because they had been taught that poverty was part of the natural order of things. This kind of thinking was supported by justifications of law, religion, and philosophy. In a rough draft, Tolstoy referred to these intellectualizations as "screens" that shielded the privileged from the sights of poverty. "If these screens did not exist, we would be able to see what one mustn't fail to see." 35 Much of the text of "What Then Must We Do?" is devoted to condemning all contemporary thought for making it seem that the existing way of life was in the nature of mankind, thus closing people's eyes to suffering.

Repudiating education and philosophy, Tolstoy called upon men to confront the truth directly and provide for their own material needs. To do this they first had to open their eyes by recognizing the falsehood of their own lives. In answer to the ubiquitous question, "What Is To Be Done?" Tolstoy prescribed first ceasing to lie to oneself. This meant renouncing the high opinions of oneself and recognizing the smallness of one's achievements and the immorality of one's life. It required a repentance of one's former life-a confession of inadequacy and an access of cathartic shame. The first answer to the question of what had to be done consisted of repentance in the full significance of the word, i.e., to change the evaluation of one's situation and activity completely: instead of the usefulness and seriousness of one's activity, to recognize its harm and triviality; instead of one's education to think of one's ignorance; instead of one's goodness to recognize one's immorality and cruelty; instead of one's loftiness to recognize one's baseness. ${ }^{36}$

The first step was to follow the example Tolstoy described in the text: to view one's earlier efforts and hopes with shame, to reject one's self and look at the horror of one's life. Then those with education would no longer attempt to repay their debt to the people with their knowledge and training.

\footnotetext{
33 Ibid., 313.

34 Ibid., 314.

35 Ibid., 636.

36 Ibid., 378.
} 
Shamed, they would see the self-serving nature of their life, and would be able to aspire to a new ideal of human life that would enable them to live without exploiting the labor and suffering of others. In this way, man would achieve "the satisfaction of the bodily and spiritual demands of his nature: to feed, clothe and take care of oneself and one's fellow men is the satisfaction of bodily need, to do the same for others is the satisfaction of his spiritual need." 37

Men would learn to care for themselves and to care for others-to play the role of nurturer. In many respects Tolstoy's virtuous life was an imitation of women. Even contemporary women were closer to the ideal than were men. The law of nature demanded labor from men; from women it demanded childbirth. "There have been hardly any deviations from the law of women." 38 Even most upper class women gave birth and in this way had gone through greater suffering, showed greater sacrifice, and thus had greater natural power than men. Once they had renounced their privileged lives they could have great beneficial influence upon succeeding generations. They would nurse their children themselves, do their own sewing and washing, and teach their children to live by their own labor. Only a mother could achieve complete submission to the will of God; only she could achieve the perfection people strove for.

Men could not achieve perfection. Even at their best, they fell short, and remained physically and morally inferior to women, whose creativity and virtue came naturally from their physical impulses. Tolstoy's perception of poverty as well as his vision of a just world arose from feelings of inadequacy before women. As victims, they prompted feelings of helplessness to remedy their condition. As intimations of the ideal, they prompted awe and worship of beings possessed of vital, natural forces, unburdened by civilization. Following the pattern of many of Tolstoy's works of this period, emphatic and aggressive assertions of a newly discovered truth culminate in passive longings for the caress of a kind and life-giving mother. "What Then Must We Do?" ends with a confession of weakness before the force of feminine love. "Yes women-mothers, in your hands, more than in anyone else's, lies the salvation of the world." 39

\footnotetext{
$37 \quad$ Ibid., 381.

38 Ibid., 406.

39 Ibid., 406-11.
} 


\section{Property Rights, Populism, and Russian Political Culture}

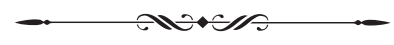

In his famous critique of the "legal obtuseness" of the Russian intelligentsia, Bogdan Kistiakovskii wrote: "The spiritual leaders of the Russian intelligentsia have constantly either completely ignored the legal (pravovye) interests of the individual, or have expressed open hostility towards them." Individual rights, he thought, could come to Russia only with the introduction of constitutional government. Kistiakovskii reserved his sharpest criticism for two of the leading ideologists of populism, Alexander Herzen and Nikolai Mikhailovskii. Both Herzen and Mikhailovskii, he claimed, had subordinated political freedom and the legal guarantees of the individual to the goal of social equality. ${ }^{1}$

Kistiakovskii's defence of individual rights made no mention of property rights. Indeed, he too looked forward to a socialist order and valued the right of property no more than the thinkers he had attacked. ${ }^{2}$ In this respect, his thought was typical of the intellectuals who led the movement against the autocracy in the first years of the twentieth century. The programs of the Constitutional Democrats as well as the various socialist parties included demands for such rights as freedom of speech, assembly, and the press as well as the right to domicile. However, none of them mentioned the second of the Declaration of the Rights of Man, the right to property. The omission

$1 \quad$ V. A. Kistiakovskii, "V zashchitu prava," Vekbi: Sbornik statei o russkoi intelligentsii (Moscow: V. M. Sablin, 1909), 132-5.

2 On Kistiakovskii's conception of right, see Susan Heuman, "A Socialist Conception of Human Rights: A Model from Prerevolutionary Russia," in Human Rights: Cultural and Ideological Perspectives, ed. A. Pollis and P. Schwab (New York:Praeger, 1982), 50-3; Kistiakovskii, "V zashchitu prava," 142-3. 
of property rights by groups seeking to defend the dignity and freedom of the individual points to a distinctive feature of the struggle for civil rights in Russia. Whether or not one deems property rights essential for human freedom, the assertion of civil rights in opposition to property rights places the Russian experience outside the western tradition that was supposed to serve as its model.

The hostility toward the concept of property reflected in part the socialist orientation of the Russian intelligentsia. But before 1905, the right of property had few consistent defenders in any political camp in Russia. Property rights were associated with the bourgeois west or the system of serfdom. Russians of divergent political persuasions favored the peasant commune with its principles of common ownership, even if their visions of its true character and ideal form differed. To be sure, there was an undercurrent of opposition to the commune in liberal circles and in the administration. However, it was the peasant uprisings of 1905 and 1906 that made the virtues of private holding clear to the Tsar, his most influential officials, and the majority of the landed nobility. ${ }^{3}$

Private property, of course, developed as a basis for the Russian agrarian and industrial economy in the late eighteenth and nineteenth centuries. However, the notion of individual property rights lacked ethical justification in Russian political culture and retained a strong stigma throughout this period. Conservatives saw in it the seed of social discord and breakdown. Liberals and socialists could not reconcile private property in land with the concepts of equality or freedom. The word "property" conveyed the sense of oppression and exploitation of an illegitimate usurpation of the possessions of all under the auspices of arbitrary and brutal political authority. Landed property symbolized not a basis for the individual's freedom, but a constraint which, by tying him to a particular place, debased his concerns to the mundane and trivial and destroyed his spiritual freedom. They felt, like Ivan Ivanych in Chekhov's story "Gooseberries," that "a man does not need three arshins of land, not an estate in the country, but the whole globe, all of nature where he can freely display all the features and peculiarities of his free spirit."

Like other western concepts, the concept of property rights in Russia was transformed by a political culture that attached to it its own connotations

3 Victor Leontovitsch, Geschichte des Liberalismus in Russland (Frankfurt-am-Main: V. Klostermann, 1957), 153. 
and associations. In the West, the modern sense of property came into usage during the French Revolution. Article 17 of the Declaration of the Rights of Man described property as "an inviolable and sacred right," yet justified the abolition of seigneurial rights by allowing that individuals could be deprived of their property "when a legally stated public necessity obviously requires it, and under the condition of a just and prior indemnity." This provision established a semantic continuity between old and new conceptions of property under the rubric of "natural right." As William Sewell has argued, it created a successful transition from the old feudal conception of property as an attribute of privilege to the new sense of property as a belonging rightfully held by all individuals. Under the rubric of natural right, the National Assembly extended the right of property to the middle classes. Detached from its feudal origins, the concept of property rights was transformed into an attribute of freedom. The Assembly defined property as "a set of physically palpable possessions that a person had annexed to himself by his labor and was free to use in any way that did not infringe on the liberty of other citizens." It meant an extension of "personhood" to be guaranteed "the same liberty as all other aspects of his person." 4

In Russia, the transition from property as an attribute of privilege to property as an attribute of freedom never took place. Indeed, property rights remained an alien element in Russian historical development and never became a fully legitimate aspect of privilege. Slavophile writers in the nineteenth century extolled the absence of a tradition of Roman law and the prevalence of an orthodox collective spirit, which, they claimed, shaped the institutions of the people. But this was a romanticized view of secular developments. It was the prevalence of the state as a moral and legal entity in the Russian past, not deep religious feelings, that prevented property rights from gaining the esteem they held in the West.

In Russia, the notion of property developed from rights to land extended by the tsarist state. There was no tradition of feudal law to justify these grants. Before Peter the Great, servitors held land either as conditional grants for service, or in hereditary tenure, but both were obliged to serve. Private property was justified by an ethos of service to the public weal, embodied in the state. When Peter eliminated what had become an obsolete distinction and made

4 W. H. Sewell, Jr., Work and Revolution in France: The Language of Labor from the Old Regime to 1848 (Cambridge: Cambridge University Press, 1980), 134-6. 
all lands hereditary in 1714 , he enforced a requirement of compulsory lifetime service for the nobility. In 1762, the nobility gained freedom from compulsory service, but the connection between land and service retained its force. Their estates remained "unfree landed property," granted on assumption of a moral, if not a legal, obligation to serve. ${ }^{5}$

When Catherine the Great granted the nobility the right of property in the Charter of 1785 and other laws of her reign, she was using a western concept without historical roots in the Russian past. From its inception, the right of property became associated with the consolidation of the nobility's power over their peasants and the abuses of the serf system. The Charter of the Nobility of 1785 uses the word "right" (pravo) only in regard to property. The word pravo approximated property to the other noble right, which was not mentioned in the charter, "bondage right" (krepostnoe pravo), or serfdom. Other concessions in the charter were termed the "personal privileges" (lichnye preimushchestva) of noblemen. In the vocabulary of early nineteenth-century autocracy, the word "right" meant merely a firmer and more important form of privilege.

The property rights bestowed by the tsarist state became identified with its despotic authority. The serf owner served as an agent of the state, performing police, judicial, and fiscal functions. The government, in turn, used the army to protect the landlord from peasant unruliness and violence. Property, in this sense, remained an attribute of authority. It carried none of the redeeming sense of autonomy that it held in the west. It could not promote the liberal values of individualism and self-reliance. Herzen sneered at Russian conceptions of property: "What really can be said on behalf of the inviolability of the landlord's private property-the landlord, the whipper-of-men, who mixes up in his concept of property, the garden plot and the peasant woman, boots and the starosta." 6

Noble property rights remained a troubling inconsistency in the system of official values. During the first half of the nineteenth century, Alexander I and Nicholas I sought to limit the landlords' power over their serfs and extend property rights to peasants as well. Such efforts aroused

5 A. V. Romanovich-Slavatinskii, Dvorianstvo v Rossii ot nachala XVIII veka do otmeny krepostnogo prava (St. Petersburg: Ministerstvo Vnutrennykh Del, 1870), 238-9.

6 Quoted in V. Chernov, Zemlia $i$ pravo (Petrograd: Partiia Sotsialistov Revoliutsionnerov, 1917), 17. 
the fears not only among the gentry, but also among many officials: peasant property independent of state authority might threaten the political order. Thus, in the deliberations of the Secret Committee (1839-1842) Count Kiselev recommended giving peasants land in use rather than as property. Peasants owning land in hereditary tenure, he warned, might demand a role in government. As "an unrestrained majority," they would "destroy the equilibrium of the parts of the state organism."7

During the eighteenth and nineteenth centuries, service continued to provide the ethos of the Russian nobility and state, even when honored mainly in the breach. "Service became the expression of a social and moral ideal," Marc Raeff wrote. ${ }^{8}$ Noblemen and their ancestors had earned their rank and land by service, predominantly in the army, and their raison d'etre continued to be service to the state rather than their own independence or honor. The notion that private property provided the basis of political virtue, which proved to be so crucial in the evolution of western political theory, was weakly developed in Russia. The nobility's virtue was expressed in their acts of sacrifice for the fatherland, not in their possession of land. Nikolai Karamzin wrote in his famous Memoir that the Russian gentry "were never anything except a brotherhood of outstanding men serving the grand princes or tsars." 9

Service to the state also provided the principal secular legitimization of the monarch's power in Russia. From Peter the Great onward, Russian emperors and empresses were depicted as servants of the state who sought "the general welfare." 10 The tsar represented the general good, and his absolute power enabled him to remain above the interests of particular groups and individuals. After the Decembrist uprising of 1825, these claims assumed moral and religious overtones. Michael Speranskii taught the tsarevich Alexander Nikolaevich that the aim of society was not the mere satisfaction of particular interests. Life in society should be a preparation for the supreme truth, "the

7 Leontovitsch, Geschichte des Liberalismus in Russland, 108. On the Secret Committee, see S. V. Mironenko, Stranitsy tainoi istorii samoderzhaviia (Moscow: Mysl', 1990), 112-95.

8 Marc Raeff, Origins of the Russian Intelligentsia (New York: Harcourt Brace, Jovanovich, 1966), 119.

9 Richard Pipes, Karamzin's Memoir on Ancient and Modern Russia: A Translation and Analysis (New York: Atheneum, 1969), 200.

10 N. I. Pavlenko, "Idei absolutizma v zakonodatel'stve XVIII v.," Absoliutizm v Rossii XVII-XVIII vv. (Moscow: Institut Istorii A. N. SSSR, 1964), 389-427. 
threshold of the highest being." The government was the conscience of society, introducing ideas of justice and duty and ensuring their observance. "Just as conscience in the internal moral order is the organ of divine justice, so the supreme authority is the organ of eternal truth in the social order when it is pure and correct." 11 The emperor was to live not for himself or particular interests, but for the nation. From his religious instruction, Alexander Nikolaevich learned that "the ruler should have no purpose but the welfare of his subjects and he should not distinguish between his advantage and theirs, not to speak of allowing the two to come into conflict." Christ was to be his example. ${ }^{12}$

Later in the century, the tsar's mission as the secular embodiment of the truth was emphasized all the more by monarchist writers. Lev Tikhomirov, the former populist, stressed the ethical essence of autocracy, which placed social good above individual interest, and obligation above right. He cited Mikhail Katkov's description of "the psychology of right: Only that right is fruitful which reflects nothing but an obligation.... There is no benefit in the fact that I have the right to do something if I do not feel obliged to do what I may." The tsar had to act as an instrument of divine justice. "Most important, the tsar must not have personal motivations. He is the executor of the Supreme Will. Where the Supreme Will indicates the need for punishment and severity, the tsar should be severe and should punish. He is only the instrument of justice."13

The tsar's presumed power to transcend human weakness provided grounds for critiques of parliamentary government, which monarchist writers claimed defended only the material interests of particular groups. Speranskii taught Alexander II that constitutional government inevitably fell into the hands of the monied classes and advanced their interests to the detriment of the good of all. Alexander III's tutor and adviser, Constantine Pobedonostsev, claimed that representative institutions turned into the despotism of unprincipled politicians and the mob and could not attain the lofty moral plane of autocracy. ${ }^{14}$

11 Gody ucheniia ego Imperatorskogo Vysochestva Naslednika Tsesarevicha (Sbornik Russkogo Istoricheskogo Obshchestva, No. 30 [St. Petersburg: Russkoe Istoricheskoe Obshchestvo, 1880], 342-4, 366-7, 436-8.

12 Ibid., 100-1, 106.

13 L. A. Tikhomirov, Monarkhicheskaia Gosudarstvennost' (Buenos Aires: Russkii Imp. Soiuz-orden, 1968), 454, 612.

14 Gody ucheniia, 366-7; C. P. Pobedonostsev, Reflections of a Russian Statesman (Ann Arbor: University of Michigan Press, 1968), 266. 
The ethos of autocracy asserted the supremacy of the moral and political sphere over the economic. The tsar's role as the moral guardian of Russian society endowed him with obligations to preserve equity in the relations between groups in Russian society. As an impartial arbiter, he was supposed to stand above economic interest and social conflict, and enforce equity and justice. ${ }^{15}$ During the eighteenth century, the tsarist state regulated and closely supervised economic relationships between estates. What Reinhard Bendix described as "the ideology of the masters" implied that the authorities must ensure that the good of the state and the preservation of authority take precedence over the interest of the individual producer. The state administration intervened in disputes between labor and management as the protector of the interests of all the people; it both reinforced the authority of the managers and on occasion rectified workers' grievances. ${ }^{16}$

This perspective led tsarist officials in the nineteenth century to view the peasant commune as an embodiment of the values of the state, ensuring both equity and order. The commune guaranteed each peasant a plot of land, and presumably served as a safeguard against impoverishment and the rise of a potentially restless proletariat. ${ }^{17}$ The commune encouraged the subordination of individualistic impulse to the good of the group and promoted the ethical principles of the autocracy. The Minister of Finance, Egor Kankrin, expressed this sentiment when he wrote in 1837, “The people's custom of equal division of the land among all settlers and inhabitants of one area is a sign of popular good will and fraternal union in which one should take pride, and which bears the splendid imprint of deep Christian feeling." 18

15 Contrast this view with the dominant attitude in the United States in the nineteenth century: "It was a century which put all the energy and attention it could into economic interests.... In most affairs one senses that men turned to non-economic issues grudgingly or as a form of diversion and excitement or in spurts of bad conscience over neglected problems (J. W. Hurst, Law and the Conditions of Freedom in the Nineteenth-Century United States [Madison, WI: University of Wisconsin Press, 1956], 29).

16 Reinhard Bendix, Work and Authority in History: Ideologies of Management in the Course of Industrialization (New York: Wiley, 1956), 166-74.

17 Alexander Gerschenkron, "Russia: Agrarian Policies and Industrialization, 18611917," Cambridge Economic History, vol. 6, Part 2 (Cambridge: Cambridge University Press, 1965), 750.

18 M. Tugan-Baranovskii, Russkaia fabrika $v$ proshlom $i$ nastoiashchem (Moscow: Moskovskii rabochii, 1922), 222. 
The justification for the emancipation of the serfs in 1861 followed the traditional pattern of subordinating the interests of the individual estates to the good of all. The state clearly encroached on the property rights of the landed nobility by assigning lands, with compensation, to the peasantry. Alexander, however, maintained the fiction that property rights remained sacrosanct by presenting the emancipation as a response to the initiative of the nobility itself. The initial rescripts were issued in response to contrived or intentionally misinterpreted "requests" from provincial noble assemblies. Official statements then described the reform as a great act of national sacrifice. The Emancipation Edict referred to the nobility's "sacrifice for the benefit of the fatherland," asserting that they had "voluntarily renounced their rights to the persons of the serfs." The emancipation, thus, tampered with noble property rights in order to defend them. ${ }^{19}$

With the emancipation, the government began strenuous efforts to convince the peasantry that they should not expect a redivision of all the lands, the "black partition" that they longed for. The Emancipation Edict, composed by the Metropolitan Filaret, referred to "misunderstandings" that had arisen in the countryside and reminded the peasants that "he who freely enjoys the blessings of society should mutually serve society by fulfilling certain obligations." After quoting Paul's admonition in the Letter to the Romans to "obey the powers that be" and to give everyone his due, it added that "the legally acquired rights of the landlords cannot be taken from them without proper compensation or voluntary concession." In subsequent years, Alexander made it clear that he considered the defense of property rights to be inseparable from the autocratic order. In his rescript to the Chairman of the Committee of Ministers, Prince P. P. Gagarin, he emphasized the importance to the welfare of the state and each of its citizens of "the complete inviolability of the right of property in all its forms, defined by the general laws and the statute of February 19, 1861.20

The emancipation of the serfs involved an effort to enhance respect for private property. However, this goal was not pursued consistently.

19 On the nobility's “initiative" see Daniel Field, The End of Serfdom: Nobility and Bureaucracy in Russia, 1855-1861 (Cambridge, MA: Harvard University Press, 1976), 77-83; S. S. Tatishchev, Imperator Aleksandr II: Ego zhizn' i tsarstvovanie (St. Petersburg: A. S. Suvorin, 1903), 1: 380-1.

20 Tatishchev, Imperator Aleksandr II, 1: 380-2. 
The maintenance and strengthening of the land commune ensured that the great majority of the peasants would not receive rights of individual property. Recent studies have shown that reformers in the Editing Commission hoped to extend the right of property to the peasantry as well and bring about the dissolution of the commune. But the reformers thought it premature to embark on a forcible dissolution of the communal system, especially since the peasantry lacked other institutional structures in the countryside. In any case, it is doubtful whether their viewpoint could have triumphed, given that both the conservative bureaucracy and most of liberal public opinion believed in the commune as a fundamental institution of Russian society and culture. Another effort to dismantle the commune led to Alexander II's approval in 1874 of a resolution to seek ways to introduce individual land-holding among the peasantry. However, the imminent international crisis and revolutionary menace precluded so drastic a reform, and the matter was dropped. After Alexander II's death, the government defended the commune as a mainstay of the autocracy and took measures for its defense. ${ }^{21}$

Nor did the state extend political rights to proprietors. The emperor came to the defence of noble property rights, but insisted on maintaining his monopoly of power. In 1862, the Committee of Ministers issued a warning to the nobility, reminding them that "the Government, at present concentrating all its attention on the reforms in various parts of the administration for the general welfare, reserves for itself the further conduct of these reforms toward their ultimate goal." In 1865, indignant at the nobility's continued requests for participation in government, Alexander issued a rescript that asserted his own "concern to improve and perfect ... the various branches of state administration," and his own exclusive right of initiative in reform. "No class

21 V. G. Chernukha, Krest'ianskii vopros v pravitel'stvennoi politike Rossii (Leningrad: Nauka, 1972), 124-64. The movement in the administration to dissolve the commune is explored by David Macey, Government and the Peasantry in Russia: The Prehistory of the Stolypin Reforms (De Kalb, IL: Northern Illinois Univesity Press, 1987). See also L. G. Zakharova, Samoderzhavie i otmena krepostnogo prava $v$ Rossii, 1856-1861 (Moscow: Moskovskii Universitet, 1984), 158-9. The most complete discussion of the implications of the emancipation for the peasant's right to property is M. D. Dolbilov, "Zemel'naia sobstvennost' i osvobozhdnie krest' ian'," in Sobstvennost' na zemliu $v$ Rossii: istoriia $i$ sovremennost', ed. D. F. Aiatskov (Moscow: Rosspen, 2002), 45-153. 
has the right to speak in the name of other classes. No one is called to take it upon himself to bring before ME petitions about the general welfare and the needs of the state."22

By defending the property rights of the nobility, Alexander impugned the ethical supremacy that justified his autocratic prerogatives, and the leaders of the intelligentsia now claimed the title to ethical leadership that the tsar had relinquished. Alexander Herzen looked towards a "social monarchy" in which the tsar promoted the cause of equality. Chernyshevskii wrote, "Only one thing is necessary: let our autocracy take to the path of economic improvement, let Alexander II finish the work begun by Alexander I and by Nicholas." Chernyshevskii envisaged a system of agricultural and industrial co-operatives introduced and operated by the state; the state would work to transform the commune into a truly socialist institution. ${ }^{23}$

The leaders of the intelligentsia rose to the task of replacing the tsar as ethical leader of the nation. Herzen could not drink the toast he had prepared to the Tsar-Liberator. "The Tsar has cheated the people," he wrote in The Bell. Serfdom had not been completely abolished. Nikolai Ogarev and N. N. Obrucher wrote an appeal called "What Do the People Need?" Their answer to the question was replied that the people needed land, freedom, and education, "The land belongs to no one but the people." The peasants should receive the land that they held at the moment, and they should be governed by their own representatives, who would apportion taxes fairly and not oppress them like the tsar's officials. ${ }^{24}$

Radical writers shared the premises of official doctrine, and contended that the tsar had violated his own fundamental principles. Their propaganda portrayed him as selfish and callous. The pamphlet "A Conversation between the Tsar and the People," written in the early 1870s, presents Alexander as indifferent to the people's pleas for help, concerned only about the collection of tax arrears. He impatiently urges the peasants to have faith in God and

22 Terence Emmons, The Russian Landed Gentry and the Peasant Emancipation of 1861 (Cambridge: Cambridge University Press, 1968), 396-7, 410-11.

23 Theodore Dan, The Origins of Bolshevism (New York: Harper and Row, 1964), 334; Franco Venturi, Roots of Revolution (London: Weidenfeld and Nicolson, 1960), $173-4$

24 Venturi, Roots of Revolution, 108-10; N. P. Ogarev, "Chto nuzhno narodu?" in Izbrannye sotsial'no-politicheskie i filosofskie proizvedeniia (Moscow: Politicheskaia Literatura, 1952), 1: 527-36. 
to learn to accept their lot. He is unable to understand the peasants' condition or to act as their guardian. ${ }^{25}$

Populist writers influential during the 1870 s asserted that property and wealth had silenced the ethical imperatives of government in Russia. Economic concerns had become paramount, as they had in the bourgeois societies of the West, which Russia had now begun to resemble. From this perspective, constitutional government and the civil rights of a liberal order seemed little more than weapons of the propertied classes. Peter Lavrov wrote in his Historical Letters that American democracy had one feature in common with the Russian Empire or Asian khanates, "the subjection of a considerable number of individuals to a juridical contract or to a class domination that these individuals have not discussed or stated their disagreement." 26 The most complete statement of populist views of government, Lavrov's The State Element in the Society of the Future, curtly dismissed the institutions of representative government, "The Lords and Commoners of England, her judges, and her coroners have become the juridical organs of the ruler of wealth over the masses. The bourgeoisie reigned in French chambers and courts after the great revolution." 27

The state, according to Lavrov, had now relinquished its role as protector of the security of the individual and society and now was "the preserver of the economic order" that had resulted from "international competition among monopolistic property owners." It assisted the exploiting classes and acted as "a vampire of society." Ethical principles could triumph only with the coming social revolution, which would usher in an era of human solidarity. Then property would belong to all, and people would labor for the general welfare. Egoistic feelings would weaken; altruistic sentiments would grow stronger and form the bases of a common life. ${ }^{28}$

Populist writers looked to the peasant commune as the mainstay of altruistic feelings in Russia and rallied to its defense against government policies that they claimed encouraged private ownership. They, like the

25 Agitatsionnaia literatura russkikh revoliutsionnykh narodnikov (Leningrad: Nauka, 1970), 462-3.

26 Peter Lavrov, Historical Letters (Berkeley, CA: University of California Press, 1967), 245.

27 Peter Lavrov, Izbrannye sochineniia na sotsial'no-politicheskie temy v vos'mi tomakh (Moscow: Vses. ob-vo politkatorzhan i ssyl'no-poselentsev, 1935), 4: 239. 
Slavophiles and Herzen, found the collective spirit in the people themselves, not in the state. Just as the Slavophiles had discerned a religious principle in the commune, the populists discovered a social ideal that they projected into the future. The absence of private property in the commune represented a potential deterrent to the prevalence of private interests. The communes' practice of repartition of the land, they believed, provided the grounds for a socialist law based on use rather than possession. The revolutionary tracts of Michael Bakunin promoted the communal system as the ideal of the people; inequality and oppression in existing communes resulted from the domination of the autocratic state. ${ }^{29}$

At the end of the 1870 s the revolutionary populists recognized the importance of winning political and civil rights. These rights were an addition to their program and fit uneasily with their principles of social and economic justice. ${ }^{30}$ The program of the People's Will in 1879 announced the revolutionaries' plans to introduce democratic suffrage and freedom of religion, speech, press, and assembly. However, their principal goal remained the elimination of private property in land. The land was to belong to the people, they declared, but as a strategic concession they promised to regard as inviolable the persons and property of those who remained neutral to the revolutionary struggle. 31

Nikolai Mikhailovskii presented the populists' argument for parliamentary government and individual rights in a series of articles he wrote for the illegal press. The tsarist government could no longer protect the population from the bestial oppression of the bourgeoisie, he argued. Only by transferring "public matters" into "public hands," by convening an "Assembly of the Land," a zemskii sobor, could the citizen's security be protected. Although Mikhailovskii assumed that democratic government would ensure political freedom, he made no mention of civil rights per se, nor of the institutional means of guaranteeing them. Indeed, he thought political freedom in Russia

29 For a comparison of populism and Slavophilism, see Abbott Gleason, Young Russia: The Genesis of Russian Radicalism in the 1860s (New York: Viking, 1980), 49-53; S. N. Valk, ed., Revoliutsionnoe narodnichestvo 70-kh godov XIX veka (Moscow: Nauka, 1965), 1: 45, 51. On peasant legal norms, see Chernov, Zemlia i pravo, 19-21, 24-5, 44-5.

30 See my book, The Crisis of Russian Populism (Cambridge: Cambridge University Press, 1967), 82-4.

31 Valk, 2: 170-4. 
presumed expropriation: a constitutional system could gain support from the peasantry only by promising them land. "The Russian people to a man will rise up only for that kind of freedom that guarantees them land." A social revolution, he suggested, was also more probable against an assembly than against a tsar, "When is a popular uprising more likely? When at the summit of the political system sits a remote, semi-mythical tsar, whom the people in their ignorance still believe in according to custom, or when the country is being governed by elected individuals, ordinary people, without any mystical aura." 32

Populist writers thus introduced the notion of political rights into programs that continued to express an egalitarian and collectivist social vision. Unlike Russian Marxists, who insisted on a bourgeois phase of development before the advent of socialism, they provided no historical precondition for these rights. They assumed that they could be imposed by a triumphant revolutionary leadership. But the decline of the revolutionary movement in the 1880s and the spread of the historical and deterministic doctrines of Marxism undermined the earlier faith in the power of the vanguard.

In the first years of the twentieth century, the resurgence of the opposition movement and the spread of peasant insurrections rekindled the revolutionary faith of the populists. Viktor Chernov provided new intellectual grounds for their assumption of the role of ethical leader of the nation. Chernov cited European critiques of Marxist theory which showed that capitalism did not always lead to economic growth. He drew the conclusion that in many countries like Russia capitalism would not develop new forms of social cooperation, as it had in the west "as a result of the blind play of particular interest." In Russia it would bring only destruction and suffering. This eventuality allowed the leaders of the intelligentsia to intervene and shape the economy according to their ideals. Chernov summoned them to "the vigorous work of taming and harmonizing egoistic tendencies, smoothing out of rough spots, the submerging of individual wills, the elimination of dissonances, the working out of an internal harmony. It is a labor of massive conscious creation." 33

32 N. K. Mikhailovskii, Revoliutionnyia stat'i (Berlin: Gugo Shteinits, 1906), 9-10, $18,21$.

33 Victor Chernov, "Tipy kapitalisticheskoi i agrarnoi evoliutsii," Russkoe bogatstvo, No. 10 (1900): 243-4. 
Chernov's writings expressed the populists' voluntarist faith in the possibilities of subordinating economic processes, viewed as ineluctable by Russian Marxists, to ethical imperatives. ${ }^{34}$ The program of the Socialist Revolutionary (SR) party, adopted in January 1906, incorporated this central populist belief. It reaffirmed the intelligentsia's role as ethical leader, using words borrowed from Lavrov and Mikhailovskii. The destructive impact of capitalism in Russia had left the field open for moral leadership. Social progress manifested itself in "the struggle for the establishment of social solidarity and for the complete and harmonious development of human individuality." The struggle presumed the evolution of impersonal class antagonisms, but above all it required "the intervention of conscious fighters for truth and justice." 35

The political section of the program developed the principles advanced by the revolutionaries of the 1880s. Political freedom would be a necessary preliminary stage for the achievement of socialism. The party recognized the inalienable rights of man and citizen: freedom of conscience, speech, press, assembly, and unionization. There would be freedom of movement, choice of work, collective refusal to work, and inviolability of person and dwelling. The agrarian section of the program, however, reaffirmed the populists' determination to do away with private property in land. "In the interests of socialism and the struggle against bourgeois-proprietorial principles" the party would rely upon the communal views and forms of life of the peasants. This meant the dissemination of the notion "that the land is no one's, and that right to its use is given only by labor." As a result, the party would work for the socialization of the land, which would be removed from commercial exchange and turned "from the private property of separate individuals or groups into the possession of the whole people (obshchenarodnoe dostoianie)." Under the management of central and local organs of popular self-government, the land would be allotted equally, on a labor principle, "to secure a norm of consumption on the basis of the application of one's own labor, either individually or in a cooperative." 36

34 On the voluntarist strain among the Socialist Revolutionaries, see Manfred Hildermeier, Die Sozialrevolutionäre Partei Russlands: Agrarsozalismus und Modernisierung im Zarenreich (1900-1914) (Cologne: Bühlau, 1978), 81-3.

35 Protokoly pervago s"ezda partii sotsialistov-revoliutsionnerov (n. p., 1906), 355, 359.

36 Ibid., 361, 363. 
The SRs' program thus retained the earlier populist view that property did not belong to the sphere of natural rights, but derived from the values and vocabulary of the system to be overthrown. Their political and legal program anticipated that the revolution would establish civil rights and the inviolability of the individual, while their agrarian program foresaw the swift end to individual property rights in land. The program did not recognize a discrepancy between the introduction of freedom and civil rights and the attack on the right of property. The socialization of the land was to take place according to the peasants' own concepts of land tenure. The leadership assumed that the peasants shared their views, and would continue to hold land collectively. They made no provision for dissenting opinions. Moreover, the SRs both countenanced and encouraged seizures of land from the nobility, which were to take place under its own direction in order to ensure the socialization of the land. Mikhail Gots even attacked the Bolsheviks' strategy of confiscation for failing to ensure that the agrarian revolution brought the village as close as possible to socialism. ${ }^{37}$

The moderate populists of the Russkoe bogatstvo group and the Popular Socialists (narodnye sotsialisty) shared the same determination to abolish private property in land, though they advocated more gradual and less violent methods. Aleksei Peshekhonov, the principal writer on the land question for Russkoe bogatstvo and a leader of the Popular Socialists, saw private land-holding as the major obstacle to the economic well-being of Russia. Individual rights, he emphasized, were not absolute, "Perfecting social forms, [humanity] strives not only to extend and secure the rights of each individual, but to limit them in the interests of the collectivity." His review of the reports of the gentry Committees on Agriculture made clear that noble property rights conflicted with the rights of man as he understood them, "The 'rights' that [the nobles] are storming about are, first, the right of individuals to turn fruits of the labors of all society to their own advantage and, second, the right of the strong classes to exploit 'the very weakest' part of the population." 38

37 Maureen Perrie, The Agrarian Policy of the Russian Socialist-Revolutionary Party from its Origin through the Revolution of 1905-1907 (Cambridge: Cambridge University Press, 1976), 102-4.

38 A. V. Peshekhonov, Zemel'nyia nuzhdy derevni (St. Petersburg: N. N. Klobukov, 1906), 66-7, 70-1. 
Peshekhonov repeated John Stuart Mill's argument that property rights derived from the labor applied to the land, and could not justify excluding others from the possibility of devoting their time and energy to that land. Nor could property rights be defended on the grounds of productivity in Russia, where it had led to impoverishment and destruction of the agricultural resources of the country. Only the transfer of land to the peasants could remedy this situation. Those who labored, he concluded, should have exclusive right to the land, "The management of these lands should be transferred to the people through the agency of central and local representation, organized on democratic principles." 39

The moderate populists favored nationalization of the land. Nationalization represented a more controlled form of land transfer than the socialization advocated by Chernov and the Socialist Revolutionary partythe Popular Socialists even supported the redemption of noble land-but they did not allow private ownership, even for peasants. Indeed, they opposed seizures and control by local committees, partly because they feared that local initiative without central control might result in kulak ownership in many areas. They were bitter critics of the Stolypin land reform. ${ }^{40}$

The 1906 program of the Popular Socialist party was based on the populist goal of the good of the whole, attained through gradual methods. The party spoke for "all laborers," and strove for the "welfare of the people" (narodnoe blago), which it would determine through "the people's will." "The people's will" would be expressed by a democratic government, which would protect individual rights. Their political program, V. N. Ginev remarks, could have been endorsed by the Constitutional Democrats. Their goal was nationalization of the land, but the means were to be peaceful, involving redemption of private property. Those lands that were being worked, trudovye khozyaistva, would remain temporarily in their owners' possession, and could be inherited on the principle of labor use. ${ }^{41}$

39 Ibid., 67, 71, 154-5.

40 Perrie, The Agrarian Policy of the Russian Socialist-Revolutionary Party, 161-2; V. N. Ginev, Bor' ba za krest' ianstvo i krizis russkogo neonarodnichestva, 1902-1914 gg. (Leningrad: Nauka, 1983), 194-6, 210. The Popular Socialists' consistent opposition to all private landowning belies the view that they represented the interests of rural bourgeoisie or farmer class, as suggested by N. D. Erofeev in his Narodnye sotsialisty $v$ pervoi russkoi revoliutsii (Moscow: Moskovskii Universitet, 1979), 62-3, 71-2.

41 Ginev, Bor'ba za krest'ianstvo..., 204-5. 
Populist views of private property reached far beyond their own circles and influenced many members of the Constitutional Democratic party, the principal champions of a constitutional regime in Russia. An articulate contingent of Kadet leaders, among them I. I. Petrunkevich, V. P. Obninskii, and V. E. Yakushkin, argued for reform leading to national ownership of land. Petrunkevich thought agrarian reform would eliminate the consciousness of private property in land. He was opposed by figures such as N. N. Kutler and L. I. Petrazhitskii, who opposed communal land tenure and favored private homesteads. The party had difficulty resolving these differences and formulating a unified approach to land tenure. Its leaders rejected the populist concept of a "labor norm," and advanced instead the notion of a "consumption norm" for determining future allotment quotas, based on each family's needs rather than the number of workers. The delegates at the Kadet party's second congress in January 1906 finally agreed to Peter Struve's proposal that land be given "in use" rather than as private property. They adopted the goal of an "inalienable" state land fund, which would allot land according to the principle of equality.

Stolypin's measures to promote separations from the peasant commune and the development of individual homesteads posed difficult problems for Kadet leaders, who were divided on the question of land tenure. In the Second Duma, the Kadet group proposed measures that would provide the commune with more protection from individual peasants than those in the Stolypin projects. When Stolypin introduced the laws on the basis of the emergency provision of the Fundamental Laws, article 87, the Kadets united in opposition to the Prime Minister's arbitrary methods of enactment rather than to the substance of the measures. ${ }^{42}$

42 On the Kadets' debates on agrarian policy in 1905 and 1906, see J. E. Zimmerman, "Between Revolution and Reaction: The Constitutional Democratic Party, October 1905 to June 1907 Ph. D. thesis Columbia University, 1967)”; see also idem, "The Kadets in the Duma," in Essays on Russian Liberalism, ed. Charles Timberlake (Columbia, MO: University of Missouri Press, 1972), 136-7; William Rosenberg, Liberals in the Russian Revolution (Princeton: Princeton University Press, 1974), 12-19. On populist influences on the liberals in the Provisional Government, see Leonard Schapiro, "The Political Thought of the First Provisional Government," in Revolutionary Russia, ed. Richard Pipes (Cambridge, MA: Harvard University Press, 1968), 97-113. 
A consistent approach to the right of property eluded the liberal intellectuals of the Kadet party. While most believed in private ownership in general, they refused to defend it as a right, for this would have meant the acceptance of noble land-holding and inequality of distribution in the countryside. Thus Kadet leaders, who looked upon themselves as heirs of the French Revolution, could not accept a transition between old and new forms of property, like that formulated by the National Assembly. In the end, many placed their faith in the Russian state-not the autocracy, of course, but a state based on acceptable, egalitarian, ethical principles. As westernized an intellectual as Pavel Miliukov branded the Stolypin reforms a "Europeanization" of the land, which, he claimed, violated Russian tradition, "The idea of private property has had a stunted development here ... the idea [of the nationalization of the land] is no novelty for Russia ... the principle of the nationalization of the land, in the sense of a recognition of the supreme right of the state to land, is an ancient Muscovite principle." 43

Among the political groups that formed before 1905, only the Marxists expressed support for the notion of private property, at least during the bourgeois stage that most of them believed must precede the socialist revolution. But this regime of private property was more of a doctrinal obligation for them than a concrete objective, and they had difficulty placing it in Russian historical development. Both Plekhanov and Lenin at first anticipated that the bourgeois revolution would lead only to a moderate reform in the countryside, the return of the otrezki, the lands taken by the landlords at the time of the emancipation. However, Marxist doctrinal constraints gave way to revolutionary and egalitarian imperatives.. When the peasants rose up in the first years of the twentieth century and demanded lands, the Social Democrats could hardly pose as the defenders of noble private property. At its second congress, the party pledged its support for the peasant movement. Lenin gave up his insistence on the return of the otrezki and his Two Tactics of Social Democracy developed the concept of a democratic alliance of workers and peasants, which presumed the seizure of landlord property. To salvage the notion of a bourgeois stage, Lenin advanced his notion of "nationalization" of the land, and the Mensheviks of "municipalization" of the land. Whether the land was under the disposition of the central state or of the localities,

43 Leontovitsch, Geschichte des Liberalismus in Russland, 196-9. 
it was clear that the Marxists' "bourgeois" stage would scarcely bring the protection of the right of private property in Russia. ${ }^{44}$

In 1905, the defense of the right of property in Russia was left to the pillars of the old order, the landed nobility and the tsarist government. As peasant insurrections swept across the country, the nobility began the work of political organization and formed the United Nobility and such political parties as the Octobrists to act on behalf of their interests. The tsarist government made the defense of noble landowning its principal goal. The identification of private property with despotism, arbitrariness, and oppression became overt as the tsar's ministers explicitly presented private property as the mainstay of the existing order. In his speech to the First Duma, the Prime Minister, Ivan Goremykin, declared that the state could not deprive some without depriving all of their rights of private ownership, "The inalienable and inviolable right of private property is the foundation stone of the popular well-being and social progress at all stages of development. Private property is the fundamental basis of a state's existence: without the right of private property there would be no state."45

In the west, property rights have historically provided the basis for other civil and political rights. Ultimately, the person has assumed the inviolability granted to property. In those western nations that have suspended the right of property selectively, there has been a respect for property rights when they are not abused, an unspoken, informal respect for property as the basis of security and limitation on the power of the state. Whether it is possible to create a society that protects civil and political rights without protecting the right of property is a question sharply disputed by political theorists. Those with liberal or conservative views tend to answer the question in the negative. They point to the historical role of private property and its effect in limiting the untrammeled exercise of governmental power. Those of a radical or socialist persuasion believe that property rights are often used to violate the rights of those without property. 46

44 Dan, The Origins of Bolshevism, 310-22; Esther Kingston-Mann, Lenin and the Problem of Marxist Peasant Revolution (New York: Oxford University Press, 1985), 66-73, 92-3, 183-8.

45 Readings in Russian Civilization, ed. Thomas Riha (Chicago: University of Chicago Press, 1969), 451-2.

46 For a sample of the various viewpoints advanced on the subject, see Property, ed. J. Roland Pennock and John W. Chapman (New York: New York University Press, 1980), and Property Profits, and Economic Justice, ed. Virginia Held (Belmont, 
The Russian experience before the 1917 revolution brings to light the problem of the establishment of civil rights in a political culture that did not confer high ethical value on the right of property. In early twentiethcentury Russia, property rights and civil rights belonged to antagonistic and irreconcilable political doctrines. On one hand, the concept of property rights had become attached to the fate of the tsarist state, which disdained and violated all other rights. On the other, the champions of civil rights, with only a few exceptions, lacked a morally viable concept of property that could sustain individual freedom in the new society. Reflecting the deep political divisions in twentieth-century Russia, the terms of discourse precluded the continuity between old and new forms of property rights that has been achieved in the West. Whether under different historical conditions Russia might have evolved a legal order protecting the rights of all its citizens is an unanswerable question. But the Russian experience, as well as that of most of the non-western world in the twentieth century, belies the assumption that an individual's civil rights can be attained easily when they are not grounded in a prior tradition of respect for his or her right of property.

CA: Wadsworth, 1980). An interesting discussion of the role of private property as a symbol of liberty leading to paradoxes of inequality is found in Jennifer Nedelsky, "American Constitutionalism and the Paradox of Private Property," in Constitutionalism and Democracy, ed. Jon Elster and Rune Slagstad (Cambridge: Cambridge University Press, 1988). 


\section{Part V}

\section{Afterthoughts and}

Remembrances

cof 



\section{Thought, Culture, and Power: Reflections of a Russianist}

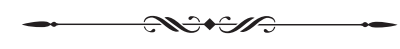

ooking back on the evolution of my scholarship over five decades, I am struck
both by my constant fascination with how systems of thought enthralled and inspired historical figures and by my approach to the changing subjects that became the object of this fascination. The ideas and sentiments propounded by great philosophers and writers established a necessary background for my work, but what engaged my interest and stirred my imagination was the varied ways these ideas were understood and acted upon. It was my reflection on the transformation of ideas into conscious views of the world that prompted my three research projects: the populists of the 1870s and 1880s, the legal reformers of the nineteenth century, and the emperors of Russia.

Such transformation of ideas is particularly evident in the history of Russian thought. The idealism of Fichte, Schelling, and Hegel, Marxism, the positivism of Mill, and Nietzsche's notions of art, morality, and the superman assumed new meanings when received in Russia. Russian intellectuals drew upon western ideas to understand Russia's political future and to guide their own life and goals. The most radical emerged as a revolutionary intelligentsia, who sought support from the people-the peasants, the workers or both, to unleash a revolution that would bring socialism to Russia. However, the conviction that foreign ideas and models could provide the content and direction for Russian historical development was shared by a broad segment of educated opinion-Slavophiles, Westernizers, even conservatives and governmental officials. ${ }^{1}$ All of them, to a greater or lesser extent, conceived

1 My master's essay "Koshelev, Samarin, and Cherkasskii: Three Views of Russia's Political Future" was the basis for my first publication, "Koshelev, Samarin and Cherkasskii and the Fate of Liberal Slavophilism." It is Article 13 in this volume. 
of the world as the realization of certain ideas they thought immanent in reality. Ideas provided the meaning for their lives, and they described their existential quests in what Lydia Ginzburg has called "the human document": diaries, memoirs, poetry and fiction of a confessional character. ${ }^{2}$

The application of individual psychology to history promised a means to approach the interaction of ideas and personality. Leopold Haimson's The Russian Marxists and the Origins of Bolshevism first exemplified this approach for me. Haimson explored the different understandings of Marxism among the leading Russian Marxists, George Plekhanov, Paul Axelrod, Julius Martov, and Vladimir Lenin by tracing the divergent paths of psychological development that led each to his own conclusions about the importance of reason and feeling in history. ${ }^{3}$ On this basis, he explained the assessments they made of the role of the conscious vanguard elite and the spontaneous revolutionary impulses of the masses in the organization of a revolutionary movement. Other biographical works with acute insights into the intelligentsia's psychology were the pre-revolutionary historian Mikhail Gershenzon's essays on the Decembrist revolutionaries and the young intellectuals of the first half of the nineteenth-century, as well as Isaiah Berlin's moving account of the idealist circles of the 1830s and 1840s, "A Remarkable Generation."4

In 1958, I began my graduate work, under Haimson's direction, at the University of Chicago. My first book, The Crisis of Russian Populism, described the responses of three populist writers, Alexander Engel'gardt, Gleb Uspenskii, and Nikolai Zlatovratskii to their experiences in Russian peasant villages during the 1870 s and 1880 s. $^{5}$ I was struck by these writers' unswerving determination to cling to their ideas in the face of the evident contradictions they encountered in the countryside. Their idealization of the peasants appeared to be based on far more than a strategic political calculation. It seemed a powerful emotional bond rooted in their psyches.

2 Lydia Ginzburg, On Psychological Prose (Princeton: Princeton University Press, 1991), 27-106.

3 Leopold H. Haimson, The Russian Marxists and the Origins of Bolshevism (Cambridge, MA: Harvard University Press, 1955).

$4 \quad$ Particularly M. O. Gershenzon, Istoriia molodoi Rossii (Moscow: I. D. Sytin, 1908) and Istoricheskie zapiski (Moscow: Kushnerov, 1910); Isaiah Berlin, "A Remarkable Generation," in Russian Thinkers (London: Penguin, 1994), 130-239. The essays were originally printed in the journal Encounter, in 1955 and 1956.

5 The Crisis of Russian Populism (Cambridge: Cambridge University Press, 1967). 
I turned as I would in my later research to the social sciences, particularly psychology and anthropology, to understand the thinking of the subjects of my study. My use of social science insights, however, has been pragmatic, as a means to find openings to the mental world of individuals governed by ideas and imagery remote from our own. I first was attracted to works on individual psychology, particularly those of Erik H. Erikson, whose influence was widespread in the 1960s. Erikson's work, particularly Childhood and Society, focused on the concept of identity and provided an analysis of the interaction between personal development in the context of the values, goals, and self-images of different societies. His use of developmental psychology sensitized me to the importance of childhood memories and experience in the intellectual evolution of the writers I studied. Memories of their early years surfaced in their works when their ideas were thrown into doubt. These ideas had taken form as they entered maturity during the era of "Great Reforms" of the 1860s, which stirred intellectuals' hopes of liberation from the legacy of the despotic past-serfdom and autocracy. The subsequent disappointment in the results of the reforms-the peasants' loss of part of the land they farmed, the refusal of the government to consider constitutional reforms-had led to disillusionment and increasing reliance on the peasantry for the hopes of the future. Yet little was known about the peasants besides their poverty and ignorance, and as in other cases, literature filled the void by depicting the nature of reality for them.

In the midst of their ideological predicament, the populist writers revealed the depth of their psychological investment in the ideology that had promised their redemption from the inequality and egoism they believed pervaded Russian society. They resorted to various defense mechanisms to dispel their doubts-rationalization, denial, self-blame, and schemes to transform the peasants in the image of the idealized figures of their imagination. Engel'gardt, a chemist, conceived of creating better peasants by training populist intellectuals to till the land and adopt collectivistic practices. Uspenskii and Zlatovratskii escaped despair by evoking fantasy images of an idealized peasantry: Uspenskii to escape painful memories of his childhood, Zlatovratskii to restore the warm relations with his family and the peasants he remembered in his family home. Populist economists V. P. Vorontsov and N. F. Danielson answered the disturbing information about the countryside with elaborate proofs that denied the possibility of the development of capitalism in Russia. 
My second book, The Development of a Russian Legal Consciousness, also focused on individual psychology as a frame and impetus for intellectual development. ${ }^{6}$ I studied the emergence and development of a mentality of reform among the group of legal reformers who appeared in the administration in the 1840s and 1850s and who pressed for, drafted, and implemented the Court Reform of 1864, which introduced a modern judiciary in Russia. However, both my high valuation of the role of ideas and individual personality and my interest in institutional mentality were at odds with dominant historical approaches of the time in the Soviet Union. MarxistLeninist ideology discouraged or prohibited such research since the state was considered an epiphenomenon, of secondary importance to economic development and class conflict.

The Soviet scholar who opened this area for serious study was Peter Zaionchkovskii of Moscow State University. I had met Zaionchkovskii during my stay in Moscow in 1961 and 1962, and I returned to work under his guidance in 1966-67. Official ideology held that events were determined by "objective" factors, the development of capitalism and the revolutionary threat of the peasantry. Without denying the importance of these objective factors, Zaionchkovskii insisted on including what he called "the subjective factor" in historical writing. This meant taking the views and the initiatives of officials into account in explaining events like the Great Reforms, particularly the emancipation of the Russian serfs, the subject of his classic monograph. ${ }^{7}$ I recall the startled reaction of students to his defense of the "subjective factor," during a lecture he delivered in 1967 before the History Faculty of Leningrad State University.

While Zaionchkovskii observed the orthodoxy in print, in his teaching, scholarly advice, and public lectures, he emphasized the importance of

6 The Development of a Russian Legal Consciousness (Chicago: University of Chicago Press, 1976). Russian translation, Vlastiteli $i$ sudii: razvitie pravovogo soznaniia $v$ imperatorskoi Rossii (Moscow: NLO, 2004). An English version of the introduction to the Russian edition, reiterating and developing my views in reference to later works, appeared in the journal Kritika: "Russian Monarchy and the Rule of Law: New Considerations of the Court Reform of 1864," Kritika vol. 6, No. 1 (Winter 2005): 145-70 (Article No. 1 in Russian Monarchy: Representation and Rule).

7 P. A. Zaionchkovskii, Otmena krepostnogo prava, $2^{\text {nd }}$ edition (Moscow: Prosveshchenie, 1968); The Abolition of Serfdom in Russia (Gulf Breeze, FL: Academic International Press, 1978). 
attitudes and ideas. Most important, as an experienced archivist he ensured that personal documents of tsarist officials were opened to young scholars, foreigners as well as Russians, and he himself published or saw to the publication of the personal papers of a number of the most significant figures, such as the diaries of Minister of Interior Peter Valuev and the War Minister, Dmitrii Miliutin. ${ }^{8}$ As a research advisor (rukovoditel') he was unequaled, a scholar who maintained the pre-revolutionary devotion to "science" (nauka), and drew our attention to crucial archival and published documents.

In my research, I sought explanations for the appearance of officials dedicated to the cause of the law in an administration that historically had subordinated the judiciary to executive authorities and allowed for the exercise of arbitrary personal will. This led me to a study of the emergence of a striving for "legality" (zakonnost') in the Russian state in the eighteenth and early nineteenth century, and particularly the efforts for legal reform and codification beginning with Peter the Great. The "reforming tsar" was a component of what I later called "the European myth," the effort of Russian rulers to cast themselves as progressive western monarchs that prevailed from Peter's reign onward.?

When Nicholas I came to the throne, he determined to place absolute monarchy as it existed in Russia on a legal basis. His first step was the codification of the laws, which had been attempted eleven times since the beginning of the eighteenth century. He assigned the task to the Second Section of his own chancellery, but he remained in charge, dictating its guiding principles, and reviewing reports carefully at every stage. His efforts resulted in the publication in 1830 of The Complete Collection of Laws, a compilation purportedly of all the laws issued in the empire since the Law Code of 1649 and in 1833 a Digest of Laws enumerating all laws presumably still in effect. He also took steps to provide legal education for future officials. In the 1830s, a "Professor's Institute" was established at Dorpat University in Estland (present day Tartu) to train young scholars in jurisprudence. They then were sent to complete their studies in Berlin under the personal direction of the

8 For example, D. A. Miliutin, Dnevnik D. A. Miliutina (Moscow: Biblioteka V. I. Lenina, 1950), 2 vols; P. A. Valuev, Dnevnik P. A. Valueva, ministra vnutrennix del (Moscow: Ak. Nauk SSSR, 1961), 2 vols.; A. A. Polovtsov, Dnevnik gosudarstvennogo sekretaria A. A. Polovtsova (Moscow: Nauka, 1966) 2 vols.

9 See Cynthia H. Whittaker, "The Reforming Tsar: The Redefinition of Autocratic Duty in Eighteenth-Century Russia," Slavic Review 51, no. 1 (Spring 1992): 77-98. 
renowned jurist Friedrich-Karl von Savigny. In 1835, at the insistence of Prince Peter Oldenburg and Michael Speranskii, Nicholas established a School of Jurisprudence, an elite school to train future legal officials.

I found key insights into the psychology of the legal reformers in Marc Raeff's Origins of the Russian Intelligentsia. Raeff described how eighteenthcentury noblemen, separated from their estates and family as young men, had little contact with their parents and looked to other authorities and intellectual doctrines as guides to their behavior. ${ }^{10}$ The noble officials I studied proved to be either orphans or individuals who grew up apart from their parents. They had been initiated into the adult world by their reading, university lectures, intellectual circles, and the comradeship of similarly disposed young men in the educated society of Moscow and Petersburg. As with the populists, intellectual influences played a decisive role in shaping mature identities and political goals.

Nicholas expected that this training would prepare students to be able and knowledgeable executors of the laws. Contrary to his expectations, many of them embraced western legal concepts on the role of the judiciary. They developed a powerful consciousness of the dignity and the role of law, a legal ethos that impelled them to consider basic reforms of the Russian court system. The diaries and writings of these officials revealed the intensity of their emotional commitment to these ideas. The diaries of Sergei Zarudnyi and Constantine Ushinskii, the memoirs of Boris Chicherin, the articles of Constantine Pobedonostsev, and the correspondence of Ivan Aksakov all attest to the depth and power of their commitment.

The School of Jurisprudence inculcated an ethos of devotion to the law, turning what had been a sphere of expertise considered inferior to the military into an exalted cause. The young noblemen were also inspired by examples of honor and triumph that they discovered in the novels of Scott, BestuzhevMarlinskii, Hugo, and Dumas. An image of a romantic hero replaced for them the passive model evoked by the sentimentalist poets of the early part of the century such as Nicholas Karamzin and Vasilii Zhukovskii. They saw themselves as active agents of change engaged in a valiant struggle to realize principles of justice in the Russian legal administration.

At the newly founded law faculties of Russian universities, noble students became devotees of German idealism, particularly the philosophy of Hegel,

10 Marc Raeff, Origins of the Russian Intelligentsia: The Eighteenth Century Nobility (San Diego, CA: Harcourt Brace Jovanovich, 1966), 129, 140-7. 
which was propounded at Moscow University in the lectures of the jurist Peter Redkin, and the historians Timothy Granovskii and Constantine Kavelin. Redkin in particular made philosophy seem to be the key to understanding the law. The students began to see law as part of the advancement of knowledge and the product of ineluctable universal progress. Juridical science then meant not an enumeration of laws, as the Ministry of Education prescribed, but as the historian and jurist Boris Chicherin wrote, "a live organism, penetrated by high principles." 11

The faith in the progress of the idea turned their work in the judicial system into a mission. The diaries and letters of the young legal scholars and later officials express an unbounded optimism. One of them, Sergei Zarudnyi, wrote in 1834 , when he was eighteen years old, "I see only the idea, I chase it." When he took charge of the Consultation of the Ministry of Justice in 1849, Zarudnyi brought both passion and intellectual rigor to his work and began to formulate a systematic approach to the legal cases. He served as mentor to the generation of younger legal officials who began to staff the Ministry. A new group appeared in the Russian state administration dedicated to an autonomous and exalted concept of the law. The Court Reform of 1864 would enable them to realize their ideals in institutions discordant with the mentality of administrative officials who served the Russian emperor and the Russian state.

The mentality of the monarch and his administrative officials, however, remained a mystery to me. The monarchs and most officials were not intellectuals. Few of them expressed a commitment to philosophy or ideas. Yet the sources I encountered in my work on legal institutions suggested that they continued to understand and justify their actions through systems of concepts, values, and esthetic and personal principles expressed in art and literature.

My first attempt to gain insight into the mental universe of Russian monarchy was a study of the upbringing and education of the heirs to the throne. In the course of my research on the judicial reform, I had examined letters and diaries of members of the imperial family that revealed an intellectual and emotional world that was absent from historical accounts, yet seemed crucial to understanding the workings of Russian monarchy. I also learned of archival documents on the heirs' preparation for the throne. In 1975, I received a Social Science Research Grant to study psychology at the Chicago

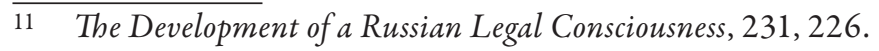


Institute of Psychoanalysis, where I took classes and participated in workshops at its Center for Psychosocial Studies. I also worked with psychoanalyst Dr. George Moraitis on the analysis of some important texts of intellectual history. ${ }^{12}$

My work focused on the heirs' relationship to their parents and tutors, and the lessons that introduced them to history, literature, and political and legal concepts. I was struck by the efforts of both parents and tutors to present an image of the monarch as strong and infallible in wielding the vast powers of autocrat, but also showing a sense of responsibility that could justify his extensive prerogatives. These insistent demands often came from the heir's father, the emperor, who embodied a confident authority that daunted the heir with lofty and often unattainable expectations. ${ }^{13}$

Both my participation in the Center's workshops and changes in the external circumstances of my research led me to recast my study of monarchy more broadly. The workshops alerted me to the limitations of applying psychoanalytical categories to the interpretation of historical figures. One session made an especially strong impression. A distinguished analyst described an assignment he had given to his students for a clinical course. He distributed detailed materials on a case and asked them to present and explain a specific diagnosis for the patient. The diagnoses differed radically. The analyst then went through each diagnosis, finally concluding that they all could be argued convincingly. The point was that the categories could never exactly describe the condition, which could be understood only through interaction with the patient in which the analyst could test his hypothesis.

I understood that this meant that any psychological analysis I undertook, considering the nature of my sources, would have to remain on a highly superficial, phenomenological level, and that the characterization of historical figures in terms of psychoanalytic categories would be arbitrary and not

12 See my articles, "Biography and the Russian Intelligentsia," in Introspection in Biography: The Biographer's Quest for Self, ed. Samuel H. Baron and Carl Pletsch (Hillsdale, NJ:The Analytic Press, 1985), 157-74; "Tolstoi and the Perception of Poverty," Rossija, No. 4 (1979): 119-32. (Article 14 in this volume.)

13 See "Power and Responsibility in the Upbringing of the Nineteenth Century Tsars," Newsletter of the Group for the Use of Psychology in History (Spring 1976): 2 and "The Russian Empress as Mother," in The Family in Imperial Russia, ed. David L. Ransel (Urbana, IL: University of Illinois Press, 1978), 60-74 (Article No. 4 in Russian Monarchy: Representation and Rule). 
particularly meaningful. At another workshop, I presented a paper on the relationship of the emperors to their fathers, which relied on an Oedipal model. The Chicago School was very much under the influence of its leading theorist, Heinz Kohut, whose teachings emphasized the importance of narcissistic disorders, which had their roots at an earlier developmental stage than Oedipal relationships. The analysts listened skeptically and suggested that my material might indicate rather a pattern of narcissistic involvement with the mother.

At the same time, I became increasingly aware of the reductionist tendencies of psychohistory, which often enclosed individual figures in a web of family antagonisms and ambivalences, diminishing if not eliminating the effect of ideas and the evolution of their intellectual consciousness. Such problems were particularly evident and troubling in psychological treatments of revolutionaries that construed revolutionary doctrines and activity as reenactments of Oedipal forms of rebellion and destruction. ${ }^{14}$ Objective analysis seemed to metamorphose into thinly veiled polemics. The revolutionaries' ideas were characterized as expressions of neurosis and the depreciation of ideas-what Stefan Possony described as the "over-valued ideas" characteristic of disturbed minds. ${ }^{15}$ Such treatments are extreme examples, but the problem seemed intrinsic to the approach. Freud himself, in a biography of Woodrow Wilson, written in collaboration with the diplomat William C. Bullitt, characterized Wilson's idealist vision as little more than a neurotic expression of unresolved Oedipal conflicts. Freud concluded that these conflicts gave rise to Wilson's grandiose conception of self and his inability to confront facts. ${ }^{16}$

Similar shortcomings beset other more scrupulous and objective historical studies. An example, close to my own interests, was Elizabeth Wirth Marvick's biography, Louis XIII: The Making of a King. Marvick drew on the diary of

14 For example, "As has been argued, the revolutionist generally is a person with severe conflicts over masculinity. He is a person on the one hand whose Oedipal hatred of his father has not been dissipated and on the other who feels unusually guilty about asserting his masculinity" (E. Victor Wolfenstein, The Revolutionary Personality: Lenin, Trotsky, Gandhi [Princeton: Princeton University Press, 1971], 228). See also Stefan T. Possony's treatment of Lenin's "psychology of destruction" in Lenin: The Compulsive Revolutionary (Chicago: Henry Regnery, 1964), 376-400.

15 Possony, Lenin, 390.

16 Sigmund Freud and William C. Bullitt, Thomas Woodrow Wilson, Twenty-Eighth President of the United States: A Psychological Study (Boston: Houghton-Mifflin, 1967), x-xiii, 102. 
the physician Jean Héroard, who cared for Louis until he was age 26. On the basis of the diary, she constructed a detailed, virtually clinical, account of the strained relations between the child Louis and his father, King Henri IV. Marvick denied that her work was "psychohistory," but it was focused on "sources of the distinctive character traits" of the king rooted in an Oedipal nexus. She argued that "attached to Louis's desire for his father's love was the fear of becoming his passive object," and that the anger the king inspired in him "had to be directed elsewhere." It was expressed, she concluded, in Louis" impulsive and unpredictable impulsive violence as heir and later king. ${ }^{17}$

Marvick based her analysis on Louis' childhood on a thorough and convincing narrative of his life as heir and first years as king. However, I found that the emphasis on unconscious motivation had obscured how Louis conceived the world, and, most important, had omitted the cultural context of French monarchy, which imposed its own determinants on the monarch's rule. A review of Marvick's book by Lawrence M. Bryant made this point most effectively: "Louis's personality cannot be separated from the cultural world and institutional traditions in which it developed and particularly cannot be seen apart from the seventeenth-century royal obsession that everything that went into or came out of the king's body be witnessed by the public. Louis's milieu identified decorum and personal conduct with the substance of political institutions and societal values."18

My intention became to use psychological insight, not to diagnose and thus introduce closure to the historical narrative, but rather to discern the emergence of the heir's personality as he began to assume the beliefs, attitudes, and tastes represented by his parents and family as exemplifications of Russian monarchy. Images, ideas, and beliefs were thus invested with affect, but they represented more than the sublimation of base instincts. They made the heir's world comprehensible. They defined his identity and the principles that would guide his conduct as monarch.

The materials I encountered about the heirs' early lives yielded increasing evidence of the importance of the milieu, particularly court and military ritual, in their personal development. The father, to be sure, as a towering image of authority, proved to be a crucial factor in his son's own self image. The heir

17 Elizabeth Firth Marvick, Louis XIII: The Making of a King (New Haven, CT: Yale University Press, 1986), xiv, 2-3, 39.

18 Journal of Modern History vol. 1, no. 3 (September 1989): 610. 
seemed to perceive and understand himself within a context of ceremony, symbols, and myth which would shape his concept of the role of emperor. The literature on Russian monarchy described individual rulers with their idiosyncratic personalities as well as concepts and manners of rule, but ignored a continuity of monarchical traditions, values, and patterns of behavior.

My research, on the other hand, indicated the importance of culture in the shaping of the ideas and practices of Russian monarchy. This culture did not coincide with the category of "political culture," which connoted character traits attributable to an entire nation, such as Nicholas Berdyaev's concept of a "Russian Idea" or dispositions to authoritarianism or messianism. Nor is it related to the later, more sophisticated political science efforts to characterize a political culture on the basis of quantitative studies and models. I understand "culture" in the more restricted sense, articulated by Mary McCauley, as a description of a pattern of thought and activity that dominated a particular group or institution. ${ }^{19} \mathrm{~A}$ pattern indicating the presence of a culture of Russian monarchy, comprising the emperor, members of the imperial family, the entourage, and the imperial suite, emerged unmistakably from my materials. The inhabitants of this milieu entertained shared ideas, symbols, and imagery that shaped their understanding of reality. It was this common manner of seeing and thinking that I now sought to understand and figure into the narrative of Russian history.

Although I did not immediately realize it, I had undertaken a project vastly more ambitious and daunting than my previous work. To pursue this project, I had to fulfill three tasks. First, I had to engage in a broad and detailed study of the ceremonial texts and other forms of representation that had remained untouched by the historical literature. Second, I had to determine how they reflected the ideas and attitudes of the monarchs and their circles-their significance as expressions of monarchical culture. Third,

19 For efforts to use the notion of political culture to understand particular Russian institutions, in this case the contemporary legal system, see Mary McAuley, "Bringing Culture Back into Political Analysis: The Reform of the Russian Judiciary," in Political Culture and Post-Communism, ed. Stephen Whitefield (Oxford: Clarendon Press, 2005); Peter H. Solomon, Jr., "Informal Practices in Russian Justice: Probing the Limits of Post-Soviet Reform," in Russia, Europe, and the Rule of Law, ed. Ferdinand Feldbrugge (Leiden: Martinus Nijhoff, 2006). 
if I was to show that the ceremonies and representations of the monarchy were more than embellishments to monarchical power, I had to integrate what I had learned about them into the historical narrative of the Russian state. Initially, I had conceived a one volume work on three emperors, Nicholas I, Alexander II, and Alexander III. It soon became clear to me that to tell the story I had to include the beginnings and bring it to its tragic end. The project lasted twenty years, and is still with me.

This reorientation of my interest, beginning in the late 1970s, accompanied two major changes in my professional and personal life. In 1975, for the first time, I was denied a visa to work in the Soviet Union. I remained persona non grata until perestroika, the late 1980s. This deprived me of access to the archives of the imperial family and many materials on the upbringing of the heirs, which I could consult only after the ban had been lifted. Ceremonial texts, on the other hand, though rare, were available in western libraries. Secondly, in 1977 I moved from the University of Chicago to Princeton, where the ideas and methods of the anthropologist Clifford Geertz were pervasive in their influence.

Geertz's semiotic approach provided a way to comprehend the "webs of significance" that prevailed in alien and distant cultures. In particular, he showed how ritual could be read to understand the mental world of a monarchy. His analyses of "cultural performances," such as the Balinese "theater state" and royal processions in Elizabethan England, Morocco, and Java, revealed the importance of ceremony as a central function of monarchy. ${ }^{20}$ He made clear that ceremonies invested authority with an aura of sacrality that set the rulers above and apart from the subject population. Although he used few illustrations in his texts, his descriptions of "charismatic centers" of power gave examples of how public displays conveyed meaning in pageantry, dress, art and architecture.

Imagery and presentation had been banished from historical accounts of Russian monarchy, thus eliminating the world of visual representation it inhabited. In the early 1980 s, I began to discover ceremonial texts, first

20 In Clifford Geertz, The Interpretation of Cultures: Selected Essays by Clifford Geertz (New York: Basic Books, 1973); Negara: The Theatre State in Nineteenth-Century Bali (Princeton: Princeton University Press, 1980); "Centers, Kings and Charisma: Reflections on the Symbolics of Power," in Rites of Power: Symbolism, Ritual, and Politics Since the Middle Ages, ed. Sean Wilentz (Philadelphia: University of Pennsylvania Press, 1985), 13-40. 
in the Russian collection of the Helsinki Slavonic Library, then, most important, in the rich collection of coronation albums and plate books in the Slavonic Division of the New York Public Library. I collaborated with the director of the Division, Edward Kasinec, on an article about the coronation albums in the division's holdings and also worked with him as co-curator for an exhibition of books from the collections of the imperial family belonging to the division. ${ }^{21}$ The pictures in these texts revealed the visual imagery of the monarchy, while the written texts suggested the meanings those images were supposed to convey.

Geertz offered synchronic glimpses into different cultures and the social structures that underlay them. But these glimpses, like a series of still photographs, lacked a sense of human agency and intention. Meaning was locked in semiotic webs with little sense of the thoughts or purposes of the individual men moved by them. Geertz referred to the mythical grounding of these performances, but the myths themselves remained in the background, explaining the source of the beliefs, but not figuring in the adaptation of these symbols to the historical situation and the dynamic processes of change in which they figured. ${ }^{22}$

During my research, I had been struck by prominent themes and imagery of conquest that suggested an overarching myth revealing a continuity of imperial representation. This led me to the writings of Marshall Sahlins, whose work emphasized the importance of myth in early monarchies. Sahlins's analyses of Polynesian myths showed how persistent mythical narratives about the outsider provided structures of understanding that evolved to meet new historical challenges and make them comprehensible.

In the heroic, mythical history of Polynesian kings, Sahlins perceived a structure that "generalizes the action of the king as the form and destiny of the society." The myths demonstrated that these rulers did not "spring from

21 Edward Kasinec and Richard Wortman, "The Mythology of Empire: Imperial Russian Coronation Albums," Biblion: The Bulletin of the New York Public Library vol. 1, No. 1 (Fall 1992): 77-100 (Article 1 in this volume). The Romanov books are described in Robert H. Davis, A Dark Mirror: Romanov and Imperial Palace Library Materials in the Holdings of the New York Public Library; A Checklist and Agenda for Research (New York: Norman Ross, 1999).

22 For a critique of this tenor, see Aletta Biersack, "Local Knowledge, Local History: Geertz and Beyond," in The New Cultural History, ed. Lynn Hunt (Berkeley, CA: University of California Press, 1989), 72-96. 
the same clay" as their subjects. Rather they came from the heavens or different ethnic groups. Sahlins concluded, "Royalty is the foreigner." "Heroic history" also dictated "an unusual capacity for sudden change or rupture: a mutation of the cultural courses as the rapid popular generalization of a heroic action." 23 Myth provided a conceptual framework to guide responses to historical conjunctures, such as the appearance of foreigners like Captain Cook, who was seen as the fertility god Lono and the introduction of commerce from abroad by the king. ${ }^{24}$

The same type of "heroic history" figured largely in the narratives of Russian monarchy. The motif of the foreigner, "the stranger king," was present in the tales of origin and the assertions of the foreign character of the Russian emperor from the beginnings of the Russian state. The central motifs of conquest, bringing with it sudden rupture and the adoption of new foreign antecedents and models, run through Russian history. They were expressed in the legendary accounts of the Vikings, "the Varangians" coming from abroad to bring order and justice to Novgorod. During the sixteenth century, the tsars of Rus' laid claim in word and ceremony to descent from the Byzantine emperors, and in the seventeenth century adopted Byzantine vestments and ceremonies. Peter the Great staged his rule as a show of the cultural and political westernization of the Russian ruler, noble elite and the state. Under Nicholas I and Alexander II, the invitation of the Varangians was presented as the central, determining event of Russian history.

The persistence of what might be described as archaic imagery, the depiction of the ruler as superhuman representative of a distant realm reflected the highly personalized character of Russian political authority, which resisted the type of institutionalization that moderated the monarch's power in the west. I traced the evolution of this imagery by close examination of the evolution of ideas,

23 Marshall Sahlins, Islands of History (Chicago: University of Chicago Press, 1987), xi, 41,78 .

24 This emerges from Sahlins's revision of Ferdinand de Saussure's distinction between langue and parole, language and speech, according to which speech represents changing expressions of the underlying structure of language. Sahlins casts this distinction on a historical grid, the myth containing the structure-langue, historical actions or events representing the parole, guided by but representing transformations of the myth (Marshall Sahlins, Historical Metaphors and Mythical Realities: Structure in the Early History of the Sandwich Islands Kingdom [Ann Arbor, MI: University of Michigan Press, 1981], 3-8, 17-22, 43-6). 
literature, art, and architecture in successive reigns. Through this process it became clear that Russian rulers, until the last decades of the nineteenth century, asserted their foreign character in order to elevate their rule-to sustain absolute dominion by creating the distance, what Nietzsche called "the pathos of distance," between themselves with their elites and the subject population, whether Russians or the other diverse nationalities of the empire. Russian monarchy was dominated by a performative imperative. While other monarchies also emulated foreign examples, a distinguishing characteristic of Russian monarchy was the perpetuation of images of foreignness.

These observations drew heavily upon the works of what is now known as the Moscow-Tartu school, which I became acquainted with in the 1980s, particularly the many articles of Iurii Lotman, Boris Uspenskii, and Victor Zhivov. The study of cultural semiotics developed in the relatively free precincts of Tartu University in Soviet Estonia under Lotman's leadership and inspiration during the 1960s and 1970s and his followers are now referred to as the Moscow-Tartu school. ${ }^{25}$ Soviet historians had not investigated or taught the history of Russian culture, since culture did not fit the MarxistLeninist conception of history as the study of the interaction of economy, class, and state. The culture and life of the nobility and merchantry were regarded as the result of their exploitation of the ruling classes, and not worthy of scholarly attention. Literary scholars and linguists, however, were given more leeway than historians in their studies of the great works of Russian literature. They began to approach culture as grounded in the science of semiotics and as a search for a universal system of signs. Their journal and conferences provided what Henrik Baran described as "a defined politically neutral space." 26 When I visited these scholars in the 1990s, my historian friends were always bemused by my interest in what they called "the formalists."

Examining the processes of the reception of foreign culture, precluded by Marxist-Leninist historiography, they showed how Russian tastes and behavior emulated first Byzantine, then European cultural models. They described a dynamic of the processes of cultural rupture that led to the adoption of one set of models and repudiation of the past. Uspenskii and

25 For a discussion of the rise and decline of the Moscow-Tartu school and its contribution see my review of Sergei Nekliudov, ed., Moskovsko-tartuskaia semioticheskaia shkola. Istoria, vospominania, razmyshleniia (Article 17 in this volume).

26 Cited in Ibid., 247. 
Zhivov explicated the changes in religious rhetoric and symbols during Peter's reform that transformed Russian Orthodoxy into a religion resembling the Erastian, natural law teachings of the German states, which elevated the ruler as a god on earth. Lotman described the cultural semiotics of noble behavior in the eighteenth and early nineteenth centuries, revealing how educated noblemen showed their western character by acting out scripts drawn from prominent works of European literature. I consulted with these scholars and participated in several of their "Lotman Conferences" (Lotmanovskie chteniia) during the 1990s.

The members of the Moscow-Tartu school made it clear that by acting as Europeans, Russian noblemen were displaying their adherence to the code of western behavior imposed by Russian emperors and in this way established their distance from the lesser estates of the realm. Most important, I recognized a similar code of acting according to western literary and philosophical scripts in the presentation of the rulers themselves. When it became possible at the end of the 1980s for me to make annual trips to Russia and to gain archival access, I began to study the scenarios of each reign with a broader range of sourcesprogram books, journal and newspaper descriptions, as well as discussions of the works of art and architecture that provided the stage effects of imperial power. The new materials and the interaction with the scholars of the MoscowTartu school enabled me to develop my interpretation and formulate the conceptualization of Russian monarchy that I set forth in my two-volume study of Russian imperial myths and representation, Scenarios of Power: Myth and Ceremony in Russian Monarchy. ${ }^{27}$

In Scenarios of Power, I traced how each successive Russian monarch, beginning with Peter the Great, presented him or herself as heroic protagonist of a myth of conquest that had its origin in early Russian legends and chronicles. Each performed the myth according to the ideals and cultural modes of the era, bringing the narrative of Russian monarchy as living representation into the present. I called these individual realizations of the myth "scenarios," the mise en scène for each reign. The scenarios communicated the emperors' tastes, goals, and style of rule to the noble elite. They were set

27 Richard S. Wortman, Scenarios of Power: Volume 1, From Peter the Great to the Death of Nicholas I (Princeton:Princeton University Press, 1995); Volume 2, From Alexander II to the Abdication of Nicholas II (Princeton: Princeton University Press, 2000). 
forth at the beginning of each reign in manifestos, panegyrics, ceremonies, culminating with the imperial coronation.

The myth created a continuity of imperial representation. The scenarios introduced notes of change, promises of renovation, while reaffirming the bond with the dynasty. The upbringing of the heirs played the crucial role in the successive transformations of the myth. On the one hand, the heir performed in his father's scenario and regarded his father as the embodiment of imperial authority. On the other, within the context of the previous scenario he began to develop a sense of his own role. This came from his teachers, who introduced him to different conceptions of monarchy, nationality, and religion. He also drew his own notions of personal feeling and deportment from his mother, grandmother, and other relatives as well as from his reading.

By the time of his accession, the heir had developed his own understanding of the office of emperor. The new scenario was announced in the opening months of his reign and established a dramatic unity that shaped the ceremonies and representations of his reign. Descriptive texts make clear that imperial ceremonies underwent significant change. Even if the rituals remained fixed, both the manner of performance and the verbal interpretations conveyed the feelings and meanings of the moment. Like plays or ballets, imperial ceremonies provided scripts that could be reinterpreted in productions that filled them with contemporary meaning. The upbringing and accession of each monarch thus lent the representation of the Russian monarchy dynamism within the reaffirmation of the continuity of the dynastic myth.

For example, we witness such changes in the imperial coronation, the principal public ceremony of Russian monarchy until the end of the empire. The crowning and anointing of the emperor both consecrated his power and promulgated his scenario. The coronation ceremonies and celebrations lasted several weeks and included, in addition to the rites of crowning and anointment in the cathedral, the gala entry into Moscow, the announcement of the coronation, parades, balls, banquets, and fireworks. All of these were described in accounts, many of them richly illustrated.

One of the most important innovations occurred at the conclusion of Nicholas I's coronation rites in 1826. After the crowning and anointment, he proceeded, according to tradition, in full regalia to the Archangel and Annunciation cathedrals and climbed the steps of the Red Staircase. There he turned and, to the traditional thunderous shouts of "Hoorah!," bowed three times to the throng of people in Kremlin square. The triple bow indicated 
for the first time a mutuality of sentiment: the people were recognizing and acclaiming their monarch; the monarch was showing recognition and gratitude to the people. The gesture prefigured the national elements in Nicholas I's scenario. It was a true example of the invention of tradition, one repeated at all future coronations and many imperial visits to Moscow. By the end of the century, it was considered "an ancient Russian tradition." 28

Alexander II introduced another significant innovation during his coronation in 1856. For the first time, a delegation of peasants marched in the procession to the Assumption Cathedral, where the rites were administered. This gave symbolic significance to the growing sentiment that peasants had to be considered members of the nation, an augur of emancipation still in secret deliberation. It also suggested that imperial ceremonies, previously functions of the elite attended by the people only for ceremonial acclamation, now would be broadened to include them as participants.

Coronation albums provided a valuable source for tracing the relationship between myth, scenarios, and ceremony. They were elaborate and luxurious volumes, published in several foreign languages as well as Russian, in limited editions in order to make known the emperor's image and scenario to both Russian and foreign elites. For example, Alexander II's coronation album gloried in the color, variety, and dashing appearance of the horsemen from the Caucasus and Central Asia, making clear the love that prevailed for the Russian monarch among the multi-ethnic imperial elite after the disastrous defeat of the Crimean war. Alexander III's coronation album, on the other hand, called attention to their subjection and acceptance of Russian domination, announcing the theme of Russian national supremacy proclaimed during his reign and that of his son, Nicholas II. See Article 1 in this volume.

The shift to an ethnic, national symbolism, suggested in the last example, indicates not only a new scenario, but the beginning of the transformation of the myth, from the European to what I call "the National Myth." The

$\overline{28}$ See my article "The Invention of Tradition and the Representation of Russian Monarchy," in Rus' Writ Large: Languages, Histories, Cultures: Essays presented in honor of Michael S. Flier on his sixty-fifth birthday, ed. Harvey Goldblatt and Nancy Shields Kollmann (Cambridge, MA: Ukrainian Research Institute, Harvard University, 2009), 651-62 (Article 6 in Russian Monarchy: Representation and Rule). 
European myth had preserved the heroic history that ensured the monarch's transcendence by identifying the ruler with western images of sovereignty and transmitting this narrative from generation to generation in the upbringing of members of the imperial family. Russian emperors from the reign of Peter the Great identified with state institutions and even presented themselves as their embodiment. At the same time, they displayed their distance from the state administration by asserting their supreme character and exerting power freely, as befit superhuman absolute monarchs.

The exercise of power and the representation of the monarch thus were reciprocal processes: absolute rule sustained the image of a transcendent monarch, which in turn warranted the untrammeled exercise of power. It was this nexus that defined absolute monarchy in Russia and that came to be understood under the term "autocracy" in the nineteenth century. The capacity of Russian monarchs to live in the context of myth explains their refusal to compromise, to accept intermediaries such as a chancellor, or parliamentary institutions in order to ensure the monarchy's survival, as in the case of the German and the Austrian emperors. Their intellectual aversion to constitutionalism reflected merely one aspect of a mentality that knew only absolute domination or utter defeat.

Until the assassination of Alexander II on March 1, 1881, the representations of the ruler as foreigner sustained the distance that enabled him to exercise absolute power in the interests of both social stability and progress. The Great Reforms of Alexander II's reign-the emancipation of the serfs, reform of the courts and local institutions, culminated a tradition that identified the monarchy with European style progress. When Alexander III ascended the throne, officials dedicated to the goals of reform dominated many high governmental organs, such as the State Council and the Senate. As heir, he had been imbued by his teachers with nationalist sentiments and became increasingly critical of his father's policies under the influence of his mentor, Constantine Pobedonostsev. When he became emperor, Alexander III denounced the liberal policies that he and his advisors regarded as incitements to revolution.

With his mentor Pobedonostsev, now Chief Procurator of the Holy Synod, Alexander III recast the myth so that it presented the emperor as the expression not only of a monarchical nation, but as the most Russian of Russians, struggling against the contagion of subversive doctrines coming from the West. Distance between ruler and ruled was now sustained by reaching back to the 
pre-Petrine past and evoking the images of Muscovite tsar who presumably exercised untrammeled patriarchal power and of the bogatyrs, the heroes of folk epics. The National Myth showed the tsar's authority emanating from his spiritual union with the Orthodox Church and the Russian people and was expressed in his image of most pious practitioner of Russian Orthodoxy.

The mythical union with people and church conjured a separation, a distrust between the emperor and the institutions of state, which he regarded with increasing suspicion and even hostility as potential threats to his power. The evocation of an ethnic nationalism, itself of European provenance, introduced an element of contradiction into the westernized culture of Russian monarchy, whose representatives continued to share the culture of European royalty. The increasingly national tenor of official statements and policy threw doubt on the multinational grounding of the emperor's authority intrinsic to the European myth and inflamed the opposition of national minorities in the empire.

For Alexander III, the ideal national monarchy was evoked as an extension of the monarch's personal power, deriving from the sanction of the Orthodox Church and centered in the Ministry of Interior, which was obedient to his will and unencumbered by law. Nicholas II distrusted both the Orthodox Church and governmental officials. His sense of self emanated from the faith that he enjoyed a direct personal relationship with God and the absolute sympathy and devotion of the Russian people. As it emerged in the first years of the twentieth century, his scenario presented him in different national personas. He appeared as a man spiritually close to simple Russian people, especially holy men, as a pilgrim, and as Muscovite tsar. These identities emphasized his distance from and spiritual superiority to educated society, the imperial administration, and after the 1905 revolution from the parliamentary institutions he had reluctantly established and strove to undermine. ${ }^{29}$ He sustained these beliefs regardless of the bloody peasant uprisings that swept the countryside during the revolution of 1905, and maintained them even after his abdication in 1917.30

29 See Andrew M. Verner, The Crisis of Russian Autocracy: Nicholas II and the 1905 Revolution (Princeton: Princeton University Press, 1990), 109-10, 239-41; Geoffrey Hosking, The Russian Constitutional Experiment: Government and Duma, 19071914 (Cambridge: Cambridge University Press, 1973), 201-5.

30 Recent scholarship has made clear Nicholas II's role in insisting on the most aggressive and brutal responses, imposing his views on his ministers, whom he often hid behind. For example, he was clearly behind Peter Stolypin's introduction of the 
Russian monarchy has been characterized as a largely reactive institution, striking out defensively to preserve the institutions of autocracy. But its mythical narratives conjured the image of an active force, building and maintaining an empire, educating and uplifting the populace, and establishing legality and order. In the late nineteenth and early twentieth centuries, on the contrary, the monarchy proved a subversive force, turning first against the institutions produced by the Great Reforms and later against the parliamentary bodies established in 1905. The violent catastrophic events of early twentieth-century Russia resulted not from a decrepit monarchy collapsing before insurgent oppositional movements, but from the clash of an insurgent monarchy, bent on restoring a mythical pre-Petrine past, with the forces of liberalism and revolution determined to transform Russia according to western models of progress.

My books have explored the mentality of members of three groups and their responses to political reality. Their modes of thinking can be described under different categories-ideology, ethos, and myth. Each involved the embrace of a picture of reality that inspired a heroic dedication and often a disregard for expedience. In each case, their solutions evolved as conscious acts that left traces in personal sources and public statements that are open to the historian's gaze. Looking back, I realize that I engaged in an ongoing process of discovery of aspects of history that had eluded historians who focused on the great ideas, major political events, or dominant social and economic trends of the period.

The process of discovery presumes a strategy of openness in approaching sources-openness to the expressions of ideas and feelings, and to the visual manifestations of political attitudes. The strategy of openness entails a wariness of the preconceptions or theoretical constructs that have possessed the academic world and can lead to premature closure of the process of discovery. It reveals the ways that ideas become objects of affect while maintaining a rational basis in consciousness. The social sciences, psychology, and anthropology have opened me to other aspects of human experience, like emotional development and symbolic expression, as objects of scholarly study and suggested avenues of approach. However, abstract universal models, when applied to a particular

notorious field court-martials in 1906 and the "Stolypin coup d'état," the change in the election law in June 1907. See Abraham Ascher, The Revolution of 1905: Authority Restored (Stanford, CA: Stanford University Press, 1992), 244-59. 
situation, can obscure the specificity and variety of human experience and impoverish the historical narrative.

By emphasizing specificity, as my books show, I do not deny the possibility of viewing these individuals in a general comparative context. The revolutionary movement, the reform of the Russian judiciary, and Russian monarchy must be understood in terms of their Western counterparts. But if comparisons are to be cogent and informative, they must be based on an understanding of the phenomena to be compared. They must take into account what might be described as a view from inside-the thinking and representations of the individuals involved-which may disclose a quite different picture from that governed by general categories and lead to quite different understandings of the motivations and ideas of the figures involved.

My goal has been to write my subjects into the narrative of Russian history. The narrative form provides a cultural and political context that makes it possible to understand the dilemmas and preoccupations that found expression in their thought. It places their ideas in a sequence that relates them to contemporary events they knew. Most important, it evokes the drama of their quests to see themselves as agents of history itself, who, gifted with special knowledge and insight, could influence its direction and outcome. 


\section{The Moscow-Tartu School: Review of S. Iu. Nekliudov, ed., Moskorsko-tartuskaia semioticheskaia shkola. Istoriia, vospominaniia, razmyshleniia}

(Mossow: Shkola “azyki russkoi kulturry", 1998)

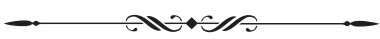

T he term "Moscow-Tartu" school describes a movement that arose during the 1960 s among linguists, specialists in literature, folklore, ethnography, and allied disciplines in the Soviet Union. Its governing doctrine was semiotics, and the theory and practice of semiotics as a science of signs continued to provide its guiding principles through the 1970s. The study of semiotics liberated scholars from Marxist-Leninist principles and institutional constraints, opening new possibilities and areas of research. It established culture as an autonomous sphere of research. By demonstrating the vitality of the Russian tradition of linguistic and literary studies, the movement restored academic pride and purpose to scholars in those areas. By the 1970s and 1980s, the intellectual interest of the leaders of the school had shifted: semiotic theory receded into the background, and many earlier adherents adopted different approaches and interests. But the school's influence endured in the works of those trained under the guidance of its leading figures and in the memories of those for whom it was a defining formative experience.

In the late 1980s and early 1990s, the school's adherents began to come to terms with historical significance and its meaning for their own personal development. This volume, edited by the folklore specialist S. Iu. Nekliudov, represents the summation of these efforts, bringing together previous published memoirs and articles and several new contributions regarding its impact abroad. The first section deals with the early history of the school, the second is devoted to memoirs, the third considers its relationship to developments in Europe and the United States. An appendix contains a summary of works on Eastern Studies by distinguished Moscow orientalists published in the 
Works on Sign Systems (Trudy po znakovym sistemam), the principal scholarly periodical of the school. The twenty-six contributions are diverse both in the assessment of the importance of the school and the authors' own personal responses. Here, rather than summarize their content, I will try to convey my own sense of what the volume tells us about the school's significance, especially for the study of Russian history.

The opening articles of the volume, by the linguists Viacheslav Ivanov and Boris Uspenskii, describe the movement's origins and early years. At the beginning of the 1960s, a group of prominent Moscow linguists endeavored to revive the pre-revolutionary and émigré traditions of Russian structuralist linguistics. Ivanov traces these to the Kazan school of I. A. Baudouin de Courtenay and N. V. Krushevskii, whose traditions were carried on after the revolution by the Prague school, and particularly N. S. Trubetskoi and Roman Jakobson. In his memoir, V. N. Toporov mentions three major events that marked the revival of linguistics and the beginnings of a semiotic school in the Soviet Union (146-47). Jakobson's visit to Moscow in 1956 inspired the formation of a Seminar on Structural and Mathematical Linguistics under the philological faculty of Moscow University. In 1960, the Presidium of the Academy of Sciences established sectors of structural linguistics in several of its institutes. Finally, the Symposium on the Structural Study of Sign Systems, held in 1962 under the auspices of the Institute of Slavic Studies and the newly formed Sector of Structural Typology, discussed an array of semiotic subjectsthe importance of signs in language, art, mythology, and even card tricks. The theses of the symposium were published in a small edition. Official organs, like Voprosy literatury, criticized them in great detail, unwittingly making their content known to a broad public.

If the Moscow founders of the school reclaimed the pre-revolutionary linguistic heritage, the Tartu component came out of the setting of early twentieth-century formalist criticism in Leningrad. When Iurii Lotman began his studies at Leningrad University in 1939, the Slavic Faculty boasted a veritable roster of luminaries, V. M. Zhirmunskii, V. Ia. Propp, M. K. Azadovskii, B. M. Eikhenbaum, B. V. Tomashevskii and G. A. Gukovskii. When Lotman returned after the war in 1946, the last three were still on the faculty, soon to fall victim to Stalin's anti-cosmopolitan campaign. After graduation, Lotman could find work only in Estonia, where the pressing need for teachers of Russian after its recent annexation gave the authorities leeway to hire Jewish candidates. Lotman also took graduate courses at Tartu University. In 1951, he defended his 
Candidate's dissertation, “A. N. Radishchev's Struggle Against the Social and Political Views and Noble Esthetic of N. M. Karamzin” at Leningrad University. The social and literary life of the late eighteenth- and early nineteenth-century nobility would remain his interest throughout his career. At this time, Lotman married Zara Mintz, a fellow graduate of the Philological Faculty of Leningrad University, specializing in the literature of the Silver Age, who became another leading figure of the Tartu school. After the death of Stalin, Lotman was appointed to the Faculty of Russian Literature at Tartu University. ${ }^{1}$

The catalytic meeting of the two currents took place during the "summer school" organized by Lotman in 1964 at the university's sports camp at Käriku in southern Estonia. This, the first of five such schools held between 1964 and 1973, resembled a conference more than a school, but a very informal conference that fostered participation and comradeship. Lotman said: "The School was entirely a series of conversations" (85); the discussions continued long after the end of the presentations. The site, rural and sequestered, where new ideas and new academic bonds could propagate encouraged a sense of distance from official centers and official thinking. Toporov invoked a neologism, "nezdeshnost"-perhaps translatable as "otherworldness"to evoke the feeling of the setting (142). The memoirs of D. M. Segal, S. D. Serebrianyi, and S. Iu. Nekliudov recall the shared experiencescollecting mushrooms, boating on the lake, long nighttime discussions before the fireplace. Both eminent scholars and students presented papers, many of which appeared in the Trudy, published under the auspices of Tartu University. The bonds persisted after the summer, creating a network of the elect that extended to Moscow, Leningrad, Riga, as well as Tartu.

In 1966 and 1967, I was astonished to meet young Russians in Moscow with an extraordinary intellectual sophistication and knowledge of western scholarship, who introduced me to others in Leningrad and Riga. All were imbued with a common sense of dedication to the tradition of literary scholarship, a contempt for the canons of official literature and criticism, and a sense of their own special mission. As a foreigner, I was treated with special respect, though my scholarly interests at the time had little to do with theirs. The sense of special designation and solidarity later evoked criticism, exemplified by the articles by Boris Gasparov and T. M. Nikolaeva in this

1 V. F. Egorov, Zhizn' i tvorchestvo Iu. M. Lotmana (Moscow: Novoe Literaturnoe Obozrenie, 1999), 17-19, 32-76. 
volume. In a controversial critique first published in 1989, Gasparov claims that the esprit of the participants in the school arose from a self-imposed alienation from their environment. Using a polemical style reminiscent of the Vekbi group's denunciations of the pre-revolutionary intelligentsia, he argues that the isolation of the rural setting heightened this sense, giving them a onesided and distorted notion of western ideas and inclining them to introspective themes and approaches. T. M. Nikolaeva indicates that the sense of corporate solidarity discouraged criticism of the ideas of other members of the group and intellectual debate. But these are minority viewpoints in the volume.

The summer schools, Serebrianyi observes, were in many respects "creative games" (128), a form of youthful protest. Boris Gasparov, in his synoptic study of the movement in its international context, included in Part 3, notes the similarity with the non-conformist and egalitarian intellectual movements in Europe and the United States in the 1960s. These movements shared a loss of respect for authority and a euphoric sense of equality, a state that the anthropologist Victor Turner called at the time "communitas"a temporary, transitional state, akin to rites of passage that marks "liminal" phases in societies, when they "are passing from one cultural state to another." The 1960s represented such a phase in Russian academic life, when the old academic hierarchy had been discredited, and new ideas required validation by a group united by common experiences.

The proponents of these ideas envisioned a science of signs, a universal system that could be applied to all languages and forms of linguistic expression and cultural systems that could be modeled on them. This inspiration came from no one less than Jakobson, himself, who in 1960 had proposed "a universal scheme of communications' acts." He hoped to formulate a methodology for a science that would approach social conduct as a system of signs. ${ }^{3}$ These principles were set forth in the theses of the 1962 symposium and in various articles in the Trudy. Jakobson's program also provided grounds for international scholarly contacts, what Henrik Baran describes as "a defined politically neutral space” (247). In 1966, Jakobson attended the second summer school.

2 Victor W. Turner, The Ritual Process (Chicago: Aldine Publishing Company, 1969), 95-6, 112-3.

3 For a more detailed discussion of Jakobson's "utopian ideas" of a scientific linguistics at the this time and its influence on the formation of the school, see Victor Zhivov, "Moskovsko-Tartuskaia semiotika: Ee dostizheniia i ee ogranicheniia," Novoe Literaturnoe Obozrenie, No. 98.4 (2000): 14-8. 
Semiotics thus represented both a scientific method that could be implicitly counterpoised to Marxist dogma and a basis for association with western scholars. It was embraced, as many ideologies were by the nineteenth-century Russian intelligentsia, as a totalistic system, grandiose in its possibilities, representing a new truth that had a markedly utopian character, as Gasparov points out in his 1989 article. It was a late flowering of positivist aspirations at a moment when positivism had lost its hold on western philosophy. Several of the articles share Serebrianyi's sense of embarrassment with this phase of the school's development. But it was precisely the ideological fervor generated by the semiotic project that energized literary and linguistic scholarship in the 1960 s and that led its practitioners along new paths in the 1970s.

The initial presentations of research took the form of scientific tracts and theses couched in esoteric, technical terminology that suggested rigorous adherence to semiotic principles. These writings followed the categories established by the father of continental semiotics, the Swiss linguist Ferdinand de Saussure, of langue and parole-language and speech. Language provided the basic structure of grammar, signs and so forth. Speech was the concrete expression of language in usage. The same relationship between structure, the fundamental codes governing expression, and the expressions themselves were found in the various forms of culture. These cultural systems were called "secondary modeling systems," a term suggested by the mathematician Vladimir Uspenskii.

By the early 1970s, the "secondary modeling systems" had eclipsed the goal of a universal semiotic system in the studies of the Moscow-Tartu school. Structuralism had fallen out of fashion in the West, supplanted by new semiotic theories and eventually overshadowed by deconstructionist criticism. Lotman's major structuralist work Lektsii po struktural'noi poetike, published in 1964, was received respectfully, but without great enthusiasm by such critics as Umberto Eco, Tzvetan Todorov, and Julia Kristeva. Members of the school who emigrated found themselves teaching among colleagues who regarded structuralism as a doctrine out of the past and Russian literature as a peripheral regional specialty, an experience described vividly in Alexander Zholkovskii's memoir. Some like Boris Gasparov moved away from the semiotic approach.

But for the study of Russia's past, the most significant tendency was the elaboration by Lotman, Boris Uspenskii, and others of a semiotics of Russian culture. We witness what may seem a paradoxical reorientation: a form 
of inquiry, striving for a universal system is transformed into a concept to study a particular national past. The result was liberating, giving authorities in literature and social attitudes, like Lotman, a methodology to understand the past in a new way. This cultural turn is described with some unease in the memoir of the linguist A. M. Piatigorskii. Piatigorskii writes in his memoir that culture became the object of their study, not because of the nature of semiotics, but because of "the concrete Russian cultural context. (We thought that we wrote about culture from the outside; it [culture] led our hand from within.)" The focus of the scholar shifted from language and the theory of semiotic systems, to texts, as semiotic expressions of that culture. The theses Piatogorskii delivered with Lotman at the 1968 summer school, published under the title "Text and Function," introduced the notion of a "text of culture." "From the point of view of the study of culture, there exist only those communications that are texts. All others virtually do not exist and are not taken in by the attention of the scholar. In this sense we can say that culture is an aggregate of texts or a complexly constructed text." 4

The search for a metaconcept of culture was now replaced by a search for concrete expressions of culture in history in the aggregate of cultural documents and texts that made up that culture. One cannot exaggerate the energizing effect of this reversal, for it immediately presumed the culture in the text, the macrocosm in the microcosm. The literary critic stepped into the intellectual void left by historical materialism. Lotman expressed it as a return to history. "In turning to a synchronic model, the historian found freedom. He was liberated from the methodological garbage piling up in historical studies, gained real freedom and a scholarly basis to return to his circle" (86). Guided by proper method and understanding of the nature of signs, even the beginning scholar could find significant answers in specific, accessible literary, historical, ethnographic, or artistic texts. It created what D. Segal calls "semiotic historicism." In a period when Russians had lost a sense of their own connection to history, Segal writes, "thanks to semiotics we learned of another sense and understanding of history-a state of existence in history" (102). Semiotics had become a means to national self-discovery.

Lotman and his students began to read texts to determine the semiotic codes or texts expressed in the social behavior of a given time. Discovering such

$\overline{4}$ Iu. M. Lotman and A. M. Piatigorskii, “Tekst i funktsiia," in Iu. M. Lotman, Izbrannye stat' $i$ (Tallin: "Aleksandra," 1993), 133. 
texts revealed to the scholar the language, the thought patterns-the mentality of the people they studied. Lotman showed the role of literary texts in guiding the social conduct of the Russian nobility in the eighteenth century and the participants in the Decembrist movement in the early nineteenth century. He focused not on the ideological contributions of the Decembrists, but on the forms of behavior prescribed by romantic literature as they understood and enacted it. The noble landed estate, masquerades, dueling, drinking, and card playing all became texts that yielded evidence of the social codes of the period. Lotman developed the notion of "theatricality" to describe the highly "semioticized" behavior of the westernized nobleman. His followers applied his approach in particular areas; to mention several notable examples, Irina Reyfman in regard to the duel in nineteenth-century Russian literature and society, Irina Paperno in her study of nihilism as a behavioral text and Marina Mogil'ner by studying the evolution of the myth of the underground man in the late nineteenth and early twentieth centuries. 5

Cultural semiotics proved so revealing about the Russian past because educated Russians were expected to act according to codes and signs borrowed from the west that made up Russian noble culture. Europeans acted like Europeans because they were Europeans; Russians acted out roles of Europeans because they were not Europeans, but had to resemble them, and the MoscowTartu school made these roles for the first time the center of historical study. The semiotics of St. Petersburg, a city built to represent the West to Russia and Russia to the West, proved equally illuminating. A volume published in 1984 on the semiotics of St. Petersburg included papers by such scholars as V. N. Toporov, M. L. Gasparov, Iu. G. Tsivian, Z. G. Mints, and Lotman himself that analyze Petersburg as a symbolic presence in Russian culture. Lotman placed the symbolism of the city in the context of the myth of empire and the forms of theatricality of Russian culture. G. V. Vilinbakhov contributed an important article on the founding of Petersburg and imperial emblems.

5 Irina Reyfman, Ritualized Violence Russian Style: The Duel in Russian Culture and Literature (Stanford, CA: Stanford University Press, 1999); Irina Paperno, Chernyshevskii and the Age of Realism: A Study in the Semiotics of Behavior (Stanford, CA: Stanford University Press, 1988); Marina Mogil'ner, Mifologiia "podpol'nogo cheloveka": Radikal'nyi mikrokosm v Rossii nachala XX veka kak predmet semioticheskogo analiza (Moscow: Novoe literaturnoe obozrenie, 1999). See Deborah Pearl's review of Mogil'ner's book in Kritika vol. 1, No. 2 (Spring 2000): 416-22. 
Several of these themes were later developed in Grigorii Kaganov's study of the symbolic space of Petersburg. ${ }^{6}$

In collaboration with Lotman, Boris Uspenskii brought the culture of early Russia into the sphere of semiotic studies, showing how the concepts encoded in Muscovite language defined sacrality, cultural attitudes, and Russian history itself. Their article of 1977, "The Role of Dual Models in the Dynamics of Russian Culture (Up to the End of the Eighteenth Century)," described a structure of dual antithetical normative signs-evil and good, past and present-dominating Russian cultural history. The dual structure encompassed oppositions and precluded a "neutral axiological zone" like that found in the west. It defined a dynamic of change that was realized most strikingly in the tenth century with the conversion, and in the eighteenth century with westernization. At these moments, the normative values of signs were reversed, the past-whether pagan or Muscovite religion-was defined as evil, the future, Christianity or Europeanization, as good. Uspenskii's article of 1976, "Historia sub specie semioticae" approached history as a process of communication, by which information was inscribed in a particular semiotic language that functioned as a code for society. He focused particularly on the cultural conflicts of the Petrine era, between the signs and the old and the new culture, a theme developed in the works of Victor Zhivov on eighteenth-century language. Uspenskii and Zhivov also examined the development of notions of political sacrality in the seventeenth and eighteenth centuries, showing how eighteenth-century language and symbols continued to reflect earlier religious conceptions of Russian empire. Uspenskii went on to devote himself to the study of religious-political ritual, particularly the significance of the Russian anointment and communion, in consecrating the tsar and patriarch. In the United States, the linguist Michael Flier published a series of semiotic analyses of the ritual, architecture, and iconography of Muscovite Rus'.7

$6 \quad$ Semiotika goroda i gorodskoi kul'tury. Peterburg (Trudy po znakovym sistemam, XVIII) (Tartu: Tartu University Press, 1984); G.Z. Kaganov, Sankt-Peterburg: obrazy prostranstva (Moscow: Indrik, 1995).

7 For example, "Court Ritual and Reform: Patriarch Nikon and the Palm Sunday Ritual," Religion and Culture in Early Modern Russia and Ukraine, ed. Samuel H. Baron and Nancy Shields Kollmann (De Kalb, IL: Northern Illinois University Press, 1997), 73-95; "Filling in the Blanks: The Church of the Intercession and the Architectonics of Medieval Muscovite Ritual, "Harvard Ukrainian Studies vol. 19, nos. 1-4 (1995): 120-37. 
As the Moscow-Tartu school moved away from structural linguistics, it seemed to move closer to western cultural anthropology, a development discussed in Baran's article. The efforts of the school to distinguish and examine a discrete sphere of "culture" resemble the notion of "thick description" of cultures set forth by Clifford Geertz in 1973. “Thick description," a concept that Geertz borrowed from the English philosopher, Gilbert Ryle, was a way, he wrote, of "sorting out the structures of signification" in cultures. "The whole point of a semiotic approach to culture is, as I have said, to aid us in gaining access to the conceptual world in which our subjects live so that we can, in some extended sense of the term, converse with them." 8 Irene Portis-Winner noted the similarity in the early 1980 s and hoped for further convergence and interchange between the schools. This convergence did not take place. PortisWinner concluded in 1994 that western scholars overlooked the views of the Moscow-Tartu school, or misunderstood them as "basically variants of the long outmoded Russian formalism, and if not that, then a strictly Saussurean binarism" (263).?

The lack of communication with western anthropologists is in part to be explained by the specifically literary and historical focus of Russian cultural semiotics, a focus that makes the works of the school so valuable for Russian specialists in the West. However, this conception of national culture omits the entire political order. To be sure, the aversion to political history enabled scholars to avoid the clichés of early treatments of politics, the "methodological garbage" Lotman referred to; but it also removed human agency, leaving the relationship between the forms of taste and behavior and the history of a specific era uncertain, and at times presenting literary, religious, and artistic categories as causal factors in themselves. Their works mention the monarch and the state principally as examples of cultural symbols and norms rather than as active forces in their own right. This contrasts with the works of Geertz, for whom the state represented the creator and the custodian of the symbols and myths uniting a society. The theater state, the concept of rulers as symbolic centers

$8 \quad$ Clifford Geertz, "Thick Description: Toward an Interpretive Theory of Culture," in The Interpretation of Cultures (New York: Basic Books, 1973), 9, 24. The similarities were discussed in relation to the question of ideology by Andre Zorin, "Ideolgiia semiotiki v interpetatsii Klifforda Girtsa," Novoe Literaturnoe Obozrenie, no. 29 (1998): 39-54.

9 Citation is from Irene Portis-Winner, Semiotics of Culture: "The Strange Intruder" (Bochum: Universitätsverlag Dr. Norbert Brockmeyer, 1994), 153. 
in various societies, showed the polity as an active symbolic force. Geertz viewed ideology, including political ideology, in terms of cultural systems.

Geertz conceived of semiotic analysis as a means to breach the conceptual barriers between cultures. The Moscow-Tartu school used it to understand the meaning of signs in the history of their own culture, which had been barred to them by the Soviet regime. In studying their own culture, many found their cultural identity. Indeed, it is the combination of the academic distance of the semiotic method with the feeling of belonging to Russian culture that made possible the resonance and power of their best works. Their contributions both opened the moribund field of cultural history in Russia and gave foreign historians and literary scholars the kind of "access to the conceptual world in which our subjects live" and the ability in some sense to "converse with them" that Geertz sought.

The achievements of the 1970s mark only a beginning. Many of the school's early adherents moved away from its doctrines. Others continue to study literary texts in terms of their historical context, applying approaches of semiotics. The most recent generation, which is not represented in this retrospective volume, has used the insights of the old school if not its specific methods to study Russian cultural history. Their research, set forth in article form and conference papers, brings a sophistication in textual analysis to bear on various historical problems. ${ }^{10}$ Culture remains a center of focus, but represents a means to understand the historical role of the Russian state, not to deny it. Many scholars are now working on the official culture of the eighteenth and nineteenth centuries. They have profited from the ideological fervor of the Moscow-Tartu school, witnessed in this volume, but now seek to bring its heritage into a post-ideological age.

10 These have been presented at recent Lotmanovskie chteniia in Moscow and some of them published in Lotmanovskii Sbornik, volume 2 (Moscow: O.G.I., 1997); Rossiial Russia. Vol. 3 [11] Kul'turnye praktiki v ideologicheskoi perspektive: Rossiia, XVIII-nachalo XX veka (Moscow-Venice: O. G. I., 1999), and in numerous recent issues of the journal Novoe Literaturnoe Obozrenie. See also Mogil'ner's book cited in note 5 . 


\section{Brief Recollection of Vladimir Nabokov}

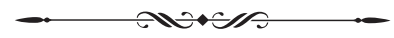

A

$s$ a student at Cornell University, I attended several of Nabokov's lectures in his survey course on European literature, I believe in the 1955-1956 academic year. I had heard a great deal about Nabokov-that he was a famous writer who delivered brilliant lectures and that his last novel could not be published in America for reasons I didn't understand, and had to be smuggled in from Europe. Nabokov's lectures were distinguished by their good humor, sweep, and witty and scornful judgments, delivered as categorical judgments that delighted the undergraduates on writers whose works were not to his taste. His wife, who attended all his lectures, sitting next to him, gave a very different impression, her intimidating gaze fixed on the rows of students before her. Together, they gave me an initial idea of stereotypical Russian characters: one generous and outgoing, with the sweeping abandon, the razmakh of the Russian soul; the other moody and hostile. In the surroundings of upstate New York in the 1950 s, they seemed something exotic, from another world.

I attended only three or four lectures and can recall only a couple of fragments from two of them, on Flaubert's Madame Bovary and Kafka's Metamorphosis. He modulated between wide-ranging generalizations about great writers and the words the authors used to describe the tiniest details in French, German, and English. He constructed his own hierarchy of great writers, based entirely on the criterion of literary style. At the summit stood Joyce, Tolstoy, Proust, and even Robert Louis Stevenson, at the bottom Thomas Mann, and even lower, Dostoevsky, whom he branded as "messenger boys," because they used literature as a vehicle for philosophical or even intellectual content. He mercilessly derided those who favored the latter as philistines, his English equivalent of meshchanstvo, and particularly liked to dwell on "ladies clubs" swooning over Mann or Dostoevsky. He made it abundantly clear that he was no "messenger boy." 
As far as I remember, he assigned six or seven novels as required reading each semester, not a great burden in a literature course of fourteen weeks. But he demanded that the students know the texts almost by heart and recall every minute detail. Examination questions focused on such details: interpretations of the texts or psychological subtleties were not of interest to him. He would ask students to identify the color of the ribbon on Emma Bovary's hair when she was seduced by Jacques in a carriage, or the brand of pomade in Jacques' hair, and then took the opportunity to expatiate on the various types of pomade in the text. Surprisingly, he made such digressions seem interesting and even necessary to understand the work.

The only substantive recollection that remains in my memory was part of his lecture devoted to Kafka's Metamorphosis. Nabokov was determined to disabuse all of us of any inclination to view the novella as an allegory, the meaning of which related to a lack of a sense of universal justice or some other profound truth, and he forcefully ridiculed such thoughts. Metamorphosis, he asserted, was not an allegory or pure fantasy: it described an event that could actually happen. He then opened a copy of the New York Daily News and declared that this tabloid was his favorite. He had read a report that morning of an episode that he believed resembled the one described in Metamorphosis. A young man and his girlfriend had decided to murder his mother to inherit her fortune. They killed her, I can't remember how, but then wondered what to do with the corpse. This matter became urgent, for now they recalled that they had invited some friends for a beer party that evening. The young man had heard somewhere that plaster of paris dissolves bones. They then proceeded to lay the corpse in the bathtub, and filled it with water mixed with plaster of paris. When the friends arrived, they encountered a grim scene. Nabokov looked out at the lecture hall with a sweet happy smile: he had proved his point. 


\section{Marc Raeff: Memorial Thoughts}

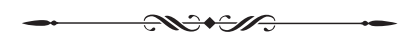

Will speak about Marc Raeff as a historian. This will make it possible for those who knew him as a scholar as well as those who didn't to reflect on the magnitude and significance of his achievement.

I first met Marc Raeff just over fifty years ago in early 1958 . I was a senior at Cornell majoring in French history, trying to decide where to pursue my planned graduate studies in Russian history. My teacher, the French historian Edward Whiting Fox, gave me good advice. He had taught two outstanding students of Russian history at Harvard; one was Marc Raeff, then teaching at Clark University, the other Leopold Haimson at the University of Chicago. I met Marc in his mother's apartment somewhere on the upper west side of Manhattan. He was very genial and gave me excellent advice. One suggestion particularly impressed me. He warned that in finding a subject for dissertation research, the student should choose a subject in his advisor's general area of expertise, but avoid working in his specific field of research. This struck me as quite sound, and I followed it later when faced with that decision.

I did not study with Marc, but we kept in contact, and he was always generous with suggestions and advice. From time to time, he would send me notes, always hand-written, pointing out a particular publication that I would not normally have come across, a particular archive that I might examine, a colleague worth consulting. Often the notes would contain a succinct, acerbic remark, sometimes distressing, but always indisputable and to the point. I received such a note shortly before his death this summer in response to an article I had published.

I was not to be one of Marc's students. But in a sense we-that is, Russian historians-have all been his students. Marc represented a model of scholarly creativity and responsibility for all of us. He came out of a European tradition pursuing scholarship as an end in itself, one might say as a sacred calling. 
He was one of that first "remarkable generation" of scholars mentored by Michael Karpovich, who laid the basis for the serious study of Russian History in the 1950s and afterward. Unlike several of his colleagues, Marc was not lured away from the scholarly calling by the enticement of political engagement. However strong his political convictions, they did not shape his understanding of or devotion to history. His dedication resulted in a large, rich, and varied contribution of books, articles, and reviews that numbered 275 in the bibliography that accompanied his Festschrift, published in 1988. Of course, he wrote more afterward.

Marc's contribution, however, is distinguished not so much by the quantity of his output, as by his achievement in opening new areas of inquiry and research and in producing books that were fundamental in the very restricted sense of the word-that they provided and indeed still provide the basis for approaching eighteenth- and nineteenth-century Russian history. I am not going to give a listing of his groundbreaking works, but will simply point out several areas of scholarship that Marc opened and the approaches he originated.

The first was the study of the Russian state and officialdom, a subject ignored after the revolution both in the Soviet Union and the West. Marc's first major publication was his 1957 biography of Michael Speranskii, the reformer of the first decades of the nineteenth century and the director of first modern codification or systematization of Russian law. His book Michael Speransky: Statesman of Imperial Russia was not the usual intellectual biography, but a work of commanding erudition and insight that revealed the entire mode of thought that animated the rationalistic constitutionalism of the reign of Alexander I.

This was a subject that had been approached within the conventional framework of an opposition between liberal constitutionalists and conservative officialdom. Marc went beyond this to reveal the presence of a bureaucratic reform ethos - a state of mind that made the events of the early nineteenth century comprehensible and meaningful. He traced the emergence of a rationalist constitutionalism that combined l'esprit de systeme with the principle of monarchical absolutism. The work remains fundamental: his description of Speranskii's reform efforts, his struggles to advance the cause of the law under Alexander I, and later, in a conservative manner under Nicholas I retains its validity and freshness today.

The same year, 1957, he published a brief article called "The Russian Autocracy and Its Officials," which, for the first time, brought the actual 
functioning of the Russian state and the mentality of its officials under serious scholarly scrutiny. Marc examined the actual workings of the Russian administration, calling upon the social sciences to open new modes of understanding. Models and concepts of Weberian sociology appear in his writings, used to frame a comparative understanding of the subject, in this case the limited degree of professionalism in the Russian administration. Under Marc's guidance at Columbia, Hans Joachim Torke wrote his definitive monograph on the Russian Officialdom in the First Half of the Nineteenth Century. Other scholars followed, and I was one of those who studied the Russian state in the nineteenth century and the institutions and social dynamics that both brought about the Great Reforms of Alexander II's reign and yet limited their extent.

Marc complemented this work with the publication of books of documents of Russian history with his own explanatory introductions. These included interpretations of the reign of Peter the Great, plans for political reform in Russia, an interpretation and documentary history of the Decembrist Movement, and his collection Russian Intellectual History, which remains in print and is widely used in classes today.

Marc's second field of exploration was the social psychology of the Russian nobility, a series of articles that culminated in The Origins of the Russian Intelligentsia. Again, Marc focused on the mentality of the group he was describing, and again his work was informed by Weberian sophistication, but not constricted by it. The book showed the centrality of concepts of service to the Russian nobleman's life and thought introduced by Peter the Great and the role of ideas and the dedication to superordinate absolute goals that, under later circumstances, they would transfer to the people. The nobility, of course, made up a large and dominant component of what came to be known as the Russian intelligentsia.

For me, the book had larger implications, for what Marc described represented an extension of the absolutist ideology of the Russian state. He explored the implications of this interpretation in his article on the Politzeistaat, the police state in Russia, and then in his book comparing the implementation of the police state policies in Russia with the institutions of the German states where the concept originated. These works may well be the most influential of his publications: there is hardly a western study of eighteenth-century Russia that does not refer to it and use it as a basis for the analysis of the emergence of the westernized Russian state and society. 
The third and fourth areas of Marc's new inquiry were in advance of the field of his time and pointed to areas that had been almost completely neglected during the Cold War. The collapse of the Soviet Union led to the revelation that Russia represented more than a national state-it was a multinational empire, and a spate of works followed about Russia as an empire and the role of nationalities in Russia's past. Marc ventured into the study of Russia as an empire long before the demise of the Soviet state.

In connection with his biography of Speranskii, in 1956, he published his book on the administrative code that Speranskii authored, a reform that became a cornerstone of Russian imperial policy. The articles he published in the 1970s_- "Patterns of Imperial Policies toward the Nationalities" (1971), "Pugachev's Uprising" (1970), and "Imperial Policies of Catherine the Great" (1977) — remain fundamental texts that we assign in our courses. They display Marc's unique qualities of concise, forceful argument as he employed his erudition to formulate arresting ideas and interpretations of Russia as empire. In this connection, I should also mention his participation in the $1990 \mathrm{~s}$ as editor and author in two volumes of articles on Ukraine, marking the beginning of the rediscovery of Ukrainian history that has been proceeding during the past decades.

Finally, as if all of this were insufficient, to Marc belongs the leadership in the field of Russian émigré studies, an area that was of course close to his heart. His book Russia Abroad, published in 1990, first brought the rich Russian émigré culture abroad between World Wars I and II into the historian's purview. The book was translated into Russian and found an admiring and sympathetic audience in Russia as well as abroad. I remember one eminent Russian scholar visiting New York, who caught sight of him at a seminar. Her jaw dropped, tears came to her eyes, and she exclaimed in wonderment "Marc Raeff!"

Eulogies are supposed to end on a note of consolation for the loss that we have sustained. Here the consolation is obvious. Marc will be with us in the future as he was with us in the past, that is, in his works, which will continue to inspire us with an example of historical scholarship and inform us with the possibility of new ways to appreciate and understand Russia’s past. 


\section{Leopold Haimson: Remembrance on the Occasion of his Memorial Service, March 25, 2011}

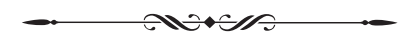

Im so happy that we have come together to remember and commemorate 1 a person who meant so much to us, who was a central figure in our scholarly development, in shaping our ideas and in many ways our lives. Leopold was more than a mentor to us-his vitality, his imagination, his devotion to scholarship, made him an inspiration and exemplar of the calling of historian. During this service we will hear brief remembrances of several of his students and friends.

I represent the first generation of Leopold's Russian history students. I began graduate work at the University of Chicago, if you can imagineI can't-more than fifty years ago, when I was twenty, and Leopold a young and brilliant Assistant Professor, age thirty-one. I can still remember registration in October 1958 - making the acquaintance of another eager entering student, Robert Crummey, who was planning to study French history, he thought.

I had met Leopold the previous year. My undergraduate teacher of French history at Cornell was Edward Fox, who had previously taught at Harvard. Two of his favorite students were Leopold and Marc Raeff, then at Clark University, and Professor Fox suggested I talk to both of them. I met Leopold in December 1957 at the meetings of the American Historical Association in New York. And of course he impressed me with his enthusiasm, eloquence, and energy. I had not encountered anyone like him; I still have not encountered anyone like him. From the conversation I remember only his warning that I not go into Russian history on a lark. I remember that well. I didn't quite understand what that meant. Why would I go into Russian history on a lark?

Well, I later found out the real meaning of the warning, for Leopold didn't do things on a lark. His commitment was great, all-embracing. The 
late fifties and early sixties were times of great exhilaration about Russia, the opening of the Soviet Union, the Thaw, Sputnik, great musicians, astonishing ballet, adventurous and rebellious writers. Leopold caught that spirit. His love for Russia and the Russian intelligentsia was passionate; he conveyed it to his students in a dramatic, moving way. And when he spoke about Russia, he became larger than life, commanding, dominating.

For Leopold, Russian history was a mission. And he involved his students personally in that mission. The relations were ones not between a distant professor and subservient student, but between friends, members of his circle, and most accurately, though I fear to use the term, comrades. And though my research goals and his soon diverged, his interest in what I was doing never flagged. He read many of my drafts, liked some, not so much others, but his observations and criticisms showed his own unique and I would say profound grasp of the subjects, yielding powerful insights about what the work could become, how it could fit in the broader interpretations of history. His incredible faculty of empathy gave one the feeling that he understood what you were really saying when it was lost in the text.

Leopold quickly and clearly distinguished between those who belonged to his circle and those who didn't- there could be no mistakes about that. But those who did belong were fired with a sense of importance, destiny, the significance of their work, a calling. He had a remarkable ability to bring people together. We met and chatted at the Social Science Tea, which took place every afternoon in the Social Science building, at a time when the University of Chicago Library was part of that building. He and Hugh Mclean, close friends at the time, threw memorable parties. They had wonderful food, drink, high spirits, Leo's razmakh, the Russian spirit of glorious abandon.

At the time I was fascinated by Russian intellectual history, and Leopold's book The Russian Marxists and the Origins of Bolshevism, which I had read before coming to Chicago, was a transformative experience, something of a revelation for me and many others. Its combination of the personal histories of the individual Marxists, illuminated by his study of anthropology and psychology, and their different visions of the revolutionary movement, was startling and new. He placed the Marxists' early evolution in the context of the intelligentsia's mentality, which swung between emphases on consciousness, the intellectuals' efforts to direct reality according to particular revolutionary programs, and spontaneity, the reliance on the masses' oppositional spirit 
of revolt, buntarstvo, to rise against the existing order. His empathy for the figures as he followed their intellectual evolution was remarkable. His language, often difficult and involuted, for us resonated with the sense of historical truth, poetic in the way of bringing concepts to life as sources of inspiration and action.

Leopold's lectures at the time were equally commanding. Unlike many of his colleagues', they were not dry factual summaries. Rather he introduced students to the great Russian historians and their historical controversies. We learned about Soloviev, Kliuchevskii, Platonov, Presniakov, Pokrovskii and others and in this way were drawn into history as part of an ongoing debate about the contesting visions of Russia's past and thereby its destinies.

In the 1960s, Leopold's interests shifted to social history. He published his landmark articles on social stability in urban Russia, in 1964 and 1965, which revealed the social and political developments that on the eve of the First Word War made a revolution likely, though he later claimed that he never argued that it was inevitable. In any case, his theses engaged the entire field in an intense debate on the origins of the revolution. I will leave mention of his succeeding works to others who will speak today.

When he moved to Columbia in 1965, Leopold maintained his intensive commitment to his graduate students. He introduced Social History Workshops to discuss the research of students and visiting scholars, and they continue to this day. The discussions I remember were lively and penetrating and often very long, the questions sharp and irreverent. We called the workshops, not completely in jest, "the little red schoolhouse." After the meetings, the participants repaired to a Chinese restaurant for ample dinners and considerable quantities of beer, though Leopold preferred margaritas.

With perestroika, his talent for bringing people together helped establish lasting contacts between American and Soviet scholars. It culminated in the remarkable series of conferences, under the aegis of the Leningrad (later St. Petersburg) Institute of History and the St. Petersburg European University, and they continue to meet. I participated in one of the first in 1991, the subject of which was the working class in early twentieth-century Russia. But Leopold made sure that I was able to deliver a paper on the representations of Nicholas II, which was published in Istoriia SSSR and stirred interest in a subject long taboo in Soviet scholarship. At the banquet afterwards, amidst the food and drink, Leopold's spirit prevailed and the participants made friendships and ties, many of which have lasted to this day. 
Leopold flourished most in Russia during the years of perestroika. He pursued his work in the archive with his usual intensity, shared his enthusiasm about discoveries that promised new understandings of Russian political life between the two revolutions. He thrived with the spirit of academic companionship, especially among the scholars at the Petersburg Institute. At night he was the bon vivant visiting his friends at their homes, going to restaurants. I can still see him, at his table in a special room in the archive, concentrating intensely on documents, chatting with the archivists, whom he charmed, drinking tea, even smoking a cigar or a cigarette. On one occasion, he lived in a suite in the old Leningrad Hotel (now part of the Astoria Hotel), where it was said the poet Esenin ended his life. He luxuriated in the old world opulence, sat on a couch reading, writing, and enjoying a drink, with Cuban cigars strewn about the room. In these years, he met and courted Natasha. He wed her in New York, where I had joined him to teach at Columbia, and there was a joyous reception in our apartment. He settled down for the first time, happy after decades of quest and wandering.

Perestroika in Russia had opened possibilities to reform and enliven the Russian historical profession together with western historians who would enrich their methodology and at the same time develop their own research on Russia's past. To a certain degree, Leopold succeeded in achieving that. But the Russia that emerged in the two decades after the collapse of the Soviet Union proved not to be what he had loved or envisioned. The idealism mixed with socialist inclinations that inspired his scholarly mission and those who joined him was subverted by the disorder and rampant materialism of the 1990s, the repudiation of socialism, and the idealization of western capitalism that he found most abhorrent. He was destined to live through one of the many sharp reversals of direction that characterize the Russian past and to join the ranks of the many members of the intelligentsia whose lofty missions, viewed from the present, are often depicted in the hues of tragedy. 


\section{Index}

Page references in boldface refer to illustrations.

1812. See events of 1812; Napoleon

absolutism. See autocracy and absolutism

Academy of Arts, 18; and lubki, 151; and Nicholas I, 101, 135-36; and Olenin/Solntsev, $102-3,105-7,109-11,137,139,140$

Academy of Sciences, 378; and coronation albums, 6, 9; and expeditions, 52, 254, 257-58, 277, 280; and non-Russian peoples, 52n 19

Adam, Victor, 16

Adamini, A. U., 168

administration. See judiciary; state administration

Admiralty College, 259

advent. See under Roman Empire; triumphal entries

Aeneas, 124

Africa, 291, 294

Ageeva, Olga, 47, 125n9

Agency for the Preparation of State Papers, 20, 23

agro-literate society, 28

Aksakov, Ivan, 204, 204n37, 317, 360

Alaska, 260, 264, 267, 269-70, 275-76

Alekseeva, M. A., 181

Aleksii (Arkhimandrite), 233

Aleutian Islands, 262, 267, 272

Alexander I (Emperor of Russia), 36, 126, 131,336,342, 390; and 1812 victory celebrations and memorials, 76n7, 157-60, 159, 165, 167-69, 171, 172n51, 173, 176-77; during 1812 wars, 84, 147-50, 155; and Alexandrine Column, 165, 240-42, 241; as angel, 146; austerity of, 15-16; and Christianity, 155-61; coronation of, 15, 53; and European myth, 134, 146; and expeditions, 263, 265, 268, 270, 274-76, 279, 293; in film, 78; and Kremlin antiquities, 106, 115; and lubki, 153-55, 155, 182, 184; at Mont Aimé ceremony (1815), 158-60; Moscow visits of, 148-49, 161; Nicholas II sees himself as heir to, 72, 98; and non-Russian peoples, 39; at prayer service in Paris (1814), 158, 159; as redeemer, 156; and Redeemer Cathedral, 103, 136, 160, 167, 171, 173; triumphal entry of (into Paris), 155, 155. See also events of 1812; Russian people 
Alexander II (Emperor of Russia), 126, 161, 391; and 1812 events, 171-72, 172n51; assassination of, 212, 216-17, 216n20, 220, 249, 373; coronation and album of, 4, 16, 18-20, 20, 41-44, 56-61, 57-58, 61, 189-91, 191, 372; and Crimean War, 168, 17172; and emancipation of the serfs, 187-97, 202-3, 307-8; and expeditions, 281, 285; in film, 78; and liberal Slavophilism/Editing Commission, 307, 313-14; and lubki, 18487, 185-86, 191-97, 193, 195-96, 205-6, 205-7; meets with workers and peasants (1861), 188-89, 194-97, 195-96; and Millennium Monument, 197-207, 205-6; and Nicholas II, 95, 97; and non-Russian peoples, 41-44, 56-63; on postage stamp, 74; and property rights, 340, 341-43; against representative government, 45, 337-38; and "Savior on the Blood," 212-13, 216, 216n20, 220; and scenario of love, 19, 42-44, 56, 59-62, 172, 187-97, 202-4, 207; and Shamil, 44, 61-62; and Varangian myth, 368. See also under empire; heroic space; Moscow; Russian people; triumphal entries

Alexander III (Emperor of Russia): and 1812 events, 172-74; and architecture, 172-74, 210-14, 220n30, 223-25, 229-31; clothing of, 21, 23, 63; coronation and album of, 4, 20-24, 22, 63-67, 73, 172, 372; dislikes Petersburg, 249; in film, 78; in lubki, 185; monument to, 78; and national myth, 63-66, 71, 210, 372-74; and Nicholas II, 95, 178; and non-Russian peoples, 63-66; on postage stamp, 74; against representative government, 338; and Russianness, 63, 65, 373-74; and Tchaikovsky, 244, 248. See also under Muscovy; Pobedonostsev; Russian Orthodox Church; Russian people

Alexander III of Macedonia, the Great, 123, 131, 181

Alexander Nevskii, Saint (Grand Prince of Vladimir; Prince of Novgorod), 160, 201n27, 225, 240; helmet of, 106, 117, 117n45, 118, 143

Alexander Nevskii Cathedral (Reval/Tallinn), 218, 219, 226, 231

Alexander Nevskii Cathedral (Warsaw), 227

Alexandra Fedorovna (1) (Empress; wife of Nicholas I; née Princess Charlotte of Prussia), 18,120

Alexandra Fedorovna (2) (Empress; wife of Nicholas II; née Princess Alix of HesseDarmstadt): crowning of, 24, 25; in Elchaninov, 89-90; and Fedorov village, 176, 235-36; in film, 77

Alexandrine Column, xx, 240-41; dedication ceremony of, 165, 166, 242-43; sources and details of, 240; Zhukovskii on, 165, 243

Alexandrinskii Theater, 76

Alexei Mikhailovich (Tsar of Russia), 74, 89, 120; breast plate of, 117-19

Alexei Nikolaevich (Tsarevich of Russia; son of Nicholas II), 83, 85, 90, 91, 92

Alexis Komnen (Alexius I Comnenus; Byzantine Emperor), 119

Alphabet of 1812 (Russkaia Azbuka; Terebenev), 153, 154

Ambrosii of Kharkov, Bishop, 174

America. See North America; Russian-American Company; United States

Amur region, 280-82, 281n21, 284, 288-91, 293

ancient times. See starina

Andronikov, Prince Michael, $81 \mathrm{n} 29$

Anna Ioannovna (Empress of Russia): coronation and album of, 3, 6-10, 8, 15, 35, 49-50; and non-Russian peoples, 50

anniversaries. See Borodino Centennial; Poltava bicentenary; tercentenary celebrations 
Annunciation Cathedral (Moscow Kremlin), 40, 236, 371

Anson, George, 278

anthropology, 357, 366, 375, 394; and Moscow-Tartu school, 385; and non-Russian peoples, 44, 292. See also ethnography; Geertz

Antiquities of the Russian State (Drevnosti rossiiskago gosudarstva), xx, 113, 114-20, 116, 118, 122, 140-44; decorativeness in, 117-20, 142-43; glorifies monarchy, 114-15, 142-44; and Official Nationality Doctrine, 115, 141; Olenin's plans for, 114, 140; volume contents described, 115n41. See also artifacts; Byzantium; helmets; Monomakh Cap; regalia; Russian national esthetic; Solntsev

antiquity. See Greece; neoclassicism; Roman Empire

Antony of Pechersk (Saint), 95, 201n27

Antsyferov, D. Y., 254

Aplaksin, Andrei, 232-33

Arakcheev, Alexei, 147

Arc de Triomphe (Paris), 242

archaeology: and Antiquities of the Russian State, 115; and church architecture, 218; and Olenin, 101, 105-6, 108-9, 137, 139; and Solntsev's illustrations, 112. See also artifacts Archangel Cathedral (Moscow Kremlin), 40, 371

arches. See triumphal arches

architecture: and Alexander I, 103, 160; and Antiquities of the Russian State, 115, 141; in India, 231-32; and mythical scenarios, xviii-xix, 370; and neoclassicism, 103-4, 13839, 160, 166-67, 209, 211; as reinvention of past, xix; revival style of, 212, 231-32; Russian national style of (see Russian national style); and Solntsev's Terem Palace, 112, 113; and torzhestvennost' of Petersburg, 239-40; in Western Europe, 211-12. See also under Byzantium; decoration; Fedorov Village; neoclassicism; ornamentation; Russian national style

Arctic Ocean, 259, 270

Armenians, 40, 42, 50, 54, 58, 62

armor. See breast plate; helmets; weapons

Around the World on the Kamchatka. See Golovnin

artifacts/antiquities: and Antiquities of the Russian State, 114-20, 140-44; Nicholas I reveres, 107, 138; Olenin collects, 105-6; Olenin fuses with classical tradition, 10810, 137-40; and Russian national esthetic, 105-20, 137-40; Solntsev creates montage of, 110-12, 117-20. See also archaeology; helmets; starina; weapons

Art Nouveau, 24, 218

Asia. See Central Asia; China; Japan

Asian borderlands, 292-94

Asiatic peoples. See non-Russian peoples

assembly. See constitutionalism

Assembly of the Land. See zemskii sobor

Assumption Cathedral (Kiev Monastery of the Caves, St. Petersburg), 220

Assumption Cathedral (Moscow Kremlin), 173; architectural style of, 104, 139, 166; during coronations, 5, 7, 12, 15, 35-36, 38, 40, 49-51, 66, 372

Assumption Cathedral (Vladimir), 104, 139, 166 
Astrakhan, 12, 32, 62

Athens, 129-30

atlases. See cartography

Atlasov, V. V., 254

Augustus Caesar, 30, 119, 124

Austria. See Hapsburg Empire

autocracy and absolutism: and 1812 events, 150, 160, 162, 174; as active vs. subversive force, 375; adopted as title by Ivan III, 28, 125; and Alexander III, 174, 178, 210, 249; architecture represents, 102, 122, 136, 144, 166, 208-9, 218-20, 229-37; Byzantium embodies, 27, 102, 136, 166, 208; coronation ceremonies emphasize, 5, 16, 32, 36; defined, 125, 373; and doubling effect, xvii; and heirs' upbringing, 362; and liberal Slavophilism, 299, 301-2, 312, 314-19; and Nicholas I, 101-2, 121, 134-36, 144, 160, 162, 166, 183, 208-9, 359; and Nicholas II, 71-72, 97, 98, 178; Petersburg as symbol of, 239; and property rights, 333, 339-42, 344; Raeff on, 390-91; as shaped by culture and cultural interlocutors, 122, 143-44; and sovereignty as defined by empire, 45-46; and theater/theatricality, 126; and tsar as general good/Supreme Will, 33739; and Varangian myth, 134. See also Official Nationality Doctrine; Russian monarch; Russian people

Axelrod, Paul, 356

Azadovskii, M. K., 378

Azov, 34, 256

Babst, Ivan, 62

Bachisarae, 39

Baer, Karl von, 282, 283

Bagration, Prince Peter, 287

Baku, 229

Bakunin, Michael, 344

Balboa, Vasco Núñez de, 289

Baltic states: church architecture in, 225; nobility in, 38-39, 49, 51, 53, 301

Baran, Henrik, 369, 380, 385

Bariatinskii, Prince Alexander, 44

barmy, 30, 33, 35

Baroque: and architecture, 233; and Catherine II's opera, 132, 144; and Olenin, 105; and Peter I's allegories, 125; and representational culture, 123, 146; and Solntsev's illustrations, 117, 121, 142, 144; and theatricality, 126; and Versailles, 123

Barrett, Thomas M., 44-45

Bashkirs, 39, 42, 50, 58, 62

Basin, Peter Vasil'evich, 109

Bassin, Mark, 255

Battle of the Nations (Leipzig), 157

battles. See Borodino; Kulikovo; Poltava

Baudouin de Courtenay, I. A., 378

Becker, Seymour, 293 
Beketov, Andrei, 285

Bell, 342

bell towers, 220, 222, 222-23, 226-27, 229, 231, 236

Belorussia, 163

Belosel'skaia-Belozerskaia, Princess, 110, 111

Belosel'skii, A. M., 105n 12

Bendix, Reinhard, 339

Benois, A. L., 229

Benois, Albert, 24

Benois, Leontii, 220n30, 223, 224, 227

Berdyaev, Nicholas, 365

Bering, Vitus, 254-55

Bering Sea, 271, 279

Bering Straits, 259, 268

Berlin, 130, 242, 285, 359-60

Berlin, Isaiah, 356

Bestuzhev-Marlinskii, Alexander, 360

Bezobrazov, A. M., 303, 305

Bezobrazov, Mikhail, 308

Bezpiatov, E. M., 76

Billings, Captain Joseph, 261

Birnbaum, F. P., 74

Black Sea, 38, 64, 130, 170, 256

Blanchard, F., 19

Blanning, T. C. W., 123, 146

Blessing of the Waters, 77, 250

Bloody Sunday, 250

Bodin, Jean, 27

bogatyrs, 66, 184, 374

Bolsheviks, 347

Bon, Girolamo, 13

borderlands. See Asian borderlands

Boris (Saint), 13, 217

Borisova, E. A., 209

Borki (Church of the Savior), 222, 222

Borki disaster, 225, 226

Borodino, Battle of, 145, 156, 157, 170, 176-78

Borodino anniversary (1831), 163

Borodino Battlefield Memorial, 164, 165, 168, 172, 175

Borodino Centennial celebrations (1912), 72, 77, 78, 80, 95, 175-79, 177-78

Borodino Savior Monastery, 168

botany: and "great Northern expedition" (1730s), 254-55; and Krusenstern, 266; and Litke, 271, 280, 282; and Pallas, 257-58; and Przheval'skii, 291; and Semenov, 285; and Veniukov, 287 
INDEX

Bougainville, Louis-Antoine de, 264

bow. See triple bows

Brandenburg Gate (Berlin), 242

breast plate of Alexei Mikhailovich (Solntsev), 117-19

Britain. See England

Brooks, Jeffrey, 80

Bruce, Jacob, 256

Brumfield, William Craft, 120, 142

Bryant, Lawrence M., 364

Bullitt, William C., 363

bureaucracy. See state administration

Buslaev, Fedor, 200-201, 201n27

Butovskii, Ivan, 165, 242-43

Butovskii, Victor, 211-12

byliny, 181

Byzantium: and Antiquities of the Russian State, 115-16, 119, 141-42; and architecture, 102-4, 136, 139, 166, 208-11, 216-17, 220, 223, 226-29; and Catherine II, 36, 38, 129; and coronations/triumphal entries, 29-30, 32-33; as fundamental model for Russian tsars, 27-28, 124-25, 208, 368-69; legal tradition of, 36; and Olenin/ Solntsev, 109-12, 139-42

Cadet Corps. See Noble Cadet Corps

California, 270, 276

Cannobio, Carlo, 132

Canton, 264

capitalism, 345-46, 357-58, 396

Caravaque, Louis, 7, 10

cartography, 51, 120, 255-56, 262, 287

Caspian Sea, 256

Cathedral of Christ the Redeemer (Moscow), 210; consecration of (1883), 172-75; as memorial to 1812 events, 150, 160, 165-67; neo-Byzantine style exemplified by, 104, 139, 166, 209; Nicholas I's vision of, 102-3, 136, 164-67; and Official Nationality, 209; Vitberg's designs for, 102-3, 136, 160, 161. See also under Alexander I

Cathedral of the Resurrection ("Church of the Savior on the Blood"; St. Petersburg), 212-22, 215; as atonement for assassination, 216-17, 216n20, 222; competitions for, 213-14; as dissonance, 220; illumination and windows in, 221; and Jerusalem, 216; Muscovitizes Petersburg, 220; Resurrection motifs in, 214-16

Cathedral of the Resurrection (Obvodnyi Canal, St. Petersburg), 220, 221, 225, 225n 43

Cathedral of the Transfiguration (Tashkent), 217n23, 229

Cathedral of Vasilii the Blessed (St. Basil's Cathedral, Moscow), 214, 223

Catherine I (Empress Catherine Alekseevna; wife of Peter I): coronation album of, 3, 4-6; coronation of, 35, 48-49, 116, 142

Catherine II, the Great (Empress of Russia), 125, 208; and archaeology, 115; and ceremonial trip, 36-39; coronation and album of, 3-4, 13-15, 14, 38, 51; and expeditions, 
51, 256-65, 274, 293; Greek Project of, 104, 105n11, 125, 129-33, 136, 137; and lubki, 182; and non-Russian peoples, 37-39, 51-52; and property rights, 336; and Shakespeare, 128, 131; in Tchaikovsky, 247-48; and theater, 75n7, 122, 126-34, 135, 144. See also under empire; Instruction

-Works: Antidote, 257; Life of Riurik, 128; Notes on History, 127; Primary Reign of Oleg (Nachal'noe upravlenie Olega), 122, 128-29, 131-34, 142

Catholicism, 221

Caucasus: and Crimean War, 56, 169; and expeditions, 289-90; Russian Orthodox churches in, 229; as symbol of Russia's expanding empire, 38-39, 44, 55-57, 58, 61-63, 67, 70, 372. See also Shamil

Cavalier-Guards, 5, 7, 19, 49. See also guards' regiments

celebrations. See Alexandrine Column; Borodino Centennial; events of 1812; Monument to the Millennium; Poltava bicentenary; tercentenary celebrations

census (1882), 323, 328

Central Asia: expeditions to, 274, 282, 284-86, 289-90, 292-94; Orthodox churches in, 229; as symbol of Russia's expanding empire, 45, 56, 70, 372

ceremonial texts and ceremonies: as fundamental expression of monarchical culture, xvii-xxi, 29, 365-67, 371-72. See also Alexandrine Column; Borodino Centennial; coronation albums; coronations; crowning ceremony; events of 1812; Monument to the Millennium; mythical narratives; Poltava bicentenary; processions; promulgation ceremony; tercentenary celebrations; triumphal entries

ceremonial trips, 29, 36-39, 52, 62

Ceremony of Crowning (Chin venchania), 4. See also coronation albums

Chaadaev, Peter, 245

Chaev, Nikolai, 76

Champagne, 158

Chariot with Figure of Winged Victory (Alexandrine Column), 242, 242

charisma: and ceremonies of power, 31, 366

Charles X (King of France; Count of Artois), 16

Charter of the Nobility, 52, 336

Chekhov, Anton, 334

Chekhov, Michael, 78

Cherkasskii, Vladimir Aleksandrovich, 297-307, 309-16, 318-19; on government and reform, 305, 310-16

Chernigov, 95

Chernov, Victor, 345-46, 348

Chernyshevskii, Nikolai, 342

Chertkov, Vladimir, 320, 326-27

Chicago Institute of Psychoanalysis, 361-63

Chichagov, Vasilii, 259

Chicherin, Boris, 360, 361

China, 253; and Amur region, 280-81; Przheval'skii in, 290-92, 294; and Russian coronations, 44, 50, 60; Semenov in, 285-86; trade with, 260, 264, 275

China Sea, 264, 275 
Chin venchania (Ceremony of Crowning), 4. See also coronation albums

Chizhov, S. I., 74

Choris, Ludovik, 268

chrism dish (Solntsev), 119

Christ. See Jesus Christ

Christianity: and Alexander I, 155-61; and conversion of Rus', 109, 111; and coronation albums, 13; and national-style architecture, 216, 225; and natives (during expeditions), 261, 269, 272; and peasant commune, 339; semiotics of, 384; and Tolstoy, 321, 322. See also Resurrection; Russian Orthodox Church

Christ the Redeemer Cathedral. See Cathedral of Christ the Redeemer

Chukchi, 52, 134, 258

church architecture. See under architecture; Byzantium; neoclassicism; Russian national style (in architecture)

Church of Maria Magdalena (Jerusalem), 229-31

Church of the Holy Sepulcher (Jerusalem), 216

Church of the Icon of the Georgian Mother of God (Moscow), 218

Church of the Savior (Borki), 222, 222

Church of the Savior (Ivanovo-Voznesensk), 217n23, 223

Church of the Tithe (Kiev), 102

Church of the Trinity (Ostankino), 218

Circassians, 40, 54, 64, 67

citizenship (grazhdanstvennost'), 62-63, 201

civil rights, 334, 343-44, 347, 351-52. See also property rights

classical antiquity. See Greece; neoclassicism; Roman Empire

clothing: of Alexander III, 21, 23, 63; in Antiquities of the Russian State, 115, 119-21, 141; as embodiment of national identity, 108-11, 119; of exotic peoples, 40-42, 44, 50, 54, 57-60, 64-65, 67-68; of Fedorov-village soldiers, 237; and Olenin, 108-9, 137, 13940; Russian style (during coronations), 40-41, 43, 54-55, 59-60, 63; Russian style (in Catherine II's play), 132-34; as sign of support for Crimean War, 171; westernized (during coronations), 36, 40-41, 49-50, 54-55. See also uniforms

Clovis. See oil of Clovis

coins. See commemorative coins

colonialism, 40, 45, 63-64. See also imperialism

colonization, 260, 286, 289-90, 292-94

Columbia University, 391, 395

Columbus, Christopher. See "Russian Christopher Columbuses"

commemorative coins, 72-74

Committee of Ministers, 197, 340, 341

Committees on Agriculture, 347

Complete Collection of Laws, 115, 141, 306, 359

conquest myth, xvii, xx-xxi, 28-29, 35, 128, 367-68, 370

Constantine I (Roman Emperor), 124, 131

Constantine IX Monomakh (Monomachus; Byzantine Emperor), 30, 116, 125, 141-42. See also "Legend of Monomakh"; Monomakh Cap 
Constantine Nikolaevich (Grand Duke of Russia; son of Nicholas I), 203, 280-81, 282

Constantine Pavlovich (Grand Duke of Russia; son of Paul I), 16-18, 131

Constantinople, 32, 102, 129, 131, 167

Constitutional Democratic Party. See Kadets

constitutionalism: of Bezobrazov circle, 303, 308; and Cherkasskii, 312, 314-16; and Great Reforms, 357; and Koshelev, 306, 308-11, 318; and Nicholas II, 95-97, 250, 374-75; and populism, 343-45, 349; and property rights, 333, 343-45, 349; Raeff on, 390; Russian monarchs reject, 45, 208, 338, 373; and Samarin, 317-19. See also Duma

Construction Statute, 213, 217n24

"Conversation between the Tsar and the People," 342

Cook, Captain James, 269, 276, 282, 368; as model for Russians, 259-64, 274-75, 278, 293 corbelled vaulting, 212, 218

Cornell University, 387, 389, 393

coronation albums (Opisaniia), xviii, xx, 3-26, 367; of Alexander II, 18-20, 20, 56-57, 58, 61, 61, 189-91, 191, 372; of Alexander III, 20-23, 22, 64, 372; of Anna and Elizabeth, 6-13, 8, 11, 14, 49-50; of Catherine I, 4-6; of Catherine II, 13-15, 14, 38,51 ; as celebration of dynasty, 15; define monarch's power and empire, 48, 372; in eighteenth vs. nineteenth centuries, 15, 26; emphasize secular celebrations instead of religious, 4-5; legitimize claims to throne, 6; and linear perspective, 13, 15, 24; of Louis XV, 6; military ceremonies first appear in, 23; of Nicholas I, 16-18, 17, 55, 55; of Nicholas II, 23-24, 25, 67, 68-69; non-Russian peoples in, 38, 40-44, 49-51, 55, 55-57, 58, 61, 64, 67, 68-69; old Russian motifs in, 20-21, 24; origins and history of, 3-4; physical prominence of monarch in, 7, 21; triumphal arches in, 12. See also coronations; engravings; lithographs

coronations (meanings and details of ): Byzantium as model for, 28-32, 125; define state hierarchy and imperial power, 48; define symbolic program for each monarch, 70, 371-72; as expression of colonial domination, 40, 63-70; as expression of national unity, 53-62; and invention of tradition, 371-72; and Kremlin Table Service, 113; and Life for the Tsar, 135; and non-Russian peoples, 38, 40-44, 49-51, 53-61, 63-70; origins of, 28-32; Peter I introduces new European regalia for, 4, 35, 48; Roman advent likened to, 33; and territorial consciousness, 51; and uniformity, 49-50; as venchanie vs. koronatsiia, 48. See also under clothing; coronation albums; coronations (of specific monarchs); crowning ceremony; empire; "Legend of Monomakh"; Monomakh Cap; peasantry; processions; Russian people; triple bows; triumphal entries

coronations (of specific monarchs): Alexander I, 15, 53; Alexander II, 41-44, 56-61, 5758, 372; Alexander III, 63-66, 73; Anna and Elizabeth, 35-36, 49-50; Catherine I, 35, 48-49, 116, 142; Catherine II, 38, 51; Charles X, 16; Fedor Alekseevich, 32; Ivan IV, 28-33; Louis XV, 6, 7; Nicholas I, 16, 40-41, 54-56, 163, 371-72; Nicholas II, $\mathrm{xx}, 66-70,73,83,85$. See also coronations (meanings and details of )

Cossacks: and Catherine II, 37-39, 51; during coronations, 42, 49-51, 53, 56-58, 64, 66-

67; and expeditions, 254, 289, 292; in lubki, 152-53, 169, 184; in Tchaikovsky, 244 costumes. See clothing; uniforms

Courtin, Louis, 16

court reform, 78, 358-61, 373, 376. See also Great Reforms; judiciary 
INDEX

Cracraft, James, 208, 255

Crews, Robert, 229

Crimea: early Russian artifacts in, 105, 137; and idea of empire, 37, 52, 130-31, 164; Nicholas II in, 77, 87, 90

Crimean War, 288, 298, 300, 372; and idea of empire, 41, 56, 170; and lubki, 169-70, 187; and memory of $1812,168-72$; Tolstoy on, 171,172

cross. See "Life-Giving Cross"

crowning ceremony: of Catherine I (first in Russia), 3-4, 6, 48; in coronation albums, 3-4, 6-9, 13-21, 14, 17, 20, 22, 24, 25; as imperial scenario, 53, 70, 371. See also coronations

Crown of Monomakh. See Monomakh Cap

Crummey, Robert, 393

cult of 1812. See events of 1812

culture: defined, 365; as means to shape imperial myth, 123-24, 144; of power, xvii-xx, 29, 124; semiotics of, 369-70, 381-86; as text, 382. See also under mythical narratives; representational culture; Russian monarch

cupolas, 160, 168, 173, 216, 223; and five-cupola structure, 104, 139, 166-67, 209, 214, 220, 229; helmet, 233; onion, 214, 217, 227

Dagestan, 45

Dal', Lev, 211

Danielson, N. F., 357

Danilevskii, Nicholas, 285

Dashkova, Princess Ekaterina Vorontsova, 105

d'Auteroche, Chappe, 257

Davis, Richard Harding, 67-68

Decembrists, 172, 337, 356; Lotman on, 383; and Nicholas I's succession, 16; Raeff on, 391; sentencing of, 134,162

Declaration of the Rights of Man, 333, 335

deconstructionism, 381

decoration/decorativeness: in church architecture, 209, 214, 218-20, 222, 231, 232, 236n66; in Solntsev, 112-13, 117-21, 142-43. See also ornamentation

"Dedication of the Millennium Monument," 205, 205

Delisle, Joseph-Nicolas, 256

Demidov, N., 260

Demut-Malinovskii, Vasilii, 189, 190

Den', 317

Derzhavin, Gavriil, 248

Description of All the Peoples Inhabiting the Russian Empire. See Georgi

Diana (expedition ship), 269, 276

Diebich, Count I. I., 163

Digest of Laws, 359

dinner service. See Kremlin Table Service

Directorate, 126-27

Dmitriev, Mikhail, 151 
Dmitrii Donskoi (Grand Prince of Moscow), 198, 201

Dmitrii Ivanovich (Tsarevich; son of Ivan IV), 117, 142

Dolbilov, Mikhail, 103n7, 136n36

Dondukov-Korsakov, Prince Alexander, 229

Dormition Cathedral (Moscow), 53, 209

Dormition Cathedral (Pochaev Monastery), 233

Dormition Cathedral (Vladimir), 209

Dorpat University. See Tartu University

Dostoevsky, Fedor, 387

double-headed eagle, 28, 113, 125, 132

doubling effect, xvii, xix, 124

Dové, Heinrich Wilhelm, 285

Dovmont of Pskov (Saint), $201 \mathrm{n} 27$

Drankov, Alexander, 78, 84

Dresden, 105

dress. See clothing; uniforms

Drevnosti rossiiskago gosudarstva. See Antiquities of the Russian State

dueling: semiotics of, 383

Duma: and church architecture, 213, 235; in Elchaninov, 83, 86,95-96; Nicholas I's conflicts with, 83, 96-98, 176, 179; and private property, 349, 351. See also constitutionalism

Dumas, Alexandre, 360

Dzhunkovskii, Vladimir, 177

eagle. See double-headed eagle

Eco, Umberto, 381

Editing Commission, 302-6, 308, 310, 312-13, 341

education: of heirs, 90, 361, 371, 373; of non-Russian peoples, 52, 62-63, 258, 266; of peasants, 342; Samarin on, 317-18; and Tolstoy, 322, 331

Efimov, N. E., 104, 138

Efremov, V., 179

Eikhenbaum, Boris, 378

Ekaterina Mikhailovna (Grand Duchess of Russia; granddaughter of Paul I), 214

Ekaterinoslav, 38, 130

Elchaninov, Andrei Georgievich: biography of, 81n29. See also Reign of the Sovereign Emperor Nicholas Aleksandrovich

Election of Michael Romanov (Chaev), 76

Elizabeth Petrovna (Empress of Russia): coronation and album of, 3, 6, 9-13, 11, 14, 15, 16, 35-36, 49-50; and non-Russian peoples, 50; and theater, 126

Elliger, Ottomar, 7

Emancipation Manifesto (1861), 187, 308, 340

emancipation of the serfs, 78, 96, 212, 372, 373; and dedication of Millennium Monument, 202-3; and Editing Commission, 302-6, 308; and expeditions, 289; and liberal Slavophilism, 297-304, 307-8, 311-14, 316, 318; and lubki, 180-81, 187-97, 207; and property rights, 340-42, 350; and Semenov, 285, 286; Zaionchkovskii on, 358 
emperor. See imperator; Russian monarch

empire: and Alexander II, 41-45, 56-63; and architecture, 209, 225-33; and cartography, 255-56; and Catherine II, 36-39, 51-53, 133-34, 256; and colonialism, 40, 45, 63-64; coronation ceremonies reinforce, 12, 32, 35-36, 38, 40-44, 48, 51, 53-60, 63-70; and Crimean War, 41, 56, 170; definitions of, 27-28, 47-48, 51, 125n9; and ethnographic myth, 37, 47, 133; expeditions as symbol of, 255-58, 261, 280-82, 290, 292-94; and imperial trips, 36-39; masquerades represent, 43, 50, 55, 59; and Millennium Monument, 197-98; and Polish Revolution, 163-64; and polonaise, 247; and scenario of love, 42, 44, 59-62; semiotics of, 383; sovereignty represented by, 27-28, 32, 36, 45-46, 47; and Tchaikovsky, 243-44; and territorial consciousness, 51, 256; and triumphal entry, 33-35. See also colonialism; colonization; expeditions; exploration; Georgi; imperialism; non-Russian peoples; Poland

Engel'gardt, Alexander, 321, 356, 357

England: and Alexander I, 270, 279; architecture in, 211; and Crimean War, 169, 171; and expeditions/colonization, 260, 263-65, 275, 277, 286, 290, 292; monarchical authority in, 27; mythological genealogies of, 30; navy of, 263-64, 269, 274, 276; populist critique of, 343; royal family of, 71 ; royal processions in, 366

engravings: in Antiquities of the Russian State, 117, 143; in coronation albums, 3, 6-7, 8, $10-15,11,14,19,38,49-50$

enlightenment: and assimilation of non-Russian peoples, 52-53, 62, 65, 69, 133-34; and expeditions, 257-58, 265, 270, 283; and liberal Slavophiles, 312, 314, 318; and monarch as mythical hero, 146; and Olenin, 109, 114n37, 140, 140n49

entry processions. See triumphal entries

Erikson, Erik H., 357

Ermak Timofeevich, 181

Eschenburg, J. J., 128

Estonia (Estland): church architecture in, 218, 219, 226-27, 228, 231. See also Baltic states; Moscow-Tartu School; Reval; Tartu University

ethnographic myth, 37, 47, 133, 133n30

ethnography: and Catherine II, 37, 51-52, 133; and expeditions, 255, 267, 271, 273, 280, 283, 287; and non-Russian peoples in imperial celebrations, 50, 56; and Olenin, 101, 105-6, 108-9, 114, 139-41; and semiotics, 377, 382. See also anthropology; expeditions; Georgi

Etruscan table service, 120

Euripides, 131

Europe. See England; France; Greece; Hapsburg Empire; Roman Empire

European myth, 146, 359, 372-74

events of 1812, 145-79; Alexander I during, 147-50, 155; Alexander I's ceremonial celebrations of, 158-60; Alexander I's religious interpretation of, 155-60; Alexander II's evocations of, 171-72, 172n51; and Borodino Centennial (Nicholas II), 175-79; and consecration of Redeemer Cathedral (Alexander III; 1883), 172-75; and Crimean War, 168-72; and lubki, 151-55, 152, 154-55, 169-70, 172, 182; and memory in relation to myth, 145-46; and Mont Aimé ceremony (1815), 158-60; Nicholas I's cult of, 162-69; official history of (by Mikhailovskii-Danilevskii), 164, 167; and Official 
Nationality Doctrine, 162, 168, 172; and Parisian prayer service (1814), 158, 159; Pushkin on, 163-64; Shishkov's manifestos on, 147-49, 156; Tchaikovsky's overture to, 174-75; Zhukovskii's poems to, 157. See also Alexandrine Column; Borodino Battlefield Memorial; Cathedral of Christ the Redeemer; Napoleon; peasantry; Russian people

Evreinov, Ivan, 254

exotic peoples. See natives; non-Russian peoples

expedition journals, 260-73, 275, 278; Cook's, 260, 263; Golovnin's, 269-70, 276;

Krusenstern's, 264-67; Lisianskii's and Langsdorff's, 267-68; as literary text, 271;

Litke's, 270-73, 279; Nevel'skoi's, 281, 281n21; Sarychev's, 262-63

expeditions, 253-94; under Alexander I, 263-73, 275-77; under Alexander II, 283-94; under Catherine II, 51-52, 115, 256-63, 274-75; "great Northern," 254-55; under Nicholas I, 273, 277-83; under Peter I, 253-56. See also Academy of Sciences; Central Asia; China; expedition journals; exploration; fur trade; merchantry; North America; Northeast Passage; North Pacific; Okhotsk; Russian-American Company; Russian Geographical Society; Siberia

exploration, 253-94; and cartography, 255-56; as colonization, 286, 289-90, 292-94; Cook as model for, 259-64, 274-75, 293; and discipline, 291-92; ethos of, 274, 281-82, 290, 293, 294; as expression of Russian national identity, 273, 280, 283-84, 289-90, 292-94; as expression of Russia's European/Western character, 253, 255, 277 , 279, 293; as form of noble service, 274, 277, 293; Golovnin as model for, 269, 27677, 278; and imperialism, 292, 294; Lomonosov on, 259; and "Russian Christopher Columbuses," 259-63; scholar-scientists replace noble officers in, 282-84; as search for exotic danger, 290-92; and territorial consciousness, 51, 256. See also Bering; Cook; England; enlightenment; ethnography; expedition journals; expeditions; geography; Georgi; Golovnin, Vasilii; Krusenstern; Litke; natives; naturalists; Przheval'skii; Semenov; Veniukov

Faibisovich, Victor, 105n11, 106, 138

family. See imperial family

fathers. See under Russian monarch

Fedor Alekseevich (Tsar of Russia), 32, 76n7

Fedorov Cathedral, 236-37, 236n66

Fedorov Mother-of-God, 235, 236

Fedorovskii Gorodetskii Monastery, 233

Fedorov Village, 235-37. See also Peterhof

Feodesii of Pechersk (Saint), $201 \mathrm{n} 27$

"Festive Dedication of the Millennium Monument," 206, 206-7

festivity. See torzhestvennost'

Fet, Afanasii, 217

feudalism, 335

Fichte, Johann Gottlieb, 355

Figaro, Le, 88

Filaret (Metropolitan of Moscow), 107, 138, 156-57, 187, 202, 203, 340 
film, 72, 76-79, 77n11,77n13, 84

Finland, 46, 66, 164

five-cupola structure. See under cupolas

Flaubert, Gustave, 387-88

Fleming, Renée, 248

Flier, Michael, 208, 214, 216, 220, 384

folk melodies, 132-33, 135, 175, 243-44

foreigners. See non-Russian peoples

foreignness: of Russian monarchs, xvii, 128, 368-69, 373

Fort Ross, 270, 276

Fox, Edward Whiting, 389, 393

France: and colonization, 286, 290; and coronations, 6, 7, 16; and Crimean War, 171; monarchical authority in, 27; mythological genealogies of, 30; and oil of Clovis, 31-32; and Polish Revolution, 163-64; populist critique of, 343; and Roman advent, 33. See also events of 1812; French people; French Revolution; Louis XIII; Napoleon; Paris

Frederick II, the Great (King of Prussia), 147

Frederick III (Holy Roman Emperor), 27, 125

Frederick Wilhelm III (King of Prussia), 158

French people: Alexander I's desire to redeem, 156, 158; in lubki, 151-53, 152, 154; Shishkov on, 156. See also France

French Revolution, 16, 134, 146n2, 148-49, 335, 350

Freud, Sigmund, 325, 363

Fundamental Laws, 349

fur trade, 260, 264, 270

Gagarin, Prince G. G., 18, 19

Gagarin, Prince P. P., 305, 340

Galatea, 123

Gapon, Father, 250

Gasfort, General G. I., 286

Gasparov, Boris, 248, 379-81

Gasparov, Mikhail, 383

Gasprinskii, Ismail-Bey, 63

Gatchina, 249

Geertz, Clifford, xix, 36; on cultural performances, 366-67; and Moscow-Tartu school, 385-86; on theater state, 239, 366; and "thick description," 385

Gellner, Ernest, 28

genealogies. See mythical genealogies

General Staff Academy, 81n29, 93, 288, 290-91

General Staff headquarters, 240

Gennep, Arnold Van, 33

geography: and eighteenth-century expeditions, 254-55, 257; and Litke, 273, 282-83; and myth of empire, 133n30; "national approach" to, 283-84, 293; and Semenov/ Veniukov, 283-87, 289, 293. See also expeditions; Russian Geographical Society 
geology, 280, 285-86, 290-91

George (Saint), 131

Georgi, Johann Gottlieb, 51-53, 56, 133-34, 258

Georgians, 40, 42, 50, 54, 58, 66

Gergiev, Valery, 244

German idealism, 162, 293, 355-56, 360-61

Germany, 45, 373

Gershenzon, Mikhail, 356

Gillis, John R., 146n2

Ginev, V. N., 348

Ginzburg, Lydia, 356

Glass Factory (St. Petersburg), 225

Glazunov, Alexander, 69

Gleb (Saint), 13, 217

Glinka, Mikhail. See Life for the Tsar

Glinka, Sergei, 148-49, 160-61

Glory of Russia (expedition ship), 261

Gmelin, Johann-Georg, 254, 258

"God Save the Tsar," 76, 174-75, 244

Godunov, Boris (Tsar of Russia), 208

Gogen, Alexander, 218, 229, 230

Gogol, Nikolai, 89; Dead Souls, 304

Golenishchev-Kutuzov, Loggin, 262

Golgotha, 216

Golitsyn, Prince A. N., 155, 157

Golitsyn, Prince Lev, 77

Goloslavskaia, S., 78

Golovkin, Gavriil, 253

Golovnin, Alexander, 283, 293

Golovnin, Dmitrii, 278

Golovnin, Vasilii, 263, 274, 278, 283-84; Around the World on the Kamchatka, 269-70, 276; biography and career of, 269-70, 276; as model for other explorers, 276-77

Gorbunov, I. F., 89

Gorchakov, Mikhail, 171

Goremykin, Ivan, 351

Gospel Cover of Natalia Naryshkina, 119

Gots, Mikhail, 347

government. See state administration and government

Graf, Henry, 16, 17, 18, 55

Granovskii, Timothy, 361

grazhdanstvennost', 62-63, 201

Great Reforms (1860s), 297, 357-61, 373, 375, 391

Great Treasury Chancellery, 115

Grech, N. I., 151 
Greece (ancient), 272; and Catherine II, 52, 129-33; and cultural genealogies, 122; music of, 132-33; and Olenin, 105, 105n11, 137, 138; and origins of terms tsar/autocrat, 124-25; in poetry/drama of eighteenth century, 129-30; in Solntsev, 111. See also neoclassicism

Greek Project, 104, 105n11, 129-31, 137

Greek war of independence (1821), 270, 279

Green Vault (Dresden), 105

Grigor'ev, Vasilii, 60-61

Grodno, 95

guards' regiments, 34, 188, 242, 248, 285; in coronations, 5-7, 10, 19, 23, 36, 49; in lubki, 182, 184, 205, 207; and Napoleonic Wars and commemorations, 172n51, 174-77, 284; uniforms of, 5, 19, 23, 194. See also Cavalier-Guards

Gudzii, N. K., 320

Gukovskii, G. A., 378

Gurko, I. V., 227

Gusev, 223, 224

Habermas, Jürgen, 123

Haimson, Leopold, 389, 393-96; Russian Marxists, 356, 394

Hapsburg Empire, 39, 158; and constitutionalism, 373; and Crimean War, 171; as Kulturstaat, 122; and mythical genealogies, 30, 124

Hawaii, 269

Hegel, Georg Wilhelm Friedrich, 297, 355, 360-61

heirs, 128, 161, 201; education of, 90, 361, 371, 373; in Elchaninov, 83, 90; in lubki, 184,

185, 186, 194, 196; psychological analysis of, 361-64

helmets, 105n13, 106, 117, 137-38, 143, 240. See also under Alexander Nevskii

Helsinki Slavonic Library, xviii, 367

Henri IV (King of France and Navarre), 364

Hercules, 34, 117, 131, 143, 152

Hermitage Theater, 132

Hermogen, Patriarch, 79

Héroard, Jean, 364

Herodotus, 50

Heroic Exploits of Russian Naval Officers (Nevel'skoi), 281

heroic history, 29, 367-68, 373

heroic space, 180, 189-97, 190, 192-93, 195-96, 200

Herzen, Alexander: and 1812 events, 170, 172; Letters on the Study of Nature, 288; on Petersburg, 239; and property rights, 333, 336, 342, 344; Who Is to Blame?, 288

His Majesty's Rifles, 43, 59-60, 73, 93, 235

historicism, 106, 121, 138, 382. See also Russian national esthetic

history: and memory, 146n2; Nicholas II's devotion to, 88-89; psychology applied to, 356-58, 360-65; semiotics of, 369-70, 381-86; and subjective factor, 358. See also heroic history

hoard of Riazan. See Riazan 
Hobbes, Thomas, 27, 267

Hocart, A. M., 33

Holy Ampulla, 31

Holy Roman Empire, 33, 124-25

Holy Synod, 75, 81, 172, 187, 225, 320, 373

Hope (expedition ship), 276

Horner, Johann Kaspar, 265

Horse-Guards regiment, 177

Hugo, Victor, 360

Humboldt, Alexander von, 282, 285-89, 293; Cosmos, 287, 288; Pictures of Nature, 288, 291

Hurst, J. W., 339n15

Iakuts, 50, 262

Iaroslavl, 126, 213, 235. See also Moscow-Iaroslavl style

icons: Antony of Pechera, 95; Fedorov Mother-of-God, 235, 236; Mother-of-God of the Joy of All the Grieving, 218, 225; Pochaev Miracle, 233; Saints Boris and Gleb, 217; Serafim, 236; Smolensk Mother of God, 177; St. Sergei, 171; “Tenderness," 236; Tercentenary, 81

idealism. See German idealism

Ignatii (Arkhimandrite), 214, 216n20

Igor Sviatoslavich (Prince). See "Lay of the Host of Igor"

Iliodor (monk at Pochaev Monastery), 233

Illustration, L', 88

illustrations. See coronation albums; engravings; lithographs; lubki; representational culture imperator: Peter I adopts title of, 34, 47-48, 125; and Roman advent, 33. See also Russian monarch; tsar

Imperial Academy of Arts. See Academy of Arts

imperial family: and culture, 365; in Elchaninov, 85, 86-87, 90; and European myth, 373; and Fedorov village, 237; in film, 77,77n11; in lubki, 184, 185, 186; and non-Russian peoples, 40-41, 54; published portraits of, 80; souvenirs of, 72, 75. See also heirs; Russian monarch

imperial image. See Reign of the Sovereign Emperor Nicholas Aleksandrovich

imperialism: and church architecture, 229; and coronations, 64; and expeditions, 292, 294.

See also colonialism; empire

imperial myth. See mythical narratives

Imperial Public Library, 103, 137

imperial trips. See ceremonial trips

Indépendance Belge, L', 41-42, 58-59

India, 231-32

Indo-Saracenic style, 232

inkwell of Tsar Michael (Solntsev), 119

Inokentii, Archbishop, 169

institutions. See state administration

Instruction to the Legislative Commission (Nakaz; Catherine II), 36, 127, 134, 256 
intelligentsia: and expeditions, 293; Haimson on, 394; and Moscow-Tartu school, 380-81; and peasantry, 321, 342; and property rights, 333-34, 342, 345-46; psychological analysis of, 355-57; Raeff on, 360, 391. See also liberal Slavophilism

Irving, Washington, 289

Isidore (Metropolitan of Petersburg and Novgorod), 202

Islam. See Muslims

Italy. See Rome (modern-day)

Itinerants. See peredvizhniki

Iur'ev Monastery, 233

Ivan III (Tsar of Russia), 27-28, 44, 60, 125, 197-98

Ivan IV, the Terrible (Tsar of Russia), 30-32, 33, 44, 60, 208

Ivanov, A. V., 218

Ivanov, Ivan Alekseevich, 106, 151, 153, 182; "Russian Scaevola," 152

Ivanov, Viacheslav, 378

Ivanovo-Voznesensk (Church of the Savior), 217n23, 223

Ivan V (Tsar of Russia), 34

Izbornik (1073), 109-10, 140

Jakobson, Roman, 378, 380

Japan, 269, 276, 294. See also Russo-Japanese War

Jerusalem, 156, 216, 231

Jesus Christ, 160, 168, 194, 216, 216n20, 338. See also Resurrection

John I Tzimisces (Byzantine Emperor), 110, 111

Joseph II (Holy Roman Emperor), 130

Jouhaud, Christian, xix, xixn6

journals. See expedition journals; periodical press

judiciary, 358-61, 376

Julius Caesar, 124

Justinian I (Byzantine Emperor), 36

Kääriku, 379

Kadets (Constitutional Democratic Party), 333, 348-50

Kafka, Franz, 387-88

Kaganov, Grigorii, 384

Kalish, 165

Kalmyks, 40, 50, 53, 54, 62, 65, 69

Kaloshes, 272

Kaluga, 44

Kamchatka, 170, 254-55, 268-71, 276, 279, 281

Kamchatka (expedition ship), 269, 270, 276, 278

Kamer-fur'erskii zhurnal, 4

Kankrin, Egor, 339

Karamzin, Nicholas, 161, 167, 285, 360; Letters of a Russian Traveler, 278; Memoir, 337

Karazin, Nikolai, 21 
Karpovich, Michael, 390

Kasinec, Edward, xviii, 367

Katkov, Mikhail, 62, 338

Kavelin, Constantine, 361

Kazan, 12, 32, 33

Kazan Cathedral (St. Petersburg), 235

Kazan school (of linguistics), 378

Khanzhonkov, Alexander, 78-79

Kheraskov, Mikhail, 129

Kherson, 38, 130

Khitrov market, 323-24, 328

Khodynka massacre, $\mathrm{xx}, 84$

Khomiakov, N. A., 310

Khvorovstovskii, Dmitrii, 248

Kiev, 102, 164. See also Rus'; Sofia Cathedral

Kievan princes. See Oleg; Riurik; Rus'; Sviatoslav; Vladimir

Kiev Monastery of the Caves, 220

Kiprenskii, Orest, 106

Kireevskii, Ivan, 300

Kirghiz, 39, 40, 50, 54, 60-61, 67

Kirichenko, Evgenia, 112, 189

Kirikov, B. M., 214

Kirilov, Ivan, 256

Kiselev, Count, 337

Kistiakovskii, Bogdan, 333

Kittlitz, Friedrich Heinrich, 271

Kivelson, Valerie, 120

Kmelnitskii, Bogdan, 164

Knabe, George, 37

Kodiak Island, 260, 267, 269

Kohut, Heinz, 363

kokoshniki: in architecture, 214, 214n 18, 217, 218, 220, 222, 223, 227, 231; in attire, 41, 43, 55, 59; defined, $214 \mathrm{n} 18$

Komarov, Vissarion, 64

Koshelev, Alexander Ivanovich, 297-303, 305-11, 313-16, 318-19; biographical background of, 300; denounces bureaucracy, 306-9; and Editing Commission, 302-3, 305-6; and gentry constitutionalism, 307-11; splits from other liberal Slavophiles, 308, 310

Kostroma, 189, 190

Kotzebue, Auguste von, 265

Kotzebue, Moritz von, 265

Kotzebue, Otto von, 265, 268

kovrovost', 112-13

Kozlovskii, Josef, 248 
Kozyrevskii, Ivan, 254

Kramskoi, Ivan, 21

Krasheninnikov, Stepan, 254, 258

Kremenchug, 39

Kremlin (Moscow): Alexander I visits, 149; Alexander II is born in, 161; and Antiquities of the Russian State, 115, 117; during coronations, 5, 10, 12, 16, 35-36; as symbol of Russia's national past, 112. See also Annunciation Cathedral; Assumption Cathedral; Moscow; New Kremlin Palace

Kremlin (Novgorod), 197, 203

Kremlin Armory, 106-7, 108, 113, 139

Kremlin Table Service, 112-13

Krichinskii, Stepan, 233-35, 234

Kristeva, Julia, 381

Krivenko, Sergei, 321

Krusenstern, Adam Johann von, 263, 270, 277, 278, 283, 293; expedition and journal of, 260n $18,264-68,274-76$

Krushevskii, N. V., 378

Kryzhanovskii, Sergei, 80

Kseniia Ioannovna (Martha; mother of Michael Romanov), 76

Kulikovo, Battle of, 197

Kulturstaat, 122

Kurbatov, V., 232

Kurile Islands, 254

Kutler, N. N., 349

Kutuzov, Mikhail, 156, 167, 168, 177, 287

labor, 321, 324, 329-32

La Harpe, Frédéric César de, 36

Langsdorff, George Heinrich von, 265-68, 276

"Last Descendants of Aeneas," 124

Lavrov, Peter, 343, 346

law: and Alexander III, 179, 374; and Catherine II, 256; codification of, 115, 141, 159, 359, 390; and mythical narratives, xvii; and Nicholas II, 86; nobility's devotion to, 360-61;

Tolstoy criticizes, 331. See also Complete Collection of Laws; court reform; judiciary; property rights

Law Code (1649), 359

Law of Succession, 124, 128. See also succession

"Lay of the Host of Igor," 105n13, 137

Lazarev, Mikhail, 263, 274

Le Fort, Marshal, 34

legality, 359, 375. See also court reform; judiciary; law

"Legend of Andrew the First-Called," 216

"Legend of Monomakh," 30-32, 33, 35, 116, 125, 141-42, 216. See also Monomakh Cap;

Vladimir II Monomakh 
Leibniz, Gottfried Wilhelm, 254

Leipzig, 157, 308

Lenin, Vladimir Il'ich, 356; Two Tactics of Social Democracy, 350. See also Marxism

Leningrad Institute of History. See St. Petersburg Institute of History

Leningrad State University, 358, 378-79

Leo VI (Byzantine Emperor), 129, 131

Le Prince, Jean, 257

liberalism: and Alexander III, 373; and expeditions/empire, 294; and Nicholas I, 134, 162; and Nicholas II, 178, 375; and property rights, 334, 336, 350, 351

liberal Slavophilism, 297-319; and constitutionalism, 306, 308-11, 314-19; as devoted to narod, 297-300, 312, 315; and Editing Commission, 302-6, 308, 310, 312-13; factions and divisions in, 305-8, 310-11, 316, 318-19; failed legacy and neglect of, 297-99, 318-19. See also Cherkasskii; emancipation; Koshelev; Samarin; Slavophilism Liebig, Justus, Baron von, 288

Lieven, Dominic, 145, 150-51

Life for the Tsar (Glinka), 21, 24, 66, 76, 95, 135

"Life-Giving Cross," 30, 33

linguistics: and Moscow-Tartu school, 369, 378, 385

Linnaeus, Carolus (Carl von Linné), 258, 285

Lisianskii, Iurii, 263, 265-68, 274, 276, 278

lithographs, 200, 287; in Antiquities of the Russian State, 114, 141; in coronation albums, 3 , $16,19,21,24,64 ;$ and lubki, 181, 183, 191-92

Lithuania, 164, 315

Litke, Fedor Petrovich, 269, 276, 280, 293; Autobiography, 277-78; biography and career of, 270-73, 277-79; contrasted to younger generation of explorers, 282-84; Voyage Around the World, 270-73, 279, 288

Liubimov, D. N., 65

Livingstone, David, 291

Loman, Captain N., 236n66

Lomonosov, Mikhail, 132; "Brief Description of Various Voyages," 259; "Peter the Great," 259,261

Lotman, Iurii, 378-85; biography and early career of, 378-79; on early Russia, 384; as founder of Moscow-Tartu school, 369, 379; on lubki, 181; on nobility, 370, 383; on Petersburg, 383; on "return to history," 382; and semiotics of culture and history, 370, 381-86; on "summer school," 379; on theatricality, 126, 181, 383; Western reception of, 381. See also Moscow-Tartu school; semiotics

-Works: Lektsii po struktural'noi poetike, 381; "Role of Dual Models," 384; "Text and Function," 382

Lotman Conferences (Lotmanovskie chteniia), 370

Louis XIII (King of France), xix, 363-64

Louis XIV (King of France), 123

Louis XV (King of France), 6, 7

Louis XVI (King of France), 158

love. See scenario of love 
Love for the Fatherland, 179

Lowe, Charles, 62-63

lubki, 180-97; and Alexander I, 153-55, 155, 182; and Alexander II, 184-87, 185-86, 193, 195-96, 205, 205-7, 206; censorship and restrictions of, 183; and Crimean War, 169-70; definition and origins of, 181-82; and emancipation of the serfs, 180-81, 187-97, 193, 195-96, 207; and events of 1812, 151-55, 152, 154-55, 172, 182; and film, 78; French soldiers in, 152, 152-53, 154; as imitated by professional artists, 151, 182; and imperial family as symbol, 184, 185-86; and Millennium Monument, 200, 205-6, 205-7; Napoleon in, 152-53, 182, 184; under Nicholas I, 183-85, 185; as political graphics, 182-83; theatrical playfulness of, 181; as visual nationalism/ patriotism, 151, 153. See also under peasantry; Russian people

Lukes, Steven, xviii

Lukomskii, George, 235

Lutheranism, 226

Luzhin, Fedor, 254

L'vov, Nikolai, 132-33

L'vov, Prince Alexei, 244

Macarius, Metropolitan, 30-31

Maikov, Apollon, 217n21

Maikov, Vasilii, 129, 144

Maiofis, Maria, 132

Maiorova, Olga, 164

Makarov, Ignatii (Arkhimandrite), 214

Makarov, M. N., 53

Makovskii, Konstantin, 21, 24

Maksimov, Vladimir, 236

Malyi Theater, 76

Manasein, Nikolai, 226, 231

maps. See cartography

Maria Aleksandrovna (Empress; wife of Alexander II; née Princess Maximilien of HesseDarmstadt), 43, 57, 188, 203; in coronation album, 19, 20; in lubki, 184, 186, 194

Maria Fedorovna (1) (Empress of Russia; wife of Paul I; née Sophie Dorothea of Württemberg), 160-61

Maria Fedorovna (2) (Empress of Russia; wife of Alexander III; née Princess Dagmar of Denmark), 21, 174

Mariinskii Theater, 76

Marin, Louis, xvii, xix, 124

Mars (Roman god), 34

Marseillaise, 174

Martha (Kseniia Ioannovna; mother of Michael Romanov), 76

Martin, Alexander, 148

Martos, Ivan, 106

Martov, Julius, 356 
Marvick, Elizabeth Wirth, 363-64

Marxism, 297, 355, 358; Haimson on, 356, 394; vs. Moscow-Tartu school, 369, 377, 381; and populism, 345-46; on private property, 350-51

masquerades: in coronation albums, 9-10; and exotic peoples at coronations, 41, 43-44, 50, 54-55, 59-60; as image of empire, 43, 50, 55, 59; semiotics of, 383

Masson, Carl, 132

Matiushkin, Fedor, 269, 276

McCauley, Mary, 365

McLean, Hugh, 394

Meck, Madame von, 244

Melikov-Zardobi, Hasan, 63

memory: definitions of, $146 \mathrm{n} 2$; and psychological approach to history, 357; in relation to imperial myth, 145-46. See also events of 1812

Mengden, Georg, 256

Mensheviks, 350

merchantry, 126, 148, 369; and architecture, 211, 232; during coronations, 38, 41, 49, 51, 54; and expeditions, 260-61, 264-65, 270, 275

Mertens, Karl Heinrich, 271

Metropolitan Opera, 248

Michael Aleksandrovich (Grand Duke of Russia; son of Alexander III), 233

Michael Fedorovich (1st Romanov; Tsar of Russia): in film, 78; in Glinka's Life for the Tsar, 76, 135; helmet of, 106, 143; inkwell of, 119; and Ivan Susanin Monument, 189, 190; and Millennium Monument, 197, 207; and Nicholas II, 73-74, 83-84, 175; on postage stamp, 74; regalia of, 116-17, 118, 142; on Tercentenary Ruble, 73, 73-74; in theater, $76 \mathrm{n} 7$

Michael of Tver (Saint; Grand Prince of Vladimir), 201n27

Middendorf, Alexander, 280, 282

Mikeshin, M. O., 198-200, 199

Mikhailovskii, Nikolai, 333, 344, 346

Mikhailovskii-Danilevskii, Alexander, 167

military. See guards' regiments; uniforms

Miliukov, Pavel, 350

Miliutin, Dmitrii, 44, 188, 359

Miliutin, Nicholas, 303-5, 307

Mill, John Stuart, 348, 355

Millennium. See Monument to the Millennium

Miloradovich, Count G. A., 43

Mincus, Ludwig, 66

Minin, Kuzma, 19, 106, 148, 198, 207

Ministry of Education, 136, 361

Ministry of Finances and Foreign Affairs building, 240-42

Ministry of Interior, 179, 187-88, 201, 225, 311, 312, 374

Ministry of Justice, 246, 361

Ministry of the Court, 23, 75-76, 101, 136 
Mints, Zara, 379, 383

Mogil'ner, Marina, 383

monarchy. See Russian monarch

Mongols, 256, 292

Moniteur Universel, 188

Monomakh Cap, 30, 33, 35, 73, 116, 116-17, 141-43. See also Constantine IX Monomakh; "Legend of Monomakh"; Vladimir II Monomakh

Monomakh regalia. See under regalia

Mont Aimé ceremony (1815), 158-60, 165

Montferrand, Auguste Ricard de, xx, 165, 240, 240

Monument to Ivan Susanin (Kostroma), 189, 190

Monument to Minin and Pozharskii (Red Square), 19, 106

Monument to the Millennium of Rus' (Novgorod), 180, 197-207, 199; ceremonial dedication of, 201-7, 204n37; description of, 197-200; and lubki, 200, 205, 205-7, 206; and Slavophiles, 200-201. See also under nobility; Russian people

Moraitis, George, 362

Mordvinov, Count Nikolai, 265

Morozov, A. V., 189

Moscow: and 1812 events/memorials, 84, 147-49, 151, 155, 157, 164, 170-71, 173, 176; Alexander I's visits to, 148-49, 161; Alexander II's birth in, 161; Alexander II's visits to, 171, 188, 194; Alexander III's emphasis on, 66; burning of, 155, 157, 164; and coronations, 4-5, 9-10, 19, 28, 49, 54, 63, 66, 70, 191, 371-72; in Life for the Tsar, 76; and lubok publishing, 183; and Millennium Monument, 198; Nicholas I's emphasis on, 120; Nicholas II's emphasis on, 70; as protector of Orthodoxy, 28; as subordinate to Petersburg, 35; and Tchaikovsky, 238; and Tolstoy, 320-24; triumphal entries in, 10, 33-36, 371. See also Kremlin; Muscovy

Moscow-Byzantine style, 104, 139, 166, 209, 227

Moscow-Iaroslavl style, 214, 218-20, 223, 226, 229

Moscow-Tartu school, 27, 377-86; as 1960s "communitas," 380; and anthropology, 38586; criticism of, 379-80; defined, 377; development and origins of, 377-81; embraces semiotics of culture and history, 369-70, 381-86; human agency and political history avoided by, 385; and Jakobson, 380; and Lotman Conferences (Lotmanovskie chteniia), 370; newest generation of, 386; and nezdeshnost', 379; as "return to history", 382; and secondary modeling system, 381; and semiotics as means to national self-discovery, 382, 386; summer schools of, 379-80, 382; and "text of culture," 382; Western reception of, 381, 385. See also Lotman; semiotics; Trudy po znakovym sistemam

Moscow University, 358, 361, 378

Moscow-Vladimir style, 166-67

Moskovskie vedomosti, 62, 79, 178, 204n37, 213

Mother-of-God of the Joy of All the Grieving (icon), 218, 225

Müller, C. W., 134

Müller, Gerhard Friedrich, 254-55, 258

Murav'ev, Mikhail, 283, 286

Murav'ev, Nikolai, 281-82, 288 
Muscovite ornamentalism, 120, 142. See also ornamentation

Muscovite style. See Moscow-Iaroslavl style

Muscovy: and Alexander III, 21, 46, 173-74, 211, 249, 374; and Antiquities of the Russian State, 115, 120; and architecture, 102, 211, 213, 226, 231, 235, 237; and Nicholas II, 46, 374; semiotics of, 384; and triple bow, 163. See also pre-Petrine Russia

music: at coronations, 66, 69-70; in Greece and Russia compared, 132-33; and Nicholas II, 75-76, 75n7, 88. See also Catherine II, Primary Reign of Oleg; folk melodies; "God Save the Tsar"; Life for the Tsar; polonaise; Tchaikovsky

Musin-Pushkin, Count A. I., 101, 102n3, 105n13, 137

Muslims, 53, 55, 55, 129, 170, 292

Myshetskii, Prince, 202

mythical genealogies, 30, 122, 124, 136

mythical narratives and scenarios (of monarchy): coronation albums as statement of, 3 ; and coronations as defining ceremony of imperial power, 48, 70; defined and explicated, xvii-xxi, 368-75; and Elchaninov, 83-84, 96-97; Geertz on, 367, 385-86; and heroic history, 29, 367-68; and idea of empire, 27-29, 36, 47, 133; and lubki, 180, 187, 207; and memory, 145-46, 146n2; and Muscovy, 46; as shaped by culture (theater/ architecture), 122-25, 130, 143-44, 146, 208. See also conquest myth; coronations; empire; European myth; events of 1812; foreignness; National Myth; Official Nationality Doctrine; representational culture; Russian monarch; Russian national esthetic; Russian national style (in architecture); scenario of love

Nabokov, Vera, 387

Nabokov, Vladimir, 387-88

Nadezhda (expedition ship), 265

Nakaz. See Instruction to the Legislative Commission

Napoleon I (Bonaparte; Emperor of France), 78, 84, 270, 273, 279; and 1812 memorials/ evocations, 145, 149, 150, 157, 163-64, 167-69, 172n51, 174, 177, 240, 287; in lubki, 152-53, 182, 184; and Shishkov, 147, 156; in Tchaikovsky, 174. See also events of 1812 Napoleonic Wars. See events of 1812 narod (people), 297-99. See also peasantry; Russian people narodnost', 101, 121, 201

narratives. See mythical narratives Natalia Kirillovna Naryshkina (Tsaritsa of Russia; wife of Alexei Mikhailovich), 119 national anthem, 174, 244. See also "God Save the Tsar"

National Assembly (France), 335, 350

national identity/spirit: and events of 1812, 160-65, 172, 175; and expeditions, 255, 258, 273, 283-84, 293-94; and lubki, 180-81, 183; and Millennium Monument, 197, 201; Solntsev embodies, 121; and Tchaikovsky, 175, 243-44. See also national myth; Russian national esthetic; Russian national style (in architecture)

nationalism: and Alexander III, 64-65, 373-74; and lubki, 151, 153; and memory, 146n2; and Nicholas II, 88; and Shishkov, 147. See also national identity; national myth; Official Nationality Doctrine

nationalities. See non-Russian peoples 
national myth: and architecture, 173, 210, 223, 229, 231-32, 237; and coronation ceremonies, 41, 54, 63; defined, 372-74; and Nicholas II, 71. See also under Alexander III

national style. See Russian national esthetic; Russian national style (in architecture)

natives (and Russian expeditions): of Africa, 294; of Alaskan islands, 267-69; Cook's attitude towards, 263; Golovnin on, 269-70, 276; and Krusenstern's voyage, 26668; and Litke, 271-72, 279; of Nukahiwa, 266-67; Sarychev on, 262; Semenov on, 284; Shelekhov on, 260-61; of Sitka, 272; and Veniukov, 289. See also non-Russian peoples; Russian-American Company

naturalists/scientists (on expeditions): in eighteenth century, 253-55, 257-58; Georgi, 257-58; Litke, 270-73, 277-79, 282-83; in nineteenth century, 263, 265-66, 27073, 275, 277-80, 282-93; Przheval'skii, 290-93; and science as expression of national identity, 283-84, 293; Semenov and Veniukov, 283-89. See also botany; geography; geology; Gmelin; Humboldt; Langsdorff

Naval Cadets Corps, 264, 274, 276, 278

Nechaev-Maltsov, N. C., 223

Nedelia stroitelia, 213

Nekliudov, S. Iu., 377, 379

Nelson, Admiral Lord Horatio (1st Viscount), 264, 269, 276

neo-Byzantine style, 104, 139, 217, 223, 229

neoclassicism: and architecture, 103-4, 138-39, 160, 166-67, 209, 211, 218; and European myth, 146; and Ivan Susanin Monument, 189; and lubki, 152; Olenin/Solntsev fuse with Russian traditions, 104-11, 120, 136-42; in poetry/drama of eighteenth century, 129-30; and St. Petersburg, 120, 238-39. See also Greece; Roman Empire; Thon

neo-Russian style, 232

Nesselrode, Count Karl, 281

Neva (expedition ship), 265, 276

Nevel'skoi, G. I., 288, 289; expedition of, 280-82; Heroic Exploits of Russian Naval Officers, $281,281 \mathrm{n} 21$

Nevskii helmet. See under Alexander Nevskii

New Jerusalem Monastery, 102, 135

New Kremlin Palace, 43, 59, 104, 112-13, 121, 139

newspapers. See periodical press

New York Daily News, 388

New York Public Library (Slavic and Baltic Division), xviii, 4, 9, 367

New York Times, 67

New York Tribune, 82n30

nezdeshnost', 379

Nicholas Aleksandrovich (Tsarevich of Russia; son of Alexander II), 45, 62, 184, 185, 186, 188,201

Nicholas I (Emperor of Russia), 43, 59, 87, 126, 336, 390; and Academy of Arts, 101, 135-36; and Alexandrine column, 165, 242-43; and Antiquities of the Russian State, 114-15, 120, 122, 140-41; and architecture, 102-4, 135-36, 138-39, 144, 164-67, 208-9, 213, 217; and Borodino Battlefield Memorial, 168, 175; and codification of 
laws, 115, 141, 359-60; coronation and album of, 4, 16-18, 17, 40-41, 53-56, 55, 163, 371-72; and Crimean War, 168-69, 171; and cult of 1812, 160, 162-69, 175; and expeditions, 273, 276-77, 279-80, 288, 293; in film, 78; and Glinka's opera, 135; and lubki, 183-84, 185; and manifesto sentencing Decembrists (1826), 134, 162; and non-Russian peoples, 40-41, 53-56; and Olenin, 101, 103-4, 136-40; oversees publication of history of Napoleonic Wars, 164, 167; and Solntsev, 107-8, 112-14, 120-21, 139; and starina, 107, 138; and Varangian myth, 368. See also under autocracy; Official Nationality; Russian national esthetic; Russian national style (in architecture); Russian Orthodox Church; Russian people; westernization

"Nicholas I Crossing the Danube" (lubok), 185

Nicholas II (Emperor of Russia), 46, 249, 334, 372; abdication of, 374; and Bloody Sunday, 250; and Borodino centenary celebrations, 175-79, 178; and commemorative coins and postage stamps, 72-75; contributes to and revises Elchaninov, 82-83; coronation and album of, xx, 4, 23-24, 25, 66-70, 68-69, 73, 83; and Duma, 9698; in Elchaninov, 81-98, 88, 88n49, 91, 94; and expeditions, 294; and Fedorov village, 235-37; and film, 76-79, 77n11; and history, 88-89; as huntsman, 87-88, 88; and imperial family, 85, 86-87, 90, 91, 225; and Khodynka massacre, 84; and non-Russian peoples, 66-70; and periodicals, 79-81; and Peter I, 84, 93; publicizes imperial image, 71-98; and souvenirs, 72, 75; and theater/opera, 75-76. See also under autocracy; constitutionalism; periodical press; Reign of the Sovereign Emperor Nicholas Aleksandrovich; Revolution of 1905; Russian Orthodox Church; Russian people; state administration; tercentenary celebrations

Nietzsche, Friedrich Wilhelm, 355, 369

Night and Day (Petipa; Mincus), 66

nihilism, 383

Nikolaeva, T. M., 379, 380

Nikon, Bishop, 75

Nikon, Patriarch, 102, 135

nobility: and 1812 events, 147-48, 151; and agro-literate society, 28-29; and architecture, 223, 232; during coronations, 35-36, 39-41, 48-51, 54-57, 59-60, 65, 70; and Editing Commission, 302-6, 308; and emancipation, 187; and expeditions, 264, 274, 277, 282-84, 287, 293; and gentry constitutionalism, 306, 309-11, 318; and imperial trips, 38-39; and legal reform, 360-61; and liberal Slavophilism, 298312, 315-16, 318; and Millennium Monument, 201-2, 204; non-Russian peoples assimilated into, 29, 37-39, 52-53, 56, 62-63; Peter I establishes and westernizes, 123-24, 143-44, 146, 245; and property rights, 334-37, 340-42, 347-48, 350-51; Raeff on, 245, 337, 360, 391; romantic hero as model for, 360; semiotics of, 369-70, 383; and Tchaikovsky, 245-46; and theater, 126-27, 129-30. See also under Baltic states; state service

Noble Cadet Corps, 126, 287

non-Russian peoples (of Russian Empire): and Alexander I, 39; under Alexander II, 41-44, 56-63, 372; under Alexander III, 63-66, 372; as Asiatic and exotic, 47; assimilated into Russian nobility, 29, 37-39, 52-53, 56, 62-63; before Catherine II, 50-51; under Catherine II, 37-39, 51-53, 133-34; and church architecture, 225-29; and 
citizenship, 62-63; and colonialism, 40, 45, 63-64; as colorful warriors, 56-59, 372; at coronations, 38, 40-44, 49-51, 53-61, 55, 58, 63-70, 68-69; as ethnically alien (inorodtsy), 65; Georgi on, 51-53, 133-34, 258; as horsemen, 39, 42, 56-57, 59, 61, 67, 68, 70, 372; and imperial trips, 38-39; and love scenario, 44, 56, 59-62, 372; and masquerades, 41, 43-44, 50, 54-55, 59-60; under Nicholas I, 40-41, 53-56; under Nicholas II, 66-70, 89, 96; as objects of curiosity, 44, 50, 53; as ornaments and trophies, 39, 44-45, 54-56, 62, 143; Russian superiority and disdain towards, 64-65; as symbol of imperial power, 40, 42, 58-59; and territorial consciousness, 51. See also Baltic states; enlightenment; natives (and Russian expeditions)

Nora, Pierra, $146 \mathrm{n} 2$

Nord, Le, 41, 43, 58, 59

Norman princes, 109, 128

Norris, Stephen, 151, 170, 183

North America (Russian expeditions to), 262, 264, 269-72, 289; Bering discovers coast of, 254; Russian settlements in, 260, 266, 270-71, 276, 293

Northeast Passage, 255, 259, 265

Northern War, 34, 253

North Pacific, 254, 259-76, 279, 289, 293

Northwest Coast. See North America

Novaia Zemlia, 270, 277

Novgorod, 108, 139, 197, 198, 236, 368. See also Monument to the Millennium

Novoe vremia, $67,74,80 \mathrm{n} 20,88$

Nukahiwa, 266-67

Numa Pompilius (King of Rome), 36

Nystadt. See Treaty of Nystadt

Obninskii, V. P., 349

Obruchev, N. N., 342

Obvodnyi Canal. See Cathedral of the Resurrection

O'Connell, Lauren, 212

Octobrists, 351

Odessa, 130, 169

Odom, Anne, 113

Oedipal conflicts, 363-64, 363n 14

Official Nationality Doctrine: and 1812 events, 162, 165, 168, 172; and Antiquities of the Russian State, 115, 141; and church architecture, 208-10; and expeditions, 273; and Millennium Monument, 197; Solntsev epitomizes, 121; and Tchaikovsky, 243-44; and Varangians, 134. See also national identity

Ogarev, Nikolai, 342

Ob, Quiet Light (Bezpiatov), 76

oil of Clovis, 31-32

Okhotsk, 254, 260-62, 264, 271, 275, 279, 281

Oldenburg, Prince Peter, 360

Oleg (Grand Prince of Kiev; founder of Rus'), 129, 131, 133, 142, 240 
Olenin, Alexei, 101-12, 137-41; and Antiquities of the Russian State, 114, 117, 119, 140-41, 143-44; and artifacts, 105-6, 108-10, 137-39; biography and career of, $101,103,105$; on clothing as symbol of culture, 109-10, 119; fuses classicism with Russian traditions, 104-6, 108-10, 120, 137-40; and Greek Project, 104-5, 105n11, 137; and helmets, 106, 137-38; Letter to Count A. I. Musin-Pushkin, 105n 13, 137; and Nicholas I, 103-4, 137-39; and patriotism of 1812, 151; proposes ethnographic publication (1841), 114, 114n37, 140, 140n49; publishes volume for ethnographic course (1832), 108-9, 140; and Russian empire style, 106, 138; Solntsev as protégé of, 101-2, 107, 110-12, 138-39; and Thon, 104, 104n9, 138, 138n42; and Winckelmann, 105, 137

onion domes. See under cupolas

On the Taking of Warsaw, 163

opera. See Catherine II, Primary Reign of Oleg; Life for the Tsar; music; Tchaikovsky

Opisaniia. See coronation albums

orb and scepter: in coronations, 5, 7, 21, 36; in Solntsev's Antiquities, 116-17, 142. See also regalia

Orenburg, 39

Orlov, Alexei, 129-30

Orlov-Davydov, Count V. P., 303

Orlovskii, Boris, 241

ornamentation: of pre-Petrine architecture, 211-12, 214; of Solntsev's illustrations, 120, 142. See also decoration; Muscovite ornamentalism

Orthodoxy. See Russian Orthodox Church

Ostankino, 218

Otechestvennye zapiski, 16, 40-41

Ottoman Empire, 102

Ozerov, Vladislav, 137

Pacific Ocean. See North Pacific; South Pacific

paintings: of coronations, 19, 21; and mythical scenarios, xviii-xix. See also watercolors

Palace of Facets (Moscow Kremlin), 5, 12

Palace Square, 165, 166, 188, 239-42, 240

Pallas (expedition ship), 261

Pallas, Peter Simon, 257-58, 288

Paperno, Irina, 383

Paris: Alexander I's prayer service in, 158, 159; Alexander I's triumphal entry into, 155, 155; architecture in, 240, 242; French monarchs' coronations/triumphal entries in, xix, 6; and Napoleonic wars, 85, 163, 171. See also France

Parland, Alfred, 214-16, 215, 221

parliamentary government. See constitutionalism

Partridge, Loren, 218

patriotism: and 1812 events, 147, 153, 175, 182; of clothing during coronations, 41, 55; and Crimean War, 171; and expeditions, 281, 287; and Glinka, 135; and lubki, 153, 182-83; and Nevskii helmet, 106; and Tchaikovsky, 175 
Paul I (Emperor of Russia), 15, 39, 126, 259, 265, 275

Paul the Apostle (Saint), 340

Pavel Aleksandrovich (Grand Duke of Russia; son of Alexander II), 82n31

Peace of Paris, 41, 171

peasant commune, 93; as embodiment of autocracy, 339, 341; and property rights, 334, 341-44, 347, 349. See also populism

peasantry: and 1812 events, 148, 150-53, 169, 176-78, 182; and Bloody Sunday, 249-

50; clothing of, 119-20; and coronations, 19, 24, 43, 59-60, 66, 372; in Glinka, 135; as idealized, 356-57; included in coronation procession for first time, 372; and liberal Slavophilism, 299, 301-3, 306, 309, 311-12, 316, 319; and lubki, 151-53, 169, 182, 191-97, 193, 196, 200; and Millennium Monument, 200, 203, 204n37, 207; and Nicholas II, 71-72, 92-97, 176, 178; and Official Nationality, 243-44; and printed word, 80; and property rights, 334, 336-37, 340-45, 347-51; Tolstoy on, 321; uprisings of (1905), 334, 374; viewed as grateful for emancipation, 187-89. See also emancipation; Monument to Ivan Susanin; narod; Russian people people. See peasantry; Russian people

People's Will, 344

peredvizhniki (Itinerants), 21

periodical press: on 1812 events, 151, 164, 169-71; as ceremonial text, xvii-xviii, xx, 370; on church architecture, 213; circulation growth of, 79n20, 96-97; and coronations, 5, 16, 40-43, 56-59, 63-64, 67-68, 70; and emancipation propaganda, 188; as interpreter of ceremonies, xx; and liberal Slavophiles, 298, 300, 302; on Millennium Monument, 201, 203-4; on Moscow-Tartu school, 378; Nicholas II's relationship to, $72,75,79-81,79 \mathrm{n} 20,82 \mathrm{n} 30,88,96-97,178$; on Polish uprising, 62

Peshekhonov, Alexei, 347-48

Peterhof, 93, 120, 176, 220n30. See also Fedorov Village; Peter-Paul Cathedral

Peter I, the Great (Emperor of Russia), xx, 75n7, 120, 125n9, 208, 317, 391; and Alexander I, 146, 147; assumes title of imperator, 47, 125; and cartography, 255-56; and Catherine I's coronation, 3, 4-6, 35, 48-49, 116, 142; establishes service nobility, 123, 245, 335-37; and expeditions, 51, 253-56, 274; as hero, xvii, 34, 124, 146, 370; and Millennium Monument, 197-200, 206; and Nicholas II, 71-72, 84, 93, 98; and non-Russian peoples, 37, 50; and Orthodox Church, 123, 370; and Petersburg as symbol, 238; on postage stamp, 74; and property rights, 335-36; as Pygmalion, 123; Russian national-style architecture opposes, 211-12, 231; semiotics of, 370, 384; and succession, 6, 124, 128; Summer Garden sculptures of, 123; and Tchaikovsky, 244, 248; and triumphal entry, 10, 33-35; and westernization as imperial myth, xvii, 123$25,143,146,238,359,368,373$

Peter II (Emperor of Russia), 7

Peter-Paul Cathedral (Peterhof), 218, 222

Petipa, Marius, 66

Petrazhitskii, L. I., 349

Petrov, P. N., 198

Petrov, Vasilii, 129, 144

Petrunkevich, I. I., 349 
philosophy, 162, 293, 320, 331, 360-61

physical labor. See labor

Piatigorskii, A. M., 382

Pierce, Richard, 261

Pistolkors, Olga (Princess Paley), 82n31

Place de la Concorde, 158, 159

Plehve, Viacheslav, 226

Plekhanov, George, 350, 356

Pliny, 50

Pobedonostsev, Constantine, 62, 320, 360; on autocracy, 338; and church architecture, 173, 220, 225, 226; and National Myth, 373

Pochaev Monastery (Kremenets), 233

Pochaevskii listok, 233

Pogodin, Mikhail, 56, 121, 134

Pogosjan, Elena, 50

Pokrovskii, Vladimir, 236

Poland: church architecture in, 217n23, 220n30, 225, 227; and Russia's view of empire, 46, 247, 256; uprisings in, 62, 163-64, 172n51, 312, 314-15. See also polonaise

Polenov, Vasilii, 21

polonaise, 41, 55, 247-48

Polovtsov, A. A., 65

Poltava, Battle of (1709), 10, 34, 172

Poltava bicentenary celebrations (1909), 72, 95, 175

Polynesia, 367-68

popular prints. See lubki

Popular Socialists, 347-48

populism: and Chernov, 345-46; and constitutionalism, 343-45; and liberal Slavophiles, 297; and peasant commune, 343-44; and property rights, 333, 343-49; psychological analysis of, 356-57, 360

Port Arthur, 229, 230

Portis-Winner, Irene, 385

Possony, Stefan, 363

postage stamps, 72, 74-75

Postels, Alexander, 271

Potemkin, Grigorii, 38, 104, 129-30, 144

Potemkin, Pavel, 129-30, 144

poteshnye, 77, 90, 92, 95

Potsdam, 102

poverty, 320-32; and census counters, 323; and labor, 324, 329-32; and shame, 325-28, 331-32; urban vs. rural, 322-24; and women, 322, 325-30, 332. See also Tolstoy, Leo power. See under culture

Pozharskii, Prince Dmitrii, 19, 106, 148, 198

Poznansky, Alexander, 246

Prague school, 378 
"Praiseworthy Podvig of Ensign Kudriavtsev" (lubok), 170

prayer service (Place de la Concorde, Paris, 1814), 158, 159

Preobrazhenskii, M., 218, 219, 226

Preobrazhenskii Guards, 23, 34

pre-Petrine Russia: and Alexander III, 21, 373-74; and architecture, 211-14, 232, 236; and

Nicholas II, 375. See also Muscovy

Prescott, Walter, 289

"Presentation of Bread and Salt to the Tsar," 194, 196

press. See periodical press

Prianishnikov, Ilarion, 172

Priatnoe chtenie, 278

Primary Chronicle, 128-29, 131

Primary Reign of Oleg. See under Catherine II

princes of Kiev. See Oleg; Riurik; Rus'; Sviatoslav; Vladimir

princes of Moscow, 27-30, 124

Princeton University, 366

prints. See lubki

private property. See property rights

processions: and 1812 celebrations, 168, 173-74, 177, 178; in coronation albums, xviii, $\mathrm{xx}, 4-5,7-12,15,19,49-51,191,191$; of the cross, 207, 222; Geertz on, 366; in Life for the Tsar, 76; and non-Russian peoples, 38, 40-42, 49-51, 54-58, 64-68; peasants included in, 372; and torzhestvennost', 239, 247. See also coronations; triumphal entries program books, xvii, $\mathrm{xx}, 370$

promulgation ceremony, 4, 7, 13

property rights, 333-52; as alien to and historically weak in Russia, 333-37; and emancipation of serfs, 340-42; and French Revolution, 335; and Kadets, 349-50; and nationalization, 348-50; and peasant commune, 334, 339, 341-44, 349; and populism, 343-49; and socialists, 333-34, 346-48, 350-51; and state service ethos, 335-37; in West, 335, 351-52. See also constitutionalism

Propp, V. Ia., 378

prostitutes, 326-27, 329

Protestantism, 221

Prus, 30

Prussia, 30, 45, 147; constitutional monarchy in, 45; and Crimean War, 171; and Napoleonic Wars, 158, 165, 242

Przheval'skii, Nikolai, 290-94

psychoanalysis, 362-63

psychohistory, 363-64

psychology: as applied to history, 356-58, 360-65, 375, 394

Pugin, A. W. N., 121, 211

Pushkin, Alexander, 84; "Anniversary of Borodino," 163-64; Eugene Onegin, 247-48; Poltava, 244; "Queen of Spades," 248; Ruslan and Ludmilla, 65, 106, 137-38; "To the Slanderers of Russia," 164, 169

Putiatin, Mikhail, 236n66 
Putilov, N. I., 223

Putilov Factory church (St. Petersburg), 223

Putynki, 218

Pygmalion, 123

Raeff, Marc, 49, 263, 393; on nobility, 245, 337, 360, 391; scholarly works and career path of, 389-92

Rappaport, S. A., 80

"rapture of submission," xxi

Rastrelli, Bartollommeo, 239

Raun, Toivo, 226

Razumovskii, Kirill, 38, 51

Réau, Louis, 220, 221

Rechtsstaat, 318

Redeemer Cathedral. See Cathedral of Christ the Redeemer

Redkin, Peter, 361

Red Square, 19, 214. See also Cathedral of Vasilii the Blessed

Red Staircase (Krasnoe Kryl'tso; Moscow Kremlin), 15, 24, 40, 149, 161, 163, 371

reform. See constitutionalism; court reform; emancipation; Great Reforms; Russian monarch

regalia: of Alexander III, 21, 65; of Anna and Elizabeth, 6-9; in Antiquities of the Russian State, 115-18, 141-42; of Catherine I, 4-5; of Catherine II, 37; and heroic space, 180; of Michael Fedorovich, 116-17, 118, 142; of Monomakh, 30-31, 115, 116, 125 , 142; of Nicholas I, 16, 40, 371; Peter I introduces new, 4, 35, 48; on Terem palace walls, 112

regiments. See guards' regiments; His Majesty's Rifles

Reign of the Sovereign Emperor Nicholas Aleksandrovich (Elchaninov), 81-98; contradictory representations in, 97; on Duma and state institutions, 83, 86, 95-96; on imperial family, 86-87, 90; military in, 93, 94; on Nicholas as "crowned toiler," 83, 85; on Nicholas as helmsman of realm, 84-86; on Nicholas's bond with Russian people, 8385, 92-98; Nicholas's contributions and revisions to, 82-83, 82n32; on Nicholas's daily schedule and workday, 85-86; on Nicholas's heroic self-sacrifice, 83-84; on Nicholas's interests (hunting, opera, history), 87-89, 88, 88n49; organizational structure of, 82; on religion, 89-90; translations of, 82, 82nn30-31; on tsarevich, 90, 91-92; validates Nicholas's idealized self-image, 97-98

religion. See Christianity; Russian Orthodox Church

Repin, Prince, 278

representational culture, xvii-xx, 122-24, 146, 239, 365-67. See also coronation albums; engravings; lithographs

representative government. See constitutionalism

Resurrection: in church architecture, 214-16

Resurrection Cathedral. See Cathedral of the Resurrection

Reval (Tallinn), 218, 219, 226, 231

Revolution of 1848, 183, 297 
Revolution of $1905,71,96,176,232,237,250,374-75,374 n 30$

Reyfman, Irina, 383

Rezanov, Nikolai, 265-66, 276

Riabushkin, Andrei, 24

Riazan, 119, 284-85, 287, 300, 303; hoard of, 108, 139

Riga, 225-26, 227, 301, 379

Ritter, Karl, 285-86, 291; Die Erdkunde, 282-83

Riurik (expedition ship), 268

Riurik (Varangian prince; legendary ruler of Kievan Rus'): in Catherine II's play, 128; and Millennium Monument, 197-200, 203

Riurik dynasty, 30, 116, 119, 142

Roberts, Edward, 266

Rodzianko, Mikhail, 176, 176n60

Roman Empire (as model for Russia): and absolutism, 27; and advent (adventus), 33; and Catherine II, 37-38, 52, 130, 257; and coronations, 5, 29-30, 63; and expeditions, 253, 257; and Kulturstaat, 122; and law, 335; and Nicholas I, 103, 120, 136; and Olenin, 105; and Peter I, 123-25; replaced by colonial model, 40; replaced by Jerusalem as model, 216; and triumphal entries, 33-34. See also neoclassicism

Romanov dynasty. See tercentenary celebrations of Romanov dynasty

Roman pavilion (Peterhof), 120

Romans (New Testament), 340

Rome (modern-day): imperial palace in, 104n9, 138n42; Trajan Column in, 240. See also Roman Empire; St. Peter's Basilica

Rosé, Gustav, 285

Rosen, Baron Egor, 135

Rossi, Carlo, 240

Rossiia (as term for Russia), 32

Rossiia (newspaper), 79-80, 79n20

Rostopchin, Fedor, 141

Rostov, 235

Rostovtsev, Ia. I., 304

Rousseau, Jean-Jacques, 266, 331

Rovinskii, Dmitrii Aleksandrovich, 10, 183

Rowland, Dan, 208

Rubinstein, Anton, 246

rubles. See under tercentenary celebrations

Rudnev, D. A., 189, 206

Rumiantsev, Count Nikolai, 265, 268

Rus' (Kievan state), 163, 384; Alexander III embodies, 65-66; baptism of, 109; and church architecture, 107, 138, 211, 237; founding of, 128, 197; and Riurik, 200; vs. Rossiia, 32; in Solntsev's illustrations, 110-11, 120, 141; and Varangians, 368. See also Monument to the Millennium; pre-Petrine Russia

Ruskoi vestnik, 148

Russell, William, 41-43, 58-59 
Russian-American Company, 265, 271,279; establishment of, 260; and treatment of natives, $261,266,268-69,272,276$

Russian-Byzantine style. See Moscow-Byzantine style

"Russian Christopher Columbuses," 259-63

Russian empire style, 106, 138

Russian formalism, 385

Russian Geographical Society, 280, 285-86, 290, 292; founding of, 273, 282; generational rift in, 283. See also geography

"Russian Hercules" (Terebenev), 152, 152

Russian Imperial Theater, 126

Russian monarch: as active vs. subversive force, 375; and agro-literate society, 28-29; based on secular valor rather than divine sanction, 32; ceremonies as fundamental expression of, xvii-xxi, 29, 365-66; compared to Polynesian kings, 367-68; contrasted to French, 31-32; culture shaped and embodied by, 101, 122-25, 143-44, 208, 365; and doubling effect, xvii, xix, 124; as father to heir, 90, 362-65, 371; as foreign, xvii, 128, 368-69, 373; as hero, xvii, 34-35, 146, 370; and heroic space, 180, 18997, 200; and historicism, 121; mythical scenarios of defined and summarized, xviixxi, 368-75; and origin of terms tsar/emperor, 28, 125; Petersburg as symbol of, 238-39, 249; and property rights, 335-37; psychological approach to, 361-64; and "rapture of submission," xxi; as redeemer, 156-57; as reformer, 93, 146, 157, 359; and representational culture, xvii-xx, 123, 146, 239; and Russianness, 63, 65, 373-74; semiotics of, 384-85; and sovereignty as represented by empire, 27-28, 32, 36, 4546, 47; as "stranger king," 368; as superhuman, 34, 72, 368, 373; as Supreme Will and general good, 337-39; and theatricality/theater, 126-27, 239; and torzhestvennost', $\mathrm{xx}$-xxi, 239. See also autocracy; ceremonial texts; conquest myth; coronation albums; empire; European myth; heirs; heroic history; imperial family; Muscovy; mythical narratives; National Myth; Reign of the Sovereign Emperor Nicholas Aleksandrovich; Russian people; scenario of love; sovereignty; state administration and government; tercentenary celebrations; theatricality

Russian national esthetic, 101-21, 134-44; and Antiquities of the Russian State, 114-20, 140-44; and artifacts, 105-20, 137-44; clothing embodies, 109-10, 119; and historicism, 106, 121, 138; and kovrovost', 112-13; Olenin fuses with classical tradition, 104-6, 108-10, 114, 120, 137-40; and opera, 135; and Russian empire style, 106, 138; Solntsev expresses with montage of artifacts, 110-13, 117, 120-21, 142-43; and starina, 107, 138. See also Kremlin Table Service; Monomakh Cap; Muscovite ornamentalism; Nicholas I; Russian national style (in architecture); Terem Palace

Russian national style (in architecture), 208-37; under Alexander III, 210-31, 237; and amenities of light and heat, 221-22; as assertion of imperial control of history, 23132, 237; as atonement and spiritual purification, 216-17, 216n20, 222; autocracy symbolized by, 122, 209, 218-20, 229-37; critics of, 232-33; distinguishes monarchy from previous reigns, 208, 231; expresses union of tsar and Russian people, 208, 21011, 214; Jerusalem identified with, 216; as means to Muscovitize Petersburg, 211, 220, 233-35; as memorial to 1812 events, 164-67; as narrative medium, 208-9; near factories, 222-23; and neo-Russian style, 232; under Nicholas I, 102-4, 135-39, 144, 
162, 164-67, 208-9; under Nicholas II, 225-37; on noble estates, 223; and realism, 211, 221; reflects national myth, 210, 229; and Resurrection theme, 214-16; as revival style, 212, 222, 231, 237; seventeenth century as model for, 211-14, 217-20, 233-37; symbolizes Russian domination over non-Russian regions, 225-29, 233; symbolizes Russian Orthodoxy abroad, 229-31; Viollet on, 212, 218. See also architecture; bell towers; Byzantium; Cathedral of Christ the Redeemer; Cathedral of the Resurrection; corbelled vaulting; cupolas; decoration; Fedorov Village; kokoshniki; MoscowByzantine style; Moscow-Iaroslavl style; ornamentation; Russian national esthetic; shirinki; St. Catherine's Church; tent forms; “Thon style”; tracery

Russianness: of Alexander III's appearance and persona, 63, 65, 373-74; in coronation albums, 20-21, 24; and expeditions, 255, 289-90, 293; and Solntsev, 120. See also under clothing; Russian national esthetic; Russian national style (in architecture)

Russian nobility. See nobility

Russian Orthodox Church: and Alexander I, 149, 155-61; and Alexander III, 63, 173-74, 210, 374; and architecture, 221, 225-31, 233; and coronation ceremonies, 27-28, 32; and Crimean War, 170; and empire, 43, 59, 63; and island natives, 269, 272; and Millennium Monument, 197-98; and Nicholas I, 103, 136, 168; and Nicholas II, 72, 75, 89-90, 98, 176, 237, 374; and Peter I, 123, 370; and Tchaikovsky, 175, 244. See also Christianity; Official Nationality Doctrine

Russian people: and 1812 events and memorials, 145, 147-53, 158-60, 162, 169, 171-74, 176-79, 182; and Alexander I, 147-50, 158; and Alexander II's scenario of love, 41-43, 59-60, 171-72, 187-200, 193, 195-96, 200, 207; and Alexander III, 173-74, 21011, 214, 374; and coronations, xxi, 5, 7, 18, 21, 372; and Crimean War, 171; as devoted to autocracy, 40, 54, 121, 160, 162-63, 180-81, 183, 187, 208; and expeditions, 284, 293-94; and liberal Slavophilism, 297-301, 307-9, 312, 315-19; and lubki, 151-53, 180-83, 187-97, 193, 195-96, 205-6, 205-7; and Millennium Monument, 19798, 200-201, 204-7, 204n37, 205-6; and national-style architecture, 208, 210-11, 214; and Nicholas I, 40, 54, 134-35, 160, 162-63, 183, 208; and Nicholas II, 71-73, 83-85, 89, 92-98, 176, 178-79, 374; and property rights, 342, 344, 348; and Savior on the Blood as expiation, 216-17, 216n20. See also heroic space; peasant commune; peasantry

Russification, 226

Russkaia Azbuka (Alphabet of 1812; Terebenev), 153, 154

Russkaia beseda, 298

Russkaia starina, 121

Russkii invalid, 88, 164, 169-70, 201

Russkii khudozhestvennyi listok, 41-42, 44, 57-59, 191-92

Russkii vestnik, 42, 58

Russkoe bogatstvo, 347

Russkoe slovo, 80, 80n20

Russo-Japanese War, 84, 93. See also Japan

Russo-Turkish War (1876-77), 170

Ryle, Gilbert, 385

Rzhanov House for the Poor, 324, 327-30 
Sahlins, Marshall, 29, 367-68, 368n24

Sakovich, A. K., 182

Saltykov, Nikolai Ivanovich, 147

Samarin, Iurii Fedorovich, 297-305, 308-13; biographical background of, 301; on government and reform, 301, 304, 316-19; "On the Serf Status," 298

Samokish-Sudkovskaia, Elena, 24

Samokish-Sudkovskii, Nikolai, 24

Sandwich Islands, 269

Sankt-Peterburgskie vedomosti, 5

Sarov, 236, 236n66

Sarti, Giuseppe, 130, 131-33

Sarychev, Grigorii, 260-63, 278

Saussure, Ferdinand de, 368n24, 381, 385

Savigny, Friedrich-Karl von, 360

"Savior on the Blood." See Cathedral of the Resurrection

Savitskii, Konstantin, 21, 64

scenario of love: and Alexander I, 146-47, 149; and Alexander II, 19, 42, 44, 56, 59-62, 172, 187-97, 202-4, 207, 372; and Alexander III, 173; and Nicholas I, 41, 54; and non-Russian peoples, 44, 56, 59-62, 70

scenarios of power. See mythical narratives and scenarios

scepter. See orb and scepter; regalia

Schelling, Friedrich, 121, 355

Schimmelpenninck, David, 294

School for Foreign Youths (Petersburg), 130

School of Jurisprudence, 360

Schwartzenberg, Prince Karl-Philip, 158

science. See Academy of Sciences; botany; expeditions; geography; geology; naturalists; semiotics; social sciences

Scott, Walter, 360

Scythians, 111

sea exploration. See expeditions; exploration

Second Section (of chancellery), 359

Secret Committee (1839-1842), 337

Segal, D. M., 379, 382

Sel'skii vestnik, 79-81, 79n20

Sel'skoe blagoustroistvo, 298, 300, 302

Semenov, Peter, 290, 292-94; biography and career of, 283-87; and Tian-Shan journey, 285-86

Semevskii, M. I., 121

semiotics, 377-86; and anthropology, 385-86; of culture and history, 369-70, 381-86; and culture as constructed text, 382; vs. deconstructionism, 381; as developed by Moscow-Tartu school, 366-67, 378-81; of early Russia, 384; and langue vs. parole, 368n24, 381; as liberation from Marxism, 369, 377, 381; as means to national selfdiscovery, 382, 386; of nobility's code of behavior, 369-70; recent approaches to, 386; 
as "return to history," 382; and "thick description," 385; in West vs. Russia, 381, 385.

See also Lotman; Moscow-Tartu school; Saussure; structuralism

Senate, 253, 373

Seneca, 37

Seniavin (expedition ship), 271

Serafim of Sarov (Saint), 89-90, 236, 236n66

Serebrianyi, S. D., 379, 380, 381

serfdom: and Cossacks, 37; and property rights, 334, 336; and theater, 126-27. See also emancipation; peasantry

Sergei of Radonezh (Saint), $20 \ln 27$

Serov, Valentin, 24

service. See state service

Sevastopol, 170-71

seventeenth century. See under Muscovy; pre-Petrine Russia; Russian national style

Severnaia pchela, 164, 171

Severnaia pochta, 188, 203-4

Sewell, William, 335

Shakespeare, William, 64, 128, 131, 285

Shakhovskoi, S. V., 226

shame, 325-28, 331-32

Shamil, 44-45, 61-62

Shchusev, Alexei, 233

Shein, General, 34

Shekhtel, Fedor, 217n23, 223

Shelekhov, Grigorii, 260-61, 263

Shemelin, Fedor, 266, 276

Sheremet'ev, A. D., 223

Shervud, Vladimir, 211

Shidlovskii, D. N., 308

shield of Igor, 131, 133

Shipov, D. N., 310

shirinki, 214, 217; defined, 214n 18

Shirinskii-Shikhmatov, A. A., 227

Shirinskii-Shikhmatov, Platon, 183

Shishkov, Alexander, 147-49, 156, 160

Shumacher, Johann, 6, 9

Shvidkovskyi, Dimitryi, 208

Siberia, 12, 32, 266, 268; expeditions to (eighteenth century), 253-55, 260-62; expeditions to (nineteenth century), 263-64, 275, 277, 280, 286, 289-90; Gmelin and Müller on, 254; identified as Asian, 255; and non-Russian peoples, 39, 50, 66

signs. See semiotics

Sitka, 272

Sitwell, Sacherevell, 18, 19

Siutaev (peasant), 321 
Slavophilism, 121, 355; and Alexander III, 249; and Millennium Monument, 200, 204; and peasant commune, 344; and property rights, 335. See also liberal Slavophilism

Slocum, John, 65

Smolensk, 151, 177, 221, 223, 290

Smolensk Mother of God (icon), 177

Snegirev, Ivan, 115, 141

Sobinov, Leonid, 76

Social Democrats, 350

socialism: and peasant commune, 342, 344; and property rights, 333-34, 344-48, 350-51

Socialist Revolutionary Party (SR), 346-48

social sciences, 357, 375, 391

Sofia Cathedral (Kiev), 107, 138

Sokolov, A. P., 21

Sokolov, Ivan, 10, 12, 50

solemnity. See torzhestvennost'

"Solemn Presentation of Bread and Salt," 194, 196

Solntsev, Fedor: and Antiquities of the Russian State, xx, 113, 114, 116, 117-20, 118, 14044; becomes Olenin's protégé, 101-2, 107, 139; biography of, 101-2, 102n3; conveys Russian national spirit with montage of artifacts, 110-13, 117-21, 142-43; creates "encyclopedia" of old Russian life, 108, 139; creates sketches used for St. Catherine Church, 104, 138; decorativeness in, 112-13, 117-21, 142-43; and "hoard of Riazan," 108, 139; illustrates Olenin's volume for ethnography course, 109; and Kremlin Armory, 108, 139; and Nicholas I, 103, 107-8, 112-13, 139; Pogodin on, 121; as reproducer of objects rather than creative artist, 111-12

-Works: breast plate of Alexei Mikhailovich, 117-19; chrism dish, 119; Gospel Cover of Natalia Naryshkina, 119; "Grand Regalia" of Tsar Michael, 116-17, 118, 142; "Helmet of Alexander Nevskii," 117, 118, 143; inkwell of Tsar Michael, 119; Kremlin Table Service, 112-13; "Meeting of Prince Sviatoslav Igorevich with Byzantine Emperor John I Tzimisces," 110-11, 111; “Monomakh Cap,” 116, 116-17, 142, 143; Terem Palace, 112, 113, 120

Solon, 36

"Song of Igor's Campaign." See "Lay of the Host of Igor"

Sophia Alekseevna (Regent of Russia; sister of Peter I), 84

South America, 275, 289

South Pacific, 266-67

souvenirs (of imperial family), 72, 75

sovereignty: as based in performance not dynastic inheritance, $\mathrm{xx}$; and cultural genealogies, 122; and European myth, 373; and expeditions, 262; popular, 134, 150, 180; represented by imperial coronations and advents, 27-28, 32-36, 42, 45-46, 59, 125; unmediated, 125. See also under empire

space. See heroic space

Sparta, 129

Speranskii, Michael, 147, 337-38, 360, 390, 392

Spiridovitch, A. I., 74 
sports: and Nicholas II, 87, 88n 49

Stalin, Joseph, 378, 379

starina, 107-8, 138

Starn, Randolph, 218

Stasov, Vasilii, 102

state administration and government: Alexander III dislikes, 373-74; Cherkasskii's view of, 311-15; Koshelev's view of, 306-11; and legal reform, 358-61; and liberal Slavophilism, 300-319; Nicholas II dislikes, 84, 86, 374-75; Petersburg as center of, 239; populist critique of, 343-44; and property rights, 336-42, 350-52; Raeff on, 390-91; Samarin's view of, 316-19. See also court reform; Great Reforms; judiciary State Council, 83, 86, 95, 103, 176, 373

state service: and coronation ceremonies, 49, 53; as established and mandated by Peter I, 123, 245, 335-36, 391; and expeditions/explorers, 274, 277-78, 283-84, 293; and liberal Slavophiles, 301, 312, 315; and property rights, 335-37; and Tchaikovsky, 24546; in theater, 127; tsar as embodiment of, 71,337. See also nobility

statues. See Alexandrine Column; Monument to Ivan Susanin; Monument to the Millennium St. Basil's Cathedral. See Cathedral of Vasilii the Blessed

St. Catherine's Church (Petersburg), 102, 104, 136, 138, 209

Steller, Georg Wilhelm, 254-55

Stenglin, Johannes, 10

St. Gabriel (expedition ship), 254

Stites, Richard, 126-27

Stolypin, Peter, 80, 93, 348-50, 374n30

Storch, Heinrich, 132, 256

St. Peter's Basilica (Rome), 130

St. Petersburg, 238-50; and Bloody Sunday, 250; and Catherine II, 130, 132; changes after Alexander II's assassination, 249; and emancipation reform, 302-3, 312-13, 316; Moscow as subordinate to, 35; Muscovitized by church architecture, 211, 214, 220, 233-35; neoclassical architecture in, 120, 238; population growth and economic development of, 249; semiotics of, 383-84; and Shamil, 44; as symbol of westernized absolute monarchy, 238-39; and Tchaikovsky, 238, 243-44, 246-49; and theater, 126; and torzhestvennost', 239, 244, 247. See also Academy of Sciences; Alexandrine Column; Cathedral of the Resurrection; General Staff Academy; Palace Square

St. Petersburg Conservatory of Music, 246

St. Petersburg European University, 395

St. Petersburg Institute of History, 395-96

"stranger king," 368-69

structuralism, 378, 381, 385. See also semiotics

Struve, Peter, 349

St. Sofia (Constantinople), 167

St. Sofia (Novgorod), 202

style russe, 121

subjective factor, 358

subjects. See Russian people 
submission: of people to monarch, xxi, 56, 67, 172; "rapture of," xxi succession, 6, 15-16, 124, 128. See also Law of Succession

Sultanov, Nikolai, 218, 222, 223

Sumarokov, Alexander, 126

Summer Garden, 123

Summerson, John, 239

Sunderland, Willard, 51, 256

Susanin, Ivan, 135, 189, 190, 200

Suvorov, Alexander, 89

Sviatoslav I Igorevich (Grand Prince of Kiev), 110, 111

Sviatoslav II Iaroslavich (Grand Prince of Kiev), 109-11, 140

Svin'in, Pavel, 16, 40-41, 54-56, 59, 106-7, 163

Sweden, 253, 264. See also Northern War

Syn otechestva, 62, 151

Sytin, Ivan, 80

table service. See Etruscan table service; Kremlin Table Service

"Tale of Igor's Campaign." See "Lay of the Host of Igor"

"Tale of Monomakh." See "Legend of Monomakh"

"Tale of the Vladimir Princes," 30

Tallinn. See Reval

Tartakovskii, A. G., 167

Tartu School. See Moscow-Tartu School

Tartu University, 359, 369, 378-79

Taruskin, Richard, 247

Tashkent, 217n23, 229

Tatars: and ceremonial trips, 39, 62; during coronations, 42, 44, 57-58, 60, 69; and Crimean War, 170; and expansion of empire, 37, 256; and Millennium Monument, 201

Tatishchev, Vasilii, 6, 255

Tauride Venus, 123

Tauris, 130

Tbilisi (Tiflis), 44

Tchaikovsky, Anatole, 246

Tchaikovsky, Ilia, 245-46

Tchaikovsky, Modest, 238, 246

Tchaikovsky, Peter, 243-49; biographical background of, 245-46; folk tunes incorporated by, 243-44; as performed during 1812 memorial celebrations, 174-75; and Petersburg, 238, 243-44, 246-49; and polonaise, 247-48; rootlessness of, 238, 246-47; and torzhestvennost', 244, 247-48; Ukrainian motifs in, 244

-Works: 1812 Overture, 174-75, 244; Eugene Onegin, 247-48; First Piano Concerto, 244; First Symphony ("Winter Dreams"), 246; Fourth Symphony, 247; Little Russian Symphony, 244; Marche Slav, 244; Mazeppa, 244; Moskva, 66; Queen of Spades, 247, 248; Slippers (Cherevichki), 244, 248; Third Orchestral Suite, 247; Third Symphony ("Polish"), 247 
Teachers' Seminary, 229

teatral'nost', 239

Temkin-Rostovskii, Prince M. M., 106

Temperance Brotherhood, 225

tent forms, 218, 226-31; belfries, 220, 222-23, 226-27, 229, 231; roofs, 212, 214, 223 , 227,236

tercentenary celebrations of Romanov dynasty (1913), 113, 175; and distribution of monarchist literature, 80-81; in Elchaninov, 84; in films, 77-78; and Nicholas II's idealized view of popular support, 98; and Nicholas II's publicity campaign, 72-81; and postage stamps with tsars, 74-75; and souvenirs of imperial family, 75; and Tercentenary Church, 233-35, 234; and Tercentenary Icon, 81; and Tercentenary Ruble, 73, 73-74. See also Reign of the Sovereign Emperor Nicholas Aleksandrovich

Terebenev, Ivan, 151, 169, 182; Alphabet of 1812 (Russkaia Azbuka), 153, 154; "Russian Hercules," 152, 152

Terem Palace, 112, 113, 120

territorial consciousness, 51, 256

theater: and ban on depiction of monarchs, 75-76,75n7; Catherine II uses to shape imperial myth, 122, 126-34, 144; as didactic, 127; history and origins of in Russia, 126-27; and Nicholas II, 75-76

theater state, 239, 385

theatricality: Geertz on, 239; Lotman on, 126, 181, 383; and lubki, 181; and Tchaikovsky, 244; and torzhestvennost', 239, 244

Thon, Constantine: Alexander III rejects style of, 211; moves from neoclassical to neoByzantine style, 104, 138-39, 166, 209. See also "Thon style"

-Works: Christ the Redeemer Cathedral, 139, 165-67, 209, 210; Imperial palace (Rome), 104n9, 138n42; New Kremlin Palace, 113, 139; St. Catherine's Church, 104, 138,209

“Thon style," 104, 138, 166, 209, 213

Tian-Shan mountains, 285-86

Tibet, $290-92$

Tiflis (Tbilisi), 44

Tikhomirov, Lev, 338

Tilesius, Wilhelm Gottfried, 265

Time of Troubles, 78, 106, 148, 176

Times (London), 41-42, 58

Timm, Vasilii, 19, 57; "Emancipation of the Peasants," 191-92, 192

Tiutchev, Fedor, 43-44, 60, 191, 204

Tmutorokan stone, $105 \mathrm{n} 13,137$

Tobolsk, 254

Todorov, Tzvetan, 381

Tolstaia, Sofia Andreevna, 230, 320, 322, 325

Tolstaia, Tatiana, 322

Tolstoi, Count M. V., 203

Tolstoi, Dmitrii, 201-2 
Tolstoi, Sergei, 322

Tolstoy, Leo, 320-32; on 1812 events, 167; criticizes his own family, 330; diaries of, 322, 325-27; at Khitrov market and Rzhanov House, 323-24, 328-29; and labor, 321, 324, 329-32; Nabokov on, 387; on the poor as complex human beings, 329; selfcondemnation of, 324-29, 331; and sexuality, 325-27; and shame, 325-28, 331-32; on suffering of war, 171-72; on urban vs. rural poverty, 322-24; and women, 322, 325-30, 332; works with census, 323, 328

-Works: Confession, 322; "On the Census in Moscow, 323; Sevastopol Sketches, 171 72; War and Peace, 167; "What Then Must We Do?" 320-32

Tomashevskii, B. V., 378

Toporov, V. N., 378, 379, 383

Torke, Hans Joachim, 391

torzhestvennost', 205, 239, 244, 247-48; defined, $\mathrm{xx}-\mathrm{xxi}$

Toyons, 267

tracery, 209, 214

Trajan column (Rome), 240

Treaty of Nerchinsk, 280

Treaty of Nystadt, 47, 50, 253

Trinity Cathedral (Pochaev Monastery), 233

triple bows, 161, 163, 371-72

triumphal arches, 10, 12, 33-34, 38

triumphal entries: of Alexander I, 155, 155; of Alexander II, 19, 56-59, 57, 191, 191; of Alexander III, 63-64, 67; of Catherine II, 38, 51; defined, 33; of Elizabeth Petrovna, 9-12, 35, 49; of Louis XIII, xix, xixn6; of Nicholas I, 54; of Nicholas II, 67; of Peter I, 33-35; Roman advent as model for, 33. See also processions; triumphal arches

Trubetskoi, Nikita Yurievich, 6, 9-10, 13

Trubetskoi, N. S., 378

Trudy po znakovym sistemam (Works on Sign Systems), 378-80. See also Moscow-Tartu school

tsar: origin of term, 28, 125. See also imperator; Russian monarch

Tsarskoe Selo, 235, 249

Tsivian, Yuri, 77, 77n 13, 383

Tuchkova, Maria, 168

Tula, 312

Tungus, 52, 134, 256, 258

Turgenev, Alexander, 151

Turgenev, Ivan, 191

Turkestan, 62, 64, 289-90, 292

Turkey, Russian wars with, 50, 102n4, 128-29, 169-70

Turks, 34, 67; in lubki, 169-70. See also Russo-Turkish War

Turner, Victor, 380

Ukraine, 163, 170, 233, 244, 301, 315, 392

Unalashka, 262, 272 
“Unforgettable Day of February 19," 194, 195

uniforms: of guards' regiments, 5, 19, 23, 177, 194; of nobility (westernized), 40-41, 54; Russian monarchs in, 19, 43, 59-60, 73, 91, 93, 173, 177, 184, 194; Russian-style, 23, 43, 59-60. See also clothing

Union of Russian People, 75

United Nobility, 351

United States, 270, 290, 339n15, 343. See also Alaska; North America; Russian-American Company

University of Chicago, 356, 366, 389, 393-94

Unkovskii, A. M., 305, 308

Urals, 39, 67, 255, 257

Ushinskii, Constantine, 360

Uspenskii, Boris, 27, 378, 381, 384

Uspenskii, Gleb, 356, 357

Uspenskii, Vladimir, 381

Uspenskii Sobor, 49

Ussuri valley, 281-82, 288, 290

Uvarov, Sergei, 134, 151, 161, 162

Valuev, Peter, 188, 198-200, 203-4, 205, 359

Varangians, 116, 128, 134, 142, 197, 368

Vasilii the Blessed. See Cathedral of Vasilii the Blessed

Vasnetsov, Victor, 24, 223, 237

Veilly, Jean Louis de, 4, 14, 15

Vekhi, 380

Velikorossiiskoe Tsarstvie, 32

Vel'tman, Alexander, 115, 141

Vendôme column (Paris), 240

Venetsianov, Alexei, 151, 153, 182

Veniukov, Mikhail, 281, 283-84, 292-94; biography and career of, 287-90

Venus of Arles, 123. See also Tauride Venus

Vereshchagin (court deacon), 202, 203

Vereshchagin, Vasilii, 21

Versailles, 123

Vertus, 158, 165. See also Mont Aimé ceremony

Victoria (Queen of England), 87, 97

Vikings. See Varangians

Vilinbakhov, G. V., 383

Vinius, Andrei, 34

Vinkovetsky, Ilya, 263, 268, 277

Viollet-le-Duc, Eugène Emmanuel, 40, 211, 216; L'Art Russe, 212, 218

Vishlenkova, Elena, 151

visual culture. See architecture; coronation albums; engravings; lithographs; lubki; representational culture; Russian national esthetic; Russian national style (in architecture) 
visual nationalism/patriotism, 151, 153

Vitberg, Alexander, 103, 136, 160, 161

Vladimir. See Assumption Cathedral (Vladimir)

Vladimir I, the Great (Saint; Grand Prince of Kiev), 109, 116, 142, 197-98

Vladimir II Monomakh (Grand Prince of Kiev), 30, 116, 119, 125, 141. See also "Legend of Monomakh"; Monomakh Cap

"Voice of the Russian People," 192-94, 193

Volkov, Fedor, 126

Voltaire (François-Marie Arouet), 129

Voprosy literatury, 378

Vorob'ev, M. N., 102

Vorontsov, V. P., 357

Vorontsov-Dashkov, I. I., 223

Voyage Around the World. See Litke

Voyage en Siberie (d'Auteroche), 257

Voznesensk, 165

Voznesenskii Convent (Moscow Kremlin), 5

Vzdornov, G. I., 108, 139

Wagner, Richard, 88

Warsaw, 220n30, 225, 227. See also Poland

watercolors: of churches, 102; of coronations, 24, 191; Solntsev's, 102, 108, 110, 116-19, 139-43

weapons: and Olenin/Solntsev, 106, 108-12, 115, 117, 139-41, 143

Weber, Max, 29, 391

Werth, Paul, 65

Western Europe. See England; France; Greece; Hapsburg Empire; Roman Empire westernization: and Alexander I, 146, 155; coronations emphasize, 35-36, 49; as established by Peter I, xvii, 123-25, 368; and European myth, 146, 359, 372-73; expeditions as means to promote, 253-56, 272-73, 277; as fundamental characteristic of nobility, 245; Nicholas I fuses with national identity, 104, 139, 160, 162, 208; and Nicholas II, 71, 93; and non-Russian peoples, 40, 51, 53, 143; Petersburg as symbol of, 238-39; Russian national-style architecture repudiates, 210, 217, 231; semiotics of, 370, 38384; and Tchaikovsky, 243-44; and theatricality/theater, 126-27

Westernizers, 297-98, 355

"What Do the People Need?" (Ogarev and Obruchev), 342

"Why is the War of 1812 Called the War for the Fatherland" (Efremov), 179

William I (King of Prussia; Emperor of Germany; brother-in-law of Nicholas I), 242

Wilson, Woodrow, 363

Winckelmann, Johann Joachim, 105, 137

Winter Palace, 96, 188, 239, 250

Wirtschafter, Elise Kimerling, 127

women: and Tolstoy, 322, 325-30, 332

work. See labor 
workers: meet with Alexander II, 188, 194, 196; and Nicholas II, 96

Works on Sign Systems (Trudy po znakovym sistemam), 378-80. See also Moscow-Tartu school

World War I, 98

Wortman, Richard (overview of scholarly works and career), 355-76; Crisis of Russian Populism, 356-57; Development of a Russian Legal Consciousness, 358-61; Scenarios of Power, 370-75

Wortmann, Christian Albert, 7

Wrangel, Ferdinand, 269, 276-77, 279, 284

Yakushkin, V. E., 349

"Year 1812" (Prianishnikov), 172

Zabelin, Ivan, 211

Zagoskin, Mikhail, 115, 141

Zaionchkovskii, Peter, 358

zakonnost', 359

Zarudnyi, Sergei, 360, 361

Zemshchina, 75

Zemskaia Duma, 310-12, 318

zemskii sobor, 299-300, 308, 344

zemstvo, 66, 210, 314, 316

Zhirmunskii, Victor, 378

Zhivov, Victor, 37, 47, 133, 369-70, 384

Zholkovskii, Alexander, 381

Zhukovskii, Vasilii: and Alexandrine column, 165, 243; "Bard in the Russian Camp," 157, 287; "Epistle to Emperor Alexander," 157; and Napoleonic Wars (1812), 151, 156-57, 161, 163; and sentimentalism, 360

Zichy, M. A., 19, 191, 191

Zlatovratskii, Nikolai, 356, 357

Zorin, Andrei, 129, 130, 156

Zubovskii, P. P., 81

Zwinger Palace (Dresden), 105 

